UNIVERSIDADE DE SÃO PAULO

INSTITUTO DE GEOCIẼNCIAS

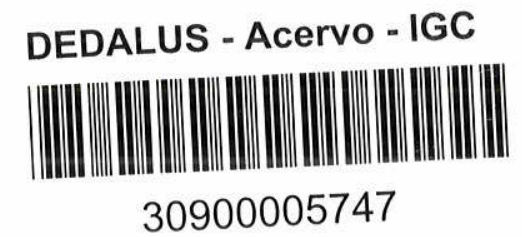

\title{
DINĀMICA SEDIMENTAR QUATERNÁRIA NO LITORAL SUL PAULISTA
}

Moysés Gonsalez Tessler

Orientador: Prof. Dr. Kenitiro Suguio

TESE DE DOUTORAMENTO

T988

COMISSÃO EXAMINADORA

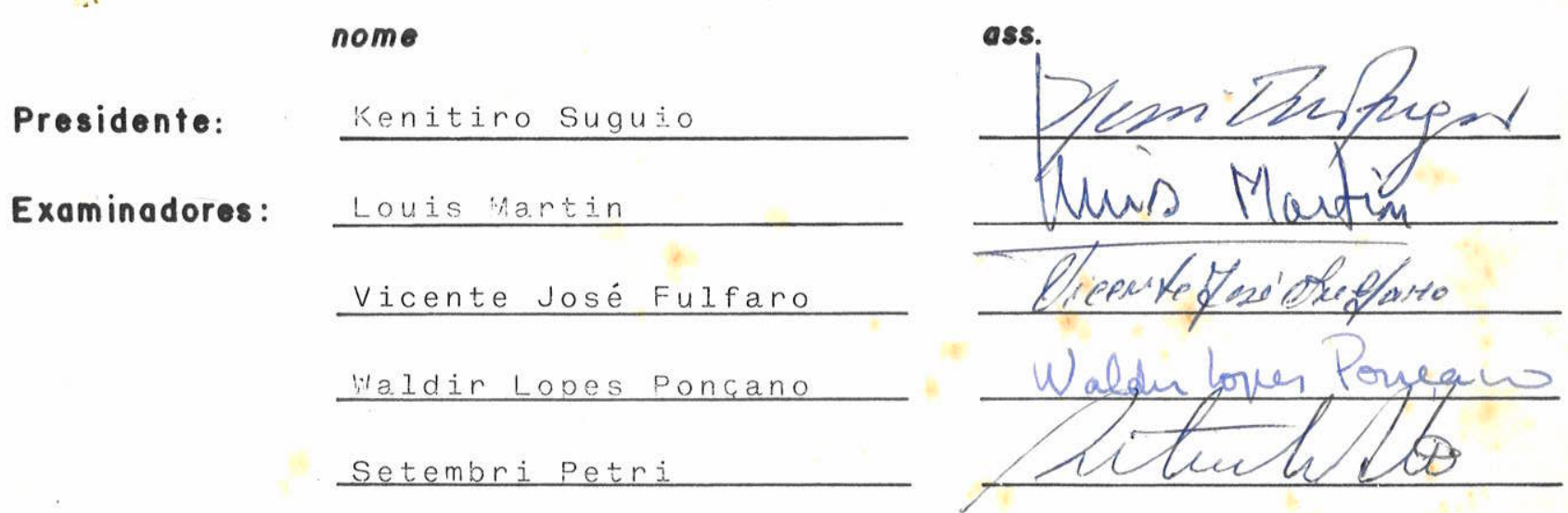

São Paulo

-1988 - 


\title{
UNIVERSIDADE DE SÃO PAULO \\ INSTITUTO DE GEOCIÊNCIAS
}

\section{DINĀMICA SEDIMENTAR QUATERNÁRIA NO LITORAL SUL PAULISTA}

Moysés Gonsalez Tessler

\author{
Orientador: Prof. Dr. Kenitiro Suguio
}

TESE DE DOUTORAMENTO

Área de Concentração: Paleontologia e Estratigrafia 


\section{RESUA:O}

\section{ABSTRACT}

1. INTROdug̃̃o $\ldots \ldots \ldots \ldots \ldots \ldots \ldots \ldots \ldots \ldots \ldots \ldots \ldots \ldots \ldots \ldots$

1.1 - objetivos............................. 1

1.2 - Área de estudo e amostragem................. 2

$1.3-011$ toral sul paulista................... 6

1.3 .1 - A planície coste1ra ................... 6

1.3 .2 - A Margem Continental .................... 9

1.3 .2 .1 - origem $\ldots \ldots \ldots \ldots \ldots \ldots \ldots \ldots \ldots \ldots \ldots \ldots \ldots \ldots \ldots \ldots \ldots$

1.3 .2 .2 - Morfologia e Fisiografia ................ 10

1.4 - Caracterização das seqüências sedimentares da planície costeira e da plataforma continental sul do Estado de são Paulo.................. 11

1.4 .1 - Formação Cananéia ..........................

1.4 .1 .1 - Denominação ...................... 13

1.4.1.2 - Características texturais e composicionais .... 14

1.4 .1 .2 .1 - Superficie ....................... 14

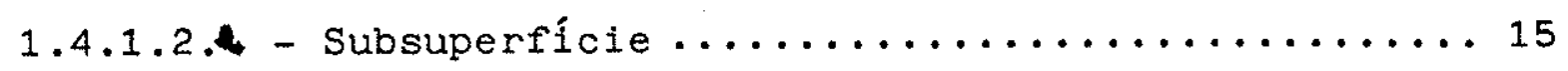

1.4 .1 .3 - Ambientes de Sedimentação .............. 16

1.4 .2 - Formação Santos .......................... 16

1.4 .2 .1 - Denominação ...................... 16

1.4.2.2 - Características texturais e composicionais .... 16

1.4 .2 .3 - Ambientes de deposição ................ 18

1.4 .3 - Sedimentos de superfície de fundo da Plataforma Continental .................... 18

1.5 - Agradecimentos ........................ 21 


\section{OS SEDIMIENTOS}

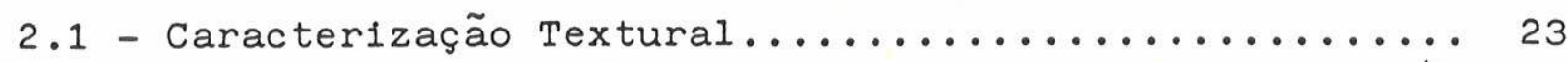

2.1 .1 - Cálculo dos parâmetros estatísticos............ 23

2.1 .2 - Caracterização granulométrica dos sedimentos..... 25

2.1.2.1 - Parâmetros estatísticos de Folk \& Ward (1957)...... 25

2.1.2.2 - Análise de frequiência dos parâmetros estatísti-

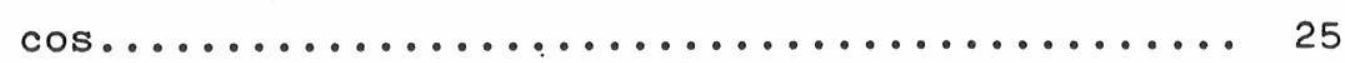

2.1 .2 .2 .1 - Área Emersa - Formação Cananéia............ 26

2.1.2.2.2 - Faixa Intermarés - Ilhas Comprida e Cardoso... 26

2.1 .2 .2 .3 - Área Submersa - Zona de Arrebentação........ 27

2.1.2.2.4 - Área Submersa - Plataforma rasa............ 29

2.1.2.2.5 - Cordões Iitorâneos - Ilha Comprida......... 31

2.1 .2 .3 - Análise do número de classes texturais........ 32

2.1.3 - Caracterização morfoscópica em grãos de quartzo... 32

2.1.3.1 - Sedimentos pleistocênicos e holocênicos da área

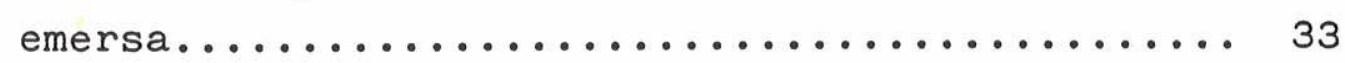

2.1 .3 .2 - Faixa Intermarés.................... 33

2.1 .3 .3 - Sedimentos de fundo.................... 34

2.1.4 - Mapas de isovalores da distribuição espacial dos

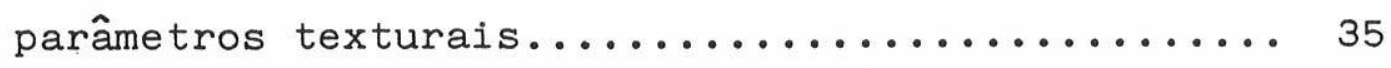

2.2 - Composição mineralógica dos sedimentos............ 45

2.2 .1 - Análise do teor de carbonato biodetrítico....... 45

2.2.2 - Análise da fração grossa - Coarse Fraction Ana-

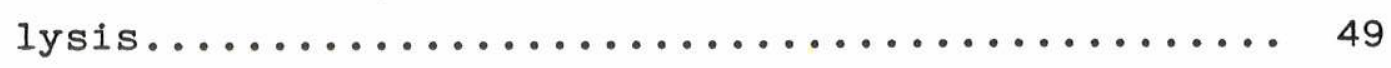

2.2 .3 - Minerais leves........................ 52

2.2 .4 - Minerais pesados...................... 56

2.2 .4 .1 - Métodos.......................... 57

2.2 .4 .2 - Área Emersa......................... 60

2.2.4.2.1 - Sedimentos pleistocênicos - Formação Cananéia. 61

2.2.4.2.2 - Cristas praiais holocênicas da Ilha Comprida.... 62

2.2 .4 .3 - Faixa Intermarés.................... 63 
2.2 .4 .4 - Área submersa.................... 63

2.2 .4 .5 - Descrição dos Minerals................. 64

2.2.4.6 - Análise de frequêncla dos minerais transparentes e não micáceos...................... 68

2.2 .4 .6 .1 - Área emersa .................... 68

2.2 .4 .6 .1 .1 - Freqüência média................ 68

2.2 .4 .6 .1 .2 - Frequência de ocorrência............ 68

2.2.4.6.1.3 - Frequiência de classes.............. 68

2.2 .4 .6 .2 - Faixa Intermarés................... 69

2.2 .4 .6 .2 .1 - Frequência média................. 69

2.2 .4 .6 .2 .2 - Frequiência de ocorrência............. 70

$2.2 .4 \cdot 6.2 .3$ - Freqüência de classes............... 70

2.2 .4 .6 .3 - Área emersa..................... 70

2.2 .4 .6 .3 .1 - Frequiência média................ 70

2.2.4.6.3.2 - Frequência de ocorrênc1a.............71

2.2.4.6.3.3 - Frequência de classes.............. 71

2.2.4.6.3.4 - Mapas de isovalores de distribuição espacial dos minerais pesados na área submersa...... 72

2.2 .4 .7 - Maturidade mineralógica................ 82

2.2 .4 .8 - Minerais pesados opacos................. 84

2.2 .4 .9 - Áreas fontes...................... 84

2.2 .4 .10 - Conclusões parciais.................. 92 


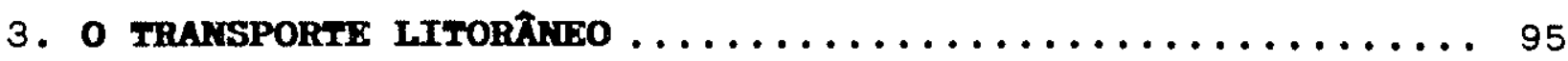

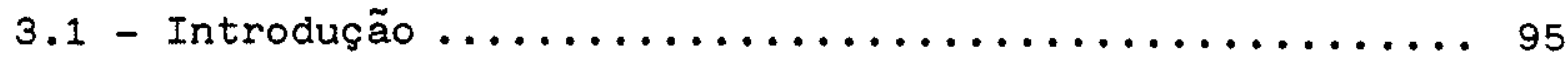

3.2 - Parâmetros Oceanográficos .................. 97

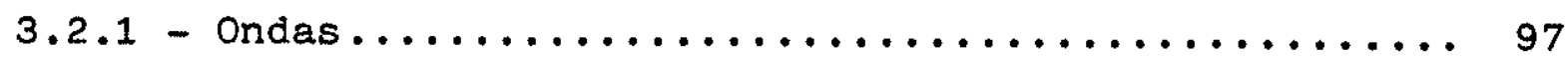

3.2.1.1 - Resultados obtidos em levantamento anteriores.. 98

3.2.1.2 - Levantamento Instituto Oceanográfico da USP -

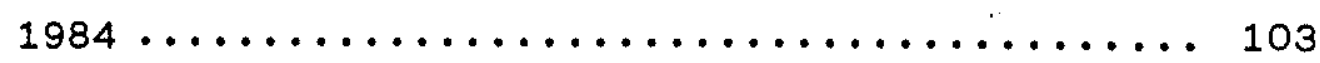

3.2 .1 .3 - Profundıdade máxima de ação efetiva das ondas na mobıl1zação dos sedimentos de fundo ....... 107

3.2 .2 - Correntes........................... 109

3.2.2.1 - Obtenção dos dados de meia-água e de fundo.... 109

3.2.2.2 - Análise dos resultados ................. 110

3.2.2.2.1 - Estação fixa de Paranaguá - $1984 \ldots \ldots \ldots \ldots \ldots 110$

3.2.2.2.2 - Estação fixa de Cananéia - 1984 .......... 114

3.2.2.2.3 - Estação fixa de Iguape - $1984 \ldots \ldots \ldots \ldots \ldots \ldots$

3.2.2.2.4 - Estação fixa de Cananéia - $1962 \ldots \ldots \ldots \ldots$.... 122

3.2 .2 .3 - Correntes de Superfície ................. 129

3.3 - Fatores meteorológicos .................. 132

3.3 .1 - Relação entre os parâmetros oceanográficos e os

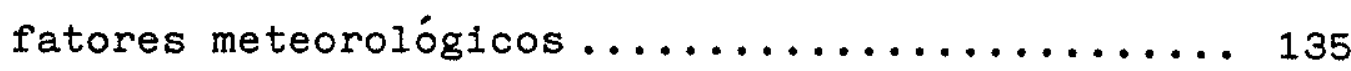

3.4 - Velocidade critica de transporte............. 137

3.4 .1 - Formulações gráficas .................. 138

3.4 .2 - Velocidades críticas de corrente para 1984 e

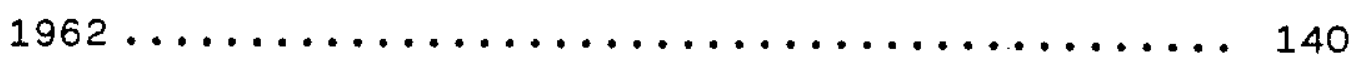

3.5 - Taxa de transporte..................... 142

3.5 .1 - Primavera de $1984 \ldots \ldots \ldots \ldots \ldots \ldots \ldots \ldots \ldots \ldots$

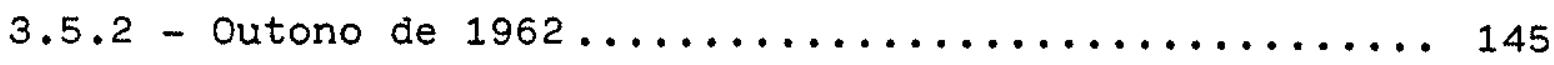

3.6 - Conclusões Parciais...................... 149 
4. GEOAETRTA dOS CORDŌES LTTORĀNEOS DA PLANÍCIE COSTEIRA SUL PaUlista .................................. 150

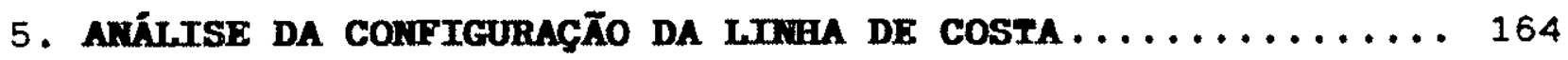

5.1 - Desembocadura lagunar de Ararapira (SP/PR) ....... 164

5.2 - Desembocadura lagunar de Cananéia (SP) .......... 168

5.3 - Desembocadura lagunar de Icapara e foz do rlo Ribei ra de Iguape $(\mathrm{SP}) \ldots \ldots \ldots \ldots \ldots \ldots \ldots \ldots \ldots \ldots \ldots \ldots$

6. conclusōes .............................. 179

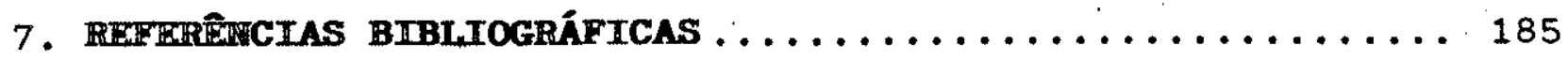




\section{F1guras e Hapas}

Mapa ne 1 - Mapa de localização das amostras coletadas

Fig. 1 - Localização da área de estudo. Planície coste1ra sul do Estado de são Paulo.... 3

Fig. 2 - Mapa geológico das regiões SW do Estado de São Pau lo e $S E$ do Estado do Paraná................. 7

Fig. 3 - Mapa de fácies sedimentares da plataforma continental localizada entre os estados de são Paulo

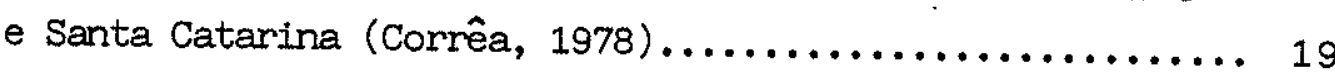

Fig. 4 - Variação longitudinal do diâmetro médio dos sedi mentos da faixa intermarés da IIha Comprida - SP....... 28

Fig. 5 - Variações transversals à costa do diâmetro médio.... 30

Fig. 6 - Mapa de isovalores do diâmetro médio, da distribuição total, das amostras de fundo da zona de

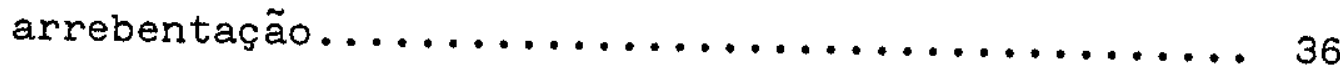

Fig. 7 - Mapa de isovalores da porcentagem de argila das amostras de fundo da zona de arrebentação...... 37

Fig. 8 - Mapa de isovalores do número de classes texturais, da distribuição granulométrica, das amostras de fundo da zona de arrebentação......... 38

Fig. 9 - Mapa de isovalores do grau de arredondamento, da fração retida na peneira $0,500 \mathrm{~mm}$, na zona de arrebentação..................... 40

Fig. 10 - Mapa de isovalores do grau de arredondamento da fração retida na peneira $0,250 \mathrm{~mm}$, na zona de arrebentação........................ 41

Fig. 11 - Mapa de isovalores do diâmetro médio, da distribuição total, das amostras de fundo da plataforma rasa. . . . 42

Fig. 12 - Mapa de isovalores da porcentagem de argila das amostras de fundo da plataforma rasa.......... 43 
Fig. 13 - Mapa de isovalores do número de classes texturais da distribuição granulométrica, das amostras de fundo da plataforma rasa............ 44

Fig. 14 - Mapa de isovalores do grau de arredondamento, da fração retıda na peneira $0,500 \mathrm{~mm}$, na plataforma rasa.... 46

Fig. 15 - Mapa de isovalores do grau de arredondamento, da fração retida na peneira $0,250 \mathrm{~mm}$, da plataforma rasa.... 47

Fig. 16 - Porcentagem de carbonato biodetritico nos sedimentos de fundo da zona de arrebentação....... 50

Fig. 17 - Porcentagem de carbonato biodetrítico nos sedimentos de fundo da plataforma rasa.......... 51

Fig. 18 - Mapa de isovalores da porcentagem de biogênicos, na fração areia grossa $(0,710-0,500 \mathrm{~mm})$ das amostras de fundo da plataforma rasa.......... 53

Fig. 19 - Mapa de isovalores da porcentagem de biogênicos, na fração areia-média $(0,350$ - 0,250 mm) das amos tras de fundo da plataforma rasa............. 54

Fig. 20 - Mapa de isovalores de porcentagens de pesados, na amostra total, da zona de arrebentação........73

Fig. 21 - Mapa de 1sovalores da frequiência de hornblenda, na fração areia fina, na zona de arrebentação.... 74

Fig. 22 - Mapa de 1sovalores da frequência média de hornblenda, na fração areia muito fina, na zona de arrebentação.. 75

Fig. 23 - Mapa de isovalores da frequência média da turmalina, na fração areia fina, na zona de arrebentação..... 76

Fig. 24 - Mapa de isovalores da frequiência média do zircão, na fração areia fina, na zona de arrebentação........ 78

Fig. 25 - Mapa de isovalores da frequiência média do zircão, na fração areia muito fina, na zona de arrebentação..... 79

Fig. 26 - Mapa de isovalores de freqüência média do zircão, na fração areia fina, na plataforma rasa........... 80

Fig. 27 - Mapa de isovalores da frequência média da turmaIIna, na fração areia muito fina, na plataforma rasa.... 
Fig. 28 - Mapa de isovalores do índice ZTR (Hubert, 1962), na fração areia multo fina, na zona de arrebenta

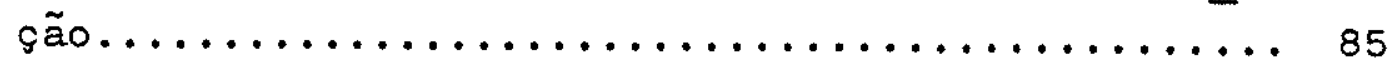

Fig. 29 - Mapa de isovalores do indice ZTR (Hubert, 1962), na fração areı fina, na zona de arrebentação.... 86

Fig. 30 - Mapa de isovalores do índice ZTR (Hubert, 1962), na fração areia fina, na plataforma rasa........ 87

Fig. 31 - Mapa de isovalores do Indice ZTR (Hubert, 1962), na fração areia muito fina, na plataforma rasa... 88

Fig. 32 - Sistemas de ondas incidentes na porção central da IIha Comprida ( $~ \operatorname{SSE}, 165^{\circ}$ e ESE, $108^{\circ}$ ), no

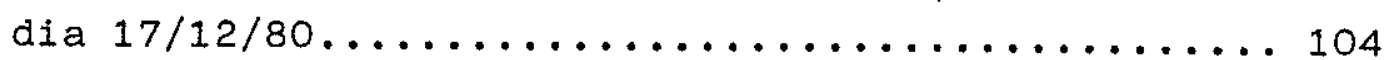

Fig. 33 - Diagrama de roseta das direções de incidência de ondas observadas nas estações de Paranaguá, Cananéia e Iguape - outubro de $1984 \ldots . . \ldots \ldots 106$

Fig. 34 - Rosas de corrente para meia-água e fundo na es tação fixa de Paranaguá, $1984 \ldots \ldots \ldots \ldots \ldots \ldots 112$

Fig. 35 - Diagrama de deslocamento médio progressivo. ES tação fixa de Paranaguá, fundo, $1984 \ldots \ldots \ldots \ldots 113$

Fig. 36 - Diagrama de deslocamento médio progressivo. Es tação fixa de Paranaguá, meia-água, 1984........ 115

Fig. 37 - Rosas de correntes para meia-água e fundo na estação fixa de Cananéia, 1984.............. 117

Fig. 38 - Diagrama de deslocamento médio progressivo. Es tação fixa de Cananéia, meia-água, 1984.........118

Fig. 39 - Diagrama de deslocamento médio progressivo. Es tação fixa de Cananéia, fundo, $1984 \ldots \ldots \ldots \ldots \ldots 119$

Fig. 40 - Rosas de correntes para meia-água e fundo na estação fixa de Iguape, $1984 \ldots \ldots \ldots \ldots \ldots \ldots 121$

Fig. 41 - Diagrama de desiocamento médio progressivo. Es tação fixa de Iguape, meia-água, $1984 \ldots \ldots \ldots \ldots \ldots 123$

Fig. 42 - Diagrama de deslocamento médio progressivo. Es tação fixa de Iguape, fundo, $1984 \ldots \ldots \ldots . . \ldots \ldots 124$

Fig. 43 - Rosas de correntes para meia-água na estação da desembocadura lagunar de Cananéia, 1962...... 126

Fig. 44 - Diagrama de decomposição dos vetores correntes (direção e intensidade), segundo eixos parale10 e perpendicular à Iinha de costa atual....... 128 
Fig. 45 - Correntes de superficie do litoral sul paulista através da interpretação das lmagens de satél1te LANDSAT - MSS, Canais 4 e 5 , de 26/06/76..... 130

Fig. 46 - Gráficos de velocidade crítica de transporte: Postma, 1967 (apud Suguio, 1980); Hjülstrom, 1956 (apud Netto, 1980); Open University, 1978 e Gadd et al., 1978 (apud Muehe \& Sucharov, 1981).. 139

Fig. 47 - Velocidade de corrente, meia-água e fundo; direção das ondas e ventos observados na estação de Iguape, no período que apresentou velocidades de correntes superiores a velocidade criti ca de transporte, outubro de $1984 \ldots \ldots \ldots \ldots \ldots \ldots 146$

Fig. 48 - Velocidade de corrente, vento e pressão atmosférica observađos na estação de Cananéia, no periodo que apresentou velocidades de correntes superiores à velocidade critica de transporte,

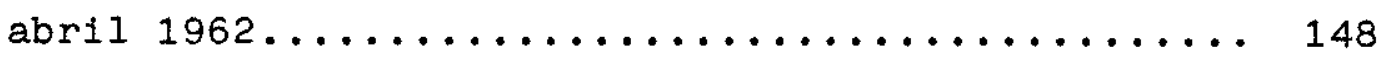

Fig. 49 - Alinhamento dos cordões litorâneos da planície costeira de Cananéia-Iguape, SP............. 153

Fig. 50 - Curva relativa de variação do nivel do mar para a planície costeira de Cananéia-Iguape, Estado de são Paulo (Suguio \& Martin, 1978)....... 155

Fig. 51 - Esquema evolutivo da Ilha Comprida durante 0 Holoceno (Suguio \& Martin, 1978)............ 155

Fig. 52 - Modelo evolutivo para a planície costeira compreendida entre Cananéia e o Morro da Juréia, Estado de São Paulo (Sû́guio \& Martin, 1978)..... 160

Fig. 53 - Evolução da desembocadura lagunar de Ararapi-

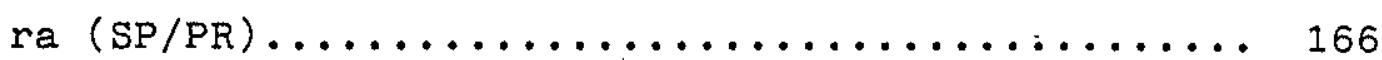

Fig. 54 - Evolução da desembocadura lagunar de Cananéia

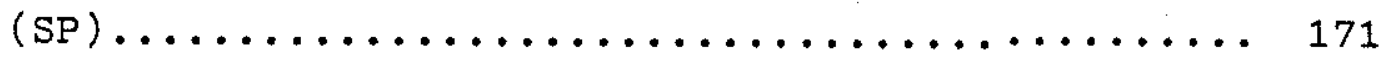

Fig. 55 - Evolução da desembocadura lagunar de Icapara e da Ilha de Iguape, SP (Geobrás, 1966)....... 176

Fig. 56 - Configuração da linha de costa nas proximida des da desembocadura lagunar de Icapara e da foz do rio Ribeira de Iguape (SP) $1981 \ldots \ldots \ldots 178$ 


\section{Tabelas}

Tab. 1 - Posição das amostras coletadas na plataforma continental do Estado de São Paulo (N/Oc."Prof. W. Besnard" - 1984)....................... 195

Tab. 2 - Posição das amostras coletadas na zona de arrebentação, Ilha Comprida - SP, (1985)......... 197

Tab. 3 - Localização dos perfís de coleta da faixa intermarés, Ilha Comprida - SP, (1985)......... 199

Tab. 4 - Dados de granulometria e teor de carbonato em sedimentos da Formação Cananéia............. 201

Tab. 5 - Dados de granulometria em sedimentos holocênicos dos cordões litorâneos da Ilha Comprida - SP... 204

Tab. 6 - Dados de granulometria e teor de carbonato em sedimentos da faixa intermarés............ 205

Tab. 7 - Dados de granulometria e teor de carbonato em sedimentos da zona de arrebentação........... 209

Tab. 8 - Dados de granulometria e teor de carbonato em sedimentos da plataforma rasa............. 211

Tab. 9 - Frequiência dos parâmetros estatísticos de Folk \& Ward (1957), para a distribuição total, dos sedimentos da Formação Cananéia............. 213

Tab. 10 - Freqüência dos parâmetros estatísticos de Folk \& Ward (1957), para a distribuição total, dos sedi mentos dos cordões litorâneos da Ilha Comprida -

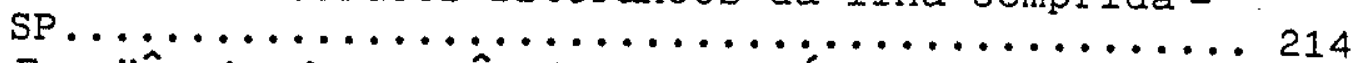

Tab. 11 - Frequência dos parâmetros estatisticos de Folk \& Ward (1957), para a distribuição total, dos se dimentos da faixa intermarés:

11.A - nível de maré baixa.............. 215

$11 . B$ - nível intermediário............. 216

11.C - nível de maré alta.............. 217

Tab. 12 - Freqüência dos parâmetros estatísticos de Folk \& Ward (1957), para a distribuição total, dos se dimentos da zona de arrebentação............. 
Tab. 13 - Frequência dos parâmetros estatisticos de Folk \& Ward (1957), para a distribuição total dos sedimentos da plataforma rasa................ 219

Tab. 14 - Frequência dos parâmetros estatisticos de Folk \& Ward (1957), para a distribuição areia, dos se dimentos da zona de arrebentação............. 220

Tab. 15 - Freqüência dos parâmetros estatísticos de Folk \& Ward (1957), para a distribuição areia, dos sedi

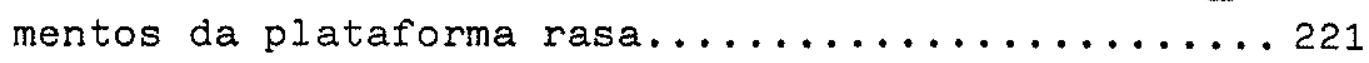

Tab. 16 - Porcentagem de frequêncla do número de classes

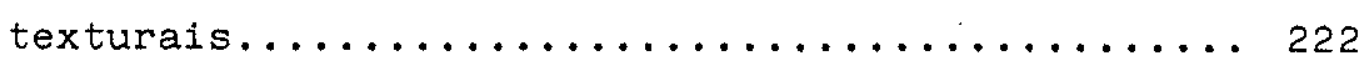

Tab. 17 - Frequência de classes, média, desvio padrão e seleção morfométrica em grãos de quartzo........ 223

Tab. 18 - Variações no teor de carbonato biodetritico..... 224

Tab. 19 - Porcentagem dos constituintes na fração grossei$\mathrm{ra},(0,710-0,500 \mathrm{~mm})$, das amostras de fundo da

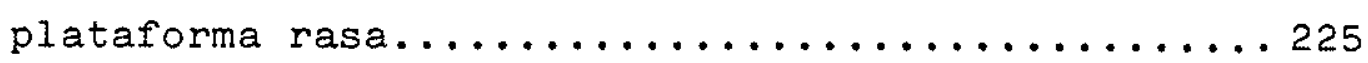

Tab. 20 - Porcentagem dos constituintes na fraçãogrossei$\mathrm{ra},(0,350-0,250 \mathrm{~mm})$ das amostras de fundo da

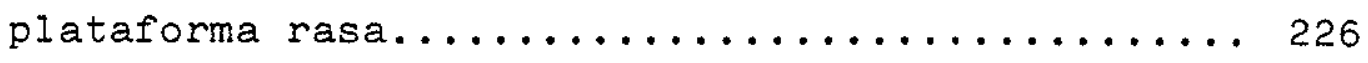

Tab. 21 - Concentração de grãos feldspáticos na fração leve... 227

Tab. 22 - Porcentagem de minerais pesados transparentes e não micáceos no intervalo areia muito fina, das amostras da Formação Cananéia............ 228

Tab. 23 - Porcentagem de minerais pesados transparentes e não micáceos, no intervalo areia fina das amostras da Formação Cananéia................ 231

Tab. 24 - Porcentagem de minerais pesados transparentes e não micáceos, no intervalo areia fina, das amos tras dos cordões litorâneos da IIha Comprida - SP . . . . 232

Tab. 25 - Porcentagem de minerais pesados transparentes e não micáceos, no intervalo areia muto fina, das amostras dos cordões litorâneos da IIha Comprida - SP.... 233 
Tab. 26 - Porcentagem de minerais pesados transparentes e não micáceos, no intervalo areia fina, das amos tras da faixa intermarés das IIhas do Cardoso e

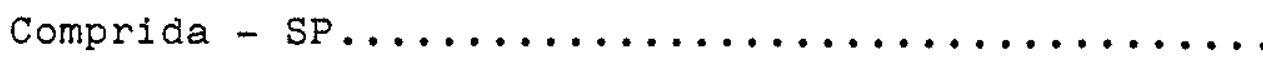

Tab. 27 - Porcentagem de minerais pesados transparentes e não micáceos, no intervalo areia mu1to fina, das amostras da falxa intermarés das Ilhas do Cardo

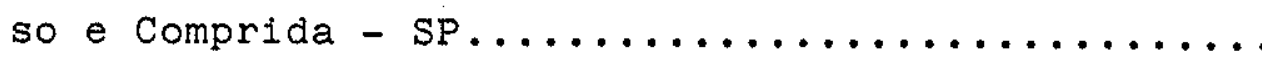

Tab. 28 - Porcentagem de minerais pesados transparentes e não micáceos, no intervalo areia fina, das amos tras da zona de arrebentação............... 236

Tab. 29 - Porcentagem de minerais pesados transparentes e não micáceos, no intervalo areia muito fina, das amostras da zona de arrebentação............. 238

Tab. 30 - Porcentagem de minerais pesados transparentes e não micáceos, no intervalo areia fina, das amos

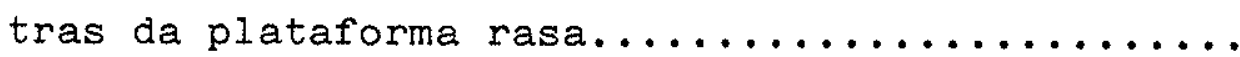

Tab. 31 - Porcentagem de minerais pesados transparentes e não micáceos, no intervalo areia muito fina, das amostras da plataforma rasa............... 248

Tab. 32 - Frequiência de classes de abundância por mineral pesado e freqüências de classes de ZTR, fração areı fina - Formação Cananéia..............

Tab. 33 - Frequiências de classes de abundância por mineral pesado e frequiências de classes de ZTR, fração areia muito fina - Formação Cananéia............ 254

Tab. 34 - Frequiências de classes de abundância por mineral pesado e frequiências de classes de ZTR, fração areia fina - Cordões Iitorâneos da Ilha Comprida - SP................................. 255

Tab. 35 - Frequiências de classes de abundância por mineral pesado e frequiências de classes de ZTR, fração areia muito fina - Cordões litorâneos da Ilha

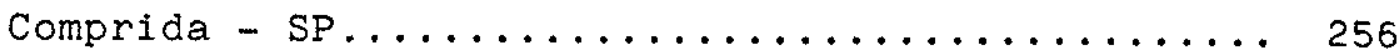


Tab. 36 - Frequîencias de classes de abundâncla por mineral pesado e frequiências de classes de $Z T R$, fração

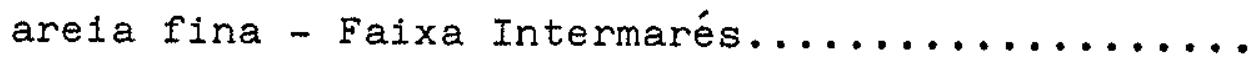

Tab. 37 - Freqüềnclas de classes de abundâncla por mineral pesado e freqüênclas de classes de ZTR, fração areia fina - Faixa Intermarés............... 258

Tab. 38 - Frequiências de classes de abundância por mineral pesado e frequiências de classes de ZTR, fração areia fina - Zona de Arrebentação............. 259

Tab. 39 - Freqüências de classes de abundância por mineral pesado e frequiências de classes de ZTR; fração areia muito fina - Zona de Arrebentação......... 260

Tab. 40 - Frequî̂ncias de classes de abundância por mineral pesadoe frequências de classes de ZTR, fração areia fina - Plataforma rasa............... 261

Tab. 41 - Frequiências de classes de abundância por mineral pesado e frequiências de classes de ZTR, fração areia muito fina - Plataforma rasa............ 262

Tab. 42 - Porcentagens, por períodos de observações das on das incidentes na região da Ilha do Bom Abrigo SP (relatório CTH - USP, 1973) - no texto........

Tab. 43 - Porcentagens de direção de propagação dos sistemas de ondas incidentes no litoral sul paulista e ventos locais de 1955 - 1959 (Geobrás, 1966)

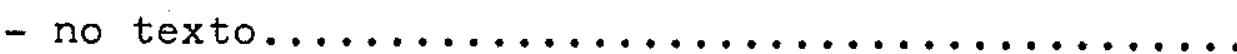
100

$\mathrm{Tab} .44$ - Direção e altura dos sistemas de ondas observados à bordo do N/Oc. "Prof. W. Besnard" durante a execução das estações de correntometria - outu-

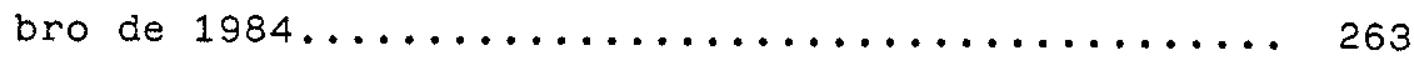

Tab. 45 - Profundidades máximas $(m)$ da ação efetiva das ondas na mobilização de sedimentos de fundo, a partir das observações realizadas à bordo do $\mathrm{N} /$ Oc. "Prof. W. Besnard" - outubro de 1984........ 264

Tab. 46 - Profundidades máximas $(m)$ da ação efetıva das ondas na mobilização de sedimentos de fundo a partir dos dados do relatório CTH/USP, 1973...... 265 
Tab. 47 - Valores de velocidade e direção de correntes medidas a meia-água e fundo. Estação fixa de Para

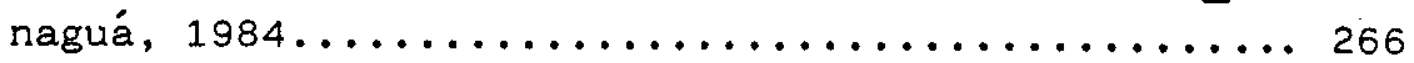

Tab. 48 - Valores de velocidade e direção de corrente para meia-água e fundo. Estação fixa de Cananéia, 1984.. 268

Tab. 49 - Valores de velocidade e direção de corrente para meia-água e fundo. Estação fixa de Iguape, 1984.... 270

Tab. 50 - Direção e intensidade do vento medido na estação meteorológica de Cananéia (I.0.USP - Base Sul) para o período de 16/04 a 02/05/62............. 272

Tab. 51 - Direção e intensidade do vento medido a bordo do N/Oc. "Prof. W. Besnard" durante a execução das estações de correntometria - outubro, 1984.......273

Tab. 52 - Valores de velocidade critica de corrente $(\mathrm{cm} / \mathrm{s})$, a $100 \mathrm{~cm}$ do fundo $\left(\mathrm{C}_{100}\right)$, para movimentação de sedimentos de diferentes diâmetros (mm) (Gadd et

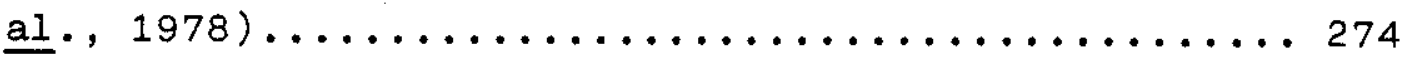

Tab. 53 - Taxas de transporte da estação de correntometria de Iguape, outubro de 1984. Equação de Bagnold (1963, apud Gadd et al., 1978).............. 275

Tab. 54 - Taxas de transporte da estação de correntometria de Cananéia, abril de 1962. Equação de Bagnold (1963, apud Gadd et al., 1978).............276 


\section{RESUAFO}

A origem e evolução das feições arenosas holocênicas, presentes no litoral sul paulista, estão vinculadas à ação da dinâmica litorânea atual, bem como ao papel representado pelos processos dinâmicos pretéritos.

Esta dinâmica atual, fortemente condicionada pelos mecanismos de circulação atmósferica do continente sulamericano tem, nas correntes de deriva litorânea geradas a par tir da interação dos trens de ondas incidentes com a linha de costa, o principal mecanismo de movimentação de sedimentos are nosos, junto ao fundo, no litoral sul paulista.

A interação entre os mecanismos de circulação. atmosférica do continente sul-americano e os trens de onda in cidentes constitui a base para a compreensão da origem $e$ do sentido de deslocamento das correntes litorâneas de fundo. A partir dos trens de onda provenientes de $\underline{S}$ e $\underline{S E}$ são geradas correntes de deriva litorânea que se propagam do litoral sul rumo ao litoral centro-sul paulista, $\mathrm{NE}$. Por outro lado, as correntes litorâneas de sentido inverso ( $\underline{\mathrm{SW}}$ ), são geradas a partir dos trens de onda incidentes dos quadrantes $\mathrm{NE}$ - E.

Esses sistemas de correntes litorâneas, de sen tidos opostos, são responsáveis pela redistribuição dos sedimentos provenientes da cobertura sedimentar atual da plataforma continental próxima, bem como dos sedimentos de origem continental, carreados principalmente pela drenagem do rio Ribeira de Iguape.

Os dois sistemas de correntes litorâneas, para SW e para NE, podem até mesmo ocorrer simultaneamente no litoral sul paulista. Porém, é curante as fases de passagem de sistemas de frentes, quando predominam os trens de onda incidentes do quadrante $\underline{S}$ - $\underline{S E}$ e portanto, correntes de deriva litorânea orientadas para $\mathrm{NE}$, que resultam no mais efetivo processo de transporte arenoso, de fundo, no litoral sul. 
As características sedimentológicas, apresenta das pelos sedimentos arenosos, dispostos em cristas praiais orientadas longitudinalmente à costa e depositados nos eventos regressivos que se seguiram aos máximos transgressivos de 120.000 anos A.P., Formação Cananéia, e de 5.100 anos A.P., For mação Santos, demonstram que, também durante a deposição desses conjuntos de sedimentos, o sentido predominante das paleocorrentes de deriva tinha rumo $\underline{\mathrm{NE}}$.

As atuais desembocaduras lagunares de Ararapira, Cananéia e Icapara representam as feições geomórficas mais instáveis do litoral sul, e são resultantes das interações entre o sistema hidrodinâmico litorâneo com os sistemas de circu lação lagunares existentes à retaguarda da linha de costa atual.

Nas áreas litorâneas, onde ocorrem atualmente estes processos de interação, entre sistemas litorâneos e lagu nares, a evolução de feições geomórficas litorâneas não pode ser utilizada, diretamente, como indicativo do sentido predominante da corrente de deriva litorânea.

Desta forma, o estudo da desembocadura lagunar de Icapara mostra uma tendência evolutiva coincidente com o ru mo predominante, para $\mathrm{NE}$, da corrente de deriva litorânea, enquanto que na região de Ararapira, a evolução desta feição geo mórfica ocorre em sentido oposto, SW.

A desembocadura lagunar de Cananéia, apresenta um mecanismo evolutivo mais complexo, fortemente condicionado pelos ciclos alternados de marés enchente e vazante. Sua configuração atual, bem como os conjuntos de bancos arenosos submersos que obstruem o canal principal de acesso à região lagunar, refletem a interação das correntes litorâneas, geradas pe los sistemas de ondas incidentes, com as correntes de marés que fluem através da desembocadura lagunar. 


\section{ABSTRACT}

The systematic study of sedimentary trends, as well as of geomorphic features, provide an useful method for evaluation of present and past shore-drift directions during the Quaternary.

The origin and the evolution of the Holocene san dy features, along the southern coast of the state of são Paulo, are related to the present and past dynamic processes. These processes are today strongly controlled by mechanisms of atmospheric circulation occurring in South America, which originate waves acting in two different directions. The first one, coming from $\underline{S}$ and $S E$, generates longshore currents toward $\underline{N E}$. By other side, the second one, coming from $\underline{N E}$ and $\underline{E}$, generates longshore currents directed toward $\underline{\mathrm{SW}}$. In southern coast of the state of São Pauio, despite these two longshore currents can occur simultaneously, the most effective longshore transport of sediments is related to the cold meteorological fronts, with dominance of wave trains coming from $\underline{S}$ and $\underline{S E}$.

The analysis of sandy beach ridges related to re gressive periods of Cananéia $(120,000$ years B.P. - 18,000 years B.P.) and Santos (5,100 years B.P. until today) transgressions showed that the prevailed longshore-drift direction, during the Upper Quaternary, was approximately the same as the presently observed in the area, that is from SW to $\mathrm{NE}$. The evolution of geomorphic features in the studied area, like tidal inlets, is also suggestive of northeastward net transportation of sediments. However, these inlets are strongly modified in areas clo se to lagoonal mouthes, and their configuration cannot be used directly as evidence of longshore drift of sediments. 


\section{INTRODUÇĀO}

\section{1 - Objetivos}

Este trabalho tem como objetivo a caracterização do transporte de sedimentos arenosos de fundos marinhos rasos, vinculado à ação dinâmica atual, bem como o papel representado pelos processos dinâmicos, atuais e pretéritos, na or 1 gem e evolução das feições arenosas holocênicas presentes no Iitoral sul do estado de são Paulo, entre a foz do rio Ribeira de Iguape e a IIha do Cardoso.

$$
\text { o objetivo viabiliza-se através de um estudo }
$$
Integrado das características sedimentológlcas dos materiais arenosos das feições litorâneas e do fundo marinho raso, em comparação com o conjunto de parâmetros hidrodinâmicos atuais. Adotou-se os seguintes procedimentos de avaliação sedimentológicos e hidrodinâmicos, a saber:

- análise da dinâmica da circulação geral, na plataforma ra sa sul paulista, e a avaliação do papel representado pelos principais parâmetros hidrodinâmicos de importância na área (ondas e correntes), no mecanismo de transporte de sedimentos de superficie de fundo na região litorânea;

- estudo da litologia e da mineralogia da fraça pesada dos materiais encontrados nas zonas de arrebentação e intermarés, vișando caracterizar a natureza dos sedimentos atual mente disponiveis ao transporte litorâneo;

- estudo da litologia e das mineralogias das fracões pesada e leve de amostras das formações Cananéla (Pleistoceno) e Santos (Holoceno), além da plataforma rasa, visando avaliar a importância desses depósitos como fonte de sedimentos sujeitos hoje em. dia ao transporte Iitorâneo;

- análise das direções de alinhamento dos cordões holocênicos, presentes na Iiha Comprida, procurando correlacioná-las ao padrão atual de circulação litorânea do litoral sul paulista;

- reconstrução paleogeográfica das feições das desembocaduras lagumares e da foz do rio Ribeira de Iguape, de forma a identificar a tendência evolutiva dessas feiçóes costeiras e sua associação com o mecanismo de transporte predominante na área. 
1.2 - Área de estudo e amostragem

$\mathrm{Na}$ região l1torânea sul paulista, área de estü do do presente trabalho (figura 1), as campanhas de amostragem seguiram critérios diferenciados em função das características e objetivos estabelecidos para cada unidade considerada.

$\mathrm{Na}$ face oceânica das 1 has do Cardoso e Compri da, em 57 pontos distantes entre si de $1500 \mathrm{~m}$, foram coletadas 171 amostras superficiais ( $0-10 \mathrm{~cm}$ de profundidade) em três niveis distintos. A primeira delas foi obtida na linha de maré baixa (nível A), outra na linha de maré alta (nivel C) e a terceira a meia distância entre esses dols pontos (nivel B). Neste trabalho optou-se por denominar esta área como zona intermarés, que constitui sua designação mais genérica.

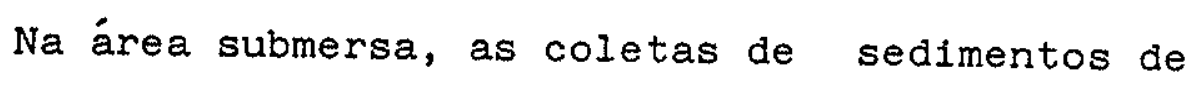
superfície de fundo, foram realizadas em duas etapas distintas. A primeira executada a bordo do navio oceanográfico "Prof. W. Besnard", no período de 25/09 a 09/10/1984, utilizando-se um pe gador de fundo do tipo Petersen modificado. Foram coletadas 49 amostras de fundo além de quatro testemunhos rasos ( $<2 \mathrm{~m}$ ) obti dos com um testemunhador de gravidade. As amostras de superfície de fundo foram coletadas ao longo de cinco perfís perpendicula res à linha de costa, situados entre as longitudes $46^{\circ} 50^{\prime}$ e $48^{\circ} 20^{\prime} \mathrm{W}$ e latitudes $24^{\circ} 30^{\prime}$ e $26^{\circ} 00^{\prime} \mathrm{s}$, na faixa compreendida en tre as 1 sóbatas de 10 e 50 metros.

Foram ainda realizadas, nas isóbatas de 20 metros nos perfís localizados nos extremos $\mathrm{SW}$ e $\mathrm{NE}$ da área de estudo (Paranaguá e Foz do Ribeira) e no perfil localizado na porção central (IIha Comprida), estações fixas de correntometria onde foram medidas as direçöes e velocidades das correntes à 10 metros (meia-água) e a 1 metro acima do fundo.

Paralelamente às medições de corrente foram ob tidas as características das ondas e dos ventos, durante no mínimo 25 horas, correspondentes a duração das estações oceanográ ficas.

Os limites extremos desta unidade; aqui designados por plataforma rasa; foram estabelecidos em função de di- 


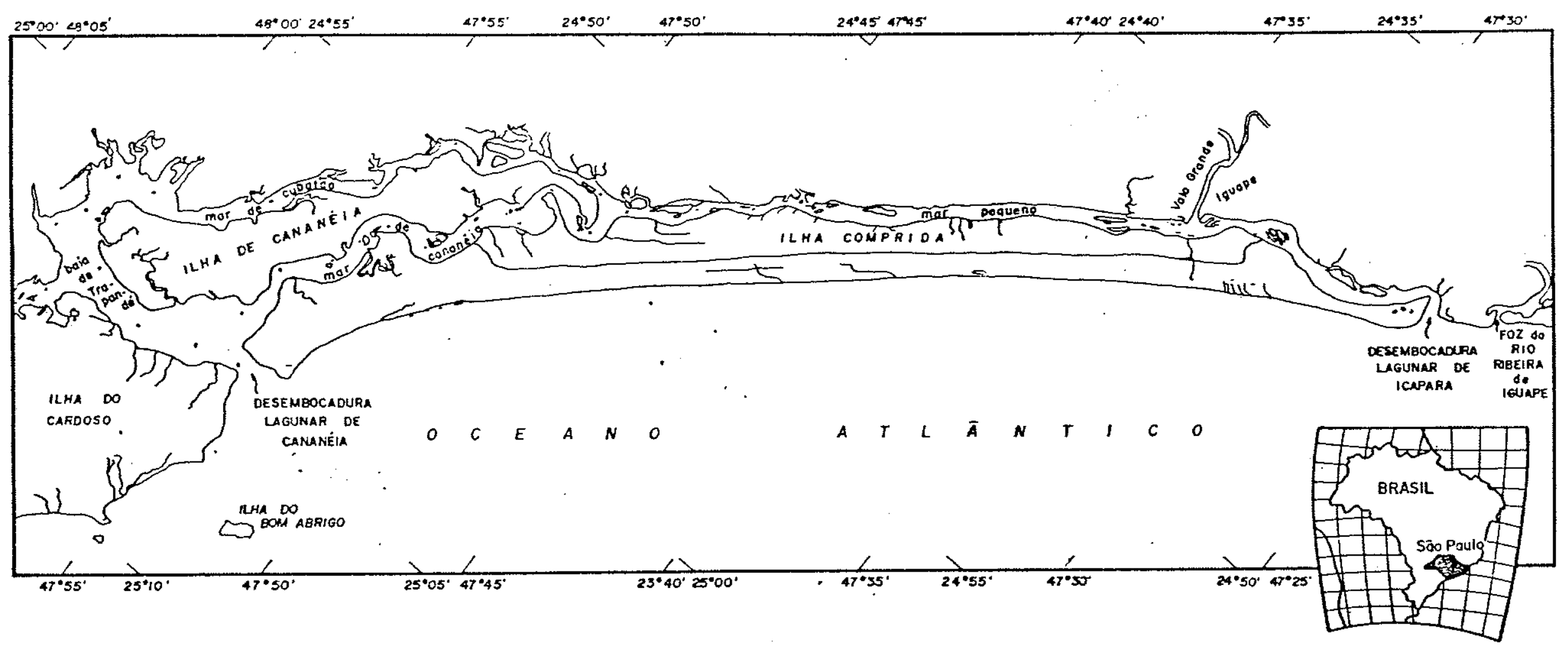

Fig. 1 - Localização da área de estudo. Planície costeira sul do Estado de São Paulo. 
versos critérios. Uma vez que os sedimentos arenosos são trans portados predominantemente junto ao fundo, ao passo que a carga pelítica é transportada em suspensão ao Iongo da coluna de água, pode se afirmar que a mistura dessas duas frações represente uma área de superposição, atual ou pretérita, desses meca nismos de deposição. Desta forma, objetivando garantir a homogeneldade da Interpretação do mecanismo atuante sobre o conjunto atual de sedimentos de fundo, no compartimento costeiro estú dado, foi adotada a isóbata de $50 \mathrm{~m}$ como limite externo da plá taforma rasa. Este valor foi adotado após examinar diversos má pas de distribuição de sedimentos elaborados por autores prévios (Corrêa, 1978; Projeto REMAC, 1979).

o limite interno de $10 \mathrm{~m}$, foi estabelecido em função dos comprimentos de onda observados, em diferentes épocas, no litoral sul paulista, pois segundo Komar \& Inman (1970) e Komar (1976), o movimento de sedimentos arenosos transportados pelas correntes de deriva litorânea, ocorre preferencialmen te, em função dos sistemas de ondas incidentes, a partir de uma isóbata próxima a $1 / 20$ dos comprimentos de onda.

Os maiores valores de comprimentos de onda ob-. servados no litoral sul são inferiores a $160 \mathrm{~m}$ (Geobrás, 1966), de forma que à profundidade máxima de $8 \mathrm{~m}$ se iniciariam, preferencialmente, a movimentação de fundo por ação de sistemas de ondas na área. Porém, como as observações existentes sobre ondas na área (Geobrás, op. cit., CTH, 1973), além de limitadas no tempo são imperfeitas, optou-se por um limite interno de $10 \mathrm{~m}$, garantindo assim uma ação hidrodinâmica atual homogênea sobre todo o conjunto de sedimentos da faixa compreendida entre as isóbatas de 10 e $50 \mathrm{~m}$.

A faixa litorânea compreendida entre as isóbatas de 0 e $10 \mathrm{~m}$, aqui denominada de zona de arrebentação, foi amostrada exclusivamente defronte à Ilha Comprida em campanha realizada durante $\circ$ mês de janeiro de 1985. Nesta área, foram coletadas também 68 amostras de superficie de fundo nos pontos de interseção de uma malha retangular executada pelo barco Albacora utilizando-se um amostrador Petersen modificado. 
Nesta faixa litorânea, um levantamento batimétrico-sismico (IPT - 1985) revelou ser a superficie de fundo essenclalmente plana, com a ocorrência de pequenas ondulações (dezenas de centímetros de alțura), apenas em áreas restritas.

Finalmente, nas amostragens das áreas emersas compostas pelas formações Cananéla e Santos, foram também usados critérios distintos em função dos diferentes graus de detaIhamento prévio existentes para essas formações.

$\mathrm{Na}$ região lagunar de Cananéia-Iguape, área de exposição mais extensa da formaça pleistocênlca, foram realizadas descricões, nas margens dos canais lagunares e fluviais, de vinte e cinco seções colunares. Destas seções, foram obtidas 121 amostras representativas das diferentes fácies texturais identificadas, de niveis que apresentavam concentraçöes anômalas de minerais máficos e/ou de estruturas sedimentares julgadas importantes na interpretação genética do depósito.

$\mathrm{Na}$ formação holocênica, cuja área de maior exposição no litoral paulista localiza-se na Ilha Comprida, foram descritas apenas 4 seções colunas e 12 amostras coletadas, previamente escolhidas a partir de levantamento existente para esta formação na área (Barcelos, 1975).

Embora Iimitada, esta pequena amostragem permitiu um detalhamento dos constituintes mineralóglcas da fração pesada. Este detalhamento permitiu ainda avaliar o grau de similaridade entre a formação holocênica com a pleistocênica, referida pelos autores prévios (Barcelos, op. cit.; Suguio \& Martin, 1978a) como uma das principais fontes de suprimento de sedi mentos da formação holocênica, como também uma comparação com a assembléia de pesados contida nos atuais sedimentos superficiais da área submersa.

Muito embora, os procedimentos tenham sido distintos, em função das particularidades de cada unidade estudada, a amostragem permitiu obter materiais para estudos de textu ra dos sedimentos, teor de carbonato biodetritico e de conteúdo mineralógico das frações leve e pesada. 
No mapa ne 1 estão apresentados os pontos de coleta das amostras submersas, além dos locais em que foram des critas as seções colunares. As Tabelas nos 1,2 e 3 apresentam a locallzação geográflca das amostras de superficie de fun do e da zona intermarés bem como do posicionamento das estacões oceanográficas.

\section{3 - O litoral sul paulista \\ 1.3 .1 - A planície costeira}

A planicie costeira situada a sul da foz do rio Ribeira, tem a forma de um vasto crescente de quase $130 \mathrm{x}$ $40 \mathrm{Km}$, cobrindo uma superfície de aproximadamente $2.500 \mathrm{~km}^{2}$. Seus limites extremos, a $\underline{\mathrm{SW}}$ e $\underline{\mathrm{NE}}$, são compostos por pontões do embasamento cristalino que alcançam o oceano.

De acordo com o relatório do Projeto SUDELA (1975), o embasamento cristalino de idade pré-cambriana, ao re dor do complexo lagunar, é de origem metamórfica vinculado ao denominado Grupo Açunguí. Os termos litológicos mais frequientes são filitos, micaxistos, migmatitos e gnaisses com intrusões de granitos, adamelitos e granodioritos (fig. 2). Cortando todo esse complexo de rochas, afloram rochas alcalinas intrusivas (Morro de são João e Morrete) e outros tipos de rocha (quartzitos, anfibolitos, diabásios, e calcoxistos) do Grupo Açungui, ao longo do rio Ribeira de Iguape.

Os rios que compõem as bacias de drenagem exibem alto gradiente, em seu trecho inicial, e suave na planicie próxima à sua foz. É comum nesses cursos fluviais a influência marinha a montante da foz por distâncias de até duas dezenas de quilômetros em relação à linha de costa atual. o sistema de drenagem, na planície, apresenta padrão de distribuicão irregular, tendo como característica geral o seu desenvolvimento a partir de "banhados" no sopé da serra. Este fato re sulta em que esses rios drenem essencialmente a planicie sedimentar, ocasionando interligações entre os canais e submetendo-os fortemente ao regime de oscilações de maré e propiciando com isso o desenvolvimento de áreas de mangue. 


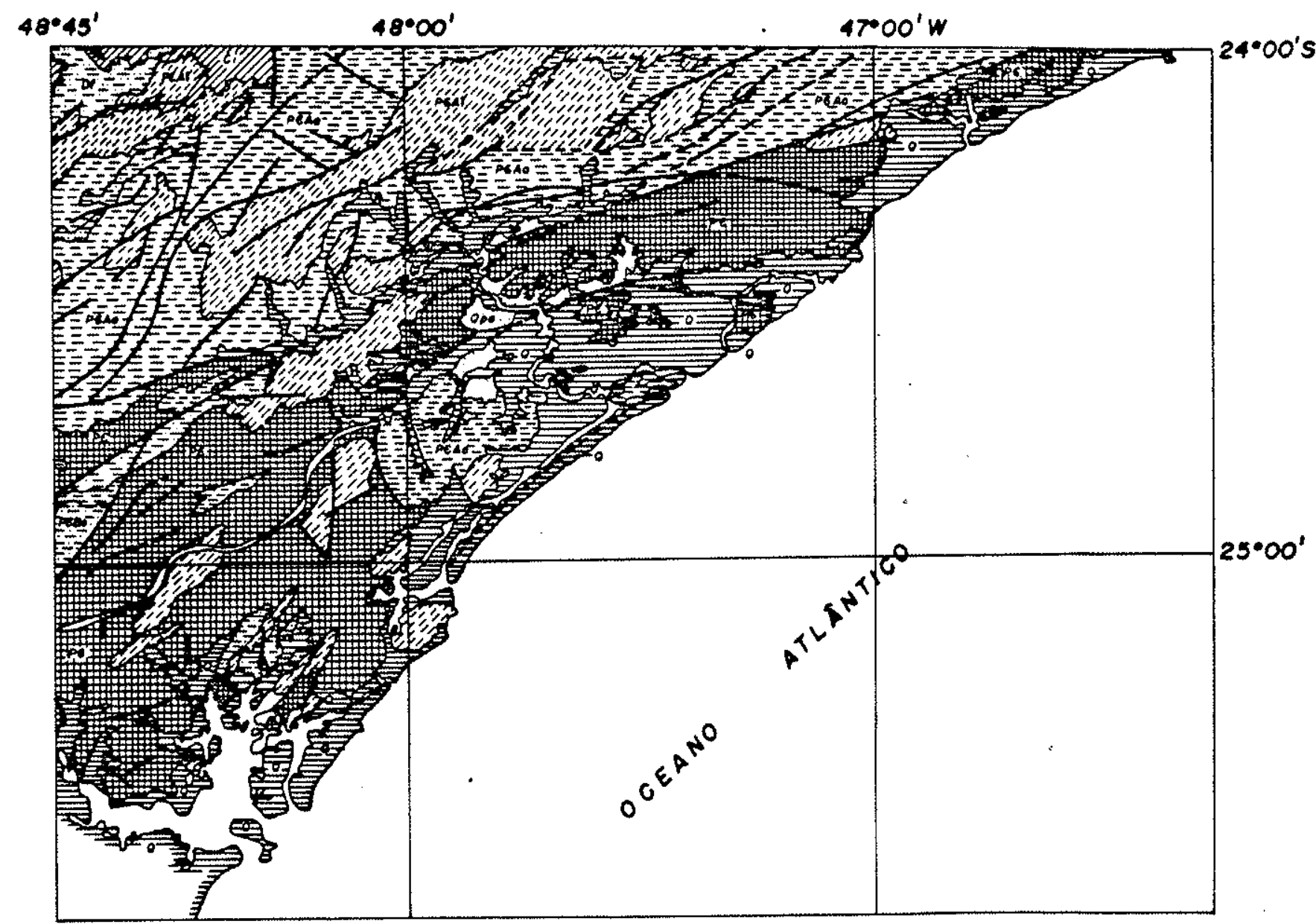

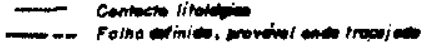
EUE Alnion.

ए E: Fot

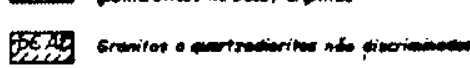

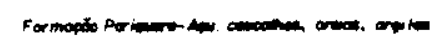

$$
\text { reamion }
$$

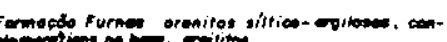

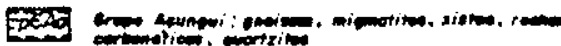

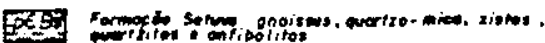

\begin{tabular}{|c|c|c|c|}
\hline OUATERNÁAIO & \multicolumn{3}{|c|}{$\begin{array}{c}\text { ARTICULACÄO OAS FOLHAS } \\
1978\end{array}$} \\
\hline CARBONIFERO & $\begin{array}{r}5 E-22 \\
\text { Goldmid }\end{array}$ & 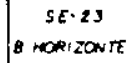 & $\begin{array}{r}S E-24 \\
\text { RIO } 00 C E\end{array}$ \\
\hline DEVONIANO & $\begin{array}{l}\text { SF-22 } \\
\text { PARANA. } \\
\text { PANEMA }\end{array}$ & RF $\begin{array}{c}5 F-23 \\
\text { RE JAMSM }\end{array}$ & $\begin{array}{l}\text { sf-id } \\
\text { vitomin }\end{array}$ \\
\hline PRÉ-EB QU SUP. ANTIGO & $\begin{array}{l}\text { SG-22 } \\
\text { CURITIEA }\end{array}$ & {$\left[\begin{array}{l}56-23 \\
16 U A P E\end{array}\right.$} & \\
\hline
\end{tabular}

LOCALIZASTO DUS FOLHAS

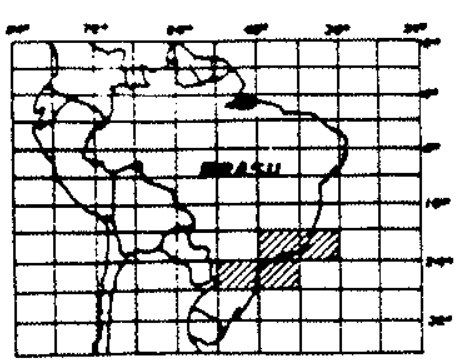

ESCALA 1:1000000

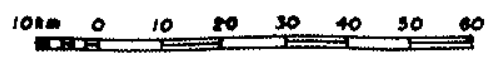

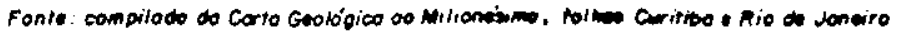
Vitorio / lguope

Fíg. 2 - Mapa geológico das regiões SW do Estado de São Paulo e SE do Estado do Paraná. 
A este padrão geral não se encalxa o rio Ribel ra de Iguape, ún1co a apresentar percurso mals longo, bacla de captação maior e influência continental até muito próxima à foz. Por conseguinte, o volume de água captado por esta bacia é multo maior, desempenhando um papel muito importante nos pro cessos evolutivos da área.

Os sistemas de lagunas e rios da região, que se comunicam ao oceano por desembocaduras lagunares denominadas de sul para norte Ararapira, Cananéia, Icapara e Ribeira, separam do continente, ao sul do Ribelra de Iguape, quatro im portantes ilhas (Cardoso, Cananéia, Comprida e Iguape) com características geomorfológlcas bem distintas.

A Ilha do Cardoso, localizada na porção mais meridional da área, é formada essencialmente por rochas précambrianas (Petri \& Fúlfaro, 1970), com depósitos quaternários localizados apenas em suas bordas junto à linha de costa atual ou ao canal de Ararapira, feiça que a separa do continente.

Com exceção de duas elevações de rochas alcali nas, de idade estimada em $\pm 82 \mathrm{m.a}$. (Amaral et al., 1967), e de um pequeno afloramento pré-cambriano na Ponta da Aroeira, na ilha de Cananéia, as ilhas Comprida e de Cananéia são forma das essencialmente de sedimentos arenosos de ldade quaternária.

A Ilha Comprida, onde a elevação rochosa denominada Morrete é o único destaque no relevo balxo e plaino, exi be altitudes quase sempre inferiores a 5 metros e possui largu ras entre 3 e $5 \mathrm{~km}$ e comprimento de $72 \mathrm{~km}$. Esta feição geomorfológica, caracterizada por Suguio \& Martin (1978a) como uma ilha-barreira quaternária, é separada do continente por uma la guna, denominada Mar Pequeno, que a sudoeste subdivide-se em duas (mar de Cubatão e mar de Cananéia) separadas entre si peIa Ilha de Cananéia.

A Ilha de Cananéia é também de constitulção are nosa, porém com cotas mais elevadas (até cerca de $10 \mathrm{~m}$ ) que a Ilha Comprida e apresenta, junto à cldade homônima, um morro com cerca de $120 \mathrm{~m}$ de altitude, denominado Morro de são João (Kutner, 1962). 
A quarta Ilha, denominada de Iguape, é artificial, tendo sido originada pela abertura, no ano de 1832 , de um canal de l1gação, entre o mar Pequeno e o rio Ribeira de Iguape, chamado Valo Grande. É composta predominantemente por morros de rochas pré-cambrianas circundados por depósitos quaternários.

As pralas do litoral sul paulista constituemse de extensas faixas arenosas paralelas à linha de costa, separadas entre si por pontões do embasamento cristalino. tipo dissipativo, evidenciado pela baixa declividade ( 1 a $5^{\circ}$ ) apresentada por essas feições arenosas, a praia da Ilha Compri da, com cerca de $72 \mathrm{~km}$ de extensão constitui a feição de maior expressão.

\section{3 .2 - A Margem Continental$$
1.3 .2 .1 \text { - Origem }
$$

Segundo Almeida (1976), a margem continental sul atlântica sofreu algumas reativações após a separação dos continentes americano e africano. Essas reativações foram tra duzidas, sobre o continente, por numerosos eventos, tais como - levantamento da Serra do Mar, a formação das bacias tectônicas do Paraíba do Sul e da Guanabara e na área submarina pela subsidência da Bacia de Santos.

Durante o Aptiano, teve inicio o desenvolvimen to da Bacia de Santos, com a invasão do mar no "rift" original, - que teria ocasionado a deposição de grande espessura de evaporitos sobre a lava basáltica do Cretáceo Inferior. Durante - Senoniano a Bacia de Santos, em subsidência progressiva, acumulou sedimentos detríticos originários da erosão da serra do Mar. Essa subsidência teria prosseguido até o Plioceno-Pleistoceno com um grande acúmulo de sedimentos na bacia e reflexos sobre o continente. 


\subsubsection{2 - Morfologia e Fisiografia}

A margem continental dos estados de são Paulo, Paraná e Santa Catarina apresenta como expressão morfológica malor a Bacla de Santos, separada de outras bacias menores por lineamentos cujo embasamento é constituldo de rochas do PréCambriano e do Paleozóico. Como felção estrutural principal ocorre a denominada falha leste de Santos, de direção aproxima da nordeste-sudoeste que delimita a bacia: a oeste.

Segundo Miranda (1970), entre à parte oeste da bacia Iimitada pelo falhamento e o continente observa-se um delgado pacote sedimentar de provável idade terciário superior a quaternária, que recobre o embasamento.

Sobre o talude continental ocorre o Arco Torres-Trindade, definido como um prolongamento desde a região de Torres (RS) até a cadeia Vitórla-Trindade. Este arco deve cons tituir o limite entre os eixos principais de deposição da Bacia de Santos, situada a oeste do platô de são Paulo.

Portanto, a análise dos componentes estruturais principais identificados na margem continental sul brasileira, em especial o localizado entre os estados de são paulo e Paraná, permite ldentificar pelo menos três ciclos tectônicos de Idades distintas:

1) Pré-Cretáceo - de grande expressão e responsável pelas estruturas de direção $\mathrm{NE}$, permitindo a formação de um "rift valley" delineador do arcabouço inicial da bacia de santos, ao qual estariam associados os sedimentos mais profundos da bacla e também as intrusivas do platô de são Paulo.

2) Cretáceo-Superior - relacionado às rochas alcalinas da área costeira, representado pelos Iineamentos de Ilha Bela, Rio de Janeiro e a ramificação sul da falha leste de Santos (Miranda, op. cit.).

3) Terciário - atuante na bacia de Santos e platô de são Paulo, especialmente ao longo das linhas de fraqueza pré-existentes. 
Do ponto de vista fisiográfico, a plataforma continental sul brasileira, adjacente aos estados do Rio de Ja neiro até Santa Catarina, apresenta largura e relevo regulares, sem grandes acidentes geográficos, tendo sido designada por Butler (1970) como Embaíamento de são Paulo. Sua largura máxima, no Estado de São Paulo, atinge $210 \mathrm{~km}$ na região da foz do rio Ribeira de Iguape, estando o limite de quebra, entre a pla taforma com declividade suave $(1 \mathrm{~m} / \mathrm{km})$ e o talude de gradiente mals acentuado $(20 \mathrm{~m} / \mathrm{km})$, situado em torno de 160 a $190 \mathrm{~m}$ de profundidade.

Perfís batimétricos, traçados perpendicularmen te à costa, evidenciam a presença de quatro niveis topográficos de quebras de relevo, respectivamente à 20 a $25 \mathrm{~m}$; 32 a $45 \mathrm{~m} ; 50 \mathrm{~m}$ e 60 a 75 metros. Segundo Corrêa (1978), estes níveis topográficos estão relacionados à variação do nível marinho durante a transgressão holocênica, denominada por suguio \& Martin (1978a) de Transgressão Santos.

1.4 - Caracterização das seqüências de sedimentação da pla nicie costeira e plataforma continental sul do estado de são paulo

A estratigrafia dos depósitos cenozóicos anteriores ao Recente, na planície costeira sul do estado de são Paulo, foi estabelecida, por Petri \& Suguio (1971a,1973) e Suguio e Petri (1973), através da análise dos testemunhos de dois pocos de sondagem executados pelo antigo Instituto Geográfico e Geológico - I.G.G. (atual Instituto Geológico SMA $\mathrm{SP})$. Baseados nas interpretações das análises granulométricas, mineralógicas e do conteúdo de foraminiferos e diatomáceas rea lizadas nos testemunhos, associados a dados geofísicos, os autores puderam subdividir os sedimentos em quatro seqüências da base para o topo, a saber:

Sequêncla I: constituída por areias e sedimentos conglomeráticos com corpos de argila arenosa subordinados;

Sequiêncla II: formada por sedimentos finos, ar gilas silticas muito ricas em diatomáceas e pobres em foramini 
feros. Os autores inferem amblentes de águas salobras para as diatomáceas presentes, além de associarem os raros foraminiferos a um ambiente intermediário entre o marinho e o continental;

Sequêncla III: formada por areias silticas superimpostas à seqüência II. São depósitos marinhos evidenciados pela presença de abundantes foraminíferos bem preservadose;

Seqüêncla IV: definida pelos autores como sendo constitulda por areias finas bem selecionadas e muito friáveis. Estes sedimentos representam a sequência deposicional mais recente, apresentando pequena espessura e larga distribui ção regional.

A sequiência de mais de 100 metros de espessura, compreendendo as unidades II e III foi correlacionada pelos autores a uma fase transgressiva, enquanto que a unidade IV, com espessura média de $30 \mathrm{~m}$ representaria um evento regressivo.

Sobre a plataforma continental do Estado de São Paulo, um testemunho coletado a $62 \mathrm{~m}$ de profundidade durante o Projeto REMAC, fol estudado por Vicalvi et al. (1977), que constataram a presença de sedimentos arenosos marinhos transgressivos, acumulados dentro de uma paleocanal e uma lama arenosa, cujo conteúdo fossilifero indicou ambiente de sedimentação marinha. Vicalvi et al. (op. cit.), observam que as seqüências presentes nos testemunhos representam a passagem de um ambiente fluvial a estuarino, passando a marinho raso e finalmente marinho médio, caracterizando um ciclo transgressivo.

Com relação às idades de todas estas sequiências, a sequiência $I$, composta por areias e sedimentos conglomeráticos, foi correlacionada por suguio \& Petri (1973) aos se dimentos grosseiros, de origem continental, de ocorrência preferencial ao longo da bacia hidrográfica do rio Ribeira de Igua pe, designados por Bigarella \& Mousinho (1965) de Formação Pariquera-Açu. Sua Idade fol considerada como plio-pleistocênica, por Bigarella e Mousinho (op. cit.), e Sundaram \& Suguio (1983), Ihe atribuiram Idade pliocênica com base em escasso es tudo polínico. 
Por outro 1ado, Sugulo (1971) e Suguio e Petri (1973) atribu1ram às sequiênclas II a IV 1dade quaternária. POS teriormente, através de numerosas datações por radiocarbono em amostras das sequências acima descritas e por correlação ao au ge mundial de elevação do nível do mar, correspondente ao interglaclal Riss/Würm de 120.000 anos A.P. (Antes do Presente), Suguio \& Martin (1978à), correlacionaram-nas a este estádio interglacial. Corroborando estas conclusões Martin et al. (1982), através de datações pelo método do U/Th em corais encontrados em sedimentos do sul da Bahia ( $\mathrm{Ba}$ ), correlacionáveis aos do 1 i toral sul paulista, encontraram idades variáveis entre 120.000 e 125.000 anos A.P.

$\mathrm{Na}$ plataforma continental, o testemunho descri to por Vicalvi et al.(1977) atravessou apenas sedimentos holo cênicos, o que permitiu aos autores afirmar que os eventos transgressivos/regressivos foram os responsáveis por intensa sedimentação nas planícies costelras sul paulista.

1.4 .1 - Formação Cananéia

1.4.1.1 - Denominação

A denominação de Formação Cananéia foi atribuida inicialmente por Suguio \& Petri (1973) somente aos sedimentos arenosos finos, bem selecionados e muito friáveis (sequiência IV) que apresentavam pequena espessura média ( $30 \mathrm{~m})$ e larga distribuição regional, representativos de evento regressivo. Posteriormente, Suguio \& Martin (1978a) ampliaram o entendimento deste evento transgressivo/regressivo associando tam bém às sequiências II e III, depositadas durante a transgressão correspondente ao evento regressivo da sequiência IV e redefiniram o concelto da Formação Cananéia. Esta designação passou então a envolver todo o pacote de sedimentos transgressivos/re gressivos de idade pleistocêntca superior, localizados nas pla nícies costelras do Estado de são Paulo. 
1.4.1.2 - Características Texturais e Composicionais 1.4 .1 .2 .1 - Superficie

A sequiência IV, descrita por Petri \& Suguio (1971a), é composta ao longo de todo o litoral centro-sul paulista por sedimentos arenosos em lençol ("sheet sand"), que ocu pam as porcões mais interiores das atuals planicies costelras. Suas cotas vão desde 5 a $6 \mathrm{~m}$ de altitudes em áreas mais próximas da Iinha de costa atual até 9 a $10 \mathrm{~m}$ nas zonas mais próximas à Serra do Mar.

Camo característica textural principal suguio \& Petri (1973), salientam a extrema uniformidade granulométrica desses sedimentos, com mais de $80 \%$ de seus constituintes compreendidos entre os intervalos $2 \varnothing$ e $3 \emptyset(0,250 \mathrm{~mm}-0,125 \mathrm{~mm})$.

Descricões detalhadas de afloramentos pleistocênicos, que possuem espessuras desde 2 a $3 \mathrm{~m}$ acima do nível do mar atual até no máximo uma dezena de metros, realizados por diversos autores (Sugu1o \& Petri, 1973 e Sugulo \& Martin, 1978a), evidenciaram a presença de intercalações de material mais fino ou mais grosseiro disseminados em sedimentos arenosos finos a muito finos.

Frequientemente, os sedimentos arenosos finos de coloração cinza a cinza amarelada da Formaça Cananéia passam, próximos ao topo, para uma coloração marrom escuro. Esses niveis de sedimentos cimentados têm sido muitas vezes designados na literatura por sua denominação popular "piçarra" (Bigarella, 1954; Petri \& Suguio, 1971a, 1973). Este fenômeno pedogenético que afetou os sedimentos de topo da Formaça Cananéia, vinha sen do atribuído a processos de limonitização mas Navarra (1982), estudando as "piçarras" do litoral centro e sul do Estado de São Paulo, demonstrou a inexistência de óxidos de ferro e sugeriu que a coloração dos grãos de quartzo teria sido produzida pela ação de ácidos húmicos, provenientes da percolação de águas superficiais ricas em matéria orgânica.

Frequientemente, conforme descrito por petri \& Suguio (1971a), as "piçarras" podem estar recobertas por finas camadas. ( 1 a $2 \mathrm{~m}$ ) de areias brancas sem estruturas visiveis 
(seqüência V). Esses sedimentos, constituídos exclusivamente de grãos de quartzo, de dimensões bastante uniformes $(0,177$ $0,088 \mathrm{~mm}$ ), têm sido referidos por diversos autores, como de ori gem eólica, retrabalhados a partir de sedimentos pleistocênicos e holocênicos marinhos (Petri \& Suguio, 1973; Suguio \& Barcelos, 1978; Suguio \& Martin, 1978a).

Do ponto de vista composicional, os sedimentos são formados, na sua quase totalidade, por minerais leves ( $>95 \%$ em peso) chegando o quartzo a constituir isoladamente $99 \%$ désse sedimento.

$\mathrm{Na}$ fração pesada, segundo os estudos realizados por Petri \& Suguio (1973), para amostras arenosas da sequiência IV, foram observados zircão, turmalina e clorita como os minerals pesados mais abundantes $(>10 \%)$ enquanto que, silli manita, granada, rutilo, cianita, apatita, andaluzita e estaurolita constituem minerais acessórios.

Excetuando-se as estruturas biogênicas, representados por tubos fósseis de Callichirus-major e bioturbações descritas por Suguio \& Martin (1976) e Suguio et al. (1984), as porções arenosas superiores da Formação Cananéia são praticamente afossiliferas. Porém, ocorrem com certa frequiência níveis de restos vegetais não carbonizados, de espessuras milimétricas, acompanhando as estratificações.

\subsubsection{2 - Subsuperfície}

Para as sequências basais da Formação Cananéia (seq. II e III) existem apenas as descrições e análises efetuadas por Petri \& Suguio (1971a, 1973), em testemunhos de sondagem e descrições de furos rasos de trado realizados por suguio \& Martin (1978a).

As sequiências II e III, segundo Petri \& Suguio (1971a), são compostas respectivamente de argilas siltosas ricas em diatomáceas e arelas silticas ricas em foraminiferos. Os autores interpretaram essas seqüências como representativas, respectivamente, de ambientes de águas salobras e intermediário entre marinho e continental. 


\subsubsection{3 - Ambientes de sedimentação}

A sequência deposicional descrita por Suguio \& Petri (1973), como de ambiente transicional na base e marinho no topo, foi posteriormente vinculada por suguio \& Martin (1978a) ao evento transgressivo/regressivo Cananéia, de idade pleistocênica.

A partir de descrições de estruturas sedimenta res da Formação Cananéia, Suguio \& Tessler (1987) associaram a porção interior da sequiência emersa a um paleoambiente subaquo so raso, caracterizado como de face praial superior ("upper shoreface"). As porções superiores, compostas de sedimentos arenosos finos, cimentados ou não, apresentam comumente estratificações plano-paralelas a subhorizontals, geralmente ressal tadas por nivels de minerais máficos. Localmente, ocorrem delgados níveis argilosos, por vezes gretados. Essas estruturas seriam sugestivas de ambientes aquosos muito rasos e sujei tos a exposições subáreas periódicas, podendo-se atribuir-Ihe o subambiente de antepraia ("foreshore").

\section{4 .2 - Formação Santos \\ 1.4.2.1 - Denominação}

Na faixa externa da planicie costeira, em rela ção à Formação Cananéia, ocorrem areias marinhas em forma de terracos cujas altitudes raramente ultrapassam $3 \mathrm{~m}$, que foram atribuidas por Suguio \& Martin (1978a) à Transgressão Santos, de idade holocênica. A esses depósitos, que apresentam cristas praiais regressivas em sua superficie e formam uma faixa praticamente contínua entre o oceano e a Formação Cananéia, tem -se designado de Formação santos.

\subsubsection{2 - Caracteristicas texturais e composicionais}

A mais extensa exposição de sedimentos da Formação Santos no litoral sul do estado de são Paulo, ocorre na I Iha Comprida, com $72 \mathrm{~km}$ de comprimento. 
Barcelos (1975) e Suguio \& Barcelos (1978) rea Iizaram estudos texturais e composicionais em mais de uma centena de amostras de vários setores da ilha, reconhecendo os se guintes subambientes deposicionais: praial; marinho raso (cris tas praials); eólico (dunas) e mangue.

As análises granulométricas dos sedimentos coletados nas cristas praials e nas praias da Ilha Comprida reve laram composição textural de areia muito fina, com predominância de dimensões entre 2 e $3 \varnothing$ (> $90 \%$ em peso), constituindo sedimentos muito bem selecionados (75\%) a bem selecionados (19\%), de assimetrias entre simétricas (48\%) e positivas (36\%) e curtoses entre mesocúrticas (46\%) e leptocúrticas (35\%). Estes re sultados, tratados pelo método de Sahu, indicaram deposição em ambiente praial, marinho raso e eólico de alta energia e baixa viscosidade.

Barcelos (1975), descrevendo o conteúdo minera lógico das areias dos cordões litorâneos holocênicos, notou a exclusiva ocorrência de grãos de quartzo na fração leve e de oito principais tipos de minerais, transparentes e não-micáceos, no residuo pesado. Destes oito minerais (cianita, epidoto, estaurolita, hornblenda, rutilo, sillimanita, turmalina e zircão), apenas a turmalina, o epídoto e a estaurolita foram detectados em todas as amostras, tanto na fração areia fina quanto na fração areia muito fina. Como minerals pesados subordinados aparecem, na fração areia fina andaluzita, granada, titanita, anatásio, apatita, hiperstênio e dumortierita. para a fração areia muito fina; andaluzita, granada e titanita.

$$
\text { Suguio \& Martin (1978a)e Suguio et al. }
$$

realizaram cerca de quatro dezenas de dataçós pelo método do radiocarbono, de fragmentos de madeira e conchas de moluscos contidos nesses sedimentos, conseguindo assim atribuir-ihe idade holocênica, em geral inferior a 6.000 anos A.P. (Antes do Presente).

Depósitos de subsuperfície correlacionados ao evento transgressivo holocênico não foram, até o momento, descritos na região de Cananéia-Iguape, sendo também escassas na Iiteratura as descrições de estruturas sedimentares identifica 
das nesta formação. Barcelos (op. cit.), apenas faz referência a estratificações plano-paralelas horizontals a sub-horizontais, por vezes ressaltadas por niveis de máficos. Sugulo \& Martin (op. cit.) referem-se a niveis orgânicos, geralmente associados a intercalações argilosas milimétricas. Observaçōes pessoais, em afloramentos da Ilha Comprida, têm revelado a existência de bioturbações.

1.4 .2 .3 - Ambiente de deposição

Não restam dúvidas, embora as estruturas sedimentares não estejam suficientemente bem estudadas na Formaৎ̧̃o Santos, que a deposição desses sedimentos esteja vinculada ao último evento transgressivo/regressivo, e que os ambientes sejam semelhantes aos que propiciaram a sedimentação da Formação Cananéia.

Cerca de quarenta (40) datações ao radiocarbono, em especial as obtidas de conchas de moluscos, obtidas de bancos com 10 a $30 \mathrm{~cm}$ de espessura, presentes em sedimentos argilosos de mangue ou de fundo da baia recobertos por sedimentos arenosos, evidenciam o carater regressivo da porção superior da Formação Santos. Além disso, por analogia com a Formação Cana néia, cuja semelhança com a Formação Santos é muito grande, é Iícito concluir, conforme Barcelos (op. cit.), por um ambiente marinho raso pouco profundo como paleoambiente deposicional da Formação Santos.

\subsection{3 - Sedimentos de superficie de fundo da Plataforma Continental}

Segundo Corrêa (1978), a plataforma continental adjacente aos estados de são Paulo e Santa Catarina achase caracterizada por uma zona de sedimentação terrígena moderna, progradando sobre uma superfície de areias relíquias quart zosas e biodetriticas. Este autor subdividiu a plataforma con tinental entre os estados de são Paulo e Santa Catarina em três zonas distintas (fig. 3 ).
a) Fácies arenosa 


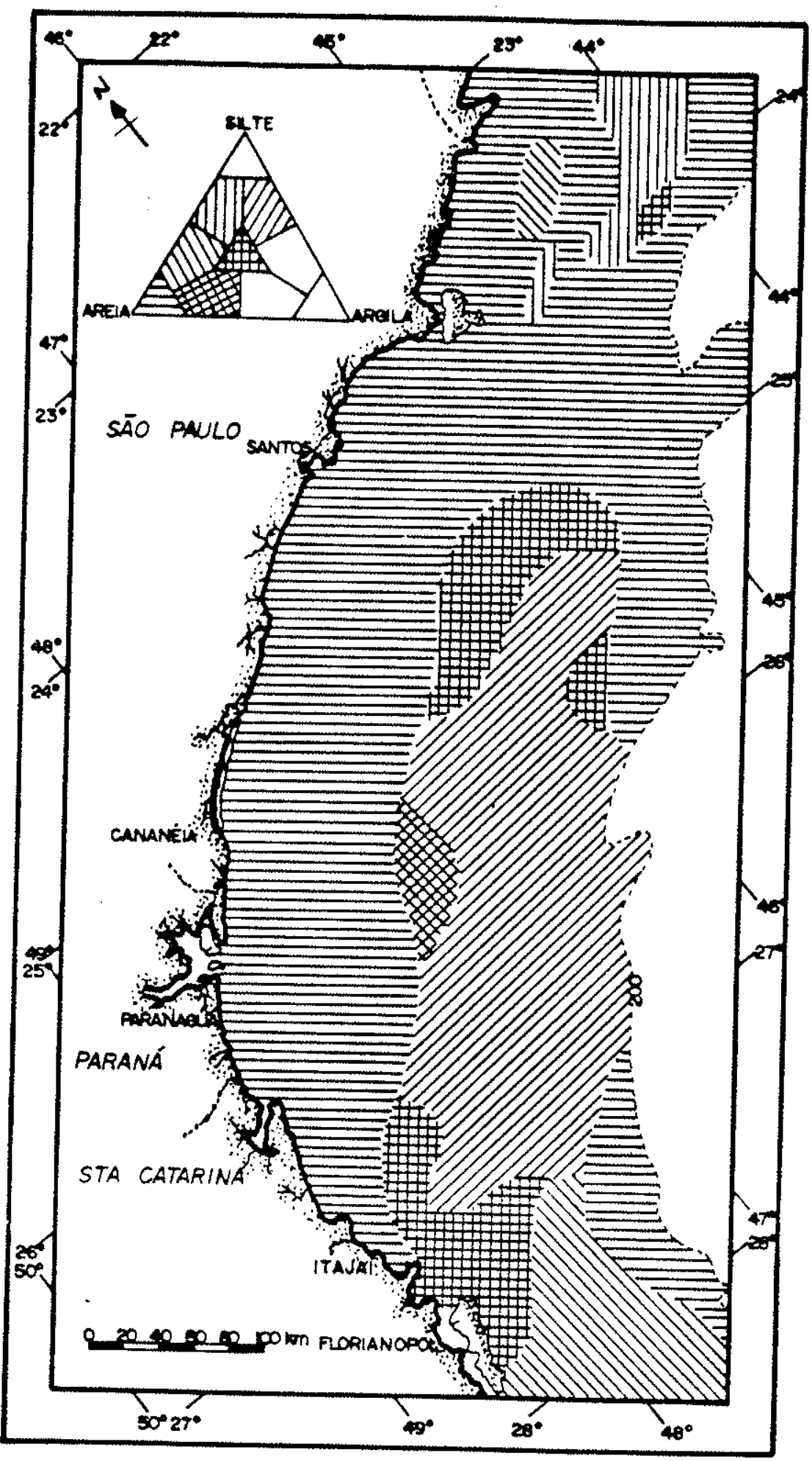

Fig. 3 - Mapa de fácies sedimentares da plataforma continental localizada entre os estados de São Paulo e Santa Catarina (Corrêa, 1978) 
b) Fácies areno-síltico-argilosa

c) Fácies lamosa

A plataforma interna exibe textura arenosa, onde predominam areias quartzosas apresentando em algumas áreas cascalho biodetritico. Na plataforma média a textura siltico-argi losa é a mais comum com pequenas áreas areno-siltico-argilosas. Já a plataforma externa apresenta uma textura arenosa composta por arelas biodetriticas e frequentes cascalhos.

A fácies arenosa, subdividida em sub-fácies de areia quartzosa, areia quartzosa com biodetritos, areia quatzosa com biodetritos e lama, e areia e cascalho biodetrítico, é constituida por areias de granulometria média a muito fina e apresenta uma composiça mineralógica essencialmente quartzosa. Em alguns casos ocorrem fragmentos mais grosseiros de calcários biodetriticos e também lama.

A fácies areno-siltico-argilosa é representada por granulometria variada, desde areia siltica a silte argiloso, além de misturas proporcionais de areia, silte e argila. Esta fácies acha-se esporadicamente distribuida nas plataformas média e interna.

A fácies lamosa é constituída por siltes argilosos e acha-se distribuida homogeneamente na plataforma média.

o carbonato exibe baixos teores na plataforma continental, variando de cerca de $5 \%$ na plataforma interna até cerca de 25\% nas áreas média e externa. Em alguns locais chegam a atingir até $50 \%$.

De acordo com Corrêa (op. cit), o carbonato apre senta-se mais frequientemente com granulação de areia, mas em áreas restritas podem ocorrer cascalhos const1tuidos principalmente de conchas inteiras ou fragmentadas.

Segundo o autor a sua deposição teria iniciado há cerca de 18.000 anos A.P., quando do inícto de um novo período de ascensão do nível marinho, após um longo período de recuo do nivel do mar que na área teria atingido cotas de $-130 \mathrm{~m}$. 


\section{5 - Agradecimentos}

Ao Prof. Dr. Kenitiro Suguio, amigo constante, pe la dedicação com que tem tratado seu orientado, antes e durante a 'realização deste trabalho.

Ao amigo Valdenir Veronese Furtado, pelas discus sões e leitura critica deste texto.

Aó amigo Michel Michaelovitch de Mahiques, por toda a colaboração nas análises, discussões, leitura crítica e auxilio na elaboração deste texto.

À Beatriz Beck Eichler, pelos muitos anos de sin cera amizade e apoio.

Ao amigo Armando Marcio Coimbra, pelo constante incentivo e pelo auxilio prestado no aprendizado das técnicas de identificação de minerais pesados, bem como pela centenas de lâminas conferidas e/ou contadas.

Ao Engenheiro Odair José de Souza, do Centro Tec nológico de Hidraúlica da USP, pelo auxilio prestado a este trabalho, principalmente na cessão dos dados oceanográficos obtidos para elaboração do modelo reduzido de Cananéia.

Aos bons e pacientes amigos Marilena de Oliveira e Clodoaldo Vieira Tolentino, por todo apoio, bem como pela ajuda nas análises dos sedimentos.

À amiga Marilza Correia, pela paciência, carinho e compreensão com este autor, bem como pelos trabalhos de datilo grafia.

A Srta. Lucy Teixeira - Diretora da DIDC, pela revisão bibliográfica e ao pessoal da Biblioteca do Instituto oceanográfico da USP, que em muito contribuiram nos trabalhos de levantamentos bibliográficos prévios para a elaboração deste tex to.

À Marizilda Magno, responsável pela arte final dos desenhos deste trabalho. 
Aos géologos Luiz Antonio Pereira de Souza e Car Ios Augusto Esteves, bem como aos técnicos da Divisão de Minas e Geologia Aplicada do Instituto de Pesquisas Tecnológicas SP, pelo auxilio na coleta de dados geofísicos.

Aos tripulantes do barco Albacora e N/Oc. "Prof. W. Besnard", pelo constante auxilio nas fases de amostragem.

À todos os funcionários da Base Sul do Instituto Oceanográfico da USP - Cananéia/SP, pela constante colaboração com este autor durante seus trabalhos de campo.

Ao Conselho Nacional de Desenvolvimento Cientifi co e Tecnológico - CNPq, pelo auxilio prestado à realizado deste trabalho, através da Bolsa - Pesquisa no 303301/84-8, na categoria de Pesquisador Cientifico III - C. 


\section{OS SEDIMENTOS}

\section{1 - Caracter1zação textural}

Inicialmente, as amostras foram secas em estufa a $60^{\circ} \mathrm{C}$ e quarteadas até cerca de $100 \mathrm{~g}$.

Nas amostras coletadas, nos diferentes sub-ambientes da região costeira, procedeu-se, em todas as amostras an tes das análises granulométricas, à eliminação do calcário biodé trítico, através de um ataque com ácido cloridrico (HCl) diluido a $10 \%$.

Em seguida, as amostras que possuiam constituin tes grosseiros e finos foram passadas, por via úmida, em uma peneira de $0,062 \mathrm{~mm}$ de malha, com a finalidade de separar as frações peliticas das arenosas.

o material fino foi colocado em suspensão, em proveta graduada de $1000 \mathrm{cc}$ contendo água destilada, à qual foi acrescentada um grama de pirofosfato de sódio $\left(\mathrm{Na}_{4} \mathrm{P}_{2} \mathrm{O}_{7}\right)$, a fim de se evitar a floculação do material. Neste material deflocula do foram realizadas as pipetagens pelo método descrito por suguio (1973).

A fração grosseira, retida na peneira de 0,062 $\mathrm{mm}$, foi seca e peneirada através de um conjunto de peneiras, com intervalos de $1 / 2 \varnothing$, utilizando-se a escala granulométrica de Wentworth (1922).

As frações retidas em cada peneira foram pesadas e a partir desses pesos e dos valores obtidos, pelo método da pipetagem, foram determinados os parâmetros estatísticos.

Posteriormente, foram avaliados visualmente os graus de arredondamento e esfericidade de 100 grãos de quartzo, em duas fraçōes granulométricas, areia grossa e areia muito fina, nas amostras que continham nesses intervalos um peso mínimo de $1 \%$ em relação a distribuição total.

2.1.1 - Cálculos dos parâmetros estatísticos

os cálculos dos parâmetros estatísticos foram feitas pelas formulas de Folk \& Ward (1957). 
o programa utilizado para execução desses cálcu Ios foi desenvolvido pelo geólogo Mauro flmio Yamamoto, no laboratório de sedimentologia do Instituto de Geociênclas da USP, em Iinguagem FORTRAN e denominado LABSE 4. Este programa utiliza como da dos básicos os pesos inicial e de cada fração granulométrica, calculando-se percentuais $\left(\phi_{5} ; \emptyset_{16} ; \phi_{25} ; \emptyset_{50}, \emptyset_{75} ; \emptyset_{84}\right.$ e $\left.\emptyset_{95}\right)$ Interpolados, pela função de Gauss, onde as porcentagens acumuladas são transformadas em escores da distribuição normal acumulada, através desta função (Colmbra, 1983).

A partir do LABSE 4 pode-se então obter:

- cálculo dos parâmetros estatísticos de Folk. \& Ward para distribuição total (intervalos areia, silte e argila) e para distribuição areia das amostras que apresentam porcentagens acima de $50 \%$ de areia;

- classificação textural da amostra segundo Shepard (1954) e,

- cálculo do número de classes texturais do sedimento, considerando apenas as classes granulométricas (conforme a escala de Wentworth, 1922) com porcentagens de pelo menos $1 \%$ da distribuição total.

Quando da avaliação do comportamento

espacial dos parâmetros granulométricos e, posteriormente, também de conteúdo mineralóglco das amostras foram utilizadas análises de dis tribuição planar de isovalores. Este método de interpretação fol o mais adequado, não apenas por ser, no presente estudo, mais confiável, mas principalmente por possibilitar uma posterior correlação, com alto grau de confiabilidade, entre as interpretações realizadas para a área submersa e a faixa intermarés.

A não utilização de recursos estatísticos mais sofisticados, deveu-se principalmente às diferentes caracteristicas geométricas existentes nas malhas de amostragem dos compartimentos estudados.

O programa de interpolação utilizado foi desenvolvido para microcomputadores do tipo $\mathrm{PC}$ e é constituído por um conjunto de aplicativos desenvolvidos pela Companhia Golden Soft ware, denominados OGrid, Topo, PlotCall e Plot. 
Este programa necessita para sua execução do es tabelecimento de uma origem, da definição das coordenadas, ( $x$, $y$ ), do ponto amostrado e da variável a ser estudada ( $z$ ).

Definida uma malha regular de amostragem e computados os valores da variável $z$, o programa estabelece uma cor relação entre as variáve1s vizịhas e 1nterpola, dentro de I1m1tes pré-estabelecidos, as curvas de isovalores.

Este procedimento resulta na obtenção de mapas que por um artificio do programa podem ter suas curvas suavizadas e que permitem, na área estudada, a identificação das tendênclas gerais dos parâmetros analisados.

Com relação aos sedimentos holocênicos aflorantes da Ilha Comprida, apenas uma dezena de amostras foram coledas e analisadas. Este procedimento visou obter informações adi cionals acerca da caracterização sedimentológica (textural e mineralógica) dos vários subambientes deposicionais da Ilha Compri da definidos por Barcelos (1975).

2.1.2 - Caracterização Granulométrica dos Sedimentos

2.1.2.1 - Parâmetros estatísticos de Folk \& Ward (1957)

Os parâmetros estatísticos dos sedimentos da faixa intermarés; zona de arrebentação, plataforma rasa, dos cor dões holocênicos da IIha Comprida e da Formação Cananéia foram obtidos através das equações propostas por Folk \& Ward (op. cit.) e seus resultados encontram-se nas Tabelas 4 a 8 .

2.1.2.2 - Análise de frequência dos parâmetros estatísticos

Os resultados obtidos dos parâmetros estatísticos foram submetidos a uma análise de frequência para a verificação do comportamento dos mesmos em conjunto. Esta análise de frequência fol efetuada para os valores de diâmetro médio, segundo a escala granulométrica de Wentworth (1922) e os valores de Folk \& Ward (op. cit.) para seleção, assimetria e curtose. Os resultados desta análise encontram-se nas Tabelas 9 a 13 . 
2.1.2.2.1 - Área Emersa - Formação Cananéia

A análise das frequências obtidas para o diâmetro médio revelou que $88 \%$ das amostras situam-se nos intervalos de areia fina e muito fina apresentando, de maneira geral, boa seleção com $75 \%$ das amostras variando de bem a muito bem selecionadas. Assimetrias variando de simétrica a muito negativa apresentam uma frequência também de $75 \%$, indicando ainda um desvio da curva no sentido de uma presença maior de sedimentos cons tituídos de termos mais grossos em relação à média, associados a una baixa frequiência de sedimentos pelíticos. A curtose varia de mesocúrtica a platicúrtica em mais de $70 \%$ das amostras estudadas.

Desta maneira as características granulométricas, dos sedimentos aflorantes da Formaça Cananéia, estão de acordo com as apresentadas anteriormente por diversos autores (Suguio \& Petri, 1973; Suguio \& Martin, 1978a; Suguio \& Tessler, 1987), permitindo caracterizar, em sua porção exposta, esta formação pleistocênica como granulometricamente homogênea onde predominam os sedimentos arenosos finos e bem selecionados.

\subsubsection{2 - Faixa Intermarés - Ilhas Comprida e Cardoso}

A predominância de sedimentos arenosos nas faixas intermarés, também pode ser verificada nos três perfís longitudinais amostrados nas ilhas Comprida e do Cardoso. As anáIises demonstram ocorrer pequena variação entre os niveis amostrados, com a moda areia fina representando mais do que $95 \%$ do conjunto das amostras.

Entre as amostras analisadas somente duas, provenientes da Ilha do Cardoso junto à ponta do Itacuruçá no nível de maré mais alta, caracterizaram-se como arelas médias.

Este conjunto de areias finas apresenta boa seleção, sendo superior a $95 \%$ a ocorrência de amostras bem a muito bem selecionadas. Os valores positivos de assimetria representam mais do que $70 \%$ das amostras analisadas, estando o restante do conjunto caracterizado por assimetrias aproximadamente simétricas. 
Para a curtose ocorre um predomínio entre curvas platicúrtica $(>50 \%)$ e leptocúrtica a muito leptocúrtica $(>35 \%)$.

Conforme verificado por Barcelos (op. cit.) na faixa intermarés da Ilha Comprida é nitida a tendência de aumen-

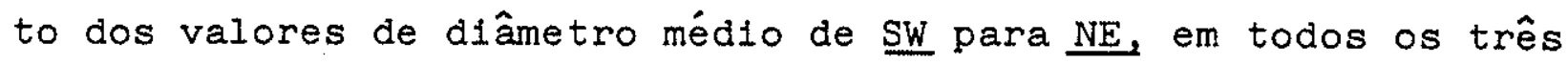
niveis amostrados (fig. 4).

Esta variação longitudinal apresenta-se mais pronunciada entre a região próxima do Valo Grande e a região cerca de $30 \mathrm{~km}$ a $\mathrm{SW}$ da desembocadura lagunar de Icapara.

Para sudoeste os valores de diâmetros médios vâ riam de modo bastante irregular, com a ocorrência de áreas com sedimentos mais grossos ao lado de outros mais finos $(2,75 \varnothing)$.

A $\underline{N E}$ da área, entre a região do Valo Grande e a desembocadura lagunar de Icapara, esta tendência de aumento dos valores de diâ metro médio ruo a $N E$ não é mais observada, provavelmente vinculada aos fenômenos de remobilização de sedimentos, comuns em regiões de desembocadura lagunar com forte predominância das correntes de maré.

\subsubsection{3 - Área submersa - zona de arrebentação}

$\mathrm{Na}$ zona de arrebentação ocorre uma predominância da frequiência dos diâmetros médios areia fina a muito fina $(88 \%)$, com seleção variando de moderadamente a muito bem selecionada em $85 \%$ das amostras.

As assimetrias variaram de muito negativa a mui to positiva, sendo que a Incidência de maior frequiência relativa recaiu em amostras aproximadamente simétricas ( $41 \%)$. Com relação às curtoses, mais de $70 \%$ das amostras apresentam curvas variando de leptocúrticas a muito leptocúrticas.

Para as amostras essencialmente arenosas, ou se ja, aquelas com mais de $50 \%$ em peso contidas no intervalo areia, foram recalculados os parâmetros estatísticos de Folk \& Ward (op. cit.) considerando-se apenas o peso da fração areía como sendo $100 \%$ da amostra total. 


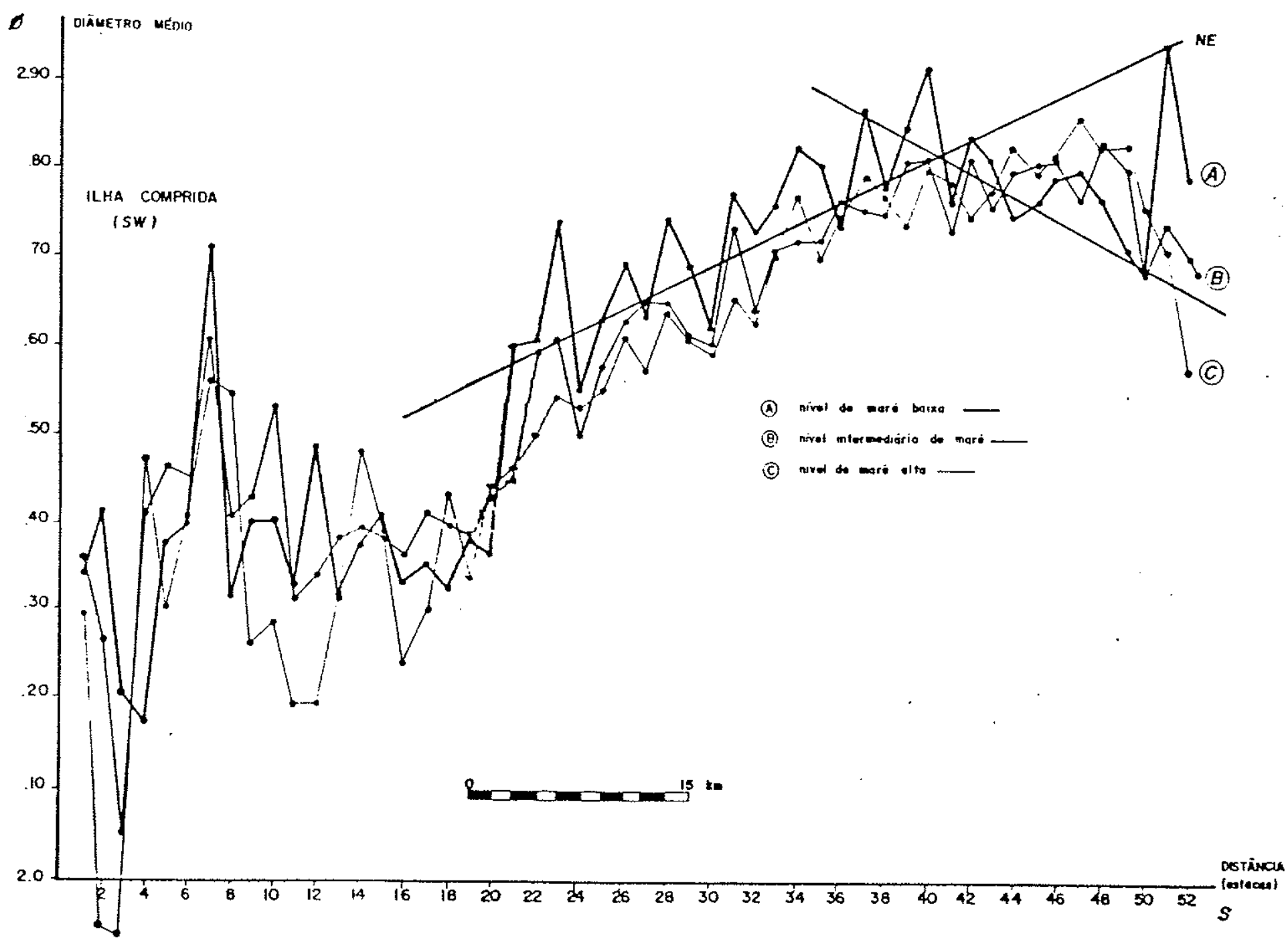

Fıg. 4 - Variação longitudinal do diâmetro médio dos sedimentos da falxa intermarés da Ilha Comprida - SP. 
Os resultados obtidos, para esse conjunto de amostras (Tabela 14), mostram uma predominância total de diâmetros médios compreendidos entre os intervalos areia fina $(28,9 \%)$ e arela multo fina $(69,6 \%)$, com seleção predominante boa a mu1to boa $(78,2 \%)$.

As assimetrias apresentaram-se predominantemente negativas $(60 \%)$, enquanto que as curtoses variaram entre meso cúrticas e muito leptocúrticas ( $87 \%)$.

\subsubsection{4 - Área submersa - Plataforma rasa}

Na plataforma rasa, as amostras analisadas revelam uma predominância de diâmetros médios compreendidos entre os intervalos areia fina e muito fina $(79,4 \%)$, apresentando grau de seleção situado entre moderado a bem selecionado (75\%). A as simetria variou entre muito negativa e aproximadamente simétrica $(60 \%)$, enquanto os valores de curtose apresentaram cerca de $76 \%$ das curvas compreendidas entre mesocúrticas a muito leptocúrticas.

Considerando-se apenas as amostras arenosas verifica-se que o diâmetro médio apresenta uma predominância de areias finas $(70,3 \%)$, secundadas pelas areias muito finas $(18,7 \%)$. A seleção varia de boa a moderada enquanto aproximadamente $57 \%$ das amostras apresentam assimetria negativa.

Com relação à curtose as amostras arenosas apre sentam curvas variando de platicúrtica a leptocúrtica, > $80 \%$, (Tabela 15).

Avaliando-se as variações do diâmetro médio, ao Iongo dos perfís transversais à costa, verifica-se que nos de Paranaguá, Ararapira e Ilha Comprida existe um padrão de variação do diâmetro médio ao longo dos perfís (fig. 5). Entre a linha de costa até aproximadamente a isóbata de 20 metros, ocorre uma tênue diminuição do valor do diâmetro médio. A partir dessa profundidade apresenta uma estabilização dos valores situados en tre 2,5 e 3,5 phi.

No perfil de Cananéla, esta mesma tendência é observada, sendo que, a profundidade aproximada onde ocorre a estabilização do diâmetro médio ao redor de $3 \varnothing$, está localizada na isóbata de 30 metros. 


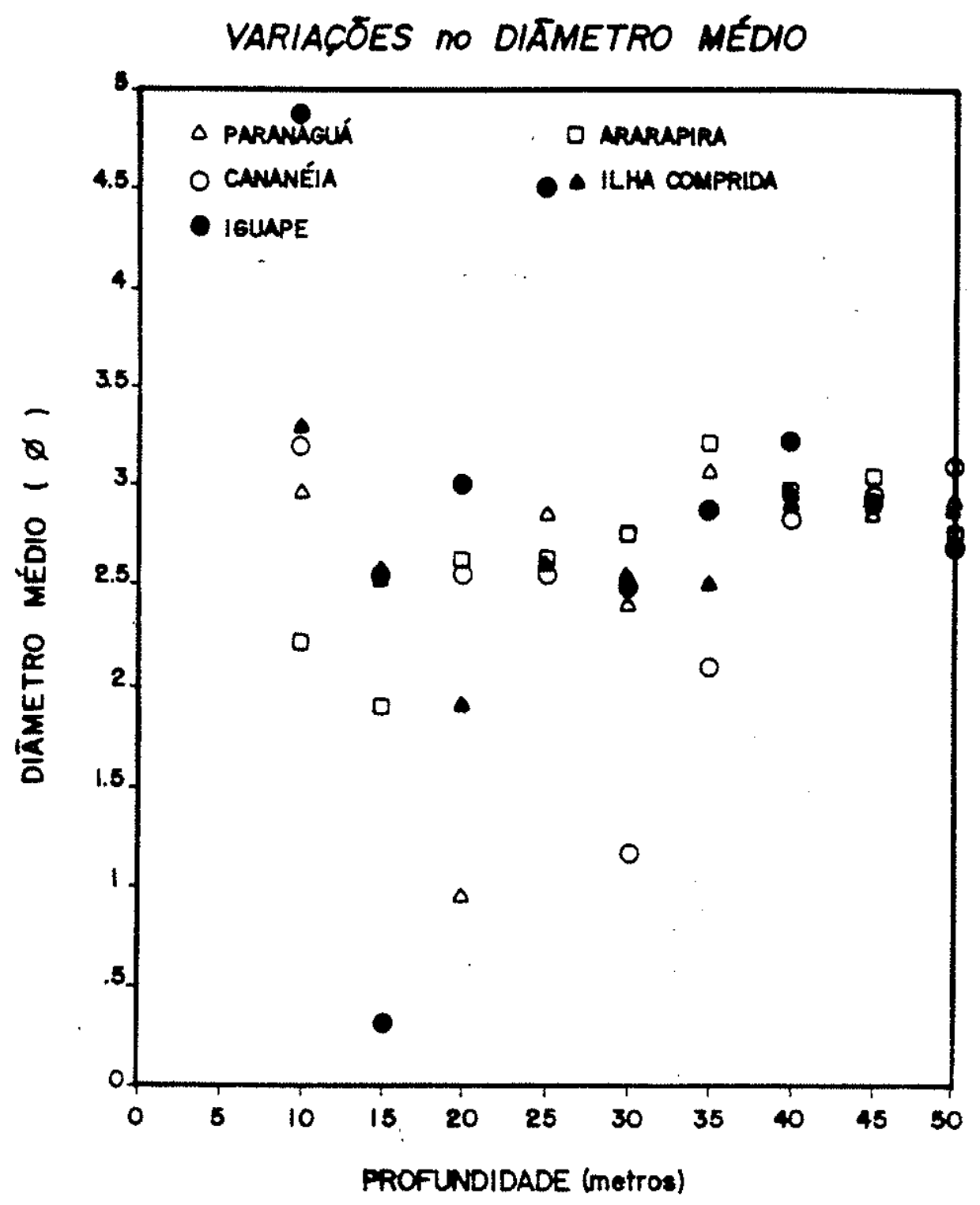

Fig. 5 - Variaçós transversais à costa do diâmetro médio. 
Para o perfil de Iguape, esta estab1lização dos valores de diâmetro médio também ocorre ao redor da isóbata de 30 metros. Porém diferentemente dos outros perfís observa-se en tre a IInha da costa e a isóbata de $25 \mathrm{~m}$ uma intensa variação dos valores de diâmetro médio.

Esta característica, observada ao longo do perfil de Iguape, deve estar associada a uma intensa movimentação de sedimentos ocasionada pela ação das correntes de maré, nas re giões da desembocadura lagunar de Icapara e foz do rio Ribeira ra de Iguape.

\subsubsection{5 - Cordões Iitorâneos - Ilha Comprida}

Barcelos (1975), analisando 126 amostras distri buídas ao Iongo de 15 seções transversais a costa, que abrangeram todos os subambientes deposicionais mapeados na Ilha Comprida, constatou a ocorrência de grande homogeneidade granulométrica dos sedimentos presentes em todos os ambientes amostrados.

$$
\text { Os resultados obtidos por Barcelos (op. cit.), }
$$

para os parâmetros estatísticos de Folk \& Ward (op. cit.), nos sedimentos arenosos da Ilha Comprida exibiram resultados semelhantes aos obtidos nas 10 amostras coletadas nos cordões litorâneos da Ilha Comprida e faixa intermarés.

A análise das frequiências obtidas para o diâmetro médio, das amostras coletadas nos cordões litorâneos, revela que $90 \%$ das amostras estão contidas no intervalo areia fina, secundadas pelas contidas no intervalo areia muito fina (10\%), apresentando boa seleção com $80 \%$ das amostras variando de bem a muito bem selecionadas.

As assimetrias apresentaram uma frequêencia de $100 \%$ de simétrica a muito negativa, enquanto que as curtoses variaram entre mesocúrtica a platicúrtica em cerca de $80 \%$ das amos tras analisadas.

Este conjunto de 10 amostras apresenta-se textü ralmente muito semelhante aos sedimentos da Formação Cananéla aflorantes no litoral sul do estado de são Paulo. 


\subsubsection{3 - Análise do número de classes texturais - (Tabela 16)}

$\mathrm{Na}$ análise de frequência do número de classes texturals só foram considerados os intervalos granulométricos com porcentagens superiores a $1 \%$ do peso total, visando com 1 sso eliminar as possivels falhas decorrentes do processamento em laboratório. As amostras analisadas nas formações quaternárias e na faixa intermarés apresentaram pequeno número de classes textu rais sendo sempre inferiores a 5 .

Este pequeno número de classes texturais, situa da entre 2 e 4, evidencia a alta seleção granulométrica dos sedí mentos constituintes da Formação Cananéia $(86,8 \%)$, cordōes litorâneos da IIha Comprida $(90 \%)$ e da faixa intermarés (100\%).

Para as áreas submersas, embora a frequência de 2 - 4 classes texturais ainda seja predominante (zona de arreben tação $64,3 \%$; plataforma rasa $58,8 \%$ ), a dispersão de valores para números maiores de ocorrência de classes texturais denota uma diminuição do selecionamento.

\subsection{3 - Caracterização morfoscópica em grãos de quartzo}

A caracterização morfoscópica em grãos de quart zo foi realizada através de uma análise comparativa, em lupa, com as tabelas gráficas de arredondamento e esfericidade de Krumbein (19.41 apud Krumbein \& Sloss, 1963).

- grau de arredondamento é um indice que refletè a maturidade de um sedimento, sendo que somente sedimentos arenosos retrabalhados em vários ciclos apresentam altas frequiênclas de grãos bem arredondados.

A subjetividade desta avaliação não permite

a atribuição de significado absoluto aos indices encontrados, sendo portanto apenas considerados por conjuntos de amostras agrupadas dentro das unidades aqui estudadas.

Os resultados obtidos estão apresentados na Tabela 17 . 
2.1.3.1 - Sedimentos pleistocênicos e holocênicos da área emersa

Nos afloramentos da Formação Cananéia da região lagunar de Cananéia - Iguape, observa-se tendência para maiores graus de arredondamento e seleção na fração areia fina, embora muito próximas aos graus de arredondamento obtido para as frações areia média e muito fina.

o predominio geral de grãos sub-angulosos a subarredondados, nas frações areia média, fina e mito fina, é observado seja quando analisado os afloramentos individualmente ou o conjunto de afloramentos alinhados paralelamente à linha de costa atual. Nesta avaliação ao Iongo da costa, a fração areia fina apresenta um tênue incremento do grau de arredondamento rumo a $\mathrm{NE}$.

Inversamente ao que se verifica nos afloramentos da Formação Cananéia, os maiores graus de arredondamento médio para os sedimentos holocênicos dos cordões litorâneos da Ina Comprida, são detectados na fração areia muito fina ao invés de areia fina.

Porém, igualmente aos sedimentos pleistocênicos os sedimentos holocênicos não apresentam variações significativas no seu grau de arredondamento ao nivel de análise de um único afloramento. Com relação às variações longitudinais à linha de costa, a quantidade de dados é muito pequena para qualquer conclu são mais precisa, muito embora pareça existir uma tendência para diminuição do grau de arredondamento médio rumo a $\mathrm{NE}$.

\subsubsection{2 - Faixa intermarés}

- grau de arredondamento dos sedimentos, coleta dos na faixa intermarés das 11has Comprida e Cardoso, apresenta valores mais elevados na fração arela muito fina do que na fina.

$\mathrm{Na}$ análise ao longo dos perfís de coleta, dispostos paralelamente a linha da costa, é clara uma tendência para decréscimo do arredondamento médio rumo a $\underline{\mathrm{NE}}$, em ambas as fra cões acompanhando uma tendência igualmente para decréscimo dos diâmetros médios. Com relação ao desvio padrão nota-se um aumento de valores na fração muito fina enquanto que para a fração 
arela fina esta análise ao longo dos perfís longitudinais apresenta uma queda dos valores de desvio padrão no rumo de $\mathbf{N E}$.

Os resultados da caracterização morfoscópica, nos sedimentos holocênicos da falxa intermarés, apresentam-se aparentemente contraditórios, pois, admite-se que o arredondamen to por abrasão em sedimentos arenosos é atingido com mais facilí dade em grãos mais grosseiros que nos grãos mais finos (suguio, 1973).

Por outro lado, Griffiths (1951) estudou sedimentos terciários de deposição subaquosa e concluiu que o aumento de seleção granulométrica, por transporte, atinge sua eficiência máxima dentro da classe areia fina, caindo gradativamente rumo às granulometrias maiores ou menores.

Esta aparente contradição, verificada nos sedimentos da faixa intermarés da Ilha Comprida, também foi detectada por Giannini (1987) ao Iongo da Planície de Peruíbe-Itanhaém.

Nestes estudos, admitindo como válida a premissa de que existe uma dependência direta entre seleção granulométrica e morfométrica Giannini (op. cit.) concluiu que também o aumento de seleção morfométrica, por abrasão devida ao transporte, atinge sua eficiência máxima dentro da classe areia fina $(0,250$ $0,125 \mathrm{~mm}$ ).

Portanto, considerando-se que o arredondamento é atingido com mais facilidade nas areias mais grossas, as carac terísticas apresentadas pelos sedimentos da faixa intermarés devem estar relacionados ou a diferenças no grau de retrabalhamento, ao qual estiveram submetidas as frações areia fina e muito fina, ou então a diferenças herdadas dos sedimentos matrizes das duas frações.

\section{$2 \cdot 1 \cdot 3.3-$ Sedimentos de fundo}

Em geral predominam, na região submersa do $1 i-$ toral sul, areias com balxo grau de arredondamento apresentando altas porcentagens de grãos de quartzo sub-angulosos. 
Na zona de arrebentação e plataforma rasa malores valores de arredondamento médio foram encontrados na fração arela fina.

2.1.4 - Mapas de isovalores da distribuição espacial dos parâmetros texturais

$\mathrm{Na}$ plataforma rasa e zona de arrebentação foram elaborados mapas de isovalores para os seguintes parâmetros texturals: o diâmetro médio da distribuição total, a porcentagem de arg1la, número de classes texturais e arredondamento médio dos intervalos areia grossa e média.

$\mathrm{Na}$ execução destes mapas não fol utilizado

$\circ$ procedimento de suavização, o que significa que as curvas geradas representam a interpolação simples entre os valores de variá veis próximas.

O mapa de diâmetro médio para a zona de arreben tação (fig. 6) apresenta, como tendência geral, um predomínio de valores compreendidos entre os intervalos areia fina e muito fina $(2 \varnothing-4 \varnothing)$.

No sentido das desembocacuras lagunares de Cananéia, a SW da área Icapara e Ribeira, a $\mathrm{NE}$, notamse um aumento dos valores dos diâmetros médios da distribuição total.

Quando confrontadas estas tendências com os mapas de isovalores de porcentagem de argila (fig. 7) e do número de classes texturais ( $f i g .8$ ), verificam-se igualmente tendências para um incremento destes parâmetros, nos rumos das desembocaduras lagunares e fluvial situadas nos limites extremos da área.

$\mathrm{Na} z o n a$ de arrebentação, onde verifica-se um predominio de sedimentos arenosos finos, observa-se no sentido dos extremos da área um incremento de termos mais finos; areia muito fina e pelítos; acarretando um padrão de variação lateral dos parâmetros analisados a partir da porção central da área.

A análise conjunta das tendências observadas, permitem supor a existência de uma duplicidade de fontes de suprimento dos sedimentos de fundo. 


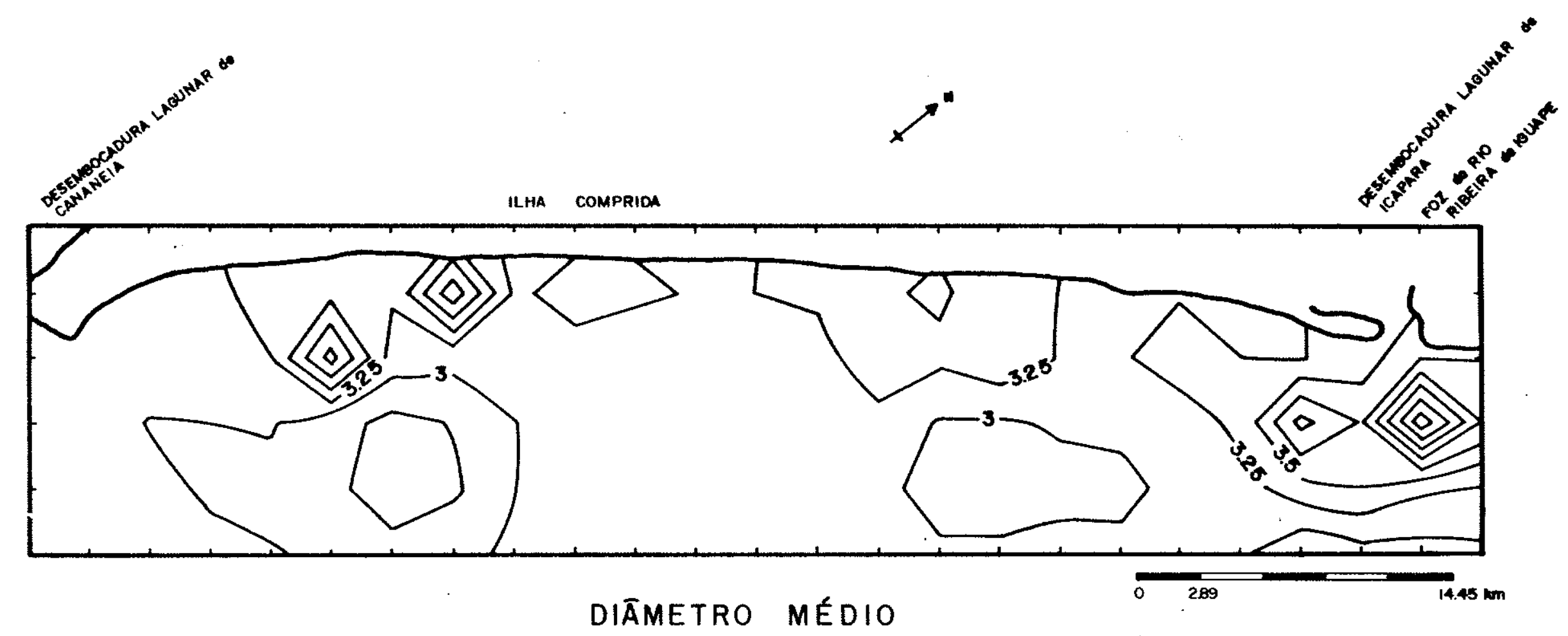

Fig. 6 - Mapa de 1sovalores do diâmetro médio, da distribuição total, das amostras de fundo da zona de arrebentação. 


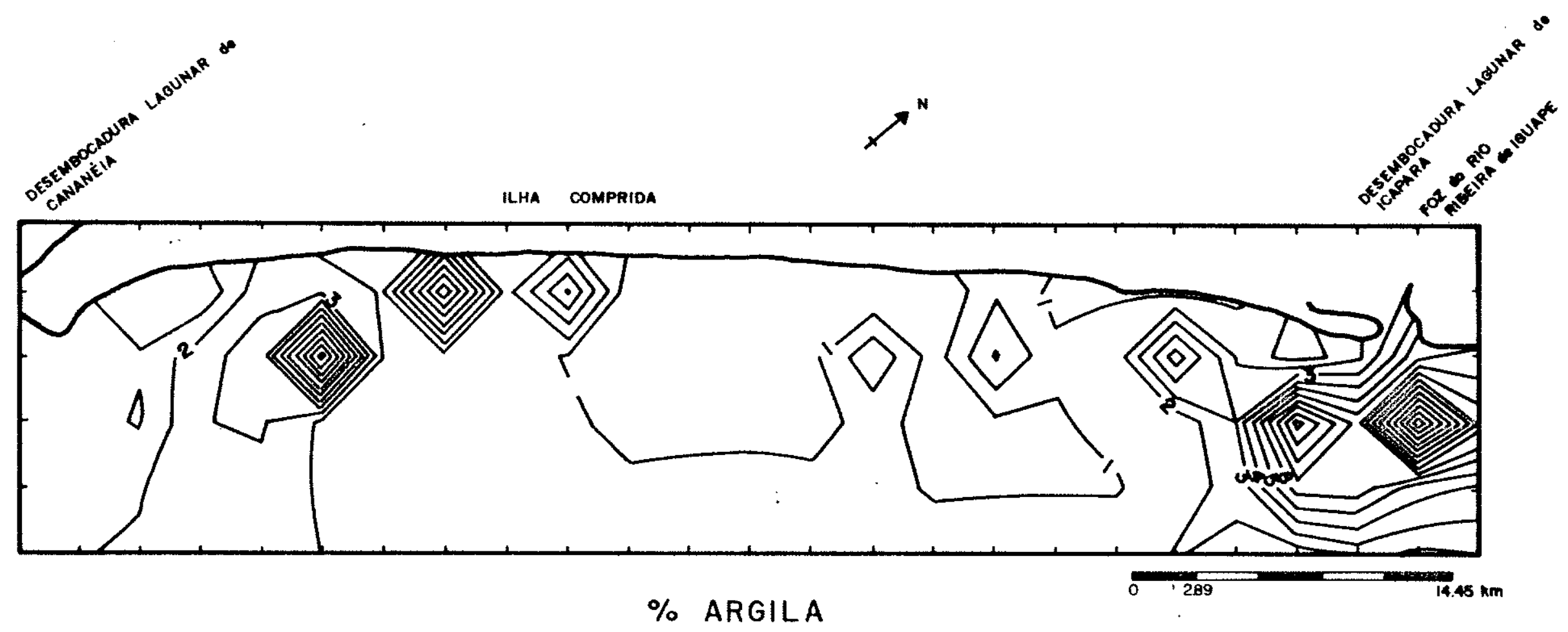

F1g. 7 - Mapa de tsovalores da porcentagem de argila das amostras de fundo da zona de arrebentação. 


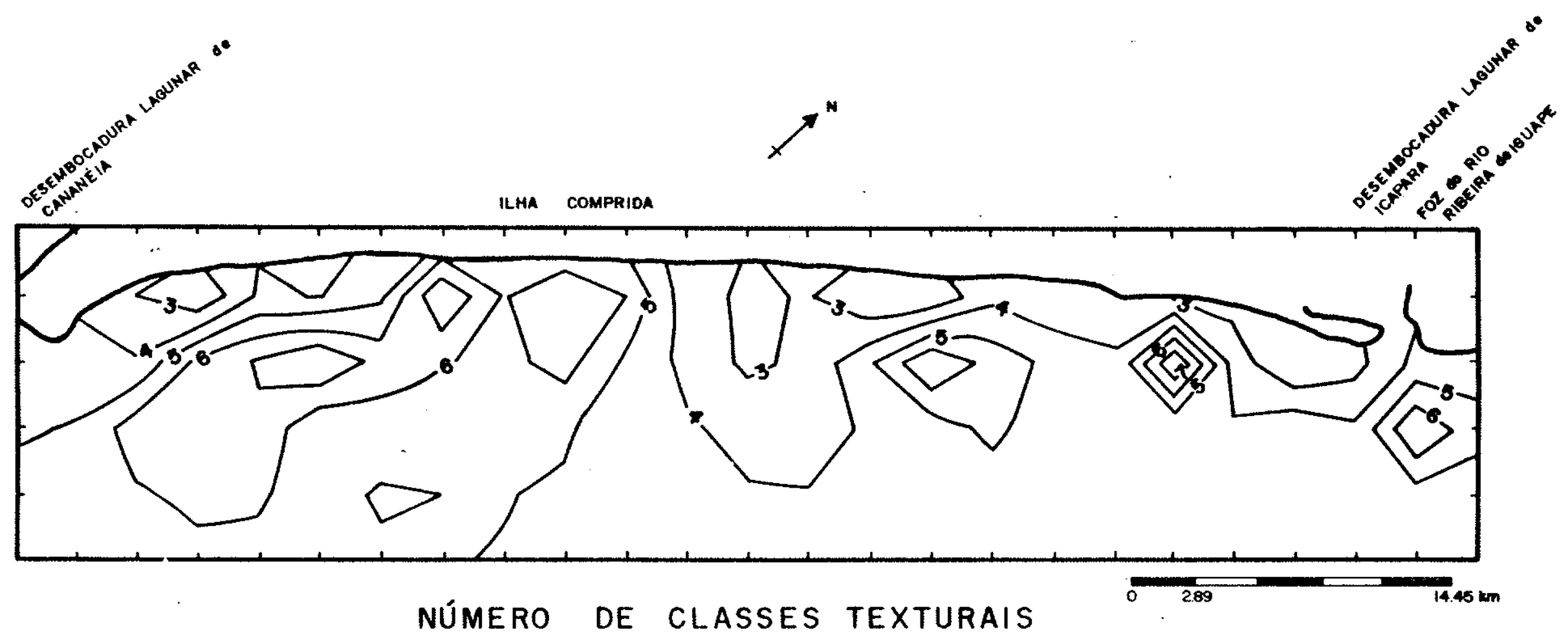

Fig. 8 - Mapa de isovalores do número de classes texturais, da distribuição granulométrica, das amostras de fundo da zona de arrebentação. 
Dada a proximidade das áreas de Influência das de sembocaduras lagunares de Cananéia e Icapara e da foz do rio Ribeira cie Iguapé, submetidas à forte influência de correntes geradas por maré (Geobrás, 1966), admite-se a existência de uma importante contribulção de sedimentos finos terrígenos ou resultantes da decom posição de matéria orgânica da vegetação de mangue, que circundá a região lagunar.

Foram traçados mapas de 1sovalores dos graus de arredondamento para as frações granulométricas que seguramente estão submetidas aos processos de transporte por tração $(0,500$ e $0,250 \mathrm{~mm})$. Os mapas apresentam concentrações de curvas represen tativas de maior grau de arredondamento nas extremidades $\underline{\mathrm{NE}}$ e $\underline{\mathrm{SW}}$ da área. Na porção localizada próximo ao centro da Ilha Comprida, verifica-se uma menor concentração de curvas, representativas de valores elevados, no rumo do oceano profundo (figs. 9 e 10).

- mapa de diâmetro médio da plataforma rasa ( $f i g$. 11) apresenta predominância de curvas com valores compreendidos entre 2.0 e $3,0 \varnothing$ areia fina).

Analogamente ao mapa de isovalores obtido para a zona de arrebentação, na plataforma rasa observa-se um aumento dos valores de diâmetro médio, junto à costa, apenas nas proximi dades das desembocaduras lagunares e foz do rio Ribeira de Iguape.

Uma tendência para aumento do valor de diâmetro médio é também observada no sentido do oceano profundo devido principalmente à sedimentação pelítica, de origem continental, parcialmente depositados além da área de maior movimentaço das massas de água litorâneas.

Quando se compara este mapa de isovalores com os mapas de porcentagem de argila (fig. 12) e do número de clas ses texturais (fig. 13), é possivel observar-se tendências semeIhantes as obtidas para o mapa de diâmetro médio.

Rumo as malores profundidades, os mapas de porcentagem de argila e número de classes texturais também apresentam tendência para aumento dos valores desses parâmetros, a partir da isóbata aproximada de 40 metros. Esta mesma tendência ma 


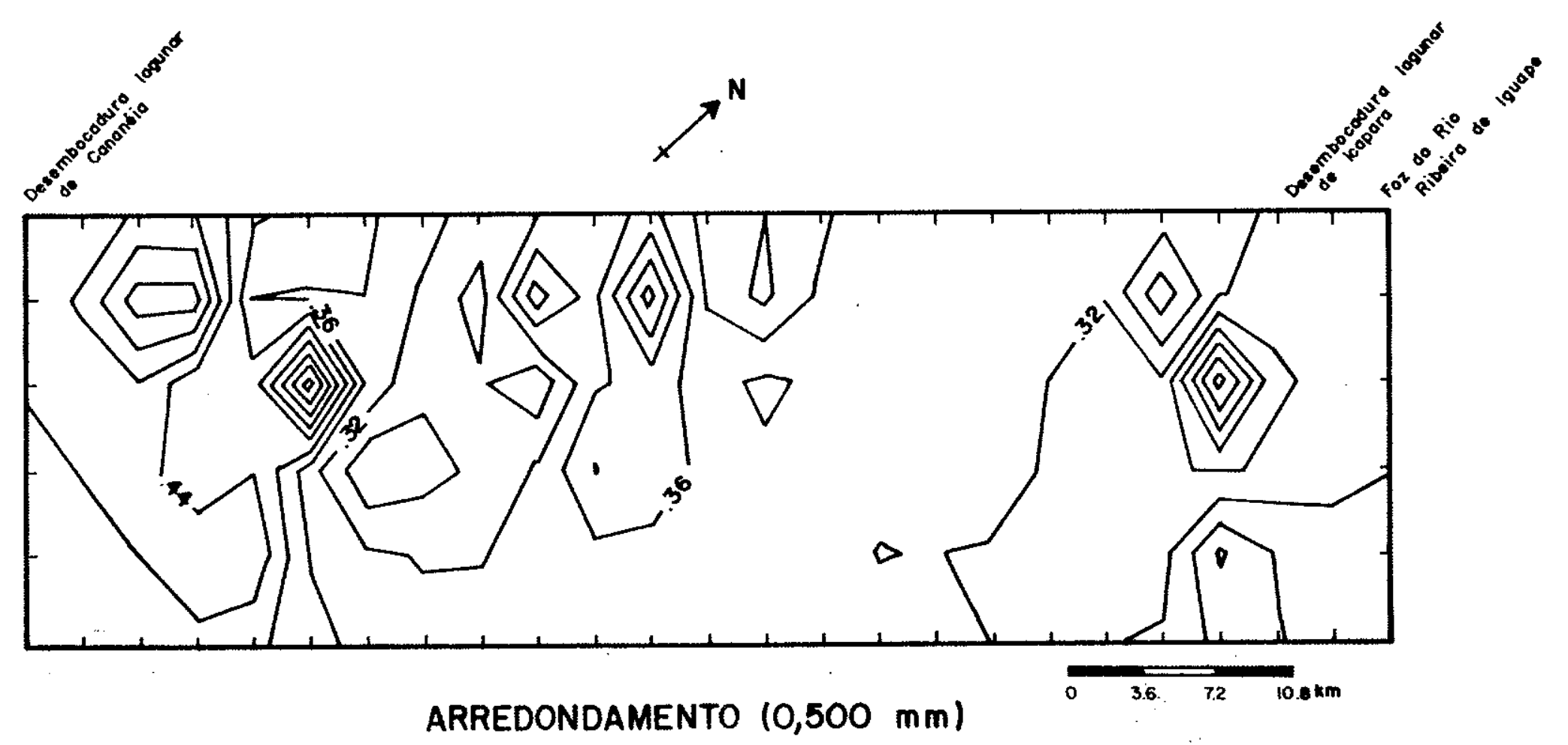

F1g. 9 - Mapa de 1sovalores do grau de arredondamento, da fração ret1da na peneira $0,500 \mathrm{~mm}$, na zona de arrebentação. 


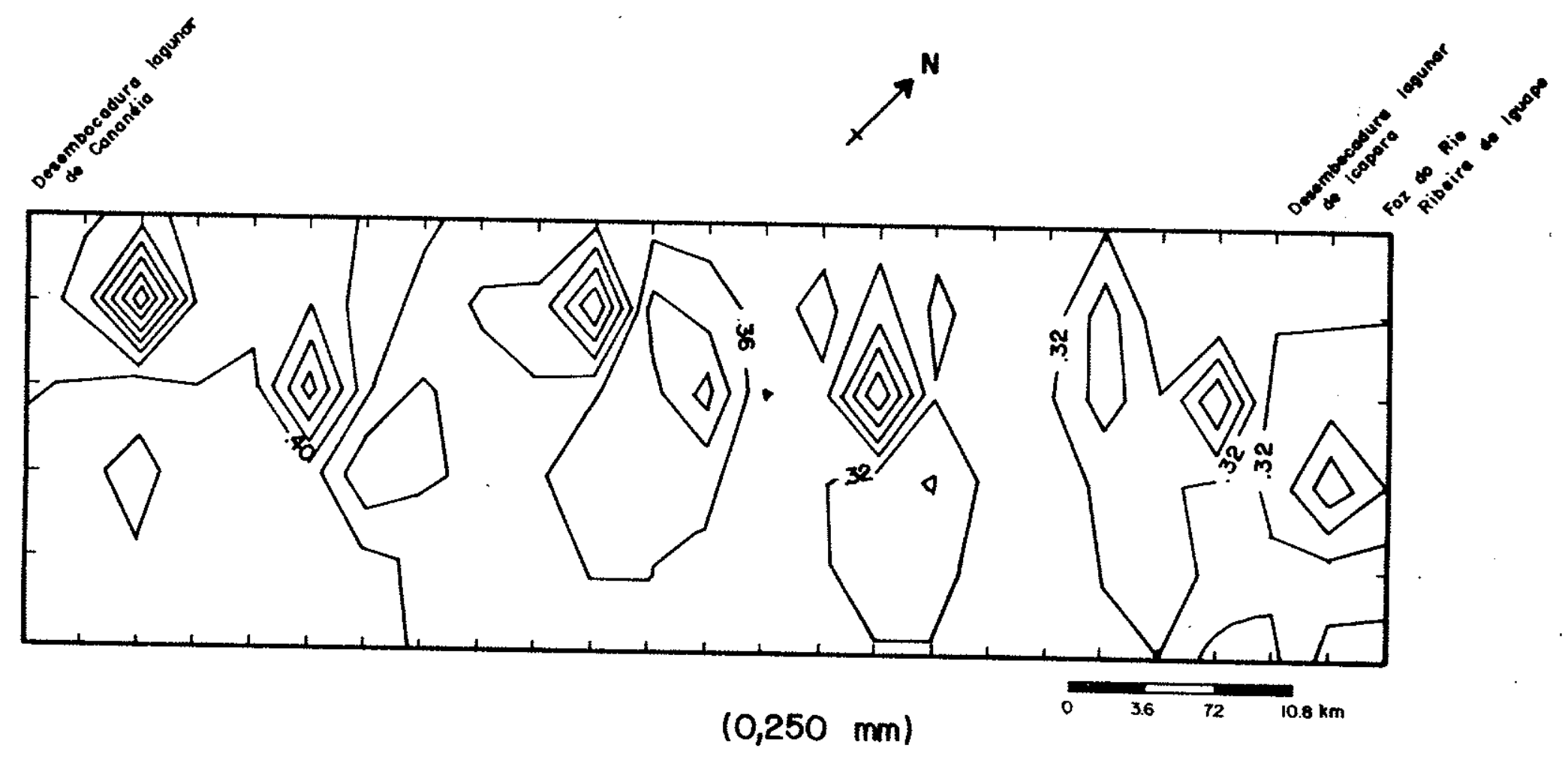

Fig. 10 - Mapa de isovalores do grau de arredondamento, da fração retida na peneira $0,250 \mathrm{~mm}$, na zona de arrebentação. 


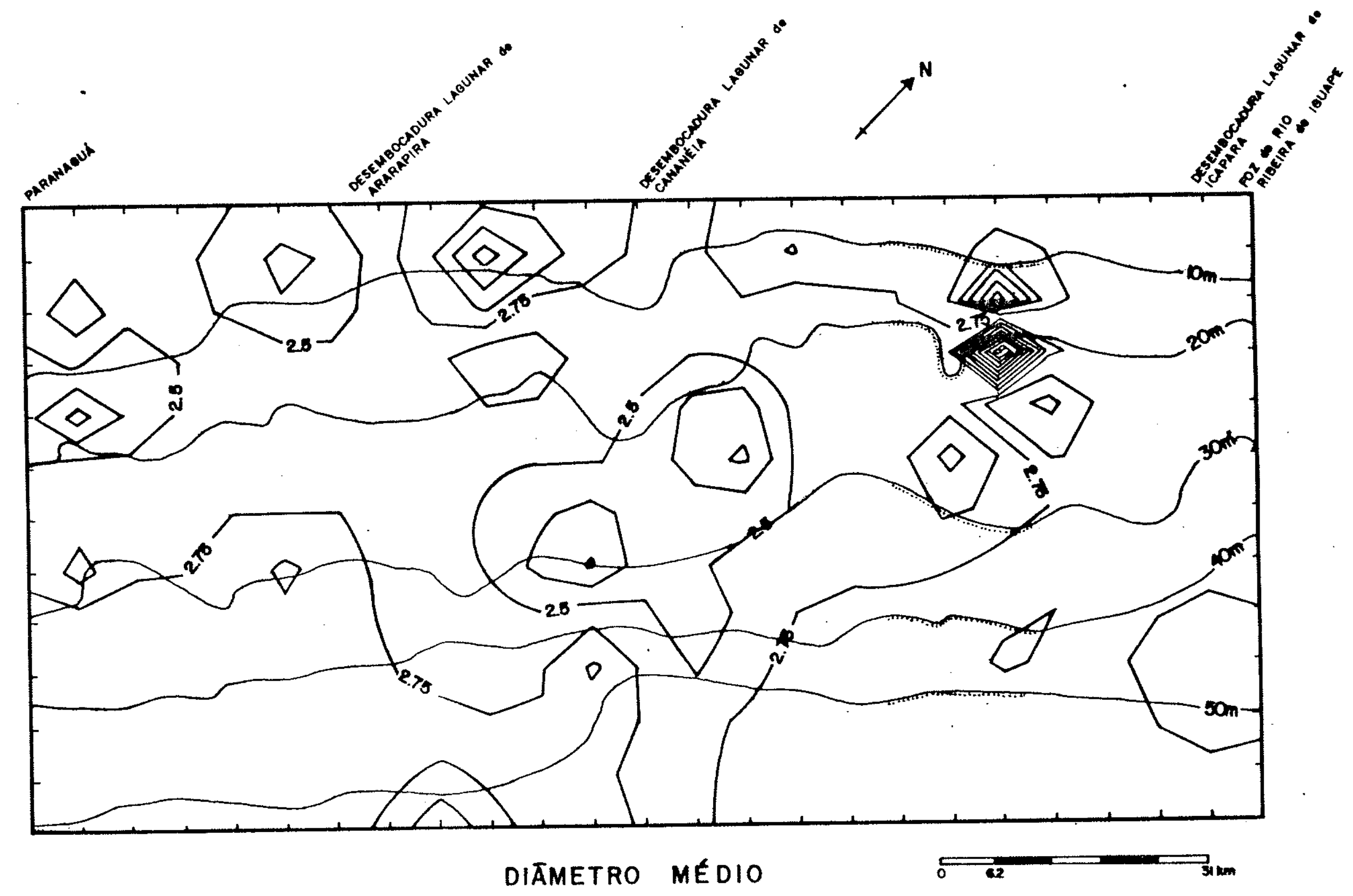

Fig. 11 - Mapa de jsovalores lo diâmetro médio, da distribuição total, das amostras de fundo da plataforma rasa. 


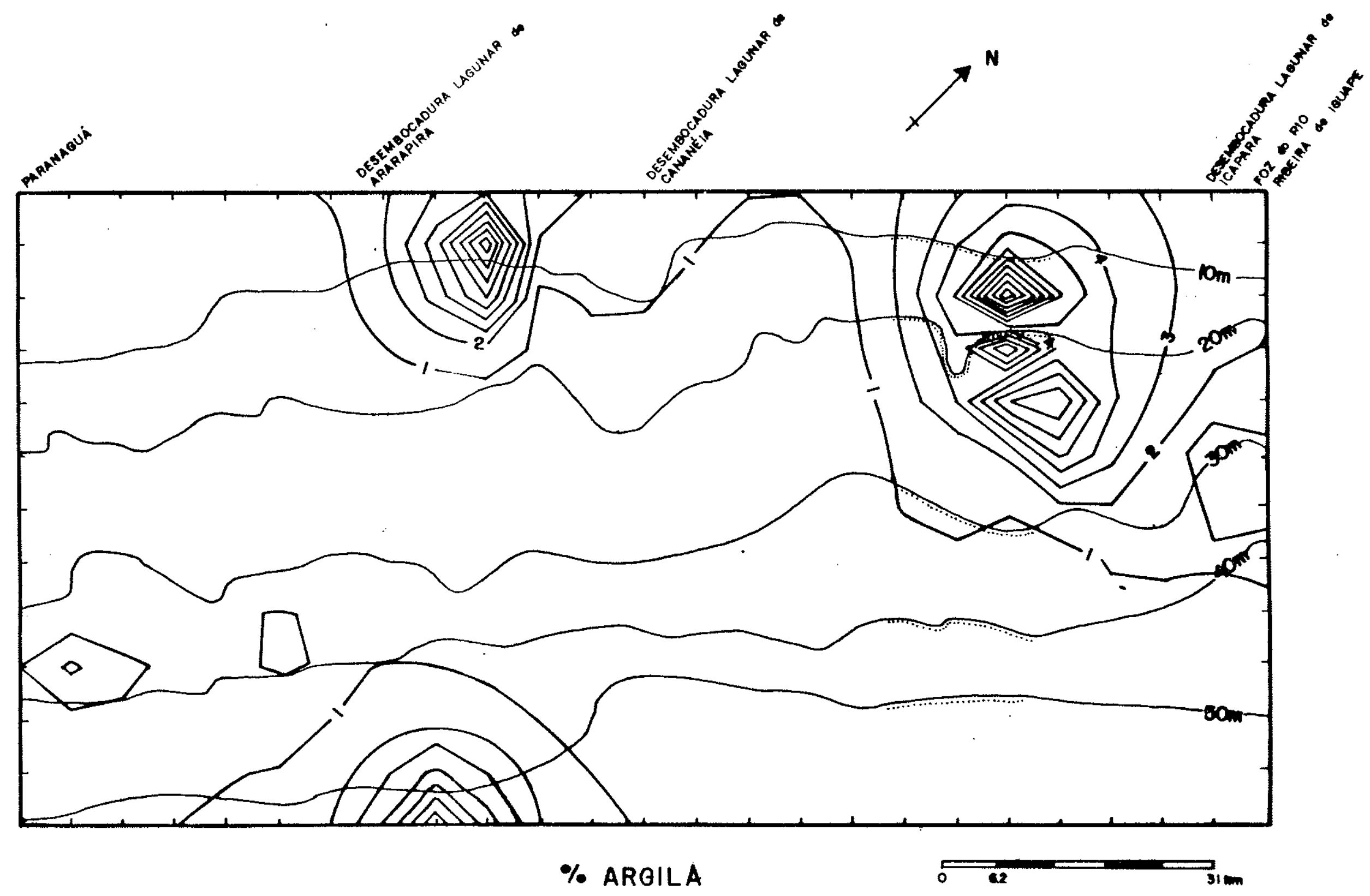

Fig. 12 - Mapa de isovalores da porcentagem de arglla das amostras de fundo da plataforma rasa. 


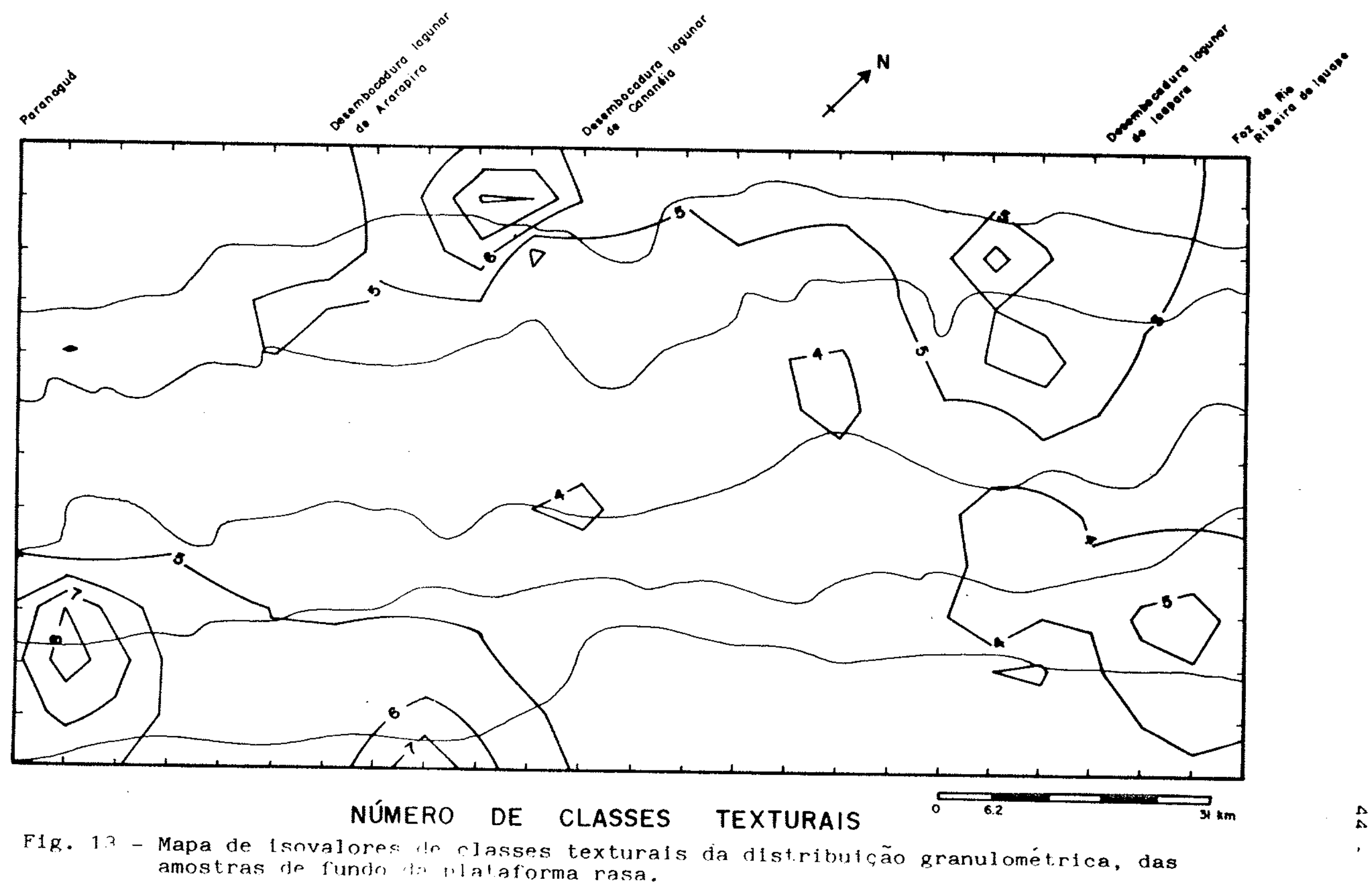


nifesta-se no sentido $\underline{S W}$ a partir da porção central da área, na direção das desembocaduras Iagunares de Icapara e Cananéia.

A estas concentrações de curvas dos parâmetros porcentagem de argila e número de classes texturais, na porção centro sul da área, associa-se uma mudança do alinhamento das curvas batimétricas no sentido do mar profundo.

Esta mudança de alinhamento, a qual está associada uma maior concentração de sedimentos finos, pode representar a resposta topográfica a uma corrente de retorno, gerada pela propagação de correntes de deriva litorânea de seritidos de deslocamento opostos, ou uma simples deflexão da corrente de deriva devido as próprias características topográficas da área.

Os mapas de isovalores de arredondamento das frações $0,500 \mathrm{~mm}$ e $0,250 \mathrm{~mm}$, apresentam também um padrão de curvas correlacionável com a feição topográfica de fundo (fig. 14 e 15).

As particulas mais arredondadas foram encontradas a SW dessa feicão entre as isóbatas de $10 \mathrm{~m}$ e 25 metros, sendo que rumo a $\underline{N E}$ e maiores profundidades ocorre diminuição do grau de arredondamento dos sedimentos de fundo.

Considerando-se apenas a porção $\underline{N E}$ da figura situada entre a foz do Ribeira de Iguape e a porção central da Ilha Comprida, observa-se que o arredondamento aumento da foz do Ribeira no sentido $\mathrm{SW}$. Este crescimento é truncado na porção média da figura, onde as curvas de isovalores se estendem perpendicularmente à costa.

Essas tendências analisadas conjuntamente fazem supor a existência de pelo menos dois sentidos distintos no transporte de fundo, cuja resultante está direcionada rumo ao oceano.

2.2 - Composição mineralógica dos sedimentos

2.2.1 - Análise do teor de carbonato biodetrítico

o teor de carbonato biodetrítico foi determinado a partir da diferença percentual de peso verificada antes e após o ataque com $\mathrm{HCl}$ diluido a $10 \%$, adicionado em quantidade sú 


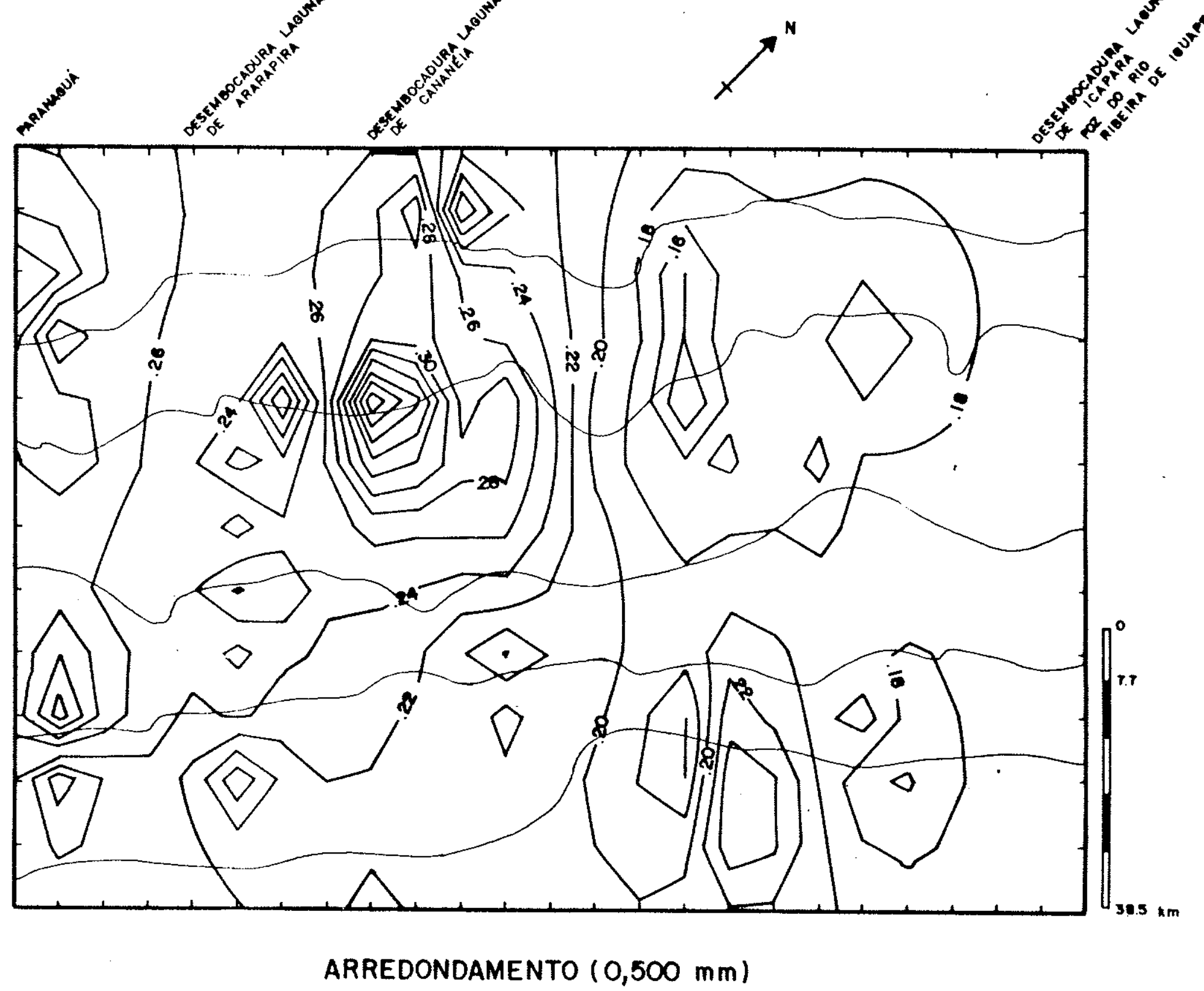

Fig. 14 - Mapa de isovalores do grau de arredondamento, da fração retida na peneim $0,500 \mathrm{~mm}$, na plataforma rasa. 


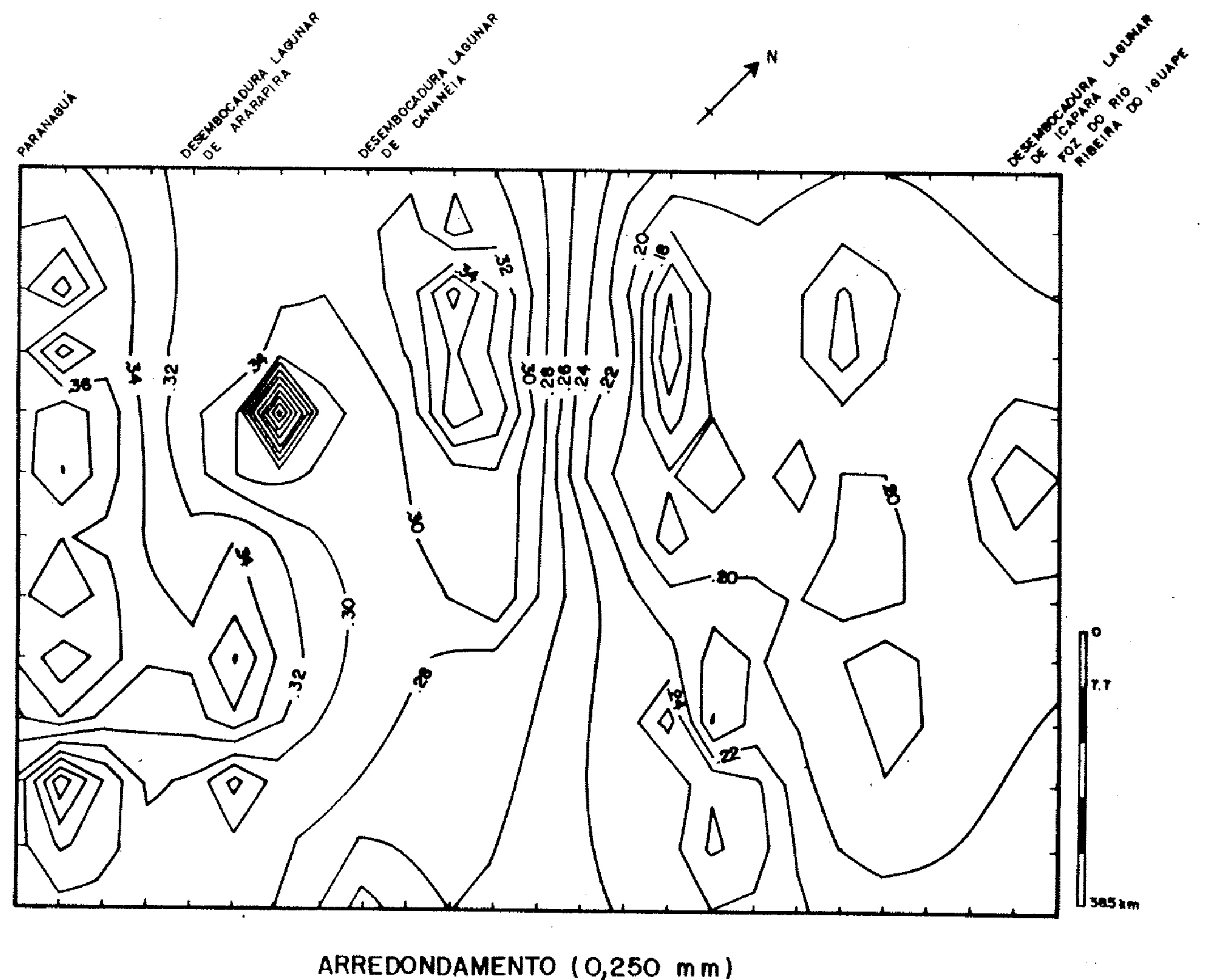

Fig. 15 - Mapa de iscratores do grau de arredondamento, da fração retida na peneira ", 250 mm, na plataforma rasa. 
ficlente para a eliminação total do carbonato. A análise foi efetuada em todas as amostras coletadas estando os resultados ex pressos nas Tabelas 4 a 8 .

As formações Cananéia e Santos apresentam teores nulos de carbonato biodetritico evidenciando, com certeza, um processo de dissolução após a sedimentação desses depósitos, com eliminação total de carbonatos eventualmente existentes por oca sião da deposição.

Entre as demais unidades a plataforma rasa é a que apresenta o maior valor $35,10 \%$, enquanto na zona de arreben tação este valor máximo diminui para $19,10 \%$ e na falxa intermarés para $3,87 \%$ (Tabela 18).

$\mathrm{Na}$ faixa intermarés a variação nos perfís alinhados paralelamente a linha de costa apresentam uma distribuicão aleatória nos níveis de maré mais alta (nivel C) e na porcão intermediária entre os extremos de maré (nivel B). Para a faixa de maré baixa, é possível ldentificar um padrão nos teores de carbonato biodetritico. Na face oceânica da Ilha Comprica, no trecho compreendido entre a localidade de Pedrinhas e o antigo canal fluvial artificial denominado Valo Grande, ocorre uma alta concentração dos valores de carbonato biodetrítico.

Esta diferença dos padrões de distribuição, nos perfís amostrados, reflete diferenças na acumulação de biodetritos ao longo da faixa intermarés.

Nas porções mais elevadas dessa unidade onde 0 transporte por deriva litorânea ocorre apenas em curtos periodos dos ciclos de maré, níveis b e c, os altos valores do conteú do de carbonato biodetritico, contido nos sedimentos, representam acumulações de vários ciclos distintos de transporte.

Para a faixa de maré mais baixa, sob constante movimentação das águas pela ação das correntes de deriva litorânea, as concentrações de carbonato biodetritico representam prin cipalmente o grau de competência do agente transportador de ação ininterrupta, antes de representar concentrações originadas de acumulações de biodetritos depositados em ciclos de transporte distintos. 
Na zona de arrebentação, o mapa de isovalores apresenta teores próximos à média da área. Uma concentração de curvas de teores mais elevados ocorre a $\underline{\text { SW }}$ da área, nas proximidades da desembocadura lagunar de Cananéia. Nesta mesma área ocorrem também as concentrações mais elevadas de material arenoso fino a pelítico provenientes da região lagunar (fig. 16).

$\mathrm{Na}$.plataforma rasa as maiores concentrações estão localizadas nas regiões mais profundas dos perfís transversais e a partir da isóbata de 40 metros, as análises indlcaram teores de carbonato biodetritico superiores à média.

Junto à costa, próximo a desembocadura lagumar de Cananéia aparece também teores mais elevados do que a média, provavelmente associados à área de maior concentração de sedimentos peliticos de origem continental (fig. 17).

Os teores mais elevados de carbonato biodetriti co estão intimamente associados a sedimentos onde ocorrem misturas de termos granulométricos, com predominância para os termos pelíticos. A estes sedimentos estão geralmente associados os mais elevados teores de matéria orgânica, como também apresentam uma maior coesão o que permite um substrato mais propício à fixa ção e desenvolvimento das comunidades animals.

Além disso, esta área de maior concentração de sedimentos peliticos representam também zonas de menor movimentação de fundo, o que reflete uma incapacidade do agente transportador em remover ou mesmo fragmentar as carapacas animais.

\subsection{2 - Anál1se da fração grossa - Coarse Fraction Analysis}

Aplicando-se uma metodologia semelhante a aplicada por Mahiques (1987), em sedimentos de fundo da Baía da Ilha Grande, foram identificados os constituintes retidos nas peneiras de $0,500 \mathrm{~mm}$ e $0,250 \mathrm{~mm}$ dos sedimentos da plataforma rasa sul paulista.

A escolha destes intervalos granulométricos deve-se a possibilidade de uma rápida identificação e diferenciação de conjuntos com características distintas, bem como uma ava liação do significado ambiental dos componentes biogênicos e ter rígenos. 


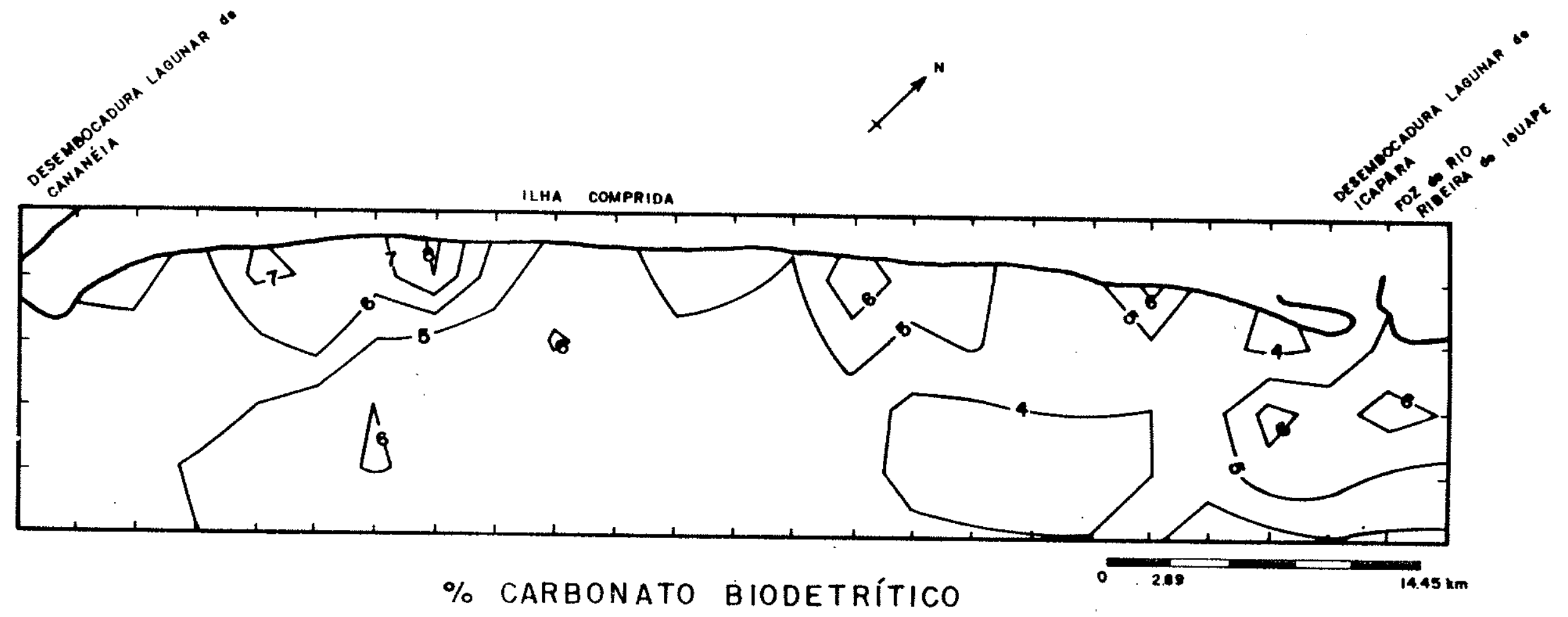

Fig. 16 - Porcentagem de carbonato biodetrítico nos sedimentos de fundo da zona de arrebentação. 


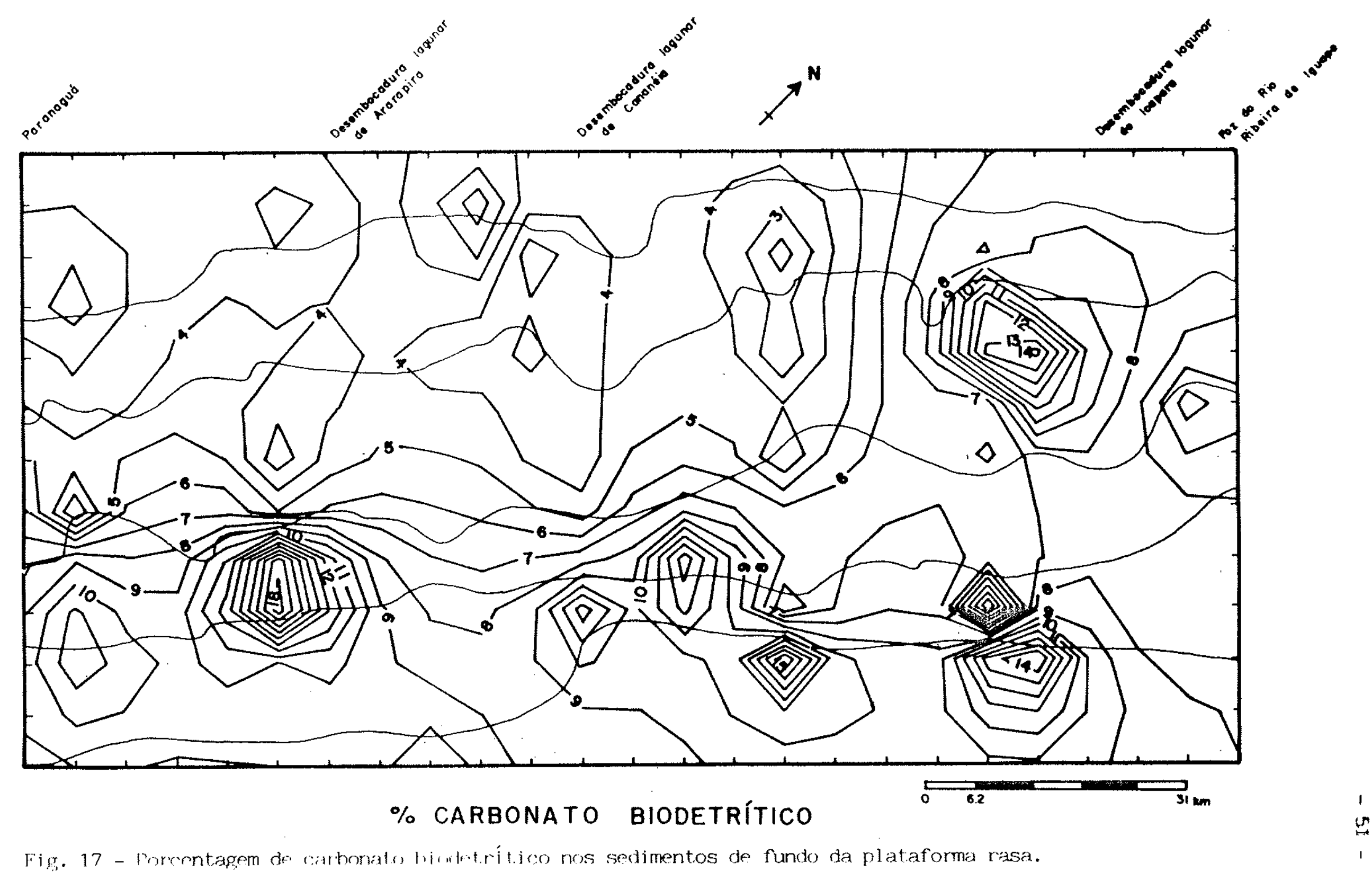


Esta técnica consiste na observação, sob lupa binocular, dos principais constituintes das frações grosseiras realizando-se uma estimativa da quantidade relativa desses constituintes, como forma de se complementar a caracterização textural dos sedimentos, na tentativa de interpretação dos ambientes recentes de deposição.

Nas frações $0,710-0,500 \mathrm{~mm}$ e $0,350-0,250 \mathrm{~mm}$ das amostras coletadas na plataforma rasa, foram contados cerca de 200 grãos, identificados os constituintes e estabelecidas as porcentagens relativas de terrigenos (quartzo, quartzo limonitizado, minerais pesados e outros fragmentos) e biogênicos (fragmentos de conchas, moluscos, testas de foraminiferos, fragmentos de animais e outros constituintes).

Da análise dos resultados, apresentados nas Tabe belas 19 e 20, e dos mapas de isovalores elaborados para a concentração de biogênicos em duas frações granulométricas (figs. 18 e 19$)$, é possivel verificar-se predominância de sedimentos terrígenos na faixa litorânea compreendida entre as isóbatas de o (zero) a aproximadamente 40 metros.

2.2 .3 - Minerais leves

Os minerais leves das frações areia fina $(0,250$ a $0,125 \mathrm{~mm})$ e areia muito fina $(0,125-0,062 \mathrm{~mm})$, bem como da so matória das fraçoes compreendidas entre areia média $(0,500$ $0,250 \mathrm{~mm})$ e areia grossa $(1,000-0,500 \mathrm{~mm})$, obtido após a separaça por líquido pesado (bromofórmio), foi submetido à determinação mineralógica pelo método colorimétrico ("staining"). Este método consiste de um leve ataque por ácido fluorídrico dos grãos montados sobre lâmina impregnada de balsamo do Canadá, sem lamínula, à qual são adicionados os corantes cobaltonitrito de sódio e o eosina. Com a adição destes corantes os feldspatos potássicos adquirem coloração laranja-amarelada, os plagioclásios ficam róseos e o quartzo permanece incolor.

As lâminas submetidas a este procedimento tiveram seus constituintes identificados, contados cerca de 200 grãos em Iupa binocu lar, e estabelecidas as porcentagens de quartzo e feldspato cujos resultados estão apresentados na Tabela 21 . 


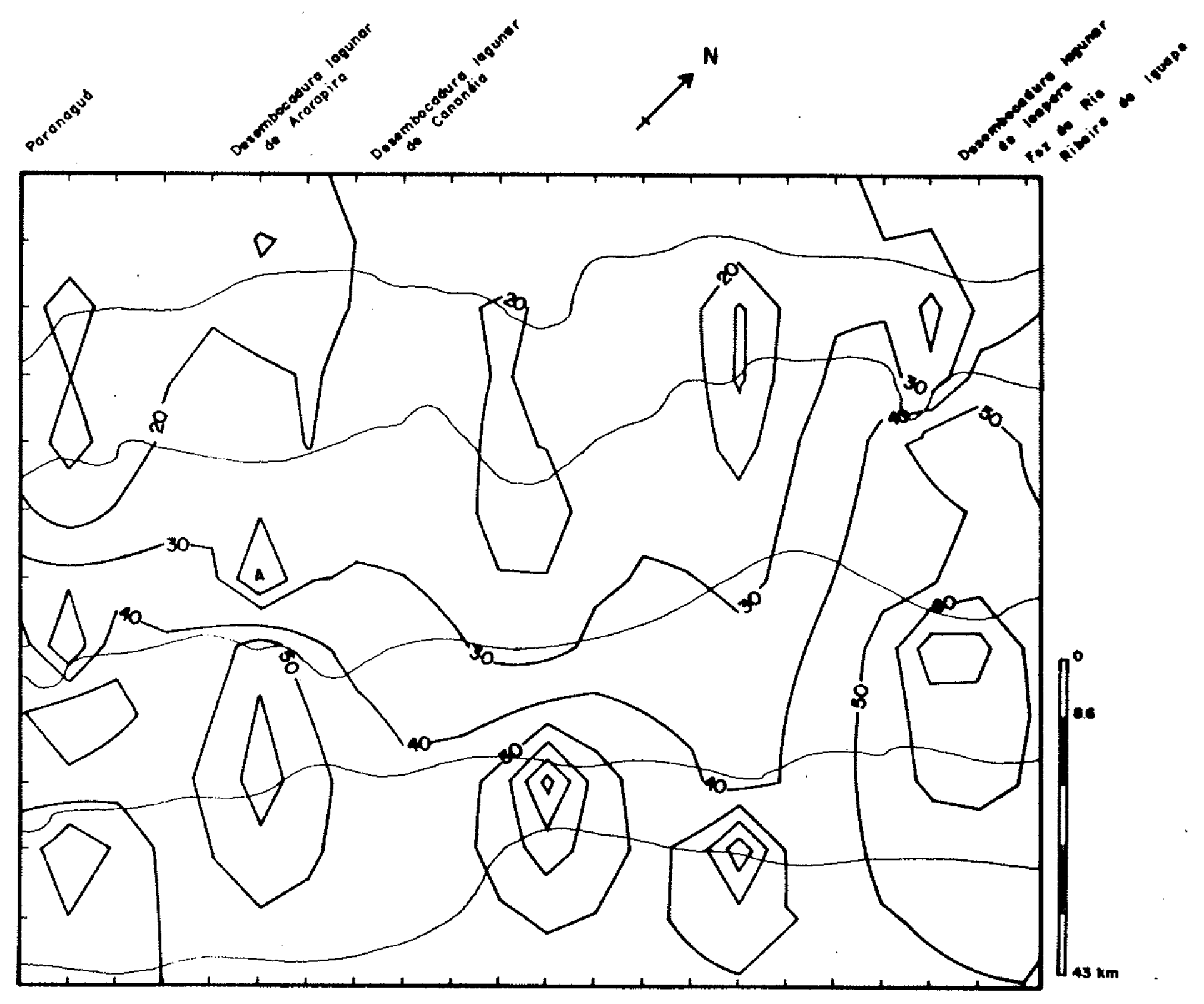

$\%$ DE BIOGENICOS $(0,710-0,500 \mathrm{~mm})$

Fig. 18 - Mama de iscrvalores da porcentagem de biogênicus, na fração areia frrat $(0,710$ - $0,500 \mathrm{~mm})$ das amostras de finrus des plataforma rasa. 


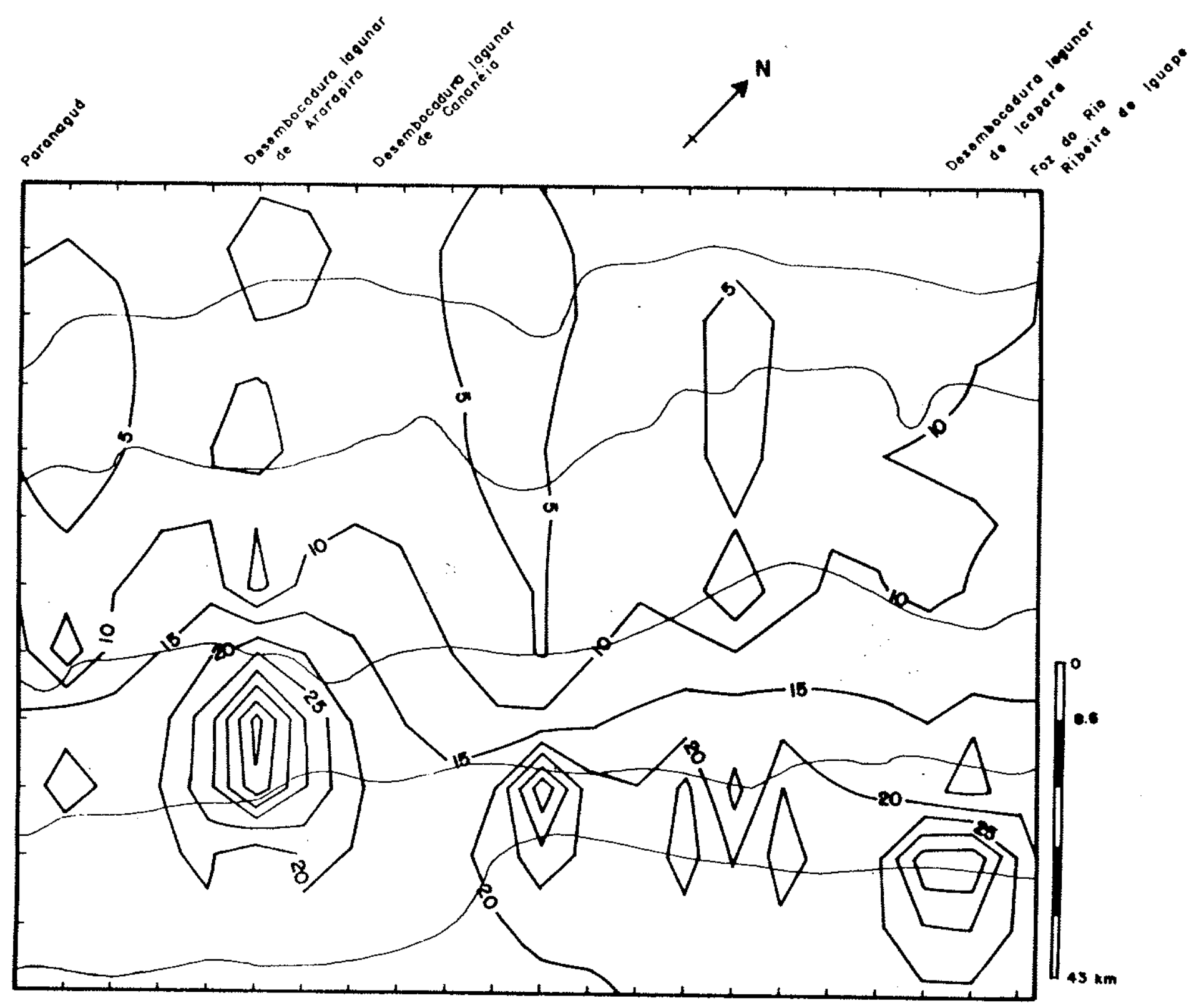

$\%$ DE BIOGENICOS $(0,350-0,250 \mathrm{~mm})$

Fig. 19 - Mapa de jsovalores da porcentagem de biogenicos, na fração areiamédia $(0,350-0,250 \mathrm{~mm})$ das anmstras de fundo da plataforma rasa. 
De maneira geral todas as unidades anal1sadas; Formação Cananéia, cordões litorâneos, falxa intermarés, zona de arrebentação e plataforma rasa; são caracterizadas por alta maturidade da fração leve apresentando precominância de grãos de quartzo ( > $90 \%)$.

Nas pequenas assemblélas de feldspatos ldentifi cadas predominaram os feldspatos potássicos sobre o plagioclásicos, sendo que, nos cordões litorâneos, faixa intermarés e zona de arrebentação a presença dos feldspatos potássicos representa $100 \%$ da contagem realizada.

Para a plataforma rasa as porcentagens de plagioclásio, presentes por lâmina, variaram de 10 a $20 \%$ nas frações arela média e grossa e de menos de $10 \%$ nas frações mais finas.

$\mathrm{Na}$ Formação Cananéia, para todas as frações os plagioclásicos representam aproximadamente $10 \%$ da assembléia dos feldspatos identificados.

Suguio \& Tessler (1987), durante os trabaihos de detalhamento das caracteristicas texturais e das estruturas sedimentares, reconheceram nos afloramentos da Formação Cananéia, da região lagunar de Cananéia-Iguape, pequenas pelotas de um material branco, pouco denso, que foi identificado como gibbsita por difratometria de raio-X.

Em função da sua desagregabilidade essas pelotas não puderam ser observadas nas assembléias de minerais leves.

A origem destas pelotas de gibbsita em afloramen tos da Formação Cananéia tem sido suposta como resultante da precipitação de soluções ricas em alumina, derivadas da lixiviação de sedimentos com alta concentração de feldspato.

Uma análise dos teores de feldspatos, potássicos e sódicos, dos afloramentos onde macroscopicamente foram iden tificadas as pelotas de gibbsita, apresentou valores semelhantes aos teores obtidos para os afloramentos em que macroscopicamente essas pelotas não foram detectadas. 
Desta maneira parece claro supor a não existêncla de uma correlação direta, em escala de afloramento, de presença ou ausência das pelotas com teores mais elevados ou mals baixos de feldspatos.

Porém, devido a alta porosidade e permeabilidą de da sequêncla arenosa de topo da Formação Cananéia, esta hipótese sobre a origem das pelotas não pode ser descartada, desde que, suponha-se que as soluções ricas em alumina provenham de fontes externas aos afloramentos que contém estas pelotas.

\subsection{4 - Minerais pesados}

Os minerais pesados presentes em uma assembléia mineralóglca, bem como suas variações locais ou regionals, podem ser interpretados como a interação de fatores diversos ligados às características das áreas - fonte (litologia e estabilidade diferencial dos minerais da rocha matriz); da resistência física dos minerais e da razão hidraúlica, além dos fenômenos pósdeposicionais (dissolução intra-estratal) e erros estatísticos (Suguio, 1980).

Alguns destes fatores, tem um efeito mais uniforme sobre todo conteúdo das assembléias de pesados, enquanto que outros como a razão hidraúlica (Rubey, 1933), devem refletir essencialmente a tendência de cada mineral concentrar-se em uma outra determinada fração granulométrica.

A dificuldade de distinção entre os fatores sin genéticos e pós-deposicionais constitue-se em um obstáculo ao ré conhecimento das causas geradoras entre as diferenças locais e regionais das assembléias de minerais pesados.

Além disso é interessante que as avaliações quantitativas das assembléias de pesados sejam complementadas com informações sobre forma dos grãos que constituem estas assem bléias, para a tentativa de distinção dos fatores singenéticos e epigenéticos. 


\subsubsection{1 - Métodos}

Utilizou-se, para a separação e identificação das assemblélas dos minerais pesados, os intervalos areia fina $(0,250-0,125 \mathrm{~mm})$ e arela muito fina $(0,125-0,062 \mathrm{~mm})$. Outros intervalos, como areias mals grosseirase pelitos foram rejeitados por apresentarem concentrações reduzidas de pesados ou grandes dificuldades de identificação óptica.

A separação gravimétrica das frações leve e pesa da foi efetuada em funís apropriados,utilizando-se como líquido denso o bromofórmio $\left(\mathrm{CHBr}_{3}\right)$ de densidade $2,89 \mathrm{~g} / \mathrm{cm}^{3}$, que corres ponde aproximadamente ao limite entre as fraços leve e pesada.

Objetivando melhor definir a presença dos minerais de interesse econômico, como a magnetita e a ilmenita nos sedimentos do litoral sul paulista, e também aumentar a concentração de minerais pesados transparentes, os concentrados foram preliminarmente submetidos a uma separação com imã de mão. Em seguida foi realizada uma separação eletromagnética em um separa dor eletromagnético Franz ajustado para campos magnéticos de $0,3 \mathrm{~A}$ e $0,5 \mathrm{~A}$, nos laboratórios do Instituto de Pesquisas Tecnoló gicas de São Paulo, IPT/SP.

A separação eletromagnética, precedida de separação com imã de mão, permitiu subdividir as frações areia fina e areia muito fina em quatro sub-frações, classificadas em função da suscetibilidade magnética em:

- assembléia de minerais fortemente magnéticos, atraídos pelo imã de mão (Mag);

- assembléia de minerais magnéticos, não atraídos pelo imã de mão mas retidos no separador Franz com campo magnético de $0,3 \mathrm{~A}(\mathrm{~F}+)$;

- assembléia de minerais fracamente magnéticos retidos no separador Franz com campo magnético entre os valores $0,3 \mathrm{~A} e$ $0,5 \mathrm{~A}(\mathrm{~F}-)$;

- assembléia de minerais não magnéticos não retidos no separa dor Franz mesmo sob campo magnético de $0,5 \mathrm{~A}$ (NM).

Para cada concentrado de minerais pesados individualizado, com exceção do concentrado fortemente magnético, 
foram montadas lâminas não permanentes com líquido de índice de refração $n=1,547$, preparado a partir de Nujol e Alfa-monobrononaftaleno.

A contagem dos grãos obedeceu a alguns procedi mentos visando alcançar um maior grau de confiabilidade dos resultados obtidos. Devido à presença de uma maior quantidade de minerais opacos nos resíduos $F(+)$ e $F(-)$, para estas sub-fra cões foram contados no mínimo duzentos grãos. Na lâmina do resí duo não magnético foram identificados e contados pelo menos cem grãos transparentes e não micáceos além dos grãos opacos.

De acordo com Hubert (1962), a contagem de 100 grãos transparentes em uma amostra com $90 \%$ de opacos, equivale à contagem de 1000 grãos do residuo original.

Portanto, como a porcentagem de opacos na amostra total, neste estudo, variou entre 10 e $80 \%$ e a contagem das lâminas do resíduo não magnético variou entre 200 e 360 grãos, tem-se uma contagem efetiva minima equivalente a 600 grãos por fração granulométrica analisada.

De posse de todas as informações, desde o peso dos minerais pesados na amostra total até as porcentagens de cada mineral nas subamostras foram calculados, através de um programa em linguagem BASIC para microcomputador da linha Apple, os teores de cada mineral por fração granulométrica bem como os teores totais dos minerais por amostra. Este procedimento é me lhor do que o tradicional, onde a frequiência relativa de cada mí neral por fração, é obtida por contagem de apenas 100 grãos trans parentes e não micáceos, conforme descrito por Hubert (op.cit), permitindo analisar mais detalhadamente os concentrados pesados, em especial as relações entre os minerais opacos e/ou magnéticos.

Por outro lado, como na análise das lâminas das sub-frações é realizada apenas uma identificação e contagem, sem a pesagem dos gräos minerals, os teores só podem ser obtidos a partir de algumas simplificações.

Estas simplificações decorrentes das imprecisões quanto as reais características de forma, volume e densidade dos minerais constituintes dessas assembléias, implicaram na adoção 
de diâmetros médios intermediários, para cada fração granulométrica analisada. A partir deste procedimento a análise de frequiência numérica realizada fol transformada diretamente em análise volumétrica.

Assumiu-se, também, não haver diversificação na forma dos minerais presentes, bem como adotou-se valores médios, expressos na literatura, para a densidade dos minerais pesados. A adoção da densidade real de alguns minerals de composição sim ples, como o zircão $\left(\mathrm{Z}_{\mathrm{r}} \mathrm{SiO}_{4}, \mathrm{~d}=4,72\right)$, é relativamente segura mas praticamente impossivel para minerais mais complexos, como a hornblenda, que apresenta variações de teores de elementos químicos presentes em sua composição.

Finalmente, para que se pudesse comparar os resultados deste trabalho com os autores prévios (Pomerancblun \& Costa, 1972; Petri \& Suguio, 1973; Barcelos, 1975 e Giannini, 1987), os teores de minerais pesados foram transformados em frequiências relativas.

As freqüências relativas dos minerais transpa-. rentes e não micáceos, das frações areia fina e muito fina, foram calculadas a partir dos teores de cada mineral nas respectivas frações, por meio de um outro programa em linguagem BASIC, também desenvolvido pelo M.Sc. Michel Michaelovitch de Mahiques.

$\mathrm{Na}$ avaliação das freqüências relativas dos minerais pesados foi usada as propostas de Coutinho \& Coimbra (1974) e Coimbra (1976, 1983) modificado por Giannini (1987), que é baseada nos seguintes limites:

Frequiência média - é a média aritmética do mineral em todas as amostras analisadas.

Frequiência de ocorrência - esta frequência porcentual é obtida dividindo o número de amostras nas quais - mineral está presente, pelo número total de amostras.

Frequiência de classes - a partir de amostras nas quais o mine ral está presente, é apresentada uma clas sificação segundo a abundância. Foi consí derado superabundante o mineral com fre- 
quiência superior a $50 \%$; abundante entre 10 e $50 \%$, comum entre 5 a $10 \%$; raro entre 2,5 a $5 \%$, muito raro maior que zero e menor que $2,5 \%$ e ausente quando o mineral não foi identificado.

A maturidade mineralógica foi definida com base no número de espécies mineralógicas, calculada a partir da soma dos minerais com frequência superior a $1 \%$.

o indice ZTR (Hubert, 1962), definido como a so ma das frequiências porcentuais de zircão, turmalina e rutilo foi avaliado a partir da classificação proposta por Coimbra ( 1976 ) onde os intervalos considerados são:

$0-10 \%=$ Superabundância de minerais instáveis

$10-40 \%=$ Abundância de minerais instáveis

$40-60 \%=$ Frequiências semelhantes de minerais instáveis e estáveis

$60-90 \%=$ Abundância de minerais estáveis

$90-100 \%=$ Superabundância de minerais estáveis

Finalmente, foi feita uma avaliação da potencia Iidade econômica da ilmenita ao longo da faixa litorânea compreendida entre a foz do rio Ribeira de Iguape e a Ilha do Cardoso no litoral sul do estado de são paulo.

2.2.4.2 - Área Emersa

2.2.4.2.1 - Sedimentos pleistocênicos - Formação Cananéia

As frequiências relativas de minerais pesados da Formação Cananéia, em ordem decrescente de abundância, conforme resultados de análise de 32 amostras de areia muito fina (Tabe1a 22) e 10 amostras de areia fina (Tabela 23), foram as seguintes:

Fração areia fina $(0,250$ - 0,125 mm) - turmalina, zircão, estaurolita, epídoto e hornblenda com frequiências médias superiores a $5 \%$, e andaluzita, monazita, cianita, sililmanita, fibrolita, hiperstênio, granada, rutilo e tremolita com porcentagens in feriores a este valor; 
Fração areia muito fina $(0,125-0,062 \mathrm{~mm})$ - zircão, turmali na, epídoto, estaurolita, rutilo, homblenda e cianita com frequiênclas médias superiores a $5 \%$ e andaluzita, sillimanita, tre molita, perowskita, granada, anatásio, hiperstênio, monazita, ti tanita com valores médios inferiores a $5 \%$.

Petri \& Suguio (1973), no estudo pioneiro do con centrado pesado da sequiência arenosa de topo da Formação Cananéla no litoral sul do estado de São Paulo, descreveram assembléias semelhantes às identificadas neste estudo com exceção da presença de dois minerais, clorita e apatita, e a ausência de dois outros, hornblenda e epidoto.

Barcelos (1975), estudando 4 amostras da Formação Cananéia coletadas na parte suI da Ilha Comprida - SP, Iden tificou na areia fina os minerais: turmalina, hornblenda, epídoto, clanita, sillimanita e estaurolita e como secundários zircão, andaluzita e rutilo.

$\mathrm{Na}$ areia muito fina são abundantes os minerais turmalina, zircão e epídoto e comuns hornblenda, cianita, rutilo e estaurolita.

De maneira geral, as assembléias descritas por Barcelos (op. cit.) assemelham-se às identificadas neste estudo, com exceção do zircão na fração areia fina, abundante nos afloramentos pleistocênicos de toda a região lagunar e praticamente ausente da porção sul da Ilha Comprida.

$\mathrm{Na}$ planicie costeira de Peruíbe - Itanhaém, situada a NE da planície de Cananéia - Iguape, a análise dos sedimentos pleistocênicos da Formação Cananéia revela sensível diferenca na assembléia de minerais pesados. Nesta planície, Gianni ni (1987) identificou, como mais abundantes, para ambas as frações granulométricas, os minerais: turmalina, sillimanita e estaurolita e como comuns, para a areia fina, o hiperstênio e a hornblenda, enquanto para a fração areia muito fina o zircão e a cianita.

Portanto, baseados apenas nas identificações das assembléias de minerais pesados, realizadas por diferentes autores em sedimentos de topo da Formacão Cananéia é possível identi 
ficar a existência de fontes distintas e/ou mecanismos de transporte e seleção diferenciados, principalmente para as sequências pleistocênicas localizadas a $\underline{N E}$ e $\underline{S W}$ do Maciço da Juréia.

\subsubsection{2 - Cristas praiais holocênicas da Ilha Comprida}

Os sedimentos holocênicos dos cordões litorâneos da face oceânica da Ilha Comprida, apresentam nos concentra dos de minerais pesados de 10 amostras analisadas (Tabelas 24 e 25), os seguintes minerais em ordem decrescente de importância:

Fração areia fina $(0,250$ - 0,125 mm) - turmalina, hornblenda, epídoto, estaurolita e sillimanita com frequiências médias superiores a 5\%; zircão, cianita, granada e fibrolita com porcentagens inferiores a $5 \%$ e maiores do que $1 \%$ e andaluzita, perowskita, titanita, tremolita, monazita e anatásio como traços;

Fração areia muito fina $(0,125$ - 0,062 mm - zircão, epídoto, turmalina, estaurolita, hornblenda, rutilo e siliimanita com frequiências médias superiores a $5 \%$ e cianita, granada e andaluzi ta com porcentagens inferiores a este valor.

As assembléias de minerais pesados encontradas nas 10 amostras analisadas são iguais às detectadas por Barcelos (1975), que executou um estudo detalhado da Ilha Comprida.

Na planjicie costeira de Peruíbe - Itanhaém, Giannini (1987) identificou assembléias semelhantes, à exceção da presença preponderante do hiperstênio, ausente nos sedimentos da IIna Comprida, e uma frequência maior da monazita entre os minerais pesados dos sedimentos holocênicos dos cordões litorâneos.

Estas diferenças detectadas nos sedimentos pleis tocênicos das planícies litorâneas sul paulista só vem reforçar a hipótese da existência de fontes locais de fornecimento de sedimentos durante a deposição, das formações pleistocênica (Fm. Cananéia) e holocênia (Fm. Santos).

A ausência de minerais autigênicos e de alteracões significativas na estrutura e forma (dissolução, crescimento secundário, etc) dos minerais pesados das formações quaterná rias litorâneas do sul do estado, demonstram a pouca importân- 
cia dos fenômenos diagenéticos no conjunto desses sedimentos I1torâneos de 1dade geológica tão recente.

\subsubsection{3 - Faixa Intermarés}

OS sedimentos arenosos das faixas intermarés das Ilhas do Cardoso e Comprida apresenta, no concentrado de minerais pesados de 10 amostras (Tabelas 26 e 27 ), os segulntes mine rais em ordem decrescente de importâncta:

Fração arela fina $(0,250$ - 0,125 mm - turmalina, epídoto, zircão, hornblenda e estaurolita com frequênctas superiores a $5 \%$; andaluzita, sillimanita, cianita, granada e rutilo com porcentagens inferiores a $5 \%$ e maiores que $1 \%$ e anatásio, monazita e titanita como traços;

Fração areia multo fina $(0,125$ - 0,062 mm - zircão, epídoto, turmalina, rutilo e estaurolita com frequêencias médias superiores a 5\%; hornblenda, cianita, sillimanita, andaluzita e granada com frequiências superiores a $1 \%$ e monazita e perowskita como traços.

Estas assembléias identificadas na faixa intermarés são iguais às descritas por Barcelos (1975) para a mesma área.

Porém, digno de nota é o perfeito zoneamento dos minerais instáveis e estáveis, estando as maiores porcentagens de instáveis na porção mais a $\underline{N E}$ da área, enquanto os estáveis es tão mais concentrados na por $\underline{\mathrm{SW}}$. Esta constatação é mais eviden te no concentrado de minerais pesados da areia fina ao passo que na areia muito fina, a alta porcentagem do zircão tende a mascarar esta tendência geral.

\section{2 .4 .4 - Área Submersa}

As assemblélas de minerais pesados identificadas, para a área submersa do litoral sul paulista, são semelhantes às da zona de arrebentação onde foram analisadas 67 amostras (Tabelas 28 e 29) e para a plataforma rasa com 58 amostras anaIisadas (Tabelas 30 e 31 ). 
Na areia fina $(0,250-0,125 \mathrm{~mm})$ os principais minerais identificados, nestas duas unidades foram: epidoto, hornblenda, turmalina e zircão, sempre com frequîencias médias su periores a $10 \%$, enquanto que estaurolita, sillimanita e andaluzi. ta aparecem também em ambas as unidades com frequiências maiores de $3 \%$.

Na areia fina da zona de arrebentação ainda estão presentes minerais acessórios como o rutilo, e a cianita e como traços em ambas as áreas, um conjunto de minerais formado por: anatásio, augita, brookita, granada, hiperstênio, monazita, perowskita, titanita e tremolita.

$\mathrm{Na}$ fração areia muito fina $(0,125-0,062 \mathrm{~mm})$ ain da predominam os mesmos quatro minerals da areia fina: epidoto, hornblenda, turmalina e zircão sempre com frequiências médias superiores a $10 \%$, secundados por rutilo, estaurolita e granada que em ambas as frações apresentam frequiências médias compreendidas entre 2 e $5 \%$.

Na categoria de traços estão presentes praticamente - mesmo conjunto de minerais identificados na fração areia fina, com destaque para a cianita e a silimanita que na fraça ão areia muito fina apresentam frequiências médias inferiores a $2 \%$.

\subsubsection{5 - Descrição dos minerais}

Epidoto:

Predominam sempre os grãos com formas equiidimen sionais arredondadas e coloração esverdeada (pistachita).

Grãos prismáticos curtos sem coloração (incolores), também foram identificados em especial na região sul da Iha Comprida, na faixa de maré mais alta.

\section{Hornblenda:}

São predominantes os grãos prismáticos com bordas arredondadas e coloração pardacenta (marrom esverdeado), porém são também comuns as variedades incolores com bordas subarredondas. 
Nos sedimentos pleistocênicos são comuns sinals de alteração do tipo denteação terminal, como também uma grande incidência de formas alongadas, subarredondadas, nos sedimentos de fundo.

\section{Turmalina:}

Apresentam uma grande variabilidade de formas e cores como parda, verde (schorlita), verde amarelada, vermelha, rósea, incolor (acroíta) e também azul (indicolita).

A mesma diversidade observada nas cores é constatada nas formas, onde predominam as prismáticas euhedrais e as equiidimensionais arredondadas, sendo que as formas prismáticas com arestas vivas ocorrem em menor proporção.

Nos grãos prismáticos de coloração pardacenta, multo comuns nos sedimentos da área submersa, são comuns as inclusões e nos da faixa intermarés grãos com crescimento secundário.

\section{Zircão:}

As diferentes unidades geológicas estudadas exi bem diferenças nos tipos de zircões. Desta maneira, nos sedimen tos holocênicos da Ilha Comprida predominam os grãos prismáticos de bordas arredondadas secundados por grãos euhedrais, enquanto que na Formação Cananéia nota-se frequiência maior de grãos com formas mais arredondadas.

Uma análise comparativa das formas dos grãos de zircão e turnalina para os sedimentos pleistocênicos e holocênicos da área emersa foi elaborada segundo as propostas de Mackenzie \& Poole (1962, apud Suguio et al., 1974 e Coimbra, 1983). Es ta análise comparativa mostrou ocorrência de grãos dos tipos 2 (prismáticos e arredondados) e 3 (equiidimensionais) em proporcões muito semelhantes e não significativamente superiores ao do tipo 1 (prismático). Desta forma, esta análise foi ineficiente como critério distintivo para o litoral sul, entre os sedimentos holocênicos e os pleistocênicos da Formação Cananéia, que teriam atuado como fonte para as formações litorâneas de idades mais recentes. 
Na faixa intermarés são comuns os grãos prismáticos de bordos arredondados, em especial na porção SW da área, enquanto que na porção $\underline{\mathrm{NE}}$ são 1dentificados uns poucos grãos bipiramidados quebrados, por vezes de coloração rósea. Na área submersa ocorre grande variabilidade de formas estando as mais arredondadas localizadas a $\mathrm{SW}$ da área.

São identiflcados também, em especial na porção $\underline{\mathrm{SW}}$ da área emersa, grãos zonados e metamictizados.

Andaluzita:

Apresenta-se sempre prismática com bordas arredondadas e coloração rósea evidenclada a partir de um intenso pleocroismo.

Cianita:

Apresenta-se como grãos de formas alongadas, arredondadas e subarredondadas.

Estaurolita:

Predominam os grãos eqüidimensionais, com bordas angulosas e coloração predominante amarelo escuro ou marrom amarelado (coco queimado).

Escassas, porém identificadas nos sedimentos da área emersa, são formas denteadas do tipo serrilhamento nas bordas dos grãos.

Granada:

São predominantes os grãos incolores, secundados pelos de tonalidade levemente rósea, apresentando frequientemente feicões superficiais de picoteamento (escamamento). Esta feição das granadas é a mais forte evidência de atuação, embora incipiente, de soluções intra-estratais, nos sedimentos qua ternários do litoral sul paulista.

Rut110:

Ocorre quase sempre como grãos prismáticos euhe drais a subeuhedrais arredondados, de coloração amarelada escura. 
Nos sedimentos da faixa intermarés e, em espe-

cial da área submersa, são comuns também grãos arredondados de coloração avinhada, em especial na porção mais a NE da área.

\section{S1111manita:}

Sempre presente como grãos prismáticos euhedrais, por vezes quebrados, com bordas pouco arredondadas e Inco lores.

São comuns as formas fibrosas (fibrolita), presentes em todas as unidades estudadas.

As caracteristicas principais de outros minerais presentes apenas como traços são as seguintes:

Anatásio:

Ocorre como grãos amarelados, quebrados, euhe

drais.

\section{Augita:}

Encontrados como grãos pouco alongados, arredon dados nas bordas.

\section{Brookita:}

É um mineral extremamente raro, incolor a levemente amarelado, de formas euhedrais.

Hiperstênio:

Ocorre como grãos prismáticos curtos, de bordas arredondadas, coloração verde escuro a verde claro, com uma feição terminal de denteamento.

\section{Monazita:}

Grãos subarredondados a arredondados de coloração amarela citrina intensa, em muito semelhantes à primeira vis ta aos grãos arredondados e sujos de epídoto.

\section{Perowskita:}

Grãos prismáticos euhedrais a subeuhedrais de coloraça vermelho amarelado. 


\section{Titanita:}

de coloração párda.

Ocorre como tormas irregulares subarredondadas

2.2.4.6 - Análise de frequência dos minerais transparentes e não micáceos

2.2.4.6.1 - Área Emersa (Tabelas 32, 33, 34 e 35)

2.2.4.6.1.1 - Frequiência média

$\mathrm{Na}$ fração areía fina $(0,250-0,125 \mathrm{~mm})$, sete $\mathrm{m} 1$ nerais (turmalina, zircão, estaurolita, epidoto, hornblenda, si I limanita, cianita) e ainda a andaluzita perfazem mais de $95 \%$ do material analisado da Formação Cananéla, enquanto que na fração areia muito fina $(0,125-0,062 \mathrm{~mm})$, o mesmo grupo de sete minerais acrescidos do rutilo e da andaluzita somam $98 \%$ das assembléias de minerais pesados.

\subsection{2 - Freqüência de ocorrêncta}

$\mathrm{Na}$ fração areia fina $(0,250$ - 0,125 mm), onze $\mathrm{mi}$ nerais (andaluzita, cianita, epidoto, estaurolita, granada, hiperstênio, hornblenda, rutilo, sililimanita, turmalina e zircão) estão presentes em mais de $50 \%$ das amostras da Formação Cananéia, enquanto que, apenas a titanita ao invés do hiperstênio, perfaz - grupo dos onze minerais com mais de 50\% de ocorrência nas amos tras dos cordões litorâneos da Ilha Comprida.

$$
\text { Quanto à fração areia muito fina }(0,125-0,062
$$
$\mathrm{mm}$ ), treze minerais (anatásio, andaluzita, cianita, epidoto, estaurolita, granada, hiperstênio, hornblenda, peroswkita, ruti10, sillimanita, turmalita e zircão), ocorrem nos sedimentos holocênicos da Ilha Comprida com porcentagens acima deste valor.

\subsection{3 - Frequência de classes}

$\mathrm{Na}$ fração areia fina $(0,250-0,125 \mathrm{~mm})$, hornblenda e turmalina apresentam-se exclusivamente como abundantes nos sedimentos da Formação Cananéla e de comuns a abundantes nos sedimentos holocênicos da Ilha Comprida. 
o epídoto e a estaurolita variam em

ambas as unidades de comuns a abundantes, enquanto que a sillamanita nos sedimentos pleistocênicos, a andaluzita e a clanita nos sedimen tos holocênicos e o zircão para ambas as unidades apresentam-se de comuns a raros.

Todos os demais minerais (anatásio, fibrolita, granada, hiperstênio, monazita, perowskita, rutilo, titanita e tremolita) são de ocorrência muito rara ou então estão ausentes, como o hiperstênio nos sedimentos holocênicos da Ilha Comprida.

Para a fração areia muito fina $(0,125-0,062 \mathrm{~mm})$ nos sedimentos pleistocênicos, observam-se os minerais turmalina, rutilo, estaurolita e epídoto como ocorrência de comum a abundan tes, enquanto o zircão chega a ser superabundante em $12,5 \%$ das amostras.

Os minerais cianita, hornblenta, sillimanita e andaluzita apresentam-se de comuns a raros, enquanto os demais (anatásio, brookita, fibrolita, granada, hiperstênio, monazita, perowskita, titanita e tremolita) ocorrem como minerais raros.

Nos sedimentos holocênicos da Ilna Comprida, o epídoto, o zircão e a turmalina são de ocorrência abundante, enquanto que a estaurolita, a hornblenda e o rutilo são de ocorrência abundante a comum.

Com exceção da andaluzita, cianita, granada e sillimanita, que variam de comuns a raros, todos os demais minerais (anatásio, fibrolita, perowskita e xenotima) são de ocorrên cia muito rara.

2.2.4.6.2 - Faixa intermarés (Tabelas 36 e 37)

2.2.4.6.2.1 - Frequiência média

$\mathrm{Na}$ fração areia fina $(0,250-0,125 \mathrm{~mm})$, oito $\mathrm{mi-}$ nerais (turmalina, epídoto, zircão, hornblenda, estaurolita, andaluzita, sillimanita e cianita) perfazem mais de $95 \%$ do concentrado pesado, enquanto que na fração areia muito fina $(0,125$ $0,062 \mathrm{~mm}$ ) os oito minerais (zircão, epídoto, turmalina, rutilo, estaurolita, hornblenda, cianita e sillimanita) representam mais de $98 \%$ do material analisado. 
2.2.4.6.2.2 - Frequiência de ocorrência

$\mathrm{Na}$ fração areia fina $(0,250-0,125 \mathrm{~mm})$, onze $\mathrm{m} \underline{1}$ nerals (andaluzita, cianita, epidoto, estaurolita, granada, horn blenda, rutilo, sillimanita, titanita, turmalina e zircão) estão presentes em mals de $50 \%$ das amostras, enquanto que para a fração arela muito fina, estes mesmos onze minèals ocorrem com fre quiências superiores a $50 \%$ das amostras analisadas.

\subsection{3 - Frequîencia de classes}

Os minerais turmalina e epidoto apresentam-se co mo abundantes em ambas as frações granulométricas analisadas.

O zircão, abundante na fração areia fina, varia de comum a abundante na fração areia muito fina, enquanto a horn blenda, abundante na fração mais grosseira é rara na fração mais fina.

Já a estaurolita varia de comum a abundante na fração areia fina e apenas de rara a comum na muito fina.

$\mathrm{Na}$ fração areia fina variam de comuns a raros os minerais andaluzita, cianita, rutilo, sillimanita e titanita. Para a fração areia muito fina, seguem o mesmo padrão de ocorrên cia de classe os minerais andaluzita, cianita, granada, rutilo e sillimanita.

\subsubsection{3 - Área Submersa (Tabelas 38, 39, 40 e 41) \\ 2.2.4.6.3.1 - Freqüência média}

Na fração areia fina $(0,250-0,125 \mathrm{~mm})$ da zona de arrebentação e plataforma rasa sete minerais (epídoto, turmalina, hornblenda, zircão, estaurolita, andaluzita e sillimanita) perfazem mais de $90 \%$ do material analisado, enquanto que na fração areia muito fina $(0,125-0,062 \mathrm{~mm})$, os minerais epídoto, tur malina, hornblenda e zircão associados aos minerais estaurolita, rutilo e granada também perfazem mais de $90 \%$ do conteúdo pesado. 
$2 \cdot 2 \cdot 4 \cdot 6 \cdot 3 \cdot 2$ - Frequência de ocorrência

$\mathrm{Na}$ fração areia fina $(0,250-0,125 \mathrm{~mm})$, treze $\mathrm{mI}$ nerais (andaluzita, cianita, epidoto, estaurolita, fibrolita, granada, hiperstênio, hornblenda, rutilo, sillimanita, tremolita, turmalina e zircão) estão presentes em mais de $50 \%$ das amos tras da zona de arrebentação e de plataforma rasa.

Para a fração areia muito fina $(0,125-0,062 \mathrm{~mm})$, catorze minerais (anatásio, andaluzita, cianita, epídoto, estaurolita, granada, hiperstênio, hornblenda, perowskita, rutilo, sillimanita, tremolita, turmalina e zircão) perfazem o conjunto de minerais com frequiência de ocorrêncla superior a $50 \%$ das amos tras estudadas.

\section{$2 \cdot 2 \cdot 4 \cdot 6 \cdot 3 \cdot 3$ - Frequiências de classes}

Na zona de arrebentação, o epídoto apresenta-se abundante na fração areia fina e de abundante a superabundante na fração areia muito fina.

Os minerais zircão, turmalina, estaurolita e hornblenda variam de comuns a abundantes para ambas as frações enquanto que o rutilo apresenta o mesmo padrão de frequiência pa ra a areia muito fina.

Apresentando ocorrência de comum a rara, encontra-se na areia fina, a andaluzita e de rara a muito rara os minerais cianita, fibrolita, granada, hiperstênio e tremolita, enquanto que para a areia multo fina apresentam distribuição de classes de rara a muito rara a andaluzita, cianita, granada, hiperstênio, perowskita, sillimanita e tremolita.

Para a plataforma rasa, na fraço areia fina, apresentam-se como abundantes o epidoto, hornblenda e turmalina, enquanto que na fração areia muito fina são abundantes o epídoto, a turmalina e o zircão.

Com frequiências de classes, entre abundante e comum apareceram na fração areia fina andaluzita, estaurolita, sillimanita e zircão e na fração areia muito fina estaurolita, hornblenda e rutilo. 
Todos os demais minerais (anatásio, augita, broo kita, fibrolita, granada, hiperstênio, monazita, perowskita, titanita, tremolita e xenotima) apresentam para ambas as fraçoes granulométricas, frequências de ocorrência compreendidas entre raras e multo raras.

\subsection{4 - Mapas de isovalores de distribuição espacial dos minerais pesados na área submersa}

$\mathrm{Na}$ zona de arrebentação a distribuição de mine-rais pesados na amostra total ( $f i g .20$ ) ocorrem maiores concentrações a $\underline{\mathrm{SW}}$ e $\underline{\mathrm{NE}}$ da área, junto a desembocadura lagunar de Cananéia e foz do rio Rlbeira de Iguape, com sensivel diminui ção rumo à porção central da Ilha Comprida.

Com relação aos quatro minerais pesados, mais frequientes e abundantes nas diferentes unidades estudadas (epidoto, hornblenda, turmalina e zircão), observa-se que entre os dois minerais mais instáveis, epidoto e hornblenda, o segundo apresenta, para ambas as frações, altas concentrações a $\underline{N E}$ da área junto à foz do rio Ribeira de Iguape, com sensivel reduça rumo a $\underline{\mathrm{SW}}$ (figs. 21 e 22 ).

Um pequeno aumento desses valores é observado nas proximidades da desembocadura lagunar de Cananéia, o que só faz acentuar as baixas frequiências presentes na porção mediana da Ilha Comprida.

Por outro lado, a distribuição do epídoto apresenta padrão geral homogêneo para ambas as frações, sem que uma tendência mais definida possa ser verificada.

Para os dois minerais mais estáveis, turmalina e zircão, apenas o segundo apresenta uma tendência bem definida para ambas as frações granulométricas, enquanto que a turmalina, apenas na fração areia fina apresenta uma tendência mais claramen te definida. O mapa de isovalores para a turmalina, na areia fi na (fig. 23), apresenta nas regiões da desembocadura lagunar de Cananéia e foz do Ribeira de Iguape baixas concentrações, com uma tendência pa ra elevação dessas concentrações rumo ao oceano e porção central da Ilha Comprida. Na porção central ocorre um encontro dessas 


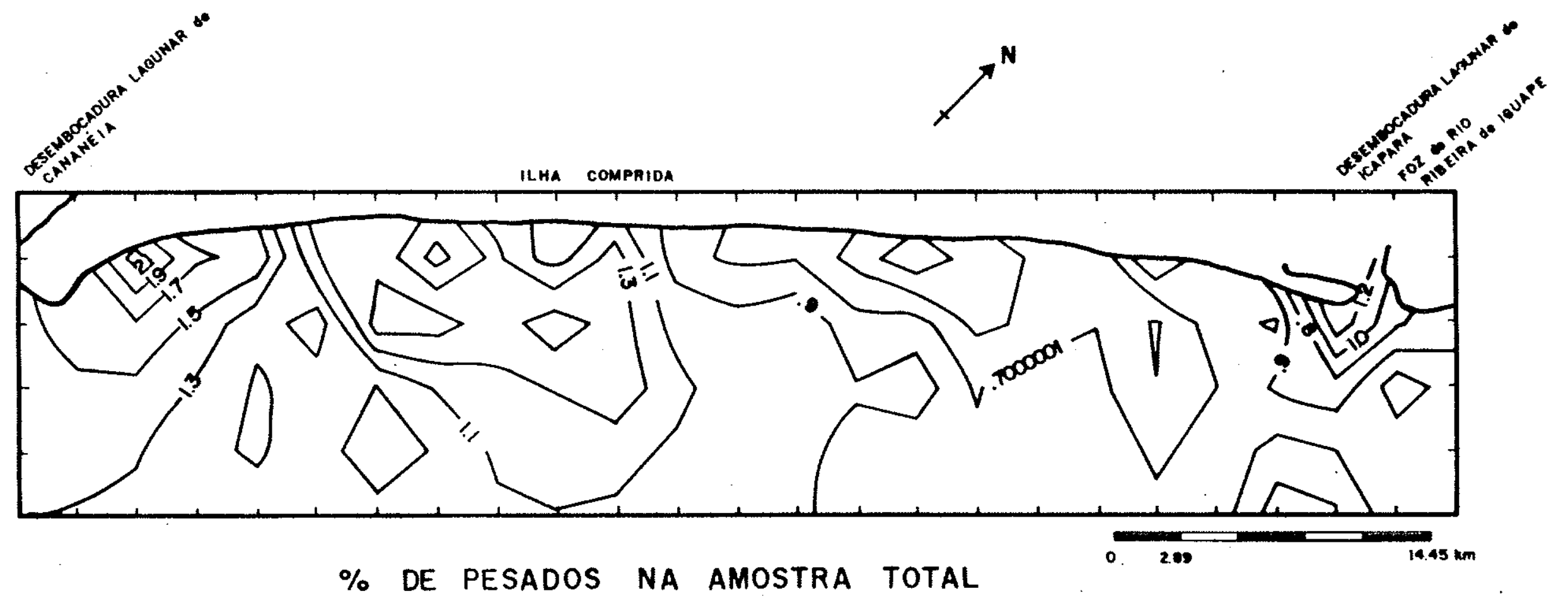

Fig. 20 - Mapa de isovalores de porcentagem de pesados, na amostra total, da zona de arrebentação. 


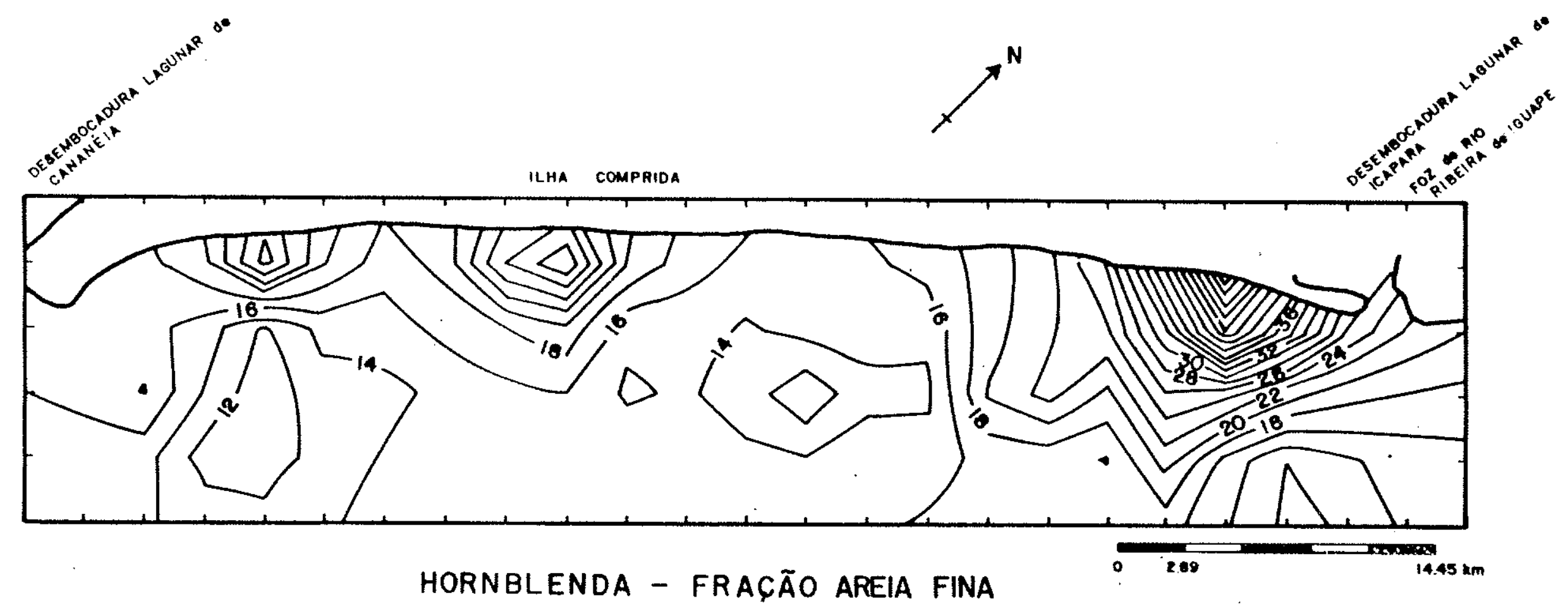

Fj.g. 21 - Mapa de isovalorcs la frequência de hornblenda, na fração areja fina, na zona de arrebentação. 


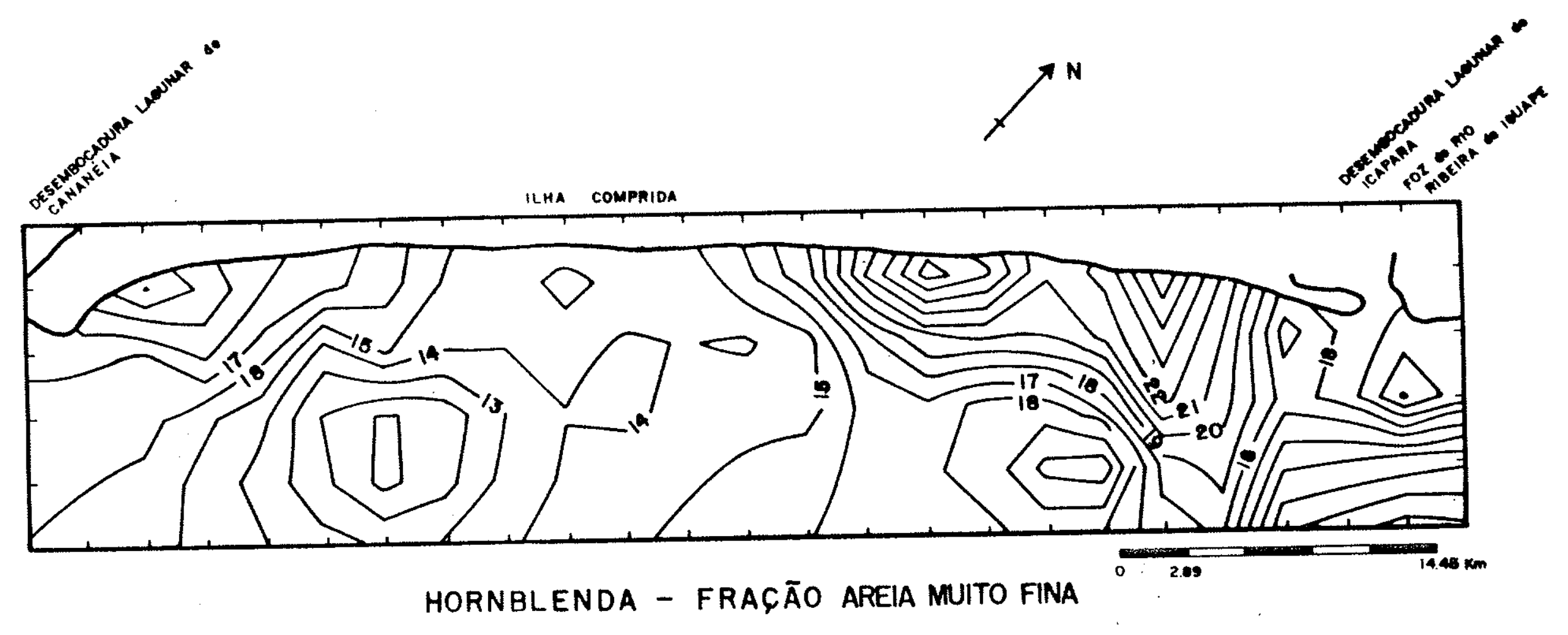

Fig. 22 - Mapa de isovalores da freqüência média de hornblenda, na fração areia muito fina, na zona de arrebentação. 


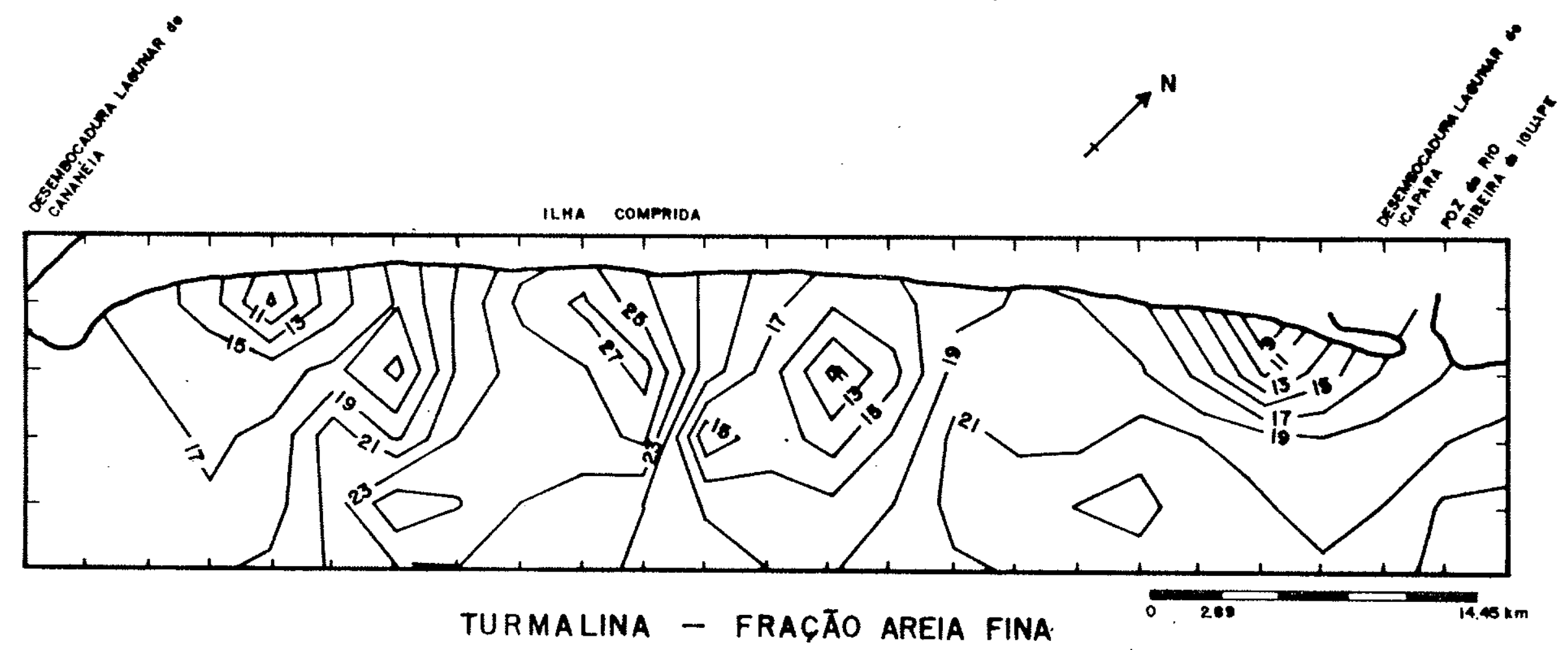

Fig. 23 - Mapa de isovalores da freqüência média da turmalina, na fração areia fina, na zona de arrebentação. 
tendênclas opostas, detectadas nas porções SW e $\underline{N E}$ da figura, ca racterizada por uma área com altos valores a oesté da porção central e uma área correspondente com valores menores situadas a leste.

Para a distribuição do zircão, o mapa de isovalores da fração grossa (fig. 24), apresenta dois centros de altas concentrações, localizados nas porções central e sudoeste da figura. No rumo $\mathrm{NE}$ da figura, ocorre uma sensível diminuição dos valores de freqtência do zircão.

Na figura referente à fração areia muito fina (fig. 25), o centro de altos valores situados a $\underline{\mathrm{SW}}$ da figura apre senta-se bem destacado enquanto que, rumo a $\underline{N E}$, há uma diminuição progressiva das porcentagens de zircão até as proximidades da desembocadura lagunar de Icapara onde, a partir da isóbata aproximada de oito metros, ocorre uma tendência à elevação des sas porcentagens rumo ao oceano.

Portanto, considerando-se apenas as tendências observadas na zona de arrebentação é licito supor que os minerais pesados mais estáveis tenham os seus centros de propagação localizados a SW da área de estudo, enquanto a hormblenda acha-se diretamente vinculada à área de infliuência da desembocadura lagunar de Icapara e foz do rio Ribeira de Iguape, situadas a NE da área.

Quando verificados os mapas de isovalores para a plataforma rasa estas tendências se confirmam, em especial as vinculadas aos minerais mais estáveis, turmalina e zircão. Para a mineralização podem ser veriflcadas ocorrências de altas porcentagens, principalmente na fração areia muito fina onde o mine ral é mais frequente, localizadas a $\mathrm{SW}$ da área entre as isóbatas de 10 a 20 metros ( $f i g .26$ ). Para a turmalina, igual tendência foi verificada, sendo nitida a concentracão de altos valores entre a porção central da Ilha Comprida e a porção SW da área, com as maiores concentrações também localizadas entre as isóbatas de 10 a 20 metros (fig. 27). 


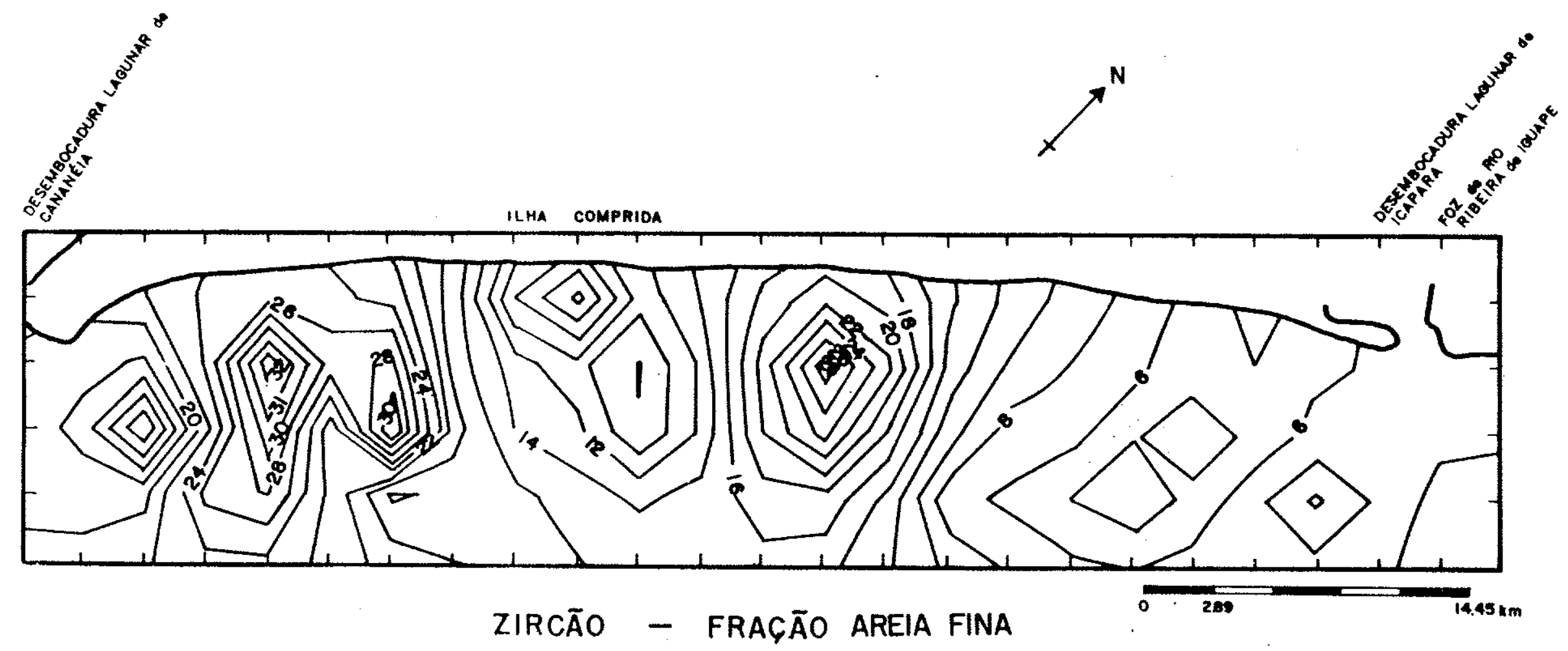

Fig. 24 - Mapa do isovalırke de freqüência média do zircão, na fração areia fina, na zona de arrebentação. 


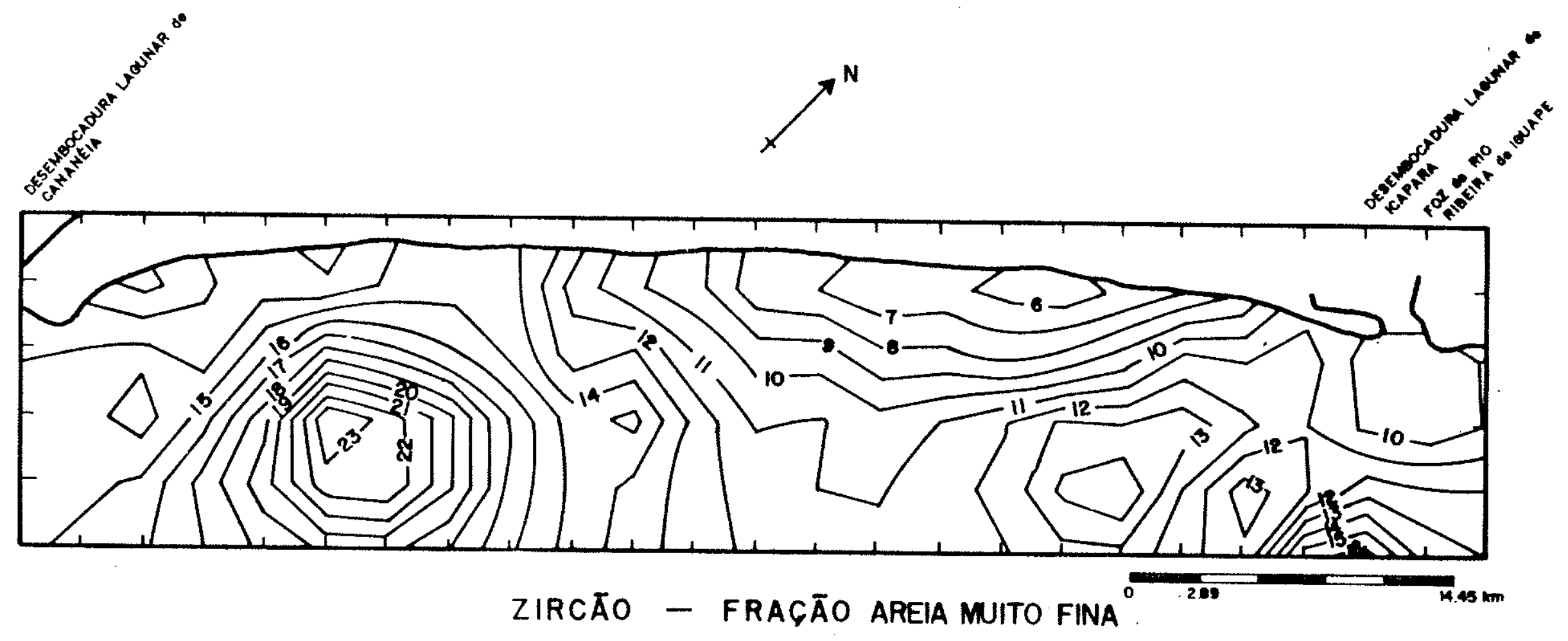

Fig. 25 - Mapa de isovalores da frequêencia méd1a do zircão, na fração areia muito fina, na zona de arrebentação. 


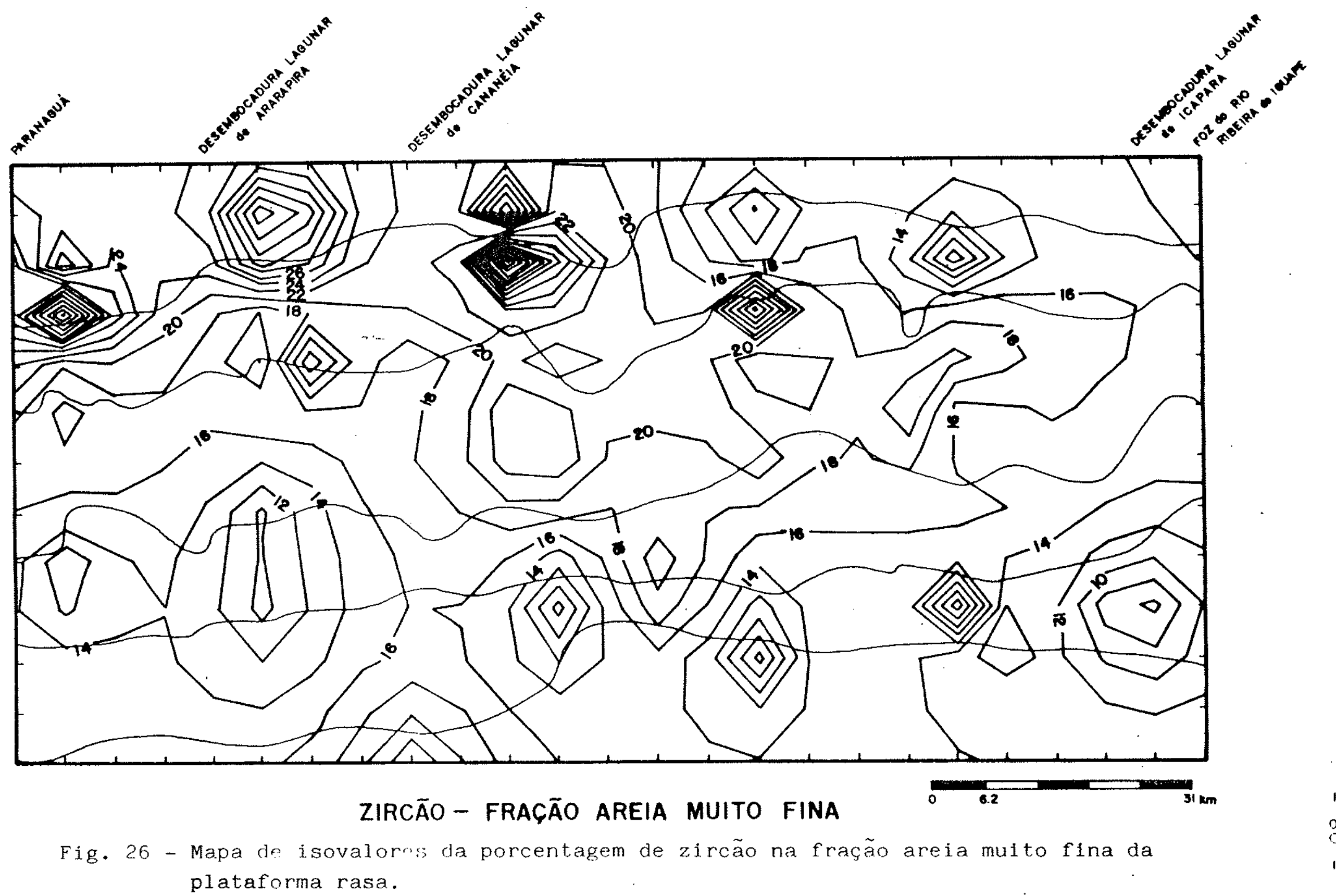




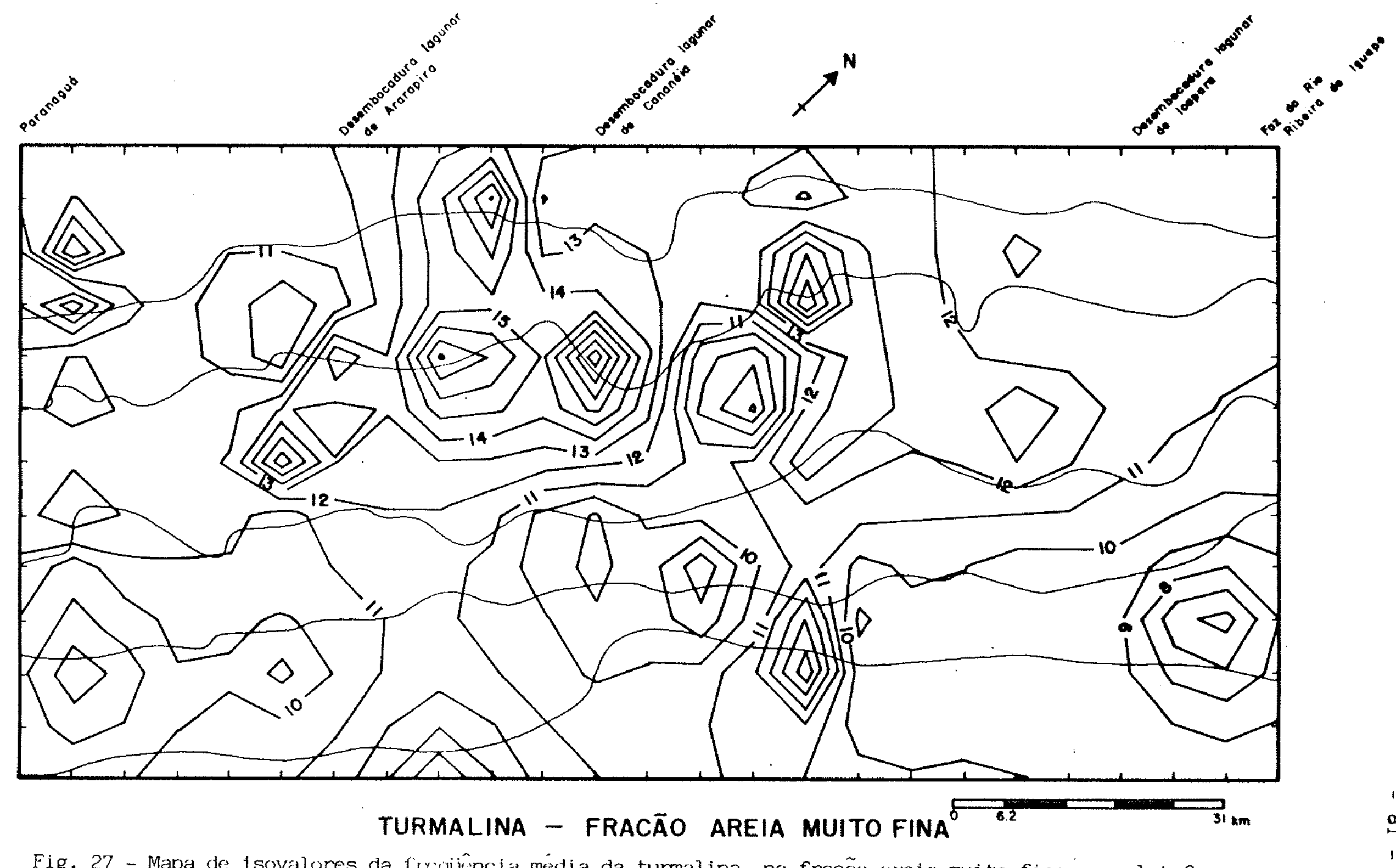

Fig. 27 - Mapa de isovalores da rirjînncia média da turmalina, na fração atria muito fina, na plataforma rasa. 
2.2.4.7 - Maturidade mineralógica

Em todas as unidades estudadas, a diversidade mineralóglca apresentou-se alta, em ambas as frações granulométricas.

Para a fração areia fina, a Formação Cananéia apresenta de 6 a 11 espécies, os cordões 11torâneos da Ilha Comprida de 7 a 10, a faixa Intermarés de 8 a 14, a zona de arreben tação de 8 a. 13 e a plataforma rasa de 6 a 13 espécies minerais com frequiência porcentual superior a $1 \%$.

Na fração areia multo fina, a Formação Cananéia apresenta de 5 a 12 espécies minerais, os cordões holocênicos de 8 a 10, a faixa intermarés de 7 a 11, a zona de arrebentação de 7 a 13 e a plataforma rasa 7 a 12 .

Com frequiências médias para o número de espécies mineralógicas temos em ambas as frações, para todas as unidades estudadas, valores ao redor de 9 espécies com desvio padrão pró ximo de 1. Esta diversidade em espécies mineralógicas evidencia a relativa imaturidade dos sedimentos quaternários do litoral sul paulista.

O Indice de estabilidade ZTR apresenta valores decrescentes a partir dos sedimentos pleistocênicos da Formação Cananéia para sedimentos mais recentes. A Formação Cananéia apre senta um valor médio para o ZTR da fração areia fina de 67,6 e desvio padrão de 7,7 e para a fração areia muito fina de 58,9 com desvio padrão de 17,7 .

Por outro lado, os cordões litorâneos da Ilha Comprida apresentam uma queda no valor do ZTR, para 44,3 com des vio padrão de 3,3 na fração areia fina e 47,6 com desvio padrão de 1,4 na fração areia multo fina.

Com relação às frequînclas de minerais instáveis e estáveis observa-se, na Formação Cananéia, um predominio de minerais estáveis na fração areia fina (80\%). Na fração areia muito fina a classe de abundância que equivale a frequêencias iguais de minerais instáveis e estáveis apresenta uma porcentagem de ocorrência de 37,5 enquanto que a classe de abundância de minerais estáveis contribui com $50 \%$ da porcentagem total da assembléia de minerais pesados. 
Para os cordões litorâneos, na fração arela fina, verificam-se frequências iguais entre os minerafs estáveis e Instáveis com porcentagens de $90 \%$ para a fração mais grosseira e $100 \%$ na fração arenosa mais fina.

A falxa intermarés apresenta un índice ZTR médio de 42,56 com desvio padrão de 17,14 , estando $80 \%$ de seus valores compreen didos entre abundância de minerais instáveis $(40 \%)$ e de frequîncias Iguais $(40 \%)$.

O Indice da fração areia muito fina, na faixa intermarés, é de 53,48 com desvio padrão de 7,15 e com $80 \%$ dos resultados refletindo frequiências de classes iguals, entre minerais estáveis e instáveis, com uma leve tendência (20\%), para a ocorrência de abundância de minerais estáveis.

Com relação ao índice ZTR, verifica-se uma dimi nuição da ocorrência dos minerais estáveis a partir da porção sul da IIha Cormprida en direção a desembocadura Iagunar de Icapara. Esta tendência, bem nitida na fração areia fina, é mascarada em parte na fração areia muito fina pela alta incidência do mineral zircão.

Esta diminuição dos valores de ZTR é atribuivel exclusivamente ao enriquecimento das amostras em minerais instáveis, significando portanto indice de imaturidade maior para os sedimentos localizados mais a $\mathrm{NE}$ da área de estudo.

$\mathrm{Na}$ zona de arrebentação e plataforma rasa os va lores de índice ZTR são bem inferiores aos observados na área emersa, tendo o mais alto valor de ZTR para a área submersa sido registrado para a fração areia fina, da zona de arrebentação, com 36,2 e desvio padrão 12,2 e abundância de minerats instáveis em $62,5 \%$ das amostras analisadas.

Quancio analisada a distribuição espacial dos ín dices ZTR, ao longo da zona de arrebentação e plataforma rasa é possivel identificar a mesma tendência já observada ao longo da falxa intermarés da Ilha Comprida, ou seja, a ocorrência de maiores concentrações de minerais estáveis e ultraestáveis entre as regiões central da Ilha Comprida e as proximidades da desembo cadura lagunar de Cananéia. 
Para a zona de arrebentação esta tendência mais nitida no intervalo areia muito fina (fig. 28); em razão dos altos teores dos minerais rutilo e zircão que se concentram em maior quantidade neste intervalo granulométrico.

Para a fração arela fina, observa-se uma pequena concentração de minerals estáveis, maiores valores de ZTR próximo à desembocadura lagunar de Icapara, porém ainda assim em quanti dades beminferiores as observadas ao sul da Ilha Comprida.

Outro fato que se repete é o da tendência ao au mento de ZTR em direção ao centro da Ilha Comprida a partir de $\underline{\mathrm{NE}}$ onde esta tendência decrescente vai conflitar com uma tendência oposta proveniente da região mais a SW (fig. 29).

Para a plataforma rasa são observadas as mesmas tendências identificadas na zona de arrebentação, entretanto os altos indices estão restritos aproximadamente às isóbatas de 25 a 30 metros, a partir das quais, rumo ao oceano, a concentração de minerals estáveis volta a diminuir (figs. 30 e 31 ).

\subsubsection{8 - Minerais pesados opacos}

Para a caracterização mineralógica dos minerais pesados opacos, obtidos após a separação dos minerais fortemente magnéticos atraídos pelo imã de mão e da separação isodinâmica, foi utilizada a difratometria de ralo-X, uma vez que, os métodos ópticos convencionais em microscopia de luz transmitida não se prestam à identificação deste grupo de minerais.

Nesta determinação mineralógica foram analisadas 3 amostras da Formação Cananéia, 7 da faixa intermarés e 9 das zonas de arrebentação e plataforma rasa.

Em todas essas amostras foi identificado apenas - mineral 1lmenita, com presença pouco importante de rutilo, nos sedimentos da faixa intermarés e da zona de arrebentação.

$$
2.2 .4 .9 \text { - Áreas fonte }
$$

Estudos de minerais pesados, na tentativa de ca racterização das fontes primárias dos sedimentos da planície cos 


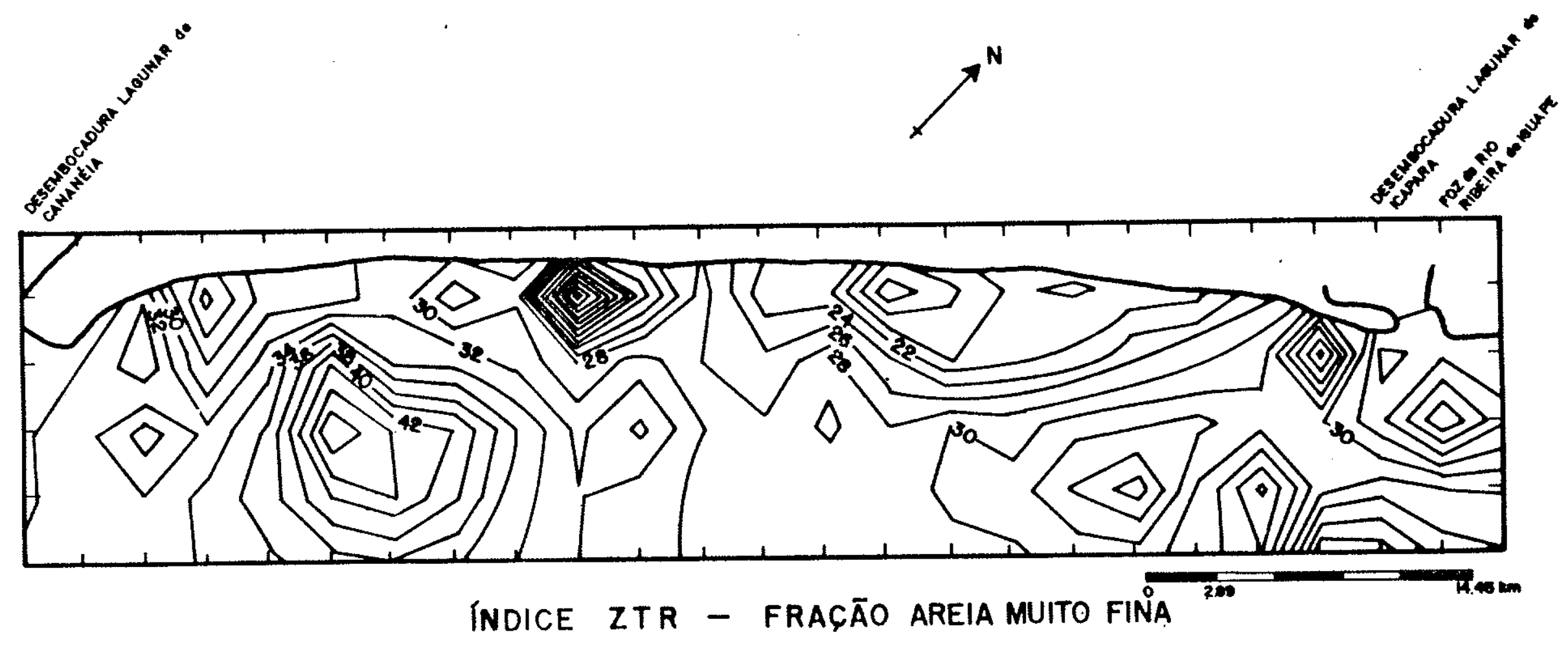

Fig. 28 - Mapa de isovalores to indice ZTR (Hubert, 1962), na fração areia muito fına, na zona de arrebentigão. 


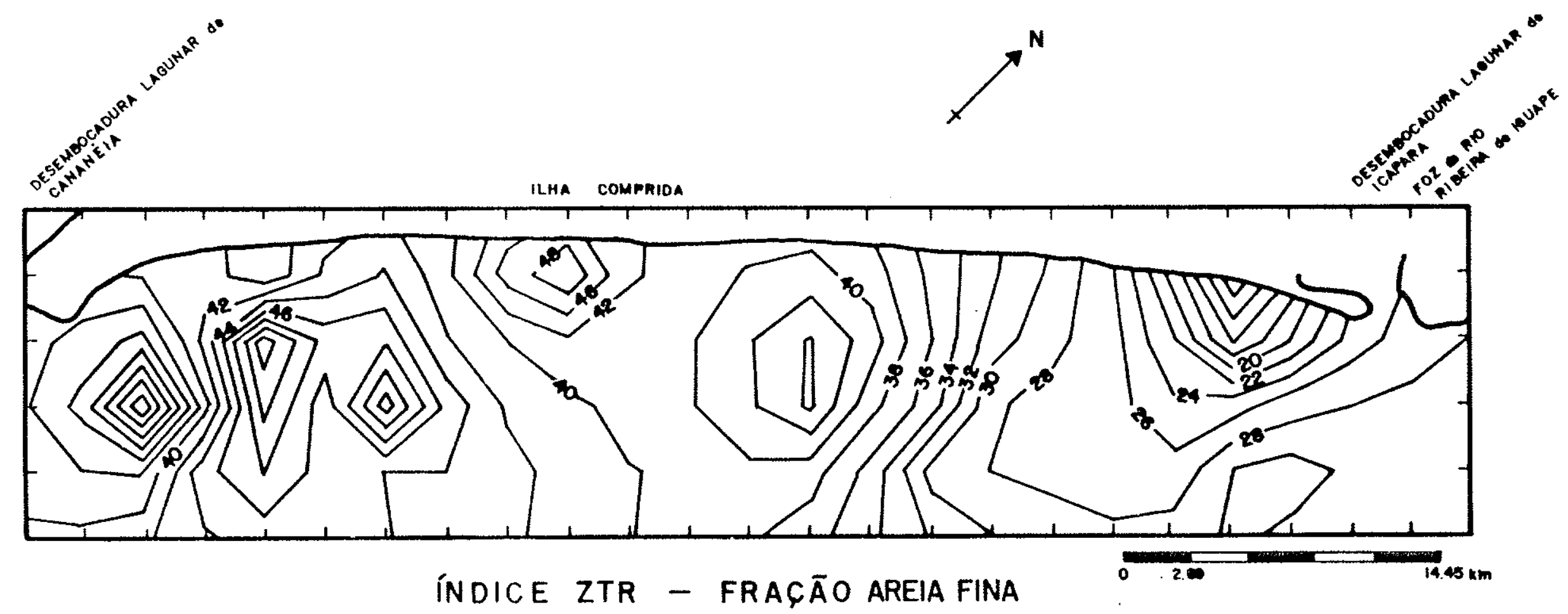

Fig. 29 - Mapa de isovalorfs do indice ZTR (Hubert, 1962), na fração areia fina, na zona de arrebentação. 


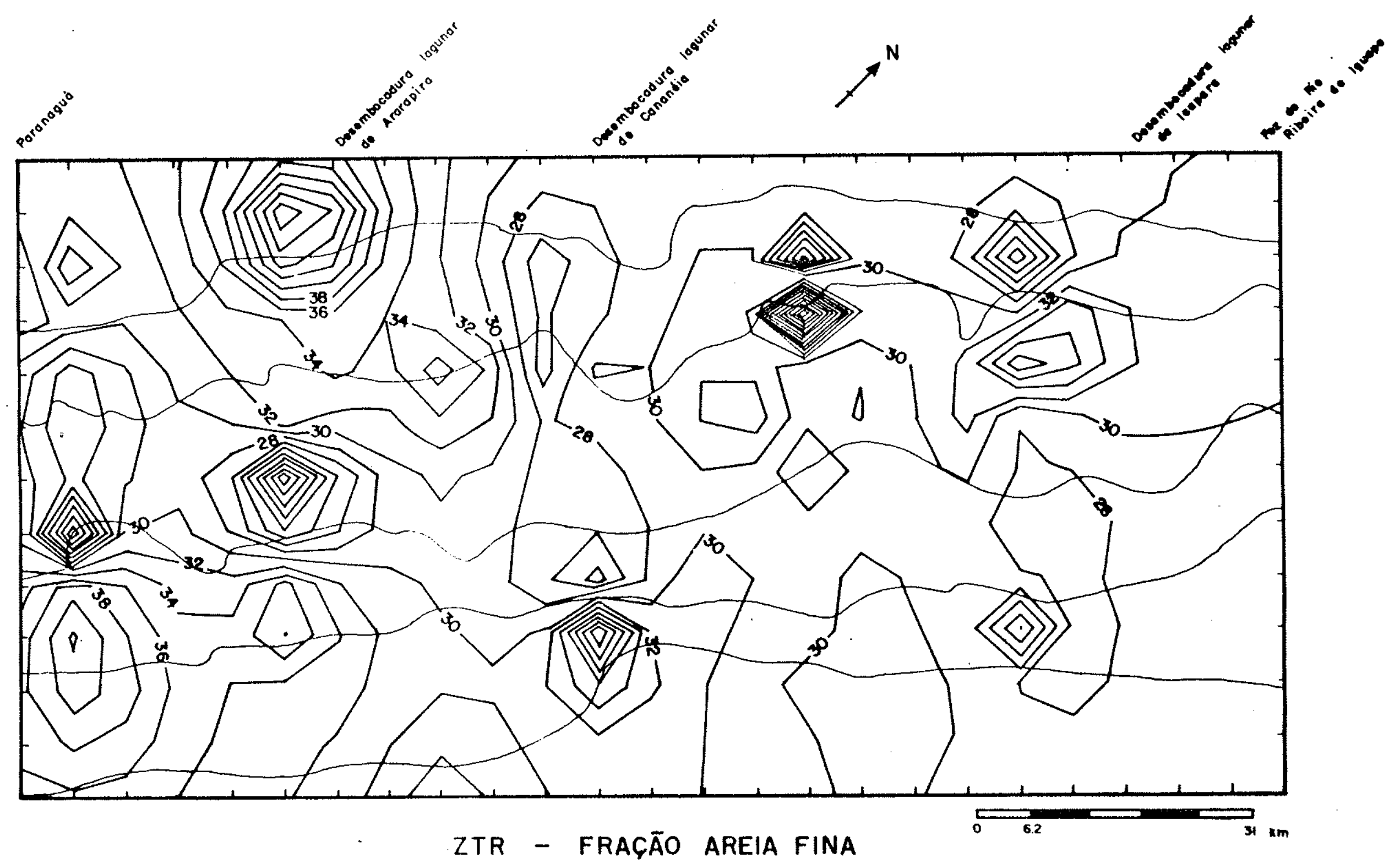

Fig. 30 - Mapa de isovalores do íntice ZTR (Hubert, 1962), na fração areia fina, na plataforma rasa. 


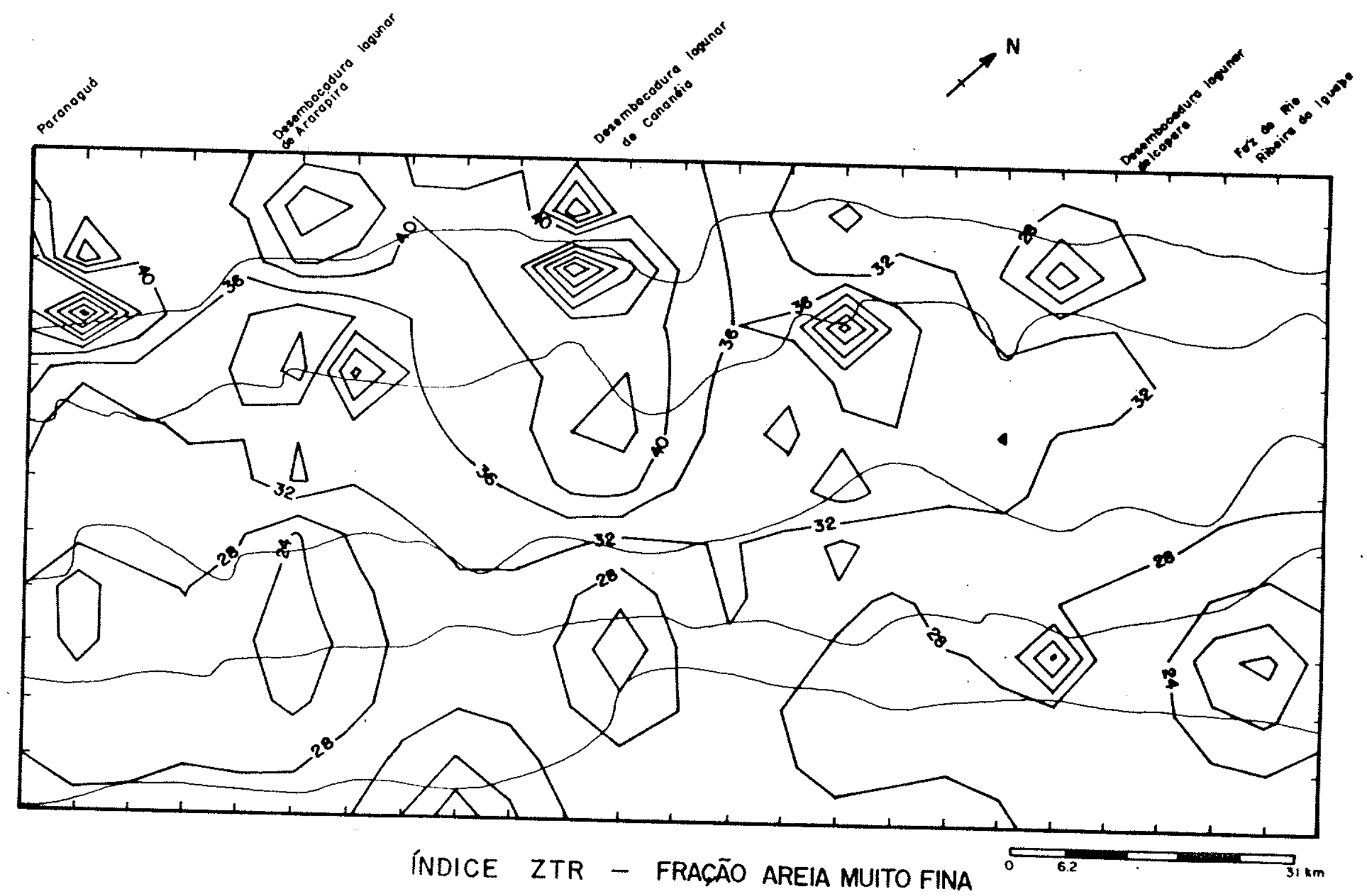

Fig. 31 - Mapa de isovalores do índice ZTR (Hubert, 1962), na fração areia miito fina, na plataforma rasa. 
teira de Cananéia-Iguape, já foram realizados por diferentes autores (Petri \& Suguio, 1973; Barcelos, 1975).

Petr1 \& Suguio (op. cit.), a partir da assembléia de minerais pesados detectados nos sedimentos quaternários das Ilhas Comprida, Cananéia e Iguape, concluiram ser essa assem bléia coincidente com a associação de minerais acessórios reconhecida por estes autores (Petri \& Suguio, 1969), em metassedimentos pré-cambrianos do Grupo Açunguí.

Barcelos (1975) identificou também çomo fonte primária dos sedimentos dos diversos ambientes deposicionals da Ilha Comprida, os metassedimentos do Grupo Açunguí, de onde teriam sido derivados cianita, estaurolita e sillimanita, e os gnais ses, migmätitos e os granitos do Complexo Cristalino, que seriam a fonte principal de turmalina, hornblenda, epidoto, zircão, rutilo, titanita, hiperstênio, monazita e apatita.

Analisando-se as prováveis origens dos dez mine rais mais frequientes (andaluzita, cianita, epidoto, estaurolita, granada, hornblenda, rutilo, sillimanita, turmalina e zircão), em todas as unidades estudadas, bem como suas caracteristicas principais, verifica-se que a presença de turmalinas prismáticas ricas em inclusões, em especial na porção SW da área, funtamente com estaurolitas, cianitas, sillimanitas, granadas e andaluzi tas indicam uma origem Ilgada a rochas metamórficas de médio a alto grau de metamorfismo.

Um aumento das frequiências de estaurolita e gra nada, nas proximidades da foz atual do rio Ribeira de Iguape e da desembocacura lagunar de Icapara, sugere ser a drenagem atual a principal fornecedora desses minerais, proveniente das rochas metamórficas, especialmente as granadas, que são provenientes de gnaisses e migmatitos homogêneos.

Por outro lado, o rutilo também seria carreado para a região costeira pelos sistemas de drenagem dos rios de serra que desaguam nos canais lagunares e da bacia de drenagem do rio Ribeira de Iguape, a partir de rochas metamórficas de alto grau, em especial dos biotita e sillimanita gnaisses, onde este mineral é abundante. Secundariamente, o rutilo poderia ser derivado dos migmatitos. 
A abundância de hornblenda possiblilta identifí car como fonte paleossomas anfiboliticos do complexo migmatiti $c o$, enquanto que pequenos corpos anfibolíticos encravados nos grupos Áçunguí - São Roque poderiam contribuir secundariamente com este mineral.

A associação de hornblenda com hiperstênio, em especial nos sedimentos pleistocênicos da Formação Cananéia e na atual área emersa, reforça a hipótese já aventada sobre a origem provável da hornblenda e sugere ainda uma possivel contribuição desses minerais a partir de corpos granulíticos, mais especificamente charnoquitos (hiperstênio - granulitos).

Desta forma, fica confirmada a importante contribuição dos metassedimentos do Grupo Açunguí, bem como de migmatitos, granitos e gnaisses do Complexo Cristalino como fontes pretérita e atual de sedimentos para a planicie costeira sul pau Iista.

A bacia do rio Ribeira Iguape, que drena áreas de rochas pré-cambrianas do Vale do Ribeira, constitui a rota principal de aporte dos sedimentos continentais terrígenos a sis temas costeiros, evidenciada principalmente pelas elevadas concentrações de minerais instáveís nas proximidades de sua foz. Os demais canais fluviais desaguam no sistema lagunar localizado a retaguarde da Ilha Comprida, implicando com isso que sua carga sedimentar seja primeiramente aprisionada neste sistema. A remobilização desses sedimentos depende de algum mecanismo de trans porte que possibilite o carreamento da assembléia de minerais pé sados para o sistema de transporte Iitorâneo atual.

Por outro lado, a presença de turmalinas com crescimento secundário e de zircão róseo nos sedimentos da Forma cão Cananéia e da atual área submersa nos dão conta de que, rochas metamórficas de baixo grau (fácies xisto verde) atuaram como fonte de sedimentos em épocas pretéritas. Segundo Yamamoto et al. (1977), as turmalinas com crescimento secundário são típicas de processos de baixo grau de metamorfismo e não oriundas de proces sos diagenéticos como admitiam autores anteriores.

A maior concentração destes minerais nas porções SW da área indica que a fonte destes minerais deve estar 1 i 
gada aos sistemas de drenagem independentes do rio Ribeira de Iguape. e que desaguam na porção mais a SW da região lagunar.

A maior efetividade desta fonte localizada a SW deve ter ocorrido durante o período de deposição da Formação Cananéia, Pleistoceno, uma vez que, nos sedimentos atuais das áreas submersas as turmalinas, com crescimento secundário, apresentam sua parte neoformada, (contorno externo), arredondada da mesma maneira que os grãos de zircões róseos, o que não ocorre nos sedimentos pleistocênicos.

Por outro lado, de acordo com Coimbra (1983), o zircão arredondado róseo poderia ser originário de metassedimentos, contrariando o fato de serem estes minerals apresentados na lite ratura como indicadores exclusivos de derivação direta de rochas ígneas.

De modo diverso, a presença de grandes porcenta gens de zircões e turmalinas (inclusive azulada) bem arredondadas, sugere a ocorrência de sedimentos pré-existentes atuando como fonte.

A perowskita, detectada ao longo de toda a faixa costeira sul e principalmente com formas subarredondadas a arredondadas na faixa intermarés da Ilha Comprida, vem de encontro à idéia da existência de sedimentos pré-existentes atuando como fonte.

Segundo informação verbal do Dr. Moacyr V. Coutinho, as características do mineral perowskita da faixa costeira sul paulista, em muito se assemelham às características deste mineral encontrado no litoral paranaense, o que poderia indicar um transporte deste mineral, ao longo da costa entre estes dois segmentos do litoral brasileiro.

Finalmente, as andaluzitas, cianitas e sillimanitas que, segundo Giannini (1987), poderiam ser derivadas de migmatitos homogêneos e as sillimanitas originárias de gnaisses e granulitos, parecem muito mais vinculadas, em função de sua distribuição espacial na faixa intermarés e na plataforma rasa aos sedimentos reliquiares da plataforma continental. De acordo com Kowsmann \& Costa, (1979), estes três minerais estão presen- 
tes entre os pesados que definem a provincia mineralógica sul brasileira localizada entre a Ilha Grande (RJ) e a lagoa dos Patos (RS).

Portanto, claro está que durante todo o ciclo erosivo/deposicional quaternário, atuante na planicie costeira sul paulista, o complexo serrano ̀̀ retaguarda da planície, bem como os sedimentos de fundo da plataforma continental, vêm atuando como fonte de suprimento de sedimentos para a região praial.

A importância de cada uma destas duas fontes de ve ter mudado, ao longo do tempo geológico, em função da maior ou menor efetividade de ação dos sistemas fluviais continentais em oposição ao sistema marinho, durante os eventos de oscilação do nivel do mar quaternário.

\section{2 .4 .10 - Conclusões parciais}

A cobertura sedimentar aflorante na Planicie de Cananéia-Iguape foi subdividida por Suguio \& Martin (1978a) em três grandes unidades arenosas, associadas aos eventos transgressivos/regressivos de idade quaternária e dispostas como faixas paralelas à Iinha de costa atual. A mais antiga, de idade pleistocênica, depositada no evento regressivo posterior ao auge transgressivo de 120.000 anos A.P., foi denominada de Formação Cananéia. A segunda fase, formada na fase posterior ao auge transgressivo holocênico de 5.500 A.P., denominada informalmente de Formação Santos encontra-se depositada paralelamente à sequiên cia arenosa depositada nos últimos 3.000 anos, correspondendo, segundo os autores, à unidade praial recente.

Para fins deste estudo esta unidade mais recente foi subdividida em duas sub-unidades, faixa intermarés e zona de arrebentação. A este conjunto litoestratigráfico foi acrescida uma quarta, denominada informalmente de plataforma rasa, cú ja cobertura sedimentar também está associada aos eventos transgres sivos/regressivos quatemários (Kowsmann \& Costa, 1979; Vicalvi, 1977).

A caracterização textural dessas unidades demonstra a existência de grande similiaridade entre elas sendo constituídas por areias finas e muito finas, em porcentagens superiores a $80 \%$. 
$\mathrm{Na}$ área submersa identifica-se, ao Iongo dos perfís amostrados, una tendência de diminuição dos valores dos diâmetros médios das amostras até aproximadamente as isóbatas de 25 a 30 metros, onde então passam a prevalecer valores de diâmetro médio situados entre 2,5 e $3,5 \varnothing$.

Verifica-se ainda malor concentração de sedimen tos com valores mais elevados de diâmetro médio, porcentagem de argila e número de classes texturais nas proximidades das desembocaduras lagunares de Cananéia e Icapara, ladeadas todas por fajxas de sedimentos arenosos, localizadas preferencialmente entre as isóbatas de 10 e 30 metros, apresentando maior grau de retrabalhamento nas frações grosseiras (areia média e grossa).

$\mathrm{Na}$ área emersa, os sedimentos pleistocênicos apresentam maior arredondamento na fração areia fina e uma tendência para incremento desse grau de arredondamento de $\underline{\mathrm{SW}}$ para NE. Nos sedimentos holocênicos da Ilha Comprida esta tendência é oposta apresentando maior grau de arredondamento na fraça areia muito fina e tendência para diminuição deste índice entre a porção média da Ilha Comprida e a desembocadura lagunar de Ica para.

Para a área submersa, o grau de arredondamento é sempre inferior ao observado para área emersa e mais elevado na fração areia fina do que nas outras frações estudados.

A feição topográfica localizada na área submersa, aproximadamente na porção central da IIha Comprida, e que se ria uma resposta geomorfológica a este mecanismo de transporte orientado no rumo do oceano, tem sua presença bem evidenciada apenas até as isóbatas de 20 e 25 metros. A partir dessas isóba tas sua definição é imprecisa no relevo de fundo, o que pode siğ nificar uma perda de competência do agente transportador.

Esta faixa marinha, localizada nas proximidades dessas isóbatas, representam a área de transição entre os conjun tos de sedimentos melhor selecionados e maturos, do conjunto de sedimentos relíctos associados atualmente aos sedimentos peliticos de origem continental, depositados a maiores profundidades na plataforma continental sul paulista. 
Quando se compara os sedimentos de fundo da área submersa com a feição topográfica de deslocamento das curvas ba.. timétricas localizadas nas proximidades da região central da IIha Comprida verifica-se que, a $\underline{\mathrm{SW}}$ desta feição são detectados os sedimentos com o maior grau de arredondamento da área submersa e que a NE desta felção este grau tende a um decréscimo rumo a desembocadura lagunar de Icapara e foz do rio Ribeira de Iguape.

Analisando-se principalmente a distribuição e a provável origem do grupo dos dez minerais pesados mais frequientes em todas as faixas litorâneas da planície sul, é possível identificar-se um padrão de distribuição atual deste conjunto de sedimentos.

As maiores concentrações de minerais pesados estão localizadas nas porções $\underline{\mathrm{SW}}$ e $\underline{\mathrm{NE}}$, próximos às desembocaduras laguna res de Cananéia e Icapara, com tendência para a ocorrência dos mi nerais pesados mais estáveis na porção $\underline{\mathrm{SW}}$ e dos mais instável na área localizada mais a $\mathrm{NE}$.

Com relação às concentrações dos minerais estáveis também é nítida a tendência para um incremento dos valores do indice ZTR entre a foz do rio Ribeira de Iguape e a porção central da IIha Comprida. Em oposição a esta tendência de incremento observa-se um de créscimo dos valores de ZTR proveniente da área de inflitiencia da desembocacura lagunar de Cananéia em direção a porção central da Ilha Comprida.

Os concentrados de minerais pesados permitem tam bém a 1dentificação de duas fontes atuais importantes de sedimentos para a área submersa, a primeira de origem continental, ligada ao rio Ribeira de Iguape que drena os metassedimentos do Grupo Açunguí, bem como os migmatitos, granitos e gnaisses do Complexo Cris talino, e a segunda vinculada a sedimentos retrabalhados da plataforma continental.

A distribuição atual destes sedimentos parece refletir não apenas a dualidade de fontes de suprimento de material, cuja importância relativa na composição de sedimentos do fundo atual é de dificil compreensão, mas também da existência de um mecanismo de transporte litorâneo, paralelo à linha de costa atual, composto por dois ramos de transporte, com sentidos opostos entre si, e uma terceira componente orientada no rumo do oceano profundo. 


\section{O TRANSPORTE LITORÂNEO}

\section{1 - Introdução}

O transporte de sedimentos arenosos de fundo em amblentes marinhos rasọs resulta sempre da interação dediferentes agentes, sendo os principals, as ondas, as correntes de diferentes origens e os ventos locais (Inman \& Shepard, 1963).

o conjunto de particulas que constitui a carga de fundo, tanto de origem terrígena como biogênica, é transportado e sedimentado. Feições deposicionais, tais como praias, barras, 1has-barreiras, refletem a origem e os mecanismos de transporte a que estiveram submetidos esses sedimentos.

Estudos sistemáticos de circulação costeira foram Iniciados no Instituto Scripps (E.U.A.) a partir da Segunda Guerra Mundial. Munk \& Taylor (1945, apud Shepard \& Inman,1950) desenvolveram um modelo de estimativa de velocidade de correntes ao longo da costa, para sistemas de ondas incidentes em praias retilineas e de isóbatas paralelas. Este trabalho constituiu a base para os estudos posteriores de transporte de sedimentos em ambiente marinho raso, denominado Sistema de Circulação Costeira por Shepard \& Inman (op. cit.).

Este Sistema tem, segundo Shepard \& Inman (op. cit.), caracteristicas de "células" de grandes dimensões consistindo seus limites laterais os pontos geradores de correntes de retorno ("rip currents"), entre os quais se desenvolvem correntes de deriva litorânea, geralmente de sentidos opostos.

A intensificação da múltipla exploração de áreas litorâneas, em especial em países de grande desenvolvimento tec nológico, tem originado un crescente interesse de pesquisadores pelos mecanismos de transporte de sedimentos arenosos de fundo em regiões marinhas rasas.

Este interesse tem se traduzido, não apenas na tentativa de caracterização dos princípios físicos teóricos que regem este transporte (Shepard \& Inman, op. cit., Simons et al. 1965; Allen, 1968; Komar, 1976; Stanley \& Swift, 1976, etc), coㅡ mo também pelas tentativas de previsão das alterações na dinâmi ca litorânea causadas pela ação antrópica. 
Em regiões litorâneas brasileiras, a ausência de medicões sistemáticas de parâmetros hidrodinâmicos, em especial de corrente de fundo e ondas, tem dificultado o estabelecimento de modelos de circulação litorânea para diferentes segmentos de costa e consequêntemente o conhecimento sobre a movimentação de sedimentos de fundo.

Entretanto, alguns trabalhos tem procurado esti mar, mesmo a partir de dados esparsos de parâmetros oceanográficos e meteorológicos, direções e volumes de sedimentos transportados ao longo de segmentos restritos do litoral brasileiro (Motta, 1965; Geobrás, 1966; Muehe \& Sueharov, 1981).

As deficiências tornam-se mais acentuadas quando das tentativas de aplicação das inúmeras equações de cálcuIos de volumes de sedimentos transportados (Einstein, 1950; Ya1in, 1963; Bagnold, 1963; Madsen \& Grant, 1976; Gadd et al.,1978; apud Pattiaratchi \& Collins, 1985) em áreas que sofrem a ação combinada de ondas e correntes de diversas origens (Motta, op. cit. e Muehe \& Sucharov, op. cit.).

Por outro lado, outros trabalhos têm procurado obter informações sobre a ação de correntes em regiões litorâneas através de análises comparativas de imagens de satélite, conjuntos de fotos aéreas e documentos cartográficos, bem como através da interpretação de registros em feições arenosas emersas do tipo alinhamento de cordões litorâneos (Sadowsky, 1952 , 1954 ; Petri \& Suguio, 1971b; CTH, 1973; Ponçano, 1976; Godolphin, 1983; Martin et al., 1984, etc).

Desta forma, verifica-se que, devido à ausência quase total de dados hidrodinâmicos mais expressivos, neces sários para a avaliação de volumes transportados, os estudos de formas sedimentares emersas e submersas adquirem grande importância na compreensão da sedimentação das regiões litorâneas do pais.

Ainda assim, são de grande significado as avaliações dos parâmetros oceanográficos (ondas, correntes, marés, etc.) e meteorológicos (ventos, precipitação, etc.) sobre a dinâmica de transporte de sedimentos arenosos de fundo, de áreas 
restritas, bem como as observações acerca das teridências existentes à construção ou destruição de feições arenosas litorâneas, mesmo que estas representem apenas um breve instante na evolução sedimentar de uma região marinha rasa.

\section{2 - Parâmetros Oceanográficos}

Os sistemas de ondas incidentes $e$ as correntes de fundo, dentro do compartimento litorâneo onde ocorre a remobilização dos sedimentos junto ao fundo, constituiram-se nos dois principais parâmetros físicos abordados ná área de estudo.

A ação dos ciclos de maré, sobre a circulação $1 \underline{1}$ torânea, e em espectal sobre as correntes de fundo, não será con siderada em virtude da escassez de informações existentes acerca de áreas não abrigadas, no litoral sul paulista.

Nas análises dos sistemas de ondas incidentes foram utilizados, além de dados coletados pelo I.O.USP, séries de dados coletados pela Missão Francesa, que se encontram disponiveis no relatório Geobrás (1966) e os dados coletados pelo Laboratório de Hidraúlica do Centro Tecnológico de Hidraúlica da USP (1973).

As medições de corrente (mela-água e fundo) foram realizadas, na primavera de 1984 durante a execução de três estações fixas de correntometria, localizadas nas porções central, sudoeste e nordeste da área estudada, além da utilização de dados coletados em outono de 1962 .

$$
3.2 .1 \text { - Ondas }
$$

No Brasil, de maneira geral, praticamente inexis tem observacões sistemáticas de longo período sobre o comportamento dos sistemas de ondas incidentes na costa.

Séries de longa duração ( > 1 ano), vêm sendo obtidas apenas em regiões especificas da costa brasileira, onde a construção, ampliação ou mesmo manutenção de portos e canais de acesso têm sido necessárias. 
Observações de longo período, acerca dos sistemas de ondas incidentes ao sul da foz do rio Ribelra do Iguape (SP), foram realizadas apenas pelo Laboratoire National D'Hidraulique - Chatou (apud Geobrás, op. cit.) e pelo laboratório de Hidraúlica (CTH-USP), durante as fases de pré-projeto da bar ra de acesso ao futuro porto de Cananéia (1968 - 1969).

\subsubsection{1 - Resultados obtidos em levantamentos anteriores}

Uma bóia de medição foi instalada pelo Laborató rio de Hidraúlica no período compreendido entre 01/03/68 a 01/08/69, nas proximidadades da Ilha do Bom Abrigo ( $=25^{\circ} 07^{\prime} .8 \mathrm{~S}$; $047^{\circ} 51^{\prime} .2 \mathrm{~W}$ ) para medições, três vezes ao dia, das características das ondas Incidentes (CTH-USP - 1973).

Devido aos fenômenos de refração causados pela pouca profundidade do ponto de ancoragem da bóia, as observações acerca da altura e direção das ondas representam valores deformados com relação às características primárias dos sistemas de ondas em sua área de geração.

Porém, este fato não inviabiliza a utilização das observações acerca do quadrante de incidência (direção) dos sistemas de ondas; estes dados representam as informações mais significativas para os estudos da circulação Iitorânea, de fundo, no litoral sul paulista.

Outra série de levantamentos foi realizada pela missão de estudos hidrográficos do "Laboratoire Nationale D'Hyđraulique" e pelo Departamento de Energia Elétrica (DAEESP) na Ilha Bom Abrigo, no período de 01 de setembro de 1955 a 31 de janeiro de 1959.

Os dados obtidos estão divulgados no relatório Geobrás (1966) e são representativos de duas medições diárias, realizadas para intervalos de tempo correspondentes à passagem de 20 ondas consecutivas, contadas quando do impacto das ondas junto aos rochedos que bordejam a ilha e na determinação visual de oito rumos possiveis de aproximação dessas ondulações.

Muito embora, essas observações resultem em imprecisões maiores, do que as obtidas pelo $\mathrm{CTH}$, algumas de suas 
conclusões gerais são relevantes para confrontação com os demais resultados obtidos, principalmente, quanto às característi cas dos comprimentos de onda dos sistemas incidentes, visto que essas informações não foram obtidas pelo CTH-USP.

Pelo levantamento realizado entre 1968 e 1969 pode-se constatar que apenas ondas incidentes a partir dos rumos $75^{\circ}$ NE e $20^{\circ}$ SW foram observadas. Desse total $89,2 \%$ tiveram suas direções originadas do quadrante $\mathrm{SE} ; 8,1 \%$ do $\underline{N E}$ e apenas $2,7 \%$ do quadrante $\mathrm{SW}$.

Este fato foi verificado a longo de todo o período de observações, conforme expresso no quadro resumo das direções de ondas (Tabela 42 ).

\begin{tabular}{|c|c|c|c|}
\hline Período & $\begin{array}{c}\mathrm{NE} \\
75^{\circ} \mathrm{NE} \text { a } 90^{\circ} \mathrm{NE}\end{array}$ & $0^{\circ} \mathrm{SE}$ a $90^{\circ} \underline{\mathrm{SE}}$ & $0^{\circ} \underline{S W}-20^{\circ} \underline{\mathrm{SW}}$ \\
\hline $\begin{array}{c}\frac{1}{1} \\
01 / 03 / 68 \text { a } \\
31 / 08 / 68\end{array}$ & 6,3 & 88,8 & 4,9 \\
\hline $\begin{array}{c}\stackrel{2}{2} \\
01 / 09 / 68 \\
28 / 02 / 69\end{array}$ & 13,2 & 85,9 & 0,9 \\
\hline $\begin{array}{c}\frac{3}{3} \\
01 / 03 / 69 \mathrm{a} \\
01 / 08 / 69\end{array}$ & 3,7 & 93,7 & 2,6 \\
\hline Total & 8,1 & 89,2 & 2,7 \\
\hline
\end{tabular}

Tabela 42 - Porcentagens, por períodos de observações, das ondas incidentes na região da Ilha do Bom Abri go - SP (relatório CTH - LH/USP, 1973)

As direções de aproximação mais frequientes, com preendidas entre os rumos $60^{\circ} \mathrm{SE}$ e $\mathrm{E}$, correspondem as ondas provenientes de áreas de geração situadas à leste do ponto de observação. 
Subordinadamente fol observada uma maior inc1dência de ondas compreendidas entre os rumos $10^{\circ} \mathrm{SE}$ e $30^{\circ} \mathrm{SE}$; correspondente à zonas de geração situadas a sul.

Uma análise das variações diárlas das direções de propagação mostrou que, com exceção de um curto período de tempo (fins de outubro 68 a inicio de janeiro 69), onde as dire gões foram quase que exclusivamente de rumo $E$, não foram verifí cadas tendências de concentrações de direções de aproximação em meses determinados do ano.

As direções de propagação, observadas no intervalo 1955 - 1959, guardam relação com os resultados obtidos pelo CTH - USP, embora as diferenças de métodos de observação não permitam uma comparação numérica direta.

A predominância de Incidência de ondas de direções $\underline{S}$ e $E$ ainda é bem marcada no levantamento do DAEE-SP, muito embora em porcentagens inferiores às registradas no levantamento CTH - USP (Tabela 43).

\begin{tabular}{|c|c|c|c|c|c|c|}
\hline & \multicolumn{4}{|c|}{ Ondas } & \multicolumn{2}{|c|}{ Ventos Iocais } \\
\hline direção & $\%$ & $\begin{array}{l}\text { Periodo } \\
\text { médio } \\
\text { (s) }\end{array}$ & $\begin{array}{l}\text { Comprimento } \\
\text { médio de on } \\
\text { da }(\mathrm{m})\end{array}$ & $\begin{array}{l}\text { Amplitude } \\
\text { máxima } \\
\text { (m) }\end{array}$ & $\%$ & $\begin{array}{l}\text { Veloci } \\
\text { dades } \\
\text { médias } \\
\text { (nós) }\end{array}$ \\
\hline$\underline{S S W}_{\mathrm{S}} \underset{\mathrm{SSE}}{\underline{n^{\prime}}}$ & 26,3 & 8,6 & 116 & 1,30 & 19,1 & 7,6 \\
\hline $\begin{array}{c}\text { SSE a ESE } \\
\mathrm{SE}\end{array}$ & 36,7 & 8,8 & 122 & 0,80 & 47,8 & 6,0 \\
\hline $\begin{array}{c}\text { ESE a ENE } \\
E\end{array}$ & 26,6 & 9,2 & 132 & 0,85 & 5,9 & 5,7 \\
\hline $\begin{array}{l}\text { Outras } \\
\text { Direções }\end{array}$ & 10,4 & - & - & - & 27,2 & - \\
\hline
\end{tabular}

Tabela 43 - Porcentagens de direção de propagação dos sistemas de ondas incidentes no litoral sul paulista e ven tos locals (1955-1959, apud - Geobrás, 1966). 
Um dos resultados mais significativos deste estudo fol comparar as observações de ondas a medições dos ventos locals, ou seja, realizadas em uma estação l1torânea próxima (Canané1a). Esta comparação permitiu concluir que os sistemas de propagação de ondas, no l1toral sul, estão vinculados exclu sivamente, a seus centros de geração em áreas oceânicas, Independente das direções dos ventos locals.

Com relação ao período das ondas incidentes, 0 levantamento CTH-USP, permitiu reconhecer a ocorrência de valores compreendidos no intervalo de 3 a $30 \mathrm{~s}$. Porém, em termos significativos de porcentagem de ocorrência, (> 5\%), verifica-se apenas a presença de períodos situados no intervalo de 6 a $20 \mathrm{~s}$ com forte predominância para os períodos entre 9 e $11 \mathrm{~s}$.

A distribuição dos períodos com relação às dire cões de aproximação das ondas é homogênea, não apresentando uma interdependência entre determinados periodos e direções de propagação.

Por outro lado, com relação às medições de altụ ra de ondas, verificou-se que praticamente $90 \%$ dos valores obti dos situavam-se entre 0,5 e $2,0 \mathrm{~m}$, estando $50 \%$ destes compreendi dos no intervalo de 1,0 a $1,5 \mathrm{~m}$ e os outros $40 \%$ distribuídos igualmente nos intervalos 0,5 a $1,0 \mathrm{~m}$ e 1,5 a $2,0 \mathrm{~m}$.

o intervalo $0,5-1,0 \mathrm{~m}$ mostrou ser predominante para direções a leste $\left(60^{\circ} \underline{\mathrm{SE}}\right.$ - $\left.\underline{\mathrm{S}}\right)$ enquanto o predomínio para as maiores alturas $(1,5-2,0 \mathrm{~m})$ estão vinculadas às direções sul $\left(\underline{\mathrm{S}}-60^{\circ} \underline{\mathrm{SE}}\right)$. Alturas de ondas com valores acima de $2,0 \mathrm{~m}$ sempre estavam vinculadas a trens de onda provenientes de direçoes a sul.

Com relação aos valores de comprimento de onda, à qual se vinculam as profundidades máximas de interação dos sis temas de ondas com o substrato marinho, o relatório CTH - USP (op. cit.), não faz nenhuma referência. Por outro lado o rela tório Geobrás (op. cit.), fornece essas informações à partir de um artificio teórico. Os comprimentos de ondas foram calculados a partir dos valores dos períodos médios mensais através da expressão: 


$$
L=\frac{g}{2 \pi} T^{2} \simeq 1,56 \mathrm{~T}^{2}
$$

$$
\begin{aligned}
& I=\text { comprimento de onda }(\mathrm{m}) \\
& g=\text { aceleração da gravidade }\left(\mathrm{m} / \mathrm{s}^{2}\right) \\
& T=\text { período médio mensal }(\mathrm{s})
\end{aligned}
$$

Os resultados obtidos indicaram comprimentos de onda mínimos ao redor de $110 \mathrm{~m}$ e máximos abaixo de $160 \mathrm{~m}$, estando a média em torno de $125 \mathrm{~m}$.

Porém, se esta expressão fosse aplicada para os períodos observados entre 1968 e 1969 teríamos como valor mínimo, para períodos significativos $(>5 \%), \simeq 56 \mathrm{~m}(6 \mathrm{~s})$. Para os maiores períodos observados (20 s) o valor calculado seria de ニ $624 \mathrm{~m}$, o que sem dúvida representa um resultado bastante superior as observações obtidas de campo.

Os períodos mais frequientes $(9-11 \mathrm{~s})$ correspon deriam à comprimentos de onda possivelmente mais reais $(=126 \mathrm{e}$ $188 \mathrm{~m}$ ).

Objetivando precisar melhor as informações ace $\underline{\underline{r}}$ ca dos comprimentos de onda tentou-se obter esta componente atra vés da observação de fotografias aéreas.

Das diversas séries de levantamentos aerofoto gramétricos disponiveis para o litoral sul paulista foi utiliza do neste trabalho, devido a sua boa definição de imagem, o reaIizado nos anos de 1979/80. Porém, devido ao limitado campo de observação das fotos, cujos pontos fotografados mais distantes da linha de costa situam-se aproximadamente na isóbata de $10 \mathrm{~m}$ e, dadas as distorções próprias deste tipo de levantamento, os comprimentos de onda $(\lambda)$ obtidos, para o momento da obtenção da Imagem, situam-se entre 80 e $100 \mathrm{~m}$.

Estes conjuntos de valores de comprimento de onda possibilitam situar o início da interação entre os trens de onda incidentes e o fundo oceânico entre as isóbatas de 40 e $50 \mathrm{~m}(\lambda / 2)$. Por analogia, na zona de arrebentação, $(\lambda / 20)$, 
- transporte por deriva litorânea teria sua ação intensificada ao redor da isóbata de $5 \mathrm{~m}$, profundidade essa superada pelas in formações de campo.

O fenômeno mais importante detectado em fotografias aéreas, em especial nas obtidas no dia 17/12/80, na porção central da Ilha Comprida, foi a observação simultânea de dols sistemas principais de onda incidentes no litoral sul paulista, em especial os detectados nos levantamentos do CTH $\operatorname{USP}\left(60^{\circ} \underline{\mathrm{SE}}-\underline{E}\right.$ e $\left.10^{\circ} \underline{\mathrm{SE}}-30^{\circ} \mathrm{SE}\right)$.

Esta coexistência de trens de onda distintos é importante na medida em que, durante os levantamentos prévios, devido às características técnicas das observações realizadas, apenas o sistema predominante podia ser detectado.

O sentido de deslocamento predominante, observado nas fotos do dia $17 / 12 / 80$ ( $f i g .32$ ), indica ondas provenientes do quadrante $\operatorname{SSE}\left(=165^{\circ}\right)$, que poderiam ser responsáveis pela geração de correntes de deriva litorânea dirigidas pa ra $\underline{N E}$. O segundo sistema, proveniente do quadrante $\operatorname{ESE}\left(\simeq 108^{\circ}\right)$ poderia, de maneira diversa, gerar correntes de sentido $\underline{\mathrm{SW}}$ ao longo da costa.

\subsubsection{2 - Levantamento do Instituto Oceanográfico da USP -} (1984)

Simultaneamente às medições de correntes reali zadas nas estações fixas de Paranaguá, Cananéia e Iguape foram obtidas informações sobre os sistemas de ondas presentes na área realizando-se observações, a períodos regulares de $30 \mathrm{mi-}$ nutos, pelo intervalo de 25 horas.

Com o auxilio da bússola de navegação foram Identificadas as direções de incidência das ondas, bem como es timadas suas alturas em relação à proa do navio.

Para o cálculo do período o número de passagens de cristas de onda $(n-1)$ pela proa do navio foi contado, durante o tempo fixo de medição adotado de 2 minutos. 


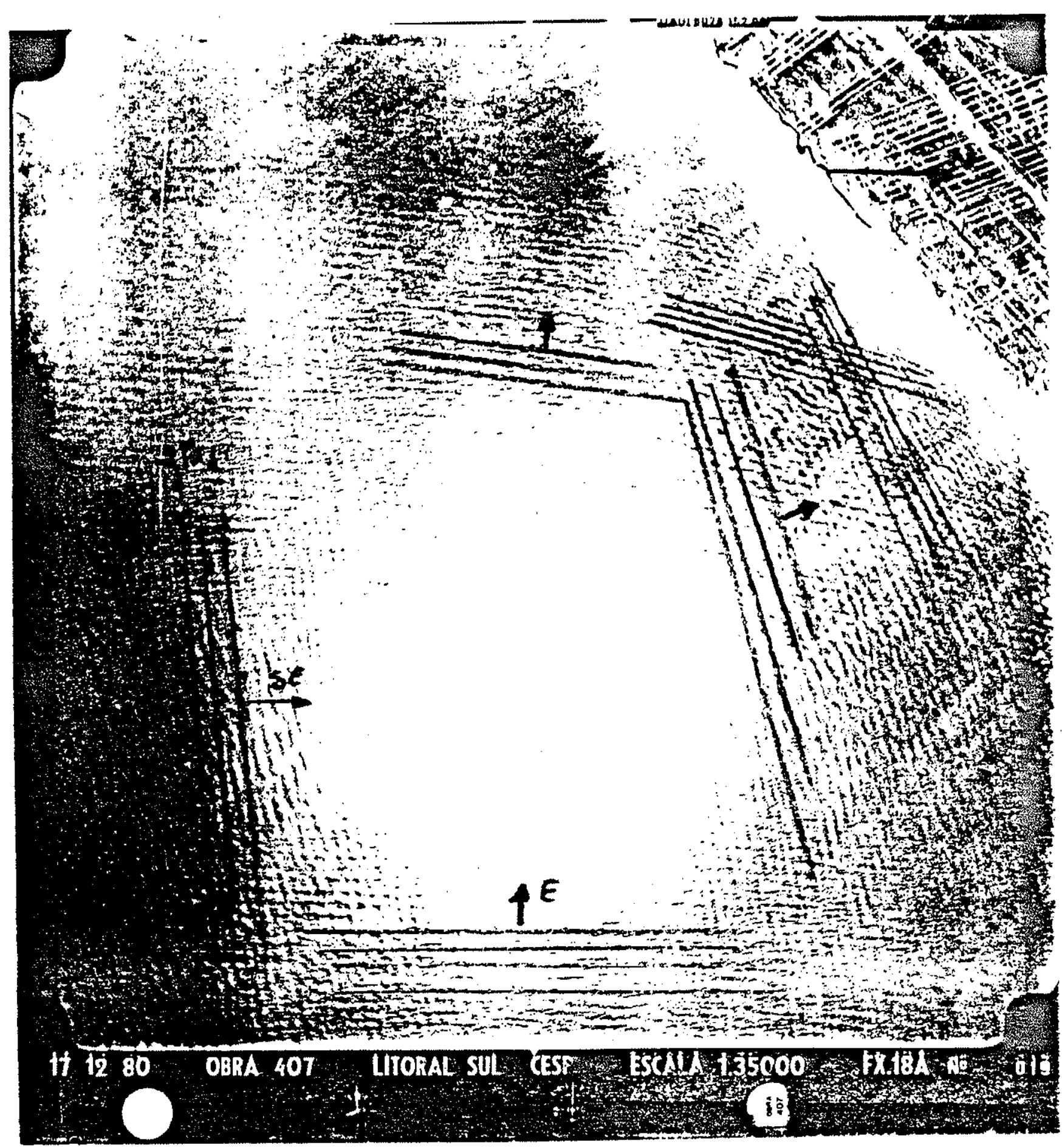

F1g. 32 - Sistemas de ondas incidentes na porção central da Ilha Comprida ( $\simeq$ SSE, $165^{\circ}$ e ESE, $108^{\circ}$ ), no dia $17 / 12 / 80$.

Escala original do levantamento 1:35.000.

Ponto 1 = profundidade aproximada de 10 metros. 
As maiores alturas, embora não ultrapassassem $2 \mathrm{~m}$, foram observadas na estação de Iguape, enquanto que as meno res $(<0,5 \mathrm{~m})$ ocorreram na estação de Paranaguá (Tabela 44).

Os períodos calculados apresentaram a estação de Paranaguá com o maior valor médio $(9,1 \pm 2,7 \mathrm{~s})$ e medido (20 s). Em Cananéia o valor médio foi de $6,7 \pm 2,3 \mathrm{~s}$, enquanto Iguape apresentou o menor valor médio para $\circ$ período de onda $(5,6 \pm 0,7$ s) e o menor medido $(4,3 \mathrm{~s})$.

Os valores de alturas e períodos de onda, obtidos em 1984, são semelhantes aos encontrados nos relatórios CTHUSP (1973) e Geobrás (1966).

Da mesma forma, com relação às direções de propa gação dos sistemas de ondas, as observações feitas à bordo do ná vio oceanográfico confirmaram as conclusões dos estudos anteriores que indicam o predomínio de trens de onda provenientes de rumos sul.

$\mathrm{Na}$ estação de Paranaguá, $50 \%$ dos trens de onda se originam de SSW e $\underline{S W}$, ao passo que na estação de Cananéia $39,6 \%$ são originários deste quadrante e $48,8 \%$ de SSE e SE. Secundariamente observam-se, em ambas as estações, ondas provenien tes de NE e ESE (fig. 33).

Em Iguape esta tendência se modifica uma vez que os sentidos observados são exclusivamente de leste ( $100 \%$ - ENE ESE).

A grande importância dos dados de ondas, obtidos em 1984, consiste em enfatizar a predominância de ondas provenientes de $\underline{S}$ e $E$ ao longo de todo o Iftoral sul paulista, e não apenas nas proximidades da Ilha do Bom Abrigo.

Além disso, essas observações reforçam a possibilldade da existência simultânea dessas direções principais em uma mesma área, como se constatou pela observação das fotos aéreas.

Portanto, apenas pela análise dos padrões de ondas observados, no litoral sul, é possivel concluir-se pela exis tência de, pelo menos, dois sentidos principais opostos de correntes longitudinais à linha de costa, $\mathrm{SW}$ e $\mathrm{NE}$. 

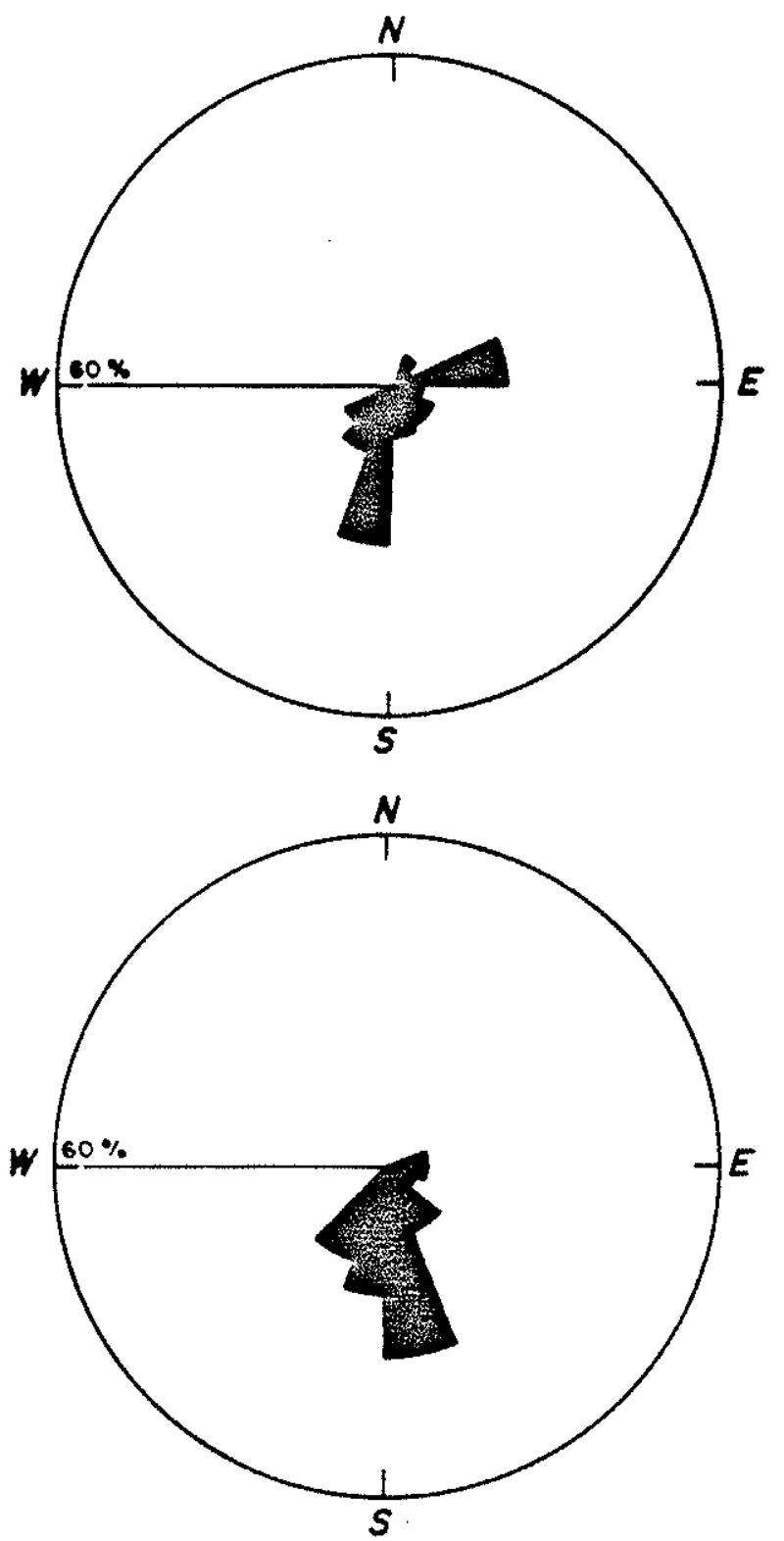

Poranagud (PR)

Canandia (SP)

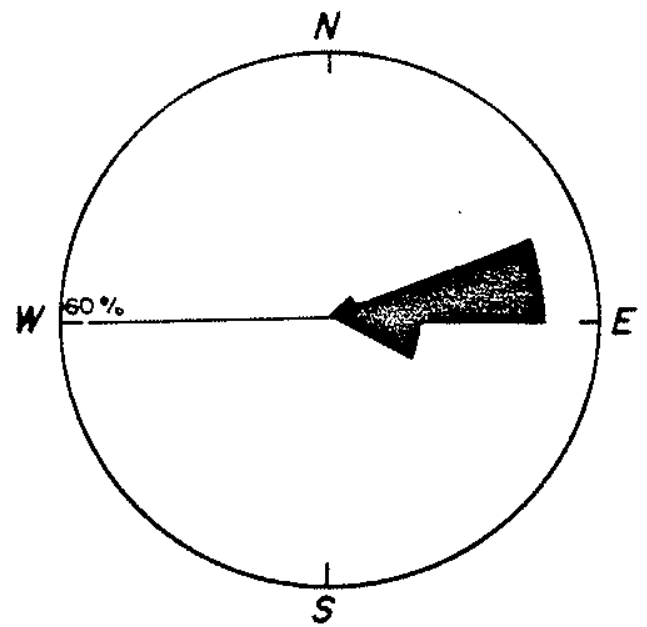

Iguape (SP)

Fig. 33 - Diagramas de roșeta das direções de inçidência de oncias observavadas nas estações de Paranaguá, Cananéia e Iguape - outubro de 1984. 
3.2.1.3 - Profundidade máxima de ação efetiva das ondas na mobilização dos sedimentos de fundo

A ação dos trens de onda atuando sobre o fundo não origina apenas correntes de direção paralela à costa, mas também movimentos de direção perpendicular à Iinha de costa denominados de costa adentro - costa afora.

A ação destas correntes ocorre em profundidades maiores do que as das correntes de deriva litorânea, estando esta profundidade, de atuação das ondas na mobilização de sedimentos rumo ao continente e/ao oceano, diretamerite vinculada à velocidade orbital (Um).

Baseado na equação que relaciona a profundidade de ação das ondas $(h)$ à velocidade orbital máxima (Um), ao diâmetro médio do sedimento (D) ao comprimento (L) e período (T) das ondas incidentes, Komar \& Miller (1975) elaboraram um programa de computador que fornece as profundidades máximas de atuação das ondas para sedimentos de quaisquer dimensões.

A expressão básica utilizada é:

$$
h=\frac{L}{2 \pi} \text { arc sen } h\left(\frac{\pi \cdot H}{T \cdot U m}\right)
$$

sendo que

$$
L=\frac{g}{2 \pi} \quad T^{2} \quad \operatorname{tg} h\left(\frac{2 \pi d}{L}\right)
$$

e

$$
U m=0,21\left(\rho_{s}-\rho\right) \frac{g}{\rho \pi 1 / 2} D^{1 / 1,5} D^{1 / 3} T^{1 / 3}
$$

onde

$$
\begin{aligned}
& \mathrm{H}=\text { altura da onda } \\
& \mathrm{d}=\text { profundidade da coluna d'água } \\
& \rho=\text { densidade do fluido } \\
& \rho_{\mathrm{S}}=\text { peso específico do sedimento }
\end{aligned}
$$


Sem a utilização da fórmula proposta por Komar \& Miller (op. cit.) a obtenção da profundidade máxima é problemátisa, na medi da em que, no cálculo para obtenção do comprimento da onda (L), a incógnita aparece em ambos os lados da equação. Esta questão fol solucionada pelos autores com o emprego de tabelas preparadas por Wiegel (1954 e 1964 apud Muehe \& Sucharov, 1981).

Os dados obtidos pela aplicação da fórmula de Komar \& Milier (op. cit.) mostraram que a profundidade, a partir da qual passa a ocorrer alguma mobilização de sedimentos de fundo pela ação de trens de onda. incidentes, é distinto para as três estações de medições realizadas, todas locallzadas na isóbata de $20 \mathrm{~m}$.

Enquanto a estação defronte a Paranaguá apresen tou apenas $2,3 \%$ do tempo total de observação onde a profundidade máxima de ação das ondas superou a isóbata do ponto de observação, em Iguape esse percentual foi de $37,5 \%$ e em Cananéia $62 \%$ (Tabela 45). Estes dados sugerem que apenas nas esta ções de Iguape e principalmente em Cananéia, poderia ocorrer mobilização de sedimentos de fundo apenas pela ação de trens de onda incidentes.

Desta maneira fica demonstrado que na plataforma rasa do litoral sul paulista, a mobilização de sedimentos da superficie de fundo só ocorrerá, em maiores profundidades, pela ação isolada de trens de onda que apresentarem períodos e altú ras de ondas elevados, da ordem de $20 \mathrm{~s}$ e maior que $2 \mathrm{~m}$.

Desta avaliação surge a confirmação de que, para os diferentes diâmetros de sedimentos obtidos $\quad(0,512 \mathrm{~mm}$; $0,170 \mathrm{~mm}$ e $0,126 \mathrm{~mm}$ ), que correspondem respectivamente aos diâmetros médios dos sedimentos coletados nas estaços de paranaguá, Cananéia e Iguape, a profundidade máxima de movimentação de sedimentos de fundo, por ação isolada do sistema de ondas, é sempre inferior a $50 \mathrm{~m}$ de profundidade. A movimentação de sedi mentos de fundo só ocorrerá em profundidades superiores à $50 \mathrm{~m}$, quando houver a conjugação entre o maior período (20 s) e a maior altura ( $2 \mathrm{~m}$ ) observados na área (Tabela 46 ). 
Considerando-se os valores médios para o período ( $9 \mathrm{~s})$ e altura $(1 \mathrm{~m})$, das ondas obtidas a partir dos dados de 1968 a 1969 verifica-se que a profundidade máxima de mobilizacão dos sedimentos é inferior a $30 \mathrm{~m}$.

\section{2 .2 - Correntes}

As características de correntes próximas ao fun do, em regiões litorâneas, representam sempre a soma vetorial de um conjunto de fatores (ondas, correntes de diferentes origens, etc.) onde é difícil a identificação da importância de ca da fator.

3.2.2.1 - Obtenção dos dados de meia-água e de fundo

As observações sobre direção e velocidade das correntes foram obtidos à bordo do N/Oc. "Prof. W. Besnard", durante a execução de três estações fixas, localizadas na isóbata de $20 \mathrm{~m}$, próximas às regiões de Paranaguá, Cananéia e Iguape.

Os tempos de duração dessas estações, realizadas na primavera de 1984 (outubro), foi sempre superior a um ci clo completo de maré $(\simeq 25 \mathrm{~h})$.

A partir do fundeio de um par de correntógrafos de rotor da marca Interocean, colocados respectivamente à $1 \mathrm{~m}$ acima da superfície do fundo marinho e $10 \mathrm{~m}$ acima do primeiro, foram registradas, continuamente, as direções e velocidades de correntes. Estes dados representam as únicas séries de medi çöes (discretas ou longas) registradas próximas à superficie de fundo, nas regiões litorâneas sul paulista e norte paranaense.

Uma outra série mais longa de medidas realizadas no decorrer de 16 dias, obtidas a meia-água na região da de sembocadura lagunar de Cananéia (1962), representam o outro úni co conjunto de medições de correntes obtidos na área.

Apenas como referência, una das poucas informações acerca de correntes litorâneas na costa sudeste do. Brasil, é encontrada no relatório Geobrás (1966), que estima a corrente litorânea, em superfície no trecho compreendido entre os lito- 
rais de Santa Catarina e sul de São Paulo, com intensidade de aproximadamente $0,20 \mathrm{~m} / \mathrm{s}$ orientada no rumo do litoral norte do estado de são Paulo.

\subsubsection{2 - Análise dos Resultados \\ 3.2.2.2.1 - Estação fixa de Paranaguá (1984)}

A estação fixa de Paranaguá estabelecida entre as coordenadas $25^{\circ} 37,7^{\prime} \mathrm{S}-048^{\circ} 07,3^{\prime} \mathrm{W}$ foi operada entre os dias 4 e 5 de outubro de 1984 e apresentou valores distintos pa ra as intensidades e direções de corrente, medidos a meia-água e próxima ao fundo (Tabela 47).

A meia-água, as velocidades variaram de um míni mo de $5 \mathrm{~cm} / \mathrm{s}$ rumo a $\underline{W}$ até um máximo de $26 \mathrm{~cm} / \mathrm{s}$ rumo a NNE. Como valor médio, para o período de 16 horas de observação, obtevese $14,4 \pm 5,1 \mathrm{~cm} / \mathrm{s}$.

Agrupando-se as direções de propagação por intervalos constantes de $22,5^{\circ}$, a partir do rumo Norte, observa-se que a meia-água, na estação de paranaguá, as maiores velocidades médias estão vinculadas aos rumos $\underline{\mathrm{SE}}(17 \mathrm{~cm} / \mathrm{s})$ e $\underline{\mathrm{SSE}}$ $\mathrm{cm} / \mathrm{s}$ ).

Junto ao fundo, as velocidades das correntes são inferiores às observadas à meia-água. o maior valor de intensidade de corrente medido foi de apenas $9 \mathrm{~cm} / \mathrm{s}$ rumo $E$, enquanto no rumo ENE foi observaco o menor valor de $3 \mathrm{~cm} / \mathrm{s}$.

Uma velocidade média, para todo o conjunto de medidas de corrente de fundo, apresenta un valor de $6,0 \pm 1,4 \mathrm{~cm} / \mathrm{s}$, sendo que apenas $10,9 \%$ das medidas obtidas representam valores acima da velocidade média calculada somada ao desvio padrão da média $(7,4 \mathrm{~cm} / \mathrm{s})$.

Comparando-se os valores de direção e intensidade obtidos simultaneamente para meia-água e fundo, verificase que as intensas variações observadas à meia-água não correspondem as variações simultâneas de igual intensidade junto ao fundo. Apenas este fato, já seria suficiente para se afirmar 
que o conjunto de fatores que influenciam mais diretamente a geração e propagação das correntes em regiões litorâneas (ondas, ventos locais, marés, etc.), têm influências distintas atra vés da coluna de água.

A análise dos diagramas de sentidos de correntes, construídos também considerando-se as direções de propagação agrupadas em intervalos de $22,5^{\circ}$, a partir do norte (fig. 34), reforça a conclusão acima, visto que enquanto à meia-água $70,8 \%$ dos sentidos observados variam entre $\underline{N E}$ e $\underline{\mathrm{SSE}}$, as de fun do apresentaram $82,8 \%$ das medidas para $\mathrm{NE}$.

É importante observar também que as correntes de fundo não apenas apresentaram uma alta porcentagem de deslocamento para uma única direção, como manteve-se este deslocamen to por um longo período sem que ocorressem variações na direção de propagação.

Para meia-água, foram ainda observados deslocamentos rumo a $\underline{N}-\underline{N E}$ e $\underline{S}-\underline{S W}$, enquanto que para o fundo observaram-se também propagações rumo a $\underline{S}-\underline{S S E}$.

Objetivando uma análise integrada do conjunto de dados e considerando-se inclusive a sequiência em que os mesmos foram obtidos construiu-se, para meia-água e fundo, os diagramas de vetor deslocamento médio progressivo.

A técnica de construção deste diagrama utiliza a somatoria dos vetores direção, a partir de uma origem adotada onde o módulo unitário do vetor adotado é representativo da média aritmética de duas medidas consecutivas de corrente que se propagam no mesmo rumo.

Este procedimento permite concluir, teoricamente, qual seria o deslocamento continuo e progressivo da corrente observada (direção e intensidade), a partir de uma soma vetorial durante um determinado período de observação.

O diagrama obtido, para as medidas de fundo, apresenta uma tendência geral de movimento da massa de água no sentido ENE (fig. 35 ).

Para a meia-água o diagrama mostra, no seu segmento inicial, tendência inicial de deslocamento para SSW alte- 


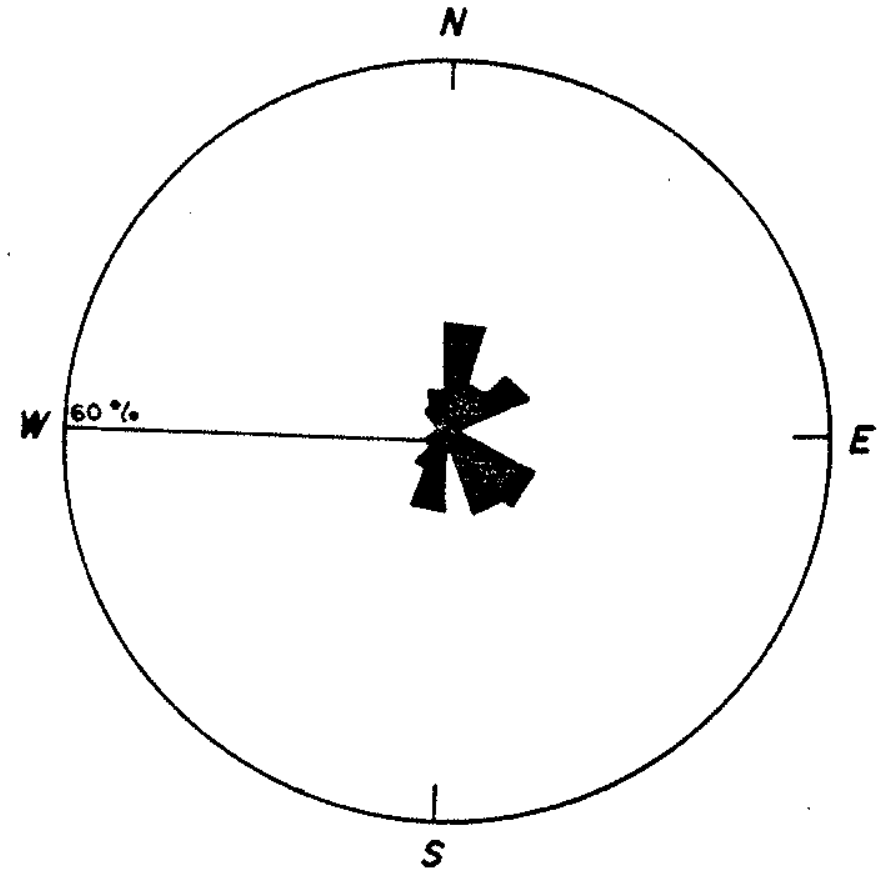

meia- dguo

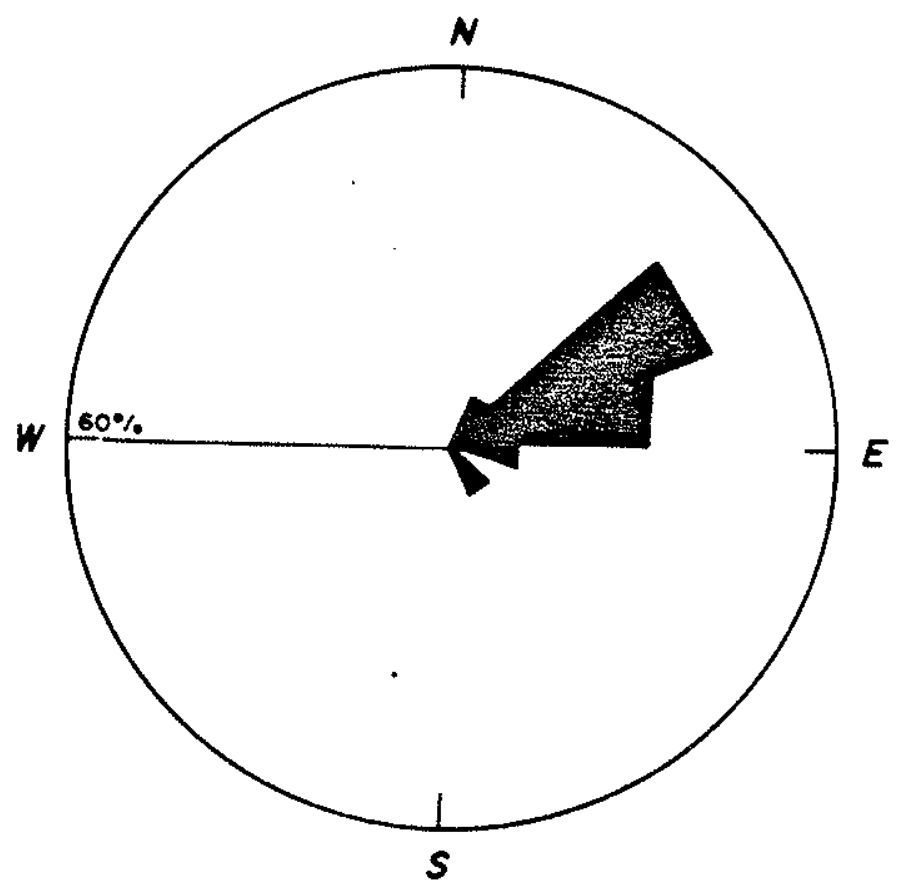

fundo

Fig. 34 - Rosas de corrente para meiá-água e fundo na estação fixa de Farariatíá. 1984. 


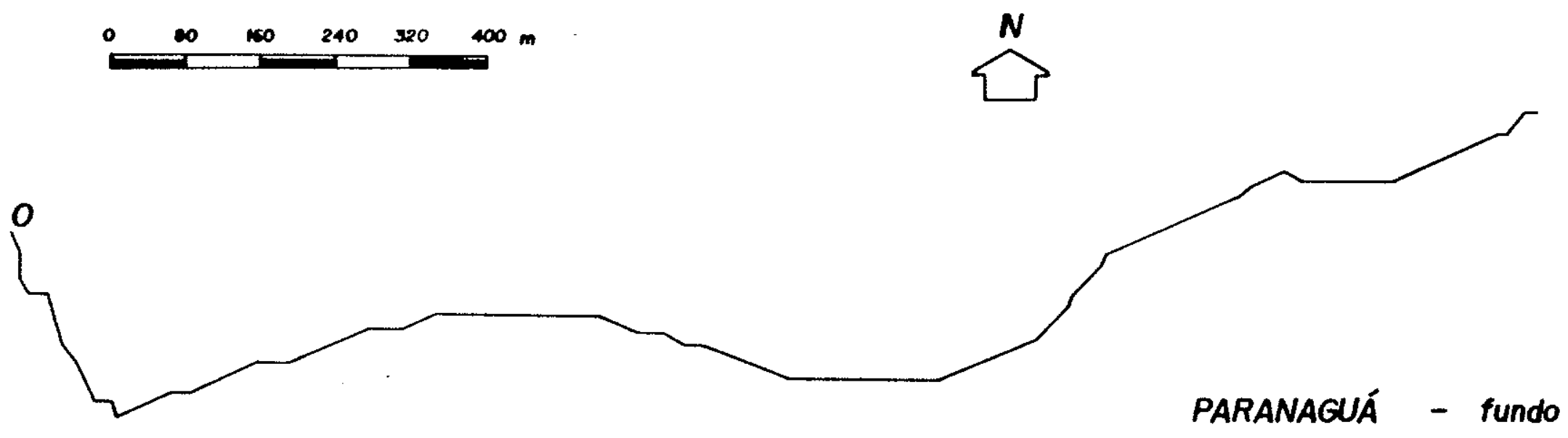

Fig. 35 - Diagrama de deslocamento médio progressivo, estação fixa de Paranaguá, fundo, 1984. 
rando posteriormente essa tendência para SE e finalizando para - rumo NE (fig. 36 ).

A presença deste pequeno giro deve estar associada ̀̀ influência de correntes geradas pela ação da maré, fato este não evidenciado no diagrama de fundo.

Apenas a partir'da interpretação destes diagramas, lembrando-se que os mesmos representam apenas um pequeno período de observações, podemos considerar a possibilidade da existência de um transporte de fundo, e em parte do material em suspensão no sentido $\mathrm{NE}$, ou seja, vindo do litoral centro-sul paranaense para o litoral sul paulista.

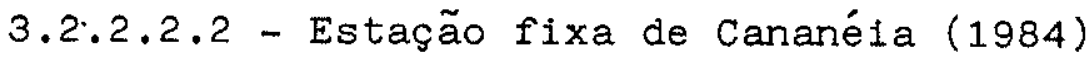

A estação fixa de Cananéia, localizada sobre a isóbata de $20 \mathrm{~m}$ em frente à desembocadura lagunar de Cananéia $\left(25^{\circ} 10,0^{\prime} \mathrm{S}-047^{\circ} 41,8^{\prime} \mathrm{W}\right)$, foi operada entre os dias 6 e 7 de outubro de 1984 .

As medidas de velocidade a meia-água variaram entre um máximo de $29 \mathrm{~cm} / \mathrm{s}$ e um mínimo de $11 \mathrm{~cm} / \mathrm{s}$, estando os maiores valores medidos orientados rumo a $\mathrm{NE}$, enquanto os menores dirigem-se para SE (Tabela 48).

A velocidade média para todo o período, de 28 ho ras de observação foi de $19,5 \pm 3,9 \mathrm{~cm} / \mathrm{s}$ com cerca de $22 \%$ de vé locidades de correntes acima da média acumulada somada ao desvio padrão $(23,4 \mathrm{~cm} / \mathrm{s})$.

À semelhança das medidas obtidas para a estação de Paranaguá as velocidades das correntes próximas ao fundo, em Cananéia, também foram significativamente inferiores às medidas à meia-água. O maior valor observado, $13 \mathrm{~cm} / \mathrm{s}$ rumo a $\underline{S E}$, apenas é superior a $3,8 \%$ dos valores de intensidade de corrente observados a meia-água, sendo que o menor valor medido foi de $3 \mathrm{~cm} / \mathrm{s}$ para WSW.

Conforme foi observado em Paranaguá, também em Cananéia as variações de velocidades e sentidos de propagação das correntes não ocorrem simultaneamente à meia-água e junto ao fundo. 


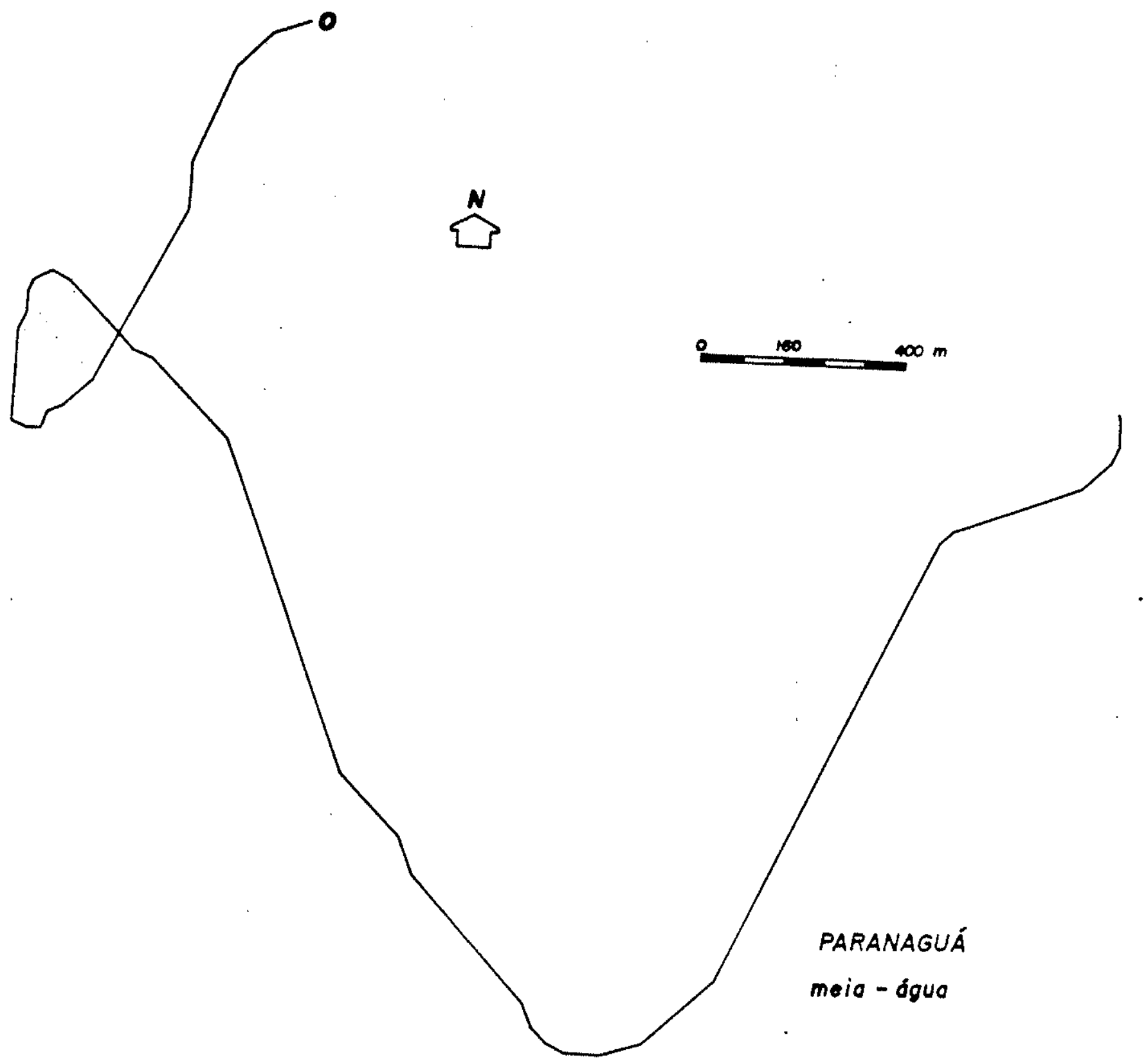

Fig. 36 - Diagrama de deslocamento médio progressivo estação fixa de Paranaguá, mela-água, 1984. 
A análise dos diagramas de rosas de correntes (fig. 37) demonstra que existe, à meia-água, o sentido principal de propagação ENE que abrange $48 \%$ das medidas efetuadas seguidas de correntes para $\underline{S}(21,4 \%)$ e $\underline{W}(16,8 \%)$.

As correntes junto ao fundo acusaram multa variação nos sentidos de propagação, porém é possivel reunílas em dois grupos orientados para $\underline{N E}$ e $\underline{S}$, respectivamente com $11 \%$ e $17 \%$ de freqüências de ocorrência. Secundariamente são também observadas correntes para $\underline{\mathrm{SW}}$ e $\underline{\mathrm{NW}}(\simeq 5 \%)$, demonstrando ter ocor rido uma grande variação nas direções de correntes junto ao fun do, durante todo o período de medição.

A análise do diagrama de deslocamento progressi vo, para meia-água ( $f i g .38$ ), evidencia de maneira clara uma tendência de deslocamento na direção ENE, porém de forma não li near, mas elíptica. Esta forma de deslocamento reforça sobrema neira a indicação já observada na estação de Paranaguá de que, para este segmento do litoral, correntes geradas pela ação da ma ré exerçam forte controle na orientação das correntes de meiaágua.

Por outro lado, diferentemente de Paranaguá, os dados da estação de Cananéia sugerem que a ação das correntes influenciadas pelas marés se propagam até o fundo, onde durante um pequeno intervalo de tempo este comportamento oscilatório pode ser identificado antes do estabelecimento de uma tendência de deslocamento rumo a SE (fig. 39).

\subsubsection{3 - Estação fixa de Iguape (1984)}

Em frente à foz do rio Ribeira de Iguape, a pro fundidade de $20 \mathrm{~m}$, foi operada a estação fixa de Iguape, na por ção mais ao norte da área estudada.

Durante 26 horas, entre os dias 08 e 09 de outu bro, ficaram fundeados os correntógrafos que realizaram as medi ções de velocidade e sentido das correntes à meia-água e junto ao fundo (Tabela 49). 


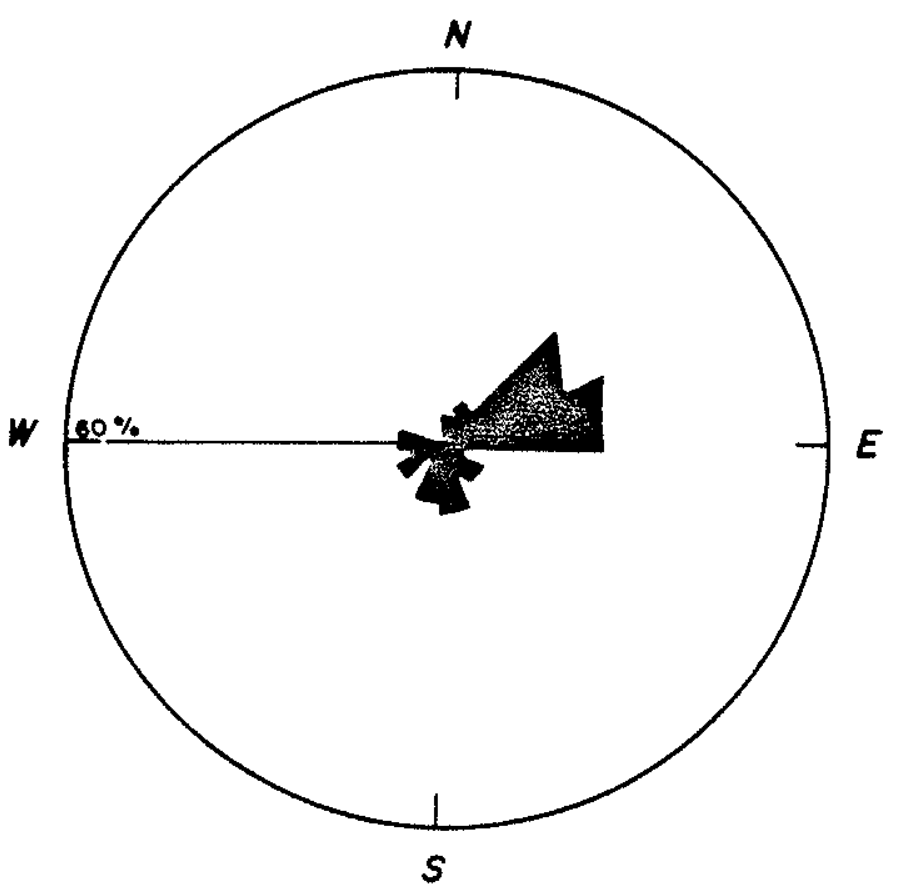

mola aguo

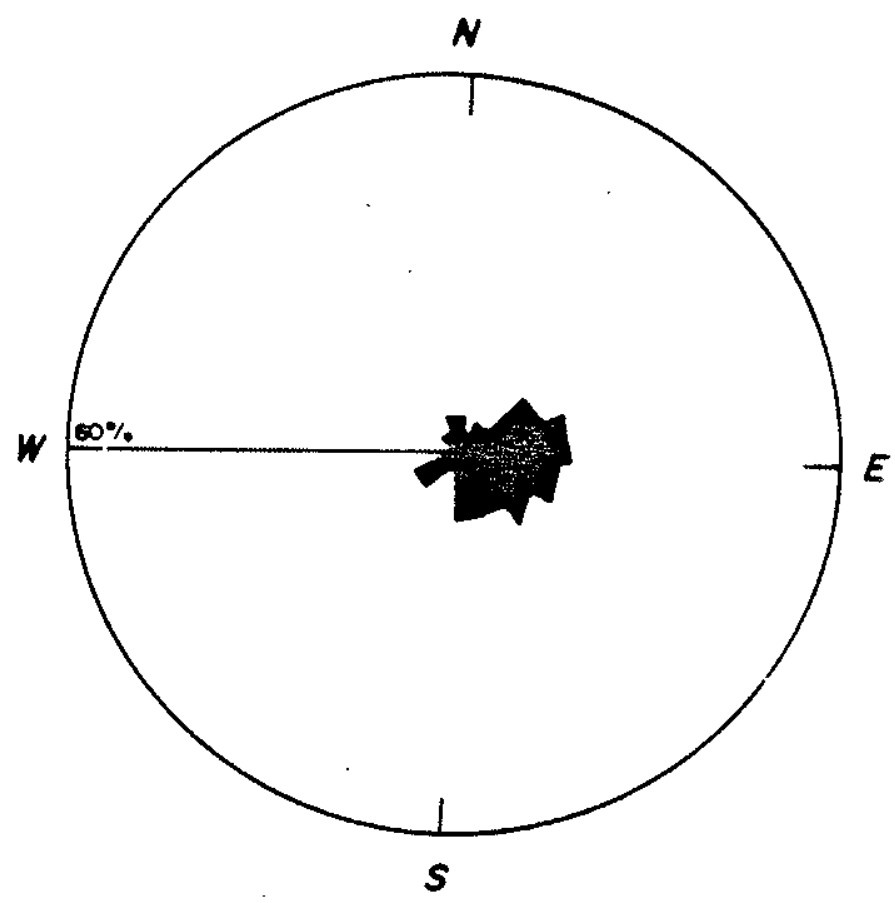

fundo

Fig. 37 - Rosas de correntes para meia-água e fundo ná estação fixa de Cananeia, 1984. 


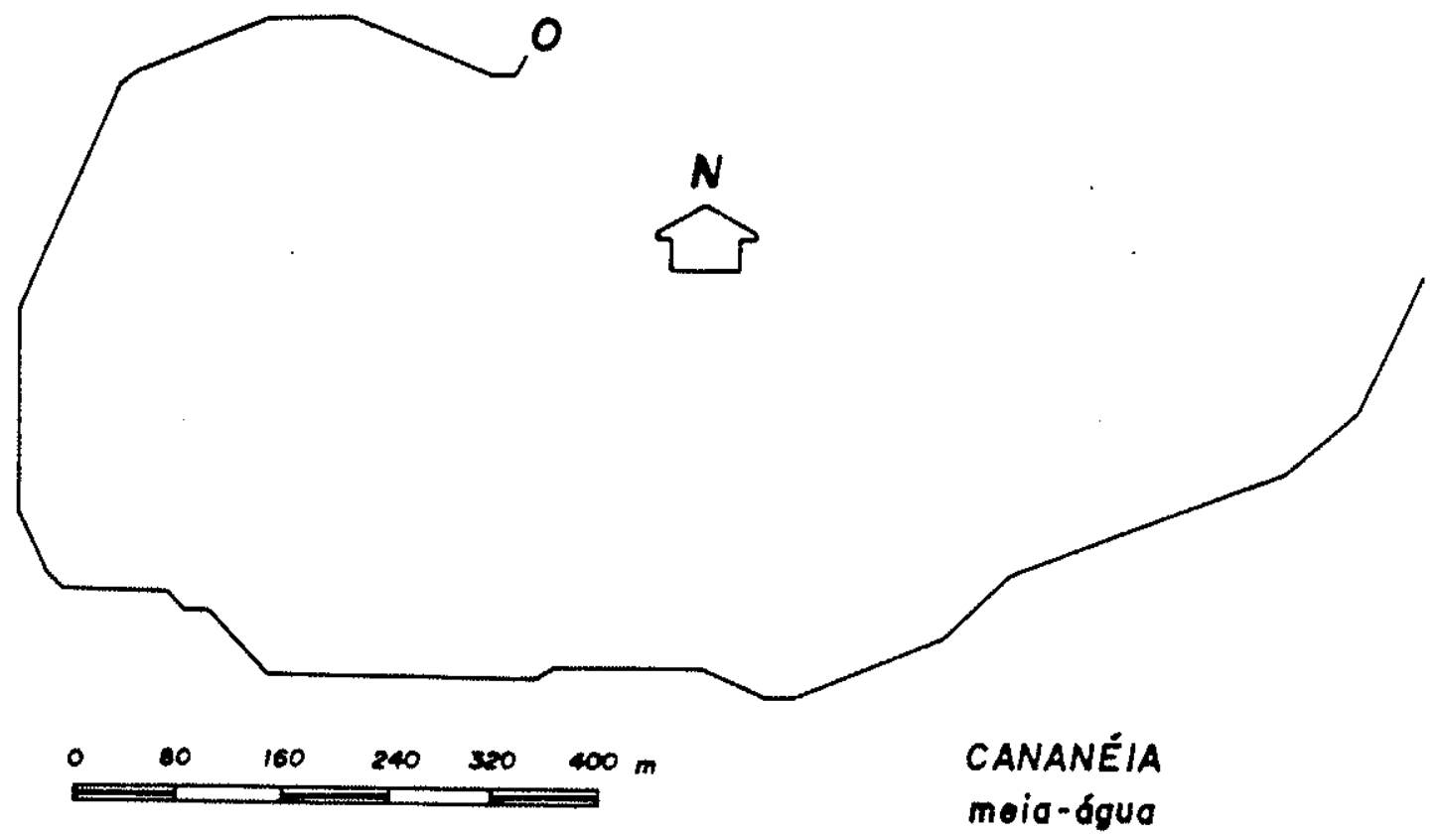

Fig. 38 - Diagrama de deslocamento médio progressivo. Estação fixa de Cananéia, meia-água, 1984. 


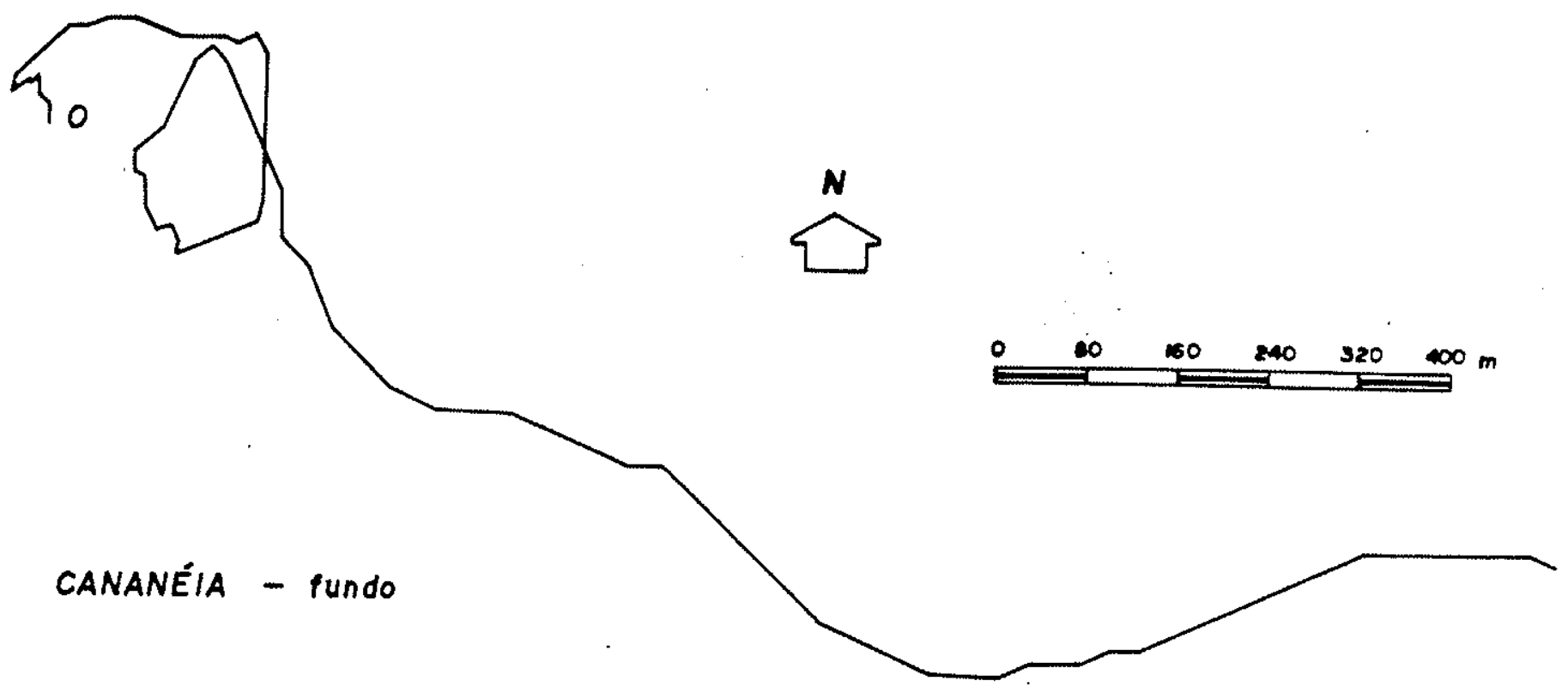

Fig. 39 - Diagrama de deslocamento médio progressivo. Estação fixa de Cananéia, fundo, 1984. 
A análise dos dados não declinados de direção de corrente, para meia-água (fig. 40), mostra uma prdominância de corrente para NNW e $\underline{N E}$, onde estão contidas $60 \%$ das medidas realizadas. Com freqüências menos significativas são ainda identificadas direções de propagação $\underline{N W}$ e $\underline{N E}$.

Por outro lado, as medições junto ao fundo indi caram uma forte tendência (61\%) para o rumo $\underline{\mathrm{SW}}$, sendo que apenas o intervalo entre as direções SW e WSW contribui com 44,5\% dos valores observados entre $180^{\circ} \mathrm{e} 270^{\circ}$. Secundariamente $(\simeq 10 \%)$ estão ainda representadas as direções de deslocamento NNE e SSE.

Da comparação entre as direções predominantes de deslocamento das correntes à meia-água e próximas ao fundo fica evidenciada a possibilidade da existência simultânea de deslocamentos opostos no litoral sul paulista, entre as camadas superiores da coluna de água e a camada mais próxima do fundo. Esta constatação pode auxiliar no entendimento do fenômeno do transporte, em sentidos opostos, de material transportado em suspensão e da carga de fundo, hipótese já aventada anteriormen te por diversos autores (Sadowsky, 1952, 1954; Geobrás, 1966).

Com relação às velocidades de corrente a meiaágua, foram medidas correntes mínimas de $9 \mathrm{~cm} / \mathrm{s}$ e máxima de 24 $\mathrm{cm} / \mathrm{s}$ respectivamente nas direções NNE e NNW.

Junto ao fundo, as velocidades medidas correspondem, de maneira geral, a valores menores do que os observados a meia-água, sendo que o maior valor de corrente medido foi de $18 \mathrm{~cm} / \mathrm{s}$, no sentido WSW, e o menor $8 \mathrm{~cm} / \mathrm{s}$ no rumo $\underline{\mathrm{S}}$.

Porém, quando comparadas as velocidades médias calculadas para as medidas de meia-água e do fundo verifica-se, diferentemente das estações de Paranaguá e Cananéia, que os valores obtidos são muito semelhantes (meia-água $=12,8 \pm 2,7 \mathrm{~cm} / \mathrm{s}$ e fundo=11,7 $\pm 2,2 \mathrm{~cm} / \mathrm{s}$ ).

A possibilidade da ocorrência simultânea de deslocamentos opostos, entre as camadas de meia-água e de fundo, também pode ser observada quando da análise dos diagramas progressivos. 


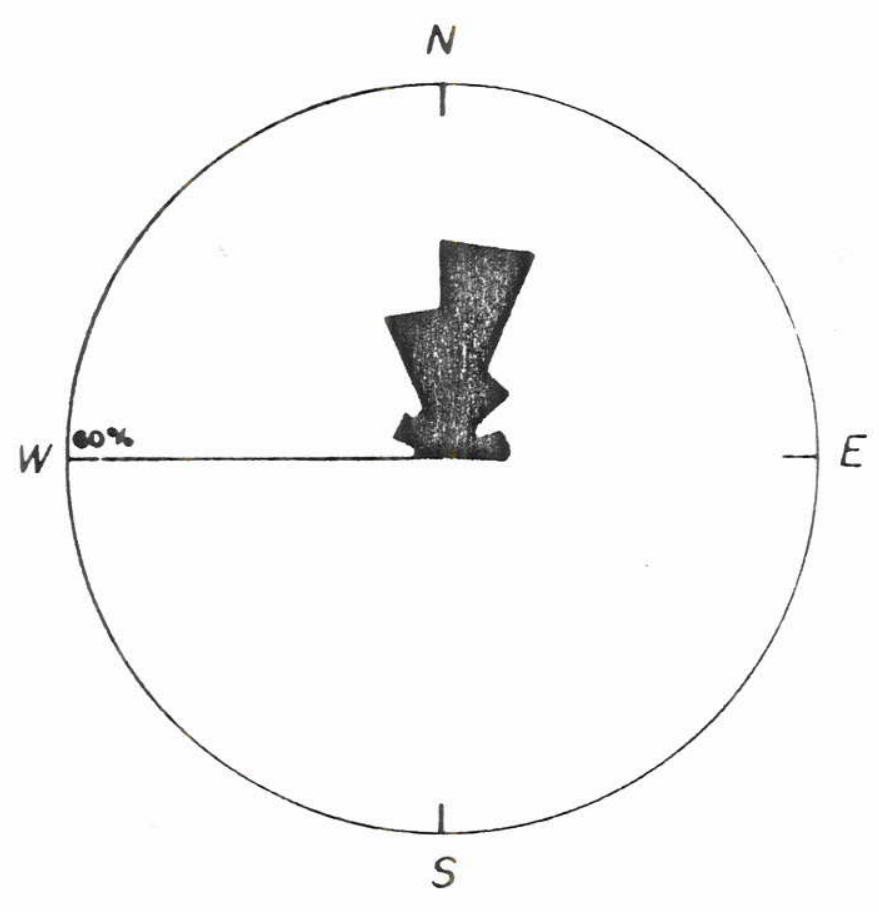

moio - dgua

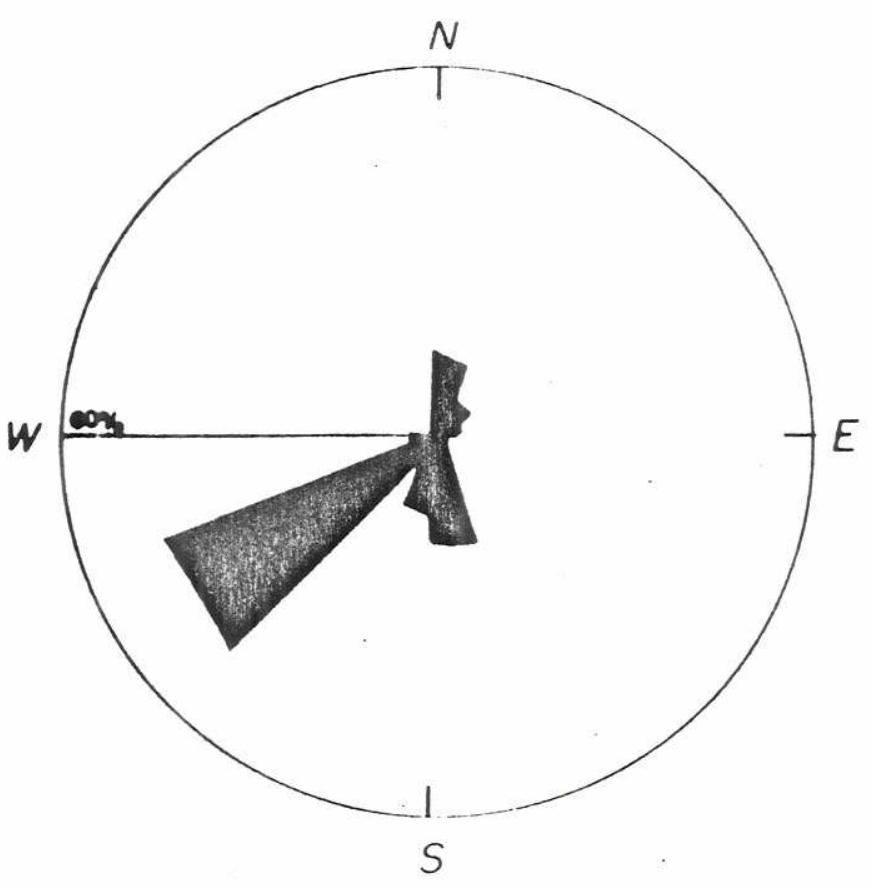

fundo

Fig. 40 - Rosas de correntes para meia-água e fundo na estação fixa de Iguape, 1984 . 
Para meia-água (fig. 41), observa-se um desloca mento para $\underline{N}$ - NNE enquanto que para a camada de fundo (fig.42), este deslocamento ocorre predominantemente para as direções $\underline{W}$ e SW.

Pela análise conjunta dos diagramas de rosas de correntes e dos diagramas de deslocamento progressivo, para a área de Iguape, fica estabelecida a possibilidade da existência de transporte de material em suspensão, no sentido da porção central do litoral paulista concomitantemente a um transporte de fundo em sentido oposto.

\subsubsection{4 - Estação fixa de Cananéia (1962)}

Por um período de 16 dias (16/04 a 02/05) durante o outono de 1962, como um estudo complementar ao realizado pela Missão Francesa na segunda metade da década de 50, foram realizados na região da desembocadura lagunar de Cananéia, a in tervalos regulares de 30 minutos, medidas de direção e intensidade de correntes.

Para essas medições, realizadas ao norte da Ilha do Bom Abrigo ( $25^{\circ} 06^{\prime} \mathrm{S}$ e $047^{\circ} 51,6^{\prime} \mathrm{W}$ ), foi utilizado um cor rentógrafo ONO, instalado provavelmente a uma profundidade de 5 metros acima do fundo, em uma área cuja profundidade atual é de cerca de nove metros.

Esta incerteza quanto às profundidades de fundeio do equipamento não permite, com segurança, extrapolar esses dados para situações mais próximas do fundo.

Desta forma, esta série de medidas fica restrita a uma situação de meia-água, em uma área cuja composição tex tural do fundo atual (areno-argilosa) representa uma exceção em relação ao padrão geral arenoso da região estudada.

A maior velocidade de corrente medida $(40 \mathrm{~cm} / \mathrm{s}-$ $\underline{N E}$ ), representa um valor cerca de nove vezes superior à corrente de menor valor $(4,6 \mathrm{~cm} / \mathrm{s}-\underline{S W})$, evidência da grande variabilidade das intensidades de corrente junto à desembocadura lagunar de Cananéia. 
IGUAPE

meia - dquo
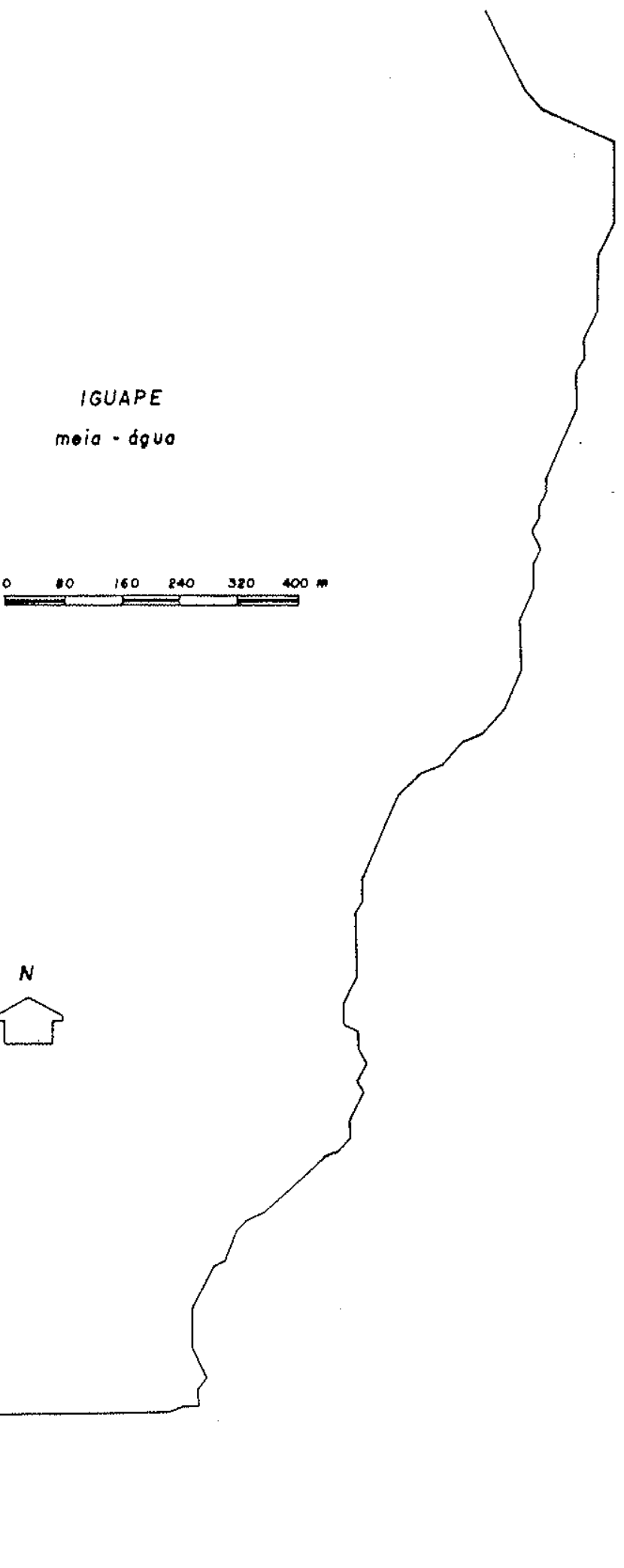

Fig. 41 - Diagrama de deslocamento médio progressivo. Estação fixa de Iguape, meia-água, 1984. 


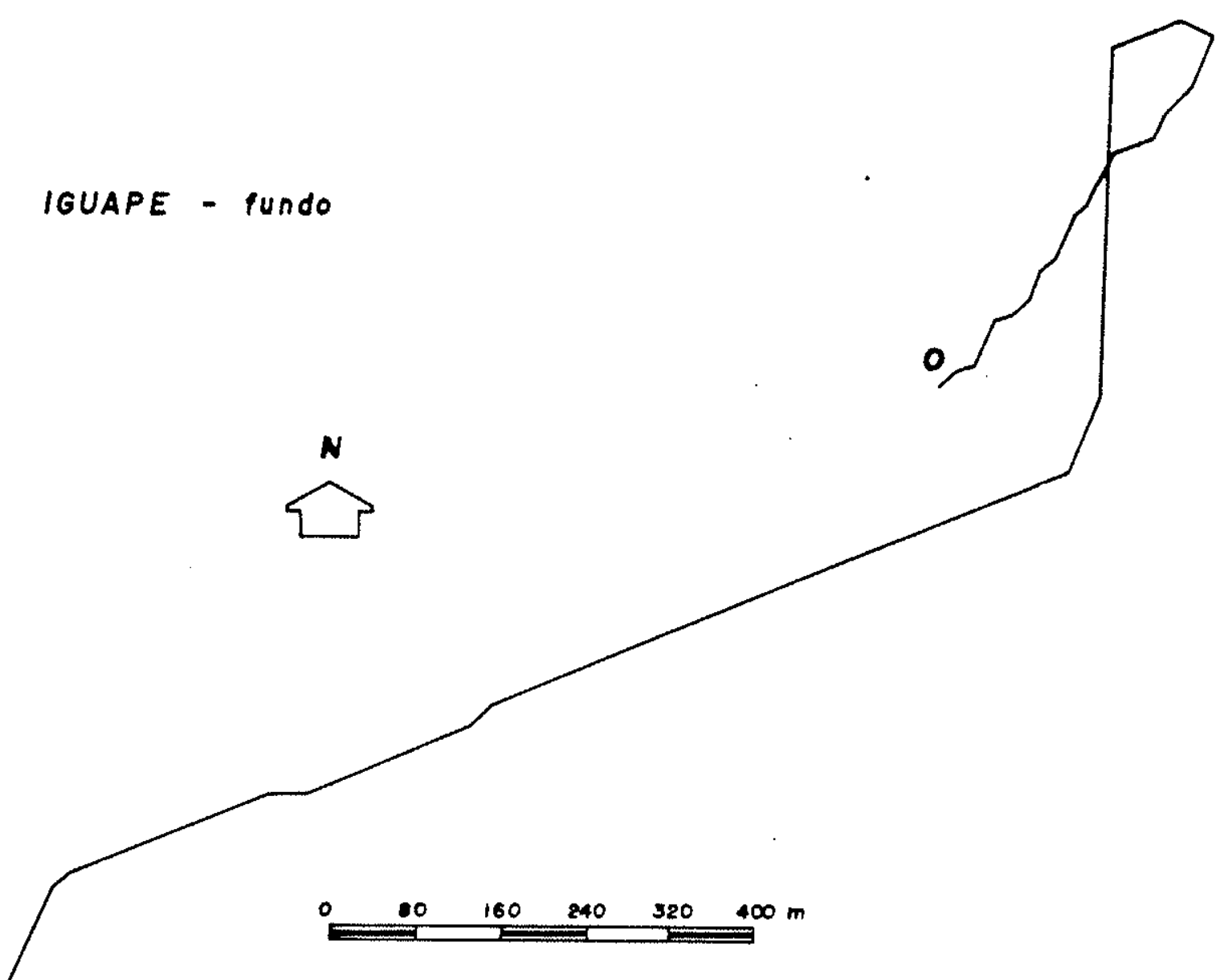

Figura 42 - Diagrama de deslocamento mëdio progressivo. Estação fixa de Iguape, fundo, 1984. 
A média das medidas de 1962 fol de $10,9 \pm 4,9 \mathrm{~cm} / \mathrm{s}$. que corresponde a um valor inferior à média calculada para meiaágua, de todas as estações operadas em 1984.

Quando analisado o conjunto de medidas por intervalos de direção de $22,5^{\circ}$, a partir do norte observa-se que apenas as correntes de rumos $\underline{N N E}$ e SSW apresentam valores médios de velocidade superiores à média obtida para todo o conjun to de dados (NNE - $11,4 \pm 6,8 \mathrm{~cm} / \mathrm{s}$ e $\underline{\mathrm{SSW}}-13,2 \pm 5,3 \mathrm{~cm} / \mathrm{s}$ ).

O diagrama de rosa de corrente (fig. 43) mostra uma predominância de correntes nos quadrantes NE (29\%) e SW $(32,6 \%)$. Entre os rumos a NE predominam o rumo NNE $(20,6 \%)$ sobre ENE, enquanto que para os rumos de $\underline{S W}$ as porcentagens de propagação entre os rumos SSW e WSW são equivalentes $(16,9 \%$ e $15,7 \%$ ).

Como o período de medição de correntes na estação de 1962 abrangeu vários ciclos consecutivos de maré, uma comparação deste diagrama com os obtidos para as estações reali zadas em 1984, abrangendo apenas um ciclo completo de maré, não seria possivel sem que algumas precauções fossem adotadas. Desta forma foram construídos diferentes diagramas utilizando-se na confeção de cada um deles conjuntos distintos de dados:

a) conjunto total de dados; b) períodos de 24 horas correspondendo ao intervalo de 0 a $24 \mathrm{hs} e \mathrm{c}$ ) conjuntos correspondentes a ciclos completos de marés (25 hs) vinculados às informações sobre os ciclos de marés obtidas no marégrafo instalado na região lagunar de Cananéia - Iguape.

Dentre os três tipos de diagramas construídos os associados aos ciclos completos de maré, independentemente do dia ou hora de obtenção da medida de corrente, foram os mais apropriados para as análises sobre os deslocamentos das correntes na área.

De comum a todos os catorze diagramas correspon dentes aos ciclos completos de maré, abrangendo o período de mediçoes, observa-se una vorticidade dos vetores deslocamento resultando da influência das marés dominantes na região próxima 


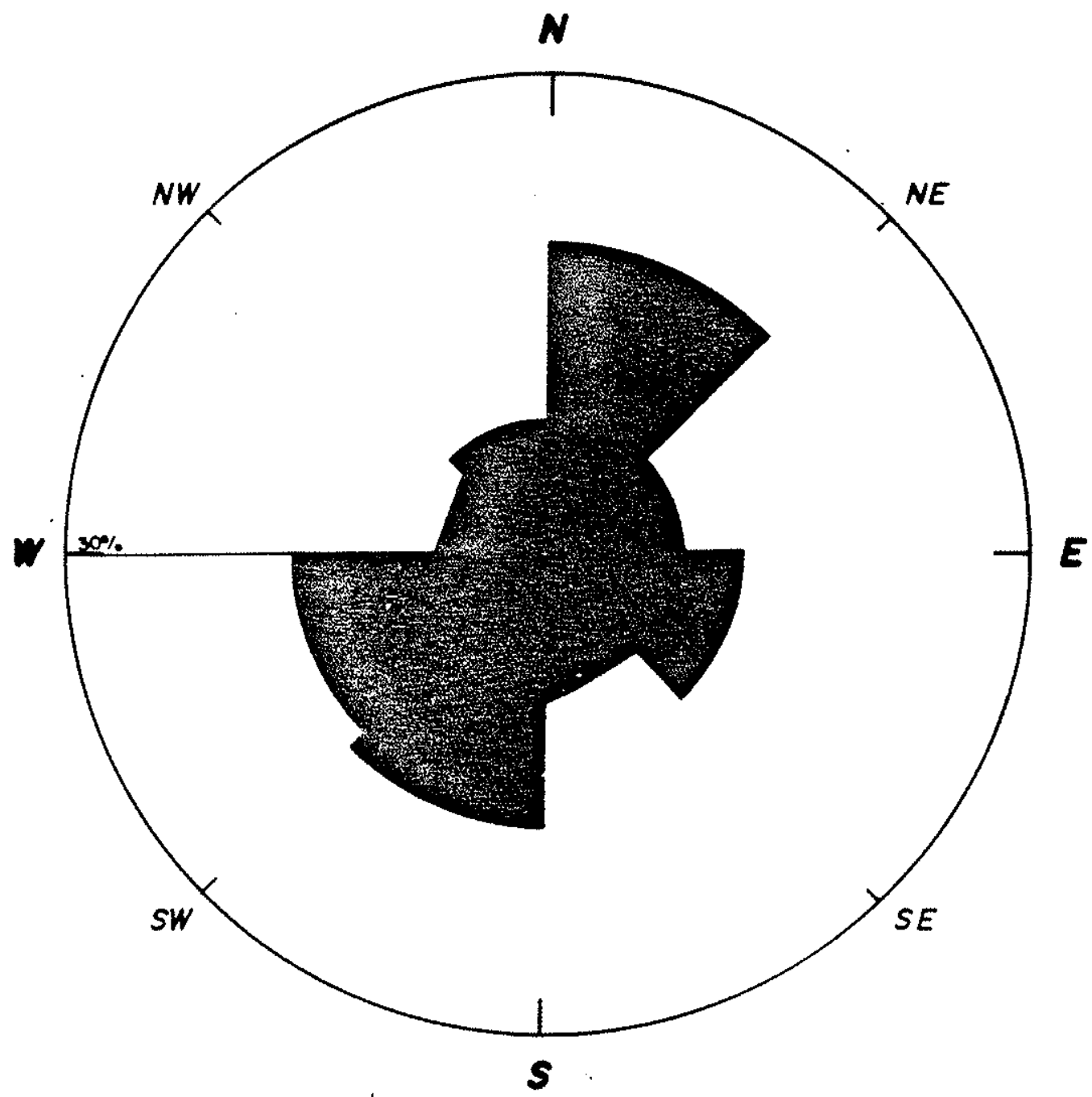

Fig. 4 - Fusas de correntes pará meia-água na estação da desembocadura lagunar de Cananéia, 1962. 
a desembocadura lagunar de Cananéla. Esta mesma tendência foi detectada, em menor escala, nos diagramas construidos para a estação fixa de Cananéia (1984), seja a mela-água como também em menor intensidade para as correntes medidas funto ao fundo.

Infelizmente, devido às peculiaridades do levantamento executado em 1962, não nos foi possivel avaliar com maior detalhe a influência da ação de marés junto ao funda nas vizinhanças da desembocadura lagunar de Cananéia. Finalmente, objetivando uma melhor compreensão da eficiência das correntes medidas no transporte de sedimento de fundo paralela e transverșalmente à linha da costa, fol realizada uma análise de decomposição dos vetores (rumo e intensidade) para cada estação de correntometria operada.

Esta decomposição vetorial, considerado 0 alinhamento de $45^{\circ}$ em relação ao norte geográfico da linha de cos ta sul paulista, foi elaborada segundo dois eixos ortogonais en tre sí, sendo o primeiro paralelo e o segundo perpendicular $\bar{a}$ linha de costa atual.

Para esta decomposição, todas as direções de corrente foram declinadas em $14,2^{\circ}$, conforme dado existente na carta naútica 1702 da Diretoria de Hidrografia e Navegação ( $D$. H.N. - MM, 1985).

Os resultados obtidos demonstram existir uma semelhança entre o comportamento das correntes, à meia-água, nas estações de Paranaguá e Cananéia. Nestas estações ocorre uma predominância de deslocamentos positivos, ao longo do eixo paralelo à costa (U) e de deslocamentos negativos, mar aberto, segundo eixo transversal (V) (fig. 44).

Já na estação de Iguape, à meia-água, ocorre um deslocamento para os valores positivos no eixo V, originando uma resultante de sentido geral $\underline{N}$, com ângulo de cerca de $40^{\circ}$ com relação à atual linha de costa.

Junto ao fundo, os resultados obtidos nas esta ções de Paranaguá e Cananéia são bastante similares aos obtidos para meia-água enquanto que para a estação de Iguape, a re sultante obtida apresenta um deslocamento oposto ao de meia- 
Fig. 44 - Diagrama de decomposição dos vetores correntes (direçao e intensidade), segundo elxos paralelos e perpendicu lar a linha de costa atual.

Valores de $(u, v)$ obtidos para as estações de:

Estação

\begin{tabular}{|c|l|c|c|}
\hline $\begin{array}{c}\text { Paranaguá } \\
1984\end{array}$ & mela-água & $+366,0$ & $-447,7$ \\
\cline { 2 - 4 } & fundo & $+466,6$ & $-231,0$ \\
\hline $\begin{array}{c}\text { Cananéla } \\
1984\end{array}$ & meia-água & $+714,9$ & $-597,6$ \\
\cline { 2 - 4 } & fundo & $+351,8$ & $-344,6$ \\
\hline $\begin{array}{c}\text { Iguape } \\
1984\end{array}$ & meia-água & $+878,2$ & $-804,0$ \\
\cline { 2 - 4 } $\begin{array}{c}\text { Cananéia } \\
1962\end{array}$ & fundo & $-704,2$ & $-49,6$ \\
\hline
\end{tabular}

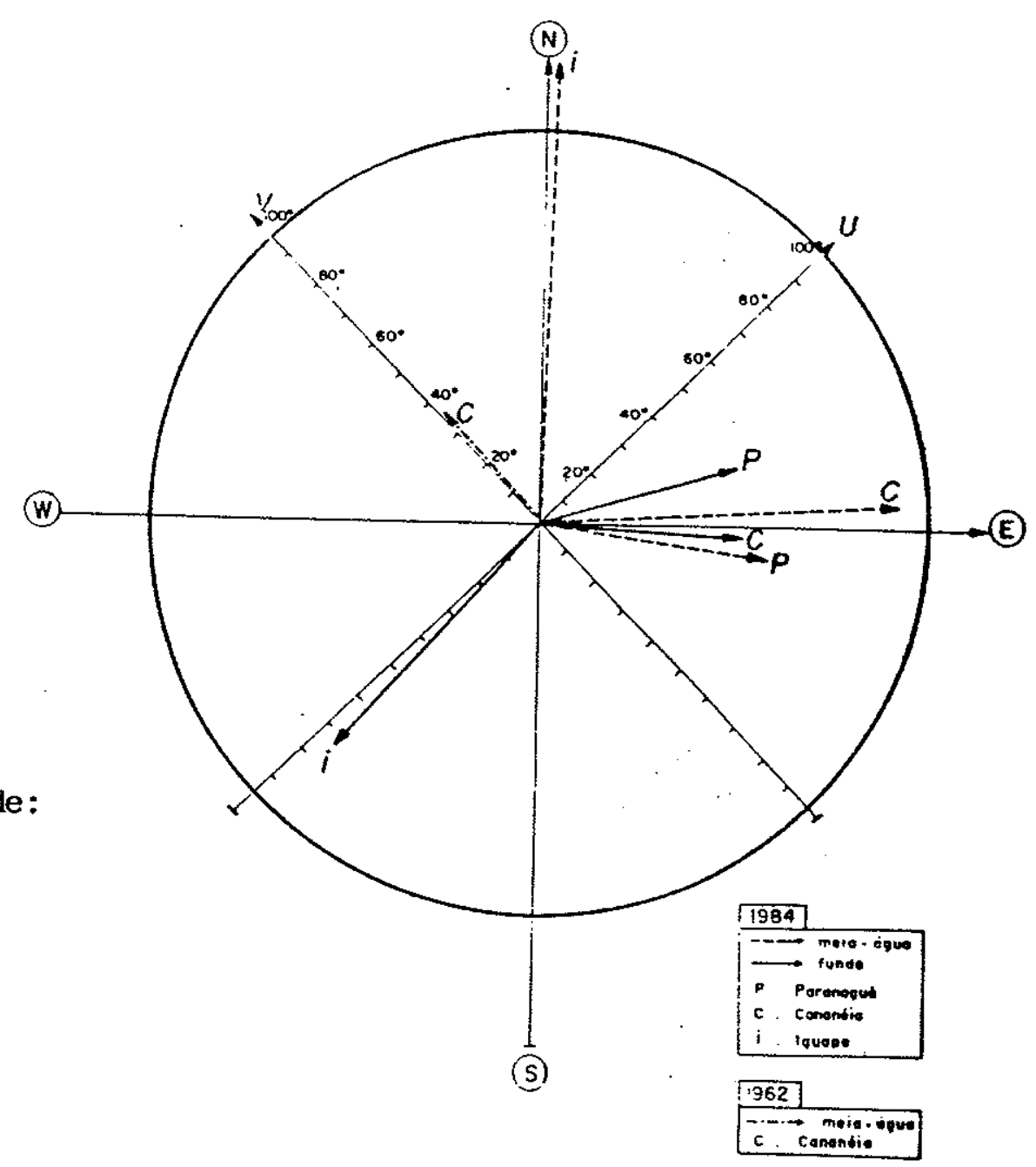


água, ou seja, aproximadamente paralela à linha de costa atual porém dirigida da porção central para o litoral sul paulista.

Observa-se, portanto, para o fundo a existêncla de correntes com sentidos praticamente opostos entre as estações de Paranaguá e Cananéia e a estação de Iguape.

Uma análise semelhante efetuada para as medidas obtidas em 1962, reforça a importância das correntes geradas pelas marés na região próxima na região próxima da desembo cadura lagunar de Cananéia, uma vez que o resultado obtido, ao longo do eixo paralelo à costa (U), é desprezivel evidencian do a predominância das correntes fluindo perpendicularmente $\bar{a}$ à linha de costa.

\subsubsection{3 - Correntes de superficie}

Sobre correntes de superfície não são conhecidos dados relacionados ao mar aberto, na região litorânea sul do estado de São Paulo. Portanto são também inexpressivas as informações existentes sobre a movimentação de sedimentos em suspensão na faixa litorânea, bem como da importância desse transporte na circulação geral da área.

Algumas informações acerca da circulação super ficial do litoral sul podem ser obtidas da interpretação de conjunto de fotografias aéreas, a partir da qual um reconhecimento da movimentação das correntes superficiais pode ser tentado utilizando-se diferenças de concentração de material em suspensão como traçador. A observação de uma imagem MSS do sa télite Landsat nos canais 4 e 5 , obtida no dia 26/06/76 em escala aproximada de $1: 1.000 .000$, permite uma avaliação de pelo menos uma situação geral de circulação em superfície para toda a área sul do estado (fig. 45). Foi notada a presença de plumas de material em suspensão bem nítidas entre a praia Grande e o Morro da Juréia, com rumo SW, além de outras, menos nitidas e com o mesmo sentido, em toda a área costeira compreendida entre Santos e a barra do rio Ribeira de Iguape.

$\mathrm{Na}$ altura da foz do RIbeira de Iguape e da de sembocadura lagunar de Icapara observam-se também densas plumas, porém em posição mais distante da linha de costa. 

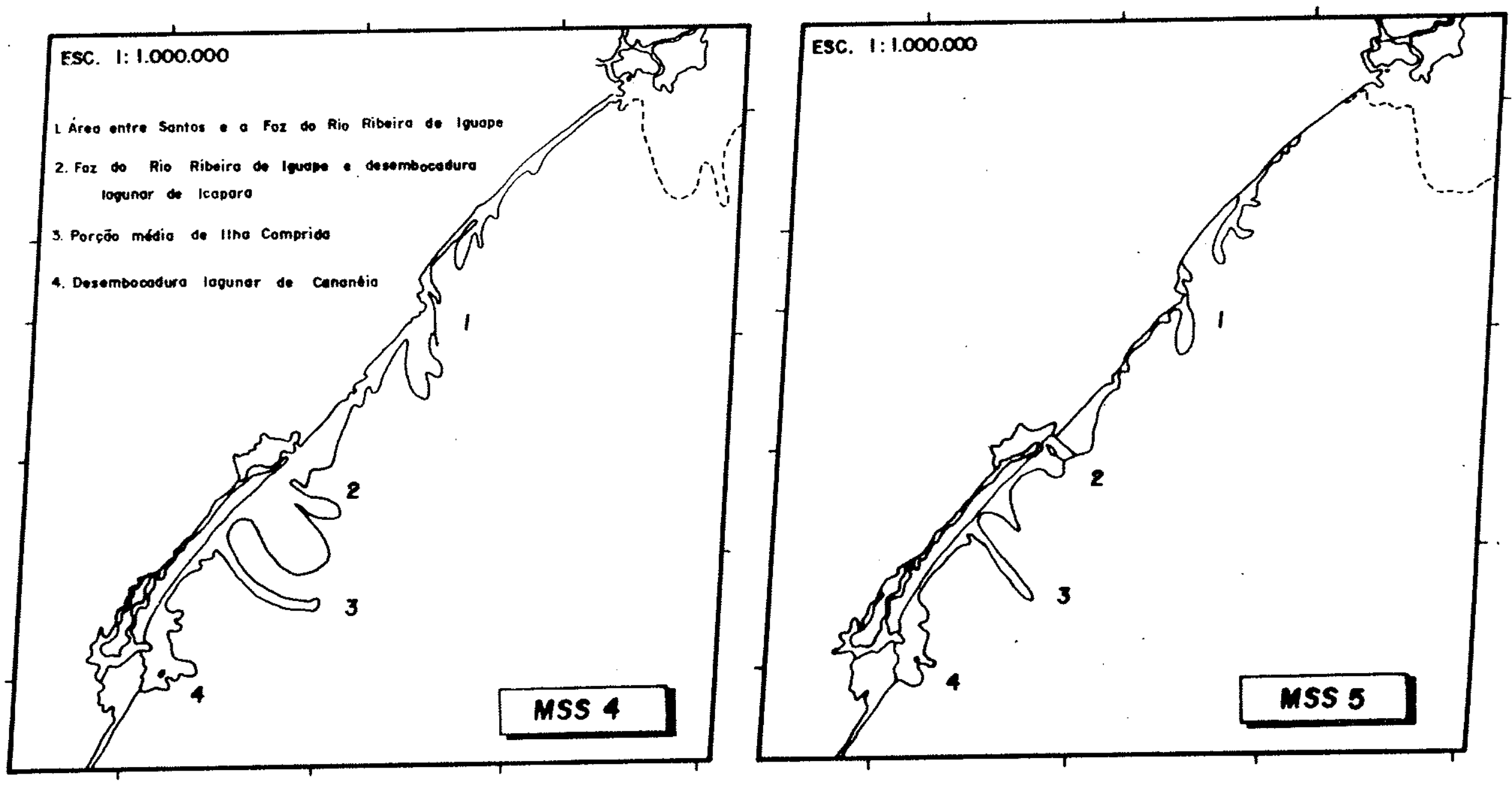

Fig. 45 - Correntes de superfície do litoral sul paulista através da interpretação das 1magens do satél1te LANDSAT - MSS, Canais 4 e 5 , de 26/06/76. 
Na porção média da Ilha Comprida nota-se uma pluma nitida, ortogonal à Iinha de costa, e direcionada para o mar aberto. Esta é uma feição interessante que será discutida adiante.

$\mathrm{Na}$ altura da desembocadura lagunar de Cananéia existe uma outra pluma de material em suspensão, porém com sentido $\mathrm{NE}$, ou seja, no rumo da IIha Comprida.

A análise das imagens permite considerar que, de maneira geral, há dois sistemas, opostos entre si, de trans porte em suspensão ao longo da costa. O primeiro que se desen volve entre Santos e a foz do Ribeira, com rumo $\underline{\mathrm{SW}}$, e o segundo que se estende da desembocadura lagunar de Cananéia até a porção norte da Ilha Comprida, portanto com rumo $\underline{\mathrm{NE}}$. Entre a extremidade norte da Ilha Comprida e a foz do Ribeira há, apa rentemente, uma área de transição com as plumas dirigidas para - mar aberto ( $\underline{\mathrm{SE}}$ ).

A feição presente na porção média da Ilha Comprida parece ser uma corrente de retorno ("rip-current"), ou seja, um fluxo que sai da costa rumo ao mar aberto, com grande capacidade de transporte e responsável, portanto, pela distribuição de material carreado em suspensão para além da zona de arrebentação das ondas. Estas correntes de retorno costumam apresentar-se como feições temporárias, que podem ser geradas a partir do encontro de duas correntes de deriva litorânea, de sentidos opostos, ou pelo desvio de apenas uma dessas correntes pelas irregularidades do fundo submarino. Portanto, estas feições estão intimamente associadas aos mecanismos de refracão das ondas que, apresentam na área, a possibilidade de gera cão de correntes de deriva litorânea de sentidos de propagação opostos.

Com respeito à periodicidade deste evento, a falta de maior número de observações não permite uma avaliação mais precisa do fenômeno. Entretanto, a ocorrência de desvios rumo ao mar aberto das curvas batimétricas, aproximadamen te retilineas e paralelas ao longo do trecho estudado, são um forte indício da ocorrência periódica deste fenômeno. 


\section{3 - Fatores meteorológicos}

A influência dos parâmetros meteorológicos, em especial dos ventos locais, sobre as direções e intensidades de correntes de fundo em regiões Iitorâneas, é pouco conhecida.

Com relação aos grandes movimentos das massas de ar, que afetam o litoral sul brasileiro e que influenciam a circulação geral da área, Garcia occhipinti (1983) identificou duas situações principais que afetam a área.

A primeira situação, que domina a área namaior parte do ano, foi denominada pelo autor como de dominio da mas sa de ar Tépido Atlântico, controlada pelo anti-ciclone subtro pical, semi-permanente do Atlântico sul. Nestas condições, no centro dessa massa a temperatura é extremamente homogênea, os ventos predominantes são de leste a noroeste, principalmente du rante o verão é sua ação se estende sobre todo o continente, ocasionando altas temperaturas provocadas pela alta insolação.

Esta situação é perturbada pela invasão de mas sas de ar polar Atlântico, resultante da circulação meridiana. Esta massa origina-se abaixo de $40^{\circ}$ de latitude sul e o ar constituinte é mais frio em qualquer época do ano. 0 contac to desta massa de ar com o ar Tépido Atlântico, forma a Frente Polar Atlântica, em latitudes da ordem de $35^{\circ}$ sul.

O avanço desta frente, rumo ao norte, provoca as conhecidas perturbações frontais, cuja passagem pela região de Cananéia provoca fortes precipitações e mudança da direção dos ventos de leste para o quadrante sul.

De um modo geral, pode-se dizer que a situação habitual do tempo na planicie costeira do sul do estado depende da massa Tépido Atlântico e da invasão das frentes frias. Em escala menor influem, também nas caracteristicas meteorológicas, as incursões das massas de ar Equatorial Continental, que raramente atingem a região no verão e das frentes de perma nência estacionária.

Especificamente com relação à importância das correntes costeiras induzidas pelos ventos locais, silva (1968) 
analisou, segundo modelo de Ekman, a Importância da geração das correntes litorâneas induzidas pelos ventos para diferentes profundidades de lâmina de água. Nesta avaliação Silva (op. cit.) concluiu que na plataforma continental interna 0 aumento da velocidade de corrente, que deveria ser esperado pelo in cremento da velocidade do vento, é neutralizado pelo efeito exercido pelo fundo à medida que decresce a relação entre a es pessura da coluna de água $(h)$ e a espessura da camada friccional de Ekman (D).

Portanto, à medida que cresce em importância a ação das ondas sobre as correntes de deriva litorânea, com a proximidade da linha de costa, a ação dos ventos locais diminui. Segundo Silva (op. cit.), os ventos locais são responsáveis pela geração de correntes da ordem de apenas $2 \mathrm{~cm} \cdot \mathrm{s}^{-1} \mathrm{em}$ áreas com profundidades inferiores a $15 \mathrm{~m}$.

Durante as medições de corrente, na primavera de 1984 e no outono de 1962, as duas principais situações meteorológicas descritas por Garcia Occhipinti (op. cit.) puderam ser identificadas.

Nas medições de 1962 , dois momentos de passagem de frente foram identificados em 22/04 e 01/05, conforme pode ser constatado pela análise das cartas sinóticas produzidas pela Diretoria de Hidrografia e Navegação - Ministério da Marinha e confirmadas pela queda da pressão atmosférica medida na estação meteorológica de Cananéia.

Analisando-se o padrão de vento na área durante o período de medição (Tabela 50) e, em especial do período de passagem da frente fria do dia 22/04, verifica-se o predomí nio dos ventos dos quadrantes $\underline{S}$ e $\underline{W}$ onde durante o dia 22/04 foram observados os mais altos valores de intensidade absoluta $(6,5 \mathrm{~m} / \mathrm{s})$ e média $(4,3 \mathrm{~m} / \mathrm{s})$ de todo o período.

Desta maneira é perfeita a analogia entre os parâmetros medidos na área e a situação meteorológica descrita por Garcia Occhipinti (op. cit.).

No período de outono e inverno quando se verifica uma constante invasão do ar de origem polar nestas latitú des, as perturbações são muito freqüentes. Com a aproximação 
da frente. os ventos passam a soprar de direções próximas de NNE defletindo para $\mathrm{NW}$, na cava pré-frontal, até atingirem direções WSW após a passagem da frente.

São nestes momentos de aproximação e passagem da frente, que os mais altos valores de intensidade de deslocamen to dos ventos foram registrados $(6,5 \mathrm{~m} / \mathrm{s})$, tanto para a fase de aproximação (NNE), quanto para o instante pós-frontal (WSW). Pa ra a primavera de 1984 também foi identificado um fenômeno do tipo frente, entre os dias 05 e 06/10, ou seja, após a operacão das estações. fixas de Paranaguá e Cananéia.e anteriormente à execução da estação fixa de Iguape. Desta maneira, a aná Iise do padrão de ventos realizada à bordo do navio oceanográfico, conjuntamente às medições de corrente, mostra padrão dis tinto para as situações pré e pós frontal.

A estação fixa de Paranaguá apresentou predomi nância de ventos provenientes de $\underline{S}$ e $\underline{S W}(61,5 \%)$ com velocidades médias variando entre 2 e 5,8 nós (Tabela 51). Esta predominância de ventos sul foi acentuada durante as medições na esta ção de Cananéia, quando $77,7 \%$ das observações indicaram ventos originários de $S$ e SSW com elevadas velocidades.

Os dados de direção e intensidade de ventos nas estações de Paranaguá e Cananéia, quando confrontados com a car ta sinótica da Diretoria de Hidrografia e Navegaça do Ministé rio da Marinha, mostram-se coerentes com o fenômeno de perturbação do tipo frente estacionária, de fraca intensidade. Esta situação meteorológica, que já perdurava há alguns dias com um fraco deslocamento, a partir de altas latitudes, foi a responsável pela geração dos ventos provenientes do sul, bem como pelas características de ondas medidas à bordo do navio oceanográfico.

$\mathrm{Na}$ estação de Iguape predominaram os ventos provenientes de NE e ESE (68\%) e secundariamente (34,6\%) os ventos provenientes das direções SE e ESE. Estas observações da estação de Iguape denotam uma mudança, dos rumos de proveniêncla dos ventos, em relação as observações das estações de Paranaguá e Cananéia. 
Embora este padrão não representasse uma situa cão típica de fase pós-frontal, como descrita por Garcia Occhipinti (op. cit.), as velocidades dos ventos ainda eram relativamente altas ( $\approx 15$ nós).

Portanto, embora o litoral sul paulista apresente características meteorológicas vinculadas à circulação dinâmlca do litoral sul brasileiro, a proximidade da Serra do Mar, sem dúvida, Influi neste padrão geral pela retenção dos sistemas frontais. Porém, de qualquer forma, estas alterações locais não têm influência significativa na geraçõo das correntes costeiras, vinculadas principalmente aos sistemas de ondas geradas em áreas oceânicas, bem como no incremento das velocidades dessas correntes, pouco alteradas pela ação dos ventos 10 cais.

\subsection{1 - Relação entre os parâmetros oceanográficos e os fatores meteorológicos}

Da análise conjunta das características oceanográficas e meteorológicas observadas durante o outono de 1984 , foi possivel identificar algumas relações diretas, do tipo causa-efeito, entre os diferentes parâmetros que atuam na dinâmica de fundo da zona litorânea.

Nos extremos da área estudada, as correntes de fundo guardam relação direta com os padrões de ondas incidentes. Em Cananéia, apenas essa correspondência não é suficiente para explicar o padrão de correntes observado.

Em Paranaguá, $50 \%$ dos sistemas de ondas se pro pagam a partir de $\underline{\mathrm{SSW}}$ e $\underline{\mathrm{SW}}$ com um sistema secundário de $\underline{\mathrm{E}}$ e $\underline{\mathrm{ESE}}$ $(\simeq 27 \%)$. As correntes de fundo propagavam-se predominantemente rumo a $\underline{N E}(82,8 \%)$ e secundariamente para $\underline{S}$ e $\underline{S E}$, o que corre $\underline{S}$ ponde perfeitamente ao padrão de correntes esperado em função do padrão de ondas incidentes.

Em Iguape, esta interdependência é ainda mais direta, na medida em que o sentido predominante a partir de leste das ondas, perfazendo $83,3 \%$, implica em correntes de deriva litorânea dirigidas para $\underline{\mathrm{SW}}$. Esta interrelação é inteira- 
mente confirmada com a obtenção do rumo $\underline{\mathrm{SW}}(61 \%)$ como a predominante entre os sentidos de atuação de correntes medidas, jun to ao fundo, na estação flxa de Iguape.

Já para a região de Cananéia, embora os trens de onda apresentem uma predominância de direções SE e SW (88,7\%), as correntes de fundo distribuem-se homogeneamente entre NE e $\underline{S}$. Esta aparente ausência de correlação entre os sistemas de ondas e correntes de fundo pode ser explicada pela influência dos dois outros principais fatores; ventos locais e marés, que vetorialmente se somam às ondas na composição das correntes próximas à costa.

Os padrões de ventos locais apresentam nitida concordância com as direções de incidência das ondas, pois em Paranaguá e Cananéia predominaram os ventos orıginários do sul, à semelhança dos padrões obtidos para a incidência de ondas.

Portanto, só o caráter de vento local não serve para esclarecero padrão disperso dos sentidos das correntes de fundo observado na estação de Cananéia. Corroborando esta constatação Silva (1968), já havia concluído existir uma limitação dos ventos locais na geração de correntes litorâneas no litoral sul-sudeste brasileiro.

A componente relacionada à ação de marés, embora nos faltem dados que permitam uma melhor avaliação, poderia ser considerada como uma possivel explicação para o padrão de correntes de fundo identificado. Esta suposição está basea da principalmente nas evidências observadas nos diagramas de vetor deslocamento progressivo, construídos para a estação de Cananéia, cujas características em muito se assemelham aos padrões de correntes, em áreas oceânicas, geradas por marés.

Por outro lado, a ausência de trajetórias elíp ticas características de padrões de correntes geradas, por marés, para os diagramas de Paranaguá e Iguape, não implicam necessariamente na dissociação completa entre as correntes de fundo e a ação das marés. Porém, o conjunto de dados analisados embora limitado no tempo, permite afirmar que são as ondas - principal fator gerador de correntes litorâneas no litoral 
sul do estado de são paulo. Com estes sistemas de ondas vincu lam-se zo regime geral de circulação atmosférica do litoral sul brasileiro, é possível afirmar-se que, as direcões das correntes de fundo do compartimento 11torâneo sul paulista constituem resposta à interrelação entre a topografia de fundo muito plana e o sistema de ondas incidente.

Desta forma verifica-se que, durante un ciclo anual alternam-se períodos de dominância entre a principal direção de incidência das ondas ( $\underline{\mathrm{SE}}$ - $\underline{\mathrm{SW}}$ ), geradora de correntes de deriva litorânea de rumo geral $\mathrm{NE}$ e do sistema secundário $(\underline{E}-\underline{S E})$ do qual resultam correntes de deriva com sentido geral $\underline{\text { SW }}$.

Pela análise dos conjuntos de fotografias aéreas é também possivel observar-se que estes sistemas de ondas, ao menos em situações atmosféricas sem a passagem de frentes, não são excludentes, o que possibilitaria o surgimento simultâ neo de correntes de deriva litorânea de sentidos opostos.

\section{4 - Velocidade crítica de transporte}

Sedimentos em repouso, sobre um substrato marinho ou fluvial, apresentam tendência geral a conservar seu estado estacionário até que sua inércia seja suplantada pela energia da corrente. A velocidade mínima requerida para que os sedimentos em repouso iniciem deslocamentos é denominada ve locidade crítica de transporte (Allen, 1968).

Para sedimentos arenosos, não coesivos, é intuitivo que, quanto mais denso for o grão e mais profundo for - canal, maior será a velocidade de fluxo necessária para remo vê-1o do estado estacionário.

Em situações onde o substrato é constituído de material coesivo, fundo argiloso, ou onde o sedimento apresenta um grau de seleção multo pobre devido a misturas, em diferentes proporçoes entre sedimentos arenosos e pelíticos, as ve locidades requeridas para o inicio de transporte são mais altas do que as necessárias para remover sedimentos constituídos por materiais mais grosseiros ou mais homogêneos. Este fa- 
to recebe o nome de efeito Hjulström, sendo responsável pela preservação de delicadas lâminas argilosas em depósitos de pla nicie de maré (Suguio, 1980).

\section{4 .1 - Formulações gráficas}

Estudos teóricos e experimentais têm sido desenvolvidos objetivando determinar as velocidades críticas necessárias para a movimentação de sedimentos de diferentes granulações.

As velocidades criticas de transporte foram $f_{\underline{1}}$ xadas em função do diâmetro médio e do peso específico dos sedimentos, adotando-se como valor básico o peso específico do quartzo $\left(2,65 \mathrm{~g} \mathrm{~cm}^{-3}\right)$, para velocidades medidas a $1 \mathrm{~m}$ acima do fundo $\left(\mathrm{C}_{100}\right)$ considerado como o topo da camada limite (boundary -layer).

Dentre as principais formulações gráficas exis tentes, e que tem sido largamente utilizadas na literaturamun dial, os gráficos de Postma (1967); Hjulström (1956, apud Netta, 1980), Open University (1978) e Gadd et al. (1978, apud Muehe \& Sucharov, 1981) são sinteses representativas de todos esses es tudos (fig. 46).

De acordo com esses diagramas observa-se que a velocidade minima de corrente capaz de mover um sedimento não coesivo, de diâmetro médio areia fina a média, a partir de seu estado estacionário está em torno de $20 \mathrm{~cm} / \mathrm{s}$. Além disso, verifica-se também que os sedimentos compreendidos no intervalo areia fina são mais facilmente erodidos do que sedimentos de granulação mais fina ou grosseira.

A curva de Gadd et al. (1978) é hoje a de mais ampla aceitação por representar um experimento que considerou criticamente todos os estudos anteriores e principalmente por reequacionar a curva de Bagnold (1956, apud Muehe \& Sucharov, 1981), que até então servia de base aos cálculos do volume de material transportado em regiões litorâneas. 

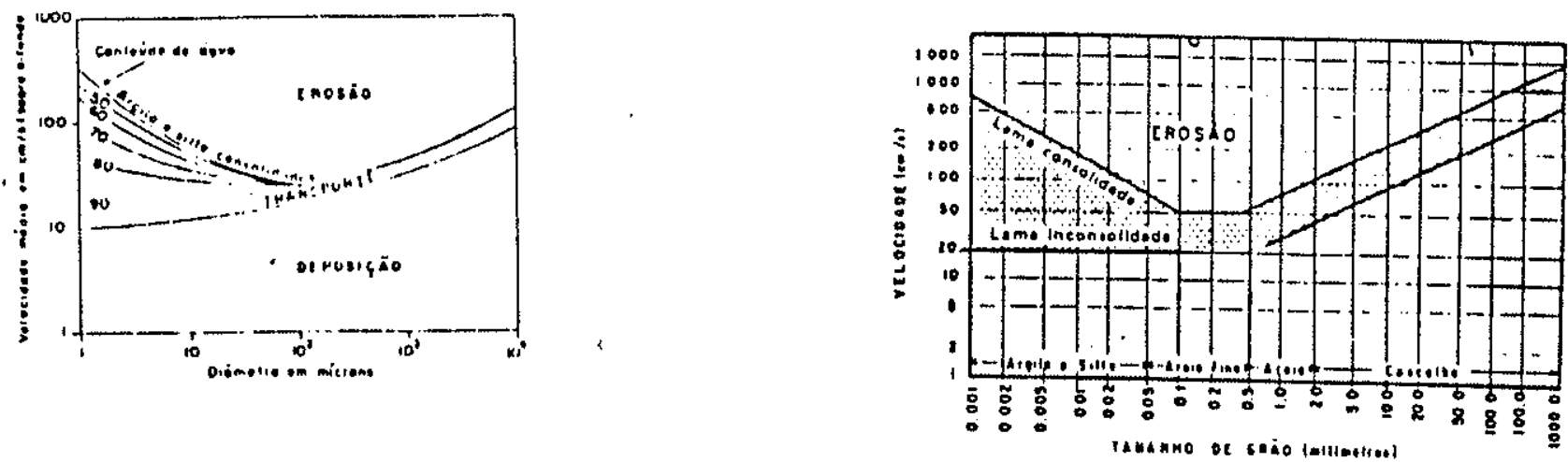

Velocidades criticas requeribils para erosão.

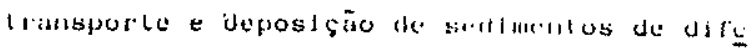

Giralico de Postma. (1967) puril velocstades de

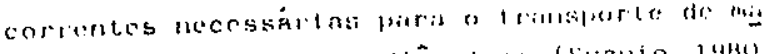

rentes granulaçöes (Netto, j980)

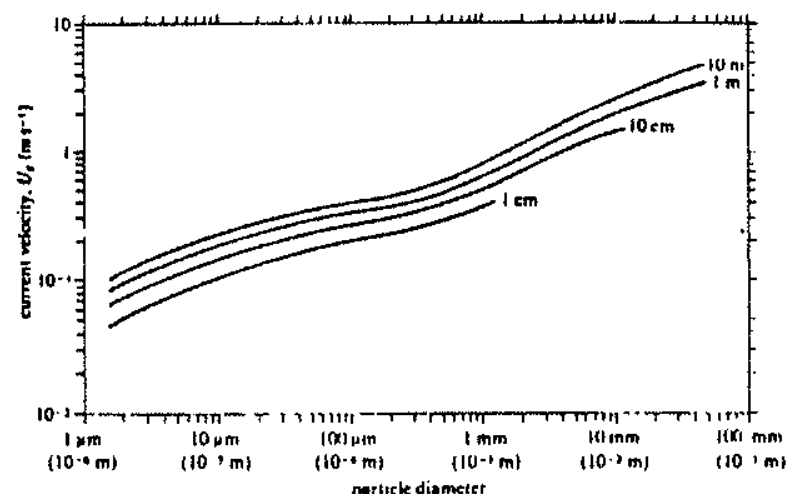

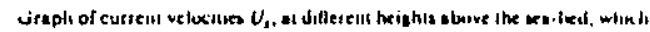
are required to move non-cohesive sedoment panicles is the range of dixnelers showt1. The paramelen used in the compitation of the eraph are: derisily of particles (yuariz): $2.63 \times 10^{5} \mathrm{~kg} \mathrm{~m}^{-1}$; density of seowater: $1.025 \times 10^{4} \mathrm{kt} \mathrm{m}^{-1}$ al is "C: vixossty:

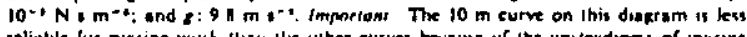
celliultente.

$-\cdots$

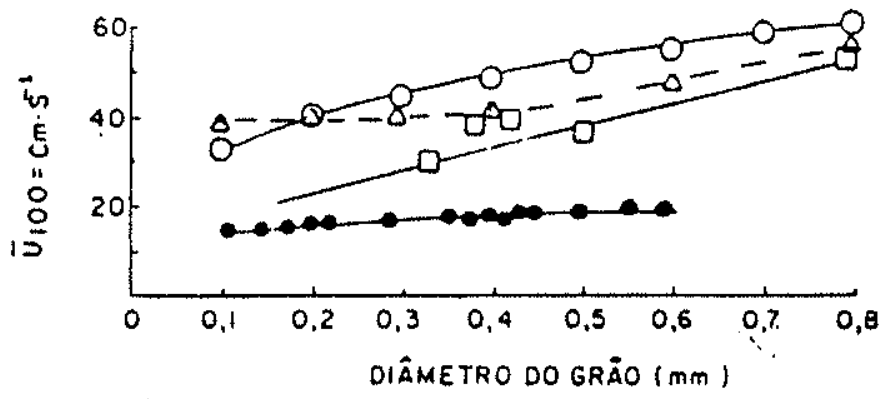

- Velisciducles criticas de 'ivind para vários diámetros de gräos com densidacle de $2.65 \mathrm{~g} . \mathrm{cm}^{\prime}$, segundo Sundborg.

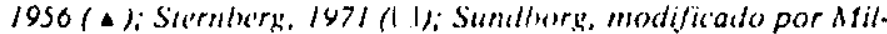
ler el al., 1977 (O); e ciadd et al., 1978'

Fig. 46 - Gráficos de velocidade critica de transporte: Postma, 1967 (apud Suguio, 1980); Hjulstrom, 1956 (apud Netto, 1980); Open Universi ty, 1978 e Gadd et al., 1978 (apud Muehe \& Such arov, 1981). 
Como todo levantamento de correntes de fundo, os executados em outubro de 1984 , foram realizados a distância de $100 \mathrm{~cm}$ do fundo $\left(\mathrm{C}_{100}\right)$ e o valor da velocidade critica de transporte adotado foi o expresso por Gadd et al. (op. cit.), para o valor de diâmetro médio do sedimento coletado no local de medição de corrente (Tabela 52).

Já para os dados de 1962, como as observações foram realizadas cinco metros acima do fundo, fora portanto da camada limite, o valor da velocldade critica de transporte não pode ser considerado a partir dos estudos de Gadd et al. (op. cit.). Desta forma, objetivando apenas avaliar as características gerais, direção e intensidade do transporte de sedi mentos junto ao fundo, na área da desembocadura lagunar de Cananéia, optou-se por utilizar como valor crítico, o expresso na curva proposta pela Open-University (op. cit.).

\section{4 .2 - Velocidades criticas de correntes para 1984 e 1962}

Dentre os sedimentos de fundo coletados nas três estações fixas de correntometria o diâmetro médio do sedi mento coletado na estação de Paranaguá apresentou o mais alto valor $(0,512 \mathrm{~mm})$, sendo que os de Iguape e Cananéia apresentaram respectivamente diâmetros médios mais baixos e mais próximos entre sí, isto é, $0,126 \mathrm{~mm}$ e $0,170 \mathrm{~mm}$.

Estes valores, quando confrontados com os estu dos de Gadd et al. (op. cit.), indicam que as velocidades críticas necessárias para o início da movimentação dos sedimentos de fundo, na região de Paranaguá, são cerca de $20 \%$ mais altas do que as velocidades necessárias para as regiões de Iguape e Cananéia.

Porém, quando confrontados os valores críticos de transporte, obtidos para o período de medição das três estações fixas, com os valores de intensidade de corrente medidas junto ao fundo, verifica-se que apenas na estagão de Iguape o valor critico $(15,5 \mathrm{~cm} / \mathrm{s})$ foi ultrapassado, ainda assim por um pequeno período do tempo de medição $(8,2 \%)$. 
Neste período de observação na estação de Igua pe, quando o valor da corrente medida ultrapassou a velocidade crítica, as direções de propagação se distribuiram 1 gualmente pelos rumos $\underline{S W}$ e W $(44,4 \%)$, estando o restante das correntes medidas $(11,2 \%)$ dirigido para SW.

Para as medicões do ano de 1962, utilizando-se aproximações das curvas da Open University (op. cit.), chega-se a um valor crítico para o transporte de fundo da ordem de $30 \mathrm{~cm} / \mathrm{s}$.

Como pairam dúvidas a respeito da real profundidade em que foram realizadas as medições de corrente em 1962 , e como possivelmente estas medidas foram realizadas fora da ca mada limite, são bastante temerárias as extrapolações dos efei tos das correntes de meia-água sobre os sedimentos de fundo.

Porém, o procedimento de adotar un valor critico considerando que as correntes à meia-água, com intensidade de deslocamento superior ao valor crítico adotado, são competentes para realizar o transporte de fundo, embora impreciso, permite que o conjunto de dados de 1962 possa, pelo menos, ser utilizado para avaliação preliminar do transporte junto à região da desembocadura lagunar de Cananéia.

Desta forma verifica-se que, ao longo de todo - período de 385 horas em que foram medidas as direções e intensidades das correntes na região da desembocadura lagunar, em apenas $0,9 \%$ ( 3,5 horas) desse período as intensidades de correntes foram superiores ao valor critico de transporte obtido da curva Open University (op. cit.). Ainda assim, a maior intensidade de corrente medida, $40 \mathrm{~cm} / \mathrm{s}$, representa apenas um vaIor $1 / 3$ superior à velocidade crítica de transporte adotada.

Os sentidos de corrente observados, durante es tes periodos de 3,5 horas, são todos para nordeste compreendidos entre $\underline{N} 35^{\circ}$ e $\underline{N} 55^{\circ}$. 


\section{5 - Taxas de transporte}

O conhecimento das correntes dominantes em um sistema de circulação litorânea e, em especial os volumes de sedimentos mobilizados nesses sistemas, tem sido baseados em postulados da hidrodinâmica clássica testados em laboratório e para situações de contato água/fundo.

A partir desses experimentos diversas equações (Einstein, 1950; Bagnold, 1963 e Yalin, 1963; apud Gadd et al. (1978) têm sido deduzidas objetivando compreender e estimar o modo e em especial, as taxas de transporte em regiões litorâneas.

Nessas regiões, em especial na zona de arreben tação das ondas, as correntes de deriva responsáveis pelo trans porte longitudinal dos sedimentos de fundo são afetadas por um grande número de fatores complexos que, dificultam os cálculos dos volumes transportados.

A equação para cálculo de transporte de sedimentos mais amplamente utilizada foi proposta por Bagnold (1963), que permite encontrar o volume dos sedimentos em função das velocidades das correntes e das caracteristicas fisicas desses sedimentos.

De acordo com esta equação, o volume transportado pode ser admitido como proporcional à energia transmitida ao fundo pela movimentação da corrente acima deste.

pela seguinte relação:

$$
\text { o conceito de Bagnold (op. cit.) é expresso }
$$

$$
q=\frac{\rho_{s}}{\left(\rho_{s}-\rho\right)_{g}} K \cdot W
$$

onde $q \dot{e} \circ$ volume de sedimentos transportados por unidade de

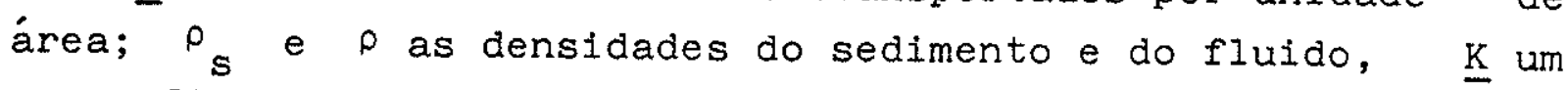
um coeficiente experimental que expressa a eficiência do fluxo transportador e $\underline{W}$ a força por unidade de área transmitida ao fundo pelo fluxo do fluido. 
Gadd et al. (1978), a partir de um estudo comparativo das diversas equações de transporte de sedimentos, rea I1zado com dados de correntes de fundo obtidos para uma área costeira, propôs a alteração da equação clássica de Bagnold (op. cit.) associando-se ao coeficiente de arrasto $\left(\mathrm{C}_{100}\right)$ e a velocidade critica de transporte $\left(\mathrm{U}_{100}\right)$.

Deste modo a equação de Bagnold (op. cit.) pode ser reescrita como:

$$
q=\frac{\rho_{s}}{\left(\rho_{s} \rho\right) g} \times C_{100}^{3 / 2} U_{100}^{3}
$$

Como consequiência das observações de sternberg (1972, apud Gadd et al. op. cit.), que verificou em regiões li torâneas onde as formas de fundo são de pequenas dimensões e os valores do coeficiente de arrasto $\left(\mathrm{C}_{100}\right)$ aproximavam-se de um valor constante $\left(3,1 \times 10^{-3}\right.$ ), Gadd et al. (op. cit.) associaram o volume transportado à terceira potência da velocida de medida, a uma distância fixa do fundo $\left(U_{100}\right)$.

Esta modificação mostrou-se em muito semelhante a uma outra, também expressa por Bagnold (1941, apud Gadd et al., op. cit.), quando estudou sedimentos transportados pe10 vento. Desta forma, Gadd et al. (op. cit.) simplificaram a equação básica de transporte de sedimentos utilizando o concei to clássico de que a movimentação de uma partícula em repouso inicia-se somente quando a corrente apresentar um valor acima da velocidade crítica de transporte $\left(\mathrm{U}_{\mathrm{TH}}\right)$.

Esta equação:

$$
q=\beta\left(U_{100}-U_{T H}\right)^{3}
$$

onde $\beta \dot{e}$ um coeficiente de proporcionalidade, tem sido largamente utilizada a partir dos anos 80 , não apenas pelo seu alto grau de simplificação, em relação às demais existentes, mas principalmente por expressar um conceito real do mecanismo de transporte de sedimentos arenosos de regiões litorâneas. 
Portanto, para velocidades iguals ou inferiores à velocidade critica de transporte, o volume transportado tende a zero independentemente das caracteristicas físicas do flu xo transportador e suas interrelações com o substrato.

Embora simples e de largà aceitação, diversos são os fatores limitantes que se interpõem a sua utilização no cálculo dos volumes transportados no litoral sul paulista. Um desses fatores está associado ao desconhecimento da influência de cada componente vetorial (corrente de deriva litorânea, cor rentes geradas pela aça das marés e ventos locais), na velocí dade da corrente medida.

Este fator limitante Implica em que o fator de proporcionalidade, $\beta$, seja utilizado com reservas, uma vez que os dados experimentais que foram utilizados para seu cálculo, representam uma situação onde a atividade das ondas foi assumida como sendo mínima, situação que não se aplica ao litoral sul paulista.

Desta forma, optou-se por utilizar o valor médio para o fator de proporcionalidade $\left(4,48 \times 10^{-5} \mathrm{~g} \mathrm{~cm}^{-4} \mathrm{~s}^{2}\right) \mathrm{con}$ forme proposta de Gadd et al. (op. cit.), para regiões pouco estudadas.

Outro fator limitante, no balanço dos volumes de sedimentos transportados na região litorânea sul, vinculase à limitação do conjunto de dados de velocidades de correntes de fundo, de significado apenas instantâneo. A ausência de medições de longa duração impede o conhecimento do grau de representatividade, desses pequenos intervalos de avaliação, no contexto geral de transporte de sedimentos de fundo do lito ral sul paulista.

Porém, embora impreciso em termos absolutos, o conhecimento das ordens de grandeza desse transporte, bem como das direções de deslocamento da carga sedimentar podem auxiliar, na região litorânea de Cananéia-Iguape, na compreensão da evolução das feições arenosas emersas existentes na região. 


\section{5 .1 - Primavera de 1984}

Das três estaçōes de correntografia, apenas a de Iguape apresentou, entre os dias 8 e 9 de outubro, valores de corrente de fundo superiores à velocidade critica de transporte.

Durante todo o período em que houve a possibilidade de transporte, este ocorreu nas direções SW e W com uma resultante de $1,9 \cdot 10^{-3} \mathrm{~g} \mathrm{~cm}^{-1} \mathrm{~s}^{-1}$ para direção $\mathrm{N} 249^{\circ}$ (Tabe la 53).

Este volume, além de representar um valor abso luto pouco significativo ocorreu durante um espaço de tempo muito pequeno de forma que, na eventual deposição desses sedimentos na zona intermarés da Ilha Comprida eles representariam um acréscimo de volume insignificante.

Quando confrontados os períodos em que a velocidade junto ao fundo ultrapassou o valor critico com as diregões de ondas e ventos incidentes na área (fig. 47), verificase que ambas são provenientes de leste, compativeis com corren tes originárias de $\underline{S W}-\underline{W}$.

Correlacionando-se estas correntes à situação meteorológica observada através das cartas sinóticas da Diretoria de Hidrografia e Navegação do Ministério da Marinha, para os dias 8 e 9 de outubro, observa-se que o padrão de corren tes de fundo observado está vinculada à circulação atmosférica denominada por Garcia Occhipinti (1963), como "situação normal". Esta "situação normal" representa a dominância da massa de ar Atlântica, controlada pelo anti-clclone subtropical, semi-permanente do Atlântico Sul, com ventos prevalecentes de leste após curtos períodos de perturbações dos fenômenos meteorológicos denominados frentes.

\section{5 .2 - Outono de 1962}

- cálculo do volume transportado para as medições de 1962, reveste-se ainda de um maior grau de imprecisão, devido as incertezas quanto à verdadeira profundidade onde essas medições foram executadas. 


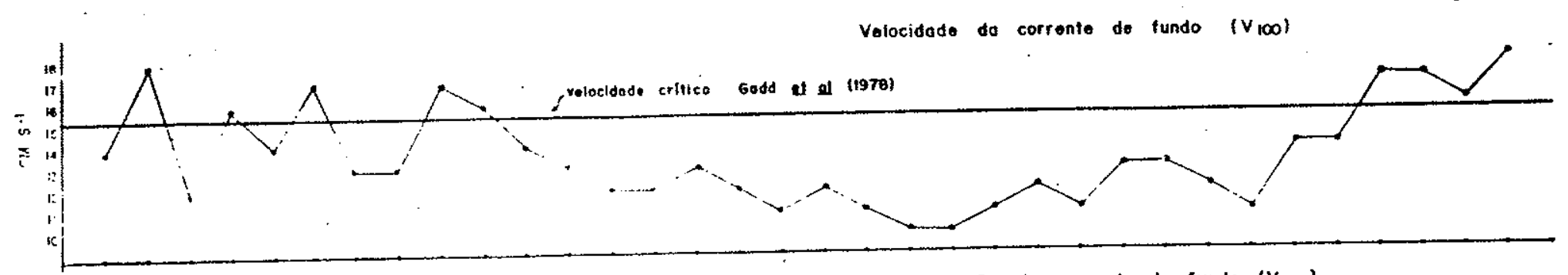

Vetocidode - direça de corrente de fundo $\left(V_{100}\right)$

$10 \mathrm{~cm}$
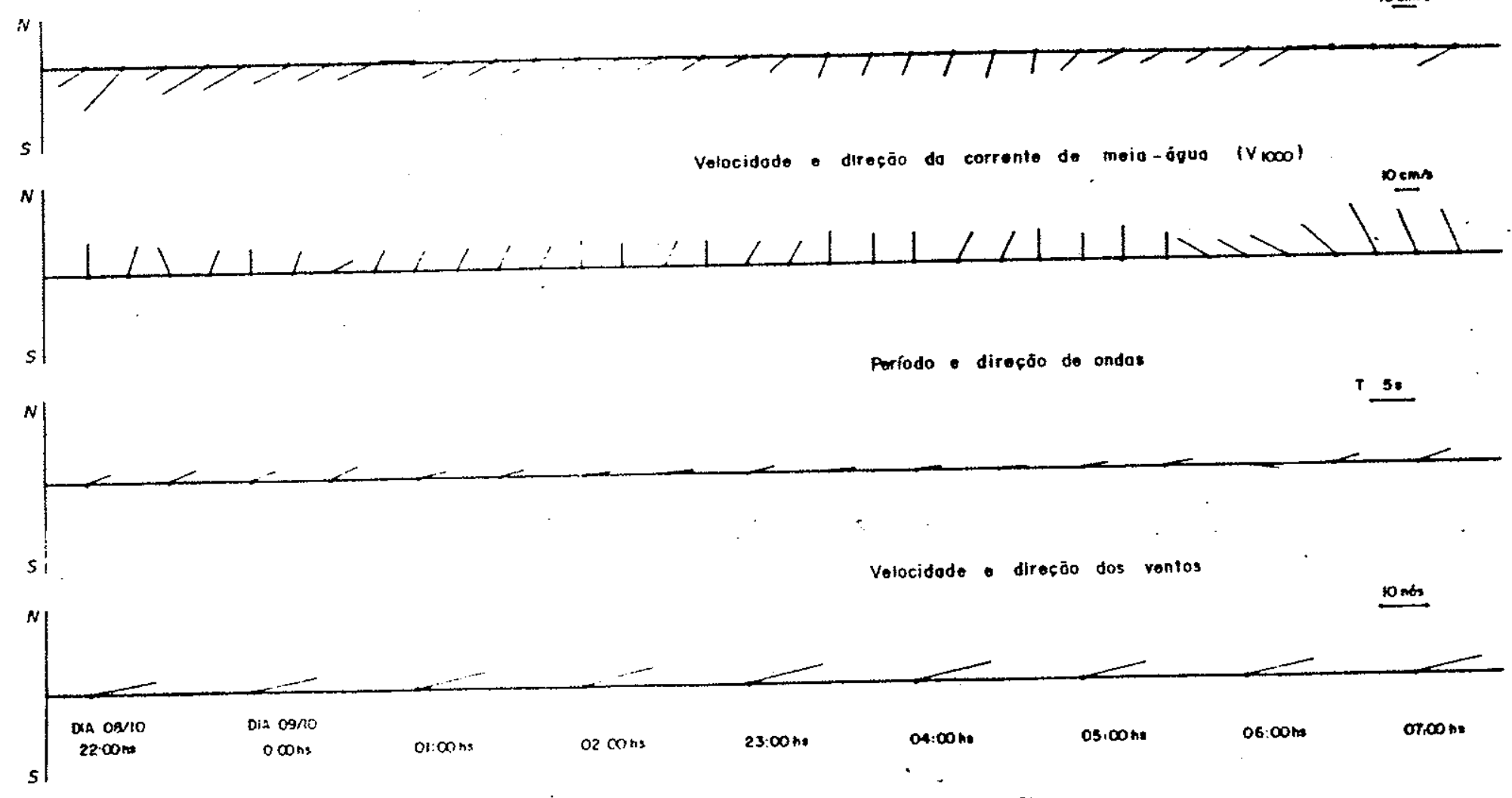

Fig. 47 - Velocidade de corrente, meia-água e fundo; direção de ondas e ventos observados na estação de Iguape, no período que apresentou velocidades de correntes superiores a velocidade crítica de transporte, outubro 1984. 
Porém, ainda assim, a análise do intervalo de 3,5 horas do dia $23 / 04$, quando as velocidades de corrente observadas foram superiores à velocidade critica de transporte, são importantes na medida em que representam condições meteoro lógicas de passagem de uma frente fria, quando ós ventos preva lecentes passam do quadrante leste para o quadrante sul.

A presença de ventos incidentes de sul e sudoeste, nas áreas de geração das ondas, acarreta a propagação das ondas a partir desses quadrantes, que segundo o relatório C.T.H. (op. cit.) são predominantes no litoral sul paulista, gerando correntes de deriva litorânea de orientação geral leste.

Desta forma, durante o período em que houve a possibilidade de mobilização de sedimentos arenosos de fundo, na região próxima à desembocadura de Cananéia, o transporte ocorreu rumo a $\underline{N E}$, ou seja, praticamente paralelo à Iinha de cos ta atual ( $f i g . \overline{48}$ ).

o volume transportado, embora quantitativamente superior ao obtido para a primavera de 1984, não significa obrigatoriamente uma predominância do transporte na direção NE sobre a direção WSW (Tabela 54).

Portanto, fica evidenciada pelo menos a possibilidade, para o litoral sul paulista, da existência de dois sentidos predominantes de transporte. O primeiro, com desloca mento da região próxima à foz do rio Ribeira de Iguape em dire ção a porção sul da Ilha Comprida, segundo direções próximas a W - WSW e a outra da área sul do estado em direção à foz do Ri beira, através de uma direção geral $\mathrm{NE}$.

Devido à pouca representatividade dos dados analisados não é possível avaliar. , sem uma análise da evolução das feições arenosas costeiras, a resultante da interação desses dois sentidos inversos de transporte, bem como suas reais interrelações com os parâmetros climatológicos, aos quais estão submetidas as regiões litorâneas de Cananéia - Iguape. 


\section{Velocldode do corrente de meio- oguo (V}

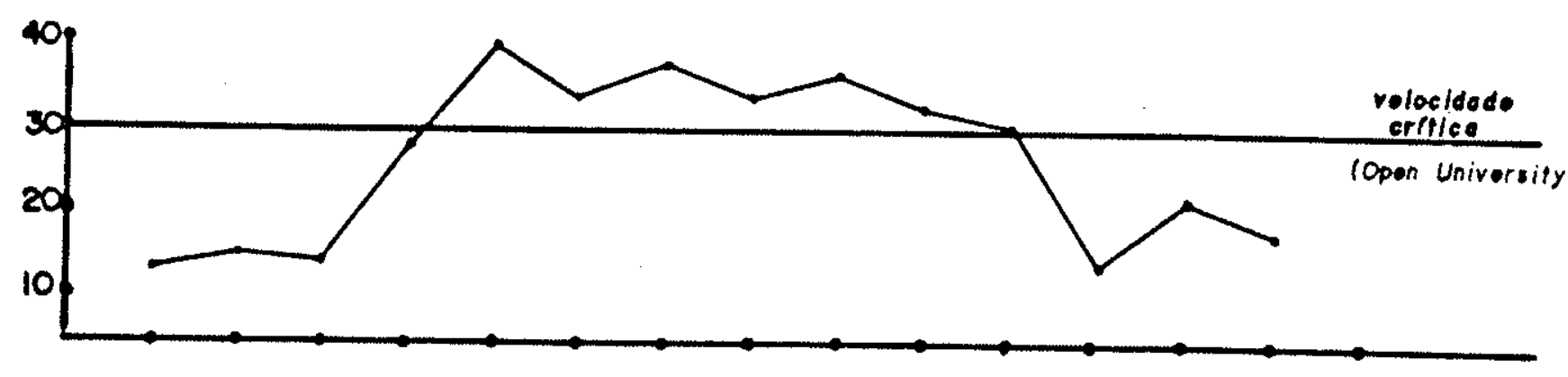

Velocidode ediresgo do corrente de moia-ógua $\left(V_{40}\right)$
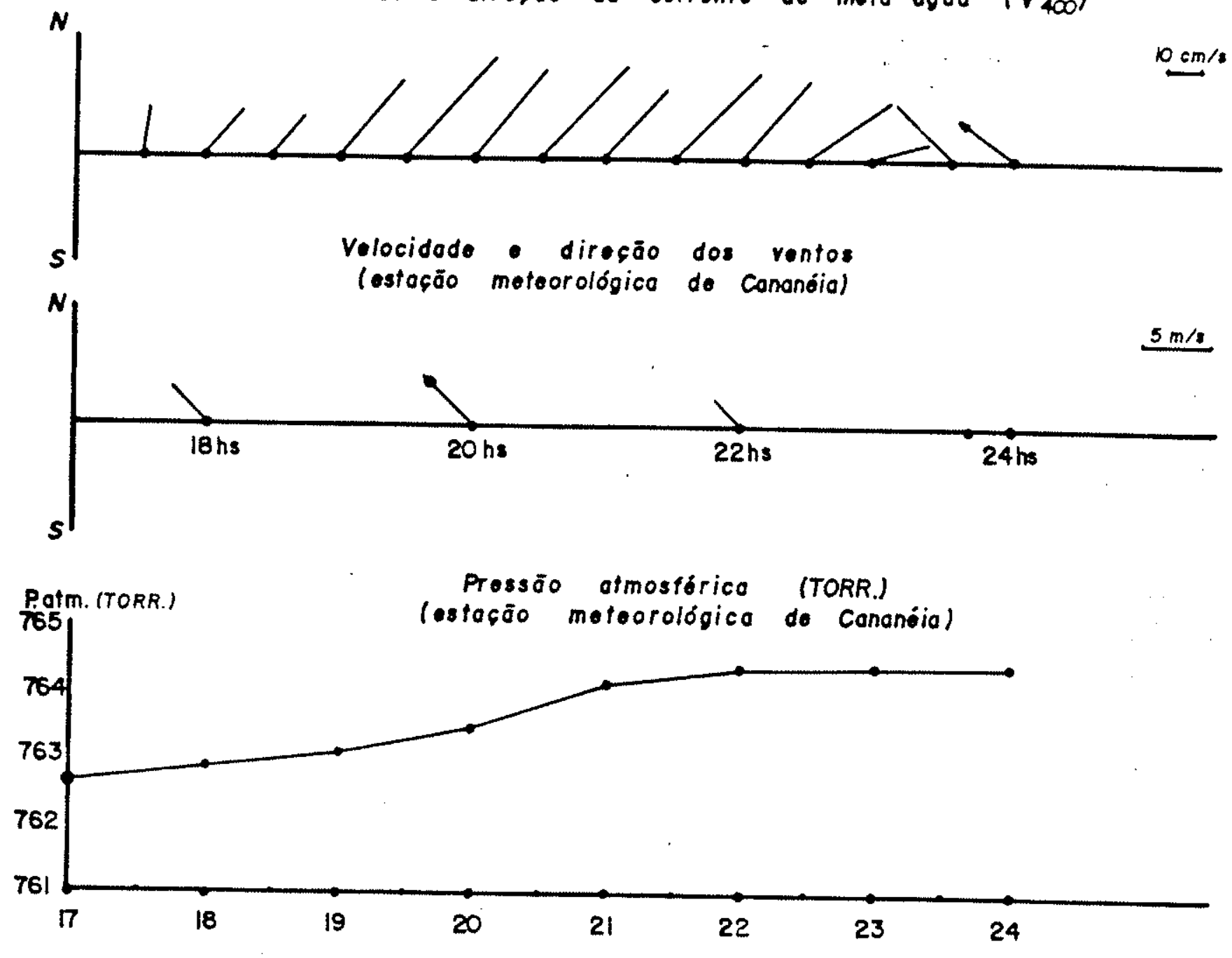

Figura 48 - Velocidade de corrente, ventos e pressão atmosfërica observados na estação de Cananëia, no período que apresentou velocidades de correntes superiores à velocidade crítica de transporte, abril 1962. 


\section{6 - Conclusões parciais}

Admitindo-se como correta a afirmação de Inman (1963), de que a movimentação de sedimentos arenosos em ambien tes marinhos rasos é função principalmente da interação de ondas, correntes de diferentes origens e ventos locais, concluise neste estudo pela predominância dos sistemas de ondas, sobre os demais fatores, na dinâmica de transporte de fundo do litoral sul paulista.

A análise dos padrões de ondas, observados à bordo do N/OC. "Prof. W. Besnard", bem como os contidos nos re latórios do Centro Tecnológico de Hidraúlica - USP (op. cit.) e Geobrás (op. cit.), possibilitam explicar satisfatoriamente as principais direções de transporte de fundo.

A interrelação entre a circulação atmosférica e a geração dos sistemas de ondas incidentes é a base para a com preensão da origem das correntes de fundo, de sentido $\underline{\mathrm{NE}}$, provenientes de sistemas de ondas de direções sul, bem como das correntes de sentido SW geradas pela incidência de sistemas com rumo geral leste.

As profundidades máximas de ação das ondas, obtidas para os dados de 1984 , permitem supor que as correntes de deriva geradas pela incidência obliqua à costa dos sistemas de ondas, podem isoladamente explicar o transporte litorâneo.

Desta maneira, pode-se concluir que salvo sob condições meteorológicas intensas, a ação das ondas sobre o fundo está restrita à isóbata máxima de $50 \mathrm{~m}$, estando a zona de arrebentação limitada às isóbatas de 5 a $6 \mathrm{~m}$.

$\mathrm{Na}$ área a influência dos ventos locais e das correntes geradas pelas marés sobre as correntes de fundo são desconhecidas. Com relação à ação dos ventos locais, Silva (1968) afirma serem insignificantes os incrementos das velocidades de corrente de fundo no litoral sul brasileiro, pela ação dos ventos locais, demonstrando a pequena importância das osci lações deste parâmetro local sobre a circulação litorânea. Por 
outro lado, as correntes de maré parecem ter relevância maior apenas nas regiões próximas as desembocaduras lagunares. onde se processam as ligações do oceano com os sistemas lagunares costeiros.

Os valores obtidos para os volumes transportados orlginados, pela interação entre as principais direções de movimentação de fundo identificadas ( $\underline{N E}, \underline{S W}$ ), não são signi ficativas na medida em que todos os parâmetros observados representam somente instantes particulares de observação.

Portanto, na impossibilidade da obtenção de respostas mais precisas acerca da resultante atual do transpor te litorâneo de fundo do compartimento sul paulista, e da ordem de grandeza deste transporte, torna-se imperativo o estudo das formas arenosas emersas e principalmente da sua evo lução recente.

Esta imposição está relacionada ao conhecimento prévio da evolução quaternária do compartimento costeiro sul paulista, onde as feições arenosas emersas respondem a interações entre os movimentos oscilatórios do nível do mar, durante o Quaternário, e às consequientes variações da dinâmica cos teira associadas a esses movimentos oscilatórios.

\section{GEOMIETRTA DOS CORDÖES LITORÂNEOS DA PLANÍCIE-COSTEIRA SUL. PAULISTA}

A gênese dos cordões litorâneos das planicies centro e sul paulista pode ser interpretada em termos do abaixamento do nível relativo do mar, durante o Holoceno, como con sequiência do aporte de areias provenientes da plataforma próxi ma (Suguio \& Martin, 1978a; Flexor et al. (1984).

De acordo com Komar (1976), na zona de arreben tação ocorre una forte liberação da energia das ondas que ocasionam a suspensão de areias e seu transporte lateral pelas correntes de deriva litorânea ("longshore currents"), geradas a partir da incidência oblíqua à costa destas ondas. 
Além deste transporte litorâneo o espralamento das ondas sobre uma costa arenosa provoca a movimentação dos se dimentos perpendicularmente a costa. A conjugação destes dois fenômenos resulta em um transporte pulsatório das areias ao longo da costa, cujo tipo de deslocamento lateral é denominado "dente de serra" ("swash transport").

Esta conjugação entre mecanismos de movimentação de areias resultantes da interação dos sistemas de ondas com ○ fundo oceânico e costas arenosas resulta em um transporte de sedimentos, cujo sentido de deslocamento é função do ângulo de incidência dos sistemas de ondas e das características do re levo de fundo.

No litoral sul paulista, devido à baixa declivi dade da topografia de fundo na zona de arrebentação $\left(\simeq 1^{\circ}\right)$, e associado ao paralelismo das isóbatas com a direção geral da $1 \underline{1}$ nha de costa atual, o ângulo de incidência do sistemas de ondas na faixa intermarés é sempre pequeno, fruto da prolongada interação dos sistemas de ondas com o fundo.

Esta interação, que seguramente passa a existir no litoral sul paulista a grandes distâncias da linha de costa atual ( > $5 \mathrm{~km}$ ), é responsável pela intensa refração sofrida pe las ondas que, ao atingirem à linha de costa encontram-se pra ticamente paralelas à direção geral da costa.

Em função deste fato, na faixa intermarés, onde ocorre a conjugação dos dois principais mecanismos de transporte das areias de praia, os deslocamentos laterais de sedimentos são de pequenas proporções devido principalmente à pequena intensidade das correntes paralelas à costa, originadas a partir de pequenos ângulos de interação $\left(5^{\circ}-10^{\circ}\right)$, entre os siste mas de ondas refratadas e a linha de costa.

Flexor et al. (op. cit.), apoiado em complementação do princípio de Brunn, a partir do qual uma elevação do nivel relativo do mar provocaria erosão na "alta-praia" e deposição de sedimentos na "ante-praia", afirmam ter as correntes de deriva litorânea desempenhado papel fundamental na construção dos cordões litorâneos da planície costeira das regiões sul 
e sudeste do Brasil. Assim, nos periodos de abaixamento do nivel relativo do mar, durante o Holoceno, ocorreu um importante aporte de arelas da plataforma continental rumo à "alta-praia" que, arrastadas pela deriva litorânea, contribuíram na construção das extensas planícies de cordões litorâneos. Portanto, sob certas circunstâncias, este avanço holocênlico da área emersa, onde os cordões que cobrem os terraços correspondem às cristas de "altas-praias" que foram sucessivamente abandonadas no decor rer da prograciação da costa (Flexor et al., op. cit.) podem registrar, na sua geometria, o sentido predominante da deriva dos sedimentos durante o transcurso do processo regressivo.

Barcelos (1975) e, especialmente Suguio \& Martin (1978b)evidenciaram, no litoral sul paulista, a existência de longos e retilíneos alinhamentos de cordões litorâneos quase sempre paralelos à linha de costa atual (fig. 49). Estes alinhamentos, bem ressaltados nos levantamentos aerofotogramétricos devido à existência de depressões entre cordões que estão quase sempre associadas a uma drenagem condicionada pelos regimes pluviais e de marés, atingem extensões na face oceânica da Ilha Comprida, de até $65 \mathrm{~km}$ de comprimento.

Os cordões holocênicos da face oceânica da IIha Comprida apresenta, como característica geral, além de suas grandes extensões, uma pequena inflexão rumo a $\mathrm{NE}$, nas porções a $\mathrm{NE}$ da ilha, deslocamento este também verificado no alinhamento geral da linha de costa atual.

Os cordões holocênicos, da porção mais interna da Ilha Comprida, não são tão contínuos e paralelos à linha de costa atual quanto os cordões da face externa. $\mathrm{Na}$ face interna estes cordões estão truncados e isolados em conjuntos de pequena extensão lateral, por um padrão de encurvamento dos cordões para $N E$, que interrompe a continuidade dos alinhamentos que se desenvolvem paralelamente a costa.

De acordo com Barcelos (1975) e Suguio \& Martin (1978a), os cordões das faces interna e externa da Ilha Comprida estão separados entre si por uma zona baixa, com cerca de $100 \mathrm{~m}$ de largura, que pode ser acompanhada por cerca de $50 \mathrm{~km}$, ocupada por sedimentos areno-argilosos de ambiente paludal. 
Estas características observadas nos cordões ho locênicos, das faces interna e externa da IIha Comprida, levou diversos autores a proporem a formação da ilha, a partir de um núcleo de idade mais antiga situado a $\underline{\mathrm{SW}}$, em duas etapas distintas (Suguio \& Martin, 1978a; Suguio \& Barcelos, 1978).

As duas etapas de evolução holocênica da 1Tha estão vinculadas ao mecanismo de oscilação do nível do mar, con forme proposta de Suguio \& Martin (op. cit.) (fig. 50).

Na primeira etapa, após o máximo transgressivo ( 5.100 anos A.P.), a ilha estendeu-se rumo ao norte, em direção a Iguape. São desta fase as seqüências de cordões truncados e recurvados que representariam as diversas etapas evolutivas da desembocadura em crescimento para nordeste da ilha, atualmente denomina da de Icapara (fig. 51).

Há aproximadamente 3.800 anos A.P., a tendência geral de emersão da área sofreu uma interrupção quando então o nível marinho atingiu seu valor minimo no período, voltando pos teriormente há cerca de 3.500 anos A.P. a atingir um outro máxí mo transgressivo (Suguio \& Martin, op. cit.).

Após este segundo máximo transgressivo, quando parece ter ocorrido uma pequena erosão dos cordões holocênicos internos, fenômeno este responsável pela formação da zona baixa entre as duas gerações de cordões, a ilha passa a sofrer um processo de alargamento pela acreção. de cordões paralelos à linha de costa atual. São dessa fase os extensos e contínuos ali nhamentos de cordões litorâneos da face externa da Ilha Comprida.

Suguio \& Barcelos (op. cit.), a partir dos resultados das análises granulométricas das areias que compõem es ses cordões litorâneos, sugerem que esta tendência de crescimento da ilha de $\underline{\mathrm{S}}$ para $\mathrm{N}$, pela ação das correntes de deriva litorânea, teve importância fundamental desde o período inicial de formação da ilha $(6.000$ anos A.P.).

$\mathrm{Na}$ análise das características hidrodinâmicas do litoral sul paulista verificamos que coexistem dois sistemas de ondas, subordinados aos mecanismos gerais de circulação atmos 


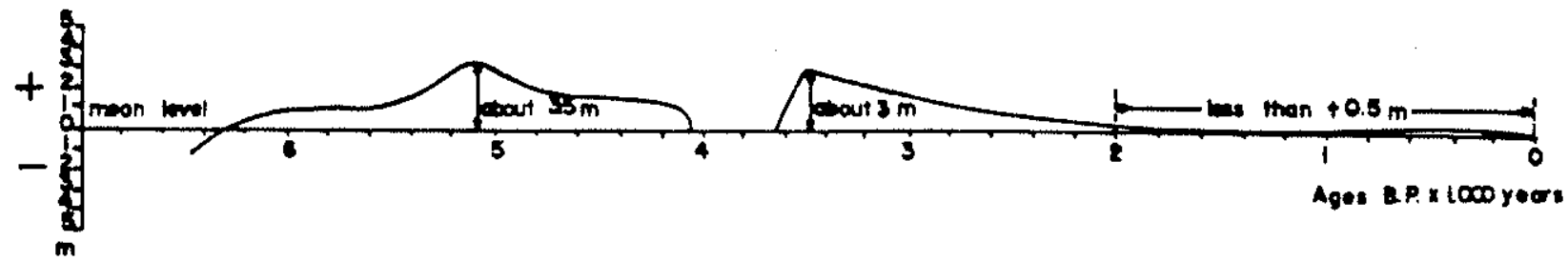

Fig. 50 - Curva relativa de variação do nível do mar para a planície costeira de Cananēia-Iguape, Estado de São Paulo (Suguio \& Martin, 1978). .

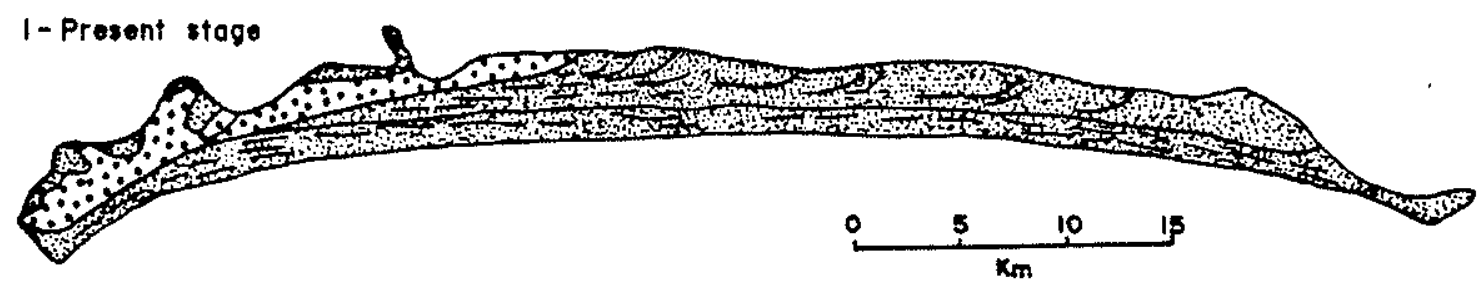

2-Maximum of 5,100 years B.P.

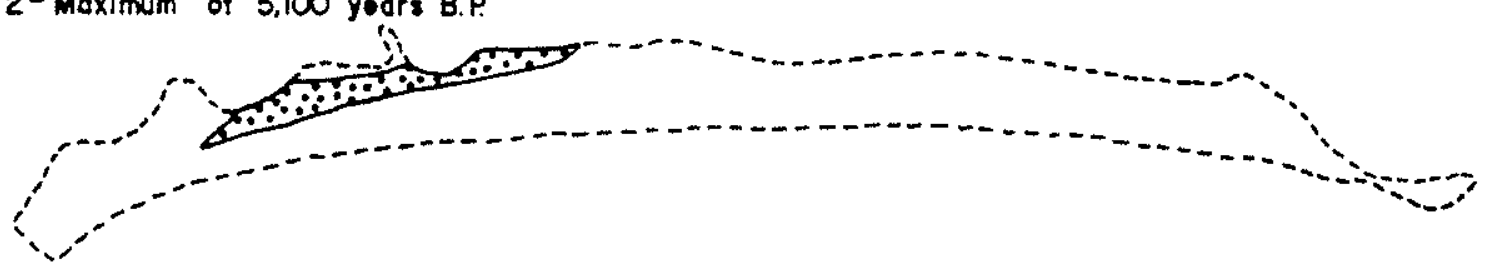

3 - Moximum of 3,500 yecrs B.P.

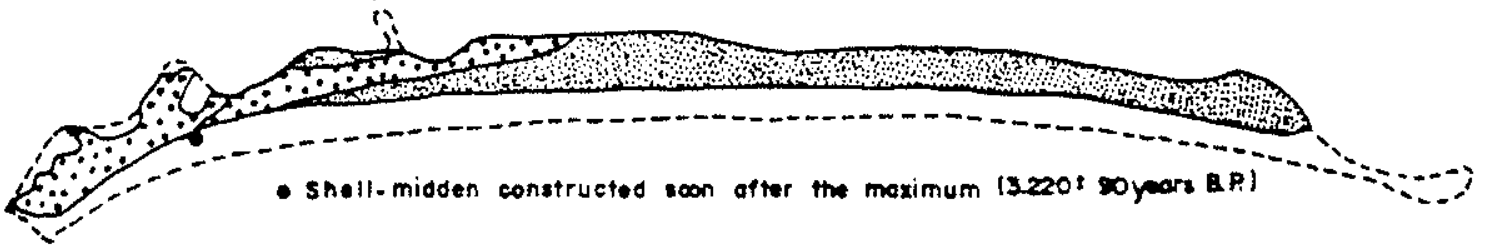

Fig. 51 - Esquema evolutivo da Ilha Comprida durante o Holoceno (Suguio \& Martin, 1978). 
férica da América do Sul, geradores também de suas direções gerais de correntes de deriva litorânea. O primeiro sistema, pro veniente de $\underline{S}$ - $\underline{S E}$ estaria vinculado a penetrações das massas polares no continente sul americano, em especial no outono e in verno, origina um mecanismo de circulação de fundo proveniente de $\mathrm{SE}$ rumo a $\mathrm{NE}$.

o segundo, de direção $E$ - $\underline{N E}$, relacionado aos mecanismos de ventos alíseos gera, na área, movimentações de fundo em sentidos opostos, possibilitando o transporte de sedimentos de NE rumo a SW

Ambas as direções de corrente poderiam ser as responsáveis, isoladamente ou em conjunto, pela geração dos ali nhamentos dos cordões holocênicos da face externa da ilha, uma vez que a direção geral da linha de costa da Ilha Comprida ( $N$ $45^{\circ} \mathrm{E}$ ), bem como as características da topografia de fundo, per mitem o transporte na faixa intermarés perfeitamente paralelo à direção da linha de costa atual.

Porém, como já havia sido constatado por suguio \& Barcelos (op. cit.), as análises texturais e composicionais dos sedimentos dos cordões litorâneos e da faixa intermarés mostram tendência geral a modificações em sua composição textural de SW para $\mathrm{NE}$.

Por outro lado, ao analisar fotos aéreas obtidas principalmente nas décadas de 50 e 60 , quando a especulação imobiliária não havia mascarado o padrão dos alinhamentos dos cordões, verifica-se que os sistemas de drenagem entre cordões da face externa da ilha, que se deslocam por quilômetros paralelamente à costa, apresentam-se em seu trecho terminal perpendiculares à linha de costa cortando os cordões mais próximos ao mar. A desembocadura desses pequenos cursos de água apresenta em sua grande maioria, na faixa intermarés, um significativo deslocamento para $\mathrm{NE}$, sugerindo com isso, a preponderância de transporte arenoso de $\mathrm{SW}$ para $\mathrm{NE}$.

Desta maneira pode-se afirmar que na plataforma sul paulista, onde coexistem dois tipos de regimes de ondas, 0 primeiro proveniente de $\underline{S}$ - " $\underline{S E}$ predomina sobre o de direção 
$E$ - NE, no transporte atual de sedimentos ao longo da faixa Iitorânea.

Além disso, associando-se esta conclusão ao padrão de desenvolvimento dos cordões litorâneos da Ilha Comprida, em especial aos da face interna, pode-se afirmar que esta predo minância de transporte ao longo da costa, de SW para NE, tem sí do preponderante no litoral sul durante toda a fase de alongamento da liha rumo a NE (últimos 3.500 anos).

Considerando-se o padrão apresentado pelos cordões mais internos da Iiha Comprida pode-se considerar que esta predominância do transporte ao longo da costa de SW para $\underline{N E}$ tem sido preponderante na área durante todo o seu desenvolvimen to holocênico, a partir do máximo transgressivo de 5.100 A.P..

A porção mais a sudoeste da planície costeira apresenta, devido as suas características geomorfológicas, toda a sedimentação pleistocênica condicionada por uma reentrância da linha de costa (paleogolfo).

Este anfiteatro de sedimentação está delimitado por três alinhamentos estruturais que afetam o embasamento précambriano, que delimita a sedimentação pleistocênica da porção mais a SW do litoral paulista. Na porção mais ao sul, os limites são estabelecidos pelos maciços rochosos da Ilha do Cardoso e do continente adjacente, que possuem sua margem interna alinhada aproximadamente segundo direção $\mathrm{N} 270^{\circ}$. Na porção a nordeste deste paleogolfo, a sedimentação foi delimitada por um pontão rochoso de cerca de $7 \mathrm{~km}$ de largura com direção geral $\mathrm{N}$ $140^{\circ}$. Este pontão rochoso, projeta-se no rumo do oceano a partir de um maciço rochoso de orientação geral NE denominado Mandira.

- Maciço Mandira, que funciona como um divisor de águas entre a bacia do rio Ribeira de Iguape, localizada à retaguarda destes morros e os pequenos rios de serra, que vão desaguar após um traçado com orientação perpendicular à costa na região lagunar, apresenta sua margem de delimitação com a planície costeira alinhada segundo uma direção geral $N 40^{\circ}$. 
- estudo da formação pleistocênica, que apresen ta sua maior área de exposição contínua no litoral paulista jus tamente neste anfiteatro de sedimentaça e em especial na Ilha de Cananéia, exibe analogamente à formação holocênica da Ilha Comprida, cordões litorâneos alinhados na direção geral NE.

Estes alinhamentos dos cordões pleistocênicos apresentam-se bastante truncados e obliterados por intensos processos erosivos e antrópico.

Os cordões pleistocênicos podem ser identifica dos através dos levantamentos aerofotogramétricos nas ilhas Com prida e Cananéia, bem como na planície costeira contígua ao con tinente. Este padrão dos cordões pleistocênicos sugere que, analogamente ao que parece ter acontecido durante o Holoceno, já há 120.000 anos passados o transporte dos sedimentos teria ocorrido predominantemente de SW para $\mathrm{NE}$.

$\mathrm{Na}$ planicie situada ao lado do continente, sepa rada da Ilha de Cananéia por um canal denominado Mar de Cubatão, a deriva litorânea de SW para NE foi dificultada pela projeção rochosa do Maciço Mandira, que também deve ter funcionado como um obstáculo à projeção da Ilha de Cananéia no rumo NE.

O pequeno desvio para SE dos alinhamentos dos cordões pleistocênicos a $\mathrm{NE}$ da Ilha de Cananéia, quando comparados com a extensa faixa de afloramentos pleistocênicos da fa ce interna da Ilha Comprida, demonstra a efetiva ação desse obstáculo à progressão dos sedimentos pleistocênicos transportados pela deriva litorânea, ao longo da paleolinha de costa da Ilha de Cananéia.

A nordeste dessa área os sedimentos pleistocênicos apresentam, apenas localmente e muito mascarados, pequenos alinhamentos de cordões litorâneos sempre paralelos à linha de costa atual.

Estes tênues alinhamentos, identificados principalmente nas imediações da bacia do rio Ribeira de Iguape, con tribuem muito pouco para o conhecimento do mecanismo de deriva litorâneo predominante durante o evento pleistocênico, uma vez que, apenas a identificação de um paralelismo de alinhamentos à 
linha de costa atual não é por si só, fato suficiente para a identificação, no litoral sul paulista, do sentido predominante de transporte.

Finalmente, com relação a origem dos canais lagunares que separam as ilhas Comprida e de Cananéia, denomina do Mar de Cananéia, a IIha de Cananéia do continente, denominado Mar de Cubatão, e que seccionam os afloramentos pleistocênicos desta área, duas hipóteses foram levantadas por diferentes autores (Geobrás, 1966; Suguio \& Martin, 1978a). No relatório Geobrás (op. cit.) é levantada a hipótese de que estes dois canais representariam resultados de captura dos cursos fluviais que, erodindo as areias e encontrando saidas para o mar a $\underline{S W}$ e NE da Ilha Comprida, teriam propiciado, não apenas o aparecimen to de correntes de maré nos recém-formados braços de mar, mas também o. fornecimento de material que possibilitou o avanço da face interna da ilha, no rumo de Iguape.

Esta hipótese, para a origem dos canais lagunares encontra hoje pouca aceitação na medida em que Miyao (1977), estudando a circulação interna da região lagunar, concluiu pela predominância da maré vazante sobre a enchente, nas proximidades do contato da coluna de água com o fundo. Posteriormente, Tessler \& Furtado (1983) corroboraram esta predominância ao iden tificarem, para as ilhas arenosas internas dos canais lagunares, tendência para crescimento rumo à desembocadura lagunar de Cana néia, SW.

A partir do conhecimento atual das característi cas hidrodinâmicas das regiões lagunares e litorâneas é mais viável supor que o material arenoso, proveniente da região lagu nar, efetivamente foi a fonte para o crescimento da IIna Compri da, juntamente com o material relíquia da plataforma. Este aporte ocorreria, predominantemente, pelas desembocaduras laguna res em especial a localizada mais ao sul, Barra de Cananéia, quando os sedimentos aprisionados pela deriva litorânea passaram a con tribuir para o crescimento da Ilha Comprida.

A segunda hipótese, proposta por suguio \& Martin (1978a) ( $f i g .52$ ) associa a origem destes canais lagunares aos eventos transgressivos/regressivos quaternários. De acordo 


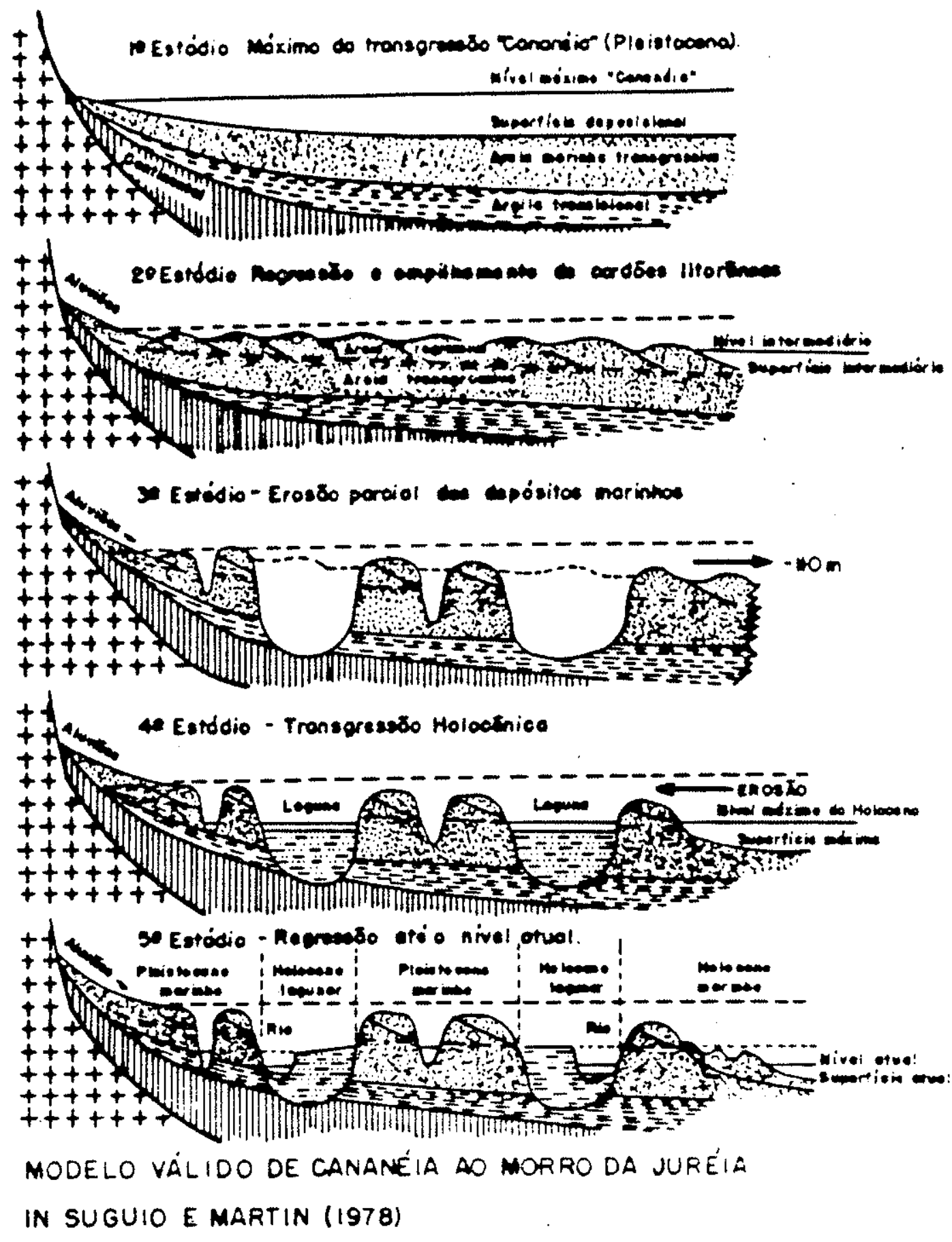

Fig. 52 - Modelo evolutivo para a planicie costeira compreen dida entre Cananéia e o Morro da Juréia, Estado de São Paulo (Suguio \& Martin, 1978). 
com estes autores, quando do máximo regressivo pleistocênico o nivel do mar atingiu cotas bem inferiores as atuais (ao redor de 17.000 anos A.P. o nivel do mar situava-se em torno de $-110 \mathrm{~m}$ ). Este evento, expôs grande parte da atual plataforma continental permitindo que a rede de drenagem erodisse mais ou menos profun damente os sedimentos depositados durante a transgressão Cana néia formando vales.

Posteriormente, durante o último período trans gressivo, o mar invadiu inicialmente as zonas mais baixas, esta belecendo o sistema lagunar. Em seguida, com a continuldade do evento transgressivo, o mar passaria a erodir as partes mais altas da Formação Cananéia, cujas areias seriam posteriormente ressedimentadas formando os depósitos marinhos holocênicos.

Porém restaria, segundo o modelo de Suguio \& Martin (op. cit.), a questão do porque um sistema de drenagem predominantemente transversal a linha de costa teria esculpido vales de orientação geral SW - $\underline{N E}$;

Uma primeira possibilidade está vinculada à pre sença de condicionantes estruturais que teriam facilitado a dre nagem a formação destes vales, em períodos em que o nível do mar estaria bem distante da costa atual. Estes condicionantes estruturais poderiam ser sistemas de fraturamento reativados, que ainda podem ser identificados nos maciços pré-cambrianos que circulam a planicie costeira.

Estes condicionantes estruturais já foram sugeridos por Suguio \& Petri (1973) quando, a partir de dados geofísicos e de perfurações identificaram desniveis do embasamento pré-cambriano na área. Estes autores propuseram como explicação destes desniveis a existência na área de dois blocos basculados, com mergulhos opostos, ou seja, um bloco com direção $\underline{\mathrm{SW}}$ mergulhando para $\underline{N E}$ e um bloco de direção $\underline{N E}$ mergulhando pa ra SW.

Cortando estes dois blocos basculados estaria atuante um falhamento, de direção geral NE, parcialmente coin cidente com o canal que separa o continente da IIha Comprida é também paralelo as estruturas condicionantes dos canais que separam a Ilha de Cananéia do continente e da Ilha Comprida. 
Riccomini et al. (1987), identificaram em afloramento da Formação Cananéia, localizado próximo à Ilha de Cananéia, estruturas possivelmente compressionais. Estas estruturas foram interpretadas como possivel produto de um evento tectônico, que teria gerado transcorrências destrais convergentes de direção ENE-WSW para $\underline{E}-\underline{W}$, causadas por transpressão que teria ocorrido provavelmente a partir do Mioceno e ativa até o PIeis toceno.

Por outro lado, pode-se supor que conforme foi Identificado na regressão holocênica, segundo a curva de Suguio \& Martin (op. cit.), a oscilação do nível marinho pleistocênico não tenha ocorrido de forma contínua, mas também interrompida por pequenos periodos transgressivos. Nestes curtos períodos de elevação do nível marinho, poderia ter ocorrido uma erosão parcial dos cordões pleistocênicos internos, formando zonas bai xas entre os cordões, onde o mar teria penetrado no transcurso da transgressão holocênica.

A idéia de formação destas zonas baixas entre cordões, não exclui a possibilidade de, anteriormente à transgressão holocênica, ter ocorrido a escavação dos atuais canais pela drenagem continental ao longo destas áreas deprimidas, con forme a idéia de Suguio \& Martin (op. cit.). Esta drenagem po deria estar condicionada ou não por sistemas de falhamentos paralelos e transversais a orientação geral da linha de costa atual.

Desta forma, admitindo-se o processo erosivo fluvial, como agente de escavação dos canais lagunares, é lícito supor que o nível de base dessa drenagem fosse correlacionável à profundidade atual da feição rochosa submersa em um dos canais lagunares denominada Lage do Argolão ( 7 metros), de forma que profundidades superiores à esta teria sido originadas por outros processos dinâmicos. Neste aspecto com a presença desta feição rochosa impeditiva do aprofundamento do canal fluvial é possivel que as atuais depressões existentes ao longo dos canais lagunares resultem da ação de "correntezas de maré" ("tidal scour") conforme descrito por Kuenen (1950). 
A partir do conhecimento de que o transporte de fundo de sentido $S W$ - $\underline{N E}$ é condicionado no litoral sul paulista pela incidência de trem de onda proveniente dos quadrantes $\underline{S}$ $\underline{S E}$, verificamos que estes sistemas de ondas e transporte de fun do foram predominantes durante a deposição dos sedimentos pleis tocênlcos e holocênicos localizados na região do paleogolfo. Desta forma, pode-se afirmar que as características hidrodinâmicas atuais identificadas na zona litorânea devem corresponder, aproximadamente, às características hidrodinâmicas gerais a que esteve submetida essa porção do litoral sul paulista, no decorrer dos máximos transgressivos e dos períodos regressivos imedia tamente subsequientes aos últimos 120.000 anos.

Desta forma, à semelhança da IIha Comprida, que se apresenta como uma ilha-barreira vinculada ao evento regressivo/transgressivo holocênico (Suguio \& Martin, 1978 a), a Ilha de Cananéia, por suas características geomorfológicas, bem como pelas estruturas sedimentares associadas (Suguio \& Tessler, 1987), poderia representar uma paleo-ilha barreira vinculada aos eventos transgressivos/regressivos pleistocênicos.

As desembocaduras lagunares de Ararapira, Cana néia e Icapara, bem como a foz do rio Ribeira de Iguape representam as feições litorâneas em intensa movimentação dinâmica atual. Estas feições são a resultante de todos os eventos deposicionais e erosivos de idade pleistocênica-holocênica, que a partir de uma intensa sedimentação arenosa preencheu os amplos anfiteatros de sedimentação existentes no litoral sul paulista.

Portanto, o conhecimento da evolução dessas fei ções costeiras nas últimas décadas permite, não apenas a identí ficação dos processos hidrodinâmicos predominantes, como a obti da pela análise dos alinhamentos dos cordões litorâneos, mas principalmente das alteraçōes deste padrão hidrodinâmico geral ao qual está submetido o litoral sul paulista. 


\section{ANÁL.ISE DA CORFTGURAÇĀO DA L.TAMA DE COSTA}

Em costas arenosas, não somente a configuração da Iinha de costa, bem como feiçoes deposicionais associadas (esporões, pontais arenosos, etc.) têm sido comumente utilizadas como indicadores geomórficos do sentido predominante do transporte litorâneo de sedimentos (Godolphim, 1983; Martin et al., 1984, etc.).

As peculiaridades geomorfológicas existentes no litoral sul paulista objetivando deduzir o sentido predominante de transporte, tem sido utilizada anteriormente por diversos autores (Sadowsky, 1952, 1954; Petri \& Suguio, 1971b, CTH, 1973; Suguio \& Tessler, 1983, etc.).

As três feições mais importantes, a partir da divisa dos estados de são Paulo e Paraná, rumo à foz do rio Ribeira de. Iguape, são as desembocaduras lagunares de Ararapira, de Cananéia e de Icapara.

\section{1 - Desembocadura lagunar de Ararapira (SP/PR)}

A desembocadura lagunar de Ararapira, feição geomorfológica costeira localizada no extremo sul do estado, constitui o divisor político costeiro entre os estados de são Paulo e Paraná.

- "mar de Ararapira", canal de interligação entre a região Iagunar localizada a $\mathrm{NE}$, e a desembocadura lagunar situada ao sul, separa do continente a Ilha do Cardoso e encontra-se separado do oceano, na sua porção mais a $\underline{\mathrm{SW}}$ por uma feicão arenosa estreita e retilínea, localmente denominada praia de Ararapira.

Este pontal arenoso inicia-se na Ilha do Cardoso e apresenta cerca de $18 \mathrm{~km}$ de comprimento e largura máxima de $300 \mathrm{~m}$. Os padrões de alinhamentos dos cordões litorâneos ob servados na praia de Ararapira são semelhantes aos observados na Ilha Comprida.

Porém, quando analisada a configuração do perímetro da desembocadura lagunar obtida a partir de levantamen- 
tos aerofotogramétricos realizados em três épocas distintas (1953, 1963 e 1981) verifica-se que, esta feição de interligação prograda rumo a $\mathrm{SW}$, ou seja, em sentido oposto ao do crescimento admitido para a Ilha Comprida (fig. 53). Esta tendência, ob servada na desembocadura lagunar poderia levar a supor que o transporte litorâneo predominante ao sul da Ilha do Cardoso, se processe de $\underline{N E}$ para $\underline{\mathrm{SW}}$.

Porém, a configuração das margens deste canal, na região próxima à desembocadura sugere que esta progradação, rumo a $\underline{\mathrm{SW}}$,-ocorre pela erosão, durante as marés vazantes, sobre os antigos depósitos arenosos de direção geral SW - NE da regịão lagunar Cananéia-Iguape.

Por outro lado, esta característica de margem erosiva está associada em continuidade lateral a uma feição do tipo esporão arenoso. Este esporão, enraizado na porção externa desta margem côncava, se desenvolve em sentido oposto à progradação do canal, ou seja, no rumo $\underline{\mathrm{NE}}$.

A margem oposta a essa feicão côncava, ou seja, a porção interna da praia de Ararapira prograda rumo a $\underline{\mathrm{SW}}$, originando feições deposicionais semelhantes às observadas nos canais lagunares localizados a NE. Nestes canais lagunares, em especial nos "mares de Cubatão" e "Cananéia" no complexo lagunar de Cananéia - Iguape, Tessler \& Furtado (1983), descreveram - crescimento de ilhas arenosas associadas a margens convexas, localizadas em margens opostas à feições erosivas, côncavas.

Este padrão é muito semelhante ao apresentado por um rio meandrante com a diferença de que nos canais lagunares os sentidos de fluxos são alternados em função dos ciclos de marés, resultando no crescimento de feições deposicionais no mesmo sentido da corrente de maré predominante. Desta forma, fica claro que o crescimento da praia de Ararapira, na sua face interna, ocorre devido à deposição dos sedimentos arenosos erodidos da margem oposta do canal.

Em sua face externa, o crescimento da praia parece estar condicionado ao mecanismo de bloqueio do transporte Iitorâneo, pelo fluxo da maré vazante da desembocadura lagunar 


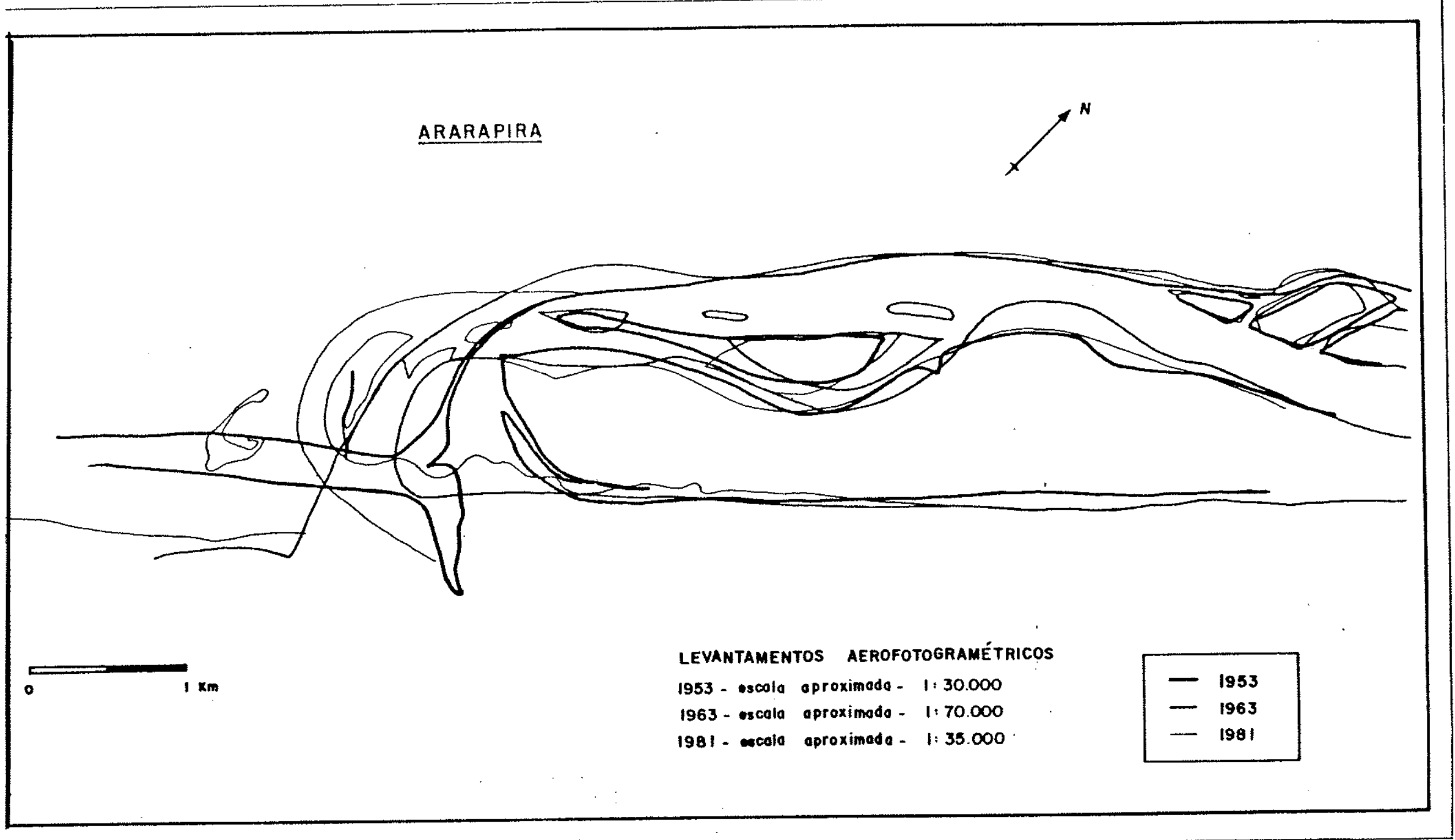

Fıg. 53 - Evolução da desembocadura lagunar de Ararapira (SP/PR) 
à semelhança do mecanismo descrito para desembocaduras fluviais por Suguio et al. (1985). Este bloqueio deve ser responsável pela formação do esporão arenoso da margem côncava do canal de Ararapira, bem como pelo abandono dos sedimentos arenosos carreados pelas águas provenientes do canal, na região marinha pró xima à desembocadura lagunar.

Este mecanismo é mais eficiente quanto maior for a intensidade do fluxo de água que flui para fora através da desembocadura lagunar, fato que ocorre predominante mente durante as passagens de frentes frias.

Nesses períodos os ciclos de maré mais intensas e os ventos provenientes de $\underline{S}$ - $\underline{S E}$, causam $\circ$ aprisionamento de águas nos sistemas lagunares, fazendo com que aumente o volume de água retido nesses sistemas, por um período de tempo superior ao dos ciclos normais de marés. Cessados os efeitos deste evento atmosférico, a maior intensidade do fluxo de maré vazante acelera o processo erosivo das margens côncavas e a alimentação das margens de deposição e ilhas lagunares por sedimentos arenosos.

Como é durante estes eventos que também ocorre - transporte litorâneo mais intenso, a construção do esporão arenoso da desembocadura e acelerada atingindo uma configuração, que somada aos bancos submersos localizados em frente à desembo cadura, tendem a obstruí-1a.

Quando advém o período de vazante mais intensa, esta obstrução é rompida com o consequente deslocamento desses sedimentos arenosos rumo ao oceano.

Posteriormente, nos intervalos de atuação dos sistemas frontais, a deriva litorânea remobiliza esses sedimentos, incorporando-os à praia de Ararapira, em especial nas áreas localizadas mais a SW. Esta incorporação arenosa, associada ao processo erosivo produzido pelas correntes de vazante do canal de Ararapira na planície costeira a SW, é responsável pelo deslocamento da desembocadura lagunar de Ararapira rumo ao $\underline{\mathrm{S}}$.

Desta forma, o deslocamento da desembocadura la gunar no rumo oposto ao transporte predominante dos sedimentos areno 
sos do litoral sul paulista, não pode ser utilizado de maneira simplista como indicador geomórfico do sentido predominante do transporte Iitorâneo.

Desembocaduras lagunares em muito se assemelham a foz de rios junto à costa, com a peculiaridade de que os sentidos de fluxos predominantes se alternam em função das marés. Portanto, essas interações ciclícas, entre os mecanismos hidrodinâmicos marinhos e lagunares, produzem formas arenosas nem sempre condicionadas simplesmente pela corrente de deriva litorânea. Este fato dificulta a utilização dessas feições diretamente como indicadores do sentido predominante de transporte como vem sendo aplicadas a feiçōes arenosas litorâneas, enralzadas em pla nícies arenosas retilineas ou pontões do embasamento cristalino, para determinar o sentido predominante do transporte litorâneo.

\section{2 - Desembocadura lagunar de Cananéia (SP)}

A desembocadura lagunar de Cananéia, por se constituir no principal canal de acesso à região lagunar do sul do Estado de São Paulo, tem merecido maior destaque em relação aos demais canais de interligação existentes na área através dos tempos. Deste modo, foram feitos diversos levantamentos ba timétricos, desde o período da colonização portuguesa até os dias atuais, abrangendo a desembocadura lagunar e regiões marinhas adjacentes (Geobrás, 1966).

Estes estudos tem demonstrado a grande variabiIidade na configuração geral deste canal, levando diversos autores a acompanhar e tentarem explicar as tendências evolutivas observadas ao Iongo do tempo (Sadowsky, 1952, 1954; Petri \& Suguio, 1971 b; Suguio \& Tessler, 1983; etc.).

Sadowsky (1954), ao analisar a seção do canal da desembocadura lagunar e verificar a ocorrência de uma desproporça entre a maior largura observada ( $1200 \mathrm{~m}$ ) e a maior pro fundidade $(20 \mathrm{~m})$ sugere ser relativamente pequena a seção do ca nal em comparação com a enorme superfície do sistema lagunar. 
Os levantamentos batimétricos realizados pela Diretoria de Hidrografia e Navegação - DHN e pelo Laboratoire Nationale D'Hydraulique Chatou - DAEE/SP (1956) (apud Suguio \& Tessler, op. cit.), demonstraram que, embora as profundidades máximas das regiões marinhas e lagunares, adjacentes ao canal principal da desembocadura, não apresentarem maiores profundidades do que 6 a $8 \mathrm{~m}$ o canal sempre conservou, ao Iongo do tempo, profundida des máximas próximas de $20 \mathrm{~m}$. Este fato levou Suguio \& Tessler (op. cit.), a supor que este canal poderia estar relacionado a um paleovale, submerso durante a transgressão holocênica, ou a uma zona de abatimento estrutural como suposto no relatório Geo brás (op. cit.).

Porém, qualquer que tenha sido sua origem, o fa to é que esta seção profunda do canal tem persistido, pelo menos, ao longo dos últimos 50 anos, permitindo afirmar que, durante todo este periodo, não tenha havido transferência de sedimentos arenosos entre as regiões marinha e lagunar, através da seção principal do canal. o exame da configuração geomorfológica das margens das ilhas do Carcioso e Comprida, contíguas a esse canal, demonstra uma evolução constante entre os anos de 1954 e 1981 .

De acordo com Sadowsky (1954), a ponta mais a leste da IIha do Cardoso, Ponta do Perigo, tem estado submetida a processo erosivo por um longo período, acarretando com isso um deslocamento da linha de costa à retaguarda dessa feiço arenosa. Segundo este autor esse recuo seria o responsável pelo embate das ondas em locais cada vez mais à retaguarda da Ilha Comprida na margem oposta do canal, acarretando com isso uma acentuada erosão das formações arenosas elevadas dessa área.

Petri \& Suguio (1971b), retomando a questão da configuração das margens do canal e usando informações obtidas a partir de levantamentos aerofotogramétricos e trabalhos de campo admitem que, embora a tendência desta costa sul consista no crescimento às expensas do mar atenuando os ásperos recortes paleogeográficos, localmente os ventos dominantes e as correntes de maré podem erodir rapidamente porções menos resistentes daquela orla litorânea. Desta forma, os autores afirmam que a 
erosão da costa leste da Ilha do Cardoso, cuja magnitude foi tal que sua projeção de direção noroeste, passa a oeste do Pontal da Trincheira penetrando no Mar de Cananéia, foi originada pela ação de correntes longitudinais vindas de sudeste.

Posteriormente, Suguio \& Tessler (1983), sobrepondo um levantamento aerofotogramétrico executado em 1973 ao mapa de configuração da desembocadura de Cananéia executado por suguio \& Petri (op. cit.), concluem pela conservação das tendências evolutivas encontradas nos estudos anteriores, além de observar uma tendência de crescimento dos bancos arenosos submersos da desembocadura lagunar.

Superpondo-se os resultados prévios a um levantamento executado pelo laboratório de Hidraúlica da Universidade de São - CTH/USP (1973) e aos mapas de contorno da costa, ob tidos de levantamentos aerofotogramétricos executados em 1954 e 1981, verifica-se uma tendência generalizada de recuo da face leste e avanço da parte sul da Ilha do Cardoso, acompanhada de tendência de erosão da margem da Ilha Comprida (fig. 54).

o crescimento da IIha do Cardoso na sua porção mais ao sul parece estar ligado ao transporte litorâneo de SW para NE.

O transporte Iitorâneo de sedimentos arenosos ao Iongo do trecho situado a leste da desembocadura de Ararapira é bloqueado pela projeção rochosa da I Iha do Cardoso, denominada Pon ta do Itacurussá, gerando um acúmulo de sedimentos arenosos a barlamar desta ponta. No momento de acúmulo máximo a aça das correntes Iitorâneas consegue sobrepujar o obstáculo, quando então os sedimentos excedentes são mobilizados para NE, sendo aprisionados entre a Ponta do Itacurussá e o canal da desembocadura lagunar de Cananéia.

Observando-se o padrão dos alinhamentos dos cor dões litorâneos holocênicos da Ilha do Cardoso, na porção próxima à ponta de Itacurussá, verifica-se que eles apresentam direção geral $\underline{N E}$ - $\underline{S W}$, com uma forte curvatura na função desses cordões com a rocha pré-cambriana.

Este padrão demonstra a efetividade, não apenas das correntes litorâneas para NE como também da difração

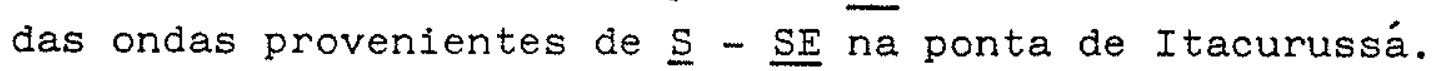




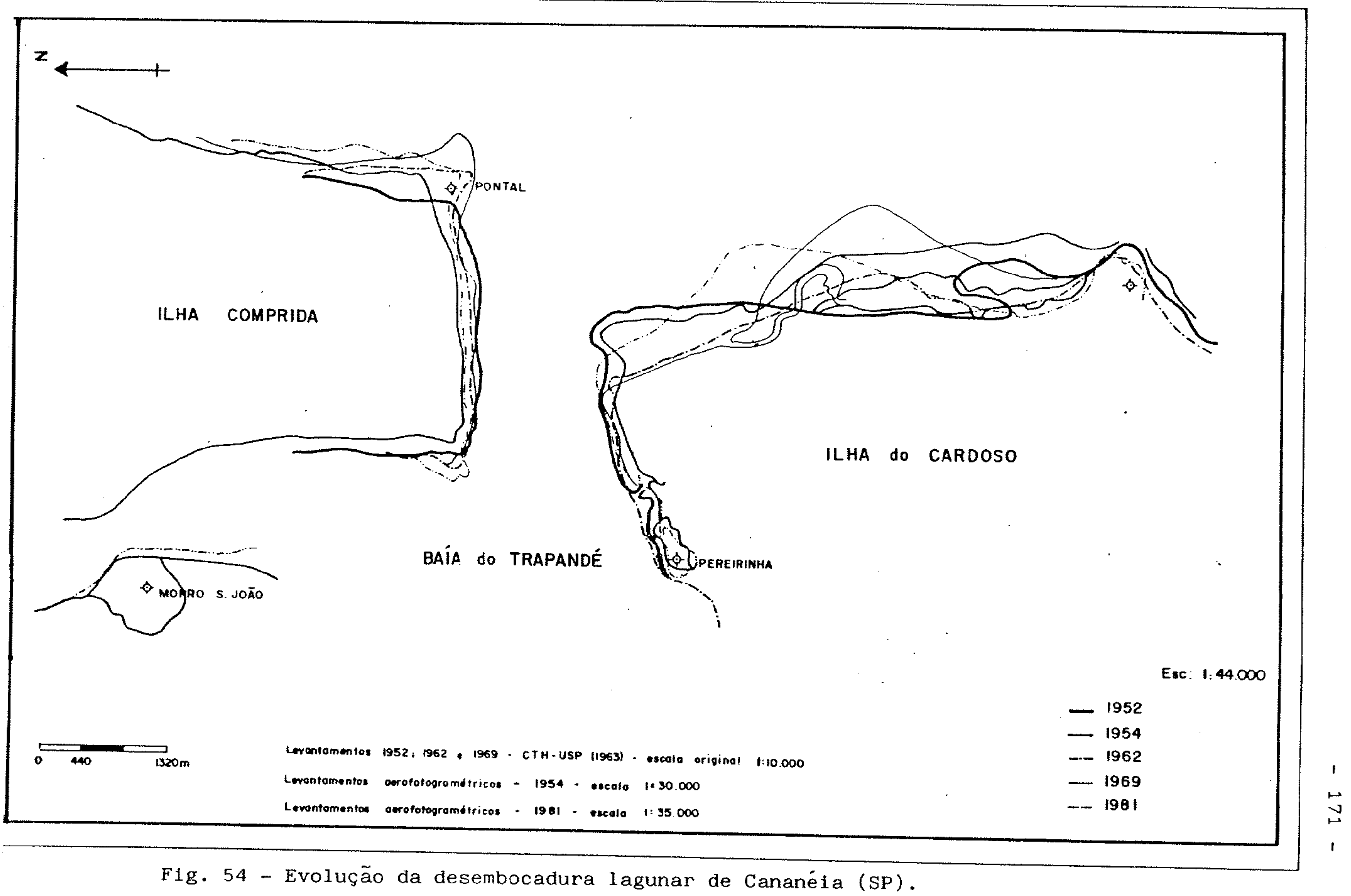


Portanto, parece ser lícito supor que o mecanis mo de transporte I1torâneo de sentido SW - NE tem predominado durante os últimos 5000 anos na região costeira mais ao sul do Estado de são Paulo.

Desta forma, o fenômeno acompanhado por Sadowsky (1954), de gênese de uma nova ilha arenosa posteriormente in corporada à prala sul da Ilha do Cardoso no decorrer dos anos de 1952 a 1954, representou provavelmente apenas mais uma etapa da acumulação de sedimentos transportados pelas correntes litorâneas, provenientes de $\underline{\mathrm{SW}}$, que foram bloqueadas pelas correntes de maré vazante da desembocadura lagunar de Cananéia.

Este fato, já havia sido sugerido por Sadowsky (1954), ao identificar seixos originários de rochas aflorantes na Ponta do Itacurussá, na linha de costa em crescimento da nova ilha arenosa.

Na região da desembocadura lagunar de Cananéia, - deslocamento à retaguarda da Ponta do Perigo, bem como da face mais a oeste da Ilha Comprida, constitui resposta à aça com binada das correntes de maré intensas das ondas e correntes de deriva Iitorânea.

Na região lagunar, nas proximidades da desembocadura lagunar Miyao (1977) verificou o predominio das correntes de maré vazante sobre as de enchente.

Esse predomínio é manifestado pelo contínuo avan ço da Ponta da Trincheira, na porção mais interna da margem do canal da Ilha Comprida, onde a maré vazante proveniente do mar de Cananéla encontra-se com a maré vazante proveniente da baía de Trapandé, antes de fluir pela desembocadura lagunar rumo ao oceano.

Quando da ocorrência de fenômenos meteorológicos muito intensos, gerando a retenção de grande volume de água nos canais lagunares, a porção terminal deste pontão arenoso che ga, na vazante subsequiente, a ser rompida.

De acordo com informações de moradores locais, este pontão arenoso progradou entre os anos de 1940 e 1970 cerca de 100 metros, quando então diminuiu a intensidade de avan- 
co rumo ao canal central. Esta época é coincidente, de acordo com Petri \& Suguio (op. cit.), com o deslocamento do alinhamento da costa da Ilha do Cardoso para oeste da Ponta da Trincheira, expondo-a ao embate direto da ação das ondas. Da mesma maneira, o recuo da Ponta do Perigo, na Ilha do Cardoso, é respos ta à intensa ação erósiva das correntes de maré vazante que deslocaria os sedimentos arenosos desta região rumo ao oceano.

O embate da corrente de maré vazante com a corrente de deriva litorânea e as ondas, de direção de incidência predominante dos quadrantes $\underline{S}$ e $\underline{S E}$, seria responsável pela acumulação arenosa observada na margem da IIha do Cardoso a SE da Ponta do Perigo.

$\mathrm{Na}$ área da desembocadura lagunar de Cananéia, ao bloqueio do transporte litorâneo associam-se dois outros, o da erosão da margem provocada pela ação das correntes de vazante e enchente e a ação local das correntes geradas pela incidên cia das ondas provenientes de $\underline{S}-\underline{S E}$ e $E$. Esta interação gera, não apenas o recuo da Ponta do Perigo e da formação de acumulações arenosas de direção geral $\underline{N W}$ - $\underline{S E}$ como também da rotação da margem do canal para $\mathrm{NW}$, a partir de um ponto imaginário situado na interseç̧ão da direção geral da Iinha de costa, SW - NE, com o alinhamento desta margem.

Finalmente, existem barras arenosas submersas que obstruem o acesso ao canal profundo da desembocadura lagunar de Cananéia, dispondo-se quase paralelamente à linha de cos ta atual, representando o resultado da interação entre as correntes de maré e as de deriva litorânea. Estes bancos submersos, em crescimento conforme exposto por suguio \& Tessler (op. cit.), são alimentados pelos sedimentos arenosos carreados pela corrente de vazante, a partir das margens das ilhas Comprida e Cardoso, bem como pelos sedimentos reliquia da plataforma continental próxima. Os bancos submersos se expandem, mantendo seu perfil de equilíbrio instável, até o nível de agradação máximo, quando então passam a ser erodidos. O mesmo mecanismo de deriva litorânea, gerada pela incidência do trem de onda que abandona seus sedimentos quando da interação com as correntes de maré, que fluem pela desembocadura lagunar, vão a partir da 
agradação máxima destes bancos submersos, retrabalhar e remobiIizar estes sedimentos. A arrebentação dos trens de onda diretamente sobre os bancos arenosos, quando estes atingem a super fície do oceano, novamente liberam os sedimentos para o transpor te pelas correntes de deriva, deslocando-os para outros depocentros.

A partir desses bancos arenosos submersos, que apresentam grande mobilidade, impossibilitando o estabelecimento de um único canal de acesso à região lagunar de CananéiaIguape, os sedimentos são novamente capturados pelas correntes de deriva litorânea, de sentido predominante $\underline{N E}$, e movimentados ao Iongo da praia de Fora, na Ilha Comprida, em direção à foz do rio Ribeira de Iguape.

$$
\text { A carga de sedimentos arenosos ao longo }
$$
praia de Fora da Ilha Comprida é também alimentada pelos sedimentos erodidos da própria margem da ilha, do canal de acesso ao sistema lagunar, que carreados pelas correntes de vazante fazem progradar a ponta $\underline{\mathrm{S}}$ da ilha, denominada Pontal de Fora.

Segundo informaçōes verbais do Engo Odair José de Souza do CTH/USP, durante um ano e meio em que foram realizadas as medicões de onda na Ilha do Bom Abrigo, o perfil topográfico da praia do Pontal de Fora foi levantado periodicamente a intervalos mensais. o levantamento mostrou que este perfil é instável, com fases de agradação alternadas com períodos de degradação quando os sedimentos deste pontão arenoso são transferidos para $\mathrm{NE}$, ao longo da costa da ilha.

Desta forma, a ponta sul da ilha apresenta um constante crescimento rumo ao oceano, o que pode ser constatado também pelo padrão do alinhamento dos cordões arenosos localizados junto ao Pontal de Fora, que exibem um pequeno deslocamen to para $W$ em relação aos alinhamentos dos cordões holocênicos da face oceânica da Ilha Comprida.

5.3 - Desembocadura lagunar de Icapara e foz do rio Ribeira de Iguape (SP)

A partir de um conjunto de cartas batimétricas levantadas entre os anos de 1882 e 1943 e apoiados em dois le- 
vantamentos aerofotogramétricos executados em 1953 e 1962, Geobrás (1966) realizou estudo comparativo de evolucão das ilhas Comprida e de Iguape na região da desembocadura de Icapara (f1g. 55).

Neste estudo foi detectado o crescimento

da

Ilha Comprida para $\underline{N E}$, como também ima rotação para $\underline{N}$ da desembocadura. Associado a este crescimento da Iha Comprida observou-se também a erosão da Ilha de Iguape na margem oposta do canal lagunar. Esses fenômenos de avanço da Ilha Comprida, bem como de re cuo da Ilha de Iguape, são semelhantes aos observados no canal e desembocadura lagunar de Ararapira.

A diferença básica dos mecanismos hidrodinâmicos atuantes nos canais lagunares de Ararapira e Pequeno é que, enquanto no canal de Ararapira a corrente predominante de vazante se desloca rumo SW, no Mar Pequeno o deslocamento predominante, vazante, ocorre para $\mathrm{NE}$, a partir de uma região denomi nada Pedra do Tombo, onde ocorre um encontro das marés enchentes provenientes das dẹsembocaduras lagunares de Cananéia e Ica para. Portanto, enquanto que na desembocadura lagunar de Ararapira o sentido da vazante se contrapõe ao sentido da corrente de deriva litorânea predominante NE, na desembocacura lagunar de Icapara esta corrente apresenta o mesmo sentido de deslocamento, resultando tanto em crescimento da ilha arenosa, como em erosão na margem lagunar de igual direção, NE.

Segundo a Geobrás (op. cit.), este avanço da Ilha Comprida entre os anos de 1882 e 1965 apresentou uma média de deslocamento para $\mathrm{NE}$ de $35 \mathrm{~m} /$ ano, enquanto o recuo da margem oposta, Ilha de Iguape, para o mesmo período apresentou como mé dia um valor de $32 \mathrm{~m} / a n o$. Um cálculo médio da área erodida na Ilha de Iguape demonstrou que anualmente foi retirado da margem da ilha um volume de $57000 \mathrm{~m}^{3}$ de sedimento.

Estes sedimentos, carreados em direção ao ocea no, são retidos pela ação das ondas na região da desembocadura lagunar de Icapara, criando um conjunto de bancos arenosos submersos, alinhados paralelamente à margem da desembocadura lagunar na Ilha Comprida. Desta forma, diferentemente da região da desembocadura lagunar de Cananéia onde os bancos submersos impedem a formação de um canal de acesso à região lagunar, na de- 

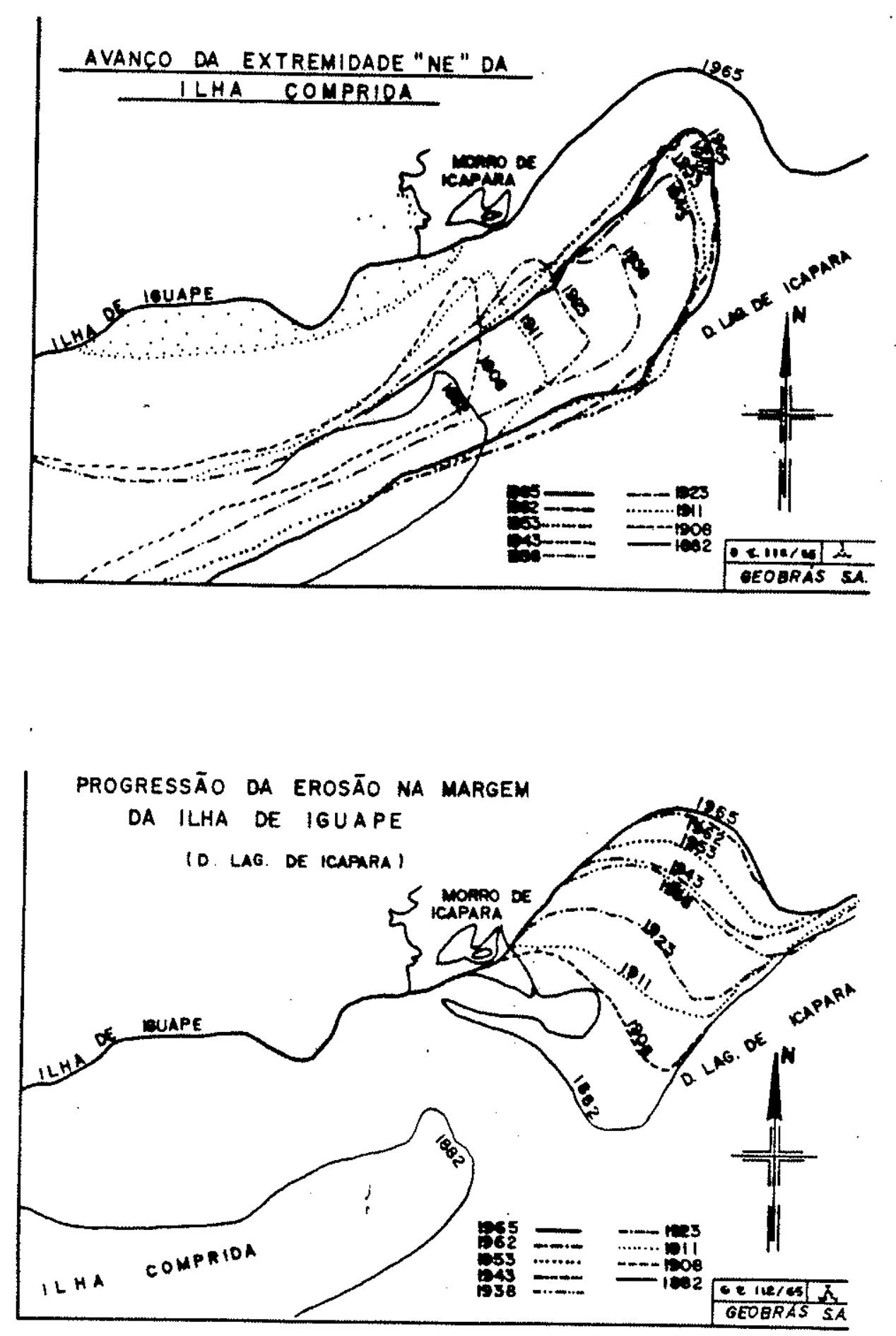

Fig. 55 - Evolução da desembocadura lagunar de Icapara e da I Iha de Iguape, SP (Geobrás, 1966). 
sembocadura lagunar de Icapara a disposição da feicão, aproximadamente $\mathrm{N}-\underline{S}$, aliada à orientação desses bancos, conserva um canal raso de acesso à desembocadura orientado para o sul.

Entre esta desembocadura lagunar e a foz do rio Ribeira encontra-se uma sequiência de depósitos arenosos, alinha dos paralelamente à costa, formados pela deposição dos sedimentos arenosos retrabalhados à partir dos depocentros submersos dos bancos arenosos da desembocadura lagunar de Icapara e foz do rio Ribeira de Iguape.

Na foz do rio Ribeira de Iguape encontra-se um esporão com sentido de crescimento $\underline{\mathrm{SW}}$, ou seja, de sentido opos to ao da corrente de deriva litorânea predominante no litoral sul (fig. 56). A propagação da corrente litorânea que se deslo ca rumo a $\mathrm{NE}$ sofre na região da desembocadura de Icapara e foz do RIbe1 ra, o bloqueio dos fluxos lagunar e fluvial que além de reter o deslocamento dos sedimentos no sentido $\underline{N E}$, também interferem nas características hidrodinâmicas locais.

Desta forma, a predominância das correntes de deriva litorânea provenientes de $\underline{\mathrm{SW}}$, geradas pelos sistemas de on das incidentes de $\underline{\mathrm{S}}$ - $\underline{\mathrm{SE}}$, só vai se restabelecer plenamente ao longo da faixa costeira localizada a $\mathrm{NE}$ da foz do rio Ribeira de Iguape.

Além disso, como foi verificado durante as observações de ondas e correntes realizadas em 1984 , nas proximidades da foz do rio Ribeira verifica-se que nesta área ocorreram as maiores freqüências de ondas provenientes de $\underline{N E}-\underline{E}$, com a consequiente geração de correntes de deriva direcionadas para $\underline{\mathrm{SW}}$, fato este corroborado pelas medições de correntes de fundo na estação de correntometria de Iguape.

Portanto, a maior frequiência de correntes de de riva litorânea geradas pelos sistemas de ondas provenientes de NE e E, associada ao bloqueio da deriva gerada pelos sistemas de ondas de $\underline{S E}$ - $\underline{S}$ na região da desembocadura lagunar de Icapara e foz do Ribeira de Iguape, propiciam o estabelecimento de um frágil esporão, na foz do rio, com tendência de crescimento para SW. 


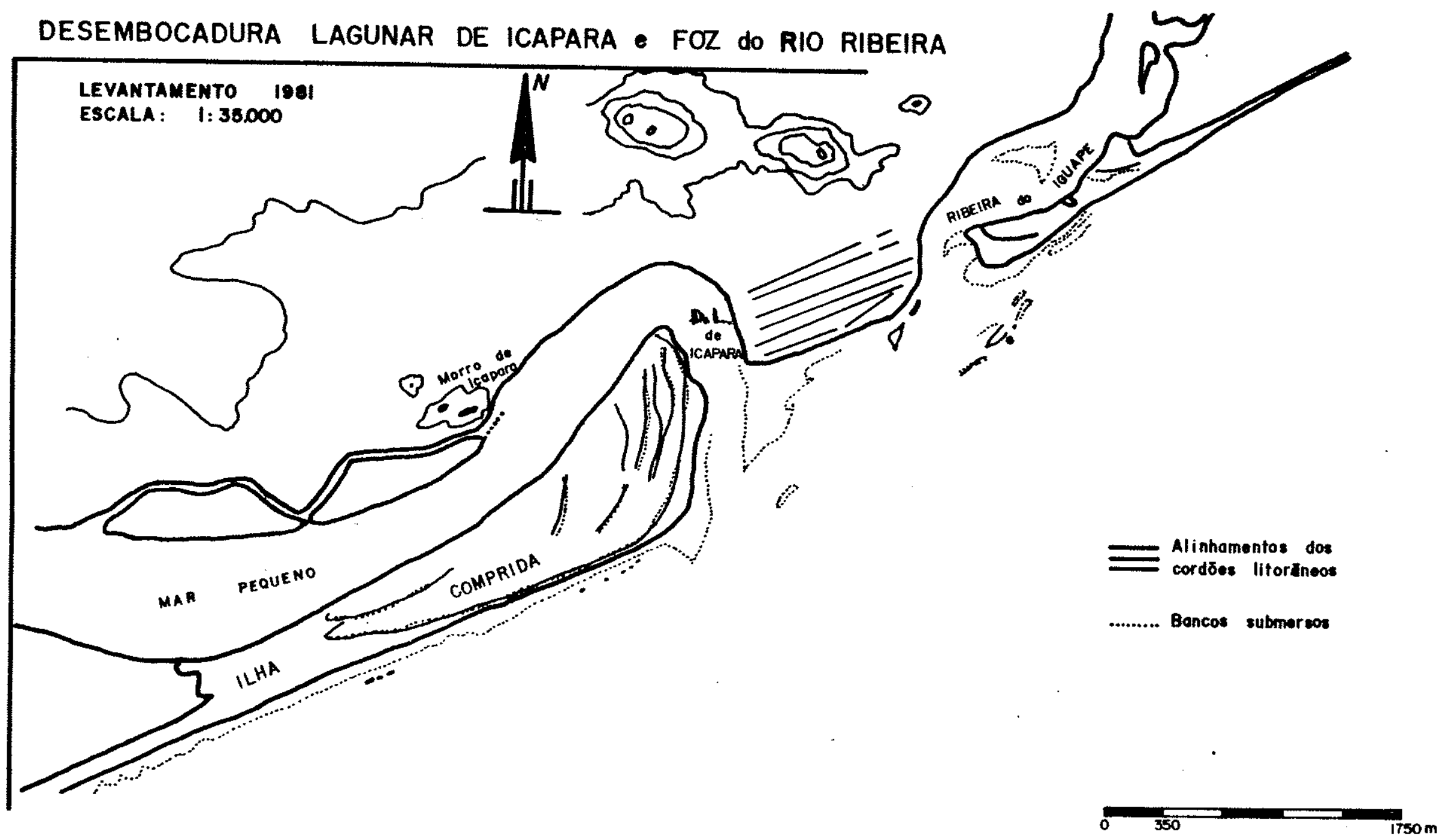

Fig. 56 - Configuração da linha de costa nas proximidades da desembocadura lagunar de Icapara e da foz do rio Ribeira de Iguape (SP) 1981. 
Finalmente, além de apresentar uma feição geomórfica atípica o rio Ribeira de Iguape também não apreșenta as características de um fluxo fluvial que barra o transporte lito râneo, qual seja a progradação da costa a barlamar do fluxo e erosão a sotamar (Suguio et al., 1985).

Portanto, a simples interpretação da dinâmica costeira a partir de indicadores geomórficos, enraizados na linha de costa, apresenta algumas limitaçoes se, na planície costeira onde estiveram associadas essas feições arenosas, também se desenvolverem sistemas lagunares e/ou estuarinos fortemente condicionados pelos ciclos de maré.

\section{COKCLUSÖES FIMAIS}

- A planície costeira de Cananéia-Iguape, Iocalizada no litoral sul paulista é constituida, na superfície, por conjuntos de sedimentos predominantemente arenosos de idade quaternária. Esses sedimentos foram depositados e remobilizados pelos eventos transgressivos/regressivos pleistocênicos e holocênicos, através do transporte desses sedimentos pelas correntes de deriva Iitorânea ao Iongo das paleolinhas de costa. Esses movimentos ao longo da costa são controlados pela interação dos parâmetros hidrodinâmicos e meteorológicos atuantes no litoral sul brasileiro.

A caracterização textural da Formação Cananéia, cordões holocênicos da İlha Comprida; faixa intermarés; zo na de arrebentação e plataforma rasa, permite verificar a exis tência de grande similiaridade entre si, sendo essas unidades constituidas por areias finas a muito finas, em porcentagens su periores a $80 \%$.

- Os sedimentos arenosos da área emersa, dispos tos ao longo de faixas paralelas à. linha de costa atual, de idâ des pleistocênica e holocênica apresentam tendência a um tênue incremento do grau de arredondamento médio rumo a $\mathrm{NE}$.

As seqüências arenosas de topo das formações Cananéia e Santos, depositadas ambas durante os eventos regres- 
sivos, que se seguiram respectivamente aos máximos transgressi vos de 120.000 anos A.P. e 5.100 anos A.P., não apresentam textural e mineralogicamente variações significativas, quando anaIisadas ao longo de seus perfís verticais ou longitudinalmente à linha de costa atual.

Portanto, seqüências arenosas de topo, textural e mineralogicamente semelhantes, depositadas em subambientes de sedimentação litorâneos rasos, em eventos regressivos subsequentes, levam-nos a admitir que as sequências arenosas emersas, de idades pleistocênica e holocênica, do litoral sul paulista, ainda não estão litoestratigraficamente bem caracterizadas como formações distintas sendo ainda melhor diferenciadas através de sua cronologia como séries cronoestratigráficas distintas.

- Na área submersa, os sedimentos relíquia da plataforma rasa apresentam tendência de diminuição dos valores dos diâmetros médios entre à linha de costa e a isóbata aproximada de $30 \mathrm{~m}$, onde passam a predominar sedimentos de moda areia fina até aproximadamente a isóbata de $50 \mathrm{~m}$. A partir desta pro fundidade, no sentido das maiores profundidades, passam a preva lecer sedimentos com valores mais elevados de diâmetro médio em função da existência de concentrações mais altas de termos peIiticos.

Essa profundidade de mudança da textura predominante dos sedimentos de superficie de fundo reflete, aproximadamente, o limite entre a região litorânea, onde os sedimen tos, carreados em suspensão e por tração junto ao fundo, estão submetidos à influência da dinâmica costeira (ondas, correntes de maré, etc.), e a região de plataforma onde os sedimentos reIíquia estão sendo atualmente recobertos por um conjunto de sedimentos finos, de origem continental, carreados a partir das desembocaduras fluviais e lagunares.

Junto à costa atual, apenas nas regiões próxi mas às desembocaduras lagunares e à foz do rio Ribeira de Iguape ocorrem concentrações limitadas de sedimentos pelíticos. 
- Com relação às áreas-fonte, fornecedoras de sedimento atuais para a região litorânea, duas fontes principais podem ser consideradas: a fonte continental, carreada para a costa preferencialmente pelo sistema fluvial do rio Ribeira de Iguape que drena os metassedimentos do Grupo Açunguí, bem como os migmatitos, granitos e gnaisses do Complexo Cristalino e a plataforma continental a partir de onde são remobilizados os sedimentos relíquias da cobertura sedimentar de fundo. Do conjunto dos dez minerais pesados mais freqüentes em todas as faixas litorâneas da planície sul paulista: andaluzita, cianita, epídoto, estaurolita, granada, hornblenda, rutilo, sillimanita, turmalina e zircão, somente os minerais andaluzita, cianita e estaurolita seriam preferencialmente provenientes da cobertura sedimentar da plataforma continental, enquanto que os outros teriam sua derivação primária a partir das rochas aflorantes no complexo serrano localizado à retaguarda da planície costeira.

- No litoral sul paulista a movimentação dos se dimentos arenosos ao longo da linha de costa atual advém da interação dos trens de onda incidentes, que condicionam as correntes de deriva litorânea e as correntes de maré, que exercem um papel importante na retenção e remobilização desses sedimentos nas proximidades das desembocaduras lagunares.

A interação entre os mecanismos de circulação atmosférica do continente sul-americano e os trens de onda incidentes constitui a base para a compreensão da origem e do sen tido de deslocamento das correntes litorâneas de fundo. A partir dos trens de onda provenientes de $\underline{S}$ - $\underline{S E}$ são geradas correntes de deriva litorânea que se propagam do litoral sul rumo ao litoral centro-sul paulista. Por outro lado, as correntes litorâneas de sentido inverso ( $\underline{\mathrm{SW}}$ ), são geradas a partir dos trens de onda. incidentes dos quadrantes $\underline{N E}-\underline{E}$.

Estes sistemas de correntes litorâneas, de sentidos opostos, são responsáveis pela redistribuição dos sedi mentos provenientes da cobertura sedimentar atual da plataforma continental próxima, bem como dos sedimentos de origem continen 
tal carreados principalmente pela drenagem do rio Ribeira

de Iguape.

A distribuição atual desses sedimentos reflete, não apenas a dualidade de fontes, cuja importância relativa na composição dos sedimentos de fundo é de difícil compreensão, como também a efetividade das correntes de deriva litorânea de sentidos opostos que, na porção central da Ilha Comprida geram, pelo encontro dessas correntes opostas, uma terceira componente orientada rumo ao oceano profundo. Uma feição topográfica loca lizada nesta área de encontro das correntes, com sentido de deslocamento oposto deve representar uma resposta geomorfológica à esse mecanismo de transporte, que resulta em um transporte de fundo, perpendicular à costa, orientado rumo ao oceano. A pre sença desta feição na superfície de fundo é bem evidenciada até as isóbatas de 20 - $25 \mathrm{~m}$, quando sua definição no relevo de fun do torna-se imprecisa. Este desaparecimento deve provavelmente significar a perda de competência do agente transportador na moviimentação dos sedimentos, visto que este movimento só ocorre a partir da interação dos trens de ondas com o fundo, que na área está restrita as isóbatas de 40 a $50 \mathrm{~m}$.

- Um cálculo dos valores absolutos dos volumes de sedimentos arenosos transportados pelas correntes de deriva litorânea no litoral sul paulista é temerário. Porém, a distribuição espacial, textura e mineralogia, dos sedimentos da área submersa e da faixa intermarés, associados à tendência generalizada de crescimento para $\mathrm{NE}$ das feições geomórficas costeiras, indicam que o balanço sedimentar entre as correntes de sentido de propagação oposto apresenta uma resultante para $\mathrm{NE}$, ou seja, do litoral sul rumo ao litoral centro-sul paulista.

Os trens de onda incidentes a partir dos qua drantes $\underline{S}$ - $\underline{S E}$ originam as correntes de deriva litorânea provenientes de SW. Portanto, como este trem de onda tem sua área de geração oceânica vinculada à ação e periodicidade dos sistemas de frente que incidem no litoral sul-americano, verifica-se que, embora os dois sistemas de correntes litorâneas, para SW e para NE, possam até mesmo ocorrer simultaneamente no litoral sul paulista, são as fases de passagem de sistemas de 
frente que resultam no mais efetivo processo de transporte are noso, de fundo, no litoral sul.

Como esses sistemas de frente são limitados em tempo, quando confrontados com os períodos denominados "nor mais" para as condições meteorológicas da área, pode-se afirmar que são mais significativos, em termos de transporte, as poucas horas em que os mecanismos hidrodinâmicos litorâneos estão vin culados aos sistemas frontais, do que os longos períodos em que essa região litorânea está sob a influência do regime de circulação atmosférica associada aos ventos alíseos.

- Os alinhamentos dos cordões litorâneos pleistocênicos e holocênicos, bem como as características sedimentológicas apresentadas longitudinalmente à costa pelos sedimentos arenosos regressivos das formações Cananéia e Santos demonstram que, durante as fases de deposição destas sequiências de topo, prevaleciam condições hidrodinâmicas muito semelhantes às obser vadas atualmente.

Portanto, após os máximos transgressivos de 120.000 anos A.P. e 5.100 anos A.P., quando se depositaram os cordões arenosos do litoral sul paulista, o rumo predominante das paleocorrentes de deriva, entre a divisa dos Estados de São Paulo e Paraná e a foz do rio Ribeira de Iguape, parece ter fluido de SW para $\mathrm{NE}$.

Nas áreas onde não ocorria o predomínio destas paleocorrentes, devido à interações do sistema hidrodinâmico litorâneo com os sistemas de circulação lagunar existente à retaguarda das paleoilhas-barreira, como na ilha de Cananéia e - núcleo inicial da Ilha Comprida, os alinhamentos de cordões litorâneos são distintos do padrão geral, $\underline{\text { SW }}$ - $\underline{N E}$.

Estas áreas restritas onde o padrão hidrodinâ mico litorâneo é perturbado estão, hoje em dia, restritas às re giões das desembocaduras lagunares (inlets) de Ararapira, Cananéia e Icapara e a foz do rio Ribeira de Iguape. 
- Feições geomórficas litorâneas são representa tivas do sentido principal de deriva litorânea, quando elas estão "enraizadas" em costas arenosas retilíneas ou a pontões ro chosos.

Porém, quando ocorrem interações entre sistemas hidrodinâmicos costeiro e continental as feições arenosas formadas são resultado desse processo interativo, o que pode significar que seu padrão de evolução não possa ser utilizado de forma direta, como indicativo do sentido predominante da dinâmica litorânea.

Este fato, observado em desembocaduras lagunares ao longo da costa, é sensivelmente mais complexo se, à retaguarda, na planície costeira onde estiverem associadas estas feições geomónficas arenosas, desenvolverem-se sistemas lagunares e/ou estuarinos fortemente condicionados pelos ciclos alternados de marés enchente e vazante.

Em áreas de influência de desembocadura lagunares, o deslocamentos destas feições depende da hidrodinâmica litorânea, que nestas regiões também é influenciada pelas correntes de maré, que fluem entre a costa e a região lagunar, à retaguarda.

Desta forma, estas feições podem muito bem apresentar uma tendência de deslocamento no rumo oposto à cortente de deriva litorânea predominante, o que torna cada desembocadura lagunar uma área onde as feições geomórficas arenosas não podem ser simplesmente descritas e utilizadas como indicativos da corrente de deriva litorânea predominante. 


\section{REFERÊFCIAS BIBLIOGRÁFICAS}

ALLEN, J.R.L. 1968. Current ripples-Amsterdam, NorthHolland, $433 \mathrm{p}$.

ALMEIDA, F.F.M. de 1976. The system of continental rifts bordering the Santos basin. In: SIMPÓSIO INTERNACIONAL SOBRE AS MARGENS CONTINENTAIS DE TIPO ATLÂNTICO, São Paulo, 1975. Anais Acad. brasil. Ciênc., 48 (supl.): 15-26.

AMARAL, G.; BUSHEE, J.; CORDANI, U.G.; KAWASHITA, K. \& REYNOLDS, J.H. 1967. Potassium-argon ages of alkaline rocks from southern Brazil. Geochim. Cosmochim. Acta, 51:117-142.

BAGNOLD, R.A. 1963. Sedimentation: beach and nearshore processes. In: Hill M.N., ed. The sea New York, Wiley Interscience. v. 3, p. 507-529.

BARCELOS, J.H. 1975. Sedimentação e subambientes deposiclonais da Ilha Comprida, São Paulo. Dissertação de mestrado. Universidade de São Paulo, Instituto de Geociências. $155 \mathrm{p}$. (Inédita).

BIGARELLA, J.J. 1954. Nota sobre os depósitos recentes do litoral sul-brasileiro. Bolm Inst. oceanogr., S Paulo, $\underline{5}(1 /$ 2) :233-239.

BIGARELLA, J.J. \& MOUSINHO, M.R. 1965. Contribuição ao estudo da Formação Pariquera-Aģu (Estado de São Paulo). Bolm paran. Geogr., (16/17):17-41.

BRUNN, P. 1962. Sea level as a cause of shore erosion. J. Watway Harb. Div. Am. Soc. Civ. Engrs, 88:117-130.

BUTLER, L.W. 1970. Shallow structure of the continental mar gin, southern Brasil and Uruguay. Bull. Geol. Soc. Am. 81:1079 -1096 .

CENTRO TECNOLÓGICO DE HIDRAÚLICA - LH/USP. 1973. Observação das características das ondas do mar de Cananéia. Relatório de projeto do Laboratório de Hidraúlica da Escola Politécnica da Universidade de São Paulo. Departamento de Águas e Energia Elétrica da Secretaria de Serviços e Obras Públicas. São Paulo. 40 p.(inédito). 
COIMBRA, A.M. 1976. Arenitos da Formação Bauru: estudo de áreas - fonte. Dissertação de mestrado. Universidade de São Paulo, Instituto de Geociências. $2 \mathrm{v}$. (inédita).

COIMBRA, A.M. 1983. Estudo sedimentológico e geoquímico do Permo-triássico da Bacia do Maranhão. Tese de doutorado. Universidade de são Paulo, Instituto de Geociências. 2 v. (inédita).

CORREAA, I.C.S. 1978. Morfologia e sedimentologia da plataforma continental entre São Paulo e Santa Catarina. Dissertação de mestrado. Untversidade Federal do Rio Grande do Sul. $147 \mathrm{p}$.

COUTINHO, J.M.V. \& COIMBRA, A.M. 1974. Os pesados do Barreiras na costa oriental brasileira: estudo de áreas fonte. In: CONGRESSO BRASILEIRO DE GEOLOGIA, 28., Porto Alegre, 1974. Anais. Porto Alegre, Sociedade Brasileira de Geologia. v. 5, p. 27-41.

DIRETORIA DE HIDROGRAFIA E NAVEGAÇÃO. MINISTÉRIO DA MARINHA, DHN - M.M., 1962/1984. Cartas sinóticas do tempo.

DIRETORIA DE HIDROGRAFIA E NAVEGAÇÃO. MINISTÉRIO DA MARINHA, DHN - M.M., 1985. Brasil - Costa Sul. Mar Pequeno (da barra de Icapara a Cananéia). Levantamentos efetuados pela Marinha do Brasil até 1982. Carta batimétrica. 2 a. ed. Escala natural 1:27500. Proj. Mercator. Rio de Janeiro, DHN. Carta náutica no 1702 .

FLEXOR, J.M.; MARTIN, L.; SUGUIO, K. \& DOMINGUES, J.M.L. 1984 . Gênese dos cordões litorâneos da parte central da costa brasileira. In: Lacerda, L.D. de; Araujo, D.S.D. de; Cerqueira, R. \& Turcq, B., org. Restingas: origem, estrutura, processos. Niterói, CEUFF. p.34-45.

FOLK, R.L. 1966. A review of grain size parameters. Sedimentology, $\underline{6}(2): 73-93$.

FOLK, R.L. \& WARD, W.C. 1957. Brazos River bar: a study in the significance of grain size parameters. J. sedim. Petrolo gy, $27(1): 3-27$. 
GADD, P.E.; LAVELLE, J.W. \& SWIFT, D.J.P. 1978. Estimate of sand transport on the New York shelf using near-bottom current meter observations. J. sedim. Petrology, 48(1):239-252.

GARCIA OCCHIPINTI, A. 1963. Climatologia dinânica do litoral sul brasileiro. Contrções Inst. oceanogr. Univ. S Pau10, sér. Oceanogr. fís., (3):1-86.

GEOBRÁS S/A 1966. Complexo Valo Grande, Mar Pequeno e Rio Ribeira de Iguape. Relatório da Geobrás S/A, Enga e Fundações para o Serviço do Vale do Ribeira do Departamento de Águas e Energia Elétrica do Estado de São Paulo. 2 v.

GIANNINI, P.C.F. 1987. Sedimentação quaternária na planície costeira de Peruíbe-Itanhaém, SP. Dissertação de mestrado. Universidade de são Paulo, Instituto de Geociências, 2 v. (inédita).

GODOLPHIM, M.F. 1983. Contribuição ao estudo da evolução da barra do Rio Grande, Brasil. Pesquisas, Inst. Geociênc. Univ. fed. Rio Grande do Sul, 15:22-43.

GRIFFITHS, J.C. 1951. Size versus sorting in some Caribbean sediments. J. Geol., 59:211-243.

HUBERT, J.F. 1962. A zircon-tourmaline-rutile maturity index and the interdependen of the composition of heavy mineral as semblages with the gross composition and texture of sandstones. J. sedim. Petrology, 32(3):440-450.

INMAN, D.L. 1963. Sediments: physical properties and mechanics of sedimentation. In: Shepard, F.P., ed. Submarine geology. 2nd ed. New York, Harper and Row. p.101-147.

INSTITUTO DE PESQUISAS TECNOLÓGICAS, IPT/SP, 1985. Relatório no 22.021 - Ensaios de perfilagem sísmica contínua e sonografia na costa da Ilha Comprida, litoral sul do Estado de são Paulo, 40 p., 10 figs. - São Paulo.

KOMAR, P.D. 1976. Nearshore currents and sediment transport and the resulting beach. In: Stanley, D.J. \& Swift, D.J.P., ed. Marine sediment transport and environmental management. New York, John Wiley. p.241-254. 
KOMAR, P.D. \& INMAN, D.L. 1970. Longshore sand transport on beaches. J. geophys. Res., 75:5914-27.

KOMAR, P.D. \& MILLER, M.C. 1975. On the comparison between the threshold of sediment motion under waves and unidirectio nal currents with a discussion of a pratical evaluation of the threshold. J. sedim. Petrology, 45(1): 362-367.

KOWSMANN, R.O. \& COSTA, M.P. de A. 1979. Sedimentação quaternária da margem continental brasileira e das áreas oceânicas adjacentes (relatório final). In: Projeto REMAC. Rio de Janeiro, PETROBRÁS-CENPES-DINTEP. $55 \mathrm{p}$. (Série Projeto REMAC, n. 8).

KRUMBEIN, W.C. \& SLOSS, L.L. 1963. Stratigraphy and sedimenta tion. 2nd ed. San Francisco, Freeman. W.H., 660 p.

KUENEN, P.H. 1950. Marine geology. New York, John Wiley. $568 \mathrm{p}$.

KUTNER, A.S. 1962. Granulometria dos sedimentos de fundo da região de Cananéia, S.P. Bolm Soc. brasil. Geol., 11(2):4154.

MAHIQUES, M.M. de 1987. Considerações sobre os sedimentos de superficie de fundo da Baía de Ilna Grande, Estado do Rio de Janeiro. Dissertação de mestrado. Universidade de são Paulo, Instituto oceanográfico. $2 \mathrm{v}$. (inédita).

MARTIN, L.; BITTENCOURT, A.C.S.P. \& VILLAS-BOAS, G.S. 1982. Primeira ocorrência de corais pleistocênicos da costa brasileira: datação do máximo da penúltima transgressão. Ciênc. Terra, 3:16-17.

MARTIN, L.; FLEXOR, J.M.; BITTENCOURT, A.C.S.P. \& DOMINGUES, J. M.L. 1984. Kegistro do bloqueio da circulação atmosférica meridiana na geometria dos cordões litorâneos da costa brasileira. In: CONGRESSO BRASILEIRO DE GEOLOGIA, 35., Rio de Janeiro, 1984. Anais. Rio de Janeiro, Sociedade Brasileira de Geologia. p.133-138.

MIRANDA, L.O.S. 1970. Geologia das bacias na plataforma sul -brasileira. In: CONGRESSO BRASILEIRO DE GEOLOGIA, 24., Bra silia, 1970. Anais. Brasilia, Sociedade Brasileira de Geolo gia. p.129-140. 
MIYAO, S.Y. 1977. Contribuição ao estudo da oceanografia f主 sica da região de Cananéia (lat. $25^{\circ} \mathrm{S}$ long. $48^{\circ} \mathrm{W}$ ). Dissertação de mestrado. Universidade de São Paulo, Instituto Ocea nográfico. $87 \mathrm{p}$. (inédita).

MOTTA, V.F.: 1965. Resultados de algumas medições de transporte litorâneo em modelo costelro esquemático. Anais Acad. brasil. Ciênc., 37( supl.):109-130.

MUEHE, D. \& SUCHAROV, E.C. 1981. Considerações sobre o transporte de sedimentos na plataforma continental nas proxi midades das Ilhas Maricás, R.J. Revta brasil. Geoc. 11(4): $238-246$.

NAVARRA, C.T. 1982. Piçarras e tabatingas do litoral paulis ta. In: Suguio, K.; M.R.M. de Meis \& Tessler, M.G., ed. SIMPósio DO QUATERNÁRIO NO BRASIL, 4., Rio de Janeiro, 1981. Atas. Rio de Janeiro, CENPES-PETROBRÁS. p.259-274.

NETTO, A.S.T. 1980. Manual de sedimentologia. Rio de Janeiro, PETROBRÁS-SEPES-DIVEN. ' $194 \mathrm{p}$.

OPEN UNIVERSITY. 1978. Oceanography. Science: a third level course. Units 11-12: Sediments. Walton Hall, Open Universi ty Press. v. 5 .

PATTIARATCHI, C.B. \& COLIINS, M.B. 1985. Sand transport under the combined influence of waves and tidal currents: an assessment of available formulae. Mar. Geol. 67(1/2):83-100.

PETRI, S. \& FÚLFARO, V.J. 1970. Nota sobre a geologia e ter raços marinhos da Ilha do Cardoso, SP. Notic. Geomorf., 10 (20) : $21-31$.

PETRI, S. \& SUGUIO, K. 1969. Sobre os metassedimentos do Grupo Açunguí do extremo sul do Estado de são Paulo. São Pau 10, Secretaria dos Serviços e Obras públicas. 98 p.

PETRI, S. \& SUGUIO, K. 1971 a. Some aspects of the Neocenozoic sedimentation in the Cananéia - Iguape lagoonal region, São Paulo, Brazil. Estudos sedimentol., Univ. Fed. Rio Gran de do Norte, $1(1): 25-33$. 
PETRI, S. \& SUGUIO, K. $1971 \mathrm{~b}$. Exemplo de trabalho do mar no litoral sul do Brasil. Notic. geomorf., 11(21):61-66.

PETRI, S. \& SUGUIO, K. 1973. Stratigraphy of the Iguape-Cananéia lagoonal region sedimentary deposits, São Paulo, Brasil - Part II: Heavy mineral studies, micro-organisms inventories and stratigraphical interpretations. Bolm I.G., Inst. Geoc. Univ. S Paulo, $4: 71-85$.

POMERANCBLUN, M. \& COSTA, M.P.A. 1972. Integração de informação sobre os minerais pesados na plataforma continental brasileira. In: CONGRESSO BRASILEIRO DE GEOLOGIA, $26 . \mathrm{Be}-$ lém, 1972. Anais. Belém, Sociedade Brasileira de Geologia, v. $2, p \cdot 179-186$.

PONÇANO, W.L. 1976. Sedimentação atual na Baía de sepetiba, Estado do Rio de Janeiro: contribuição à avaliação de viabilidade geotécnica da implantação de um porto. Dissertação de mestrado. Universidade de são Paulo, Instituto de Geociências, 2 v. (inédito).

POSTMA, H. 1967. Sediment transport and sedimentation in the estuarine environment. In: Lauff, G.H., ed. Estuaries. Am. Ass. Advmt Sci. Publs, (83):158-179.

PROJETO REMAC. 1979. Coleção de mapas. Escalas 1:5.592.000 e 1:3.500.000. Proj. Mercator. Rio de Janeiro, PETROBRÁSCENPES-DINTEP. 16 mapas: color. (Série Projeto REMAC, n. 11). RICCOMINI, C.; TESSLER, M.G. \& SUGUIO, K. 1987. Novas evidências de atividade tectônica moderna no sudeste brasileiro: Os depósitos falhados da Formação Pariquera-Açu. Publção Ass. brasil. Estudos Quaternário, (2):29-42.

RUBEY, W.W. 1933. Settling velocities of gravel, sand and silt particles. Am. J. Sci., Ser. 5, 25:325-338.

SADOWSKY, V. 1952. Observações sobre as modificações em cur so na entrada de Cananéia de sua barra e da região adjacente. Bolm Inst. oceanogr., S Paulo, 3(1/2):201-212.

SADOWSKY, V. 1954. Novas contribuições ao estudo da entrada da barra de Cananéia. Bolm Inst. oceanogr., S Paulo, $\underline{5}(1 / 2)$ :151-178. 
SHEPARD, F.P. 1954. Nomenclature based on sand-silt clay ratios. J. sedim. Petrology, 24(3):151-158.

SHEPARD, F.P. \& INMAN, D.L. 1950. Nearshore circulation in beach processes and coastal hydrodynamics. In: Fisher, J.S. \& Dolan, R. edts. Benchmark papers in Geology, 39:152-161, Dowden, Hutchingon \& Ross.

SILVA, P. de C.M. da 1968. Correntes litorais produzidas pe 10 ventio. Publção Inst. Pesq. marin., (20):1-21.

STANLEY, D.J. \& SWIFT, D.J.P., eds 1976. Marine sediment transport and environmental management. New York, John Wiley \& Sons, $602 \mathrm{p}$.

SUDELPA - Superintendência do Desenvolvimento do Litoral Paulis ta. 1975. Localização das ocorrências cadastradas até 31/12/73. Mapeamento executado pela CPRM, escala 1:250.000, São Paulo.

SUGUIO, K. 1971. Textural modifications of well sorted sands as a response to dynamic processes in sedimentary environments. J. mar. Geo1., 7(1):13-25. Japan.

SUGUIO, K. 1973. Introdução à sedimentologia. são Paulo, Edgard Blücher/EDUSP. $317 \mathrm{p}$.

SUGUIO, K. 1980. Rochas sedimentares: propriedades, gênese, importância econômica. São Paulo, Edgard Blücher/EDUSP. $500 \mathrm{p}$.

SUGUIO, K. \& BARCELOS, J.H. 1978. Quaternary sedimentary en vironments in Comprida Island, State of São Paulo, Brasil. Bolm IG, Inst. Geoc. Univ. S Paulo, 9:203-211.

SUGUIO, K.; COIMBRA, A.M. \& GUARDADO, L.R. 1974. Correlação sedimentológica de arenitos da Bacia do Paraná. Bolm IG, Inst. Geoc. Univ. S Paulo, 4:85-116.

SUGUIO, K. \& MARTIN, L. 1976. Mecanismos de gênese das planícies quaternárias do litoral do Estado de São Paulo. In: CONGRESSO BRASILEIRO DE GEOLOGIA, 29., Belo Horizonte, 1976. Anais. Belo Horizonte, v. 1: 295-305. Sociedade Brasileira de Geologia. 
SUGUIO, K. \& MARTIN, L. 1978 a. Formações quaternárias marinhas do litoral paulista e sul fluminense. In: INTERNATIONAL SYMPOSIUM ON COASTAL EVOLUTION IN THE QUATERNARY, São PauIo, 1978. Speclal Publication no 1. São Paulo, The Brazilian National Working Group for The IGCP, Project 61/Instituto de Geociências-USP/Socledade Brasileira de Geologia. 55 p.

SUGUIO, K. \& MARTIN, L. 1978 b. Mapa geológico do Iitoral paulista, Folhas Cananéia e Iguape. Escala 1:100.000. São Paulo, Estado. Secretaria de Obras e do Meio Ambiente, Departamento de Águas e Energia Elétrica. Universidade de são Paulo, são Paulo.

SUGUIO, K.; MARTIN, L.; BITTENCOURT, A.C.S.P.; DOMINGUES, J.M.

L.; FLEXOR, J.M. \& AZEVEDO, A.E.G. 1985. Flutuações do nivel relativo do mar durante o Quaternário Superior ao Iongo do litoral brasileiro e suas implicações na sedimentação costeira. Revta brasil. Geoc.,15(4):273-286.

SUGUIO, K. \& PETRI, S. 1973. Stratigraphy of the Iguape-Cananéia lagoonal region sedimentary deposits, são Paulo state, Brazil. Part I: Field observations and grain size analy sis. Bolm IG, Inst. Geoc. Univ.S Paulo, (4) :1-20.

SUGUIO, K.; RODRIGUES, S. de A.; TESSLER, M.G. \& LAMBOOY, E.E. 1984. Tubos de ophimorphas e outras feições de bioturbação na Formação Cananéia, Pleistoceno da planície costeira Cananéia-Iguape, SP. In: Lacerda, L.D. de; Araujo, D.S. de; Cer queira, R. \& Turcq, B., org. Restingas: origem, estrutura, processos. Niterói, CEUFF. p.111-122.

SUGUTO, K. \& TESSLER, M.G. 1983. Intense coastal sedimentation and erosion in the Cananéia outlet southern state of São Paulo, Brazil. Bolm Inst. oceanogr., S Paulo, 32(1):7175 .

SUGUIO, K. \& TESSLER, M.G. 1987. Characteristics of a PIeis tocene nearshore deposits: an example from southern São Paulo state coastal plain. (Trabalho apresentado no CONGRESS OF INQUA, QUATERNARY OF SOUTH AMERICA AND ANTARCTIC PENINSULA SESSION, 12., OTTAWA, CANADÁ - Bolm Programme with Abstracts p 272 . 
SUNDARAM, D. \& SUGUIO, K. 1983. Nota preliminar sobre uma assembléla mioflorística da Formação Pariquera-Açu, Estado de são Paulo. In: CONGRESSO BRASILEIRO DE PALEONTOLOGIA, SO ciedade Brasileira de Paleontologia, 8, Rio de Janeiro, 1983. Resumo das comunicações. Rio de Janeiro. p.89.

TESSLER, M.G. \& FURTADO, V.V. 1983. Dinâmica de sedimentação das feições de assoreamento da região lagunar CananélaIguape, Estado de São Paulo. Bolm Inst. oceanogr., S Pau10, $32(2): 117-124$.

VICALVI, M.A.; KOTZIAN, S.C.B. \& FORTI-ESTEVES;.I.R. 1977. A ocorrência de microfauna estuarina no Quaternário da plataforma continental de são Paulo. In: Projeto REMAC. Evolução sedimentar holocênica da plataforma continental e do taIude do sul do Brasil. Rio de Janeiro, PETROBRÁS-CENPESDINTEP. p.77-96. (Série Projeto REMAC, n.2).

WENTWORTH, C.K. 1922. A scale of grade and class terms for clastic sediments. J. Geol., 30:377-392.

YAMAMOTO, J.K.; SUGUIO, K. \& COIMBRA, A.M. 1977. Caracterização sedimentológica do perfíl geológico entre Rifaina e França. In: SIMPÓSIO DE GEOLOGIA REGIONAL, 1., SÃO PAULO, 1977. Atas. São Paulo, Sociedade Brasileira de Geologia, Nú cleo de são Paulo. p.282-302. 
TA B E L A S 
TABELA 1 - Posições das amostras coletadas na plataforma continental do Estado de São Paulo. (N/Oc. Prof. W. Besnard - 1984)

\begin{tabular}{|c|c|c|c|}
\hline Ne da Amostra & Lat1 tude (S) & Longitude (W) & Prof. \\
\hline 149 & $25^{\circ} \cdot 10^{\prime}$ & $047^{\circ} 03^{\prime}$ & 50 \\
\hline 150 & $25^{\circ} 38^{\prime}$ & $047^{\circ} 21^{\prime}$ & 55 \\
\hline 151 & $25^{\circ} 40^{\prime}$ & $048^{\circ} 53^{\prime}$ & 17 \\
\hline 152 & $25^{\circ} 40^{\prime}$ & $048^{\circ} 16^{\prime}$ & 18 \\
\hline 153 & $26^{\circ} 07^{\prime}$ & $047^{\circ} 51^{\prime}$ & 54 \\
\hline 154 & $25^{\circ} 53.4^{\prime}$ & $047^{\circ} 46.2^{\prime}$ & 50 \\
\hline 155 & $25^{\circ} 51.0^{\prime}$ & $047^{\circ} 49.8^{\prime}$ & 45 \\
\hline 156 & $25^{\circ} 47.8^{\prime}$ & $047^{\circ} 54.0^{\prime}$ & 40 \\
\hline 157 & $25^{\circ} 47.8^{\prime}$ & $047^{\circ} 54.7^{\prime}$ & 35 \\
\hline 158 & $25^{\circ} 45.5^{\prime}$ & $047^{\circ} 57.0^{\prime}$ & 30 \\
\hline 159 & $25^{\circ} 40.0^{\prime}$ & $048^{\circ} 04.4^{\prime}$ & 25 \\
\hline 160 & $25^{\circ} 37.7^{1}$ & $048^{\circ} 07.3^{\prime}$ & 20 \\
\hline 161 & $25^{\circ} 36.0^{\prime}$ & $048^{\circ} 10.0^{\prime}$ & 15 \\
\hline 162 & $25^{\circ} 34.1^{\prime}$ & $048^{\circ} 12.6^{\prime}$ & 10 \\
\hline 163 & $25^{\circ} 18.7^{\prime}$ & $048^{\circ} 04.4^{\prime}$ & 10 \\
\hline 164 & $25^{\circ} 19.4^{\prime}$ & $048^{\circ} 03.3^{\prime}$ & 15 \\
\hline 165 & $25^{\circ} 25.2^{\prime}$ & $047^{\circ} 56.3^{\prime}$ & 20 \\
\hline 166 & $25^{\circ} 28.2^{\prime}$ & $047^{\circ} 52.7 !$ & 25 \\
\hline 167 & $25^{\circ} 31.7^{\prime}$ & $047^{\circ} 48.5^{\prime}$ & 30 \\
\hline 168 & $25^{\circ} 33.6^{\prime}$ & $047^{\circ} 46.2^{\prime}$ & 35 \\
\hline 169 & $25^{\circ} 35.8^{\prime}$ & $047^{\circ} 43.5^{\prime}$ & 40 \\
\hline 170 & $25^{\circ} 38.6^{\prime}$ & $047^{\circ} 40.1^{\prime}$ & 45 \\
\hline 171 & $25^{\circ} 41.3^{\prime}$ & $047^{\circ} 37.0^{\prime}$ & 50 \\
\hline 172 & $25^{\circ} 23.0^{\prime}$ & $047^{\circ} 21.6^{\prime}$ & 50 \\
\hline 173 & $25^{\circ} 21.2^{\prime}$ & $047^{\circ} 24.5^{\prime}$ & 45 \\
\hline 174 & $25^{\circ} 19.5^{\prime}$ & $047^{\circ} 27.4^{\prime}$ & 40 \\
\hline 175 & $25^{\circ} 19.2^{\prime}$ & $047^{\circ} 29.0^{\prime}$ & 35 \\
\hline 176 & $25^{\circ} 17.0^{\prime}$ & $047^{\circ} 31.0^{\prime}$ & 30 \\
\hline 177 & $25^{\circ} 14.5^{\prime}$ & $047^{\circ} 35.0^{\prime}$ & 25 \\
\hline 178 & $25^{\circ} 10.0^{\prime}$ & $047^{\circ} 41.8^{\prime}$ & 20 \\
\hline 179 & $25^{\circ} 06.0^{\prime}$ & $047^{\circ} 50.7^{\prime}$ & 15 \\
\hline 180 & $25^{\circ} 51.3^{\prime}$ & $047^{\circ} 36.3^{\prime}$ & 10 \\
\hline 181 & $24^{\circ} 51.3^{\prime}$ & $047^{\circ} 36.3^{\prime}$ & 10 \\
\hline
\end{tabular}




\begin{tabular}{|c|c|c|c|}
\hline 182 & $24^{\circ} 52.0^{\prime}$ & $047^{\circ} 34.0^{\prime}$ & 15 \\
\hline 183 & $24^{\circ} 54.5^{\prime}$ & $047^{\circ} 31.1^{\prime}$ & 20 \\
\hline 184 & $24^{\circ} 58.0^{\prime}$ & $047^{\circ} 27.0^{\prime}$ & 25 \\
\hline 185 & $25^{\circ} 02.5^{\prime}$ & $047^{\circ} 21.0^{\prime}$ & 30 \\
\hline 186 & $25^{\circ} 06.3^{\prime}$ & $047^{\circ} 15.5^{\prime}$ & 35 \\
\hline 187 & $25^{\circ} 09.2^{\prime}$ & $047^{\circ} 12.1$ & 40 \\
\hline 188 & $25^{\circ} 11.0^{\prime}$ & $047^{\circ} 10.0^{\prime}$ & 45 \\
\hline 189 & $25^{\circ} 13.0^{\prime}$ & $047^{\circ} 08.2^{\prime}$ & 50 \\
\hline 190 & $24^{\circ} 59.0^{\prime}$ & $046^{\circ} 56.0^{\prime}$ & 50 \\
\hline 191 & $24^{\circ} 56.0^{\prime}$ & $046^{\circ} 59.0^{\prime}$ & 45 \\
\hline 192 & $24^{\circ} 54.5^{\prime}$ & $047^{\circ} 02.0^{\prime}$ & 40 \\
\hline 193 & $24^{\circ} 52.0^{\prime}$ & $047^{\circ} 05.5^{\prime}$ & 35 \\
\hline 194 & $24^{\circ} 48.5^{\prime}$ & $047^{\circ} 11.5^{\prime}$ & 30 \\
\hline 195 & $24^{\circ} 45.0^{\prime}$ & $047^{\circ} 14.0^{\prime}$ & 25 \\
\hline 196 & $24^{\circ} 43.5^{\prime}$ & $047^{\circ} 18.4^{\prime}$ & 20 \\
\hline 197 & $24^{\circ} 42.5^{\prime}$ & $047^{\circ} 19.6^{\prime}$ & 15 \\
\hline 198 & $24^{\circ} 41.3^{\prime}$ & $047^{\circ} 21.2^{\prime}$ & 10 \\
\hline 199 & $24^{\circ} 38.5^{\prime}$ & $046^{\circ} 26.2^{\prime}$ & 59 \\
\hline 273 & $24^{\circ} 41.5^{\prime}$ & $046^{\circ} 42.5^{\prime}$ & 44 \\
\hline 274 & $24^{\circ} 48.0^{\prime}$ & $046^{\circ} 50.0^{\prime}$ & 41 \\
\hline 275 & $24^{\circ} 57.5^{\prime}$ & $047^{\circ} 00.0^{\prime}$ & 42 \\
\hline 276 & $25^{\circ} 06.0^{\prime}$ & $047^{\circ} 10.0^{\prime}$ & 42 \\
\hline 277 & $25^{\circ} 14.0^{\prime}$ & $047^{\circ} 18.5^{\prime}$ & 43 \\
\hline 278 & $25^{\circ} 25.0^{\prime}$ & $047^{\circ} 53.0^{\prime}$ & 24 \\
\hline 279 & $25^{\circ} 18.0^{\prime}$ & $047^{\circ} 45.0^{\prime}$ & 24 \\
\hline 280 & $25^{\circ} 10.5^{\prime}$ & $047^{\circ} 37.5^{\prime}$ & 27 \\
\hline 281 & $25^{\circ} 02.8^{\prime}$ & $047^{\circ} 29.5^{\prime}$ & 29 \\
\hline 282 & $24^{\circ} 56.5^{\prime}$ & $047^{\circ} 23.4^{\prime}$ & 29 \\
\hline 283 & $24^{\circ} 50.0^{1}$ & $047^{\circ} 14.0^{\prime}$ & 26 \\
\hline 284 & $24^{\circ} 36.0^{\prime}$ & $047^{\circ} 01.0^{\prime}$ & 26 \\
\hline 321 & $25^{\circ} 19.0^{\prime}$ & $047^{\circ} 00.0^{\prime}$ & 60 \\
\hline 322 & $25^{\circ} 26.1^{\prime}$ & $046^{\circ} 50.8^{\prime}$ & 70 \\
\hline 323 & $25^{\circ} 31.8^{\prime}$ & $046^{\circ} 44.0^{\prime}$ & 80 \\
\hline 324 & $25^{\circ} 34.0^{\prime}$ & $046^{\circ} 40.6^{\prime}$ & 90 \\
\hline 325 & $25^{\circ} 36.5^{\prime}$ & $046^{\circ} 37.7^{\prime}$ & 100 \\
\hline
\end{tabular}


Tabela 2 - Posicionamento das amostras coletadas na zona de arrebentação, Ilha Comprida - SP (1985)

Ne da amostra

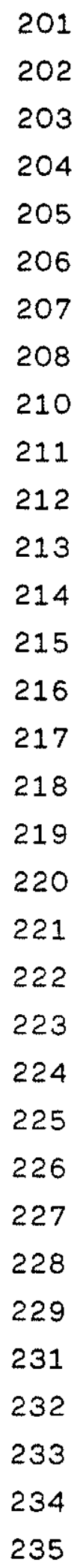

Lat1 tude (S)

$$
25^{\circ} 03.54^{\prime}
$$$$
25^{\circ} 04.28^{\prime}
$$$$
25^{\circ} 01.83^{\prime}
$$$$
25^{\circ} 00.03^{\prime}
$$$$
24^{\circ} 55.92^{\prime}
$$$$
24^{\circ} 56.79^{\prime}
$$$$
25^{\circ} 00.62^{\prime}
$$$$
25^{\circ} 02.68^{\prime}
$$$$
25^{\circ} 00.70^{\prime}
$$$$
25^{\circ} 03.71^{\prime}
$$$$
24^{\circ} 55.49^{\prime}
$$$$
24^{\circ} 58.09^{\prime}
$$$$
25^{\circ} 00.47^{\prime}
$$$$
25^{\circ} 01.59^{\prime}
$$$$
25^{\circ} 00.45^{\prime}
$$$$
24^{\circ} 55.99^{\prime}
$$$$
24^{\circ} 57.62^{\prime}
$$$$
24^{\circ} 44.07 \text { ' }
$$$$
24^{\circ} 44.84^{\prime}
$$$$
24^{\circ} 57.91^{\prime}
$$$$
24^{\circ} 58.47^{\prime}
$$$$
24^{\circ} 59.40^{\prime}
$$$$
24^{\circ} 54.30^{\prime}
$$$$
24^{\circ} 59.61^{\prime}
$$$$
24^{\circ} 58.88^{\prime}
$$$$
24^{\circ} 57.09^{\prime}
$$$$
24^{\circ} 51.73^{\prime}
$$$$
24^{\circ} 52.75^{\prime}
$$$$
24^{\circ} 53.04^{\prime}
$$$$
24^{\circ} 53.31^{\prime}
$$$$
24^{\circ} 54.35^{\prime}
$$$$
24^{\circ} 55.07^{\prime}
$$$$
24^{\circ} 51.79^{\prime}
$$

Long1 tude (W)

$$
047^{\circ} 51.14^{\prime}
$$$$
047^{\circ} 49.85^{\prime}
$$$$
047^{\circ} 48.76^{\prime}
$$$$
047^{\circ} 48.23^{\prime}
$$$$
047^{\circ} 49.16^{\prime}
$$$$
047^{\circ} 49.87^{\prime}
$$$$
047^{\circ} 51.94^{\prime}
$$$$
047^{\circ} 49.48^{\prime}
$$

$047^{\circ} 52.10^{\prime}$

$047^{\circ} 49.14^{\prime}$

$047^{\circ} 51.11^{\prime}$

$047^{\circ} 48.66^{\prime}$

$047^{\circ} 49.82^{\prime}$

$047^{\circ} 47.74^{\prime}$

$047^{\circ} 46.63^{\prime}$

$047^{\circ} 45.95^{\prime}$

$047^{\circ} 48.97^{\prime}$

$047^{\circ} 45.06^{\prime}$

$047^{\circ} 43.80^{\prime}$

$047^{\circ} 46.57^{\prime}$

$047^{\circ} 47.96^{\prime}$

$047^{\circ} 45.83^{\prime}$

$047^{\circ} 44.54^{\prime}$

$047^{\circ} 46.58^{\prime}$

$047^{\circ} 45.68^{\prime}$

$047^{\circ} 44.64^{\prime}$

$047^{\circ} 41.91^{\prime}$

$047^{\circ} 40.61^{\prime}$

$047^{\circ} 43.52^{\prime}$

$047^{\circ} 43.57^{\prime}$

$047^{\circ} 43.03^{\prime}$

$047^{\circ} 41.95^{\prime}$

$047^{\circ} 41.63^{\prime}$ 
continuação...

\begin{tabular}{|c|c|c|}
\hline 236 & $24^{\circ} 54.04^{\prime}$ & $047^{\circ} 43.60^{\prime}$ \\
\hline 237 & $24^{\circ} 51.72^{\prime}$ & $047^{\circ} 41.98^{\prime}$ \\
\hline 238 & $24^{\circ} 52.44^{\prime}$ & $047^{\circ} 40.78^{\prime}$ \\
\hline 239 & $24^{\circ} 53.41^{\prime}$ & $047^{\circ} 38.64^{\prime}$ \\
\hline 240 & $24^{\circ} 51.46^{\prime}$ & $047^{\circ} 37.13^{\prime}$ \\
\hline 241 & $24^{\circ} 50.64^{\prime}$ & $047^{\circ} 39.23^{\prime}$ \\
\hline 242 & $24^{\circ} 50.08^{\prime}$ & $047^{\circ} 39.81^{\prime}$ \\
\hline 243 & $24^{\circ} 51.73^{\prime}$ & $047^{\circ} 42.071$ \\
\hline 244 & $24^{\circ} 51: 08^{\prime}$ & $047^{\circ} 41.21^{\prime}$ \\
\hline 245 & $24^{\circ} 51.38^{\prime}$ & $047^{\circ} 40.36^{\prime}$ \\
\hline 246 & $24^{\circ} 52.41^{\prime}$ & $047^{\circ} 37.63^{\prime}$ \\
\hline 247 & $24^{\circ} 47.34^{\prime}$ & $047^{\circ} 36.09^{\prime}$ \\
\hline 248 & $24^{\circ} 48.02^{\prime}$ & $047^{\circ} 33.49^{\prime}$ \\
\hline 249 & $24^{\circ} 49.40^{\prime}$ & $047^{\circ} 34.22^{\prime}$ \\
\hline 250 & $24^{\circ} 51.90^{\prime}$ & $047^{\circ} 35.62^{\prime}$ \\
\hline 251 & $24^{\circ} 49.91^{\prime}$ & $047^{\circ} 37.36^{\prime}$ \\
\hline 252 & $24^{\circ} 49.12^{\prime}$ & $047^{\circ} 38.71^{\prime}$ \\
\hline 253 & $24^{\circ} 48.09^{\prime}$ & $047^{\circ} 36.76^{\prime}$ \\
\hline 254 & $24^{\circ} 48.82^{\prime}$ & $047^{\circ} 36.73^{\prime}$ \\
\hline 255 & $24^{\circ} 49.79^{\prime}$ & $047^{\circ} 35.95^{\prime}$ \\
\hline 256 & $24^{\circ} 44.70^{\prime}$ & $047^{\circ} 32.12^{\prime}$ \\
\hline 257 & $24^{\circ} 46.06^{\prime}$ & $047^{\circ} 31.23^{\prime}$ \\
\hline 258 & $24^{\circ} 47.52^{\prime}$ & $047^{\circ} 30.34^{\prime}$ \\
\hline 259 & $24^{\circ} 49.38^{\prime}$ & $047^{\circ} 32.60^{\prime}$ \\
\hline 260 & $24^{\circ} 46.52^{\prime}$ & $047^{\circ} 34.88^{\prime}$ \\
\hline 261 & $24^{\circ} 45.50^{\prime}$ & $047^{\circ} 31.37^{\prime}$ \\
\hline 262 & $24^{\circ} 42.52^{\prime}$ & $047^{\circ} 27.81^{\prime}$ \\
\hline 263 & $24^{\circ} 42.23^{\prime}$ & $047^{\circ} 26.26^{\prime}$ \\
\hline 264 & $24^{\circ} 45.80^{\prime}$ & $047^{\circ} 24.67^{\prime}$ \\
\hline 265 & $24^{\circ} 47.52^{\prime}$ & $047^{\circ} 27.56^{\prime}$ \\
\hline 266 & $24^{\circ} 43.92^{\prime}$ & $047^{\circ} 30.70^{\prime}$ \\
\hline 267 & $24^{\circ} 43.73^{\prime}$ & $047^{\circ} 28.55^{\prime}$ \\
\hline 268 & $24^{\circ} 42.36^{\prime}$ & $047^{\circ} 24.32^{\prime}$ \\
\hline 269 & $24^{\circ} 43.63^{\prime}$ & $047^{\circ} 22.75^{\prime}$ \\
\hline 270 & $24^{\circ} 45.51^{\prime}$ & $047^{\circ} 25.34^{\prime}$ \\
\hline 271 & $24^{\circ} 42.59^{\prime}$ & $047^{\circ} 27.81^{\prime}$ \\
\hline 272 & $24^{\circ} 42.83^{\prime}$ & $047^{\circ} 26.45^{\prime}$ \\
\hline
\end{tabular}


TABELA 3 - Localização dos perfís de coleta da falxa intermarés, Ilha Comprida - SP - 1985

\begin{tabular}{|c|c|c|c|}
\hline Perfil & Amostra $\mathrm{n}^{2}$ & Latitude (S) & Longitude (W) \\
\hline LT 1 & 301 & $25^{\circ} 02.18^{\prime}$ & $047^{\circ} 53.29^{\prime}$ \\
\hline 2 & 302 & $25^{\circ} 02.47^{\prime}$ & $047^{\circ} 53.12^{\prime}$ \\
\hline 3 & 303 & $25^{\circ} 02.06^{\prime}$ & $047^{\circ} 53.05^{\prime}$ \\
\hline 4 & 304 & $25^{\circ} 01.60^{\prime}$ & $047^{\circ} 52.90^{\prime}$ \\
\hline 5 & 305 & $25^{\circ} 01.27^{\prime}$ & $047^{\circ} 52.75^{\prime}$ \\
\hline 6 & 306 & $25^{\circ} 00.62^{\prime}$ & $047^{\circ} 52.35^{\prime}$ \\
\hline 7 & 307 & $24^{\circ} 55.03^{\prime}$ & $047^{\circ} 51.89^{\prime}$ \\
\hline 8 & 308 & $24^{\circ} 55.58^{\prime}$ & $047^{\circ} 51.391$ \\
\hline 9 & 309 & $24^{\circ} 56.16^{\prime}$ & $047^{\circ} 50.86^{\prime}$ \\
\hline 10 & 310 & $24^{\circ} 56.38^{\prime}$ & $047^{\circ} 50.64^{\prime}$ \\
\hline 11 & 311 & $24^{\circ} 57.22^{\prime}$ & $047^{\circ} 49.84^{\prime}$ \\
\hline 12 & 312 & $24^{\circ} 57.94^{\prime}$ & $047^{\circ} 49.08^{\prime}$ \\
\hline 13 & 313 & $24^{\circ} 58.40^{\prime}$ & $047^{\circ} 48.55^{\prime}$ \\
\hline 14 & 314 & $24^{\circ} 58.90^{\prime}$ & $047^{\circ} 47.96^{\prime}$ \\
\hline 15 & 315 & $24^{\circ} 59.28^{\prime}$ & $047^{\circ} 47.49^{\prime}$ \\
\hline 16 & 316 & $24^{\circ} 59.47^{\prime}$ & $047^{\circ} 47.28^{\prime}$ \\
\hline 17 & 317 & $24^{\circ} 59.82^{\prime}$ & $047^{\circ} 46.82^{\prime}$ \\
\hline 18 & 318 & $24^{\circ} 49.84^{\prime}$ & $047^{\circ} 46.45^{\prime}$ \\
\hline 19 & 319 & $24^{\circ} 49.51^{\prime}$ & $047^{\circ} 46.02^{\prime}$ \\
\hline 20 & 320 & $24^{\circ} 44.05^{\prime}$ & $047^{\circ} 45.44^{\prime}$ \\
\hline 21 & 321 & $24^{\circ} 43.82^{\prime}$ & $047^{\circ} 45.16^{\prime}$ \\
\hline 22 & 322 & $24^{\circ} 53.31^{\prime}$ & $047^{\circ} 44.05^{\prime}$ \\
\hline 23 & 323 & $24^{\circ} 52.51^{\prime}$ & $047^{\circ} 43.68^{\prime}$ \\
\hline 24 & 324 & $24^{\circ} 52.43^{\prime}$ & $047^{\circ} 43.42^{\prime}$ \\
\hline 25 & 325 & $24^{\circ} 51.90^{\prime}$ & $047^{\circ} 42.75^{\prime}$ \\
\hline 26 & 326 & $24^{\circ} 51.54^{\prime}$ & $047^{\circ} 42.15^{\prime}$ \\
\hline 27 & 327 & $24^{\circ} 51.23^{\prime}$ & $047^{\circ} 41.88^{\prime}$ \\
\hline 28 & 328 & $24^{\circ} 50.88^{\prime}$ & $047^{\circ} 41.44^{\prime}$ \\
\hline 29 & 329 & $24^{\circ} 50.58^{\prime}$ & $047^{\circ} 41.02^{\prime}$ \\
\hline 30 & 330 & $24^{\circ} 50.27^{\prime}$ & $047^{\circ} 40.62^{\prime}$ \\
\hline 31 & 331 & $24^{\circ} 49.82^{\prime}$ & $047^{\circ} 40.03^{\prime}$ \\
\hline 32 & 332 & $24^{\circ} 49.47^{\prime}$ & $047^{\circ} 39.56^{\prime}$ \\
\hline 33 & 333 & $24^{\circ} 48.97^{\prime}$ & $047^{\circ} 38.92^{\prime}$ \\
\hline 34 & 334 & $24^{\circ} 48.97^{\prime}$ & $047^{\circ} 38.25^{\prime}$ \\
\hline
\end{tabular}


cont1nuação...

$\begin{array}{ll}35 & 335 \\ 36 & 336 \\ 37 & 337 \\ 38 & 338 \\ 39 & 339 \\ 40 & 340 \\ 41 & 341 \\ 42 & 342 \\ 43 & 343 \\ 44 & 344 \\ 45 & 345 \\ 46 & 346 \\ 47 & 347 \\ 48 & 348 \\ 49 & 349 \\ 50 & 350 \\ 51 & 351 \\ 52 & 352\end{array}$

$\begin{array}{ll}24^{\circ} 47.90^{\prime} & 047^{\circ} 37.49^{\prime} \\ 24^{\circ} 47.52^{\prime} & 047^{\circ} 47.00^{\prime} \\ 24^{\circ} 47.09^{\prime} & 047^{\circ} 36.35^{\prime} \\ 24^{\circ} 46.53^{\prime} & 047^{\circ} 35.71^{\prime} \\ 24^{\circ} 46.21^{\prime} & 047^{\circ} 35.07^{\prime} \\ 24^{\circ} 45.79^{\prime} & 047^{\circ} 34.35^{\prime} \\ 24^{\circ} 45.38^{\prime} & 047^{\circ} 33.73^{\prime} \\ 24^{\circ} 45.00^{\prime} & 047^{\circ} 33.05^{\prime} \\ 24^{\circ} 44.55^{\prime} & 047^{\circ} 32.31^{\prime} \\ 24^{\circ} 44.16^{\prime} & 047^{\circ} 31^{\prime} .60^{\prime} \\ 24^{\circ} 43.75^{\prime} & 047^{\circ} 30.89^{\prime} \\ 24^{\circ} 43.37^{\prime} & 047^{\circ} 30.21^{\prime} \\ 24^{\circ} 45.70^{\prime} & 047^{\circ} 29.44^{\prime} \\ 24^{\circ} 42.66^{\prime} & 047^{\circ} 28.73^{\prime} \\ 24^{\circ} 42.22^{\prime} & 047^{\circ} 28.03^{\prime} \\ 24^{\circ} 42.03^{\prime} & 047^{\circ} 27.31^{\prime} \\ 24^{\circ} 41.63^{\prime} & 047^{\circ} 26.42^{\prime} \\ 24^{\circ} 41.37^{\prime} & 047^{\circ} 26.07^{\prime}\end{array}$


TABELA 4 . DADOS DE GRANLLOMETRTA E TEOR DE CARBONATO EM SEDIMENTOS DA FORMACAO CAINANETA

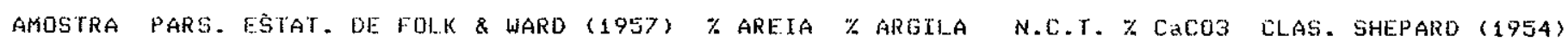

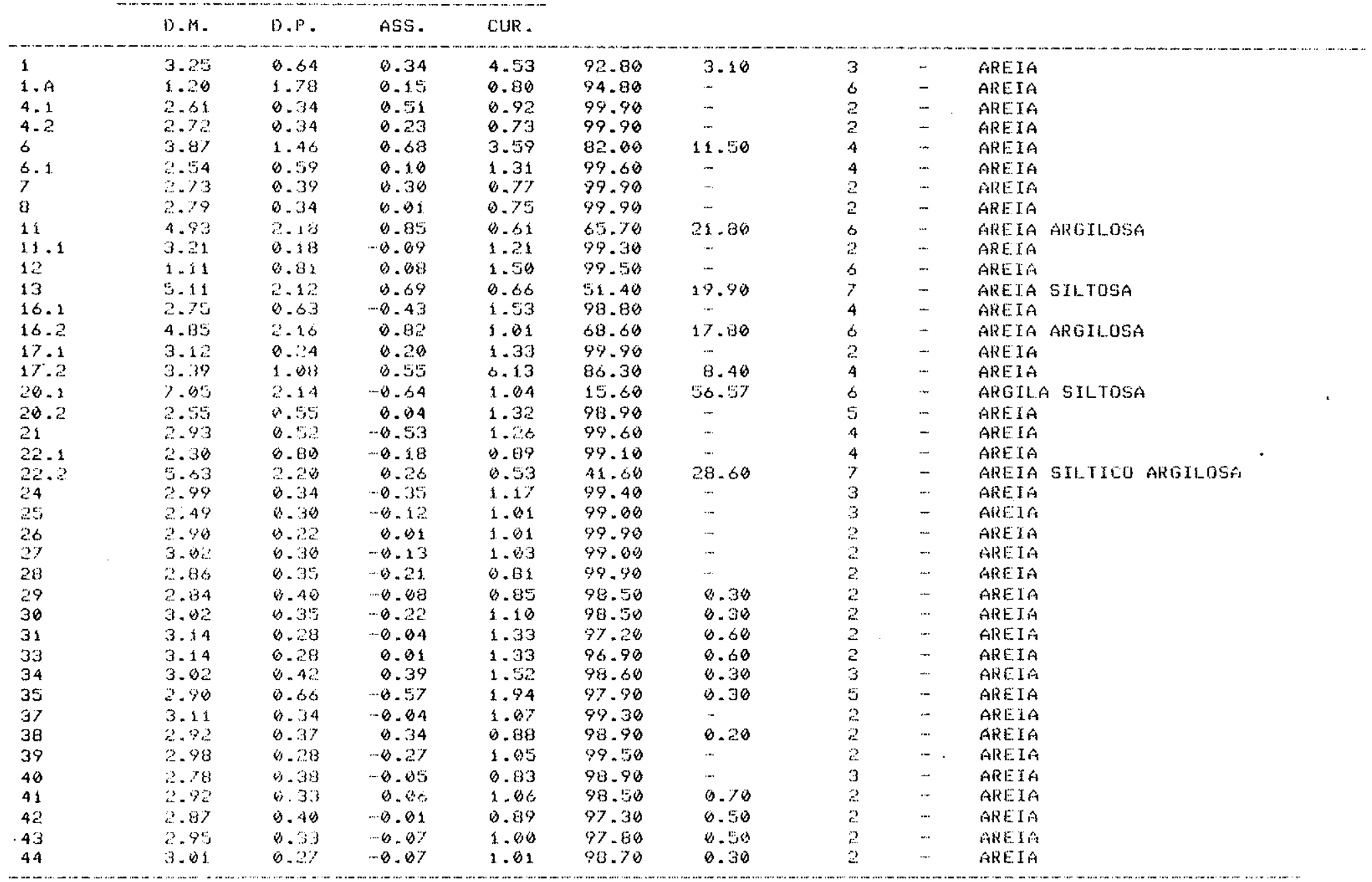


TABELA4 - (CONT.)

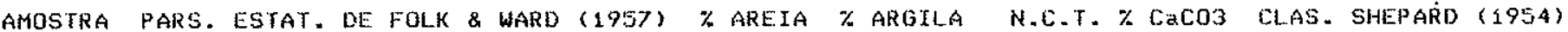

\begin{tabular}{|c|c|c|c|c|c|c|c|c|c|c|}
\hline & D.M. & D.P. & ASS. & CUR - & & & & & & \\
\hline 45 & 2.87 & 6.37 & -0.07 & 0.83 & 98.18 & 0.40 & 2 & - & AREIA & \\
\hline 47 & 2.87 & 0.34 & -0.03 & 0.93 & 98.90 & - & 3 & - & AREIA & \\
\hline 48 & 2.92 & 0.35 & -6.36 & 0.90 & 99.70 & -- & 2 & -- & ARETA & \\
\hline 49 & 2.70 & 0.39 & 0.03 & 0.84 & 99.70 & $\sim$ & 3 & - & AREIA & \\
\hline 50.1 & 4.89 & 3.18 & 0.35 & 0.57 & 63.58 & 24.00 & 9 & - & AREIA & ARGILOSA \\
\hline 50.2 & 2.38 & 0.33 & 0.19 & 0.90 & 99.30 & -- & 2 & - & AREIA & \\
\hline 50.3 & 4.57 & 2..57 & 6.59 & 0.86 & 66.60 & 18.80 & 9 & - & ARE IA & ARGILOSA \\
\hline 50.4 & 2.89 & 0.36 & -0.33 & 0.83 & 99.90 & -. & 2 & - & AREIA & \\
\hline 50.5 & 2.94 & 0.33 & $-8.4 \theta$ & 1.04 & 99.90 & - & 3 & -- & AREIA & \\
\hline $5 i .1$ & 2.86 & 0.32 & -0.17 & 0.84 & 99.90 & - & 2 & - & AREIA & \\
\hline 51.2 & 2.69 & 0.41 & -0.08 & 0.30 & 99.96 & - & 3 & - & AREIA & \\
\hline 51.3 & 2.63 & 0.43 & 0.02 & 0.81 & 99.90 & - & 3 & - & AREIA & \\
\hline 51.4 & 2.68 & 0.35 & 0.05 & 1.04 & 99.90 & - & 3 & - & AREIA & \\
\hline 51.5 & 3.84 & 0.37 & -0.29 & 0.93 & 99.90 & - & 3 & $\cdots$ & AREIA & \\
\hline 52 & 2.77 & 0.50 & -0.32 & 0.95 & 99.20 & $\cdots$ & 3 & -- & AREIA & \\
\hline 52.1 & 2.86 & 0.42 & -0.06 & 0.82 & 97.90 & 0.40 & 2 & - & AREIA & \\
\hline 53.1 & 2.76 & 0.39 & 0.16 & 0.85 & 99.90 & - & 3 & -- & ARETA & \\
\hline 53.2 & 2.71 & 0.35 & 0.15 & 0.79 & 99.60 & -. & 2 & - & AREIA & \\
\hline 53.3 & 2.74 & 0.10 & 0.00 & 0.81 & 99.48 & - & 3 & - & AREIA & \\
\hline 53.4 & 2.82 & 0.38 & -0.02 & 0.80 & 98.70 & 0.30 & 2 & - & AREIA & \\
\hline 54.1 & 2.77 & 0.37 & -8.16 & 0.75 & 99.90 & - & 2 & - & AREETA & \\
\hline 54.2 & 2.59 & 0.54 & -0.06 & 1.00 & 99.20 & - & 4 & - & AREIA & \\
\hline 54.3 & 2.72 & 0.38 & -0.01 & 0.75 & 99.90 & - & 3 & $\cdots$ & $A R E T A$ & \\
\hline 54.4 & a. 84 & 0.35 & -0.19 & 0.83 & 99.60 & - & 2 & - & AREIA & \\
\hline 54.5 & 2.96 & 0.28 & 0.00 & 1.00 & 99.00 & - & 3 & - & ARETA & \\
\hline 55.1 & 2.79 & 0.42 & -0.22 & 0.85 & 99.50 & - & 3 & - & AREIA & \\
\hline 55.2 & 2.82 & 0.36 & -0.02 & 0.80 & 99.60 & -- & 2 & - & AREIA & \\
\hline 56 & 2.80 & 0.34 & -0.04 & 0.77 & 99.90 & - & 2 & - & AREJA & \\
\hline 57 & 2.92 & 0.38 & -0.41 & 0.99 & 99.60 & - & 3 & - & AREIA & \\
\hline 58.1 & 6.41 & 2.08 & -0.18 & 0.69 & 16.90 & 38.80 & 6 & - & SILTE & ARGILOSO \\
\hline 58.2 & 3.22 & 0.25 & $-0.0 B$ & 1.54 & .98 .90 & 0.20 & 2 & - & AREIA & \\
\hline 58.3 & 2.57 & 0.49 & 0.21 & 1.07 & 97.90 & 0.40 & 4 & - & AREIA & \\
\hline 59.1 & 5.17 & 2.23 & 0.66 & 0.53 & 50.10 & 26.50 & 7 & - & ARE IA & ARGILOSA \\
\hline 59.2 & 3.20 & 0.23 & -0.11 & 1.35 & 99.90 & - & 2 & - & AREIA & \\
\hline 59.3 & 3.21 & 0.23 & -6.10 & 1.37 & 99.86 & -- & 2 & - & AREIA & - \\
\hline 59.4 & 2.2 .6 & 0.81 & -0.27 & 0.71 & 99.80 & - & 4 & - & AREIA & \\
\hline 59.5 & 2.61 & 0.39 & 0.24 & 0.77 & 99.80 & - & 3 & - & AREE IA & \\
\hline 60 & 2.63 & 0.52. & -0.11 & 0.88 & 99.70 & - & 3 & - & AREIA & \\
\hline 61.1 & 2.99 & 0.37 & -0.42 & 1.29 & 99.40 & -- & 3 & - & AREIA & \\
\hline 61.2 & 2.70 & 0.53 & -0.23 & 0.98 & 99.20 & - & 4 & - & AREIA & \\
\hline
\end{tabular}


TABELA4 . (CONT.)

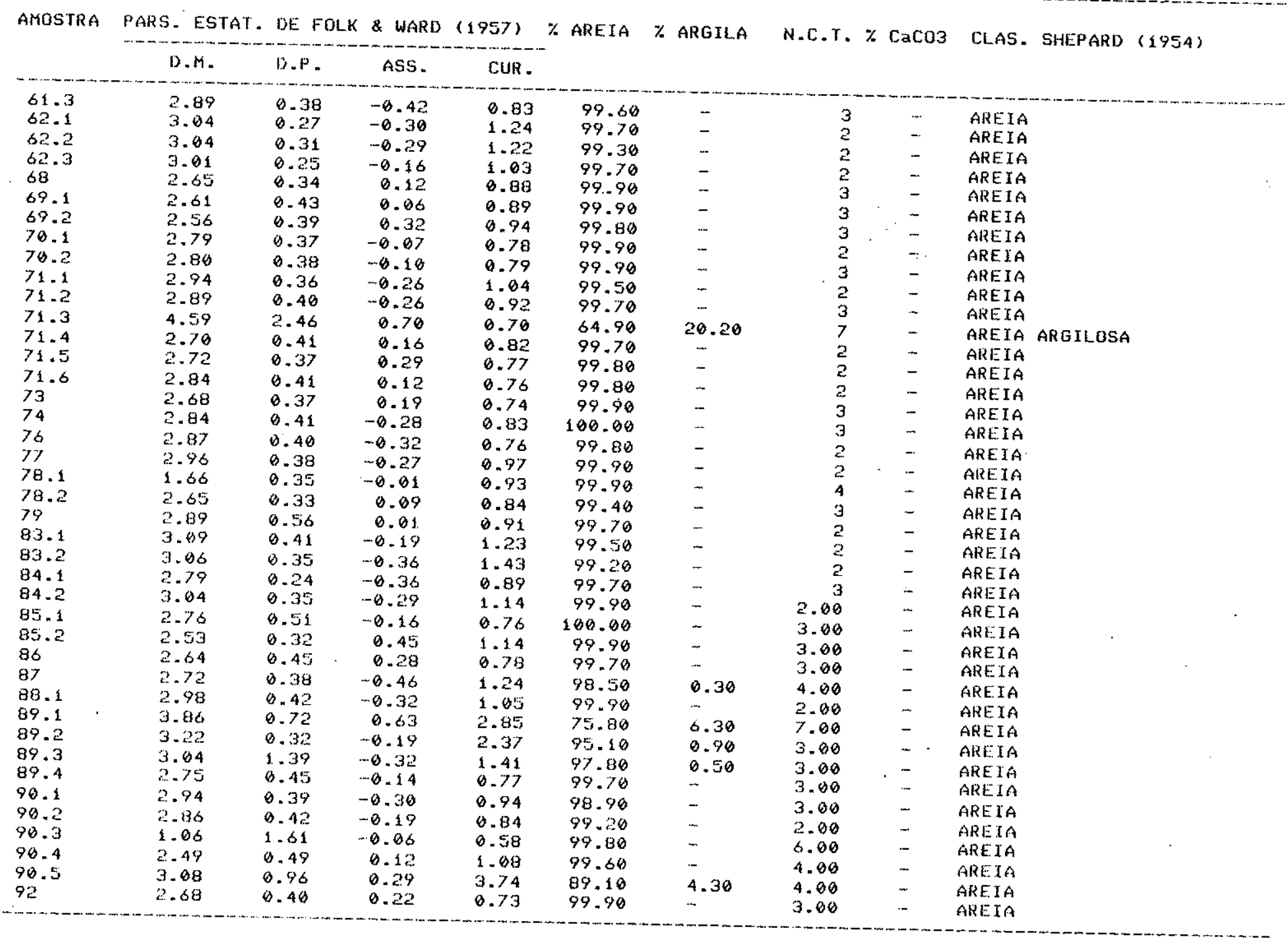




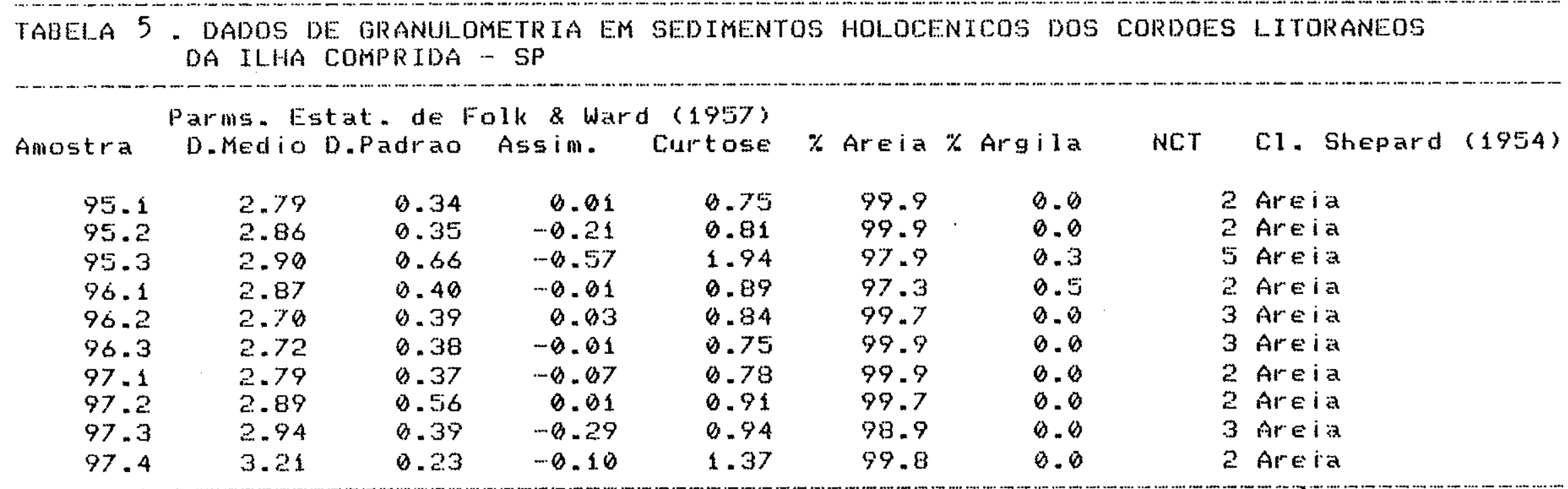


TABELA 6 - DADOS DE GRANULOMETRIA E TEOR DE CARBONATO EM SEOTMENTOS DA FAIXA INTERMARES

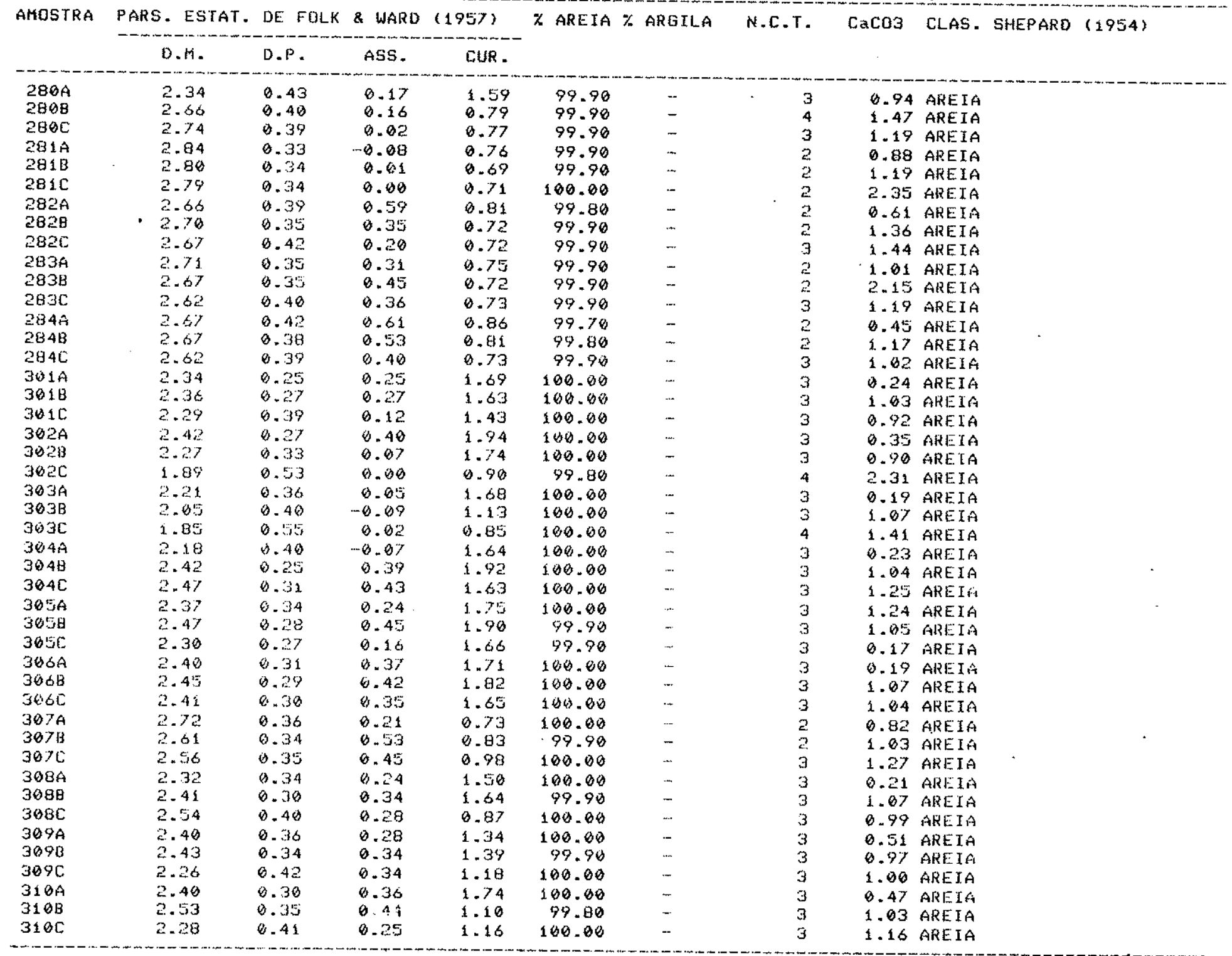




\begin{tabular}{|c|c|c|c|c|c|c|c|c|c|c|}
\hline \multirow[t]{2}{*}{ AMOSTRA } & PARS. ESTAT & DE: FOBLK & \& WARD & $957)$ & $\%$ AREIA \% & ARGILA & N.C.T. & $\mathrm{CaCO} 3$ & CLAS. SHEPARD & $(1954)$ \\
\hline & D.M. & D.P. & ASS. & CUR - & & & & & & \\
\hline $\begin{array}{l}311 A \\
311 B\end{array}$ & 2.33 & 0.31 & 0.23 & $1.5 ?$ & 100.00 & - & 3 & 8.43 & ARELA & \\
\hline $31 \mathrm{AB}$ & 2.31 & 0.30 & 0.21 & 1.59 & 99.90 & - & 3 & 0.81 & AREIA & \\
\hline $\begin{array}{l}311 \mathrm{C} \\
312^{2} \mathrm{~A}\end{array}$ & $\begin{array}{l}2.19 \\
2.48\end{array}$ & $\begin{array}{l}0.36 \\
0.33\end{array}$ & 0.18 & 1.29 & 100.00 & $\cdots$ & $\begin{array}{l}3 \\
3\end{array}$ & $\begin{array}{l}1.14 \\
0.46\end{array}$ & $\begin{array}{l}\text { AREIA } \\
\text { AREIA }\end{array}$ & \\
\hline $\begin{array}{l}312 A \\
312 B\end{array}$ & $\begin{array}{l}2 \cdot 48 \\
3.34\end{array}$ & $\begin{array}{l}0.33 \\
0.20\end{array}$ & $\begin{array}{l}0.45 \\
0.27\end{array}$ & $\begin{array}{l}1.61 \\
1.97\end{array}$ & $\begin{array}{l}99.90 \\
99.96\end{array}$ & ... & $\begin{array}{l}3 \\
3\end{array}$ & $\begin{array}{l}0.46 \\
0.95\end{array}$ & $\begin{array}{l}\text { AREIA } \\
\text { AREIA }\end{array}$ & \\
\hline $312 \mathrm{C}$ & 2.19 & $\begin{array}{l}0.28 \\
0.34\end{array}$ & 0.17 & 1.31 & 100.00 & $\cdots$ & 3 & 0.99 & $\begin{array}{l}\text { AREIA } \\
\text { AREIA }\end{array}$ & \\
\hline $313 A$ & 2.32 & 0.25 & 0.2 & 1.76 & 99.90 & $\cdots$ & 3 & 0.40 & ARE IA & \\
\hline $313 B$ & 2.38 & 0.26 & 0.33 & 1.84 & 99.90 & 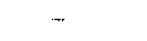 & 3 & 0.87 & AREIA & \\
\hline 3130 & 2.32 & 0.27 & 0.23 & i. .66 & 99.96 & $\ldots$ & 3 & 1.07 & AREIfA & \\
\hline $314 A$ & 2.37 & 0.24 & 0.30 & 2.01 & 99.90 & $\cdots$ & 3 & 0.60 & AREIA & \\
\hline $314 B$ & 2.39 & 6.24 & 0.35 & 1.99 & 99.90 & -- & 3 & 3.68 & AREYA & \\
\hline $314 C$ & 2.48 & 0.34 & 0.42 & 1.42 & 100.00 & $\cdots$ & 3 & 1.06 & ARETA & \\
\hline $\begin{array}{l}3454 \\
3158\end{array}$ & $\begin{array}{l}2.41 \\
2.383\end{array}$ & 0.27 & 0.39 & 2.06 & 99.98 & $\cdots$ & 3 & 0.53 & AREIf & \\
\hline $\begin{array}{l}3158 \\
3150\end{array}$ & $\begin{array}{l}2.38 \\
2.37\end{array}$ & 0.24 & 0.32 & 2.00 & 99.90 & -.. & 3 & 0.54 & AREIA & \\
\hline $\begin{array}{l}3150 \\
316 A\end{array}$ & $\begin{array}{l}2.37 \\
2.33\end{array}$ & $\begin{array}{l}0.29 \\
0.23\end{array}$ & 0.31 & 1.66 & 100.00 & $\cdots \cdot$ & 3 & 1.25 & AREIA & \\
\hline $316 B$ & $\begin{array}{l}2.33 \\
2.35\end{array}$ & $\begin{array}{l}0.23 \\
0.25\end{array}$ & 0.25 & 2.03 & 99.90 & -.. & 3 & 0.38 & $\begin{array}{l}\text { AREIA } \\
\text { AREIAA }\end{array}$ & \\
\hline 32.60 & 2.24 & $\begin{array}{l}0.25 \\
0.29\end{array}$ & $\begin{array}{l}0.31 \\
0.1 .4\end{array}$ & $\begin{array}{l}1.883 \\
1.49\end{array}$ & $\begin{array}{r}99.90 \\
100.00\end{array}$ & $\cdots$ & $\begin{array}{l}3 \\
3\end{array}$ & $\begin{array}{l}0.67 \\
0.95\end{array}$ & $\begin{array}{l}\text { AREEIA } \\
\text { AREIAA }\end{array}$ & \\
\hline $317 A$ & 2.35 & $0 . .25$ & $\begin{array}{l}0.14 \\
0.30\end{array}$ & $\begin{array}{l}1.49 \\
2.22\end{array}$ & $\begin{array}{r}100.00 \\
99.960\end{array}$ & $\cdots$ & $\begin{array}{l}3 \\
3\end{array}$ & 0.93 & $\begin{array}{l}\text { AREIA } \\
\text { ARELÁA }\end{array}$ & \\
\hline 3178 & 2.41 & $b .27$ & 0.39 & 1.97 & 99.90 & - & 3 & 2.16 & AREIA & \\
\hline $31 \% 0$ & 2.38 & $0.2 \%$ & 0.00 & 1.69 & 100.00 & ". & 3 & 0.76 & AREIA & \\
\hline $318 A$ & 2.33 & 0.23 & 0.22 & 1.77 & 100.00 & .... & 3 & 0.42 & AREIA & \\
\hline 3288 & $2.4 \%$ & 0.27 & 0.35 & 1.83 & 99.90 & $\cdots$ & 3 & 6.82 & ARELA & \\
\hline $3183 \mathrm{C}$ & 2.43 & 0.58 & 0.48 & 1. . 88 & $9 \% .90$ & $\cdots$ & 3 & 0.42 & AREIA & \\
\hline 3196 & 2.38 & 0.26 & 0.35 & 2.84 & 97.90 & $\cdots$ & 3 & 0.43 & AREIA & \\
\hline $3 \pm 98$ & 2.38 & $0.2 B$ & 0.35 & 1.91 & 99.90 & $\cdots$ & 3 & 0.96 & AREIA & \\
\hline 3190 & 2.34 & 0.28 & 0.27 & 1.69 & 100.00 & $\cdots$ & 3 & 1.01 & AREYA & \\
\hline $320 A$ & 2.37 & 0.23 & 0.31 & 2.10 & 99.90 & $\cdots$ & 3 & 0.35 & AREYA & \\
\hline $320 \mathrm{~B}$ & 2.43 & 0.27 & 6.42 & 2.05 & 99.90 & .. & 3 & 0.86 & AREIA & \\
\hline 3205 & 2.44 & 0.28 & 0.44 & 2.03 & 100.00 & $\cdots$ & 3 & (3) 81 & AREIA & \\
\hline $\begin{array}{l}321 A \\
3218\end{array}$ & 2.86 & 0.42 & 0.60 & 1.11 & 99.80 & $\cdots$ & 3 & 0.51 & AREIA & \\
\hline $\begin{array}{l}3218 \\
3210\end{array}$ & 2.45 & 5.28 & 0.46 & 2.10 & 99.90 & $\cdots$ & 3 & 0.70 & AREIA & \\
\hline 32213 & $\begin{array}{l}2.41 \\
2.59\end{array}$ & $\begin{array}{l}0.46 \\
0.37\end{array}$ & 0.50 & $\begin{array}{l}1.12 \\
1.18\end{array}$ & $\begin{array}{l}99.80 \\
99.80\end{array}$ & - & $\begin{array}{l}2 \\
2\end{array}$ & $\begin{array}{l}0.58 \\
0.78\end{array}$ & $\begin{array}{l}\text { ARETA } \\
\text { AREIAA }\end{array}$ & \\
\hline $322 \mathrm{C}$ & 2.50 & 0.30 & 0.47 & $\begin{array}{l}1.18 \\
1.47\end{array}$ & 99.90 & - & 3 & 0.81 & $\begin{array}{l}\text { ARE IA } \\
\text { ARETA }\end{array}$ & \\
\hline $\begin{array}{l}3234 \\
323 \mathrm{~B}\end{array}$ & 2.74 & 3.49 & 0.67 & 0.713 & 99.40 & - & 3 & 0.75 & AREIA & \\
\hline $\begin{array}{l}323 \mathrm{~B} \\
323 \mathrm{C}\end{array}$ & 2.61 & 0.36 & 0.59 & 1.01 & 99.80 & - & 2 & 0.55 & AREIA & \\
\hline $\begin{array}{l}323 \mathrm{C} \\
324 \mathrm{~A}\end{array}$ & $\begin{array}{l}2.54 \\
2.55\end{array}$ & $\begin{array}{l}0.34 \\
0.34\end{array}$ & $0.5 ?$ & 1.28 & 99.918 & $\ldots$ & & $\begin{array}{l}0.85 \\
0.56\end{array}$ & $\begin{array}{l}\text { ARELA } \\
\text { AREIA }\end{array}$ & \\
\hline $\begin{array}{l}32413 \\
3241\end{array}$ & 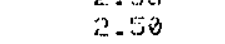 & $\begin{array}{l}0.34 \\
0.32\end{array}$ & $\begin{array}{l}0.57 \\
0.52\end{array}$ & $\begin{array}{l}1.52 \\
1.85\end{array}$ & $\begin{array}{l}99.80 \\
99.80\end{array}$ & - & $\frac{2}{2}$ & $\begin{array}{l}0.56 \\
1.06\end{array}$ & $\begin{array}{l}\text { AREIA } \\
\text { AIREIA }\end{array}$ & \\
\hline $324 \mathrm{C}$ & 2.53 & 0.33 & 0.51 & 1.31 & 99.90 & $\ldots$ & & $\begin{array}{l}1.08 \\
1.02\end{array}$ & AREIA & \\
\hline $325 A_{4}$ & 2.63 & 0.41 & 0.62 & 0.94 & 99.70 & .- & 2 & 0.74 & AREYA & . \\
\hline 3258 & 2.58 & 0.34 & 0.56 & 1.11 & 99.90 &.- & 2 & 1.02 & ARELA & \\
\hline 3250 & 2.55 & 0.34 & 8.54 & 1.26 & 100.00 & $\ldots$ & 2 & 1.81 & AREI $\hat{n}$ & \\
\hline
\end{tabular}




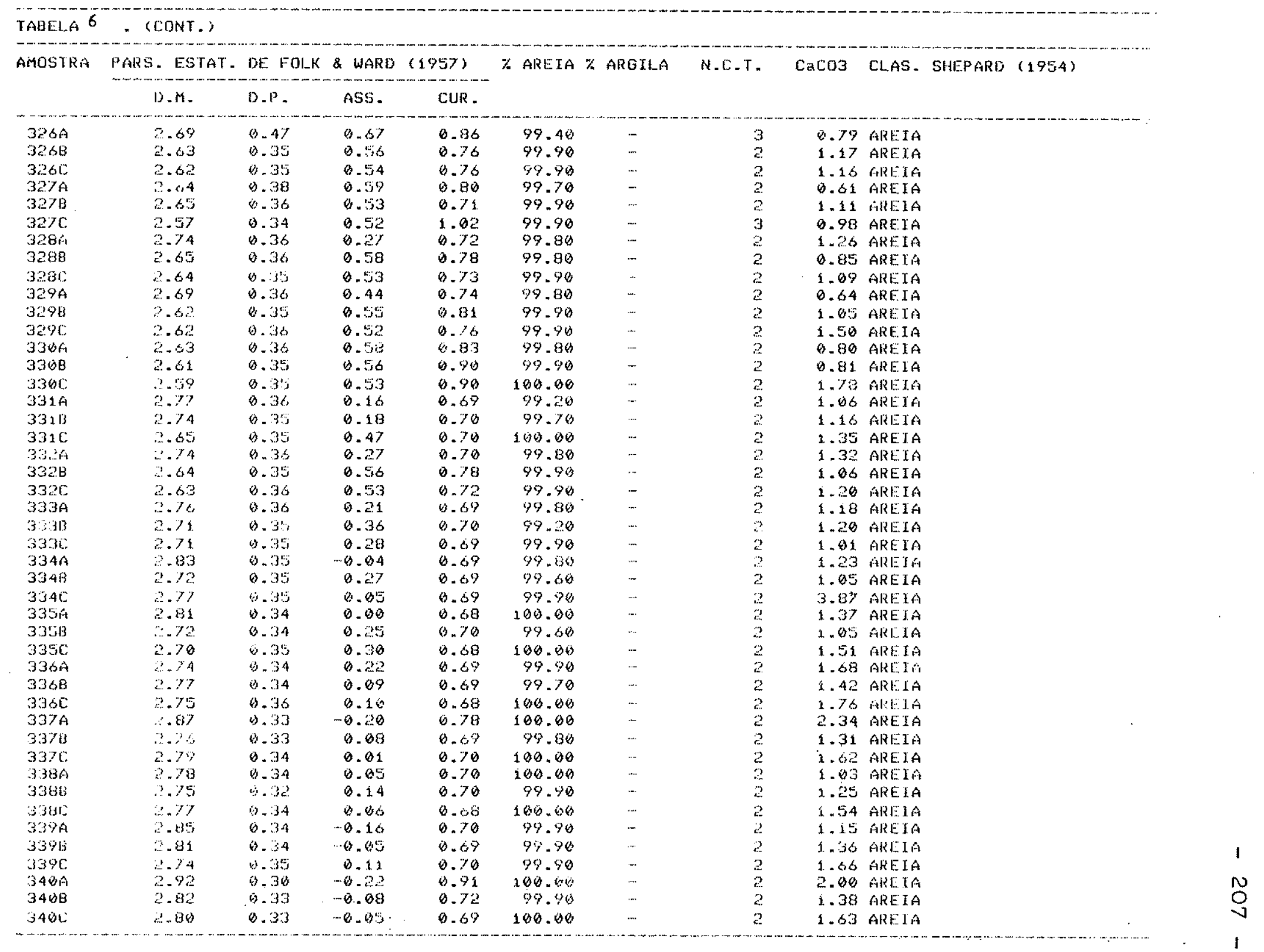




\begin{tabular}{|c|c|c|c|c|c|c|c|c|c|}
\hline \multirow[t]{2}{*}{ AMOSIRA } & PAKS. ESTAT. & be FUL... & \& WARD & $957)$ & $\%$ AREIA $\%$ & \% ARGILA & N.C.T. & $\mathrm{CaCO} 3$ & CLAS. SHEPAARD (1954) \\
\hline & B.M. & $0 . P^{3}$ & ASS. & CUR. & & & & & \\
\hline $341 \mathrm{~A}$ & 2.77 & 0.34 & 0.07 & 0.70 & 100.00 & - & 2 & 1.24 & AREE IA \\
\hline 3418 & 2.73 & 0.33 & 0.17 & 0.70 & 99.90 & -- & 2 & 1.14 & AREIA \\
\hline 3410 & 2.73 & 8.34 & 0.01 & 0.69 & 100.00 & -. & $?$ & 0.89 & AREIA \\
\hline $342 \mathrm{~A}$ & 2.84 & 0.34 & -0.10 & 0.71 & 99.90 & - & 2 & 0.65 & AREIA \\
\hline $342 B$ & 2.82 & 0.33 & -0.07 & 0.73 & 99.96 & - & 2 & $1 . \$ 4$ & AREIA \\
\hline 3420 & 2.75 & 8.93 & $0.0 \%$ & 0.71 & 100.00 & - & 2 & 1.47 & AREIA \\
\hline $343 \mathrm{fA}$ & 2.82 & 0.34 & $-\infty .87$ & 0.09 & 100.00 & - & 2 & 0.56 & AREIA \\
\hline 3438 & 2.76 & 0.33 & 0.09 & 0.67 & 99.90 & $\ldots$ & 2 & 1.33 & AREIA \\
\hline उ१3c & 2.77 & 0.34 & 6.84 & 0.70 & 100.00 & $\cdots$ & 2 & 1.52 & AREI If \\
\hline $344 \hat{A}$ & 2.75 & 0.33 & 0.17 & 0.68 & 100.00 & $\ldots$ & 2 & 0.75 & GREIA \\
\hline $344 B$ & 2.80 & 8.33 & -6.62 & 0.76 & 99.90 & $\ldots$ & 2 & 1.41 & AREIA \\
\hline $344 \mathrm{C}$ & 2.93 & 0.32 & -0.10 & 0.79 & 100.00 & - & 2 & 1.53 & ARETA \\
\hline 3451 & 2.77 & 0.33 & 8.46 & 0.73 & 99.90 & $\ldots$ & 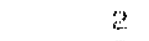 & 0.88 & ARPEIA \\
\hline $345 B$ & 2.81 & 0.32 & -0.04 & 0.76 & 99.90 & -- & 2 & 1.54 & AREIA \\
\hline $345 c$ & $=130$ & 0.32 & $\cdots 0.82$ & 0.75 & 99.90 & $\ldots$ & 2 & 2.43 & $A R E T A$ \\
\hline $346 \mathrm{~A}$ & 2.79 & 0.33 & 0.05 & 0.72 & 99.90 & $\ldots$ & 2 & 0.49 & ARE:IA \\
\hline$\exists A G B$ & 281 & $\theta .31$ & $\cdots 0.83$ & 0.80 & 90.96 & $\ldots$ & 2 & 1.03 & AREIA \\
\hline 3460. & $\therefore 832$ & 0.33 & -0.07 & 0.72 & 100.00 & -. & 2 & 1.34 & AREIA \\
\hline $347 \mathrm{~A}$ & $2: 300$ & 6.34 & 0.03 & 0.68 & 99.90 & $\ldots$ & 2 & 0.51 & AREIA \\
\hline $347 B$ & 3.77 & 0.33 & 0.07 & 0.71 & 99.90 & -- & 2 & 0.98 & AREIÁ \\
\hline $347 C$ & $2.8 s$ & 0.31 & -0.14 & 0.83 & 100.00 & - & 2 & 1.48 & ARETA \\
\hline $34 B A$ & $\therefore 77$ & 0.33 & 0.10 & 0.72 & 97.90 & $\ldots$ & 2 & 1.46 & AREYA \\
\hline $34 \& 5$ & 2.83 & 9.33 & $-\theta .87$ & 0.75 & 99.90 & $\ldots$ & 2 & 2.26 & ARE IA \\
\hline $3480:$ & $\therefore 83$ & 0.31 & $\cdots 0.08$ & 0.81 & 100.00 & $\ldots$ & 2 & 1.57 & AREIA \\
\hline $349 \mathrm{~A}$ & $\therefore 74$ & 8.34 & 0.28 & 0.77 & 100.00 & $\cdots$ & z & 1.01 & ARELAA \\
\hline $349 B$ & 2.80 & 0.33 & 0.02 & 0.77 & 99.80 & - & 2 & 2.26 & ARETA \\
\hline 3490 & 2.83 & $19.3 ?$ & -0.86 & 0.63 & 99.96 & $\ldots$ & 2 & 1.26 & AREIA \\
\hline $350 \mathrm{~A}$ & $c .69$ & 0.34 & 0.37 & 0.79 & 99.80 & ... & 2 & 0.72 & AREIA \\
\hline $3601: i$ & 3.69 & 0.39 & $0.4 \theta$ & 0.71 & 98.68 & $\ldots$ & 2 & 1.68 & AREIA \\
\hline उËDE: & $\therefore 70$ & 0.36 & 0.10 & 0.80 & 99.70 & -. & 2 & 1.10 & ARE 1 A \\
\hline 3) & 2.94 & 0.51 & 8.19 & 0.66 & 98.90 & .... & 2 & 9.73 & AREEIA \\
\hline 3518 & 2.74 & 0.36 & 0.26 & 0.75 & 99.80 & -.. & 2 & 1.19 & AREIA \\
\hline 3510 & 3.72 & 0.37 & 0.29 & Q.82 & 99.70 & $\ldots .$. & 3 & 1.08 & AREIA \\
\hline $353 \mathrm{~A}$ & 3.39 & 0.34 & 0.05 & 0.72 & 100.00 & - & 2 & 1.00 & ARE IA \\
\hline $352 \mathrm{~B}$ & $\therefore 20$ & 0.34 & 0.299 & 0.72 & 99.90 & $\ldots$ & 2 & 0.92 & AREIA \\
\hline 3520 & 2.57 & 0.32 & 0.50 & 1,02 & 100.00 & - & 2 & 8.87 & AREIA \\
\hline
\end{tabular}


TABELA 7 - DADOS DE. GRANUIJOMETRIA E TEOR dE CARBONATO EM SEDIMENTOS DA ZONA DE aRREBENTACAO

AMOSTRA PARS. ESTAT. DE FOLK \& WARD (1957) * ARETA \% ARGTLA N.C.T. \% CaCO3 CLAS. DE SHEPARD (1954)

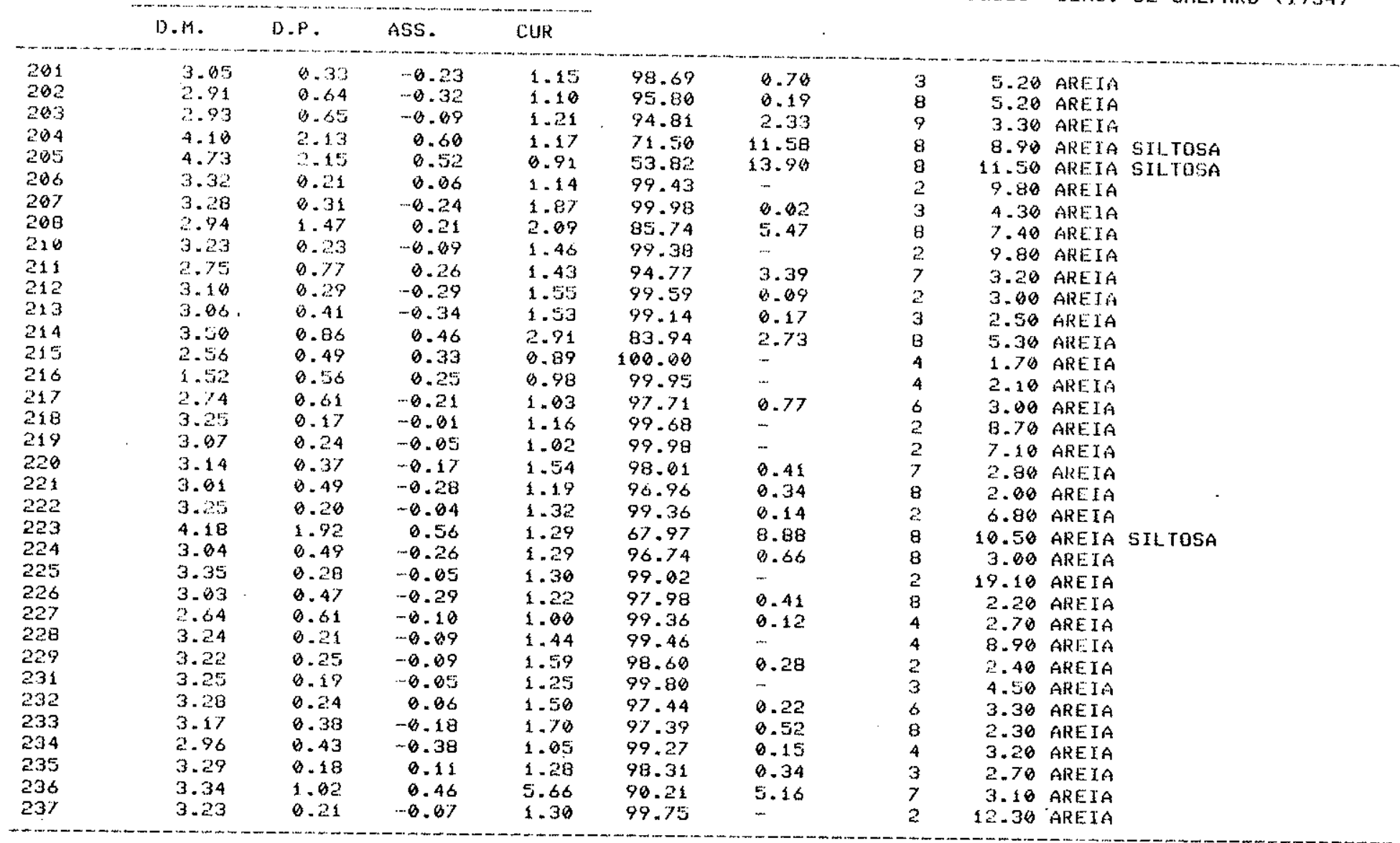


TABELA 7 - (CONT.)

AMOSTRA PARS. ESTAT. DE FOLK \& WARD (1957) \% ARETA \% ARGILA N.C.T. \% CaCO3 CLAS. DE SHEPARD (1954)

\begin{tabular}{|c|c|c|c|c|c|c|c|c|c|c|}
\hline & D.M. & D.P. & Ass. & CUR . & & & . & & & \\
\hline 238 & 3.24 & 0.25 & -0.06 & 1.59 & 98.27 & - & 3 & 6.30 & ARETA & \\
\hline 239 & 3.07 & $0.35 i$ & -0.36 & 1.62 & 99.48 & 0.11 & 3 & 2.70 & AREIA & \\
\hline 240 & 2.98 & 0.47 & -0.49 & 1.68 & 99.25 & 0.15 & 4 & 2.70 & AREIA & \\
\hline 241 & 4.17 & 1. .57 & 0.78 & 2.32 & 73.75 & 0.75 & 8 & 10.40 & AREIA & SILTOSA \\
\hline 242 & 3.29 & 0.16 & 0.06 & 1.13 & 99.85 & - & 2 & 11.90 & AREIA & \\
\hline 243 & 3.24 & 0.19 & -0.01 & 1.23 & 99.39 & 0.13 & 2 & 2.90 & AREIA & \\
\hline 244 & 3.26 & 0.14 & 0.00 & 1.00 & 99.44 & 0.12 & 2 & 2.70 & ARE IA & \\
\hline 245 & 3.21 & 0.23 & -0.56 & 1.61 & 98.93 & 0.21 & 2 & 2.10 & AREIA & \\
\hline 246 & 3.02 & 0.40 & -0.39 & 1.34 & 99.17 & 0.15 & 3 & 2.40 & AREIA & \\
\hline 247 & 3.19 & 0.19 & -0.10 & 1.27 & 99.71 & - & ? & 2.30 & AREIA & \\
\hline 248 & 3.25 & 0.35 & 0.00 & 2.13 & 94.91 & - & 6 & 4.80 & AREIA & \\
\hline 249 & 2.92 & 0.53 & -0.45 & 1.17 & 99.24 & 0.15 & 4 & 3.80 & AREE IA & \\
\hline 250 & 2.17 & 0.44 & -6.03 & 1.90 & 99.95 & $\therefore$ & 4 & 1.60 & ARE IA & \\
\hline 251 & 3.30 & 0.19 & 0.15 & f. .41 & 97.54 & 0.50 & 7 & 2.80 & AREIA & \\
\hline 252 & 3.21 & 0.17 & -0.87 & 1.18 & 99.88 & - & 2 & 5.30 & AREIA & \\
\hline 253 & 3.24 & 0.15 & -0.03 & 1.06 & 99.60 & - & 3 & 5.60 & AREIA & \\
\hline 254 & 4.72 & 2.01 & 0.76 & 1.86 & 69.01 & 1.3 .78 & 7 & 12.10 & ARE IA & SILTOSA \\
\hline 255 & 2.97 & 0.50 & -6.37 & 0.88 & 97.96 & 0.41 & 8 & 2.10 & AREIA & \\
\hline 256 & 3.21 & 0.21 & -0.83 & 1.26 & 99.79 & - & 2 & 12.50 & AREIA & \\
\hline 257 & 3.23 & 0.26 & -0.08 & 1.66 & 98.47 & 0.32 & 3 & 2.10 & AREIA & \\
\hline 258 & 2.93 & 0.61 & -0.48 & 1.46 & 98.24 & 0.31 & 4 & 3.20 & AREIf & \\
\hline 259 & 2.64 & 0.53 & 0.14 & 0.84 & 99.73 & - & 4 & 2.00 & AREIA & \\
\hline 260 & 3.21 & 0.17 & -0.08 & 1.19 & 99.58 & -- & 3 & 3.50 & AREIA & \\
\hline 261 & 3.39 & 1.81 & 0.53 & 6.74 & 87.86 & 5.54 & 8 & 5.56 & AREIA & \\
\hline 262 & 3.20 & 0.17 & -0.09 & 1.22 & 99.67 & - & 2 & 2.90 & AREIA & \\
\hline 263 & 5.97 & 2.38 & -0.24 & 0.65 & 27.17 & 29.63 & 8 & 17.50 & SILTE & ARGILO ARENOSO \\
\hline 264 & 2.38 & 0.68 & 0.09 & 1.61 & 99.92 & - & 4 & 2.16 & AREIA & \\
\hline 265 & 2.89 & 0.47 & -0.42 & 0.610 & 99.59 & - & 5 & 2.10 & AREIA & \\
\hline 266 & 3.03 & 0.29 & -6.31 & 1.21 & 99.90 & - & 2 & 2.60 & AREIA & \\
\hline 267 & 3.24 & 0.26 & -0.06 & 1.63 & 98.34 & 0.34 & 2 & 2.48 & AREIA & \\
\hline 268 & 4.91 & 2.84 & 0.82 & 0.77 & 61.13 & 15.65 & 7 & 7.70 & AREYA & SILTOSA \\
\hline $26 \%$ & 2.57 & 0.55 & 0.19 & 0.91 & 99.78 & - & 4 & 2.00 & AREIA & \\
\hline 276 & 2.60 & 0.49 & 0.33 & 0.82 & 99.80 & - & 4 & 2.00 & AREIA & \\
\hline $27 \hat{i}$ & 3.26 & 0.22 & 0.05 & 1.37 & 98.21 & 0.37 & 2 & 3.60 & AREXA & \\
\hline 272 & 3.25 & 0.19 & -0.02 & 1.31 & 98.81 & $0.7 \div 5$ & 2 & 2.26 & AREIA & \\
\hline
\end{tabular}


TABELA ${ }^{8}$. DADOS DE GRAMULDIJETRIA E TEOR DE CARBONATO EM SEDTMENTOS Da PLATAFORMÁ EASA AMOSTRA PARS. ESTAT. DE FOLK \& WARD (1957) \% AREIA \% ARGILA N.C.T. \% CaCO3 CLAS. SHEPARD (19S4) AMOSIRA PARS. ESTAT. DE FDLK Q WARD (19ST) D.M. D.P. ASS. CUR.

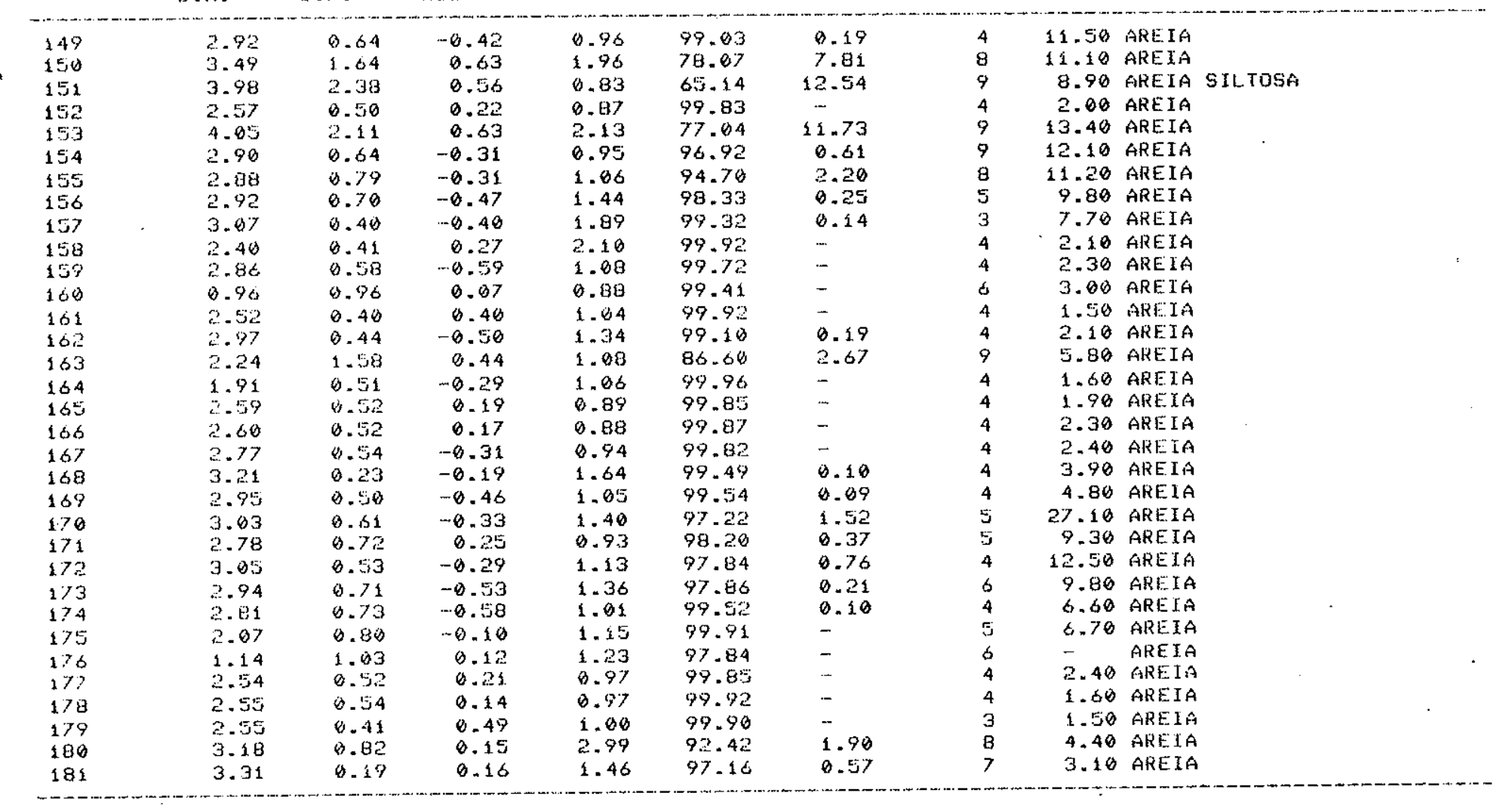


TABELAA 8 - (CONT.)

AMOSTRA PARS. ESTAT. DE FOLK \& WARD (1957) \% ARETA \% ARGILA N.C.T. \% CaCO3 CLAS. SHEPARD (1954) D.M. D.P. ASS. CUR.

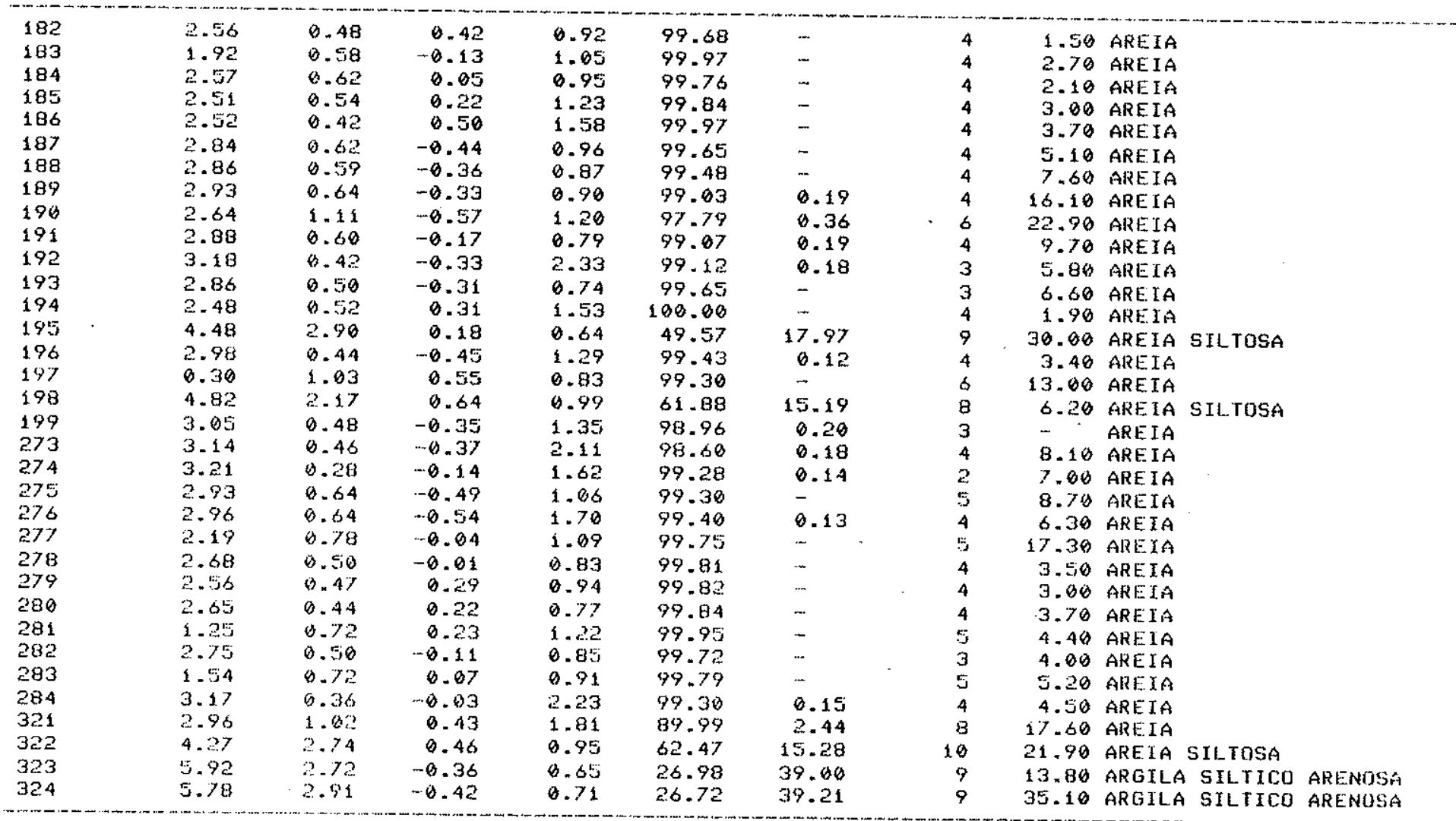




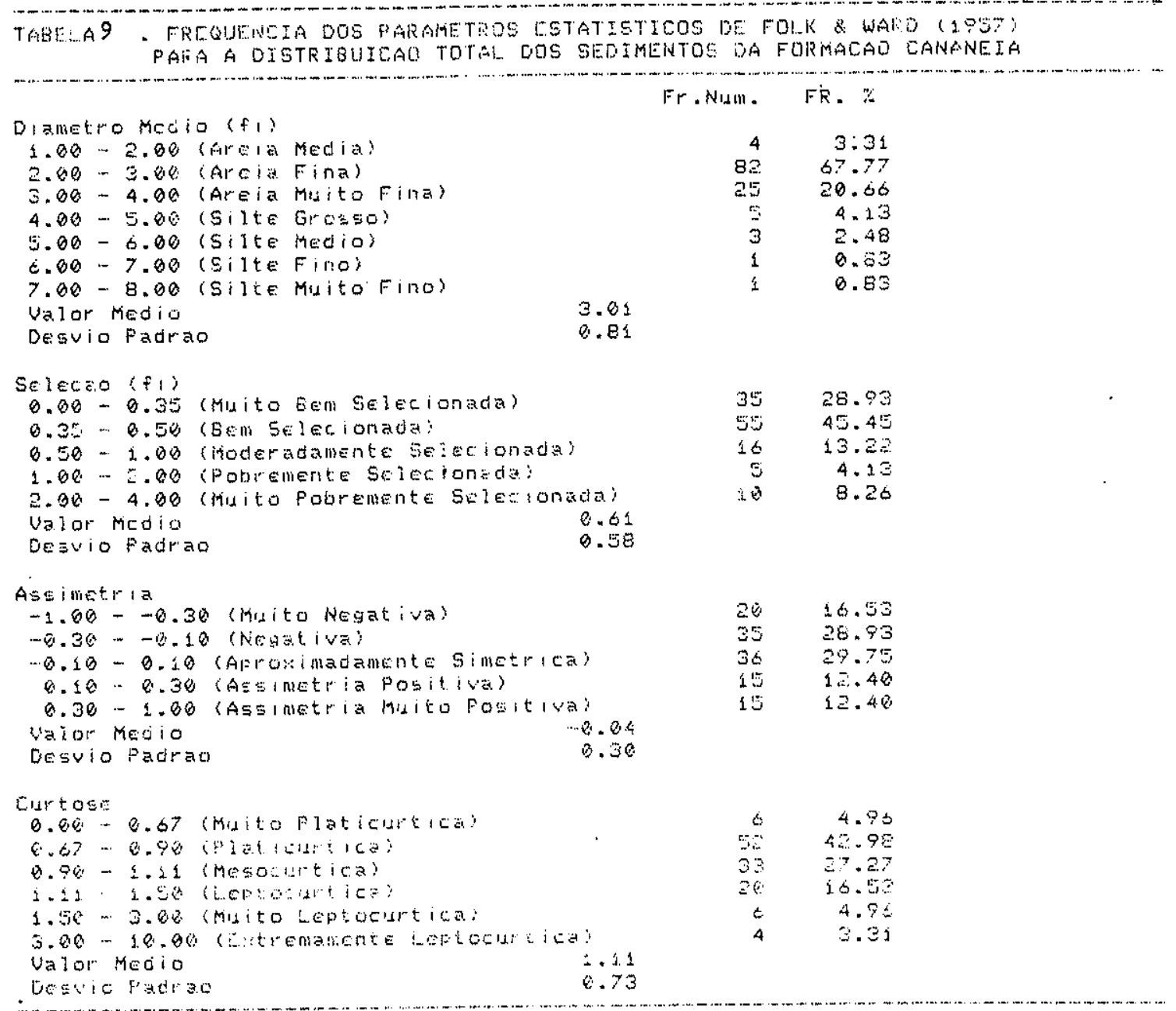




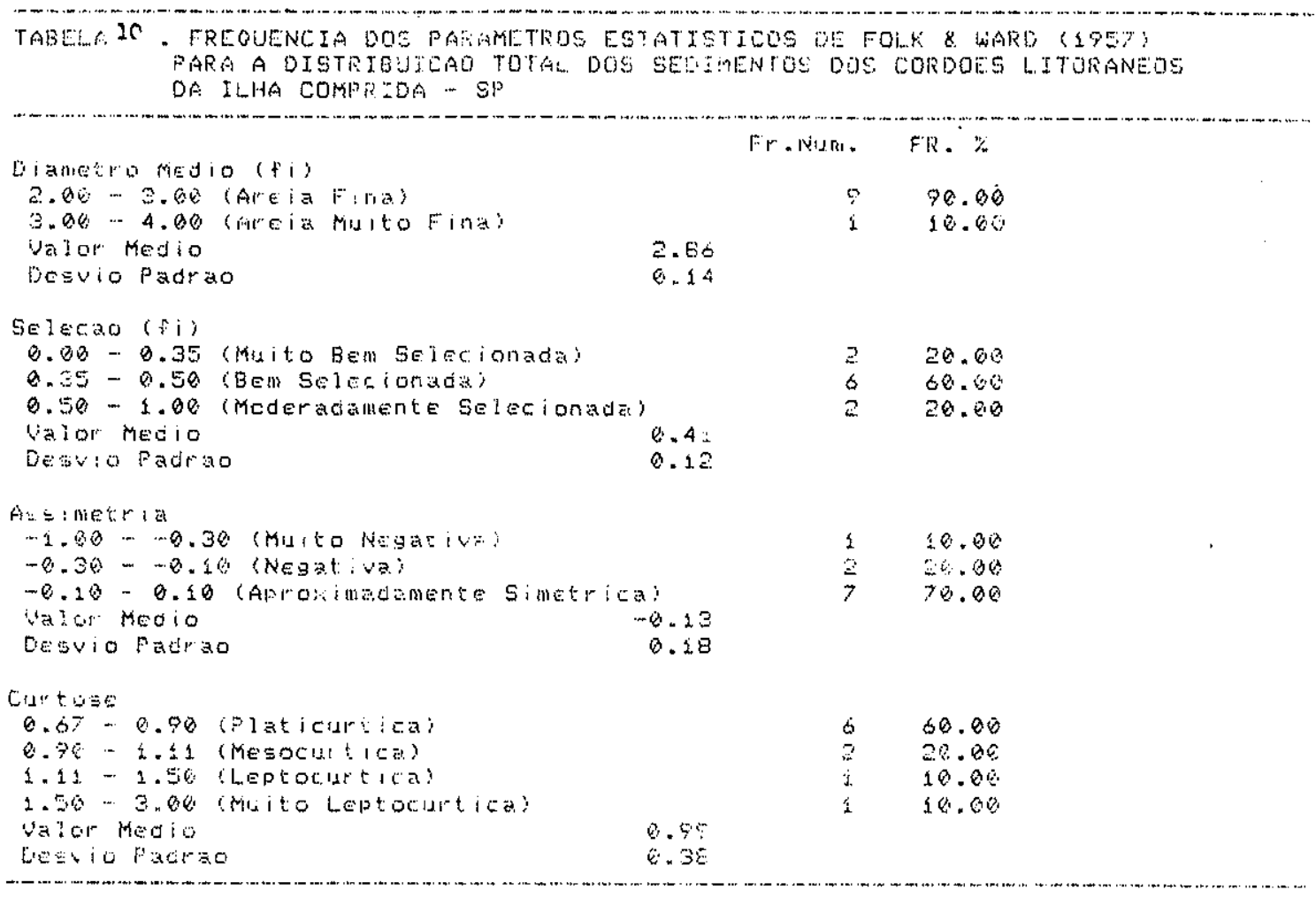


TAPEIA 11. FREQUENCYA DOS PARAMICTKOS ESTATHETICOE DC FOLK 8 WARO 2957 PAR A DISTRIEUICAO TOTAL. DOS GEDIMENTUOS DA FAIXA INTERMARES NIVEL OE MARE BAIXA (NIVEL A)

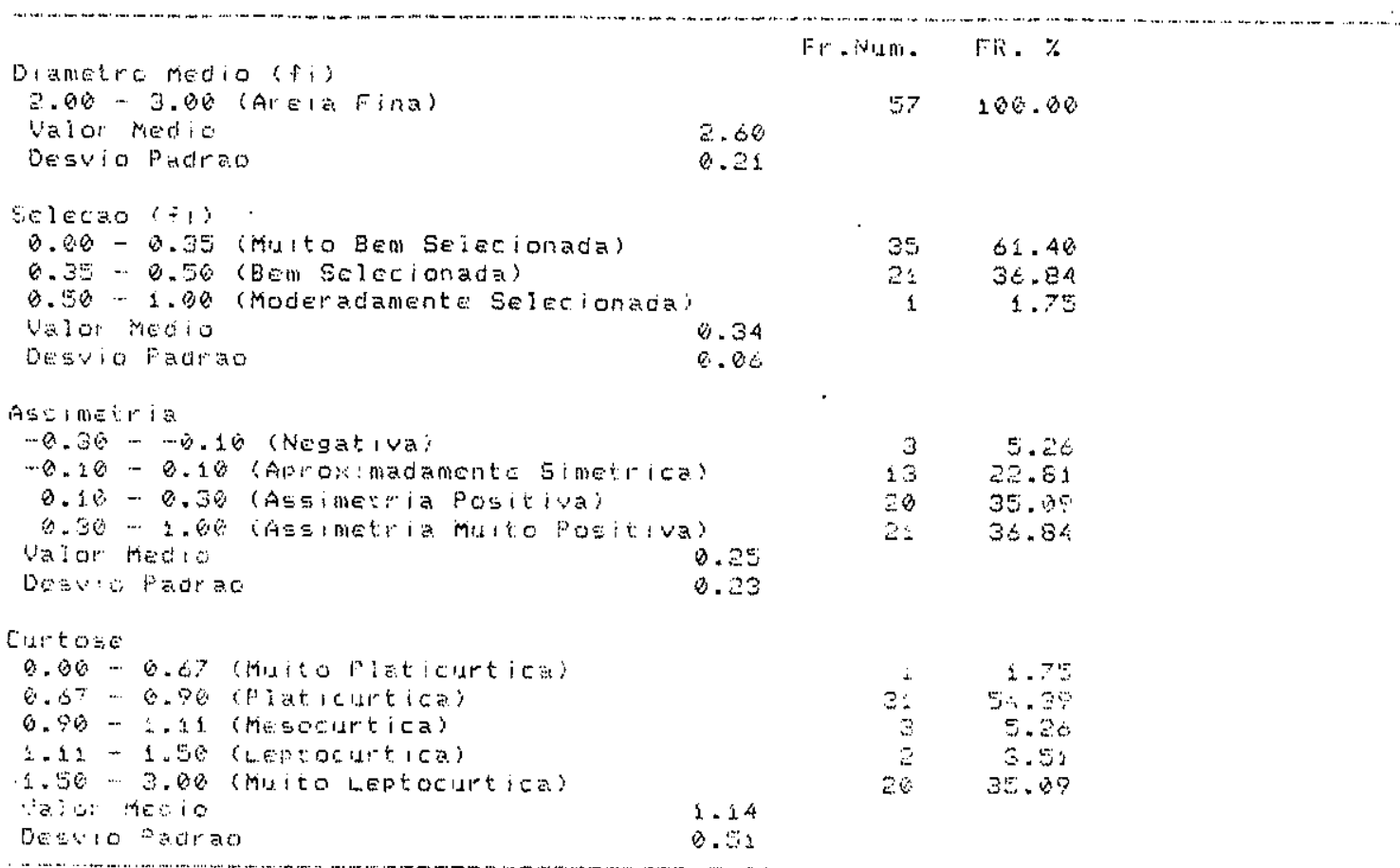


TAGLATIO FREOUENCIA DOS PARAMETROS ESTATISTICOS DE FOLK \& WARE (19F?

PARA A OTSTRIEUICAO TOTAL DUS SEDIMENTOS DA FAIXA INTERMARES NIVEL INTERMEDIARTO (NIVEL B)

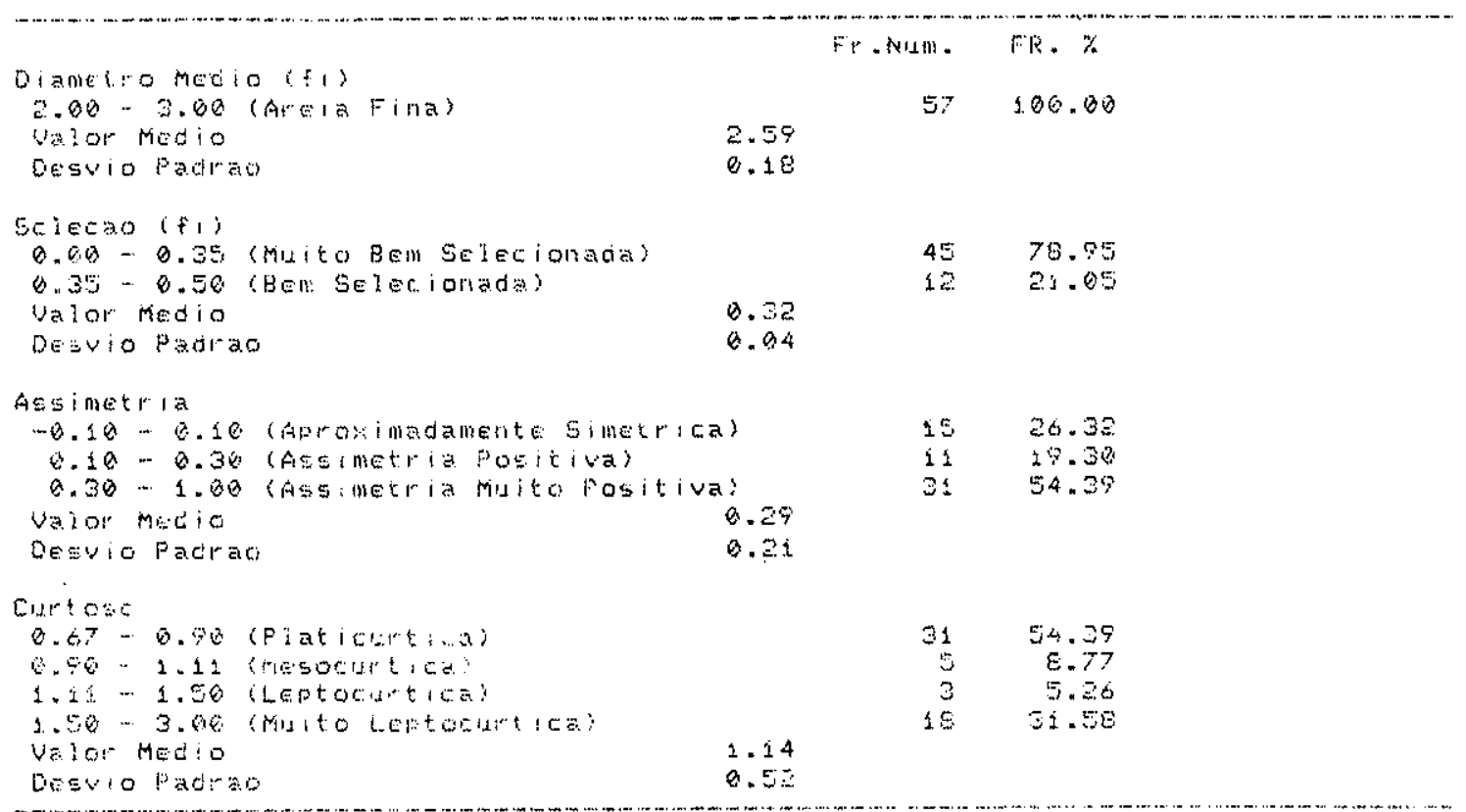




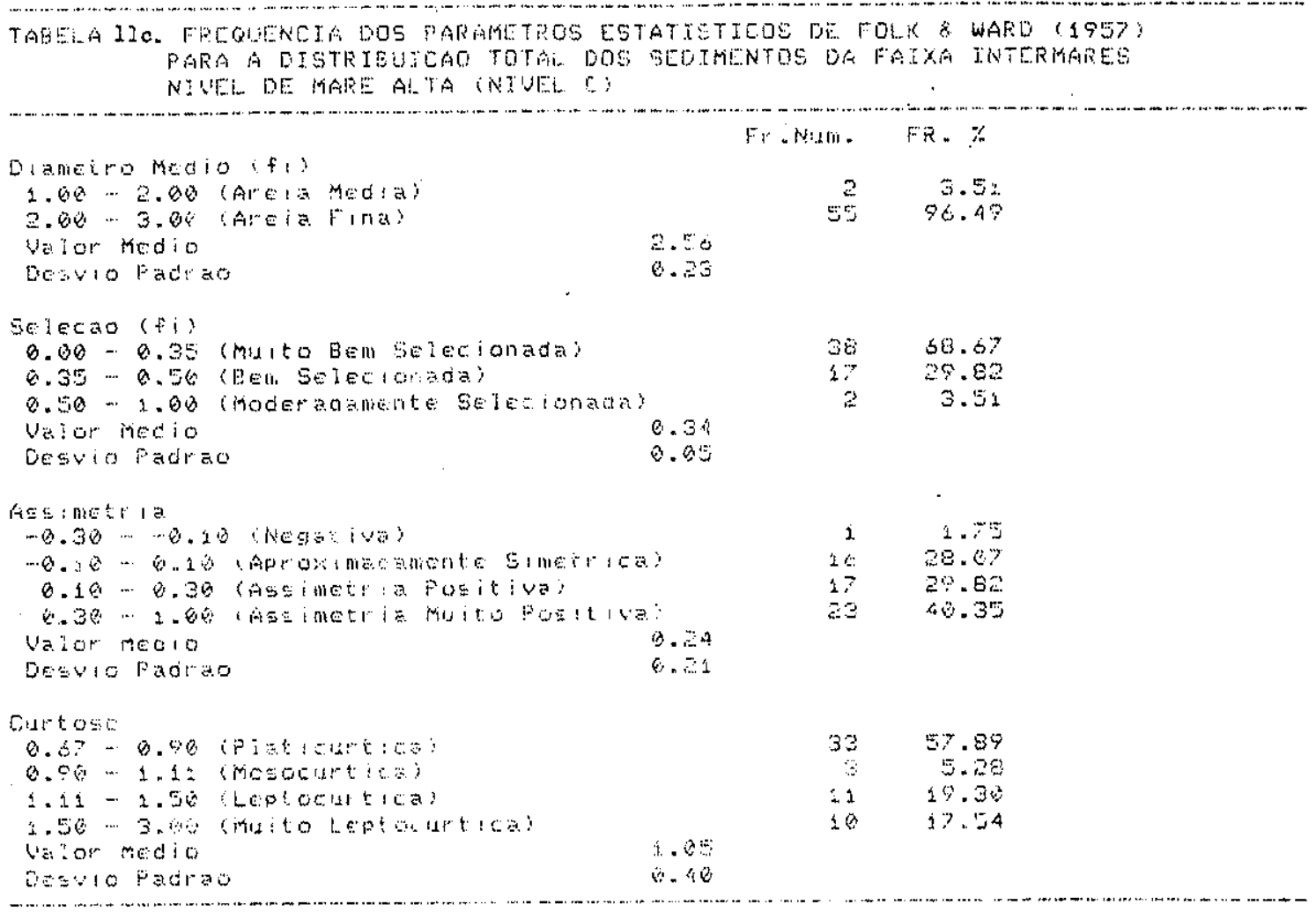




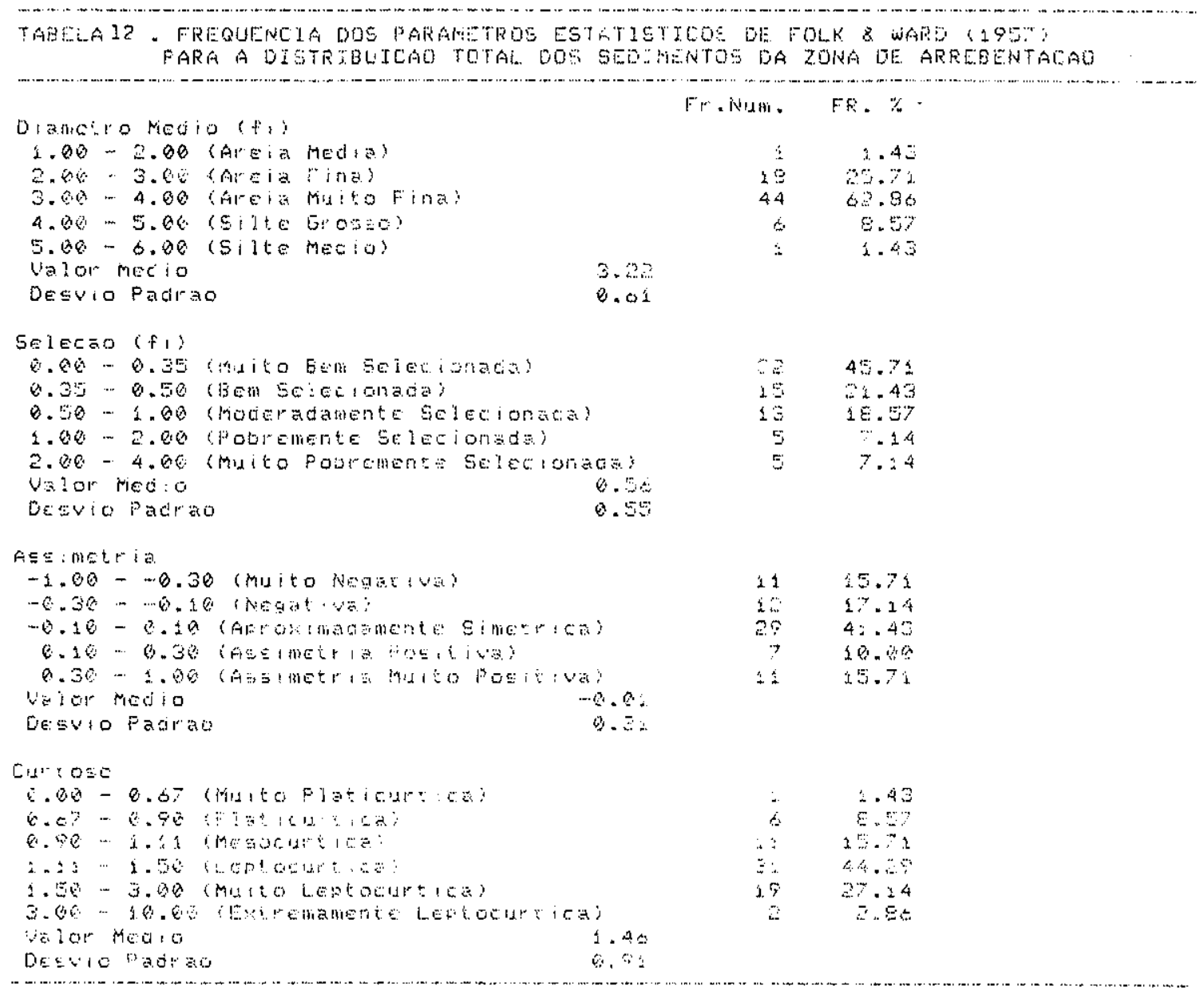




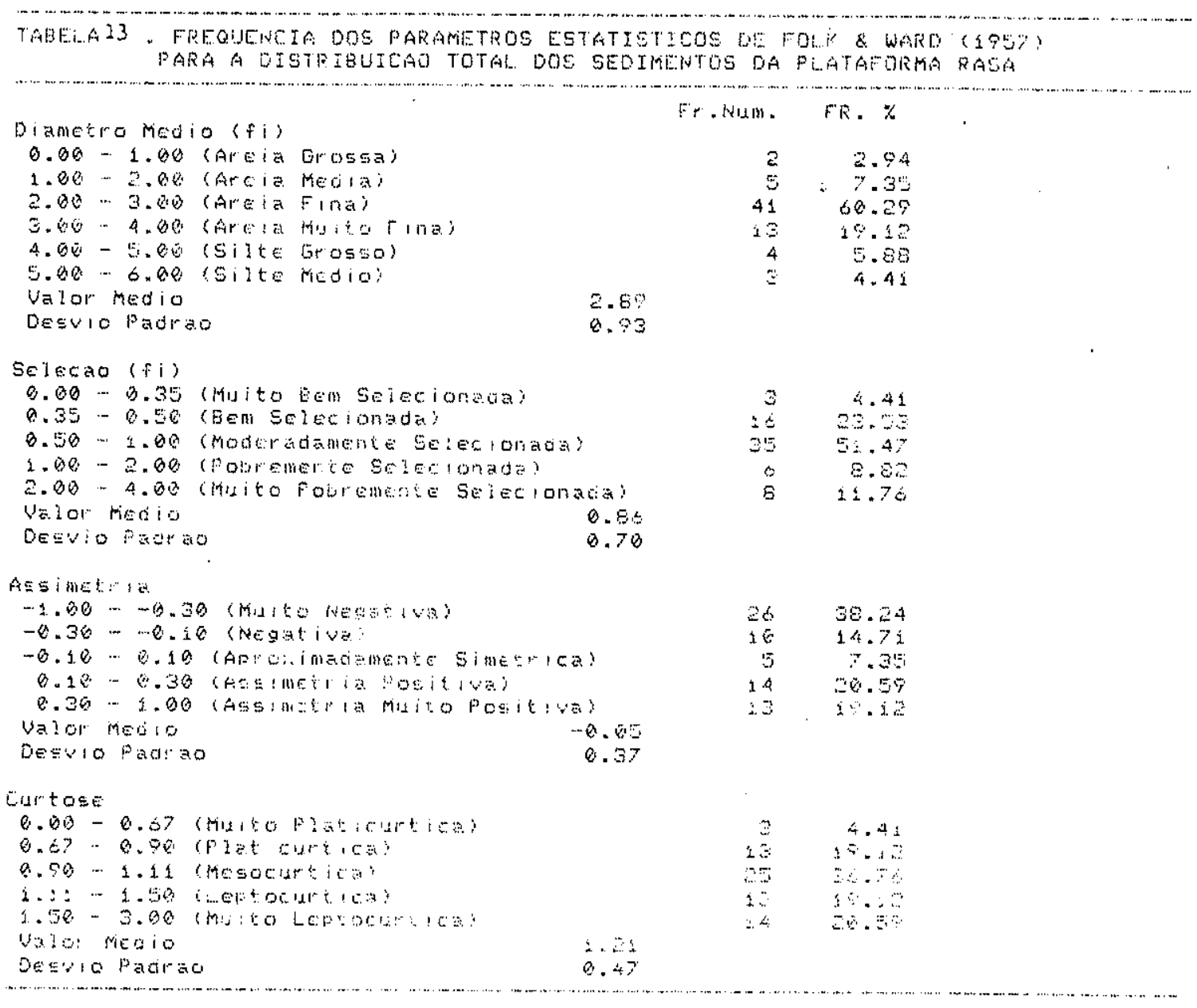




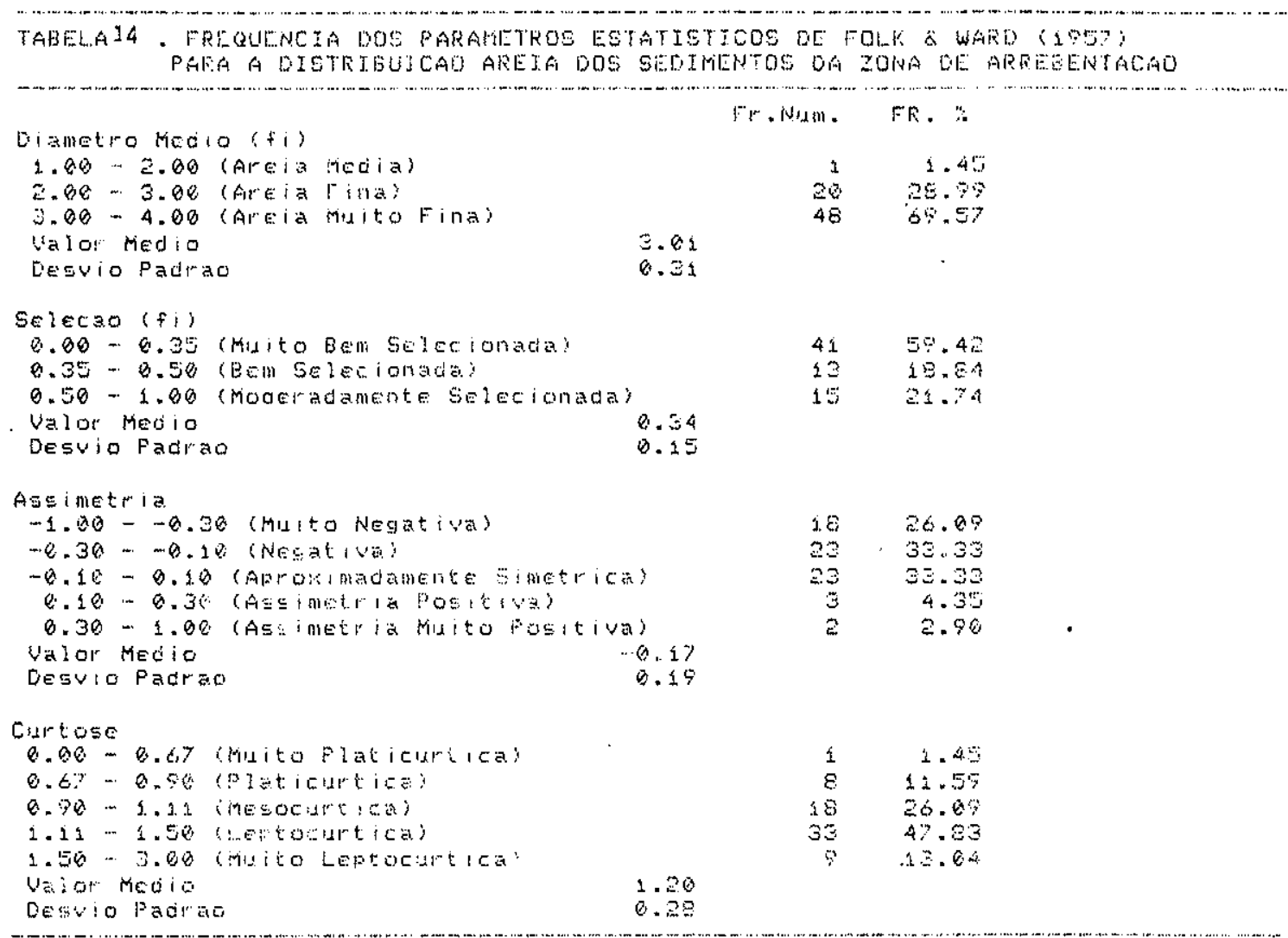




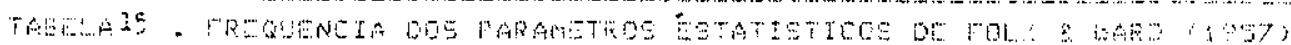

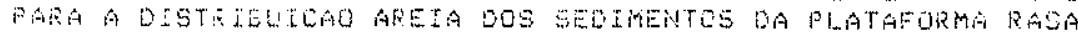

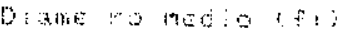

Fr. Hum. FR. \%

Q

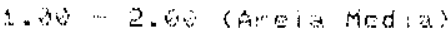

$2.30-3.00$ (AN

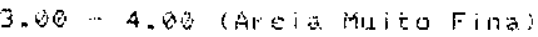

Valor Med:o

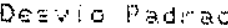

$\begin{array}{rr}3 & 3.13 \\ 3 & 7.81 \\ 45 & 70.31 \\ 12 & 18.75\end{array}$

$2 \cdot 61$

Selet:

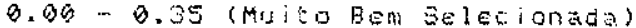

Q.35- - U.

Q.56 - 1.86 (Moderadamente: Se 1 ecionada)

1.06 z. zo (Pobremente Selacionada)

Valor Medio

$\begin{array}{ll}17 & 29.6 \% \\ 37 & 57.85\end{array}$

Desto $P 3 a r a 0$

0.57

6.25

Assimet: i a

$-1.00--0.30$ (Mitito Negativa)

$-0.34-\cdots .10$ chegativa:

- $0.10-0.10$ (Amprowinacinente simetrica)

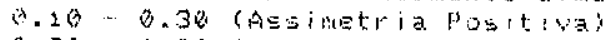

Q.30-1.00 (ASEimetria Mrito Positiva)

Vais or Medio

Desido PaAra

$\cdots 015$

$\begin{array}{rr}27 & 42.19 \\ 10 & 15.63 \\ 7 & 10.94 \\ 14 & 21.83 \\ 6 & 9.38\end{array}$

Cint tose

$0.50 \cdots 0.67$ imito plat:curtics:

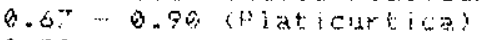

$\cdots, 34$

$6.90-2.11$ iMesocist asa)

$\therefore 11$ m 1.50 il.eptootar ic

1.50-3.00 (Muto Leptocat iea)

Valor hedis

0escio padrao bो. 30

$1 \cdot 1.2$

2
$1 \%$

$21 \quad 32.81$

14 21.06 
TABELA 16 . PORCENTAGEM DE FREQUENCIA DO NUMERO DE CLASSES TEXTURAIS

\begin{tabular}{|c|c|c|c|c|c|c|c|c|c|c|}
\hline . & 1 & 2 & 3 & 4 & 5 & $b$ & 7 & 8 & 9 & 10 \\
\hline Fm. Cananeia & - & 42.1 & $33 . i$ & 11.6 & 1.6 & 5.8 & 4.1 &.-- & 1.6 & $\ldots$ \\
\hline $\begin{array}{l}\text { Cord. Litoraneos } \\
\text { I tha Compridat }\end{array}$ & $\cdots$ & 60.0 & 30.6 & -- & 10.0 & - & - & - & $\cdots$ & -.. \\
\hline $\begin{array}{l}\text { Faixa Intermares } \\
\text { I. Comprida E } \\
\text { I. Cardoso }\end{array}$ & $\cdots$ & 57.3 & 40.9 & 1.8 & -- & - & $\cdots$ & - & $\cdots$ & -- \\
\hline Z. Arrebentacao & - & 30.0 & 15.7 & 18.6 & 1.4 & 4.3 & 8.5 & 20.0 & 1.4 & - \\
\hline Plataforma Rasa & - & 1.5 & 8.8 & 48.5 & 11.8 & 7.3 & 1.5 & 7.3 & 11.8 & 1.5 \\
\hline
\end{tabular}


TABELA 17 - FREQUENCIAS DE CLASSES DE ARREDONDAMENTO, MEDIA, DESUTO PADRAO E SELECAO MORFOMETRICA EM GRAOS DE QUARTZO

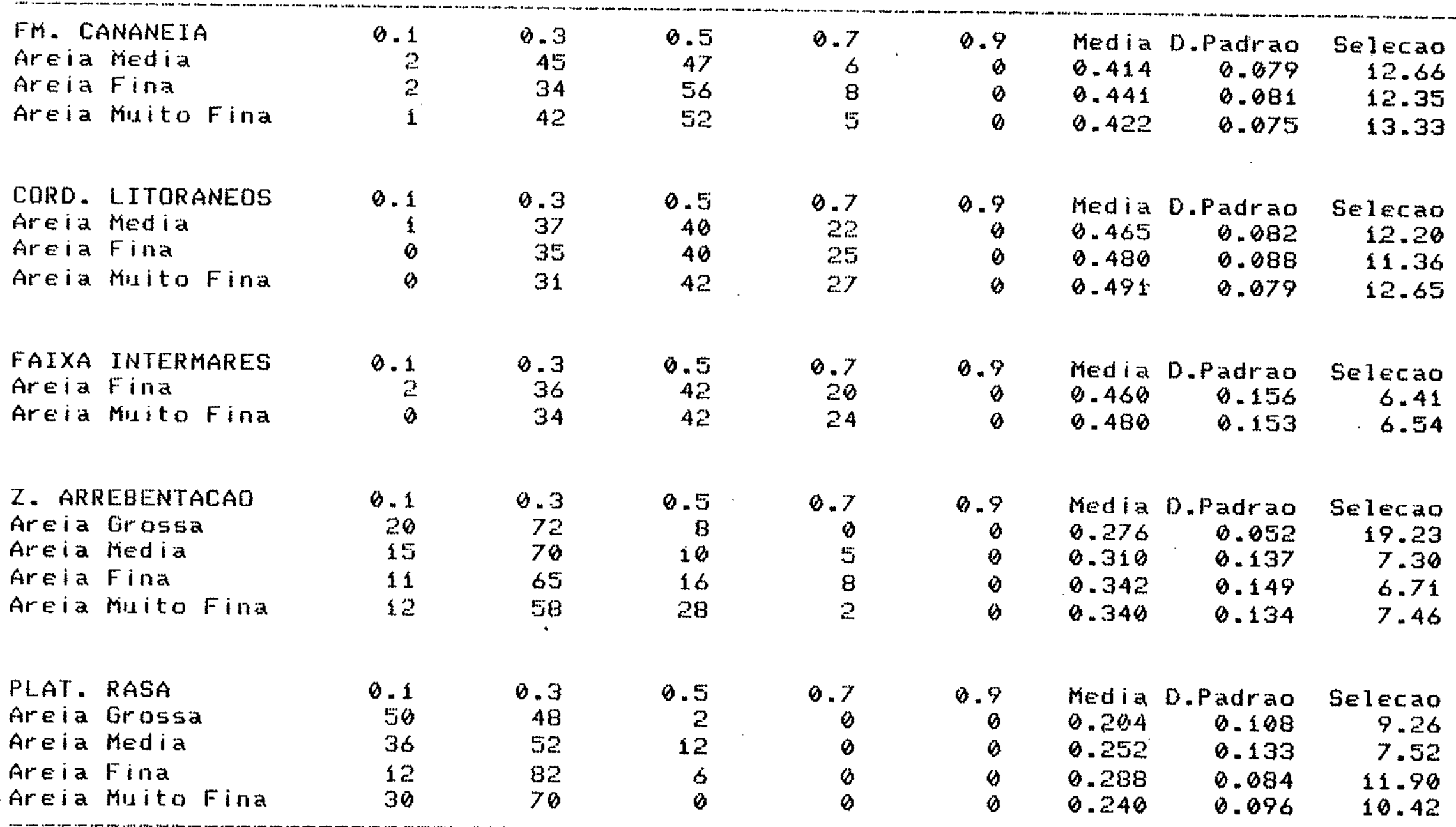


TABELA18 . VARTACOES NO TEOR DE CARBONATO B IODETRITICO

\begin{tabular}{|c|c|c|c|c|c|c|c|c|}
\hline & 1 Maior & Valor & 1 Menor & Va $10 r^{n}$ & 1 & Hed i a & 1 & Desvio Padrao \\
\hline Faixa Intermares & 1 & & 1 & & 1 & & 1 & \\
\hline Nivel Mare Baiqa & $\mathbf{i}$ & 2.54 & 1 & 0.19 & $i$ & 0.78 & 1 & 0.44 \\
\hline Faixa Intermares & 1 & & 1 & & 1 & & 1 & \\
\hline W. Intermediario & 1 & 3.08 & 1 & 0.55 & 1 & 1.17 & 1 & 0.44 \\
\hline Faika Intermares & 1 & & 1 & & 1 & & 1 & \\
\hline Wivel Mare Alta & 1 & 3.87 & 1 & 0.17 & 1 & 1.27 & 1 & 6.51 \\
\hline Faixa Intermars & 1 & & 1 & & 1 & & 1 & \\
\hline Tres Niveis & 1 & 3.87 & 1 & 0.17 & 1 & 1. .97 & 1 & 0.51 \\
\hline Zona de & $\mathrm{i}$ & & 1 & & 1 & & 1 & \\
\hline Arrebentacao & 1 & 19.10 & 1 & 1.60 & 1 & 5.06 & 1 & 3.57 \\
\hline Plataforma & 1 & & 1 & & 1 & . & 1 & \\
\hline$R a \equiv$ & 1 & 36.10 & 1 & 8.00 & 1 & 7.64 & 1 & 7.9 .9 \\
\hline
\end{tabular}


TABELA 70 . CONSTITUINTES DA FRACAO GROSSEIRA

$$
\text { FRACAO O. } 500 \text { nam }
$$

\begin{tabular}{|c|c|c|c|c|c|c|c|c|c|c|}
\hline AMOSTRA & $G Z$ & Q.I.IM. & $M . P E S$. & O. TER . & $F R=C O N$. & $F R . A N$. & MOL. & FORAM. & D.BIO. & TER_/ IO IO. \\
\hline 154 & 19.4 & pr & 0.9 & 1.9 & 73.5 & 2.8 & 0.5 & 1.0 & pr & 4.5 \\
\hline 155 & 50.5 & - & 2.0 & pr & 47.5 & $p r$ & - & $\mathrm{pr}$ & - & $7 . a$ \\
\hline 156 & 44.8 & 0.5 & 1.0 & - & 49.5 & 3.0 & 1.5 & 0.5 & - & 0.8 \\
\hline 157 & 6.7 & - & $\ldots$ & - & 87.2 & 3.9 & 1.5 & 0.5 & - & 0.1 \\
\hline 158 & 78.9 & $\cdots$ & 0.5 & 0.5 & 19.1 & pr & 1.0 & - & - & 2.7 \\
\hline 159 & 89.8 &. & 1.4 & - & 6.8 & 1.9 & $\mathrm{pr}$ & - & - & 10.6 \\
\hline 160 & .77 .9 & 15.7 & 1.5 & 4.8 & $\mathrm{pr}$ & - & - & - & - & 10.0 \\
\hline 161 & 90.0 & - & - & -- & 9.5 & 0.5 & pr & - & - & 5.8 \\
\hline 162 & 87.1 & 0.5 & 4.5 & 1.0 & 5.5 & 1.5 & - & - & - & 10.0 \\
\hline 163 & 88.2 & 5.4 & 2.0 & 3.0 & 1.0 & $\ldots$ & - & $\ldots$ & 0.5 & 10.0 \\
\hline 164 & 59.2 & 36.8 & 1.0 & $\mathrm{pr}$ & 3.0 & pr & - & - & - & 10.0 \\
\hline 165 & 82.9 & 0.5 & 1.5 & 2.0 & 11.2 & 0.5 & 1.0 & - & - & 4.5 \\
\hline 166 & 81.3 & 0.5 & pr & 1.0 & 16.3 & 1.0 & - & - & - & 4.5 \\
\hline 167 & 39.5 & 0.4 & 0.8 & 0.8 & 7.5 & 0.8 & $\mathrm{pr}$ & - & - & 10.0 \\
\hline 168 & 30.8 & 1.0 & 1.0 & 0.5 & 61.1 & 4.3 & 1.0 & 0.5 & - & 0.6 \\
\hline 169 & 48.7 & - & 0.8 & - & 46.6 & 2.1 & 8.8 & $0 . \theta$ & - & 0.8 \\
\hline 178 & 25.1 & -. & pr & 6.5 & 66.6 & 4.3 & 1.8 & 1.8 & - & 0.4 \\
\hline 171 & 38.7 & - & 1.0 & 1.0 & 54.5 & 3.3 & 0.5 & 1.0 & -. & 0.8 \\
\hline 172 & 16.7 & - & pr & pr & 74.9 & 5.6 & 1.4 & 1.4 & - & 0.2 \\
\hline 173 & 29.4 & - & 0.5 & 0.5 & 61.3 & 5.9 & 1.5 & 1.0 & - & 8.6 \\
\hline 174 & 58.2 & - & 1.5 & 1.5 & 35.6 & 1.9 & 1.8 & - & - & 1.8 \\
\hline 475 & 83.3 & 2.0 & 1.8 & 1.0 & 10.3 & 1.5 & pr & - & - & 4.5 \\
\hline 176 & 69.4 & 4.8 & - & - & 19.4 & 2.9 & 1.9 & 0.5 & $\cdots$ & 2.7 \\
\hline 177 & 95.5 & 0.5 & 0.5 & 0.5 & 3.0 & pr & - & -- & - & 10.0 \\
\hline 178 & 84.1 & - & - & - & 13.6 & 2.3 & - & - & - & 4.5 \\
\hline 179 & 84.0 & - & $\cdots$ & - & 11.8 & 3.8 & 0.5 & - & - & 4.5 \\
\hline 180 & 67.6 & - & 0.5 & 0.5 & 1.6 .2 & 12.9 & 0.5 & - & 0.5 & 2.7 \\
\hline 181 & 63.1 & - & - & 5.3 & 21.6 & $\cdots$ & - & -- & 10.5 & 1.8 \\
\hline 183 & $B G .2$ & .- & 5.4 & 3.8 & 7.6 & 1.0 & - & - & $\cdots$ & 10.6 \\
\hline 183 & 84.4 & 2.3 & 1.8 & 3.3 & 7.2 & 1.0 & $\mathrm{pr}$ & - & - & 10.0 \\
\hline 184 & 83.8 & $p r$ & 0.5 & 1.5 & 11.8 & 2.0 & 0.5 & - & - & 4.5 \\
\hline 185 & 72.9 & - & $p r$ & 1.0 & 8.2 & 16.9 & 1.8 & - & - & 2.7 \\
\hline 186 & 55.9 & pr & 1.5 & 1.0 & 34.3 & 6.4 & 0.5 & pr & - & 1.2 \\
\hline 187 & 65.0 & - & 0.5 & - & 30.6 & 3.8 & pr & 0.5 & - & 1.8 \\
\hline 188 & 68.4 & - & 1.9 & 1.5 & 19.4 & 7.3 & 1.0 & pr & - & 2.7 \\
\hline 189 & 21.2 & $\cdots$ & 0.5 & 1.0 & 65.0 & 9.8 & 5.5 & 0.5 & -- & 0.1 \\
\hline 190 & 47.8 & 1.0 & 3.0 & 1.5 & 43.3 & 2.5 & 0.5 & 1.0 & - & 1.2 \\
\hline 191 & 26.8 & .. & 1.5 & - & 64.4 & 4.4 & 1.9 & 0.5 & - & 6.4 \\
\hline 192 & 32.1 & 0.5 & 0.5 & 0.5 & 59.3 & 3.8 & 1.9 & 1.0 & - & 0.6 \\
\hline 193 & 8.9 & - & 2.0 & 1.5 & $8 i .1$ & 5.6 & 0.5 & 1.4 & - & 0.2 \\
\hline 194 & 64.9 & $\therefore$ & - & 0.5 & 32.7 & 1.0 & 1.0 & 0.5 & - & 1.8 \\
\hline 195 & 29.1 & .... & - & 0.4 & 61.1 & 9.1 & 8.4 & pr & - & 0.4 \\
\hline 196 & 24.8 & - & 1.9 & 1.0 & 65.0 & 6.8 & 0.5 & - & - & 0.4 \\
\hline 197 & 75.8 & - & 2.4 & 0.5 & 14.7 & 6.6 & $\mathrm{pr}$ & - & - & 2.7 \\
\hline 198 & 73.1 & 1.4 & - & 3.7 & 8.3 & 7.9 & pr & - & 5.5 & 2.7 \\
\hline 321 & 8.3 & - & $\mathrm{PI}^{\prime \cdots}$ & -- & 82.1 & 8.3 & - & 1.4 & - & 0.1 \\
\hline 322 & 57.6 & - & - & 0.4 & 39.4 & 2.2 & - & 0.4 & - & 4.2 \\
\hline 323 & 33.2 & $\cdots$ & 0.5 & 0.5 & $\$ 3.4$ & 4.8 & pr & 7.7 & - & 0.6 \\
\hline 324 & 7.0 & 0.5 & $\cdots$ & - & 47.4 & 22.5 & - & 22.5 & - & 0.1 \\
\hline
\end{tabular}




\begin{tabular}{|c|c|c|c|c|c|c|c|c|c|c|}
\hline AMOSTRA & $Q Z$ & Q.LIM. & M.PES. & O. TER. & FR. CON. & FR.AN. & MOL. & FORAM. & 0.BIO. & TER . / BIO. \\
\hline 154 & 80.5 & 0.9 & 0.9 & 0.4 & 14.1 & 2.6 & $\mathrm{pr}$ & 0.4 & - & 4.5 \\
\hline 155 & 75.5 & 1.8 & 1.4 & - & 15.4 & 5.8 & $\mathrm{Pr}$ & 1.0 & - & 2.7 \\
\hline 156 & 80.0 & pr & 0.5 & - & 12.4 & 4.8 & $\mathrm{pr}$ & 2.4 & - & 4.5 \\
\hline 157 & 79.6 & 1.9 & 1.8 & - & 7.7 & 5.3 & $\mathrm{pr}$ & 2.4 & - & 4.5 \\
\hline 158 & 97.0 & 0.5 & 1.0 & - & 1.5 & $p r$ & - & - & - & 10.0 \\
\hline 159 & 97.1 & 8.5 & 0.5 & $\mathrm{pr}$ & pr & 1.0 & -- & 1.8 & - & 10.8 \\
\hline 160 & 88.3 & 6.3 & 1.8 & 3.9 & $\mathrm{pr}$ & 0.5 & -- & - & - & 10.0 \\
\hline 161 & 98.6 & - & 0.5 & 0.5 & 8.5 & $\mathrm{Pr}$ & - & - & - & 18.6 \\
\hline 162 & 91.4 & 0.9 & 1.9 & 2.4 & 1.9 & 1.4 & $\mathrm{pr}$ & - & - & 10.0 \\
\hline 163 & 92.2 & 4.4 & 1.5 & 1.0 & pr & 0.5 & - & - & 0.5 & 10.0 \\
\hline 164 & 91.8 & 6.3 & 1.9 & - & pr & $\mathrm{pr}$ & - & - & - & 10.0 \\
\hline 165 & 96.6 & 0.5 & 2.8 & pr & 0.5 & 0.5 & $\mathrm{pr}$ & - & -- & 10.0 \\
\hline 166 & 96.1 & 1.9 & 1.6 & 0.4 & 0.4 & pr & - & 0.4 & - & 10.0 \\
\hline 167 & 91.5 & 3.5 & 1.0 & 1.8 & 2.0 & pr & pr & 1.0 & - & 10.8 \\
\hline 168 & 70.0 & 6.5 & 1.4 & - & 22.7 & 1.0 & Pr & 4.3 & - & 2.7 \\
\hline 169 & 67.6 & 0.5 & 1.4 & - & 17.1 & 6.3 & -- & 7.2 & - & 8.6 \\
\hline 170 & 29.1 & 1.0 & $\mathrm{Pr}$ & 0.5 & 47.5 & 20.1 & - & 1.5 & - & 4.5 \\
\hline 171 & 86.3 & 1.6 & 1.8 & 0.5 & 7.8 & 2.4 & - & 1.8 & - & 1.8 \\
\hline 172 & 58.5 & 1.5 & 1.5 & $\mathrm{pr}$ & 33.0 & 3.5 & $\mathrm{Pr}$ & 2.5 & - & 2.7 \\
\hline 173 & 73.5 & 2.8 & 1.5 & - & 15.5 & 7.8 & Pr & 0.5 & - & 10.0 \\
\hline 174 & 90.6 & 2.5 & 1.9 & - & 4.4 & 0.4 & pr & 0.4 & - & 10.0 \\
\hline 175 & 91.9 & 4.3 & 0.5 & 0.5 & 8.9 & $\mathrm{pr}$ & - & 0.9 & - & 18.0 \\
\hline 176 & 90.4 & 6.2 & 1.0 & - & 1.4 & 0.5 & - & 0.5 & - & 10.0 \\
\hline 177 & 92.4 & 4.3 & 1.0 & 0.5 & 1.8 & 1.8 & - & pr & - & 18.0 \\
\hline 178 & 97.5 & $\mathrm{pr}$ & 1.0 & - & 1.0 & 0.5 & - & - & - & 10.0 \\
\hline 179 & 96.7 & 2.3 & $\mathrm{Pr}^{-}$ & 0.5 & 0.5 & pr & - & - & - & 10.0 \\
\hline 180 & 96.3 & 0.5 & 0.9 & $\mathrm{pr}$ & 0.9 & 1.4 & - & - & - & 10.0 \\
\hline 181 & 86.7 & - & 0.4 & 3.0 & 6.8 & 2.6 & - & - & 0.4 & 10.0 \\
\hline 182 & 93.9 & 1.9 & 0.9 & 1.9 & 0.9 & 0.5 & - & - & - & 10.0 \\
\hline 183 & 95.7 & 1.9 & 1.4 & $\mathrm{pr}$ & 8.5 & 0.5 & -. & -- & - & 10.8 \\
\hline 184 & 97.2 & 2.3 & $\mathrm{pr}$ & pr & 0.5 & $\mathrm{pr}$ & $p r$ & $\mathrm{pr}$ & - & 10.0 \\
\hline 185 & 97.0 & pr & 2.5 & - & 0.5 & $\mathrm{pr}$ & - & pr & - & 18.0 \\
\hline 186 & 75.6 & 3.8 & 1.9 & 0.5 & 11.5 & 3.8 & pr & 2.9 & $\ldots$ & 4.5 \\
\hline 187 & 85.8 & pr & 8.4 & 8.4 & 11.0 & 8.4 & 0.4 & 1.4 & - & 4.5 \\
\hline 188 & 34.8 & 3.6 & 2.3 & - & 46.6 & 10.0 & $\mathrm{Pr}$ & 2.7 & - & 0.8 \\
\hline 189 & 77.7 & 0.5 & 2.4 & - & 14.1 & 3.9 & - & 1.5 & - & 4.5 \\
\hline 190 & 46.5 & $\mathrm{pr}$ & 3.5 & - & 39.6 & 9.5 & - & 1.5 & - & 1.8 \\
\hline 101 & 94.0 & 1.5 & - & - & 3.5 & 1.8 & pr & pr & - & 10.0 \\
\hline 192 & 81.2 & 0.5 & 1.0 & - & 14.9 & 2.5 & - & $\mathrm{pr}$ & - & 4.5 \\
\hline 193 & 78.3 & 3.3 & 1.4 & 0.9 & 13.2 & 1.4 & - & 0.9 & - & 4.5 \\
\hline 194 & 97.0 & 8.4 & 0.9 & - & 1.7 & $\mathrm{pr}$ & - & pr & - & 10.0 \\
\hline 195 & 88.6 & - & 0.5 & - & 5.5 & 5.0 & - & 0.5 & - & 4.5 \\
\hline 196 & 78.7 & 0.5 & 2.4 & 0.5 & 7.2 & 8.7 & 1.0 & 1.0 & 0.5 & 4.5 \\
\hline 197 & 87.2 & 4.4 & 3.1 & $\mathrm{pr}$ & 4.4 & 0.9 & $\mathrm{pr}$ & - & - & 18.8 \\
\hline 198 & 91.8 & 1.4 & 0.4 & 2.3 & 1.4 & 2.3 & - & 0.4 & 0.9 & 10.0 \\
\hline 321 & 28.6 & - & 0.9 & -- & 49.8 & 16.9 & - & 3.8 & - & 0.4 \\
\hline 322 & 17.8 & pr & pr & - & 43.6 & 24.2 & - & 14.3 & - & 0.2 \\
\hline 323 & 65.8 & 0.5 & 2.0 & - & 13.9 & 9.9 & - & 7.9 & - & 1.8 \\
\hline 324 & 7.4 & - & pr & - & 23.4 & 33.4 & - & 36.0 & - & 0.1 \\
\hline
\end{tabular}




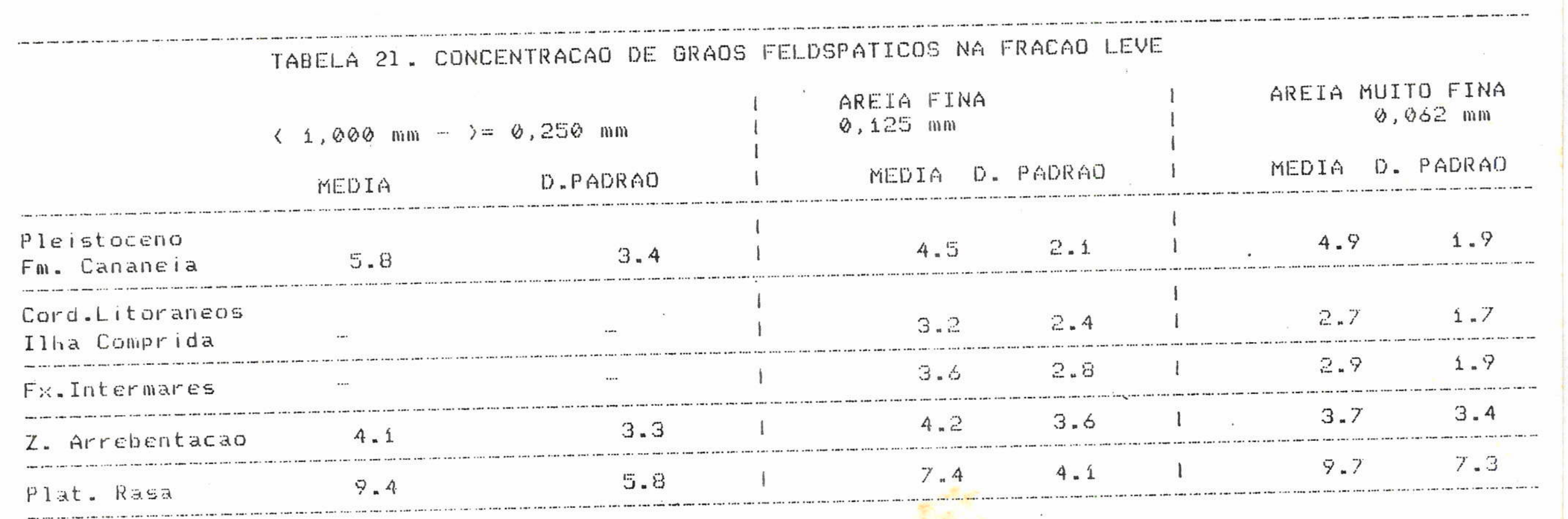




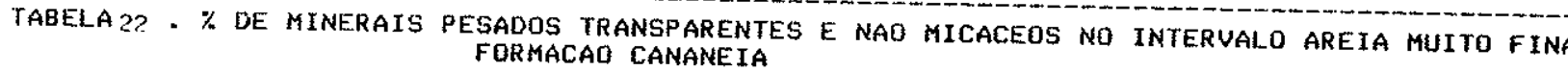

\begin{tabular}{|c|c|c|c|c|c|c|c|c|c|c|c|}
\hline & 1 & 4.1 & 4.2 & 6 & 6.1 & 7 & 8 & 24 & 25 & 29 & 41 \\
\hline ANATASIO & 1.33 & 1.05 & 0.71 & 0.46 & 0.71 & 0.91 & 0.40 & 8.81 & - & 0.95 & - \\
\hline $\begin{array}{l}\text { ANOALUZITA } \\
\text { AUGITA }\end{array}$ & 4.81 & - & 0.34 & 4.26 & 7.00 & $\cdots$ & - & 2.46 & 2.76 & 2.39 & 5.33 \\
\hline BROOKITA & $\ldots$ & - & - & - & - & - & - & - & - & - & - \\
\hline CIANITA & 9.63 & 2.10 & 5.43 & 1.89 & 8.51 & 0.45 & 1.30 & $\bar{z}_{45}$ & 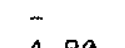 & - & - \\
\hline COR INDON & & - & - & & & & & 7.45 & 4.80 & 4.33 & 10.67 \\
\hline EP IDOTO & 4.10 & 15.48 & 17.27 & 16.21 & 5.90 & 1.86 & 6.32 & 1.05 & 0.96 & 0.95 & 4.24 \\
\hline $\begin{array}{l}\text { ESTAUROLITA } \\
\text { FIBROLITA }\end{array}$ & 7.58 & 8.43 & 11.09 & 3.79 & 9.06 & 6.61 & 4.41 & 7.45 & 9.66 & 6.28 & 12.26 \\
\hline GRANADA & 0.76 & $\ldots$ & 0.87 & 0.55 & 0.55 & - & 0.45 & $-\overline{0.96}$ & - & $=$ & $\overline{0} .37$ \\
\hline HIPERSTENIO & - & - & 0.71 & - & 0.55 & 0.41 & $\ldots$ & $\begin{array}{l}0.40 \\
1.52\end{array}$ & - & - & $\begin{array}{l}0.37 \\
-2\end{array}$ \\
\hline HORNBLENDA & 1.47 & 2.39 & 3.00 & 4.40 & 1.66 & 0.45 & 3.66 & 16.20 & - & - & .- \\
\hline MONAZITA & $\overline{0} .66$ & $-a=$ & - & $\cdots$ & 1.66 & 0.91 & 0.85 & - & - & - & - \\
\hline PEROWSKITA & $\begin{array}{r}0.66 \\
11.01\end{array}$ & $\begin{array}{r}1.05 \\
12.21\end{array}$ & 1.07 & 0.92 & & 0.41 & - & - & - & - & 0.53 \\
\hline RUTILO & $\begin{array}{r}11.81 \\
2.71\end{array}$ & 12.21 & 9.82 & 14.17 & 4.43 & 6.20 & 7.12 & 12.68 & 14.38 & 7.27 & 8.52 \\
\hline $\begin{array}{l}\text { SILLIMANITA } \\
\text { TITANITA }\end{array}$ & 2.71 & 2.03 & $\begin{array}{l}2.48 \\
6.34\end{array}$ & 0.46 & 1.66 & 0.45 & 1.36 & - & 0.66 & 2.39 & 3.18 \\
\hline TREMOLITA & 1.33 & 0.50 & 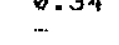 & 0.93 & - & - & $\overline{0} .40$ & $\overline{4} .83$ & - & - & - \\
\hline TURMALINA & 26.94 & 24.42 & 20.25 & 17.97 & 23.76 & - & $\begin{array}{l}0.40 \\
8.93\end{array}$ & $\begin{array}{r}4.83 \\
31.61\end{array}$ & - & - & 0.53 \\
\hline ZIRCAO & 27.61 & 30.27 & 27.45 & 33.36 & $\begin{array}{l}23.76 \\
34.49\end{array}$ & $\begin{array}{r}6.20 \\
75.10\end{array}$ & $\begin{array}{r}8.93 \\
64.80\end{array}$ & $\begin{array}{l}31.61 \\
13.52\end{array}$ & $\begin{array}{l}24.80 \\
41.94\end{array}$ & $\begin{array}{l}34.14 \\
41.26\end{array}$ & $\begin{array}{l}34.17 \\
20.16\end{array}$ \\
\hline DUtros & & - & $-\ldots$ & $\begin{array}{r}0.55 \\
\text { notima }\end{array}$ & & & & & & & \\
\hline $\begin{array}{l}\text { INST/EST (IA) } \\
\text { ZTR }\end{array}$ & $\begin{array}{r}0.33 \\
65.69\end{array}$ & $\begin{array}{r}0.43 \\
66.96\end{array}$ & $\begin{array}{r}0.50 \\
56.70\end{array}$ & $\begin{array}{r}\text { not ina } \\
0.50 \\
65.50\end{array}$ & $\begin{array}{r}0.29 \\
62.70\end{array}$ & $\begin{array}{r}0.22 \\
87.50\end{array}$ & $\begin{array}{r}0.25 \\
80.80\end{array}$ & $\begin{array}{r}0.50 \\
57.20\end{array}$ & $\begin{array}{r}0.25 \\
81.10\end{array}$ & $\begin{array}{r}0.22 \\
82.70\end{array}$ & $\begin{array}{r}0.29 \\
62.90\end{array}$ \\
\hline DIUER . MINERAL. & 11 & 18 & 9 & 8 & 10 & 5 & 8 & 10 & $\begin{array}{r}01.28 \\
6\end{array}$ & $\begin{array}{r}82.70 \\
7\end{array}$ & $\begin{array}{r}0.96 \\
8\end{array}$ \\
\hline N.MINERAIS & 13 & 11 & 14 & 14 & 13 & 12 & 11 & 12 & 8 & 9 & 11 \\
\hline
\end{tabular}


TABELLA ZZ. \% DE MINERAIS PESADOS TRANSPARENTES E NAO MICACEOS NO IMTERUALO AREIA MUITO FING FORMACAO CANANEIG (com, ․)

\begin{tabular}{|c|c|c|c|c|c|c|c|c|c|c|c|}
\hline & 43 & 48 & 50.1 & 50.2 & 51.4 & 54.4 & 59.5 & 60 & 61.2 & 61.3 & 62.1 \\
\hline ANATASIO & - & 1.19 & - & 1.40 & 0.73 & -. & - & 0.76 & 0.58 & 1.86 & $\cdots$ \\
\hline $\begin{array}{l}\text { ANDALUZITA } \\
\text { AUGITA }\end{array}$ & 1.28 & 0.59 & 0.54 & 0.45 & 4.45 & 0.71 & 0.62 & 1.56 & 6.25 & 1.86 & 2.85 \\
\hline BROOK ITA & - & $\ldots$ & .. & 0.45 & - & $\ldots$ & $\ldots$ & - & $\ldots$ & $\ldots$ & - \\
\hline $\begin{array}{l}\text { CIANITA } \\
\text { CORINDON }\end{array}$ & .5 .99 & 7.25 & 8.21 & $\begin{array}{l}4.79 \\
-\end{array}$ & 11.22 & 10.20 & 1.25 & 4.00 & 5.70 & 3.12 & 1.70 \\
\hline EPIEOTO & - & 26.58 & 24.69 & 12.98 & 30.37 & 5.80 & -. & 44.90 & 15.24 & 15.16 & 34.52 \\
\hline $\begin{array}{l}\text { ESTAUROLITA } \\
\text { FIBROLITA }\end{array}$ & 11.31 & 6.63 & 9.83 & 7.02 & 6.39 & 16.04 & 15.34 & 8.79 & 6.33 & $\begin{array}{l}8.11 \\
6.60\end{array}$ & 5.91 \\
\hline GRANADA & ... & - & - & 1.71 & 0.84 & 1.14 & -. & $\ldots$ & 0.51 & 0.28 & 1.21 \\
\hline HIPERSTENIO & - & 0.78 & 1.15 & 0.39 & 0.40 & - & 2.36 & 1.23 & 0.51 & 1.31 & 6.75 \\
\hline HORNBLENDA & - & 4.61 & 3.51 & 2.68 & 2.88 & 4.04 & 2.04 & 11.29 & 6.33 & 8.62 & 7.62 \\
\hline MONAZITA & - & $\cdots$ & - & - & - & - & - & - & - & - & - \\
\hline PEROWSK ITA & 1.28 & 1.19 & -- & 1.89 & 0.73 & 2.15 & - & 1.56 & 0.58 & - & - \\
\hline RUTILO & 12.69 & 8.46 & - & 6.72 & 1.46 & 7.27 & 9.72 & 10.06 & 6.25 & 6.90 & 4.01 \\
\hline SILLIMANITA & 3.32 & 1.80 & 1.62 & 1.83 & - & 2.15 & 1.92 & 2.38 & 4.41 & 1.86 & 5.54 \\
\hline $\begin{array}{l}\text { TITANITA } \\
\text { TREMOLITA }\end{array}$ & $\overline{-}$ & $\overline{1.80}$ & $-\overline{-}$ & $\overline{1} .89$ & $-\overline{0}, 73$ & - & $\overline{9} 62$ & 3.85 & $\bar{s}$ & - & -8 \\
\hline TURMALINA & 25.37 & 34.81 & 23.57 & 29.82 & 37.53 & 37.34 & 28.88 & $\begin{array}{l}2.85 \\
1.78\end{array}$ & $\begin{array}{r}1.25 \\
39.65\end{array}$ & 31.42 & $\begin{array}{r}1.32 \\
26.47\end{array}$ \\
\hline ZIRCAO & 38.72 & 4.23 & 26.85 & 25.48 & 2.22 & 13.11 & 37.19 & 8.79 & 6.33 & 18.83 & 8.05 \\
\hline \multicolumn{12}{|c|}{ Xenot $i$ ana } \\
\hline $\begin{array}{l}\text { INST/EST (IA) } \\
\text { ZTR }\end{array}$ & $\begin{array}{r}0.33 \\
76.88\end{array}$ & $\begin{array}{r}0.80 \\
47.56\end{array}$ & $\begin{array}{r}0.67 \\
56.40\end{array}$ & $\begin{array}{r}0.50 \\
82.00\end{array}$ & $\begin{array}{r}1.00 \\
41.2 \theta\end{array}$ & $\begin{array}{r}0.33 \\
57.76\end{array}$ & $\begin{array}{r}0.29 \\
75.80\end{array}$ & $\begin{array}{r}3.50 \\
20.60\end{array}$ & $\begin{array}{r}0.60 \\
52.20\end{array}$ & $\begin{array}{r}0.50 \\
57.20\end{array}$ & $\begin{array}{r}1.25 \\
38.50\end{array}$ \\
\hline DIUER . HINERAL. & 8 & 11 & 8 & 12 & 8 & 10 & 8 & 12 & 10 & 10 & 11 \\
\hline N.MINERAIS & 8 & 13 & 9 & 16 & 13 & 11 & 10 & 13 & 14 & 14 & 12 \\
\hline
\end{tabular}




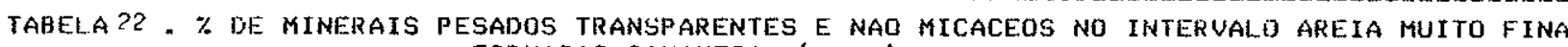
FORMACGO CANANEIA (co:th.)

\begin{tabular}{|c|c|c|c|c|c|c|c|c|c|c|}
\hline & $70.2^{2}$ & 71.4 & 71.5 & 71.6 & 85.1 & 87 & 89.1 & 90.1 & 90.2 & 92 \\
\hline ANATASIO & - & $\cdots$ & -. & - & 0.47 & 1.79 & 6.68 & 0.95 & -- & 0.63 \\
\hline ANDALUZITA & 4.01 & $\ldots$ & 0.75 & $\ldots$ & 1.45 & 2.40 & 1.41 & 2.43 & 0.50 & 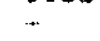 \\
\hline AUG ITA & - & - & $\ldots$ &.- & - & - & - & - & - & - \\
\hline BRDOK ITA & $\cdots$ & - & - & - & - & - & - & $\ldots$ & - & - \\
\hline $\begin{array}{l}\text { CIANITA } \\
\text { CORINDON }\end{array}$ & 2.64 & 2.34 & 0.75 & 1.13 & 4.89 & 4.85 & 3.56 & 4.39 & 8.95 & 4.56 \\
\hline EP IDOTO & 26.08 & 10.58 & 5.67 & 1.72 & 33.27 & 6.08 & 28.83 & 44.29 & 23.91 & 17.89 \\
\hline $\begin{array}{l}\text { ESTAUROLITA } \\
\text { FIBROLITA }\end{array}$ & 10.55 & 13.48 & 4.50 & 8.84 & $\begin{array}{l}8.81 \\
0.47\end{array}$ & 10.41 & 8.11 & 5.69 & 8.09 & 13.96 \\
\hline GRANADA & 0.64 & 1.56 & 0.91 & 1.13 & 1.56 & 1.57 & 0.93 & 1.35 & 0.62 & - \\
\hline HIPERSTENIO & 0.44 & 0.52 & 0.91 & $\ldots$ & 0.58 & - & - & 1.35 & 1.13 & - \\
\hline HORNBLENDA & 7.42 & 3.38 & - & - & 24.46 & 2.40 & 3.81 & 11.14 & 6.50 & 2.88 \\
\hline MONAZITA & 8.64 & $\ldots$ & 2.25 & 0.53 & $\ldots$ & 0.56 & $\ldots$ & - & 0.58 & - \\
\hline PEROWSK ITA & $\ldots$ & 2.34 & 5.25 & 0.53 & 0.47 & 2.40 & - & ... & 0.50 & - \\
\hline RUTILO & 4.69 & 4.68 & 9.86 & 5.28 & 6.95 & 8.5 .3 & 7.86 & 1.93 & 4.18 & 6.52 \\
\hline SILLIMANITA & 0.64 & -. & 0.37 & - & 1.15 & 6.69 & 0.68 & 1.79 & 0.41 & 5.19 \\
\hline TITANITA & - & - & - & -.. & 0.47 & - & $\ldots$ & - & 0.50 & 0.63 \\
\hline TREMOLITA & 0.44 & $\cdots$ & - & - & 1.84 & - & 1.66 & 0.66 & 1.04 & - \\
\hline TURMAL INA & 34.39 & 21.16 & 8.30 & 13.53 & 16.68 & 19.16 & 11.19 & 16.72 & 24.65 & 29.42 \\
\hline ZIRCAO & 7.38 & 39.93 & 60.49 & 67.25 & 2.44 & 33.68 & 31.22 & 7.84 & 18.43 & 18.27 \\
\hline OUTROS & $\ldots$ & $\ldots$ & - & - & - & - & & & $\ldots$ & - \\
\hline $\begin{array}{l}\text { INST/EST (I I) } \\
\text { ZTR }\end{array}$ & 0.86 & 0.43 & 0.25 & 0.22 & 2.33 & 0.33 & 0.67 & 2.33 & 0.80 & 0.60 \\
\hline ZTR & 46.56 & 65.80 & 78.60 & 86.16 & 20.10 & 60.80 & 50.30 & 26.50 & 47.30 & 54.20 \\
\hline DIUER.MINERAL. & 8 & 9 & 7 & 7 & 10 & 12 & 9 & $\$ 1$ & 9 & 8 \\
\hline N.MINERAIS & 13 & 10 & 12 & 9 & 16 & 13 & 12 & 13 & 15 & 10 \\
\hline
\end{tabular}


TABELAP3 - \% DE MINERAIS PESADOS TRANSPARENTES E NAO MICACEOS NO INTERUALO AREIA FINA FORMACAO CANANETA

\begin{tabular}{|c|c|c|c|c|c|c|c|c|c|c|}
\hline & 4.1 & 4.2 & 6.1 & 7 & 8 & 12 & 29 & 71.4 & 71.5 & 71.6 \\
\hline ANATASIO & - & .. & $\cdots$ & 1.28 & - & $\ldots$ & -- & - & - & - \\
\hline $\begin{array}{l}\text { ANDALUZITA } \\
\text { AUGITA }\end{array}$ & 5.08 & 7.76 & 9.69 & 1.97 & 1.35 & 1.43 & 7.23 & 2.05 & 2.71 & 0.52 \\
\hline $\begin{array}{l}\text { BROOKITA } \\
\text { CIANIYA }\end{array}$ & .. & - & - & - & $\cdots$ & $\cdots$ & $\cdots$ & - & - & - \\
\hline EPIOOTO & 10.20 & 10.46 & $\overline{4} .74$ & $=35$ & $\overline{2} .80$ & 3.95 & - & 9.08 & 10.20 & 3.78 \\
\hline ESTAUROL. ITA & 8.47 & 9.87 & $\begin{array}{l}4.74 \\
4.74\end{array}$ & $\begin{array}{r}5.35 \\
12.10\end{array}$ & 11.56 & 7.31 & 10.65 & 7.31 & 3.38 & 25.66 \\
\hline FIBROLITA & - & - & 2.34 & ... & -- & - & 0.63 & - & 1.32 & 1.30 \\
\hline GRANADA & 2.21 & 1.14 & 1.63 & 0.58 & 1.26 & 0.59 & - & 0.69 & 1.80 & 1.00 \\
\hline HIPERSTENIO & 1.00 & 0.37 & 1.21 & - & -- & - & - & 1.39 & 2.30 & 1.30 \\
\hline HORNBLENDA & 4.68 & 10.71 & 6.84 & 1.97 & 4.60 & $\cdots$ & - & 9.64 & 7.99 & 1.69 \\
\hline MONAZITA & -- & - & - & $\cdots$ & $\ldots$ & 2.15 & - & - & - & 3.46 \\
\hline PEKOWSK ITA & -- & -- & - & - & - & -. & - & - & - & 0.52 \\
\hline RUTILO & 0.32 & - & 1.55 & 1.28 & - & .- & 2.53 & 2.05 & 0.66 & 6.52 \\
\hline SILLIMANITA & 2.01 & 1.24 & $\cdots$ & 2.67 & 2.67 & 0.59 & 3.29 & 4.14 & 2.49 & 1.11 \\
\hline TITANITA & - & - & - & - & - & - & - & - & & - \\
\hline IREMOLITA & - & 0.37 & 1.55 & - & 1.98 & - & - & - & 0.47 & - \\
\hline TURMAL INA & 58.95 & 45.99 & 54.59 & 45.86 & 48.41 & 31.77 & 53.04 & 58.38 & 46.88 & 34.74 \\
\hline ZIRCAO & 5.08 & 8.60 & 10.32 & 24.21 & 24.57 & 46.40 & 22.58 & 5.21 & 18.42 & 23.64 \\
\hline OUTROS & $\ldots$ & - & - & - & - & - & - & - & & $\cdots$ \\
\hline $\begin{array}{l}\text { INST/EST (IA) } \\
\text { ZTK }\end{array}$ & $\begin{array}{r}0.43 \\
64.35\end{array}$ & $\begin{array}{r}0.67 \\
54.59\end{array}$ & $\begin{array}{r}0.25 \\
66.46\end{array}$ & $\begin{array}{r}0.25 \\
71.35\end{array}$ & $\begin{array}{r}0.25 \\
72.98\end{array}$ & $\begin{array}{r}8.22 \\
78.17\end{array}$ & $\begin{array}{r}0.22 \\
73.15\end{array}$ & $\begin{array}{r}0.29 \\
65.64\end{array}$ & $\begin{array}{r}0.43 \\
65.96\end{array}$ & $\begin{array}{r}0.29 \\
58.90\end{array}$ \\
\hline DIUER - MINERAL. & 10 & 9 & 11 & 10 & 10 & 7 & 6 & 9 & 11 & 10 \\
\hline N.MINERAIS & 11 & is & 12 & $1 \mathfrak{1}$ & 10 & 9 & 7 & 10 & 13 & 13 \\
\hline
\end{tabular}


TABELA 24. \% DE MINERAIS PESADOS TRANSPARENTES E NAO MICACEOS NO INTERVALO AREIA FINA

CORDOES LITORANEOS DA ILHA COMPRIDA - SP

\begin{tabular}{|c|c|c|c|c|c|c|c|c|c|c|}
\hline & 95.1 & 95.2 & 95.3 & 96.1 & 96.2 & 96.3 & 97.1 & 97.2 & 97.3 & 97.4 \\
\hline ANATASIO & $\ldots$ & .. & - & - & - & $\ldots$ & 0.92 & 0.26 & - & - \\
\hline ANDALUZ ITA & 0.21 & 0.48 & $\cdots$ & 2.29 & 1.21 & 0.86 & 0.93 & 0.75 & 1.28 & 0.70 \\
\hline AUSITA & $\cdots$ & - & - & - & - & - & - & -- & -- & - \\
\hline BROOK ITA & - & - & $\ldots$ & $\ldots$ & .. & -- & - & - & - & - \\
\hline $\begin{array}{l}\text { CIANITA } \\
\text { CORINGON }\end{array}$ & 4.67 & 3.22 & 1.84 & 2.10 & 3.82 & 2.74 & 2.26 & 3.77 & 2.69 & $1.41^{\circ}$ \\
\hline EPIDOTO & 18.42 & 20.16 & 18.32 & 9.08 & 12.33 & 16.75 & 20.74 & 11.67 & 18.74 & 20.42 \\
\hline ESTAUROLITA & 4.00 & 8.6 .3 & 15.41 & 7.25 & 7.37 & 4.48 & 5.76 & 9.83 & 12.29 & 10.05 \\
\hline FIBROLITA & - & 1.01 & ..... & $\ldots$ & 0.40 & 1.86 & 1.46 & - & - & $\therefore$ \\
\hline GRANAQA & 1.26 & 0.75 & 1.63 & - & - & 2.19 & 1.88 & 0.40 & - & 0.61 \\
\hline HIPERSTENIO & - & $\cdots$ & - & .. & - & $\cdots$ & $\sim$ & $\ldots$ & -. & - \\
\hline HORNBLENDA & 23.40 & 12.44 & 19.64 & 22.14 & 26.31 & 20.89 & 16.02 & 18.94 & 20.44 & 17.37 \\
\hline MONAZITA & - & - & 0.14 & - & - & - & 0.47 & - & - & - \\
\hline PEROWSKITA & $\cdots$ & $\ddot{a}$ & 0.17 & - & - & 0.64 & 1.23 & - & - & 0.86 \\
\hline RUTILO & $\approx$ & 0.94 & 0.53 & 1.65 & - & $\ldots$ & 0.46 & $\therefore$ & 0.61 & - \\
\hline SILLIMANITA & 2.33 & 4.64 & - & 6.09 & 7.84 & 6.86 & 8.12 & 5.77 & . & 4.32 \\
\hline TITANITA & 1.41 & -- & $\ldots$ & 0.26 & -- & - & 0.32 & 1.86 & - & 1.02 \\
\hline TREMOLITA & $\ldots$ & - & 0.48 & - & - & 0.26 & - & 0.41 & -- & 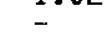 \\
\hline TURMAL INA & 38.60 & 42.82 & 36.60 & 44.74 & 38.40 & 39.71 & 35.43 & 41.00 & 39.23 & 46.32 \\
\hline ZIRCAO & 5.70 & 5.01 & 5.24 & 4.40 & 3.23 & 2.76 & 4.00 & 5.34 & 4.72 & 2.92 \\
\hline OUTROS & - & - & 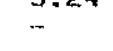 & -2 & - & 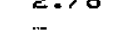 & -1.0 & -2.34 & 4.16 & $\therefore-9 c^{\circ}$ \\
\hline INST/EST (II) & 1.00 & 0.83 & 0.80 & 0.67 & 1.00 & 1.00 & 1.08 & 0.67 & 1.00 & 0.83 \\
\hline ZTR & 44.30 & 48.67 & 42.37 & 50.79 & 41.63 & 42.47 & 39.89 & 46.34 & 44.56 & 43.24 \\
\hline DIUER . MINERAL. & 9 & B & 7 & 9 & $B$ & 9 & 10 & 8 & 7 & 8 \\
\hline N.MINERAIS & 10 & $1 \hat{1}$ & 11 & 10 & 9 & 12 & 15 & 12 & 8 & if \\
\hline
\end{tabular}


TABELA25 * \% DE MINERAIS PESADOS TRANSPARENTES E MAO MICACEOS MO INTERVALO AREIA MUTOFINA CORDOES INTARENTES E NAO MICACEOS NO INTERUALO AREIA MUITO FINA

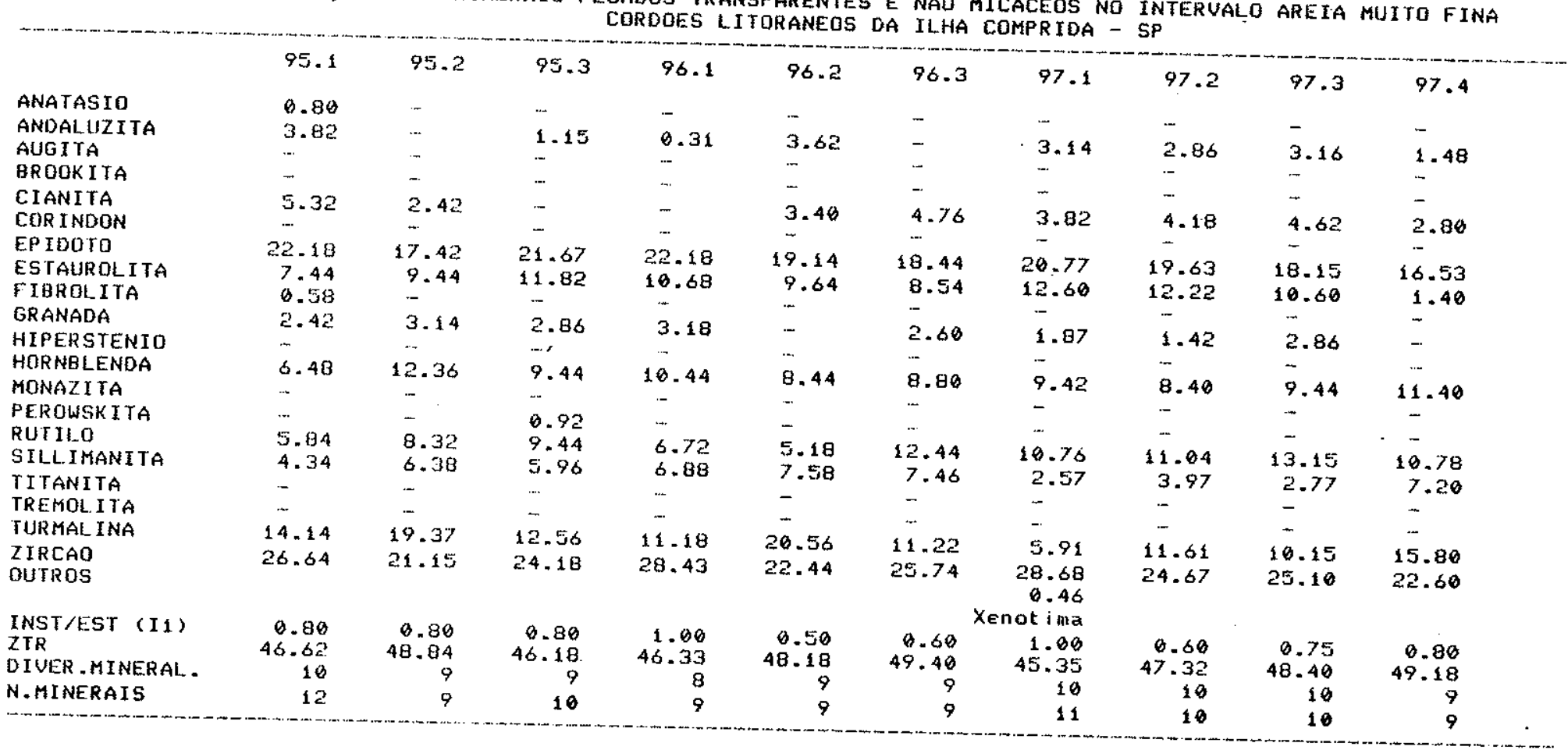


TABELA 26 - \% DE MINERAIS PESADOS TRANSPARENTES E NAO MICACEOS NO INTERVALO AREIA FINA FAIXA INTERMARES

\begin{tabular}{|c|c|c|c|c|c|c|c|c|c|c|}
\hline & 2848 & $303 \mathrm{~A}$ & $319 \mathrm{~A}$ & $322 \mathrm{~A}$ & $324 C$ & $32.6 \mathrm{~A}$ & 3478 & $349 \mathrm{C}$ & $350 \mathrm{~A}$ & $351 B$ \\
\hline GENAIASSIO & 0.00 & & & 2.36 & & & $\cdots$ & .. & " & \\
\hline $\begin{array}{l}\text { ANDALUZIIA } \\
\text { AUGIIA }\end{array}$ & 6.30 & 4.50 & $\because$ & 3.16 & 6.44 & 3.12 & 3.64 & $\begin{array}{l}3.40 \\
0.84\end{array}$ & $2 \cdot 134$ & $3.2 \%$ \\
\hline BROOK ITA & - & $\cdots$ & - & 0.84 & - & - & - & - & - & . \\
\hline $\begin{array}{l}\text { CIANITA } \\
\text { CORINDON }\end{array}$ & 3.60 & 1.80 & 1.20 & 2.18 & 3.86 & 3.44 & 2.34 & 2.40 & 2.42 & - \\
\hline $\begin{array}{l}\text { EPIDOTO } \\
\text { ESTAUROLITA } \\
\text { FIBROLITA }\end{array}$ & $\begin{array}{r}12.36 \\
10.70 \\
-\end{array}$ & $\begin{array}{r}9.10 \\
11.80 \\
-\end{array}$ & $\begin{array}{r}12.32 \\
12.42 \\
-\end{array}$ & $\begin{array}{r}10.14 \\
8.44 \\
3.86\end{array}$ & $\begin{array}{r}18.68 \\
10.46 \\
7\end{array}$ & $\begin{array}{l}26.12 \\
12.36 \\
-\end{array}$ & $\begin{array}{l}32.18 \\
12.00 \\
-\end{array}$ & $\begin{array}{r}36.42 \\
8.32\end{array}$ & $\begin{array}{r}38.64 \\
5.42\end{array}$ & $\begin{array}{r}44.60 \\
1.94\end{array}$ \\
\hline $\begin{array}{l}\text { GRANADA } \\
\text { HIPERSTENIO }\end{array}$ & 0.90 & 1.80 & - & 1.88 & $\begin{array}{l}2.18 \\
1.46\end{array}$ & - & $\because$ & 3.86 & 1.80 & $\begin{array}{l}- \\
-\end{array}$ \\
\hline HORNBLENDA & 4.30 & 1.90 & 4.84 & 10.44 & 12.46 & 11.80 & 14.84 & 18.54 & 12.44 & 24.64 \\
\hline $\begin{array}{l}\text { MONAZITA } \\
\text { PEROWSKITA }\end{array}$ & 6.60 & - & $\cdots$ & 2.42 & - & - & $\ldots$ & - & 0.86 & - \\
\hline $\begin{array}{l}\text { RUTILO } \\
\text { SILLIMANITA }\end{array}$ & 2.30 & 2.70 & $\begin{array}{l}2.64 \\
1.62\end{array}$ & $\begin{array}{l}1.86 \\
4.88\end{array}$ & $\overline{2.14}$ & $\begin{array}{l}2.32 \\
2.62\end{array}$ & $-\overline{3.96}$ & 1.00 & 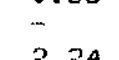 & 1.24 \\
\hline $\begin{array}{l}\text { IITANITA } \\
\text { TREMOLITA }\end{array}$ & $=$ & $=$ & $\because$ & 2.64 & $=$ & $\begin{array}{l}2+62 \\
- \\
\cdots\end{array}$ & $\begin{array}{l}3.96 \\
2.64 \\
\ldots\end{array}$ & $\begin{array}{l}2.40 \\
1.52 \\
-\end{array}$ & $\begin{array}{l}2.24 \\
0.34 \\
-\end{array}$ & $\begin{array}{l}2.86 \\
2.42 \\
--\end{array}$ \\
\hline $\begin{array}{l}\text { TURMALINA } \\
\text { ZIRCAO } \\
\text { OUTROS }\end{array}$ & $\begin{array}{l}40.60 \\
17.80 \\
-.\end{array}$ & $\begin{array}{l}46.40 \\
20.00 \\
-\end{array}$ & $\begin{array}{l}36.32 \\
28.64 \\
\ldots .\end{array}$ & $\begin{array}{l}28.62 \\
16.18 \\
\ldots\end{array}$ & $\begin{array}{l}26.42 \\
15.98 \\
-\end{array}$ & $\begin{array}{l}20.62 \\
17.60 \\
\ldots\end{array}$ & $\begin{array}{r}21.74 \\
6.66 \\
-\end{array}$ & $\begin{array}{c}18.30 \\
3.00 \\
--\end{array}$ & $\begin{array}{c}20.64 \\
12.36 \\
-\end{array}$ & $\begin{array}{r}12.62 \\
6.46 \\
-\end{array}$ \\
\hline $\begin{array}{l}\text { INST/EST (II) } \\
\text { ZTR }\end{array}$ & $\begin{array}{r}0.43 \\
58.40\end{array}$ & $\begin{array}{r}0.38 \\
66.08\end{array}$ & $\begin{array}{r}0.43 \\
67.60\end{array}$ & $\begin{array}{r}0.80 \\
46.66\end{array}$ & $\begin{array}{r}0.80 \\
42.40\end{array}$ & $\begin{array}{r}1.80 \\
40.54\end{array}$ & $\begin{array}{r}1.25 \\
28.40\end{array}$ & $\begin{array}{r}2.00 \\
22.30\end{array}$ & $\begin{array}{r}1.20 \\
33.00\end{array}$ & $\begin{array}{r}2.67 \\
20.32\end{array}$ \\
\hline DI UER . MINERAL. & 8 & 9 & 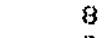 & 14 & 10 & 9 & 9 & 11 & 9 & 9 \\
\hline N.MINERAIS & 11 & 9 & 8 & 15 & 10 & 9 & 9 & 12 & 11 & 9 \\
\hline
\end{tabular}


TABELA 27 . \% DE MINERAIS PESADOS TRANSPARENTES E NAO MICACEOS NO INTERVALO aReia MUITO FINA

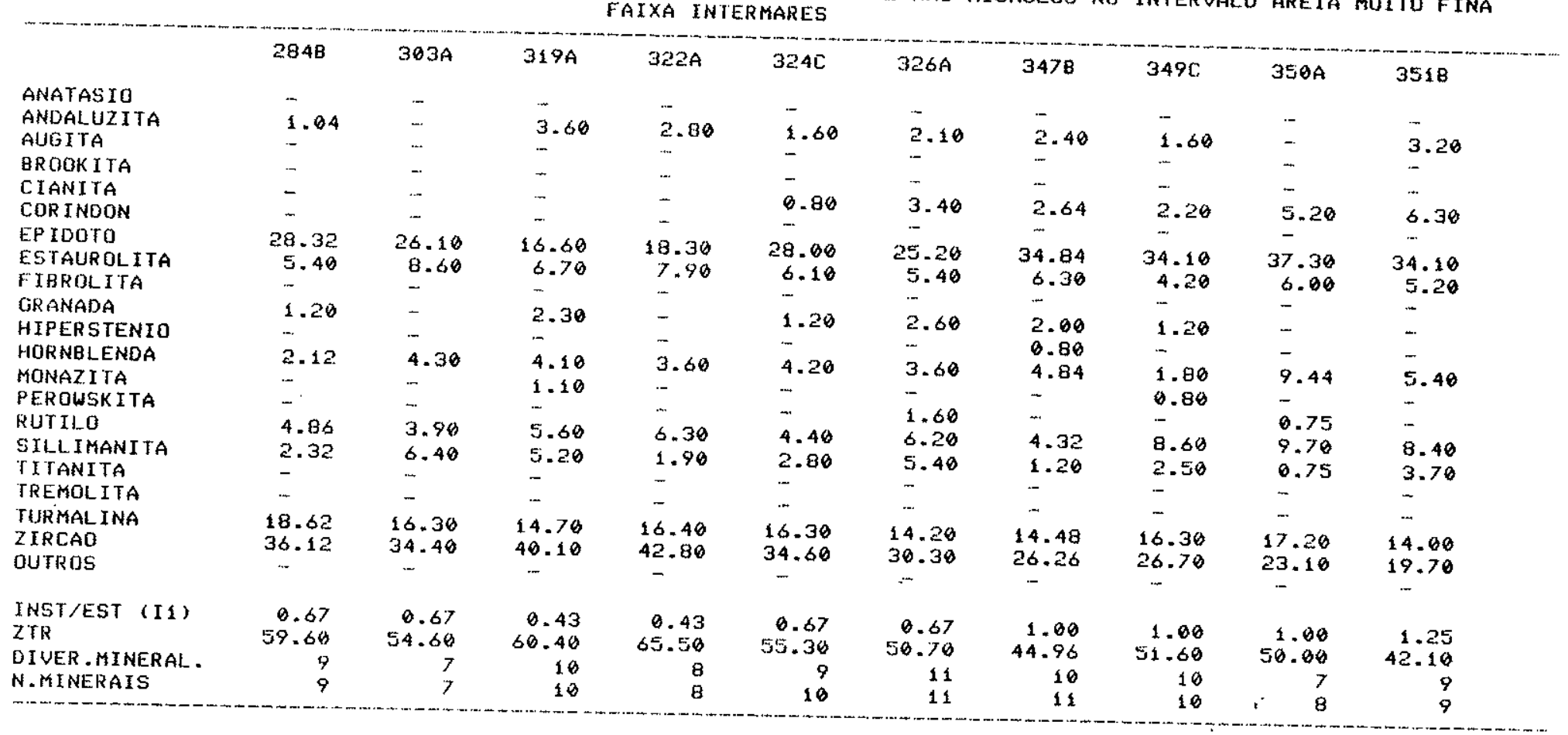


TAGELA 28 - \% DE MINERATS PESADOS TRANSPaRENTES E NAO GICACEOS NO INTERvalo aREIA FINA ZONA DE ARREBENTACAD

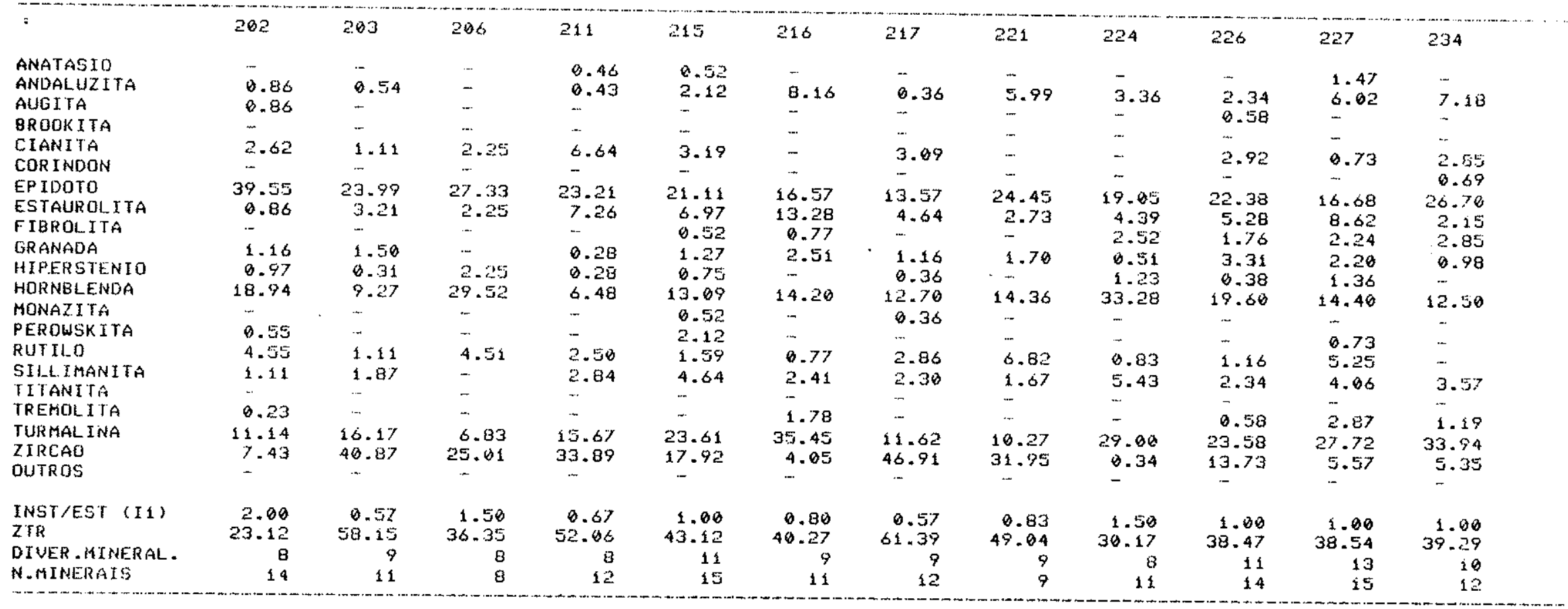


TABELA $28 \cdot(C O N T$.

\begin{tabular}{|c|c|c|c|c|c|c|c|c|c|c|c|c|}
\hline & 239 & 240 & 246 & 249 & 250 & 258 & 259 & 364 & 265 & 266 & 269 & 270 \\
\hline ANATASIO & - & $\ldots$ & $\ldots$ & - & $\ldots$ & .. & .. & - & $\ldots$ & - & $\ldots$ & - \\
\hline ANDALIJZITA & 2.13 & $3.1 \%$ & 1.17 & 1.05 & 5.81 & 3.96 & 5.77 & 2.89 & 4.25 & 3.13 & - & .. \\
\hline AUGI TA & - & - & - & - & - & 0.22 & - & - & - & - & - & - \\
\hline QROOK ITA & - & $-\overline{-}$ & - & - & - & $\ldots$ & - & - & $\ldots$ & - & - & - \\
\hline $\begin{array}{l}\text { CIANITA } \\
\text { CORINDON }\end{array}$ & $\ldots$ & 0.16 & 3.56 & 1.60 & 0.57 & 0.98 & 1.12 & 0.95 & 4.22 & 1.15 & 2.77 & 1.33 \\
\hline EP IDUTO & 33.55 & 35.34 & 26.85 & 26.23 & 30.04 & 24.69 & 27.61 & 34.77 & 32.24 & 13.48 & 34.82 & 30.30 \\
\hline ESTAUROL ITA & 4.31 & 3.94 & 2.13 & 3.71 & 9.35 & 8.94 & 12.48 & 12.09 & 6.85 & 1.11 & 7.64 & 3.35 \\
\hline $\begin{array}{l}\text { FIBROL ITA } \\
\text { GRANADA }\end{array}$ & 1.69 & 2.24 & -7 & 3.21 & 4.05 & 3.47 & 1.72 & 1.44 & 1.92 & 4.32 & 1.37 & 7.41 \\
\hline $\begin{array}{l}\text { GRANADA } \\
\text { HIPERSTENIOO }\end{array}$ & 0.40 & 30 & 1.73 & 1.56 & 1.78 & 3.00 & .2 .05 & 3.09 & 8.63 & 1.21 & 3.15 & 2.12 \\
\hline $\begin{array}{l}\text { HIPERSTENIO } \\
\text { HORNELENDA }\end{array}$ & $\begin{array}{l}0.69 \\
7.68\end{array}$ & $\begin{array}{r}0.91 \\
12.24\end{array}$ & $\{b .31$ & $\begin{array}{r}3.16 \\
26.44\end{array}$ & $\begin{array}{r}8.88 \\
14.10\end{array}$ & $\begin{array}{r}8.49 \\
37.30\end{array}$ & 0.65 & 6.59 & $\cdots$ & 3.26 & 0.37 & - \\
\hline MONAZITIA & $\ldots$ & 0.75 & 1.17 &.-7 & 14.10 & $=-2-26$ & 13.57 & 10.32 & 12.84 & 53.77 & 14.44 & 18.58 \\
\hline PEROWSK ITA & -. & - & 8.58 & 0.50 & $\ldots$ & .. & $\ldots$ & - & 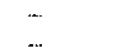 & - & - &. \\
\hline RUTILO & 6.79 & 3.78 & $4 .\{8$ & .. & 1.73 & 0.47 & .. & 0.46 & 1.30 & 0.78 & 0.91 & 0.66 \\
\hline SILLINANTTA & 1.15 & 2.43 & 1.76 & 7.48 & 5.39 & 2.66 & 7.59 & 4.83 & 5.36 & 3.04 & 4.09 & 12.13 \\
\hline TITANITA & 0.53 & 0.75 & $\cdots$ & & $\cdots$ & 0.22 & - & 0.46 & $\ldots$ & 0.39 & $\ldots$ & . \\
\hline TREMOOLITA & 1.14 & $\cdots$ & 6.34 & 1.23 & 4.88 & 4.49 & 1.23 & $\ldots$ & -. & 1.90 & 1.58 & 3.84 \\
\hline TURMAL INA & 13.28 & 21.78 & 8.83 & 19.2 .8 & 23.62 & 21.46 & 25.60 & 22.74 & 21.96 & 4.32 & 25.26 & $1 B .99$ \\
\hline $\begin{array}{l}\text { ZIRCAO } \\
\text { OUTROS }\end{array}$ & 26.70 & 12.43 & 31.31 & 7.48 & 1.73 & 1.48 & 0.55 & 5.32 & 8.38 & 2.74 & 3.44 & 12.13 \\
\hline INST/EST (IS) & 1.00 & 120 & 1.00 & 2.00 & 1.56 & 1.50 & 1.25 & 1.50 & 1.50 & 4.60 & 1.50 & 1.58 \\
\hline ZTR & 46.77 & 37.99 & 44.32 & 26.76 & 24.67 & 23.43 & 26.15 & 28.52 & 31.64 & 7.84 & 29.61 & 31.78 \\
\hline GIVER -MINERALL. & 10 & 9 & 11 & 11 & 10 & 9 & 10 & 9 & 10 & 12 & 16 & 9 \\
\hline N.MINERAIS & 13 & 13 & 13 & 13 & 13 & 15 & 12 & 13 & 11 & 14 & 12 & 11 \\
\hline
\end{tabular}




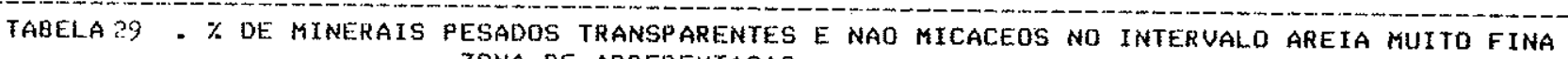

\begin{tabular}{|c|c|c|c|c|c|c|c|c|c|c|c|c|}
\hline & 201 & 202 & 203 & 204 & 205 & 207 & 208 & 210 & 211 & 212 & 213 & 214 \\
\hline $\begin{array}{l}\text { ANATASIO } \\
\text { ANDALUZITA }\end{array}$ & 0.57 & -7 & 0.44 & - & - & 1.03 & - & - & 1.09 & 2.04 & 0.57 & - \\
\hline AUGITA & - & 0.79 & 0.56 & 0.52 & 0.46 & 1.03 & 0.88 & 2.08 & 0.80 & 1.02 & 2.53 & - \\
\hline BROOK ITA & -.. & - & 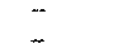 & $\overline{-}$ & - & - & - & - & - & $\sim$ & 0.27 & - \\
\hline CIANITA & 4.10 & 2.27 & 0.91 & 2.10 & 1.87 & 5.33 & $\overline{1} .58$ & 3.13 & 1.09 & 1.02 & - & -5 \\
\hline CORINDON & - & - & - & $\ldots$ & - & - & - & $-\infty$ & \pm-87 & $\begin{array}{l}1.62 \\
-\end{array}$ & $\begin{array}{l}1.96 \\
-\end{array}$ & $\begin{array}{l}0.69 \\
-\end{array}$ \\
\hline $\begin{array}{l}\text { EPIDOTO } \\
\text { ESTAUROLITA }\end{array}$ & $\begin{array}{r}32.48 \\
1.73\end{array}$ & $\begin{array}{r}46.54 \\
2.85\end{array}$ & $\begin{array}{r}32.09 \\
3.72\end{array}$ & $\begin{array}{r}41.36 \\
3.19\end{array}$ & $\begin{array}{r}40.51 \\
3.86\end{array}$ & $\begin{array}{r}34.60 \\
4.57\end{array}$ & $\begin{array}{r}46.86 \\
1.53\end{array}$ & 33.65 & 39.04 & 42.06 & 32.88 & 42.95 \\
\hline FIBROLITA & 0.57 & - & - & $\ldots$ & - & 4.37 & 1.03 & 4.89 & 2.19 & 3.09 & 5.45 & 3.02 \\
\hline GRANADA & 0.35 & 2.56 & 2.24 & 1.64 & 3.86 & 2.97 & 1.97 & - & $\overline{3} .32$ & 0.49 & 0.27 & - \\
\hline HIPERSTENIO & 1.09 & 0.97 & 1.83 & 0.52 & 0.93 & 1.99 & 0.24 & 2.89 & -3.32 & $\begin{array}{l}2.64 \\
3.84\end{array}$ & 1.69 & 4.97 \\
\hline HORNBLENDA & 12.34 & 18.94 & 14.68 & 7.96 & 10.18 & 13.14 & 11.75 & 31.74 & 12.14 & 18.99 & 12.91 & 33.50 \\
\hline MONAZITA & - & -- & 4.38 & $\therefore$ & - & - & - & - & - & - & 0.57 & - \\
\hline PEROWSK ITA & - & 0.55 & 1.38 & 0.52 & 0.84 & - & 0.38 & 1.03 & $0.5 i$ & 0.49 & 1.71 & - \\
\hline RUTILO & 7.66 & 4.55 & 7.91 & 8.00 & 7.00 & 9.63 & 2.64 & 4.16 & 7.50 & 7.77 & 8.03 & $1 . \$ 4$ \\
\hline $\begin{array}{l}\text { SILLIMANTTA } \\
\text { TITANITA }\end{array}$ & 1.73 & 1.11 & 2.30 & - & $\overline{-}$ & 1.34 & 0.79 & 3.64 & 1.09 & 1.54 & 2.21 & 0.34 \\
\hline $\begin{array}{l}\text { TITANITA } \\
\text { TREMOLITA }\end{array}$ & 0.73 & 0.23 & 0.26 & - & 0.35 & - & - & 0.27 & $\ldots$ & - & 1.14 & 1.57 \\
\hline TURMALL INA & 17.70 & 11.14 & 10.79 & 11.71 & 16.14 & 9.63 & 15.66 & 7.31 & 8.34 & . & 16.87 & 8.76 \\
\hline ZIRCAO & 18.89 & 7.43 & 20.03 & 22.42 & 19.95 & 14.66 & 15.66 & 5.75 & 22.83 & 15.55 & 12.26 & 1.38 \\
\hline OUTROS & - & - & .. & - & - & -. & - & - & - & & & \\
\hline INST/EST (I1) & 1.25 & 2.34 & 1.50 & 1.20 & 2.34 & 2.00 & 1.75 & 4.00 & 1.50 & 3.50 & 1.50 & 4.50 \\
\hline ZTK & $41 \ldots$ & 23.12 & 38.93 & 42.13 & 37.09 & $33.9 c^{\prime 2}$ & 33.96 & 17.22 & 38.67 & 23.32 & 37.16 & 11.16 \\
\hline DIVER . MINERAL. & 9 & 9 & 11 & 8 & 8 & 12 & 8 & 11. & 10 & 11 & 12 & 4 \\
\hline N.MINERAIS & 14 & 13 & 15 & 11 & 12 & 12 & 12 & 12 & 12 & 13 & 16 & 11 \\
\hline
\end{tabular}




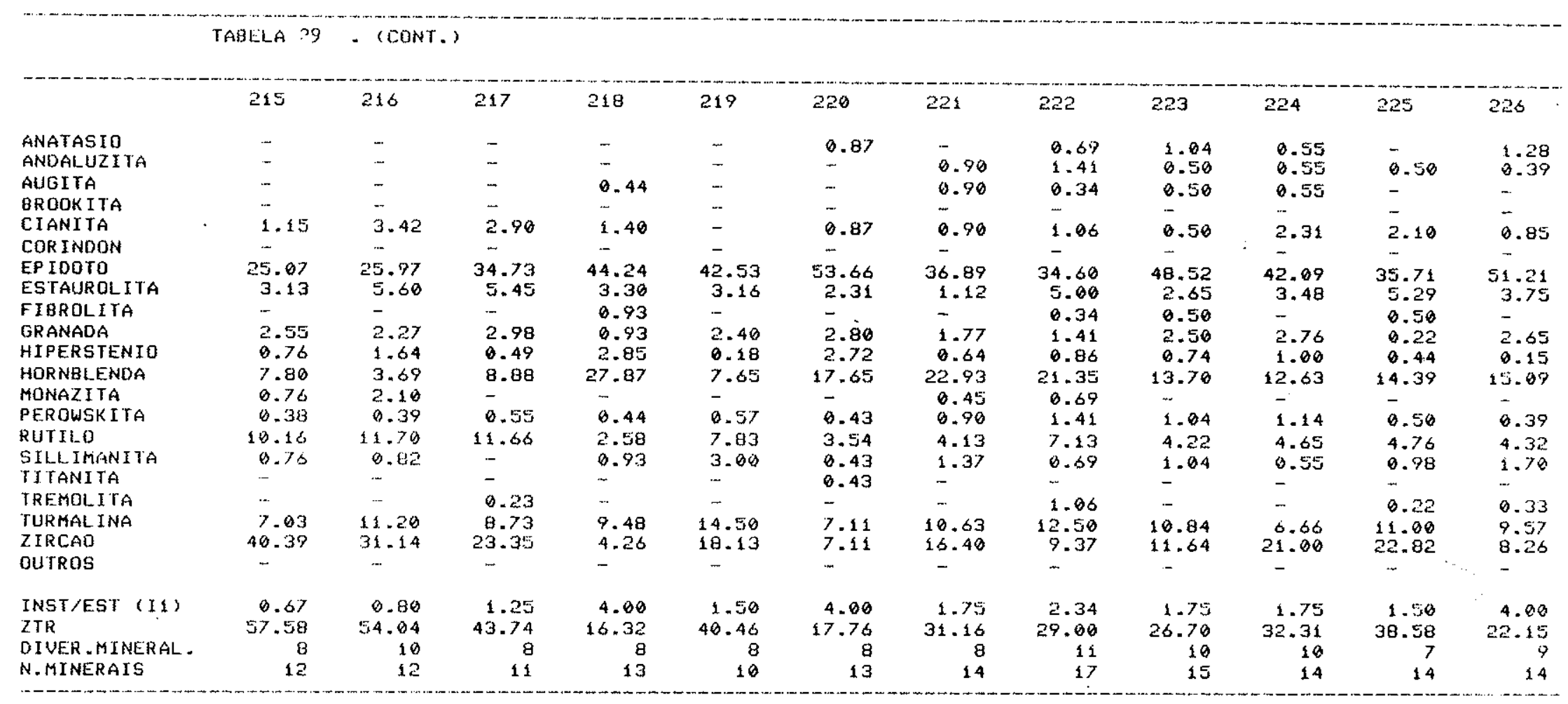


TABELA 29 - (CONT.)

\begin{tabular}{|c|c|c|c|c|c|c|c|c|c|c|c|c|}
\hline & 227 & 228 & 229 & 231 & 232 & 233 & 234 & 235 & 236 & 237 & 238 & 239 \\
\hline $\begin{array}{l}\text { ANATASIO } \\
\text { ANDALUZITA }\end{array}$ & $\begin{array}{l}0.97 \\
0.28\end{array}$ & - & $\begin{array}{l}6.41 \\
0.41\end{array}$ & $\overline{0.76}$ & $\begin{array}{l}1.17 \\
0.55\end{array}$ & 0.71 & $\begin{array}{l}1.05 \\
0.51\end{array}$ & $\begin{array}{l}0.53 \\
1.65\end{array}$ & $\begin{array}{l}1.35 \\
0.32\end{array}$ & $\overline{1.22}$ & 1.51 & $\begin{array}{l}1.54 \\
0.86\end{array}$ \\
\hline AUGITA & - & - & - & - & - & - & - & 0.53 & - & - & $\cdots$ & - \\
\hline BROOKITA & - & -. & - & - & - & $\sim$ & - & - & - & - & - & 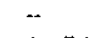 \\
\hline CIANITA & 2.32 & 1.91 & 0.86 & 2.32 & - & - & 1.60 & 4.44 & 0.67 & 2.78 & - & 1.21 \\
\hline CORINDON & - & - & - & - & - & - & - & - & - & - & - & - \\
\hline $\begin{array}{l}\text { EP IDOTO } \\
\text { ESTAUROLITA }\end{array}$ & $\begin{array}{r}23.05 \\
6.65\end{array}$ & $\begin{array}{r}45.46 \\
5.39\end{array}$ & $\begin{array}{r}52.51 \\
1.42\end{array}$ & $\begin{array}{r}52.38 \\
3.40\end{array}$ & $\begin{array}{r}52.48 \\
4.13\end{array}$ & $\begin{array}{r}48.01 \\
2.28\end{array}$ & $\begin{array}{r}30.36 \\
5.66\end{array}$ & $\begin{array}{r}49.63 \\
2.18\end{array}$ & $\begin{array}{r}52.63 \\
1.70\end{array}$ & $\begin{array}{r}45.28 \\
4.03\end{array}$ & $\begin{array}{r}52.42 \\
4.72\end{array}$ & $\begin{array}{r}40.23 \\
5.21\end{array}$ \\
\hline FIBROLITA & - & 0.61 & - & - & - & - & - & - & - & - & 0.50 & 0.15 \\
\hline $\begin{array}{l}\text { GRANADA } \\
\text { HIPER STENIO }\end{array}$ & $\begin{array}{l}3.61 \\
0.32\end{array}$ & $\begin{array}{l}1.68 \\
0.25\end{array}$ & $\begin{array}{l}2.85 \\
1.15\end{array}$ & $\begin{array}{l}1.01 \\
0.28\end{array}$ & $\begin{array}{l}0.97 \\
1.95\end{array}$ & $\begin{array}{l}3.93 \\
0.78\end{array}$ & $\begin{array}{l}4.03 \\
0.57\end{array}$ & $\begin{array}{l}0.78 \\
2.61\end{array}$ & $\begin{array}{l}3.97 \\
0.17\end{array}$ & 0.77 & $\begin{array}{l}4.28 \\
0.56\end{array}$ & 0.86 \\
\hline HORNBLENDA & 7.05 & 9.30 & 9.69 & 9.31 & 16.20 & 10.89 & 11.40 & 22.00 & 26.11 & 17.76 & 10.73 & $11: 17$ \\
\hline MONAZITA & 0.65 & - & - & - & $\cdots$ & - & 0.51 & 0.53 & - & - & - & 1.83 \\
\hline PEROWSKITA & 1.63 & 1.54 & 1.75 & 0.76 & 1.17 & - & - & - & 1.60 & - & 0.50 & 0.56 \\
\hline RUTIL.O & 9.99 & 7.05 & 5.73 & 7.79 & 4.71 & 8.27 & 9.70 & 2.20 & 2.37 & 3.61 & 4.54 & 7.32 \\
\hline SIILIMANITA & 2.32 & 0.61 & 1.75 & 0.28 & 0.55 & - & 0.57 & 3.86 & 2.04 & 1.73 & 1.01 & 1.72 \\
\hline TITANITA & - & - & -- & - & - & - & - & - & 0.32 & - & 0.50 & 0.50 \\
\hline TREMOL ITA & - & 0.25 & - & 1.84 & -. & -- & 0.80 & - & 2.55 & 0.51 & - & - \\
\hline $\begin{array}{l}\text { TURMAL INA } \\
\text { ZIRCAO }\end{array}$ & $\begin{array}{l}16.31 \\
25.37\end{array}$ & 15.00 & 9.67 & 11.22 & 7.15 & 10.78 & $\begin{array}{r}7.81 \\
25.36\end{array}$ & 7.76 & $\begin{array}{l}3.38 \\
1.00\end{array}$ & $\begin{array}{r}17.76 \\
4.50\end{array}$ & $\begin{array}{r}11.00 \\
7.61\end{array}$ & $\begin{array}{l}12.92 \\
14.72\end{array}$ \\
\hline DUTROS & $\begin{array}{l}25.37 \\
-\end{array}$ & $\begin{array}{l}10.90 \\
-\end{array}$ & 11.53 & 8.58 & $\begin{array}{l}8.91 \\
-\end{array}$ & $\frac{14.30}{-}$ & 25.36 & $\begin{array}{l}1.04 \\
-\end{array}$ & $\begin{array}{r}0.32 \\
\text { Dunort }\end{array}$ & - & - & - \\
\hline INST/EST (I1) & 0.80 & 1.58 & 2.34 & 2.34 & 4.00 & 1.75 & 1.50 & 4.88 & 4.50 & 2.34 & 2.67 & 1.75 \\
\hline $2 T R$ & 51.67 & 32.95 & 27.13 & $27.5 ?$ & 20.77 & 33.35 & 42.87 & 11.85 & 6.75 & 25.87 & 23.21 & 34.90 \\
\hline DIUER MINERAL. & 10 & 9 & 10 & 9 & 9 & 7 & 9 & 10 & 11 & 9 & 9 & 10 \\
\hline N.MINERAIS & 14 & 13 & 13 & 13 & 12 & 9 & 14 & 14 & 16 & 11 & 13 & 15 \\
\hline
\end{tabular}


TABELA 29 - (CONT.)

\begin{tabular}{|c|c|c|c|c|c|c|c|c|c|c|c|c|}
\hline & $240^{\circ}$ & 241 & 242 & 243 & 244 & 245 & 246 & 247 & 248 & 249 & 250 & 251 \\
\hline ANATASIO & - & 0.53 & 0.57 & 0.68 & - & - & 0.56 & - & 0.51 & - & 1.26 & - \\
\hline ANDALUZITA & 0.50 & 1.09 & 1.72 & - & - & - & 8.56 & 1.08 & 1.55 & 1.08 & & 1.67 \\
\hline AUGITA & - & - & - & - & 0.57 & - & - & - & - & - & - & - \\
\hline BROOK ITA & - & 0.53 & - & - & & $\overline{1}$ & & $-\overline{-1}$ & - & - & - & - \\
\hline $\begin{array}{l}\text { CIANITA } \\
\text { CORINGON }\end{array}$ & 1.03 & 0.53 & $\overline{-}$ & 1.40 & 2.98 & 1.38 & 4.05 & 2.78 & 3.67 & 1.46 & 1.87 & 1.07 \\
\hline $\begin{array}{l}\text { EP IDOTO } \\
\text { ESTAUROLITA }\end{array}$ & $\begin{array}{r}36.14 \\
3.27\end{array}$ & $\begin{array}{r}54.51 \\
2.40\end{array}$ & $\begin{array}{r}43.61 \\
3.06\end{array}$ & $\begin{array}{r}41.06 \\
3.52\end{array}$ & $\begin{array}{r}51.94 \\
6.55\end{array}$ & $\begin{array}{r}54.34 \\
8.45\end{array}$ & $\begin{array}{r}41.25 \\
5.93\end{array}$ & $\begin{array}{r}49.95 \\
3.84\end{array}$ & $\begin{array}{r}43.34 \\
2.07\end{array}$ & $\begin{array}{r}34.07 \\
5.10\end{array}$ & $\begin{array}{r}29.28 \\
9.85\end{array}$ & $\begin{array}{r}54.33 \\
0.52\end{array}$ \\
\hline FIBROLITA & - & - & 1.14 & - & - & - & 0.56 & - & - & $\ldots$ & - & - \\
\hline $\begin{array}{l}\text { GRANADA } \\
\text { HIPERSTENIO }\end{array}$ & $\begin{array}{l}4.51 \\
2.48\end{array}$ & $\begin{array}{l}1.58 \\
1.29\end{array}$ & $\begin{array}{l}1.03 \\
1.85\end{array}$ & $\begin{array}{l}2.15 \\
0.61\end{array}$ & 6.67 & 1.50 & $\begin{array}{l}2.74 \\
0.30\end{array}$ & $\begin{array}{l}1.21 \\
0.59\end{array}$ & $\begin{array}{l}2.66 \\
3.22\end{array}$ & $\begin{array}{l}4.20 \\
1.42\end{array}$ & $\begin{array}{l}3.45 \\
-\end{array}$ & $\begin{array}{l}0.61 \\
0.19\end{array}$ \\
\hline HORNBLENDA & 16.71 & 17.61 & 28.98 & 11.28 & 20.60 & 13.94 & 9.07 & 17.10 & 23.20 & 11.85 & 14.13 & 19.67 \\
\hline MONAZITA & - & - & $\cdots$ & - & - & $\ddot{z}$ &.- & - & - & - & - & - \\
\hline PEROWSK ITA & 0.50 & 1.09 & 0.57 & - & - & 2.67 & - & - & 0.51 & 1.46 & 1.26 & 0.52 \\
\hline RUTILO & 8.86 & 4.40 & 2.31 & 9. 44 & 2.61 & 5.83 & 3.48 & 1.92 & 1.30 & 6.26 & 9.49 & 2.72 \\
\hline $\begin{array}{l}\text { SILLIMANITA } \\
\text { TITANITA }\end{array}$ & 1.83 & 1.09 & 2.31 & 0.68 & 0.57. & 0.69 & 2.31 & $\begin{array}{l}3.57 \\
-\end{array}$ & 2.88 & 2.92 & 1.87 & 2.17 \\
\hline TREMOL ITA & 1.47 & 0.24 & 0.57 & - & 0.89 & 0.21 & - & 0.29 & 1.30 & 1.31 & 0.23 & - \\
\hline TURMAL INA & 9.89 & 11.38 & 9.30 & 17.44 & 10.78 & 13.28 & 15.74 & 14.88 & 9.49 & 8.48 & 13.30 & 9.35 \\
\hline ZIRCAO & 13.55 & 2.20 & 2.91 & 12.68 & $\{.77$ & 6.28 & 13.38 & 2.73 & 4.21 & 20.33 & 13.95 & 7.70 \\
\hline OUTROS & - & - & - & - & - & - & - & - & - & - & - & - \\
\hline $\begin{array}{l}\text { INST/EST (I1) } \\
\text { ZTR }\end{array}$ & $\begin{array}{r}2.00 \\
32.30\end{array}$ & 2.67 & $\begin{array}{r}4.00 \\
14.5 ?\end{array}$ & $\begin{array}{r}1.75 \\
38.56\end{array}$ & $\begin{array}{r}3.00 \\
15.16\end{array}$ & $\begin{array}{r}2.67 \\
25.39\end{array}$ & 1.50 & $2 \cdot 34$ & 4.00 & 1.50 & 1.25 & 4.08 \\
\hline DIUER . MINERAI. & $\begin{array}{r}32 \cdot 30 \\
11\end{array}$ & $\begin{array}{r}17.98 \\
11\end{array}$ & $\begin{array}{l}14.52 \\
11\end{array}$ & $\begin{array}{r}38.56 \\
8\end{array}$ & $\begin{array}{r}15.16 \\
7\end{array}$ & $\begin{array}{r}25.39 \\
8\end{array}$ & $\begin{array}{r}32.60 \\
9\end{array}$ & $\begin{array}{r}19.53 \\
10\end{array}$ & 15.00 & $\begin{array}{r}35.67 \\
13\end{array}$ & $\begin{array}{r}36.74 \\
11\end{array}$ & 19.77 \\
\hline N.MINERAIS & 13 & 14 & 14 & 11 & 11 & 11 & 13 & 42 & 14 & 13 & 12 & 12 \\
\hline
\end{tabular}


TABELA 29 - (CONT.)

\begin{tabular}{|c|c|c|c|c|c|c|c|c|c|c|c|c|}
\hline & 252 & 253 & 254 & 255 & 256 & 257 & 259 & 260 & 261 & 262 & 264 & 205 \\
\hline AISATASIO & .. & - & $\bullet .35$ & 1.91 & 0.30 & 1.55 & 0.82 & - & - & - & - & 0.39 \\
\hline $\begin{array}{l}\text { FNOBALUZITA } \\
\text { ALGITA }\end{array}$ & $\ldots$ & 1.57 & 1.49 & $\cdots$ & 1.59 & 0.77 & 6.82 & 1. it & 1.54 & $\sim$ & 0.49 & 1.02 \\
\hline ISR $20 \%$ I TA & .. & $\ldots .$. & .. & $\cdots$ & $\ldots$ & + & - & 1.16 & 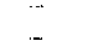 & - & $\overline{-}$ & . \\
\hline $\begin{array}{l}\text { CIANITA } \\
\text { CORINDON }\end{array}$ & 3.18 & 0.38 & 0.73 & 0.91 & 0.94 & 3.20 & 2.75 & 3.52 & 1.64 & 6.93 & 4.33 & 2.62 \\
\hline EPIDOTO & 33.75 & 36.26 & 44.67 & 55.45 & $31.2^{2} 4$ & 4.21 & 32.97 & 45.43 & 44.43 & 43.82 & 28.12 & 44.85 \\
\hline $\begin{array}{l}\text { ESTALUROLITA } \\
\text { FYBROLITA }\end{array}$ & 3.16 & 2.30 & 1.10 & 1.95 & 3.18 & 3.80 & 8.98 & 4.20 & 3.21 & 9.75 & 3.97 & 3.61 \\
\hline $\begin{array}{l}\text { FYBROLITA } \\
\text { GRANADA }\end{array}$ & - & 0.38 & 0.35 & $\cdot-$ & 0.62 & & - & 1.16 & - & - & 0.49 & - \\
\hline $\begin{array}{l}\text { GRANALA } \\
\text { HIPERSTENIO }\end{array}$ & 0.95 & 0.24 & 1.03 & 2.64 & 1.70 & 2.63 & & 2.13 & 1.40 & 1.00 & 3.43 & 2.84 \\
\hline $\begin{array}{l}\text { HIPERSTENIO } \\
\text { HORNBLENDA }\end{array}$ & $\begin{array}{r}0.41 \\
37.37\end{array}$ & $\begin{array}{r}0.17 \\
35 j .36\end{array}$ & $\begin{array}{r}1.46 \\
27.87\end{array}$ & $\begin{array}{l}1.33 \\
9.87\end{array}$ & $\begin{array}{r}2.07 \\
38.89\end{array}$ & $\begin{array}{r}2.38 \\
37.08\end{array}$ & $\overline{2} .65$ & 33.32 & 16.69 & & & 0.10 \\
\hline MONAZITA & - & - & - & $\ldots$ & - & $\ldots$ & - & 23.35 & $\begin{array}{r}16.69 \\
0.54\end{array}$ & 18.69 & 3.41 & 24.82 \\
\hline PEROWSK ITA & - & 0.38 & - & $=$ & 0.30 & 0.77 & 0.82 & .. & $\ldots .$. & 3.88 & 3.49 & 0.39 \\
\hline RUTILD & 1.B. & 2.38 & 1.47 & 8.64 & 2.86 & 6.41 & 8.57 & - & 3.87 & 2.88 & 6.50 & 0.78 \\
\hline $\begin{array}{l}\text { SILLIKANITA } \\
\text { TITAISITA }\end{array}$ & 3.64 & 1.17 & 2.64 & 1.41 & 2.86 & 1.55 & 2.23 & 2.41 & 2.42 & 0.93 & 6.79 & 3.63 \\
\hline $\begin{array}{l}\text { TITAKITA } \\
\text { TREMULITA }\end{array}$ & $\cdots$ & $\begin{array}{l}0.38 \\
1.57\end{array}$ & 0.73 & .... & $\cdots 3 a$ & 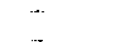 & $\cdots$ & - & - - & 0.93 & & - \\
\hline $\begin{array}{l}\text { TREMUL ITA } \\
\text { FURMAL INA }\end{array}$ & & $\begin{array}{r}1.57 \\
12.45\end{array}$ & 0.92 & $\cdots$ & 0.30 & - & 0.41 & - & 0.76 & - & 0.45 & -- \\
\hline $\begin{array}{l}\text { IURMAL INA } \\
\text { ZIRCAO }\end{array}$ & $\begin{array}{r}14.15 \\
4.54\end{array}$ & 12.95 & 14.65 & 5.28 & 12.47 & 10.43 & 13.80 & 15.01 & 12.65 & 9.09 & 14.35 & $13.5 ?$ \\
\hline $\begin{array}{l}\text { ZLRCAO } \\
\text { OUTROS }\end{array}$ & 4.54 & 4.37 & 1.16 & 10.56 & 0.62 & 24.95 & 22.37 & 0.46 & 20.78 & 9.44 & 29.93 & 3.43 \\
\hline OUTROS & $\cdots$ & - & -.. & - & $\approx$ & - & - & - & & - & - & -- \\
\hline INST/EST (IL) & 2.67 & 2.67 & 2.67 & 2.34 & $2.6 \%$ & 1.00 & 1.00 & 2.67 & 1.75 & 3.56 & 0.80 & 2.57 \\
\hline ZTR & 17.50 & 19.70 & 17.22 & 24.48 & 15.95 & 41.79 & 44.74 & 15.47 & 27.22 & 21.41 & 50.76 & 16.80 \\
\hline DIUER .MINERAL . & 8 & 9 & 10 & 18 & 9 & 11 & 9 & 10 & 18 & 8 & $\theta$ & 9 \\
\hline N.MINERAIS & 16 & 35 & 15 & 15 & 15 & 13 & 13 & 11 & 12 & 11 & 13 & 13 \\
\hline
\end{tabular}




\begin{tabular}{|c|c|c|c|c|c|c|c|}
\hline & 266 & 267 & 268 & 269 & 276 & 271 & 272 \\
\hline ANATASTD & 0.30 & 0.76 & $\therefore$ & $2.2 \theta$ & $\cdots$ & 0.23 & 1.67 \\
\hline & 1.62 & 1.17 & 0.33 & 1.75 & 2.00 & 0.75 & - \\
\hline $\begin{array}{l}\text { ALGITA } \\
\text { UROOKITA }\end{array}$ & 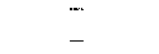 & 0.35 & 1.84 & - & - & 2.23 & $\overline{-}$ \\
\hline $\begin{array}{l}\text { CIANITA } \\
\text { CORINDON }\end{array}$ & 1.21 & 2.75 & 0.66 & 0.42 & 1.50 & 2.23 & 2.75 \\
\hline EPTDOTO & 37.39 & 30.81 & 42.76 & 39.11 & 40.97 & 30.29 & 38.34 \\
\hline $\begin{array}{l}\text { ESTALROLITA } \\
\text { FIBROLITA }\end{array}$ & $\begin{array}{l}5.94 \\
6.38\end{array}$ & 5.86 & $\begin{array}{l}3.12 \\
0.33\end{array}$ & 5.57 & $\begin{array}{l}4.54 \\
0.47\end{array}$ & 3.86 & $\begin{array}{l}5.86 \\
1.88\end{array}$ \\
\hline GRANADA & 1.8 .2 & $1.6 ?$ & 3.64 & 3.74 & 2.95 & 1.73 & 5.81 \\
\hline HLPERSTENIO & 0.20 & 0.67 & 0.21 & 0.62 & 0.47 & -- & 2.01 \\
\hline HORNBLENDA & 21.71 & 10.03 & 25.57 & 5.96 & 11.43 & 11.58 & 22.66 \\
\hline MONAZITA & - & - & - & 0.42 & - & - & $\ldots$ \\
\hline PEROWSK ITA & 1.21 & 1.17 & - & 0.85 & 1.80 & 0.23 & 0.54 \\
\hline RUTILO & 3.65 & 7.51 & 3.94 & 6.12 & 4.04 & 7.51 & $3.8 B$ \\
\hline $\begin{array}{l}\text { SILLIMANITA } \\
\text { TITANITA }\end{array}$ & $\begin{array}{l}4.45 \\
0.38\end{array}$ & 1.96 & 1.72 & 2.61 & 2.51 & 1.49 & 3.73 \\
\hline TREMOLITA & $\ldots$ & 2.01 & 0.91 & 0.42 & - & 1.02 & 1.32 \\
\hline TURHAL INA & 14.90 & 17.01 & 8.62 & 16.69 & 21.28 & 22.56 & 8.94 \\
\hline $\begin{array}{l}\text { ZIRCAO } \\
\text { DUTROS }\end{array}$ & 4.68 & 16.22 & 7.69 & 14.35 & 6.08 & 16.26 & 2.21 \\
\hline $\begin{array}{l}\text { INST/EST (IS) } \\
\text { ZTR }\end{array}$ & $\begin{array}{r}2.34 \\
23.23\end{array}$ & $\begin{array}{r}1.50 \\
40.74\end{array}$ & $\begin{array}{r}4.00 \\
20.25\end{array}$ & $\begin{array}{r}1.25 \\
37.15\end{array}$ & $\begin{array}{r}1.75 \\
31.40\end{array}$ & $\begin{array}{r}1.20 \\
46.33\end{array}$ & $\begin{array}{r}3.50 \\
15.03\end{array}$ \\
\hline DIVER . MINERAL. & 11 & 12 & 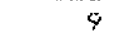 & 10 & is & 10 & 13 \\
\hline N.MINERAIS & 15 & 15 & 14 & 15 & 13 & 14 & 14 \\
\hline
\end{tabular}




\begin{tabular}{|c|c|c|c|c|c|c|c|c|c|c|c|c|}
\hline & FABELA 30 & \% DE & ERAIS $\mathrm{P}$ & ADOS TR & $\begin{array}{l}\text { SPARENT } \\
\text { ATAFORM }\end{array}$ & $\underset{\text { EASA }}{E N A O}$ & ICACEOS NO & INTERV & O AREIA & INA & & \\
\hline & 149 & 156 & 152 & 153 & 154 & 155 & 156 & 157 & 158 & 159 & 161 & 162 \\
\hline ALATAOSIO & - & 0.37 & $\ldots$ & $\ldots$ & $\ldots$ & 0.40 & - & $\cdots$ & 0.32 & 1.01 & - & - \\
\hline $\begin{array}{l}\text { ANDAIUZTTA } \\
\text { AUGITA }\end{array}$ & 3.82 & 3.65 & 4.24 & 1.98 & $\begin{array}{l}1.32 \\
0.60\end{array}$ & 1.19 & $\begin{array}{l}1.13 \\
0.77\end{array}$ & 1.57 & 1.00 & 4.09 & 4.33 & 4.44 \\
\hline BROOKITA & 0.55 & 0.74 & $\cdots$ & - & $\ldots$ & $\ldots$ & . & 1.56 & $\bar{z}$ & - & 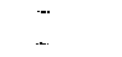 & $\cdots$ \\
\hline $\begin{array}{l}\text { CIANITA } \\
\text { CORINDON }\end{array}$ & 1.90 & 1.91 & 4.2 .4 & $\begin{array}{l}4.36 \\
\ldots\end{array}$ & 2.13 & 1.79 & 3.57 & 1.74 & 0.66 & 1.50 & 3.59 & 3.18 \\
\hline EP IDOTO & 22.130 & 25.85 & 47.50 & 29.83 & 30.27 & 37.08 & 29.07 & 26.55 & 18.98 & 28.77 & 26.69 & 2c.39 \\
\hline $\begin{array}{l}\text { EGTAIJROLITA } \\
\text { FIBROLITA }\end{array}$ & 4.52 & 4.84 & $\begin{array}{l}5.93 \\
0.37\end{array}$ & 4.50 & 2.44 & 1.56 & 2.60 & 5.10 & 0.58 & 4.89 & 3.59 & 3.92 \\
\hline GRANADA & 1.67 & 2.32 & $\begin{array}{l}0.37 \\
1.00\end{array}$ & 2.36 & 2.04 & in & $\overline{3}$ & 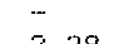 & $\bar{a} 7 a$ & - & 0.71 & 0.01 \\
\hline HIPERSTENIO & 0.00 & 2.18 & 1.20 & 1.17 & $\begin{array}{l}2.04 \\
0.28\end{array}$ & $\begin{array}{l}1.18 \\
6.36\end{array}$ & 2.46 & $\begin{array}{l}2.29 \\
0.88\end{array}$ & $\begin{array}{l}0.70 \\
2.72\end{array}$ & $\begin{array}{l}2.19 \\
1.76\end{array}$ & & 1.69 \\
\hline HORNBLENDA & 22.82 & 26.10 & 26.51 & 29.55 & 16.55 & 9.60 & 17.81 & 16.00 & 59.88 & 32.79 & $\begin{array}{r}1.31 \\
24.65\end{array}$ & $\begin{array}{r}1.89 \\
3.3 .41\end{array}$ \\
\hline MONAZITA & 0.98 & 0.37 & $\cdots$ & $\cdots$ & 0.43 & $\cdots$ & 0.44 & 0.59 & - & 0.49 & $\ldots$ &.- \\
\hline PEROWSK ITA & 1.55 & $\cdots$ & $\cdots$ & - & 1.20 & 0.08 & - & 0.59 & .. & $\ldots$ & -. & - \\
\hline RUFILO & 1.33 & 0.74 & 1.69 & 0.38 & 4.05 & 3.68 & 0.23 & 2.52 & 0.66 & 0.49 & - & 0.61 \\
\hline $\begin{array}{l}\text { SILLIMANITA } \\
\text { TITANITA }\end{array}$ & $\begin{array}{l}4.87 \\
\cdots\end{array}$ & 5.06 & 2.52 & 1.57 & 8.91 & $\begin{array}{l}2.21 \\
1.74\end{array}$ & 1.79 & 3.43 & 0.93 & $\begin{array}{l}2.32 \\
-\end{array}$ & $\begin{array}{l}7.21 \\
-.\end{array}$ & 1.89 \\
\hline TREMOLITA & 0.70 & 1.51 & 0.37 & $\{.58$ & - & 0.49 & 0.64 & - & - & 0.26 & 2.22 & 9.25 \\
\hline TURMAL INA & 20.89 & 19.48 & 20.27 & 15.53 & 18.37 & 11.81 & $16.4 B$ & 20.12 & 9.91 & 11.26 & 28.55 & 22.58 \\
\hline $\begin{array}{l}\text { ZIRCAO } \\
\text { OUTRQS }\end{array}$ & 12.25 & 6.20 & 8.08 & 7.95 & 19.35 & 26.83 & 24.35 & 16.98 & 3.61 & 9.00 & 10.86 & 3.18 \\
\hline $\begin{array}{l}\text { INSTIEST (I1) } \\
\text { ZTR }\end{array}$ & $\begin{array}{r}1.28 \\
34.37\end{array}$ & $\begin{array}{r}2.06 \\
26.42\end{array}$ & $\begin{array}{r}1.25 \\
36.04\end{array}$ & $\begin{array}{r}2.80 \\
23.85\end{array}$ & $\begin{array}{r}1.50 \\
41.67\end{array}$ & $\begin{array}{r}1.80 \\
42.32\end{array}$ & $\begin{array}{r}1.00 \\
41.06\end{array}$ & $\begin{array}{r}2.06 \\
39.62\end{array}$ & $\begin{array}{r}4.08 \\
14.18\end{array}$ & $\begin{array}{r}2.34 \\
20.75\end{array}$ & $\begin{array}{r}1.20 \\
31.41\end{array}$ & $\begin{array}{r}1.75 \\
26.37\end{array}$ \\
\hline DIVER . MINERAL. & 11 & 11 & 11 & i1 & 10 & $1 \hat{1}$ & 9 & 11 & 6 & 11 & 10 & 10 \\
\hline N.MINERAIS & 15 & 15 & 13 & 12 & 14 & 15 & 13 & 14 & 12 & 14 & 12 & 12 \\
\hline
\end{tabular}


TABELA 30 - (CON1.)

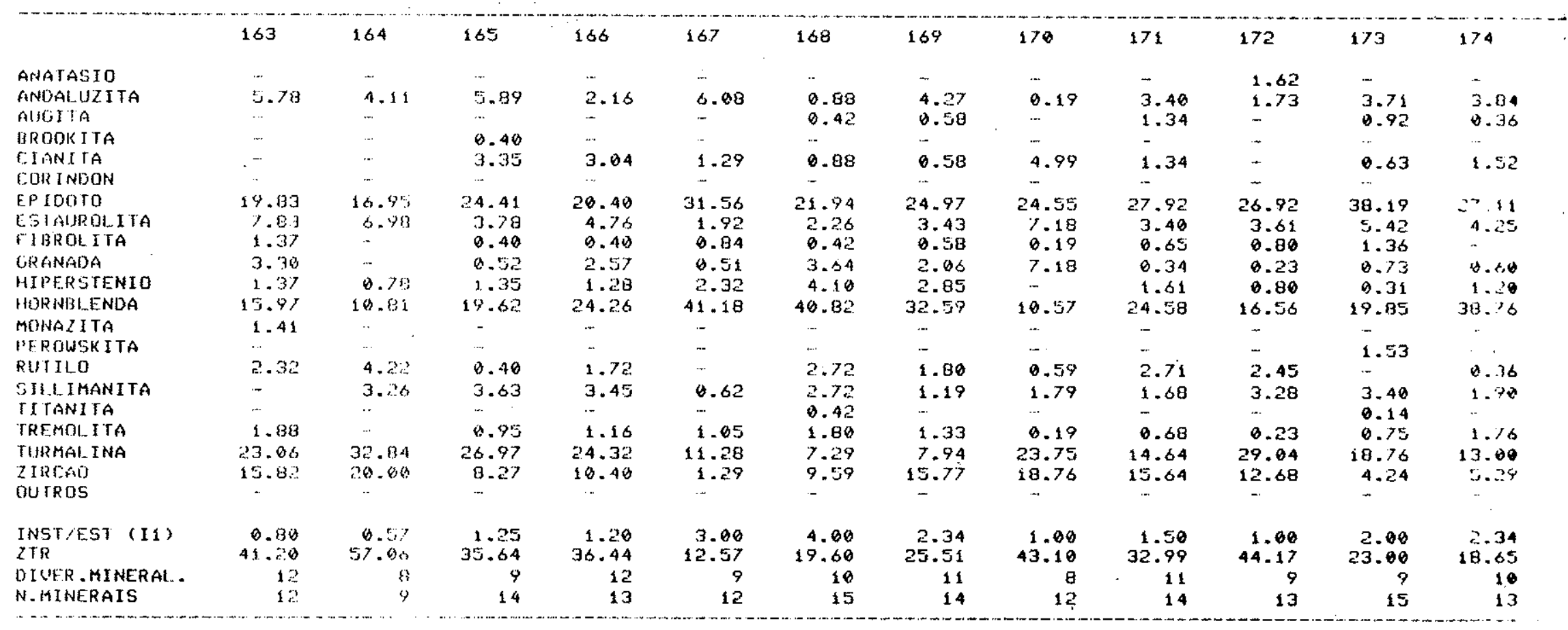


TABELA 30 - (CONT.;

\begin{tabular}{|c|c|c|c|c|c|c|c|c|c|c|c|c|}
\hline & 189 & 190 & 191. & 193 & 194 & 156 & 197 & 198 & 199 & 275 & 276 & 277 \\
\hline ANATASTO & -. & $\cdots$ & $\cdots$ & - & 0.45 & 0.60 & 0.50 & $\cdot 0.26$ & 0.28 & - & .. & 0.49 \\
\hline ANDALUZITA & 7.04 & 2.67 & 2.71 & 7.05 & 3.22 & 1.81 & 1.15 & 0.26 & 1.44 & 5.55 & 1.39 & 3.58 \\
\hline ALIGITA & $\infty$ & - & $\cdots$ & 1.62 & - & 0.60 & 1.15 & - & 1.37 & - & & $\cdots$ \\
\hline $\begin{array}{l}\text { BROOK ITA } \\
\text { CTANITA }\end{array}$ & $\therefore$ & .. & .. & ..- & - & -- & - & $\ldots$ & $\cdots$ & -.. & $\ldots$ & \\
\hline $\begin{array}{l}\text { CIANITA } \\
\text { CORINDON }\end{array}$ & 1.65 & - & 4.08 & 1.20 & 2.04 & 1.01 & 1.15 & 1.06 & - & 3.05 & - & 1.51 \\
\hline EPIDOTO & 33.53 & 30.51 & 20.25 & 31.48 & 34.06 & 23.46 & 49.79 & 47.08 & 37.90 & 22.84 & 22.89 & 22.58 \\
\hline ESTAUROLITA & 6.67 & 9.07 & $4.7 \mathrm{~s}$ & 0.77 & 5.47 & 3.88 & 2.13 & 2.95 & 5.24 & 6.91 & 2.89 & 9.41 \\
\hline F I GROL. ITA & 0.72 & 0.66 & $\cdots$ & 1.76 & 2.77 & 0.39 & $\cdots$ & - & 0.17 & 1.85 & 1.05 & 1.02 \\
\hline $\begin{array}{l}\text { GRANADA } \\
\text { HIPERSTENIO }\end{array}$ & - & 0.97 & 1.26 & 0.87 & 0.34 & 0.79 & 1.20 & 1.58 & 0.99 & 2.71 & 2.89 & 4.33 \\
\hline $\begin{array}{l}\text { HIPERSTENIO } \\
\text { HORNBLENDA }\end{array}$ & $\begin{array}{l}1.36 \\
17.36\end{array}$ & $\begin{array}{r}1.14 \\
23.8 \%\end{array}$ & & $\begin{array}{r}0.16 \\
22.01\end{array}$ & 2.51 & 0.19 & 1.20 & 0.98 & - & 1.35 & 2.14 & 0.68 \\
\hline $\begin{array}{l}\text { MORNALERUA } \\
\text { MONAZA }\end{array}$ & 17.36 & $\begin{array}{l}23.87 \\
--\end{array}$ & $\begin{array}{l}32.34 \\
\ldots .\end{array}$ & $\begin{array}{r}22.01 \\
0.41\end{array}$ & 22.08 & 6.16 & 16.65 & 29.96 & 14.38 & 31.66 & 32.36 & 17.86 \\
\hline PEROWSKITA & - & $\ldots$ & 0.65 & 0.59 & - & 0.19 & $\cdots$ & 0.18 & 0.48 & 0.60 & $\cdot$ & 1.62 \\
\hline RUIILO & 1.74 & 0.66 & 0.96 & 1.35 & ... & 4.51 & 5.85 & 1.33 & 2.46 & $\overline{-}$ & $i .60$ & 0.49 \\
\hline SILITKANITA & - & 4.33 & 5.29 & 6.39 & 1.38 & 3.67 & 1.15 & 0.65 & 1.26 & 0.60 & -. & 3.86 \\
\hline TI TANI I TA & $\cdots$ & $\cdots$ & 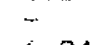 & 0.41 & $\cdots$ & - & - & - & - & 0.60 & . & - \\
\hline TREMOLITA & - & -. & 1.34 & 0.51 & 2.46 & 3.67 & - & 8.58 & 0.28 & 0.60 & 0.95 & 0.34 \\
\hline TURMALINA & 22.51 & 23.01 & 19.16 & 21.13 & 22.26 & 19.75 & 7.00 & 10.65 & 16.27 & 21.07 & 13.00 & 27.64 \\
\hline ZIRCAO & $7.3 \mathrm{E}$ & $3.3 \%$ & 5.45 & 2.82 & 8.91 & 30.65 & 16.96 & 2.41 & 17.41 & 1.20 & 16.81 & 5.51 \\
\hline OUTROS & $\cdots$ & $\cdots$ & 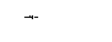 & .- & 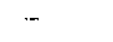 & - & $-\cdots$ & m & - & - & - & - \\
\hline INST/EST (IA) & 1.58 & 1.75 & 2.34 & 1.75 & 1.75 & 0.67 & 2.34 & 2.67 & 1.50 & 1.75 & 1.75 & 1.25 \\
\hline $\begin{array}{l}\text { ZTR } \\
\text { OUUER MYNERAL }\end{array}$ & 31.60 & 27.04 & 25.51 & 25.30 & 23.17 & 54.91 & 29.81 & 14.39 & 36.14 & 22.27 & 33.41 & 33.64 \\
\hline $\begin{array}{l}\text { OIVER MINERAL. } \\
\text { N.MINERAIS }\end{array}$ & 19 & $\begin{array}{r}a \\
11\end{array}$ & $\begin{array}{l}11 \\
13\end{array}$ & $\frac{10}{17}$ & $\begin{array}{l}16 \\
13\end{array}$ & $\begin{array}{l}10 \\
16\end{array}$ & $\begin{array}{l}12 \\
13\end{array}$ & $\begin{array}{r}8 \\
+4\end{array}$ & $\begin{array}{r}9 \\
14\end{array}$ & $\begin{array}{l}10 \\
14\end{array}$ & 18 & 11 \\
\hline & & 12 & 1.5 & & & & & & & 14 & 11 & 15 \\
\hline
\end{tabular}




\begin{tabular}{|c|c|c|c|c|c|c|c|}
\hline & ABEL_A 30 & $(\operatorname{CONT}$ & & & & & \\
\hline & 279 & 280 & 281 & 282 & 283 & 321 & 322 \\
\hline ANATASIO & - & . & - & - & 0.44 & .. & .- \\
\hline $\begin{array}{l}\text { ANDALIUZITA } \\
\text { AUGITA }\end{array}$ & 1.09 & 3.42 & 4.86 & 6.14 & 7.34 & 4.12 & 4.75 \\
\hline BROOKITA & $\begin{array}{l}1.69 \\
\ldots\end{array}$ & $\cdots$ & - & $\ldots$ & -.. & $\begin{array}{l}8.39 \\
-\end{array}$ & - \\
\hline $\begin{array}{l}\text { CIANITA } \\
\text { COR INDON }\end{array}$ & 3.54 & 0.77 & 0.79 & 0.47 & 0.90 & $\overline{0.81}$ & $\cdots$ \\
\hline EP IDORO & 23.61 & 33.29 & 18.19 & 34.30 & 19.94 & 22.60 & 22.98 \\
\hline $\begin{array}{l}\text { ESTAUROL ITA } \\
\text { FIBROL ITA }\end{array}$ & $\begin{array}{l}3.49 \\
1.28\end{array}$ & $\begin{array}{l}2.65 \\
0.25\end{array}$ & $\begin{array}{r}16.34 \\
2.84\end{array}$ & $\begin{array}{l}6.56 \\
1.62\end{array}$ & 10.11 & 3.48 & 4.25 \\
\hline GRANADA & 8.93 & $\ldots$ & 3.66 & 8.05 & $\begin{array}{l}2.75 \\
3.13\end{array}$ & $\begin{array}{l}0.81 \\
0.49\end{array}$ & 1.05 \\
\hline HIPERSTENIO & 0.13 & 0.23 & $\ldots$ & 0.31 & 0.48 & $\therefore=77$ & $\begin{array}{l}4.1 .7 \\
2.31\end{array}$ \\
\hline HORNBLENDA & 21.29 & 24.58 & $\{1.23$ & 18.97 & 10.76 & 38.56 & 32.20 \\
\hline MONAZITA & 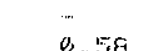 & $\ldots$ & $\cdots$ & $\cdots$ & .. & $\cdots$ & $\cdots$ \\
\hline $\begin{array}{l}\text { PEROWSKITA } \\
\text { RUTILO }\end{array}$ & $\begin{array}{l}0.58 \\
0.93\end{array}$ & 0.94 & $\cdots$ & $\cdots$ & 0.44 & 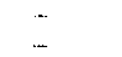 & - \\
\hline $\begin{array}{l}\text { RUTILO } \\
\text { SILILIMANITA } \\
\text { TITALITA }\end{array}$ & 2.53 & 1.81 & 4.87 & 1.96 & 5.60 & 4.11 & 3.80 \\
\hline $\begin{array}{l}\text { TKEHOL ITA } \\
\text { TURMAL TKA }\end{array}$ & $\begin{array}{r}9.43 \\
34.17\end{array}$ & $\begin{array}{r}0.51 \\
26.34\end{array}$ & $\begin{array}{r}0.18 \\
37.01\end{array}$ & $\begin{array}{r}1.78 \\
22.94\end{array}$ & $\begin{array}{r}2.87 \\
34.73\end{array}$ & 24.58 & $\begin{array}{r}0.35 \\
23.59\end{array}$ \\
\hline$Z[R C A O$ & 4.85 & $4.8 E$ & 8.79 & 4.0 .4 & 0.44 & ... & 0.50 \\
\hline OUTROS & $\ldots$ & $\begin{array}{r}0.23 \\
\text { nost inat }\end{array}$ & $\ldots$ & 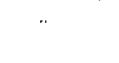 & - & -. & $\ldots$ \\
\hline INST/EST (II) & 1.20 & 1.75 & 8.80 & 3.50 & 0.80 & 2.34 & 1.75 \\
\hline ZTR & 39.95 & 32.19 & 37.86 & 26.98 & 35.81 & 24.58 & 24.09 \\
\hline O I UER - MINERALI. & 18 & 7 & 8 & 9 & 3. & 6 & 9 \\
\hline N.MINERAIS & 15 & 13 & 11 & 12 & 14 & 10 & $1 i$ \\
\hline
\end{tabular}




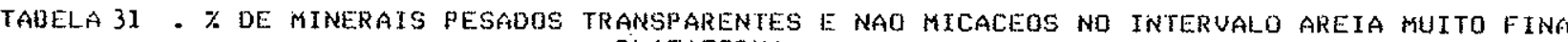
PLATAFORKA RASD

\begin{tabular}{|c|c|c|c|c|c|c|c|c|c|c|c|c|}
\hline & 149 & $15 \theta$ & 151 & 152 & 153 & 154 & 155 & 156 & 157 & 158 & 159 & 161 \\
\hline ANATASTO & 0.82 & $\cdots$ & $\cdots$ & $\cdots$ & 0.62 & 9.35 & 0.46 & 0.55 & $\cdots$ & 0.35 & 0.53 & - \\
\hline ANDALUZITA & 0.62 & 1.55 & 0.72 & 0.39 & - & 0.37 & 0.59 & - & 0.67 & 0.35 & $\ldots$ & $\ldots$ \\
\hline AUGITA & $0.6 a^{3}$ & 0.94 & 0.86 & 0.78 & 0.62 & 2.38 & 2.37 & 3.66 & 1.41 & 4.00 & 1.59 & - \\
\hline BKOOK ITA & $\cdot-$ & - & ... & $\cdots$ & - & - & - & - & - & - & . & $\ldots$ \\
\hline $\begin{array}{l}\text { CIANITA } \\
\text { CORINDON }\end{array}$ & 1.94 & 1.61 & 3.41 & 3.83 & $\begin{array}{l}0.31 \\
\cdots\end{array}$ & 0.66 & 1.26 & $\ddot{-}$ & 1.56 & 0.70 & 1.57 & 4.22 \\
\hline EIP IDOTO & 26.89 & 31.50 & 29.92 & 22.66 & 34.67 & 30.04 & 45.24 & 38.65 & 35.46 & 32.99 & 48.50 & 15.98 \\
\hline $\begin{array}{l}\text { ESTAUROLITA } \\
\text { FIBROLITA }\end{array}$ & 0.91 & 3.77 & 5.21 & 8.06 & 1.74 & 2.24 & 1.68 & 0.84 & 2.82 & 5.75 & $\begin{array}{l}2.315 \\
0.53\end{array}$ & 0.19 \\
\hline GRGANADA & 2.52 & 1.73 & 0.26 & 1.52 & 3.91 & 3.84 & - . & 4.05 & 3.16 & 1.56 & 1.87 & 1.84 \\
\hline HIPERSTENIO & 7.77 & 0.65 & 0.60 & 0.63 & 5.27 & 5.82 & 1.10 & 7.28 & 0.33 & 1.77 & 0.81 & 0.41 \\
\hline I HOR HBLENDA & 27.94 & 14.47 & 11.24 & 9.09 & 2.1 .28 & 26.81 & 21.92 & 29.33 & 11.78 & 21.50 & $1 \Xi .87$ & $2.9 ?$ \\
\hline MONAZITA & - & 0.47 & 0.82 & 0.39 & - & 1.98 & - & $\ldots$ & - & 0.35 & - & 2.09 \\
\hline PEROWSK ITA & 0.62 & 0.17 & 0.46 & 0.39 & 0.62 & 0.37 & -.. & - & 0.51 & 0.35 & - & 0.83 \\
\hline RUTILO & 4.71 & 3.82 & 4.36 & 6.42 & 3.14 & 4.36 & 2.27 & 1.39 & 3.16 & 1.45 & 3.42 & $0.1 \% 0$ \\
\hline SILLIMANITA & 0.91 & .. & 2.30 & 0.78 & ... & 0.37 & 2.05 & 0.67 & 0.67 & 0.35 & 3.20 & 0.82 \\
\hline TITANI TA & 0.93 & - & - & .. & 0.62 & - & 8.59 & -- & 0.33 & - & - & - \\
\hline TREMOLITA & 0.19 & 0.29 & - & - & $\cdots$ & -- & $\ldots$ & $\ldots$ & 0.69 & $\cdots$ & 0.73 & 0.41 \\
\hline TURMALINA & 7.62 & $15.0 \mathrm{~L}$ & 19.87 & 13.92 & 10.07 & 6.77 & 8.70 & 7.61 & 15.22 & 12.77 & 9.71 & 15.69 \\
\hline $\begin{array}{l}\text { ZIRCAO } \\
\text { OUTROS }\end{array}$ & 15.13 & 23.77 & 17.97 & 31.88 & .47 .63 & $1 \pm .16$ & 11.73 & 5.92 & 22.25 & 15.70 & 12.43 & 42.70 \\
\hline $\begin{array}{l}\text { INST/EST (IS) } \\
\text { ZTR }\end{array}$ & $\begin{array}{r}1.33 \\
27.46\end{array}$ & $\begin{array}{r}1.20 \\
42.60\end{array}$ & $\begin{array}{r}\lambda .25 \\
44.20\end{array}$ & $\begin{array}{r}0.67 \\
51.42\end{array}$ & $\begin{array}{r}1.75 \\
30.84\end{array}$ & $\begin{array}{r}2.33 \\
20.29\end{array}$ & $\begin{array}{r}2.67 \\
22.76\end{array}$ & $\begin{array}{r}3.50 \\
14.92\end{array}$ & $\begin{array}{r}1.20 \\
40.63\end{array}$ & $\begin{array}{r}1.75 \\
29.92\end{array}$ & $\begin{array}{r}2.34 \\
25.56\end{array}$ & $\begin{array}{r}0.43 \\
65.14\end{array}$ \\
\hline W WER - MINERAL . & 8 & 9 & 8 & \% & 8 & $\{6$ & 10 & 8 & 9 & 9 & 9 & 3 \\
\hline N. MINERAIS & 16 & $\{4$ & 14 & 19 & 13 & 15 & 13 & 1.1 & 15 & 15 & 14 & 23 \\
\hline
\end{tabular}




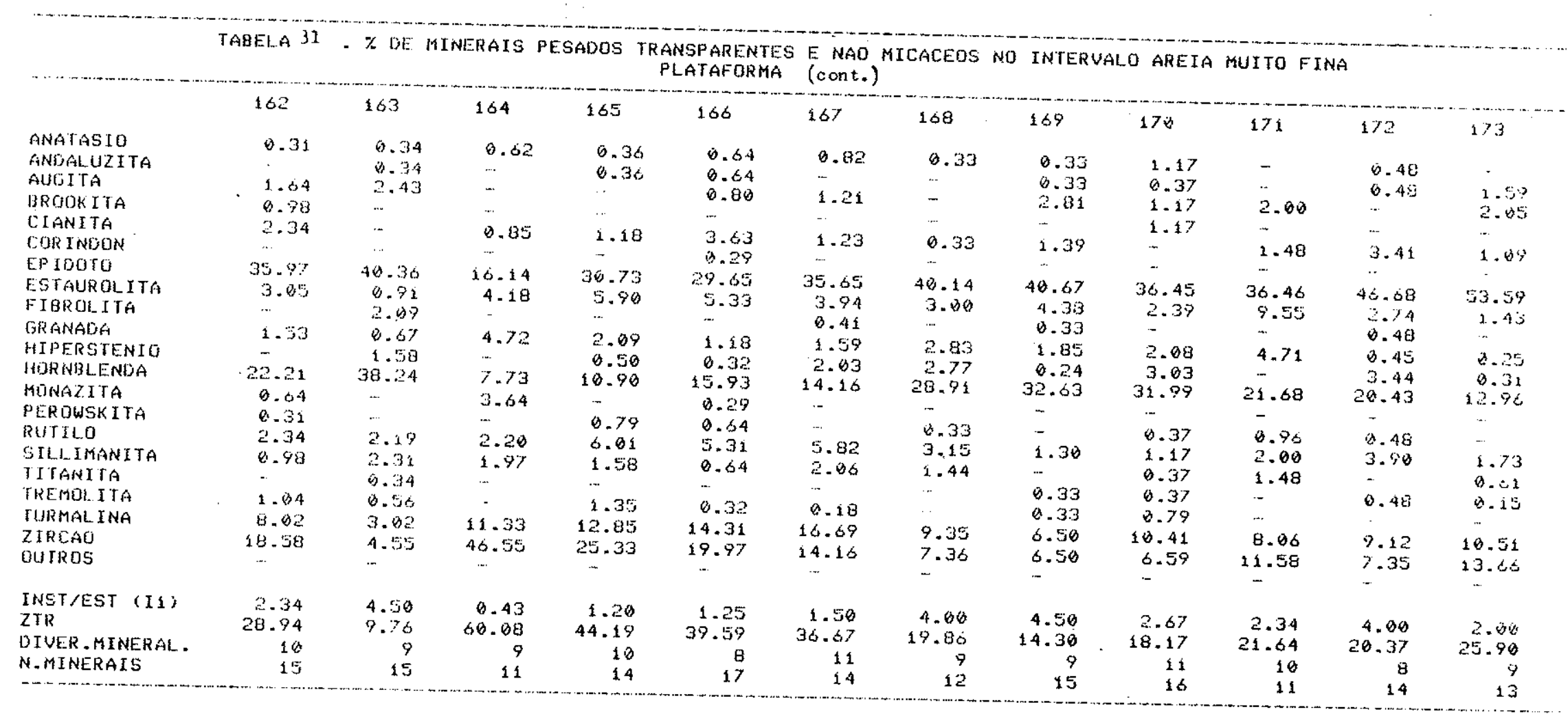




\begin{tabular}{|c|c|c|c|c|c|c|c|c|c|c|c|c|}
\hline & TABELÁ 31 & $\% O E$ & ERAIS $P$ & ADOS TR & $\begin{array}{l}\text { ISPARENTES } \\
\text { ATAFORMAA }\end{array}$ & $\begin{array}{l}\text { E NAO M } \\
\text { (cont.) }\end{array}$ & CACEOS & 0 INTE & O AREIA & MUIro & & \\
\hline & 174 & $17: 3$ & 177 & 178 & $\{79$ & 130 & 181 & 182 & 183 & 185 & 186 & 187 \\
\hline ANATASTO & $\ldots$ & 0.41 & ... & 0.73 & . & 0.64 & 0.76 & - & - & 1.19 & 0.45 & 0.36 \\
\hline ANDALUZITA & $\ldots$ & 0.41 & 0.87 & 1.50 & - & $\ldots$ & - & - & 2.11 & 0.79 & - & $\$ .36$ \\
\hline AUGITA & .1 .40 & & - & 0.73 & - & 0.55 & $\cdots$ & 0.45 & 0.24 & 0.39 & $\{.36$ & 0.26 \\
\hline $\begin{array}{l}\text { BROOK ITA } \\
\text { CIANITA }\end{array}$ & - & 0.80 & $\cdots .08$ & 2.67 & $i_{20}$ & $3+3$ & 3.36 & - & - & - & - & \\
\hline $\begin{array}{l}\text { CIANITA } \\
\text { COSRINDON }\end{array}$ & $\ldots$ & 6.86 & $\therefore .08$ & 2.67 & 1.20 & 1.73 & 0.36 & 3.25 & $\cdots$ & 0.79 & 1.36 & 1.14 \\
\hline EPIDOTO & 35.38 & 32.07 & 20.43 & 28.46 & $\$ 3.73$ & 53.64 & 50.86 & 35.46 & 20.31 & 30.71 & 35.67 & 38.94 \\
\hline $\begin{array}{l}\text { ESTALSROLITA } \\
\text { FBROLLITA }\end{array}$ & 1.27 & 2.18 & $\begin{array}{l}5.24 \\
0.41\end{array}$ & 5.21 & 4.95 & 1.34 & $\begin{array}{l}9.94 \\
0.36\end{array}$ & $\begin{array}{l}5.98 \\
0.45\end{array}$ & $\begin{array}{l}3.54 \\
0.44\end{array}$ & 4.19 & 5.58 & 0.91 \\
\hline GRAINAOA & 3.07 & $2^{2}-68$ & 1.32 & 3.67 & 0.28 & 1.21 & 2.55 & 1.15 & 6.54 & $\begin{array}{l}1.59 \\
8.95\end{array}$ & 1.92 & 3214 \\
\hline HIPERSTENTO & 3.42 & 2.33 & 1.97 & 1.00 & 0.28 & 0.11 & 1.59 & 0.96 & & 0.15 & 1.89 & $\begin{array}{l}-10 \\
4.32\end{array}$ \\
\hline HORYNBLENDA & 32.24 & 22.26 & 18.74 & 13.61 & 4.67 & 21.23 & 25.67 & 18.47 & 7.77 & 17.68 & 20.28 & 20.57 \\
\hline nONAZTTA & - & 0.82 & 0.41 & $\ldots$ & 1.20 & $\cdots$ & $\ldots$ & - & 3.04 & - & 0.90 & 1.40 \\
\hline PEROWSK ITA & 0.58 & 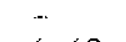 & 0.41 & 1.13 & 0.50 & 0.11 & - & $\ldots$ & 8.44 & 0.39 & 0.70 & \\
\hline RUTXLO & 4.72 & 1.69 & 0.73 & 5.48 & 6.84 & 4.59 & 4.52 & 2.31 & 3.04 & 4.04 & 3.20 & 2.29 \\
\hline $\begin{array}{l}\text { SILLIMANITAA } \\
\text { TITANITA }\end{array}$ & $\begin{array}{l}1.40 \\
6.93\end{array}$ & 0.41 & 1.32 & 2.50 & 0.60 & $\begin{array}{l}2.44 \\
1.75\end{array}$ & $1 .+15$ & 1.60 & 1.37 & 0.75 & 0.90 & 1.03 \\
\hline TREMOLITA & $\ldots$ & 0.49 & 0.75 & $\ldots$ & - & 0.64 & 0.83 & .. & 0.44 & 0.70 & 1.16 & 0.23 \\
\hline TURMAL INA & 7.35 & 7.72 & 12.83 & 3.4 .21 & 12.48 & 11.94 & 8.46 & 15.83 & 17.90 & 13.76 & 10.11 & 14.02 \\
\hline $\begin{array}{l}\text { ZIRCAO } \\
\text { DUTROS }\end{array}$ & 8.07 & 21.36 & 32.39 & 20.53 & 53.10 & 8.00 & 5.48 & 13.03 & 32.75 & $\begin{array}{l}25.70 \\
21.64 \\
z\end{array}$ & 13.34 & 11.18 \\
\hline $\begin{array}{l}\text { INST/EST (IS) } \\
\text { ZTR }\end{array}$ & $\begin{array}{r}4.08 \\
20.14\end{array}$ & 1.79 & $=1.09$ & 1.00 & 3.38 & 2.87 & 4.50 & 1.50 & 0.80 & 1.23 & 1.75 & 1.73 \\
\hline $\begin{array}{l}\text { ZTR } \\
\text { OIVIR. MINERAL. }\end{array}$ & $=0+14$ & 34.8 & $\begin{array}{r}53.95 \\
12\end{array}$ & 40.32 & 72.42 & 24.53 & 18.46 & 34.17 & 53.69 & 39.44 & 26.65 & 27.49 \\
\hline $\begin{array}{l}\text { W.MREMALERAL. } \\
\text { N.TINERAYS }\end{array}$ & 12 & 1's & $\begin{array}{l}12 \\
15\end{array}$ & 12 & 8 & 16 & 9 & 9 & 10 & 8 & 11 & 18 \\
\hline
\end{tabular}




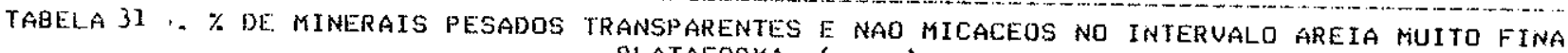
PLATAFORKA (cont.)

\begin{tabular}{|c|c|c|c|c|c|c|c|c|c|c|c|c|}
\hline & $\{8 B$ & 180 & 190. & 191 & 193 & 194 & 196 & 198 & 199 & 273 & 274 & 275 \\
\hline $\begin{array}{l}\text { ANATAASIO } \\
\text { ANUALLUZITA }\end{array}$ & $\ldots$ & 0.62 & 0.42 & 1.03 & $\because$ & 0.32 & 0.26 & 0.26 & $\ldots$ & 0.75 & 0.36 & 0.51 \\
\hline AUGITA & - & 1.09 & 4.42 & 0.50 & 1.11 & 1.02 & 0.41 & 0.26 & - & 0.37 & -. & $\therefore$ \\
\hline BROOK ITA & - & - & $\ldots$ & - no & 0.75 & - & - & - & 2.75 & 0.37 & 0.89 & $\cdots$ \\
\hline CIANITA & 1.12 & 0.71 & 0.42 & 0.50 & 2.46 & 1.24 & 0.70 & 1.06 & 1.53 & $\overline{1.46}$ & $\cdots$ & 8 \\
\hline $\begin{array}{l}\text { CORINDON } \\
\text { EPTDOTO }\end{array}$ & 40.46 & & & & & & & & & .2 .40 & 1.28 & 8.51 \\
\hline $\begin{array}{l}\text { EP TDOTO } \\
\text { ESTAUROLITA }\end{array}$ & $\begin{array}{r}40.46 \\
2.87\end{array}$ & $\begin{array}{r}49.89 \\
3.10\end{array}$ & 38.77 & 42.20 & 45.25 & 42.76 & 35.87 & 47.08 & 35.71 & $41 . .94$ & 59.86 & 47.83 \\
\hline $\begin{array}{l}\text { ESTAUROLITA } \\
\text { FIBROLITA }\end{array}$ & $\ldots$ & & 3.67 & $\begin{array}{l}4.05 \\
1.03\end{array}$ & 4.30 & $\begin{array}{l}4.58 \\
0.32\end{array}$ & 9.17 & 2.95 & 2.17 & .4 .08 & 5.16 & 7.74 \\
\hline GRANAOA & 1.79 & $\ldots$ & 6.58 & 2.28 & $\ldots$ & $\begin{array}{l}0.32 \\
2.11\end{array}$ & & - & - & .. & - & $\cdots$ \\
\hline HIPERSTENTO & 1.12 & . & 0.69 & 1.71 & 0.33 & $\begin{array}{l}2.11 \\
0.79\end{array}$ & $\begin{array}{l}2.20 \\
0.13\end{array}$ & $\begin{array}{l}1.58 \\
0.98\end{array}$ & 1.17 & $\begin{array}{l}3.74 \\
0.81\end{array}$ & 1.13 & $\begin{array}{l}3.46 \\
0.07\end{array}$ \\
\hline HORNBBLENEA & $22.2 \theta$ & 18.10 & 20.64 & 22.06 & 11.67 & $\{7.95$ & 6.80 & 29.96 & 13.04 & 11.18 & 15.50 & 17.29 \\
\hline HONAZITA & -- & $\cdots$ & - & $\cdots$ & 1.38 & $\ldots$ & 1.40 & - & $\ldots$ & $\cdots$ & - & $\ldots$ \\
\hline PEROWSK ITA & $\cdots$ & - & 0.42 & 1.56 & - & -- & 0.41 & 0.18 & 1.17 & 7.35 & 1.09 & 0.51 \\
\hline RUTHEO & 3.86 & 2.98 & 3.56 & 2.66 & 1.76 & 1.36 & 4.57 & 1.33 & 6.12 & 0.75 & 3.68 & 2.65 \\
\hline SILL IMANITA & 0.74 & 6.57 & & 1.56 & 1.74 & 0.19 & 0.55 & 6.65 & 0.61 & - & 2.11 & 0.51 \\
\hline I I TANITA & $\cdots$ & 0.90 & 1.32 & 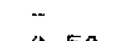 & 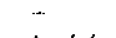 & 0.67 & 0.41 & - & 0.71 & - & 2 & 1.85 \\
\hline TREMOLITA & 0.74 & 0.45 & - & 0.50 & 1.16 & 0.89 & 0.41 & 0.58 & 0.43 & 1.80 & $\cdots$ & 0.21 \\
\hline TURMAL INA & 9.79 & 15.70 & 10.27 & 9.59 & 11.08 & 15.59 & 11.09 & 10.65 & 9.31 & 7.90 & 4.84 & 6.41 \\
\hline $\begin{array}{l}\text { ZIRCAO } \\
\text { GUTROS }\end{array}$ & 15.30 & 5.39 & 9.76 & 8.17 & 16.75 & 10.13 & 25.44 & 2.41 & 25.18 & $18-24$ & 4.84 & 10.39 \\
\hline$\underset{Z T R}{\operatorname{INST} / E S T}(I q) \cdot$ & 2.67 & 2.34 & 2.34 & 4.80 & 1.75 & 1.75 & 1.25 & 2.67 & 1.50 & 2.34 & 4.06 & 2.34 \\
\hline $\begin{array}{l}\text { ZTR } \\
\text { DIUER, MINERAL. }\end{array}$ & 28.89 & 24.07 & 23.59 & 20.42 & 29.79 & 27.88 & 41.10 & 14.39 & 40.61 & 26.89 & 12.50 & 19.45 \\
\hline $\begin{array}{l}\text { DIUER, MINERAL. } \\
\text { N. MINERAIS }\end{array}$ & $\cdot{ }_{11}^{7}$ & $\begin{array}{r}7 \\
1.3\end{array}$ & $\begin{array}{r}8 \\
13\end{array}$ & 12 & 11 & $\phi$ & 8 & 9 & 10 & 9 & $2 \theta$ & $E$ \\
\hline & & & 13 & 16 & 13 & 15 & 17 & .14 & 13 & 14 & 12 & 14 \\
\hline
\end{tabular}




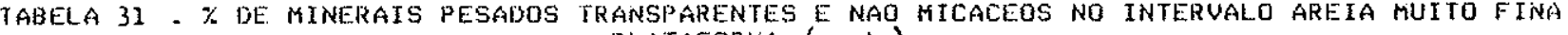
PLATAFORMA (cont.)

\begin{tabular}{|c|c|c|c|c|c|c|c|c|c|c|}
\hline & 276 & 277 & 278 & 279 & 280 & 281 & 282 & 283 & 321 & 322 \\
\hline ANATASIO & $\ldots$ & & $\ldots$ & 0.34 & - & 0.89 & -. & ... & - & 0.35 \\
\hline ANDALUZITA & .. & - & ..- & 0.34 & 0.85 & 0.89 & 1.49 & 1.78 & 0.82 & 2.57 \\
\hline AUG ITA & 0.65 & $\ldots$ & 0.43 & 0.34 & 1.03 & $\cdots$ & - & 0.43 & 0.15 & $\ldots$ \\
\hline BROOK ITA & $\cdots$ & $\cdots$ & $\cdots$ & - & $\cdots$ & .. & $\cdots$ & -.. & $\ldots$ & - \\
\hline CIANITA & 1.55 & 2.36 & 4.63 & 3.35 & 3.21 & $B .44$ & 0.57 & 8.43 & 1.56 & 2.20 \\
\hline CORIINDON & $\cdots$ & $\cdots$ & & & & 8.44 & & & & \\
\hline EPIDORO & 46.79 & 31.99 & 30.197 & $3 i .60$ & 30.34 & $\because 2,82$ & 33.91 & 31.47 & 54.88 & 32.64 \\
\hline & 3.39 & 1.99 & 2.63 & 2.26 & 0.99 & 2.99 & 0.66 & $\begin{array}{l}0.86 \\
3.30\end{array}$ & - & $\overline{2}, 56$ \\
\hline HIPERSTENIO & 0.57 & 8.84 & 0.38 & 0.44 & 0.13 & 6.94 & 2.69 & 2.81 & . & $\begin{array}{l}2.56 \\
2.11\end{array}$ \\
\hline HORNELENDA & 17.54 & 24.43 & 9.02 & 15.16 & 9.34 & 23.17 & 14.72 & 9.75 & 7.94 & 24.39 \\
\hline MONAZITA & 0.36 &... & $\ldots$ & $\ldots$ & - & 2.24 & - & .... & $\ldots$ & - \\
\hline PEROWSK ITA & 0.36 & - & 2.29 & 0.73 & 0.13 & 0.44 & $\ldots$ & 0.43 & $\ldots$ & - \\
\hline RUTILO & 2.31 & 4.35 & 4.6 .3 & 2.98 & 6.63 & 2.69 & 4.16 & 1.30 & 2.68 & 0.71 \\
\hline SILLTMANITA & 8.76 & $\cdots$ & 0.43 & 0.51 & 0.89 & 1.34 & 2.38 & 1.95 & 0.49 & 3.14 \\
\hline TITANITA & 0.36 & 2.15 & $\cdots$ & - & - & .. & 0.24 & - & - & - \\
\hline TREMOLITA & 0.97 & 8.10 & - & $\ldots$ & - & 1.34 & $\cdots$ & - & $\cdots$ & 0.70 \\
\hline TURHALINA & 7.39 & E. A & 14.87 & 21.20 & 23.50 & 1.79 & 15.64 & 12.18 & 21.35 & 19.52 \\
\hline ZIPCAO & 14.80 & 24.89 & 25.59 & 15.81 & 16.59 & 23.27 & 17.62 & 26.65 & 6.58 & 5.89 \\
\hline DUTROS & $\cdots$ & - & .. & $\cdots$ & -- & $\cdots$ & - & $\cdots$ & - & - \\
\hline INST/EST (If) & 2.34 & 1.75 & 1.00 & 1.29 & 1.08 & 1.50 & $\begin{array}{r}1.50 \\
37.42\end{array}$ & $\begin{array}{r}1.80 \\
48.13\end{array}$ & $\begin{array}{r}1.75 \\
30.61\end{array}$ & $\begin{array}{r}2.34 \\
26.12\end{array}$ \\
\hline ZTR & 24.56 & 33.90 & 45.09 & 39.09 & 46.72 & & 37.42 & $\begin{array}{r}48.13 \\
10\end{array}$ & $\begin{array}{r}30.01 \\
7\end{array}$ & 10 \\
\hline DIVER . MINERAL. & 8 & 9 & 9 & 8 & 8 & io & 9 & $\begin{array}{l}18 \\
14\end{array}$ & 10 & $\begin{array}{l}10 \\
13\end{array}$ \\
\hline N.MINERAIS & 15 & 11 & 12 & 14 & 13 & 16 & 12 & & 10 & \\
\hline
\end{tabular}


TABELA 32. FREQUENCIAS DE CLASSES DE ABUNDANCIA POR MINERAL E FREQUENCIAS DE CLASSES DE ZTR

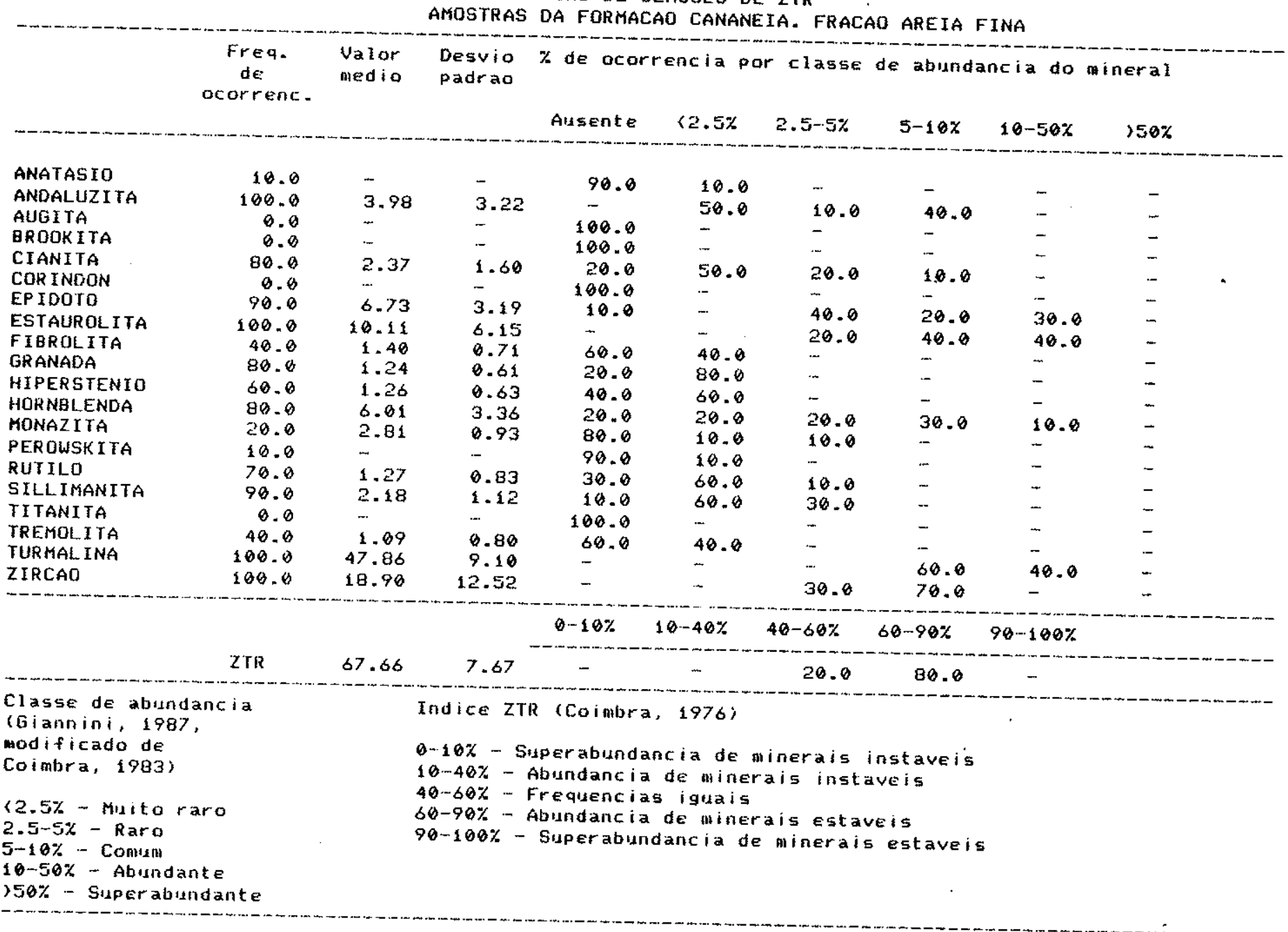


TAGELA 33 - FREQUENCIAS DE CLASSES DE ABUNDANCIA POR MINERAL

E FREQUENCIAS DE CL.ASSES DE ZTR
AMOSTRAS DA FORMACAO CANANEIA. FRACAO AREIA MUITO FINA

\begin{tabular}{|c|c|c|c|c|c|c|c|c|c|}
\hline & \multirow{2}{*}{$\begin{array}{l}\text { Frea. } \\
\text { de: } \\
\text { ocorrenc. }\end{array}$} & \multirow[t]{2}{*}{$\begin{array}{l}\text { Valor } \\
\text { medio }\end{array}$} & \multirow[t]{2}{*}{$\begin{array}{l}\text { Desvio } \\
\text { padrao }\end{array}$} & \multicolumn{2}{|c|}{ \% de ocorrencia po } & r classe & \multicolumn{2}{|c|}{ de abundancia do n } & neral \\
\hline & & & & Alsente & $<2.5 \%$ & $2.5-5 \%$ & $5-10 \%$ & $10-50 \%$ & $250 \%$ \\
\hline ANATASIO & 62.5 & 0.92 & 0.41 & 37.5 & 62.5 & - & - & - & - \\
\hline ANDALUZITA & 81.2 & 2.44 & 1.92 & 18.8 & 50.0 & 21.9 & 9.4 & - & - \\
\hline AUGITA & 0.0 & - & - & 100.0 & - & - & - & - & $\ldots$ \\
\hline BROOKITA & 3.1 & - & - & 96.9 & 3.1 & -. & - & - & - \\
\hline CIANITA. & 100.0 & 4.94 & 3.12 & - & 28.1 & 34.4 & 28.1 & 9.4 & - \\
\hline COR INDON & 0.0 & - & - & 100.0 & - &.- & - & $-\infty$ & - \\
\hline EPIDQTO & 93.8 & 16.10 & 13.81 & 6.3 & 15.6 & 6.3 & 15.6 & 56.2 & - \\
\hline ESTAUROLITA & 100.0 & 8.76 & 3.89 & $\ldots$ & - & 9.4 & 62.5 & 28.1. & - \\
\hline FIBROLITA & 6.3 & 6.54 & 0.09 & 93.7 & 6.3 & - & $-\cdots$ & - & - \\
\hline GRANADA & 68.6 & 0.93 & 0.42 & 31.4 & 68.6 & - & -. & - & -. \\
\hline HIPERSTENIO & 59.4 & 0.89 & 0.51 & 40.6 & 59.4 & - & - & - & - \\
\hline HORNAL_ENDA & 81.3 & 5.72 & 5.25 & 18.7 & 15.6 & 21.9 & $3 i .3$ & 12.5 & - \\
\hline MONAZITA & 25.0 & 0.99 & 0.63 & 75.0 & 25.6 & - & & - & - \\
\hline PEROWSK ITA & 59.4 & 1.34 & 1.15 & 40.6 & 56.3 & - & $3 . \mathbf{1}$ & - & - \\
\hline RUTILO & 96.9 & 7.58 & 3.52 & 3.1 & 9.4 & 15.6 & 53.1 & 18.8 & - \\
\hline SILLIMANITA & 87.5 & 2.18 & 1.62 & 12.5 & 65.6 & 12.5 & 9.4 & - & - \\
\hline TITANITA & 12.5 & 0.49 & 0.12 & .87 .5 & 12.5 & - & - & - & - \\
\hline TREMOLITA & 56.3 & 1.37 & 1.08 & 43.7 & 50.0 & 6.3 & - & - & $\ldots$ \\
\hline TURMALINA & 100.0 & 23.89 & 9.82 & - & 3.1 & & 9.4 & 87.5 & - \\
\hline ZIRCAO & 100.8 & 27.69 & 19.44 & - & 6.3 & 3.1 & 15.6 & 62.5 & 12.5 \\
\hline \multirow[t]{3}{*}{ XENOTIMA } & 6.30 & 0.47 & 0.11 & 93.70 & 6.30 & $\cdots$ & - & - & - \\
\hline & & & & $0 \cdots 10 \%$ & $10-40 x$ & $40 \cdots 60 \%$ & $60-90 x$ & $90-100 \%$ & \\
\hline & ZTR & 56.93 & 17.72 & -. & 12.5 & 37.5 & 50.0 & - & \\
\hline \multicolumn{2}{|c|}{$\begin{array}{l}\text { Classe de abundancia } \\
\text { (Giannini, I9B7, } \\
\text { modificado de } \\
\text { Coimbra, 1983) }\end{array}$} & & \multicolumn{7}{|c|}{$\begin{array}{l}0-10 \% \text { - Superabundancia de ninerais instaveis } \\
10-40 \% \text { - Abundancia de ninerais instaveis } \\
40-60 \% \text {.. Frequencias igladis }\end{array}$} \\
\hline \multicolumn{3}{|c|}{$\begin{array}{l}\text { 2.5\% - Muito raro } \\
2.5-5 \% \text { - Raro } \\
5-10 \% \text { - Comum } \\
10-50 \% \text { - Abundante } \\
>56 \% \text { - Superabundante }\end{array}$} & \multicolumn{7}{|c|}{$\begin{array}{l}60-90 \% \text { - Abundancia de minerais estaveis } \\
90-100 \% \text { - Superabundancia de minerais estaveis }\end{array}$} \\
\hline
\end{tabular}


TABELA 34 . FREQUENCIAS DE CLASSES DE ABUNDANCIA POR MINERAL

E FREQUENCIAS OE CLASSES DE ZTR

AMOSTRAS DOS CORDOES LITORANEOS. FRACAO AREIA FINA

\begin{tabular}{|c|c|c|c|c|c|c|c|c|c|}
\hline & \multirow{2}{*}{$\begin{array}{l}\text { Frea. } \\
\text { de } \\
\text { ocorrenc. }\end{array}$} & \multirow[t]{2}{*}{$\begin{array}{l}\text { Valor } \\
\text { medio }\end{array}$} & \multirow[t]{2}{*}{$\begin{array}{l}\text { Desvio } \\
\text { padrao }\end{array}$} & \multicolumn{2}{|c|}{ * de ocorrencia po } & or classe & \multicolumn{2}{|c|}{ de abundancia do } & \multirow{2}{*}{$\begin{array}{l}\text { neral } \\
250 \%\end{array}$} \\
\hline & & & & Ausente & $22.5 x$ & $2.5-5 x$ & $5-10 x$ & $10-50 x$ & \\
\hline ANATASIO & 20.0 & 0.59 & 0.47 & 80.0 & 20.0 & .. & - & - & - \\
\hline ANDALUZITA & 90.0 & 0.98 & 0.59 & 10.0 & 90.0 & _- & - & - & .. \\
\hline AUG ITA & 0.0 & - & - & 100.0 & - & - & - & - & - \\
\hline BROOK ITA & 0.0 & -- & - & 100.0 & - & -. & - & .- & - \\
\hline CIANITA. & 100.0 & 2.85 & 1.02 & - & 40.0 & 60.0 & - & - & - \\
\hline CORINDON & 0.0 & $\ldots$ & - & 100.0 & $\therefore$ & - & -- & .. & - \\
\hline EPIDOTO & 100.0 & 16.66 & 4.14 & - & - & - & 10.0 & 90.6 & - \\
\hline ESTAUROLITA & 100.0 & 0.51 & 3.54 & - & - & 20.0 & 50.0 & 30.0 & - \\
\hline FIBROLITA & 40.0 & 1.18 & 0.63 & 60.0 & 40.0 & - & $\therefore$ & - & - \\
\hline GRANADA & 70.0 & 1.25 & 0.68 & 30.0 & 70.0 & -. & -- & - & - \\
\hline HIPERSTENIO & - & - & - & $\cdots$ & - & - & $=$ & - & - \\
\hline HORNBLENDA & 100.0 & 19.76 & 3.91 & - & - & -- & $\therefore$ & 100.0 & - \\
\hline MONAZI TA & 20.0 & 0.31 & 0.23 & 80.6 & 20.0 & - & - & $-\infty$ & - \\
\hline PEROWSK ITA & 46.0 & 0.73 & 0.44 & 60.0 & 48.0 & - & - & - & - \\
\hline RUTILO & 50.0 & 0.82 & 0.49 & 50.0 & 50.0 & - & - & -. & - \\
\hline STLLIMANITA & 80.8 & 5.75 & 1.94 & 20.0 & 10.0 & 20.0 & 50.0 & - & - \\
\hline TITANITA & 50.0 & 0.97 & 0.69 & 50.0 & 50.0 & - & - & - & - \\
\hline TREMOL ITA & 30.0 & 0.38 & Q.11 & 70.0 & 30.0 & - & - & $\ldots$ & $\approx$ \\
\hline TURMALINA & 100.0 & 39.63 & 2.83 & $\because$ & $\ldots$ & - & - & 100.0 & - \\
\hline ZIRCAO & 100.0 & 4.33 & 1.86 & - & -. & 60.0 & 40.0 & - & 12.5 \\
\hline \multirow[t]{3}{*}{ XENOTIMA } & 0.00 & - & - & 100.00 & - & - & - & - & \\
\hline & & & & $0-10 \%$ & $10-40 \%$ & $40-60 \%$ & $60-907$ & $90-100 \%$ & \\
\hline & ZTR & 44.43 & 3.33 & - & 10.0 & 90.0 & - & - & \\
\hline \multicolumn{2}{|c|}{$\begin{array}{l}\text { Classe de abundancia } \\
\text { (Giannini, } 1987 \text {. } \\
\text { modificado de } \\
\text { Coimbra, } 1983 \text { ) }\end{array}$} & & \multicolumn{5}{|c|}{$\begin{array}{l}0-10 \% \text { - Superabundancia de ninerais instaveis } \\
10-40 \% \text { - Abundancia de ninerais instaveis } \\
40-60 \% \text { - Frequencias iguais }\end{array}$} & & \\
\hline \multicolumn{3}{|c|}{$\begin{array}{l}<2.57 \text { - Muito raro } \\
2.5-5 \% \text { - Raro } \\
5-10 \%-\text { Contum } \\
10-50 \% \text { - Abundante } \\
>50 \% \text { - Super abundante }\end{array}$} & \multicolumn{6}{|c|}{$\begin{array}{l}60-90 \% \text { - Abundancia de ninerais estaveis } \\
90-100 \% \text { - Superabundancia de minerais Estaveis }\end{array}$} & \\
\hline
\end{tabular}


TABELA 35 . FREQUENCIAS DE CLASSES DE ABUNDANCIA POR MINERAL

E FREQUENCIAS DE CLASSES OE ZTR

AMOSTRAS DOS CORDOES ITORANEOS. FRACAO AREIA MUITO FINA

\begin{tabular}{|c|c|c|c|c|c|c|c|c|c|}
\hline \multirow[b]{2}{*}{$\cdot$} & \multirow{2}{*}{$\begin{array}{l}\text { Frea. } \\
\text { de } \\
\text { ocorrenc. }\end{array}$} & \multirow{2}{*}{$\begin{array}{l}\text { Valor } \\
\text { medio }\end{array}$} & \multirow{2}{*}{$\begin{array}{l}\text { Desuio } \\
\text { padrao }\end{array}$} & \multicolumn{2}{|c|}{ \% de ocorrencia po } & classe & \multicolumn{3}{|c|}{ de abundancia do mineral } \\
\hline & & & & Alusente & $12.5 \%$ & $2.5-5 z$ & $5-10 \%$ & $10-50 \%$ & $150 x$ \\
\hline ANATASIO & 10.0 & -. & - & 90.0 & 10.0 & - & - & - & - \\
\hline ANDALUZITA & $8 \theta .0$ & 2.44 & 1.29 & 20.0 & 30.0 & 50.0 & - & - & - \\
\hline AUGITA & 0.0 & - & - & 100.0 & - & - & $\ldots$ & - & - \\
\hline BROOK ITA & 0.0 & -- & -- & 100.0 & - & - & ..- & - & - \\
\hline CIANITA & 80.0 & 3.82 & 1.00 & 20.0 & 10.0 & 60.0 & 16.0 & - & - \\
\hline CORINDON' & 0.0 & $\ldots$ & - & 160.0 & -- & - & - & - & - \\
\hline EPIOOTO & 100.0 & 19.61 & 2.02 & - & - & - & - & 100.0 & - \\
\hline ESTAUROLITA & 100.6 & 16.44 & 1.67 & - & - & -- & 40.0 & 60.0 & - \\
\hline FIBROLITA & 100.0 & - & - & 90.0 & 10.0 & - & - & - & - \\
\hline GRANADA & 80.0 & 2.54 & 0.62 & 20.0 & 36.0 & 50.0 & - & - & - \\
\hline HIPERSTENIO & 0.0 & - & - & 160.0 & - & - & - & - & - \\
\hline HORNBLENDA & 100.0 & 9.46 & 1.65 & - & - & - & 70.6 & 38.8 & - \\
\hline MONAZITA & 0.0 & - & - & 100.0 & - & - & - & - & - \\
\hline PEROWSK ITA & 10.0 & - & - & 90.0 & 10.0 & - & - & - & -. \\
\hline RUTILO & 100.0 & 9.37 & 2.76 & - & - & - & 50.0 & 50.0 & - \\
\hline SILLIMANITA & 100.0 & 5.51 & 1.93 & - & - & 40.0 & 60.0 & - & - \\
\hline TITANITA & 0.0 & $-\quad \cdot$ & - & 100.0 & $\cdots$ & - & - & - & - \\
\hline TREMOL I TA & 0.0 & $\ldots$ & - & 100.0 & - & - & - & - & -. \\
\hline TURMALINA & 100.0 & 13.25 & 4.39 & $\ldots$ & - & - & 10.0 & 90.0 & - \\
\hline ZIRCAO & 100.8 & 24.96 & 2.56 & - & - & - & - & 100.0 & - \\
\hline \multirow[t]{3}{*}{ XENOT IMA } & 10.00 & - & - & 90.00 & 10.00 & $\cdots$ & - & - & - \\
\hline & & & & $0-10 \%$ & $10-40 \%$ & $40-60 \%$ & $60-90 x$ & $90-100 x$ & \\
\hline & $\overline{Z T R}$ & 47.58 & 1.41 & - & - & 100.0 & - & - & \\
\hline \multicolumn{3}{|c|}{$\begin{array}{l}\text { Classe de abundancia } \\
\text { (Giannini, } 1987 \text {. } \\
\text { modificado de } \\
\text { Coimbra, } 1983)\end{array}$} & $\begin{array}{l}\text { Indice } Z T \\
0-10 \%-5 \\
10-40 \%- \\
40-60 \%-\end{array}$ & $\begin{array}{l}\text { TR C Coimbr: } \\
\text { Superabund } \\
\text { Abundanci } \\
\text { Frequenci }\end{array}$ & $\begin{array}{l}\text { 1976) } \\
\text { ancia de } \\
\text { de mine } \\
\text { is iguig }\end{array}$ & $\begin{array}{l}\text { ainerais } \\
\text { ais inst }\end{array}$ & $\begin{array}{l}\text { instave is } \\
\text { aveis }\end{array}$ & & \\
\hline \multicolumn{3}{|c|}{$\begin{array}{l}2.5 \% \text { - Muito raro } \\
2.5-5 \% \text { - Raro } \\
5-10 \% \text { - Contum } \\
10-50 \% \text { - Abundante } \\
256 \% \text { - Superabundante }\end{array}$} & \multicolumn{7}{|c|}{$\begin{array}{l}60-90 \% \text { - Abundanc } \\
90-100 \% \text { - Superabi }\end{array}$} \\
\hline
\end{tabular}


TABELA36 FREQUENCIAS DE CLASSES DE ABUNDANCIA POR MINERAL

E FREQUENCIAS DE CLASSES DE ZTR

AMOSTRAS DA FAIXA INTERMARES. FRACAO AREIA FINA

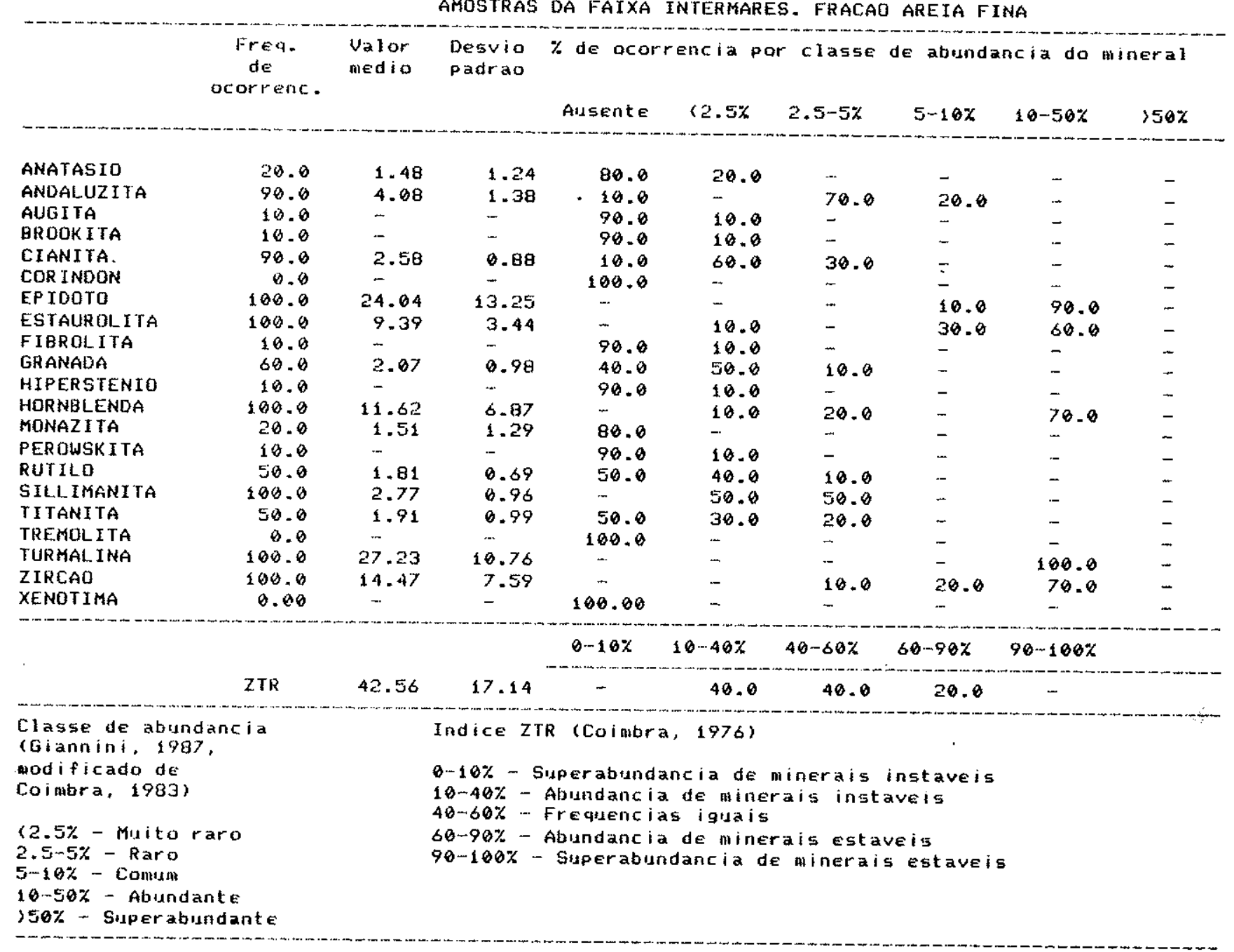


TABELA 37 - FREQUENCIAS DE CLASSES DE ABUNDANCIA POR MINERAL

E FREQUENCIAS DE CLASSES DE ZTR

AMOSTRAS DA FAIXA INTERMARES. FRACAO AREIA MUITO FINA

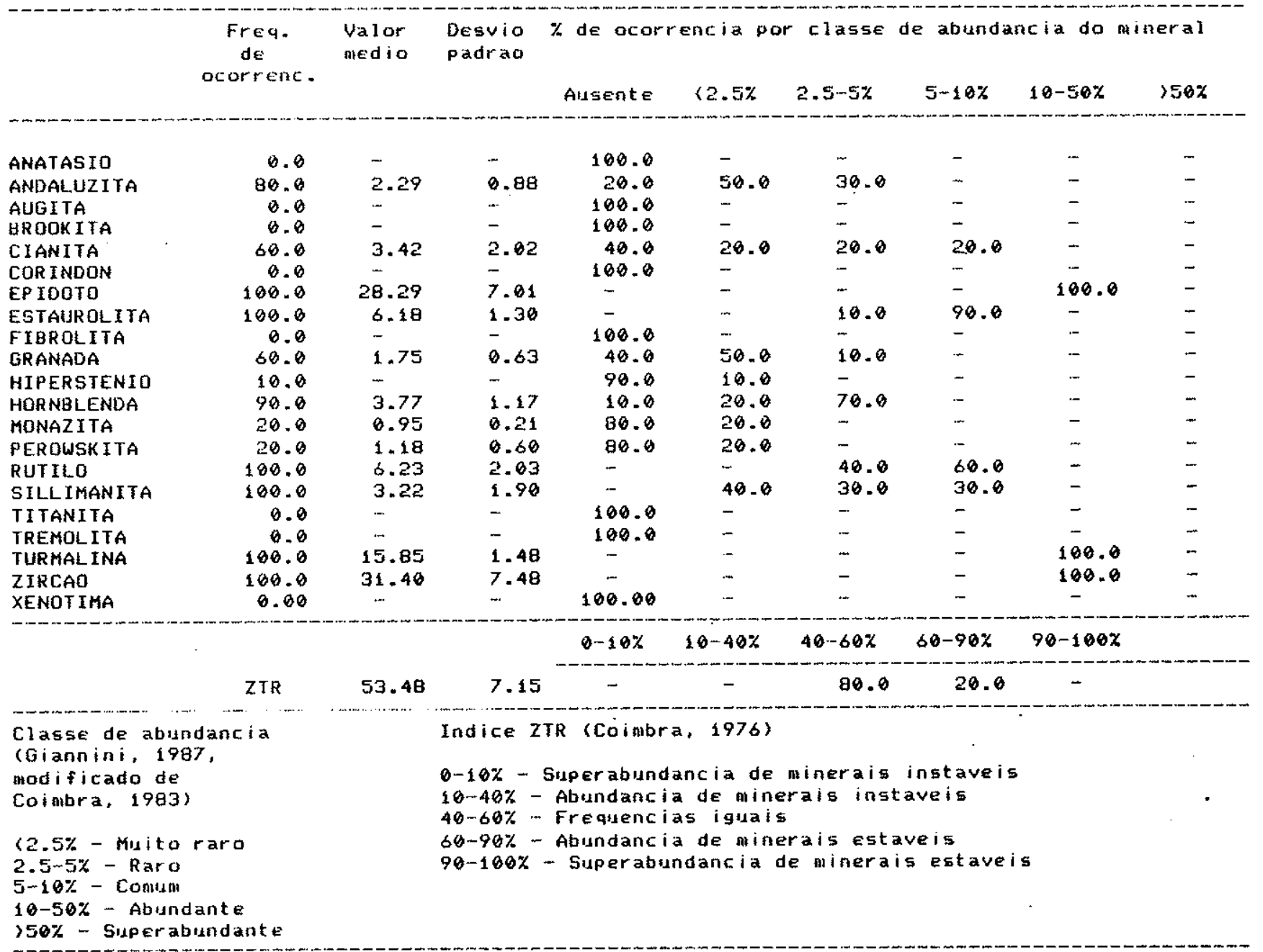


TABEA 38 FREGUENCTAS DE CLASSES DE ABUNDANCIA POR MTNERAL

FREQUENCIAS DE CLASSES DE ZTR

ARREBENTACAO FRACAO AREIA FINA

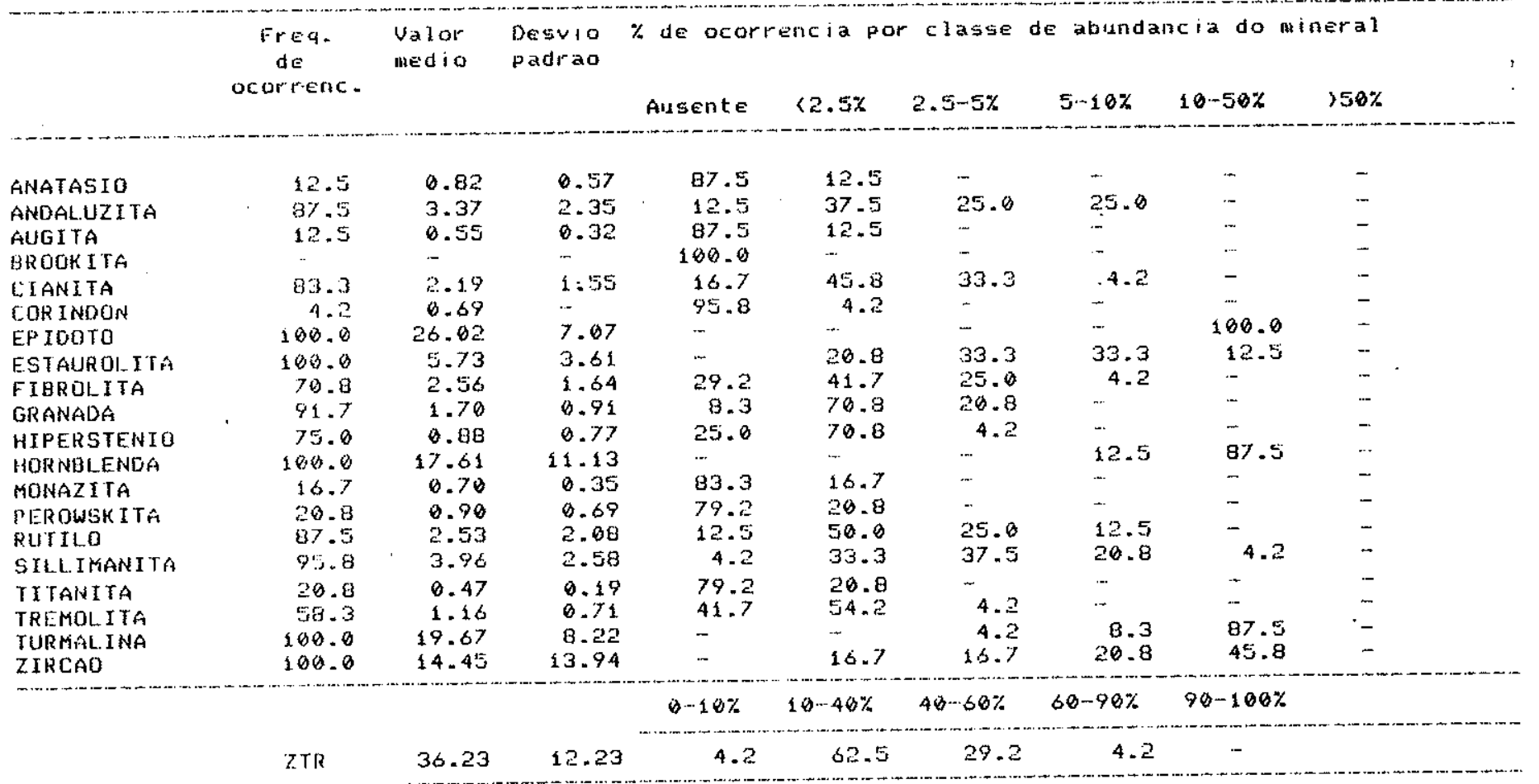

Classe de athundancia

Indice ZTR (Coinata, 1976)

Classe de abundand
Caiannini, 1987 .

modificado de

-10\% - Superabundancia de ninerais instaveis

Coimbra, 19839

10-48\% ... Abundancia de minerats instaveis

$40 \cdots 60 \%$ - Frequencias igluais

<2.5\% - Muito raro

$50-90 \%$ - Abundancia de minerais estavei

2.5-5\% - Raro

$5-10 \%$ - Cominn

$10-50 x$ - Abindante

$550 \%$... Superaburadante 
TABELA 39 . FREGUENCIAS DE CLASSES DE ABUNDANCIA POR MINERAL

E FREQUENCIAS DE CLASSES DE ZTR

AMOSTRAS DA ZONA DE ARREBENTACAO. FRACAO AREIA MUITO FINA

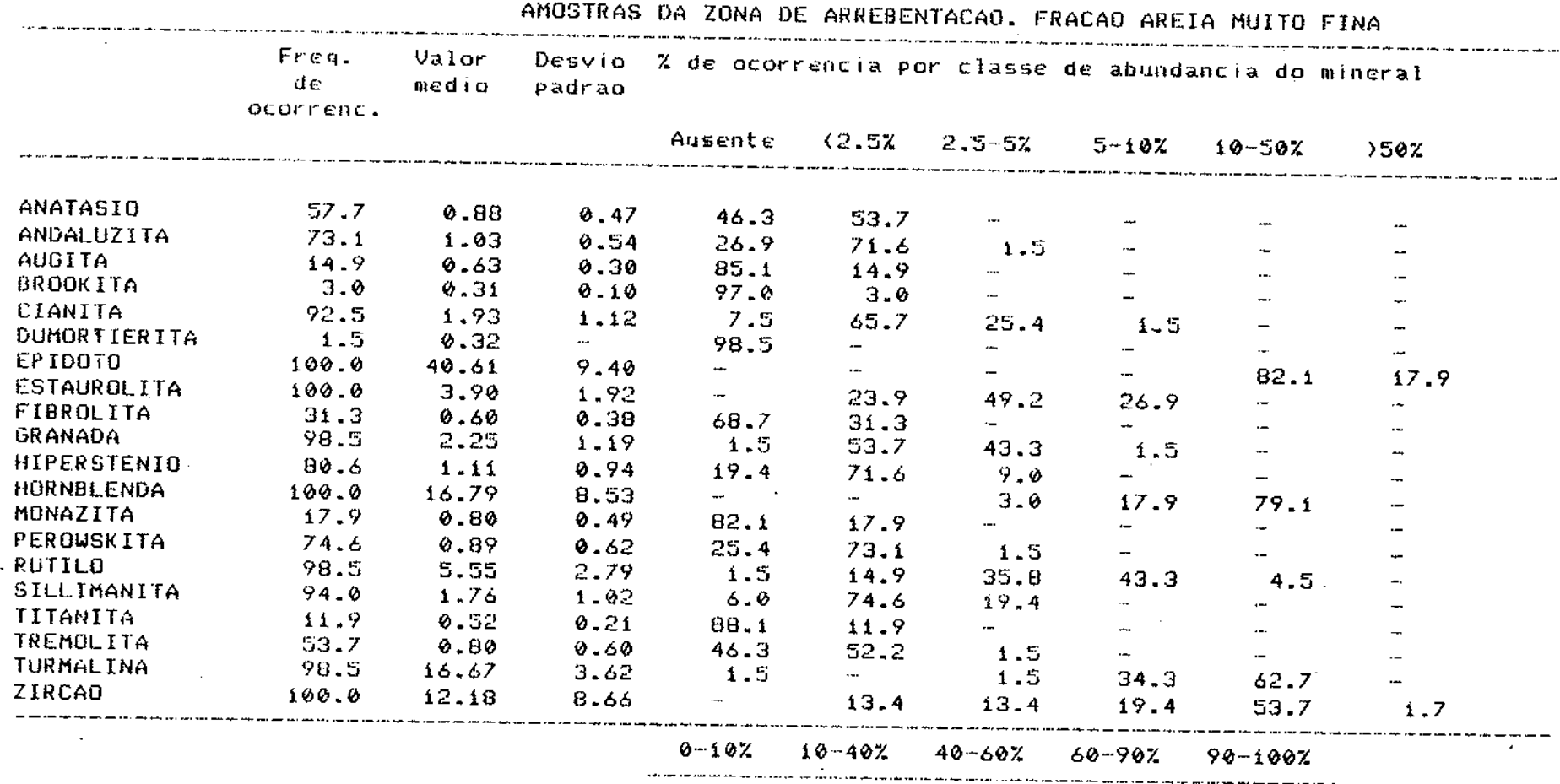

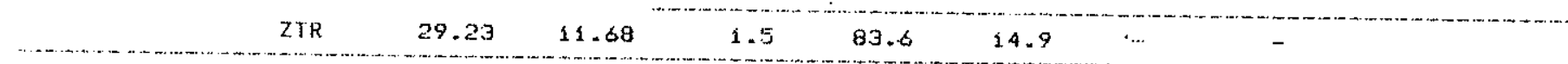

Classe de aburdancia

(Giannini, 1987

Modificado de

Indice ZrR (Coimbra, 1976)

Coimbra, 1983

Q-16\% - Superabundancia de minerais instaveis

10-40\% -... Abundancia de minerais instaveis

(2.5\% Mito raro

$2.5-57-$ - Raro

$40-60 \%$ - Frequencias iguais

$5.10 \%-$ - Compla
$10-50 \%$ - Abundante

150\% - Superabundante 
TABEIA 40 . FREQUENCIAS DE CLASSES DE ABUNDANCIA POR MINERAL

E FREQUENCIAS DE CLASSES DE ZTR

AMOSTRAS DA PLATAFORMA. FRACAO AREIA FINA.

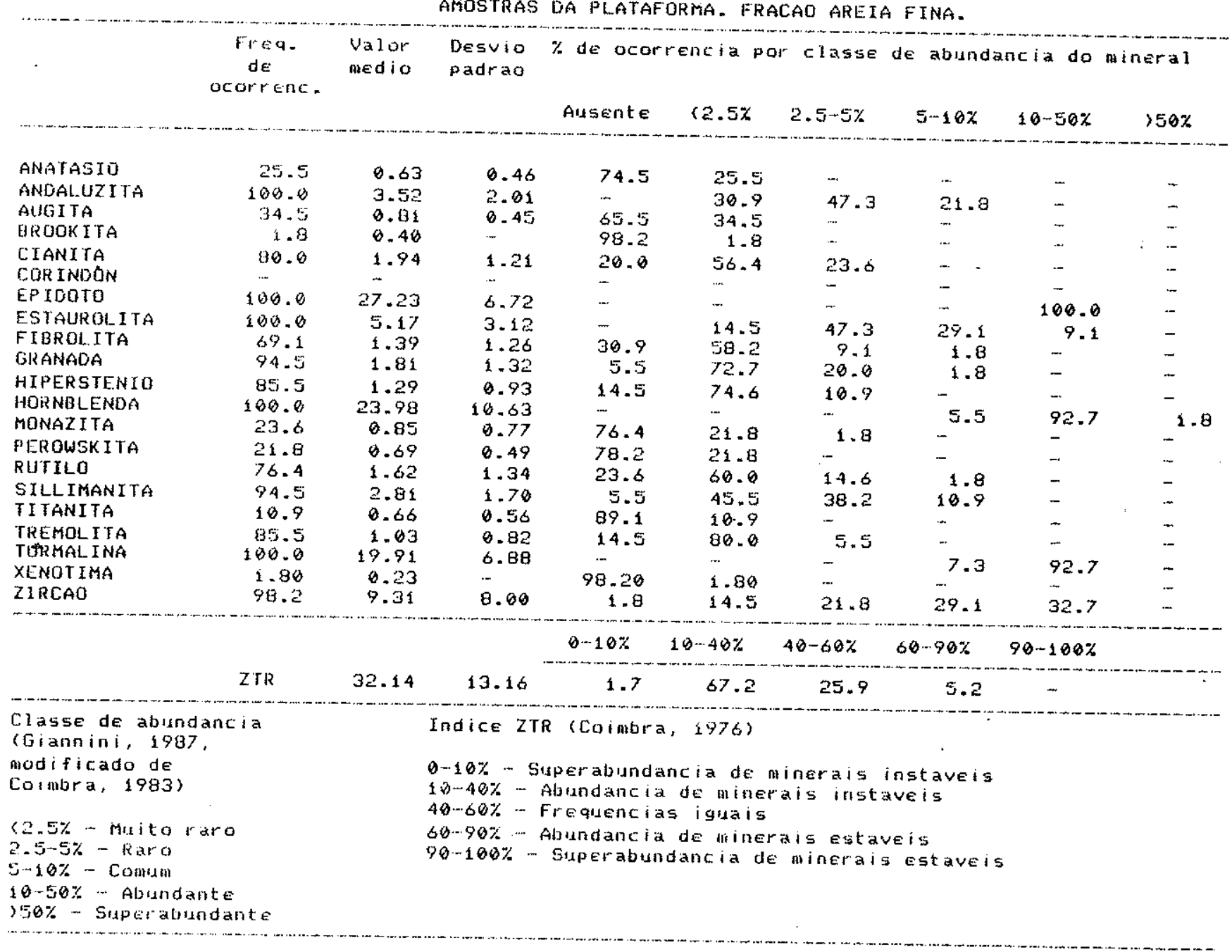


TABELA 41 . FREQUENCIAS DE CLASSES DE ABUNDANCIA POR MINERAL

FREQUENCIAS DE CLASSES DE ZTR

AMOSTRAS DA PLATAFORMA. FRACAO AREIA MUITO FINA

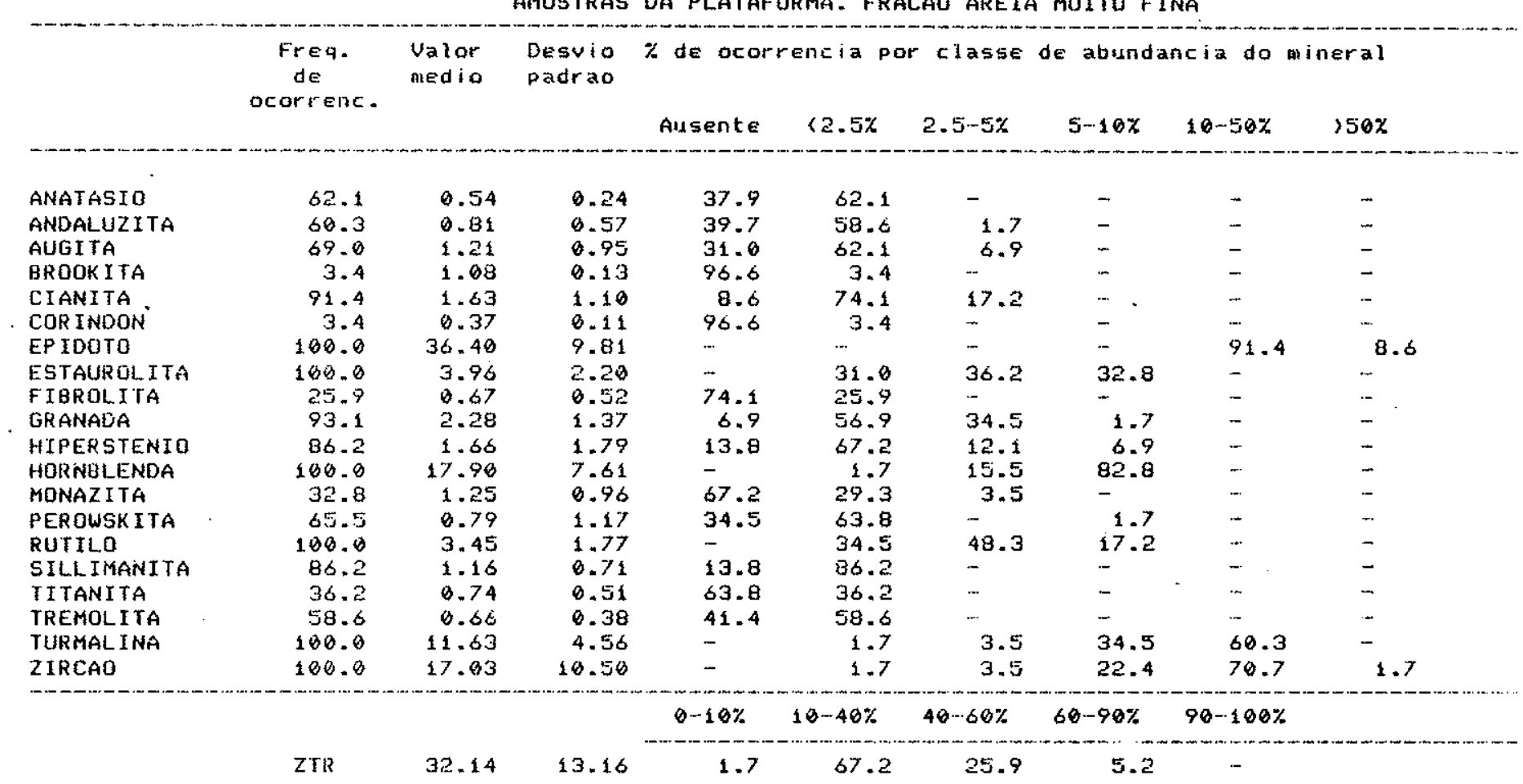

ZTR $\quad 32.14 \quad 13.16$

Indice ZTR (Coimbra, 1976)

Classe de abundanci

Giannini, 1987

codificado de

B-10\% - Superabundancia de minerais instaveis

10-40\% - Abundancia de minerais instaveis

40-60\% - Frequencias iguals

(2.5\% - Mito raro

$2.5-5 x$ - Rara

is estaveis

$5-10 \%-C o n+1 n$
$10-50 \%$ - Abindante

I56\% - Superabundante 
TABELA 44 - DIRECAO E ALTURA DOS SISTEMAS DE ONDA OBSERVADOS A BORDO DO N.OC. Prof.W. Besnard

\begin{tabular}{|c|c|c|c|c|c|c|c|c|c|c|c|}
\hline $\begin{array}{l}\text { Tenpo } \\
\left(30^{\prime}\right)\end{array}$ & $\begin{array}{l}\text { Periodo } \\
\text { (s) }\end{array}$ & $\begin{array}{l}\text { PARANAGUA } \\
\text { Altura } \\
\text { (nt) }\end{array}$ & Direcao & $\begin{array}{l}1 \\
1 \\
1\end{array}$ & $\begin{array}{l}\text { Periodo } \\
\text { (s) }\end{array}$ & $\begin{array}{c}\text { CANANEIA } \\
\text { Altara } \\
\text { (m) }\end{array}$ & Direcao & $\begin{array}{l}1 \\
1 \\
1\end{array}$ & $\begin{array}{l}\text { Periodo } \\
\text { (s) }\end{array}$ & $\begin{array}{l}\text { IGUAPE } \\
\text { Altura } \\
\text { (a) }\end{array}$ & Direcao \\
\hline 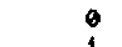 & 7.1 & 1.0 & 165 & 1 & 8.0 & 1.0 & 175 & $i$ & 4.8 & 1.0 & 75 \\
\hline 1 & 6.3 & 1.0 & 165 & $i$ & 7.1 & 1.0 & 165 & 1 & 4.3 & 1.0 & 75 \\
\hline 2 & 6.3 & 1.0 & 165 & 1 & 5.5 & 1.5 & 175 & 1 & 5.5 & 1.0 & 95 \\
\hline 4 & 9.2 & 0.5 & 155 & 1 & 5.5 & 1.5 & 185 & 1 & 4.8 & 1.0 & 75 \\
\hline 5 & 8.0 & 0.5 & 185 & 1 & 7.1 & 1.5 & 205 & $i$ & 5.2 & 1.0 & 75 \\
\hline 6 & 8.6 & 0.5 & 185 & 1 & 6.0 & 1.5 & 205 & 1 & 5.0 & 1.0 & 75 \\
\hline 7 & 9.2 & 0.5 & 185 & 1 & 5.0 & 1.5 & 205 & 1 & 5.2 & 1.0 & 85 \\
\hline 8 & 7.5 & 0.5 & 205 & 1 & 5.5 & 1.5 & 225 &.$t$ & 4.6 & 1.0 & 85 \\
\hline 9 & 6.3 & 0.5 & 205 & 1 & 5.0 & 1.5 & 225 & 1 & 5.0 & 1.0 & 75 \\
\hline 10 & 12.0 & 18.5 & 195 & 1 & 7.5 & 1.0 & 205 & 1 & 4.4 & 1.0 & 95 \\
\hline 11 & 12.0 & 1.0 & 200 & 1 & 6.6 & 0.5 & 205 & 1 & 4.8 & 1.0 & 75 \\
\hline 12 & 20.0 & 0.5 & 185 & 1 & 17.1 & 10.5 & 205 & 1 & 5.2 & 1.8 & 95 \\
\hline 13 & 15.0 & 0.5 & 185 & 1 & 0.0 & 0.0 & 0 & 1 & 5.5 & 1.0 & 85 \\
\hline 14 & 13.3 & 10.5 & 155 & 1 & 0.0 & 0.0 & 0 & 1 & 5.2 & 1.0 & 75 \\
\hline 15 & 6.0 & 1.0 & 175 & 1 & 0.0 & 0.0 & $\theta$ & 1 & 7.5 & 1.0 & 75 \\
\hline 16 & 8.6 & 0.5 & 195 & 1 & 8.6 & 0.5 & 75 & i & 7.1 & 1.0 & 85 \\
\hline 17 & 10.0 & $<0.5$ & 200 & 1 & 9.2 & 1.0 & 85 & 1 & 6.3 & 1.0 & 75 \\
\hline 18 & 10.9 & 10.5 & 225 & 1 & 1.3 .3 & 0.5 & 95 & 1 & 5.5 & 1.5 & 115 \\
\hline 19 & 13.3 & 10.5 & 225 & 1 & 8.6 & 0.5 & 165 & 1 & 6.3 & 1.5 & 75 \\
\hline 26 & 10.0 & $<0.5$ & 245 & 1 & 0.0 & 0.0 & 0 & 1 & 5.2 & 1.5 & 85 \\
\hline 21 & 8.6 & 10.5 & 235 & 1 & 0.0 & 0.0 & 0 & 1 & 5.7 & 1.5 & 75 \\
\hline 22 & 9.2 & $<0.5$ & 230 & 1 & 7.5 & 1.0 & 165 & 1 & 5.7 & 2.0 & 75 \\
\hline 23 & 7.1 & 10.5 & 200 & 1 & 4.8 & 1.0 & 165 & 1 & 5.0 & 2.0 & 75 \\
\hline 24 & 6.3 & 0.5 & 205 & 1 & 5.6 & 1.0 & 165 & 1 & 6.3 & 2.6 & 85 \\
\hline 25 & 10.9 & 0.5 & 235 & 1 & $5: 5$ & 1.0 & 175 & $t$ & 6.3 & 2.0 & 85 \\
\hline 26 & 7.5 & 0.5 & 185 & 1 & 4.4 & 1.0 & 165 & 1 & 5.2 & 2.6 & 65 \\
\hline 27 & 8.0 & 1.0 & 185 & 1 & 4.8 & 1.0 & 165 & 1 & 5.5 & 2.0 & 75 \\
\hline 28 & 7.1 & 1.0 & 155 & 1 & 4.8 & 1.0 & 155 & 1 & 5.7 & 2.0 & 85 \\
\hline 29 & 8.6 & 1.0 & 125 & 1 & 5.7 & 1.0 & 155 & 1 & 5.7 & 2.0 & 105 \\
\hline 30 & 8.6 & 1.0 & 115 & 1 & 4.8 & 1.0 & 165 & 1 & 6.3 & 2.0 & 95 \\
\hline 31 & 9.2 & $\angle 0.5$ & 135 & 1 & 5.2 & 1.0 & 165 & 1 & 6.0 & 1.5 & 75 \\
\hline 32 & 0.0 & $\angle 0.5$ & 0 & 1 & 6.3 & 1.0 & 175 & i & 6.0 & 2.0 & 65 \\
\hline 33 & 0.0 & 10.5 & 25 & 1 & 4.8 & 1.0 & 195 & 1 & 5.7 & 2.0 & 65 \\
\hline 34 & 7.5 & 1.0 & 165 & 1 & 6.3 & 1.5 & 205 & 1 & 5.7 & 1.0 & 55 \\
\hline 35 & 7.1 & 1.0 & 105 & 1 & 5.7 & 1.5 & 205 & 1 & 6.0 & 1.0 & 75 \\
\hline 36 & 7.1 & $<6.5$ & 85 & 1 & 6.3 & 1.5 & 195 & 1 & 5.2 & 1.0 & 75 \\
\hline 37 & 7.1 & 18.5 & 85 & i & 6.3 & 1.5 & 195 & 1 & 5.5 & 1.0 & 85 \\
\hline 38 & 7.1 & $<0.5$ & 75 & 1 & 6.3 & 1.5 & 185 & $i$ & 6.0 & 1.8 & 85 \\
\hline 39 & 7.1 & $<0.5$ & 75 & 1 & 6.3 & 1.5 & 185 & 1 & 5.2 & 1.0 & 75 \\
\hline 40 & 6.3 & 10.5 & 75 & 1 & 0.0 & 0.0 & 8 & 1 & 4.8 & 1.0 & 85 \\
\hline 41 & 10.0 & $<0.5$ & 70 & 1 & 6.6 & 1.0 & 165 & 1 & 5.2 & 1.0 & 75 \\
\hline 42 & 10.0 & 10.5 & 75 & 1 & 6.0 & 1.8 & 165 & 1 & 5.5 & 1.0 & 85 \\
\hline 43 & 8.6 & 10.5 & 70 & 1 & 7.5 & 1.0 & 135 & 1 & 5.7 & 1.0 & 75 \\
\hline 44 & 10.0 & 10.5 & 65 & 1 & 8.6 & 1.0 & 165 & 1 & 6.3 & 1.0 & 75 \\
\hline 45 & 10.9 & $<6.5$ & 65 & 1 & 7.5 & 1.0 & 175 & 1 & 7.1 & 1.5 & 95 \\
\hline 46 & 13.3 & $<0.5$ & $e$ & 1 & 7.5 & 1.5 & 155 & 1 & 6.0 & 1.5 & 65 \\
\hline 47 & 0.0 & 0.0 & 0 & 1 & 6.6 & 1.5 & 155 & 1 & 7.5 & 1.0 & 65 \\
\hline \multirow[t]{2}{*}{48} & 0.0 & 0.0 & $\theta$ & 1 & 6.0 & 1.5 & 140 & 1 & 0.0 & 0.0 & 0 \\
\hline & & & & 1 & & & & 1 & & & \\
\hline Hedia & $9.1+-2.7$ & & & 1 & $6.7+-2.3$ & & & 1 & $5.6+-0.7$ & & \\
\hline
\end{tabular}


TABELA 45. PROFUNDIDADES MAXIMAS DA ACAO EFETIUA DE DNGAS INA MOBILIZACAO DOS SEOIMENTOS DE FUNDO A PARTIR DAS OBSERVACOES DE DNDAS REALIZADAS A BORDO DO N.UC. "Prof.w.Besnard" … 4984

\begin{tabular}{|c|c|}
\hline & $\begin{array}{l}\text { Parangua } \\
d=0.512 \mathrm{~mm}\end{array}$ \\
\hline Tempo & (m) \\
\hline
\end{tabular}

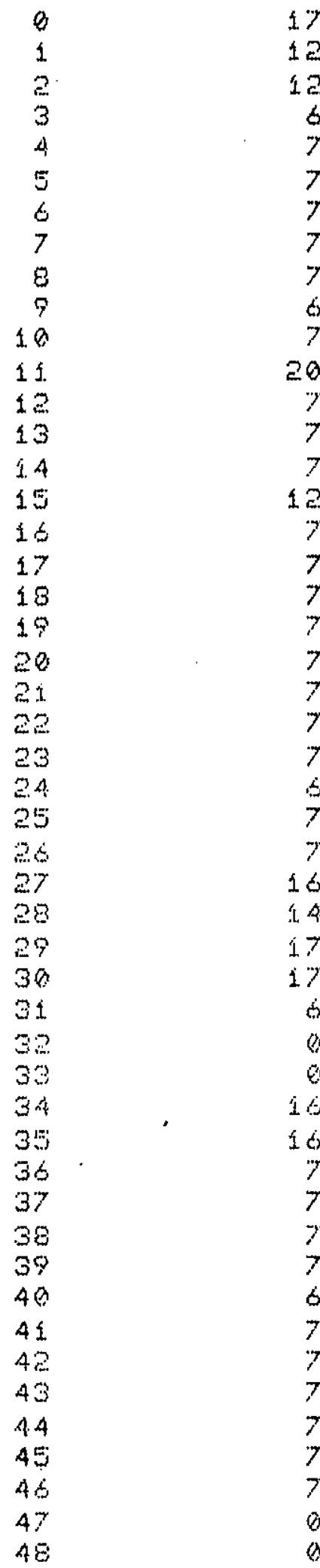

23

20

21

21.

21

26

21

16

21

16

23

11

12

0

Q

0

13

26

13

13

0

0

23

13

43

2.

10

is

13

17

13

13

17

13

2i

21

21

21

ai

21.

0

20

21

23

26

23

26

20

21
14

10

18

1. 4

i. 4

14

14

14

14

14

10

14

14

18

44

25

22

48

22

2.

I)

를

24

18

24

24

18

24

24

2.4

24

$2 ?$

24

24

18

10

4.4

10

18

14

14

14

18

10

18

26

20

26 
TABELA 46 PROFUNLIDADES MAXIMAS DA ACAO EFETIVA DAS DNDAS NA MOB TLIZACAO

TABEE OBTIDOS PELO CTH(1973)

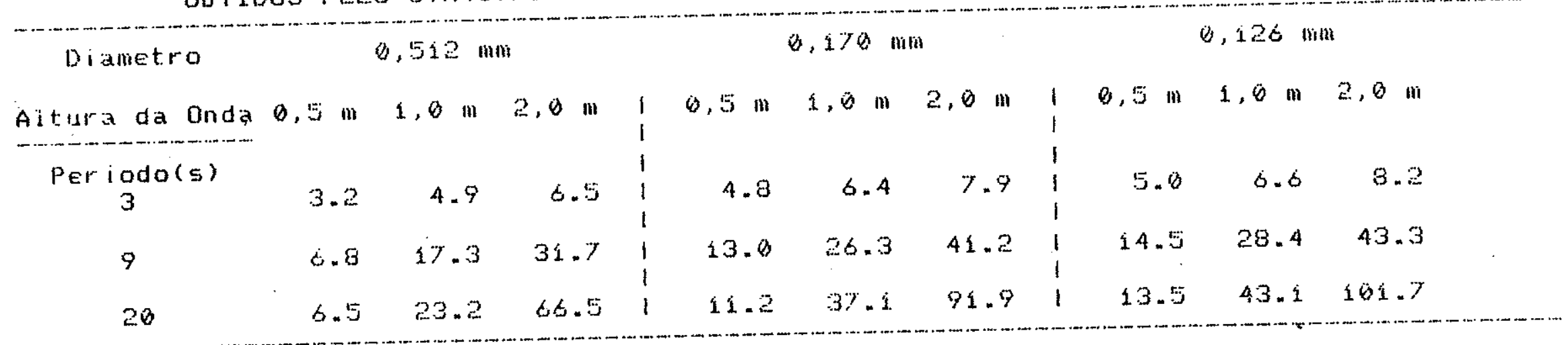




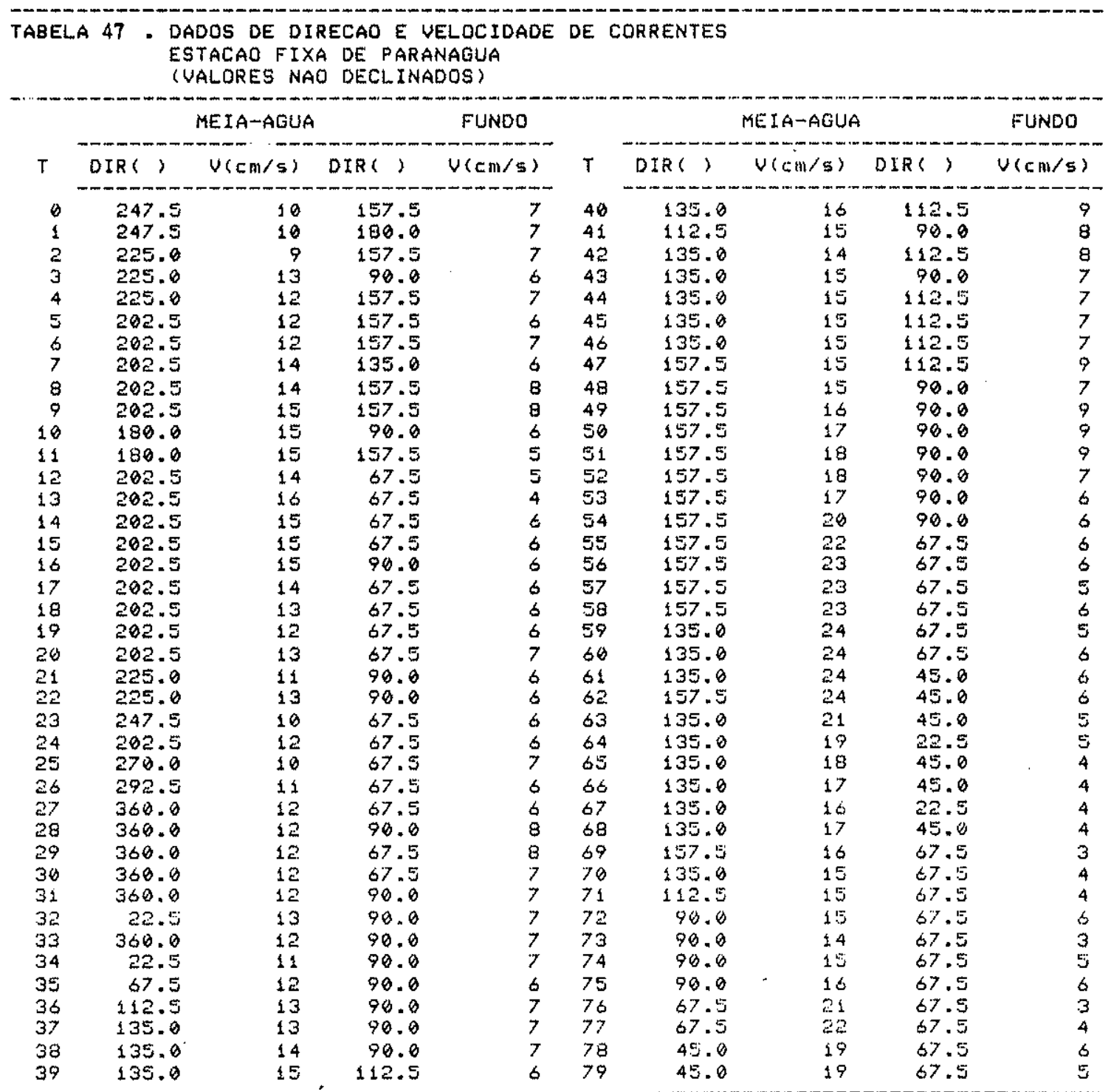




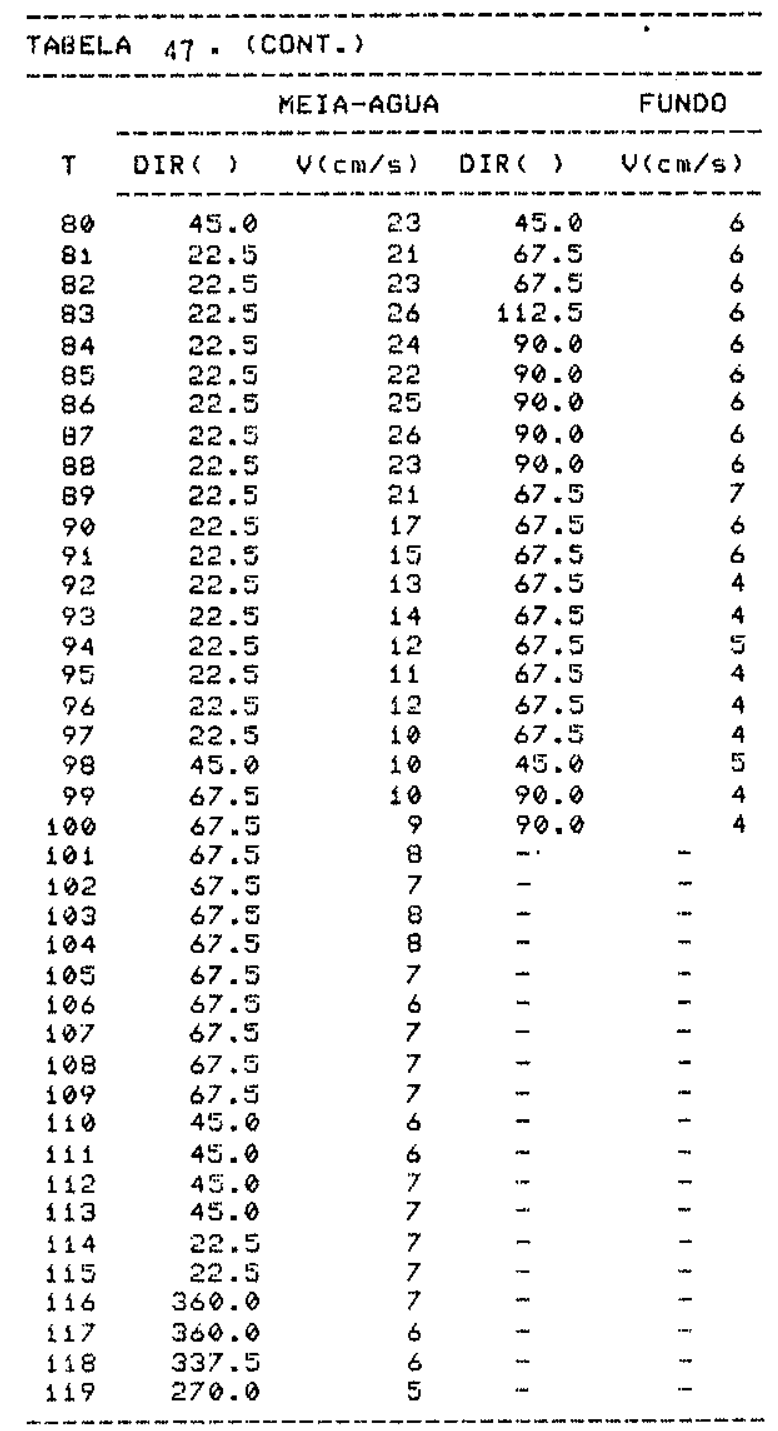




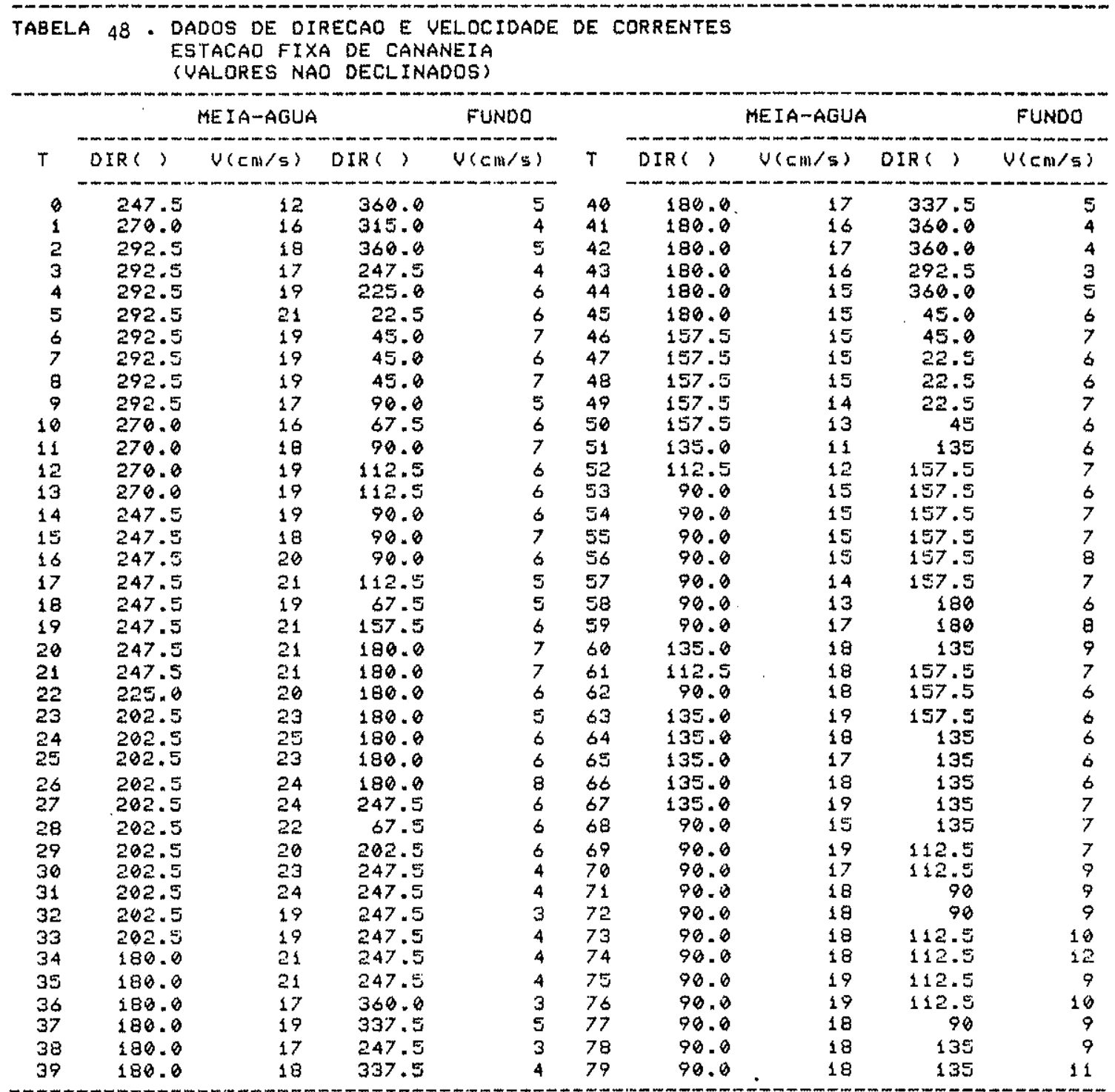




\begin{tabular}{|c|c|c|c|c|c|c|c|c|c|}
\hline & & MEIA-AGUA & & FUNDD & & & $M E I A-A G \cup A$ & & FUNDO \\
\hline$T$ & DIR( ) & $v(\mathrm{~cm} / \mathrm{s})$ & DIR( ) & $V(\mathrm{~cm} / \mathrm{s})$ & $\mathrm{T}$ & DIR（） & $U(c n) / s)$ & DIR & $V(c m / s)$ \\
\hline 80 & 90.0 & 20 & 135.0 & 12 & 120 & 67.5 & 28 & - & - \\
\hline 81 & 90.0 & 19 & 135.0 & 13 & 121 & 45.0 & 29 & - & - \\
\hline 82 & 90.0 & 26 & 135.0 & 9 & 122 & 45.0 & 28 & - & - \\
\hline 83 & 67.5 & 24 & 135.0 & $\mathfrak{i} \mathfrak{i}$ & 123 & 45.0 & 24 & - & - \\
\hline 84 & 90.0. & 27 & 112.5 & 12 & 124 & 45.8 & 23 & - & - \\
\hline $\begin{array}{l}85 \\
86\end{array}$ & $\begin{array}{l}90.0 \\
90.0\end{array}$ & $\begin{array}{l}26 \\
26\end{array}$ & $\begin{array}{l}112.5 \\
112.5\end{array}$ & $\begin{array}{r}10 \\
9\end{array}$ & $\begin{array}{l}125 \\
126\end{array}$ & $\begin{array}{l}22.5 \\
22.5\end{array}$ & $\begin{array}{l}26 \\
26\end{array}$ & - & - \\
\hline 87 & 90.0 & 19 & 112.5 & 9 & 127 & 22.5 & 26 & - & - \\
\hline 88 & $90 . a$ & 21 & 112.5 & 10 & 128 & 22.5 & 24 & - & - \\
\hline 89 & 90.0 & 23 & 112.5 & 9 & 129 & 22.5 & 24 & - & - \\
\hline 90 & 112.5 & 25 & 90.0 & 9 & 136 & 22.5 & 21 & - & - \\
\hline 91 & 112.5 & 26 & 90.0 & 10 & & & & & \\
\hline 92 & 112.5 & 21 & 67.5 & 8 & & & & & \\
\hline 93 & 90.0 & 24 & 90.0 & 9 & & & & & \\
\hline 94 & 67.5 & 18 & 90.0 & 9 & & & & & \\
\hline 95 & 67.5 & 16 & 67.5 & 10 & & & & & \\
\hline 96 & 67.5 & 15 & 90.0 & 7 & & & & & \\
\hline 97 & 67.5 & 16 & 67.5 & 8 & & & & & \\
\hline 98 & 67.5 & 16 & 67.5 & 10 & & & & & \\
\hline 99 & 67.5 & 15 & 67.5 & 9 & & & & & \\
\hline 100 & 67.5 & 15 & 67.5 & 7 & & & & & \\
\hline 101 & 67.5 & 16 & 67.5 & 8 & & & & & \\
\hline 102 & 67.5 & 16 & 67.5 & 9 & & & & & \\
\hline 103 & 67.5 & 17 & 67.5 & 7 & & & & & \\
\hline 104 & 45 & 17 & 67.5 & 7 & & & & & ${ }^{\circ}$ \\
\hline 105 & 45 & 28 & 67.5 & 8 & & & & & \\
\hline 106 & 45 & 18 & 90 & 9 & & & & & \\
\hline 107 & 45 & 17 & 90 & 8 & & & & & \\
\hline 108 & 45 & 18 & 90 & 7 & & & & & \\
\hline 109 & 67.5 & 18 & 90 & 9 & & & & & \\
\hline 110 & 67.5 & 20 & 90 & 7 & & & & & \\
\hline 111 & 67.5 & 24 & 90 & $B$ & & & & & \\
\hline 112 & 67.5 & 27 & 112.5 & 7 & & & & & \\
\hline 113 & 67.5 & 25 & $\sim$ & - & & & & & \\
\hline 114 & 67.5 & 24 & - & - & & & & & \\
\hline 115 & 67.5 & 22 & - & - & & & & & \\
\hline 116 & 67.5 & 24 & - & - & & & & & \\
\hline 117 & 67.5 & 26 & - & - & & & & & \\
\hline 118 & 67.5 & 26 & - & - & & & & & \\
\hline 119 & 67.5 & 27 & - & - & & & & & \\
\hline
\end{tabular}




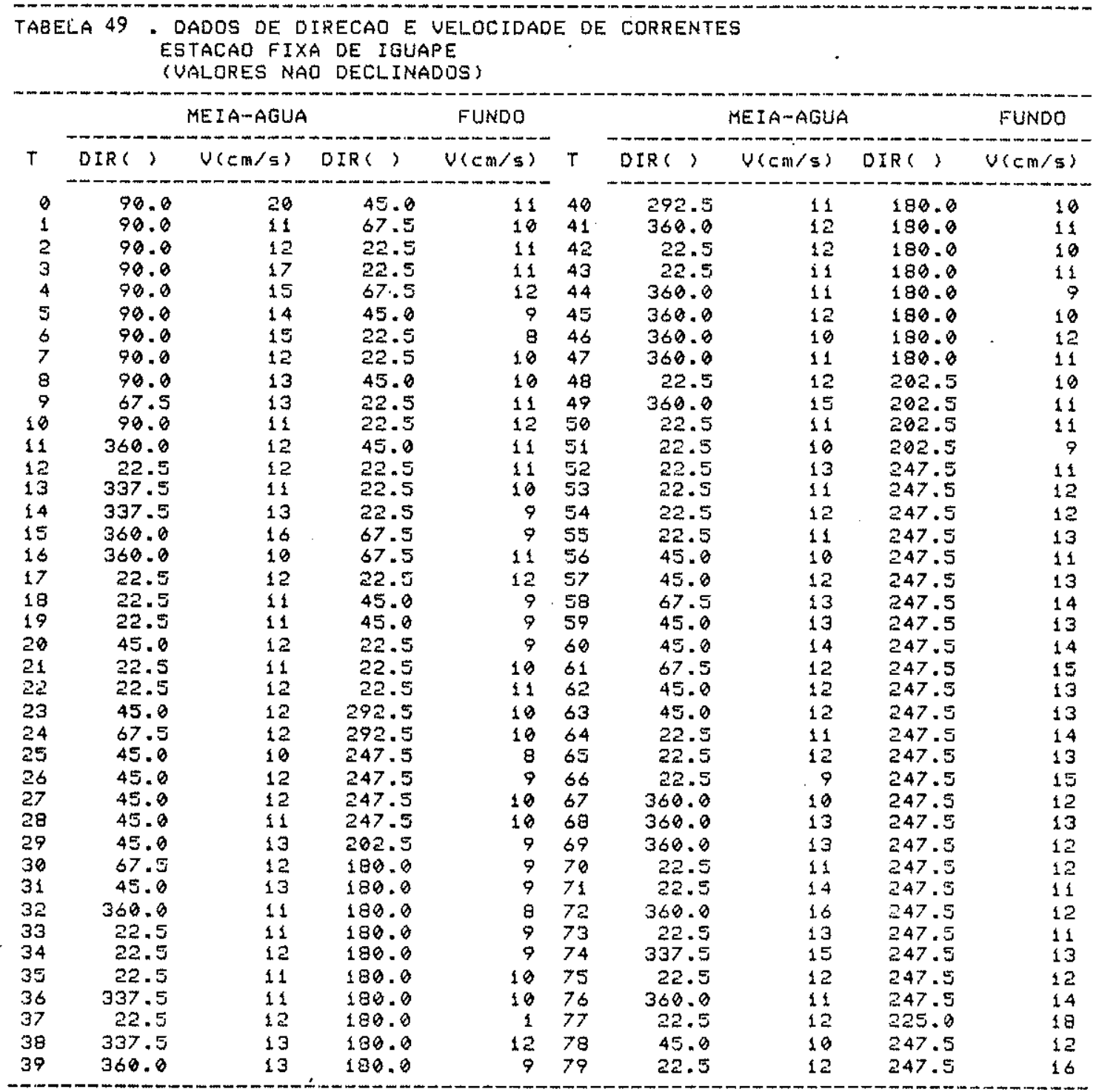




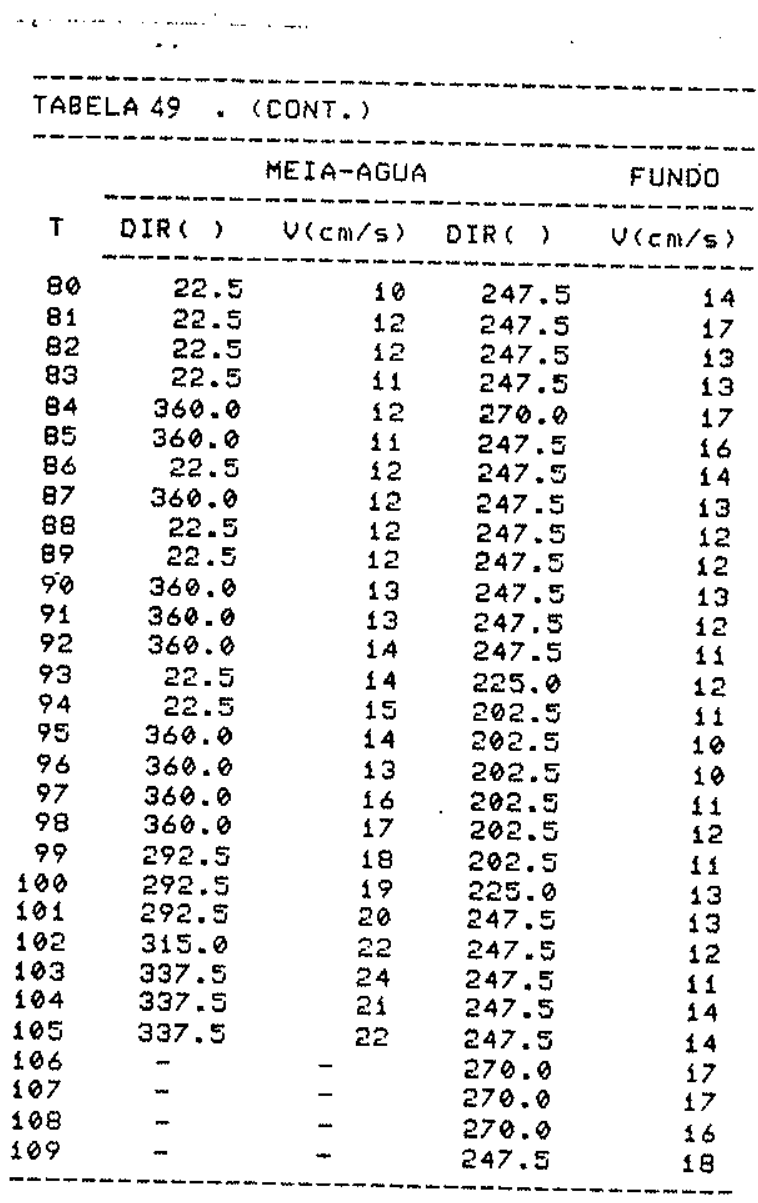




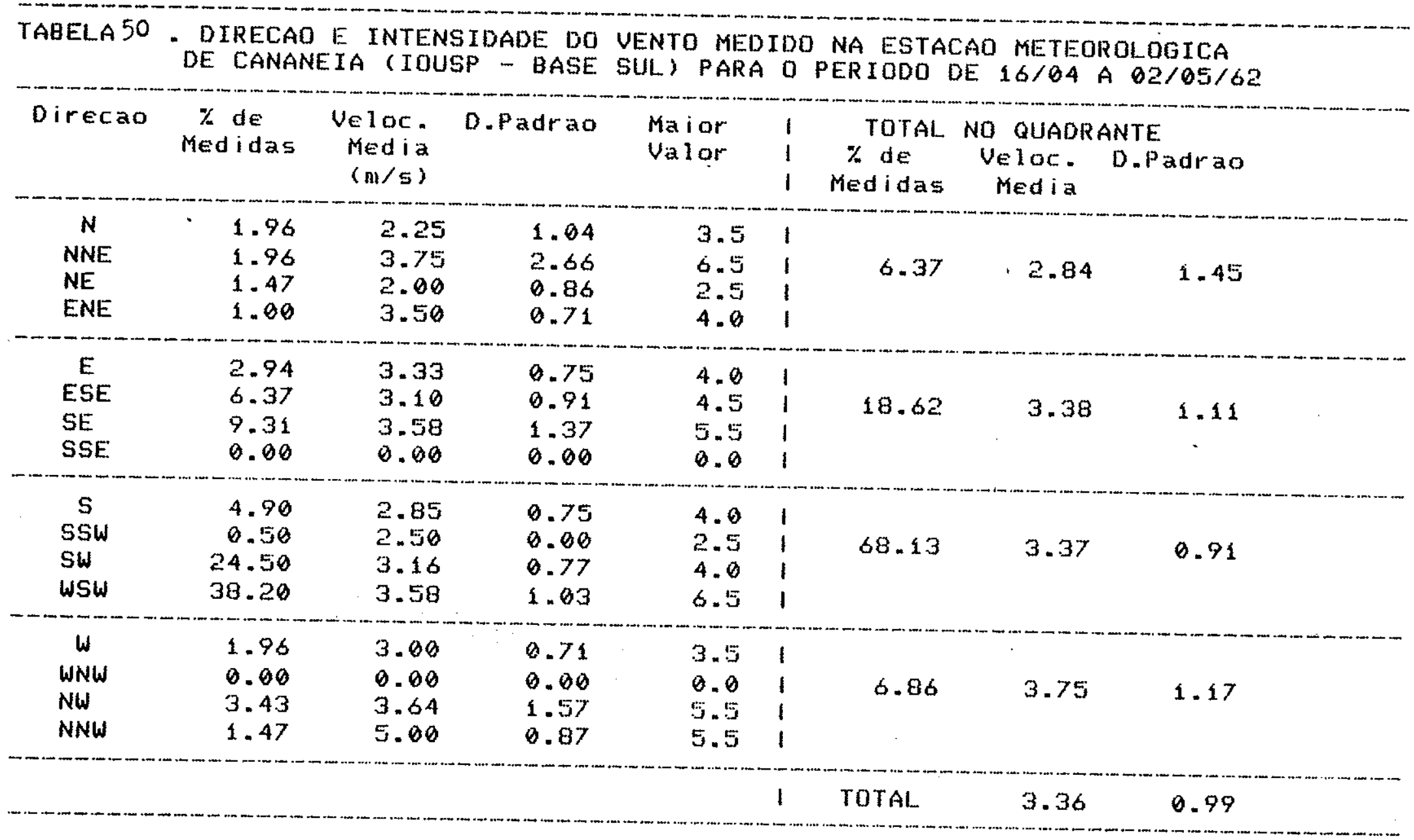




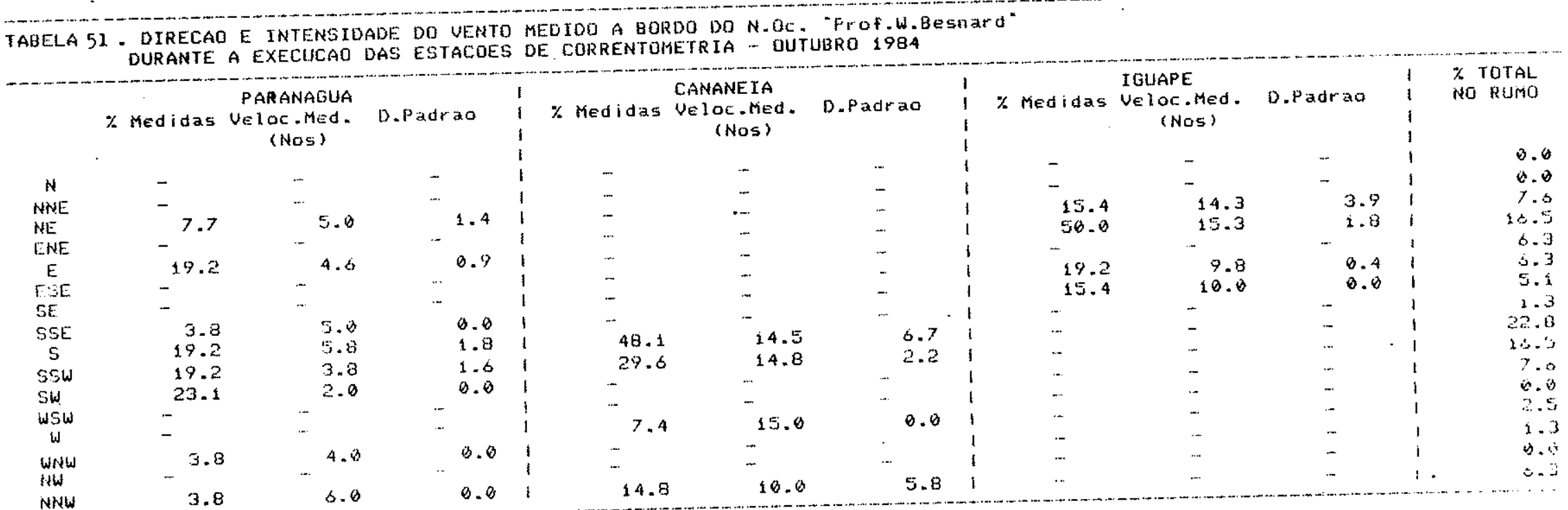




\section{TABELA 52. VALORES DE VELOCIDACE CRITICA QE CORRENTES (CMIS) A $100 \mathrm{CM}$ DO FUNDO (CIOQ) PARA MOUIMENTACAO DE SEDIMENTOS DE DIFERENTES DIAMETROS MEDIOS (mM) (GADO ET AL.. 1978)}

Diametro Medio Veloc. Critica

( $\mathrm{mm}$ )

$$
0.116
$$

0.149

0.178

0.210

0.220

0.290

0.345

0.355

0.378

0.395

0.418

0.420

0.430

0.490

0.502

Q. .5.50

0.560

$(c m / s)$

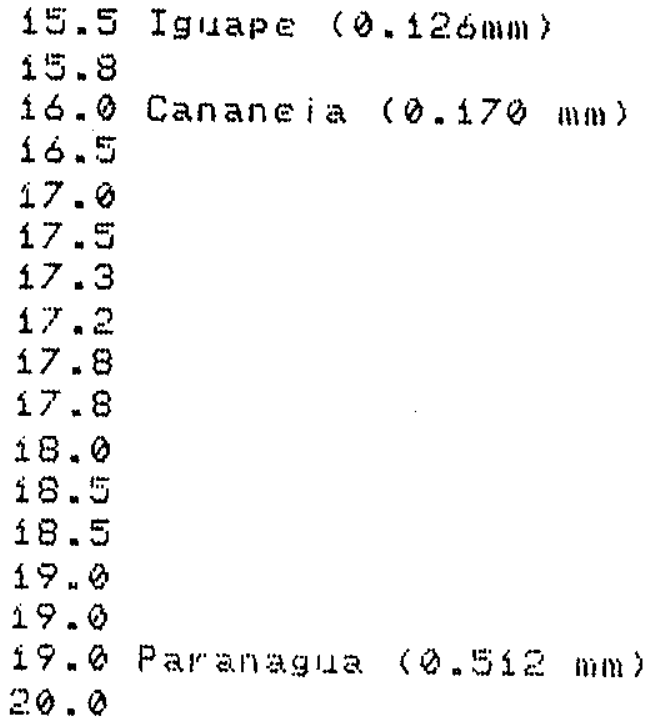


TABELA 53. TAXAS DE TRANSPORTE DA ESTACAO DE CORRENTOMETRIA DE IGUAPE

DUTUBRO 1984 - EQUACAO DE BAGNOLD (1963, APLLD GADD ET AL., 1978

\begin{tabular}{|c|c|c|c|c|}
\hline $\begin{array}{l}\text { Velocidade } \\
\text { da Corrente }\end{array}$ & $\begin{array}{l}\text { Indice de Transporte } \\
(U 100-U t h) \wedge 3 . \mathrm{Cm}^{\wedge} 3\end{array}$ & $\begin{array}{l}\text { Taxa de fransporte } \\
\text { (q).9.cn^-1.5^-1 }\end{array}$ & Direcao & $\begin{array}{l}\text { Somatoria da } \\
\text { tawa de transporte }\end{array}$ \\
\hline $\begin{array}{l}16 \\
17 \\
16 \\
18\end{array}$ & $\begin{array}{r}0.125 \\
3.380 \\
0.125 \\
15.628\end{array}$ & $\begin{array}{l}5.60 E-06 \\
1.51 E-64 \\
5.60 E-06 \\
7.00 E-64\end{array}$ & $\begin{array}{l}247.5 \\
247.5 \\
247.5 \\
247.5\end{array}$ & $8.62 E-04 \mathrm{~g} \cdot \mathrm{CAl} \mathrm{l}^{\wedge}-1.5^{\wedge}-1$ \\
\hline $\begin{array}{l}17 \\
17 \\
17 \\
16\end{array}$ & $\begin{array}{l}3.380 \\
3.380 \\
3.380 \\
0.125\end{array}$ & $\begin{array}{l}1.51 E-64 \\
1.51 E-04 \\
1.51 E-64 \\
5.60 E-66\end{array}$ & $\begin{array}{l}270.0 \\
270.0 \\
270.0 \\
270.0\end{array}$ & $4.59 E-04$ g.cman $\mathrm{cm}^{n}-1.5^{n}-1$ \\
\hline 18 & 15.620 & $7.00 \mathrm{E}-04$ & 225.0 & $7.00 E-04 \mathrm{~g} . \mathrm{cm}^{\wedge}-1.5^{\wedge}-1$ \\
\hline mpo total de & transporte $=2.00 \mathrm{~h}$ & & 249.0 & $1.90 E-63$ g. CA1 ${ }^{\wedge}-1.5^{n}-1$ \\
\hline
\end{tabular}

Tempo tatal de transporte $=2.00$ horas

sid t ante: 
TABELA 54. TAXAS DE TRANSPORTE DA ESTACAO DE CORRENTOMETRIA DE CANANEIA
ABRIL 1962 - EQUACAO DE BAGNOLD (1963, APUD GADD ET AL., 1978)

\begin{tabular}{|c|c|c|c|c|}
\hline $\begin{array}{l}\text { Velocidade } \\
\text { da Corrente }\end{array}$ & $\begin{array}{l}\text { Indice de Transporte } \\
(U 4 \theta \theta-U t h)^{\wedge} 3 . \mathrm{cm}^{\wedge} 3\end{array}$ & $\begin{array}{l}\text { Taxa de Transporte } \\
\text { (q). } .9 \cdot c m^{\wedge}-1 \cdot s^{\wedge}-1\end{array}$ & Direcao & $\begin{array}{l}\text { Sonatoria da } \\
\text { taxa de transporte }\end{array}$ \\
\hline 33.9 & 59.320 & $2.66 E-83$ & 35.0 & $2.66 \mathrm{E}-03 \mathrm{~g} . \mathrm{cm}^{\wedge}-1 . \mathrm{s}^{\wedge}-1$ \\
\hline $\begin{array}{l}40.8 \\
37.6 \\
33.9 \\
32.7\end{array}$ & $\begin{array}{r}1000.000 \\
438.970 \\
59.320 \\
19.680\end{array}$ & $\begin{array}{l}4.48 E-02 \\
1.97 E-02 \\
2.66 E-03 \\
8.82 E-04\end{array}$ & $\begin{array}{l}40.0 \\
46.0 \\
40.0 \\
46.0\end{array}$ & $6.80 \mathrm{E}-02 \mathrm{~g} . \mathrm{cm}^{\wedge}-1 . \mathrm{s}^{\wedge}-1$ \\
\hline 36.3 & 250.050 & $1.12 E-62$ & 45.8 & $1.12 \mathrm{E}-\theta 2 \mathrm{~g} \cdot \mathrm{cm}^{\wedge}-1 . \mathrm{s}^{\wedge}-1$ \\
\hline 30.2 & 0.088 & $3.60 E-87$ & 55.0 & $3.60 E-67 \mathrm{~g} \cdot \mathrm{cm}^{\wedge}-1 . \mathrm{s}^{\wedge}-1$ \\
\hline Empo total de & transporte $=3: 30$ ho & Resultante: & 41.8 & $8.18 \mathrm{E}-02 \mathrm{~g} . \mathrm{cm}^{\wedge}-1 . \mathrm{s}^{\wedge}-1$ \\
\hline
\end{tabular}


